\title{
SÔBRE TURBELLARIA BRASILEIROS
}

\author{
por Ernesto Marcus
}

\author{
(com 31 estampas)
}

Minha Espôsa, Excelentíssima Snrâ. D. EVELINE DU BOIS. REYMOND MARCUS, e eu apresentamos, nas páginas seguintes, a resenha dos Macrostomida, Rhabdocoela, Alloeocoela e Tricladida Paludicola, colhidos nas circunvizinhanças da cidade de São Paulo e em algumas outras localidades mencionadas ao tratar das espécies respectivas. Dos Catenulida, falámos há pouco tempo (Marcus 1945; 1945a). Não colecionámos, por enquanto, os Tricladida Terricola, já relativamente bem conhecidos (literatura: Riester 1938), e as Temnocephalidae, ultimamente estudadas por Pereira \& Cuoculo (1941).

Considerando o estado atual dos conhecimentos sôbre Turbellaria sul-americanos limnicos, parece de pouco valor catalogar, novamente, os Tricladida Paludicola. A literatura a respeito foi completamente reunida por Beauchamp (1939, p. 70 e seg.); o único trabalho não visto por êsse autor ( $p$. 72, nota 1) nada contem, como verjficámos, que não fosse já considerado por êle mesmo. A validade da maioria das espécies da dita Seç̧ão discute-se ainda. Como escreveu, numa carta de 18 de junho de 1943, a Snra. Dra. Libbie H. Hyman, do Museu de New York, seria muito desejável fossem re-examinadas as espécies de Borelli, com base em material provindo dos lugares originais. As indicações dêstes possibilitariam o procedimento recomendado. Mas, as novas coleções não deveriam ser adiadas por largo tempo. Na América do Norte, tentou Gilbert (1935, p. 287) esclarecer a enigmática Phaenocora agassiá Graff (1912, p. 372), indo em busca dela no lugar da procedência original, e encontrou, nêste, uma estação da via férrea subterrânea. Por enquanto, tentámos determinar alguns Paludicola, sem novo material das espécies de Borelli. Este não descreveu Tricladida do Brasil.

Dos outros Turbelários límnicos da Neogea, i. é, a América do Sul e a Central, ocuparam-se os autores seguintes: $a$ ) Kennel (1888; ; b) Böhmig (1902) ; c) Martin (1908; emenda: Luther 1908) ; d) Beauchamp (1913a); e) Fuhrmann (1914); f) Beauchamp (1939).

Os países ou regiões de onde há indicação de Turbelários são: Costa Rica (d) ; ilha de Trinidad (a); Colômbia (e) ; lago de Titicaca (f) ; Paraguai (c) ; Terra do Fogo (b). As espécies são, em ordem sistemática :

Ordem Catenulida: 1. Stenostomum bicaudatum Kennel (a); 2. St. paraguayense (Martin) (c); as espécies dúbias : St. leucops (Ant. Dugès) e St. agile Silliman (ambas, e);

Ordem Rhabdocoela: 3. Dalyellia incerta (Böhmig) (b); 4. D. complicata Fuhrmann (e, f); 5. D. quadridensoides Fuhrmann (e); 6 . Strongylostoma radiatum (O. F Müller) (f) ; 7. Mesostoma mutabile 
Böhmig (b) ; 8. M. ehrenbergii (Focke) (a, f); 9. Gyratrix hermaphroditus Ehrenberg (e);

Ordem Alloeocoela: 10. Geocentrophora applanata (Kennel) (a); 11. G. metameroides (Beauchamp) (d).

Do Brasil, relatámos (Marcus 1943a ; $1944 ; 1945 ; 1945 a)$ as espécies $1,2,8$ e 10 da lista precedente, assim como Prorhynchus stagnalis M. Schultze (Alloeocoela), a 12a espécie da Neogea, e ainda: 4 espécies de Catenula; 2 de Dasyhormus; 3 de Suomina: 4 de Chordarium; 23 espécies e 1 forma de Stenostomum; e 5 espécies de Rhynchoscolex.

Chegámos, destarte, a 53 espécies válidas dos Catenulida, Rhabdocoela, e Alloeocoela límnicos da Neogea, sendo 43, 7 e 3 os números relativos às Ordens enumeradas. Do total, 46 espécies conhecem-se do Brasil, a saber: 43 Catenulida; 1 dos Rhabdocoela (Mesostoma ehrenbergii); 2 dos Alloeocoela (Prorhynchus stagnalis; Geocentrophora applanata).

Pelo modo da apresentação das espécies tencionámos possibilitar que as mesmas sejam reconhecidas pelos interessados sem a consulta de outras obras alóm da excelente sinopse de Bresslau (1933). Por isso, démos diagnoses também de espécies já bem pesquisadas. Por outro lado, nenhuma espécie foi, no trabalho faunístico presente, tratada monogràficamente, como, p. e., Dalyellia styriaca por Reisinger (1924c, p. 237-274), ou as 3 espécies de Phaenocora que constituem a base do estudo comparativo de Gilbert (1935, p. 283-386). Salientamos, porém, a necessidade das descriçóes histologicamente pormenorizadas, como foram publicadas por Luther (1921) com 1 espécie e 1 sub-espécie em 34 páginas, por Reisinger (1924b) com 2 espécies em 37 páginas, por Nassonov (1932). com 2 espécies em 62 páginas, e muitos outros autores de primeira linha. Sòmente tais ańlises completas proporcionarão a penetração progressiva no sistema natural dos Turbellaria.

À Snra. Dra. D. Libbie H. Hyman, do American Museum of Natural History de New York, somos profundamente gratos pelo auxílio contínuo que nos prestou por cartas informativas, bibliografia, e 28 séries de cortes de Dugesia tigrina. A Snra. Dra. Hyman teve a grande bondade de comparar material desta espécie, provindo de São Paulo e Porto Alegre, com espécimes norte-americanos e remeter as séries mencionadas, que garantem a nossa classificação.

Lembramos gratamente a ajuda com material da parte da Snrta. Lic. D. Gabriella Zuccari e dos Snrs. Prof. Dr. Paulo Sawaya, Dr. Otto Schubart, e Dr. Edmundo Nonato. Ao Assistente da cadeira de Zoologia, Snr. Dr. Michel Pedro Sawaya, agradeço a cuidadosa revisão linguística do manuscrito.

\section{INDICE DOS GENEROS TRATADOS}

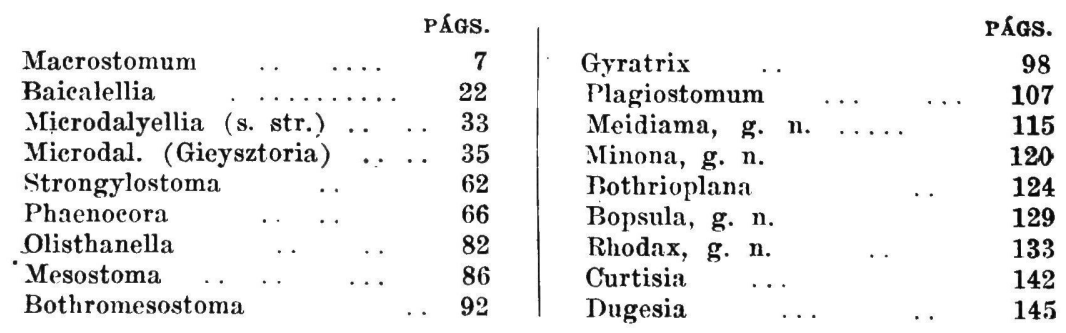




\section{Ordo: Macrostomida Meixner (Opisthandropora Bresslau)}

Dos Hysterophora Graff $(1905$, p. 69, 72), como ainda se apresentam no "Tierreich" (Graff 1913, p. 13), eliminou Steinböck (1924a, p. 241) as Prorhynchidae com "pharynx variabilis intextus" e germo-vitelários, incluindo-as nos Alloeocoela, ondo figuram ainda hoje (veja p. 104). As duas famílias restantes dos Hysterophora, a saber, as Microstomidae e as Catenulidae, possuem ovários e faringe simples. Baseado no emunctório impar (Catenulidae) e par (Microstomidae), Luther delimitou-as corretamente (1907, p. 722-723) tendo sido elevadas à categoria de Secções (em 1938: Ordens) por Meixner (1924, p. 19). Este chamou as Microstomidae, agora como Seç̧ão, de Macrostomida, porque o gênero Macrostoma foi descrito antes (Oersted 1843, vide Graff 1913, p. 46) que Microstomum (O. Schmidt 1848, p. 56). A forma "Macrostoma" ainda mantida na monografia de Luther (1905) deve ser substituida por "Macrostomum" O. Schmidt (1848, p. 54), pois o nome "Macrostoma" já tinha sido atribuido a um gênero de peixes, antes de Oersted (vide Graff 1913, p. 47).

Os nomes Notandropora Reisinger (1924b, p. 33) e Opisthandropora Bresslau (1933, p. 261) correspondem integralmente aos Catenulida e Macrostomida, respectivamente. São, destarte, neologismos escusados; Opisthandropora parece até pouco proveitoso, depois de ter Meixner (1938, p. 3 f. 4A, 35) incluido, nos Macrostomida, as Haplopharyngidae, em cujas espécies o poro masculino se situa anteriormente ao feminino.

Dos Catenulida tratámos há pouco (Marcus 1945; 1945a). Os Macrostomidà abrangem, além das Haplopharyngidae, as duas famílias Macrostomidae e Microstomidae (Bresslau 1933, p. 264). As Macrostomidae foram, como "Macrostomiens" (não "Macrostomicus" Graff 1913, p. 46), caracterizadas por Van Beneden (1870, p. 129, $133)$; as Microstomidae, no sentido atual, por Vejdovsky (1882, p. 54 ; segundo Luther 1907, p. 718), o primeiro, que separou Catenula Ant. Dugès 1832 e Stcnostomum O. Schmidt 1848 de Microstonıum O. Sehmidt 1848 e Alaurina W. Busch 1851.

$\mathrm{O}$ número e o aspecto dos cromosomas das Macrostomidae e Mierostomidae (sòmente um representante foi pesquisado) diferem muito (Ruebush 1938, p. 326), mas, apesar disso, não cedemos às sugestões taxonômicas do autor citado.

\section{Macrostomum gigas Okugawa (Fig. 1-3, Est. XXXI Fig. 1)}

Macrostomum tuba (non Macrostomum tuba Graff 1882) Gicysztor 1930, p. 305 e seg. f. 1-3

Macrostomum tuba var. gigas Okugawa 1930 , p. 77 f. $1-4$

Macrostomum tubum Hyman 1936, p. 14 e seg. f. 1-5

Maerostomi'm gigas Hyman 1943, p. $324-329,330$ f. $1-12$

Caracteres externos: O comprimento dos vermes presentes fica, com 3,2 $\mathrm{mm}$., um pouco aquém do máximo $(3,5 \mathrm{~mm}$.) do material norteamericano. I largura máxima, de $0,51 \mathrm{~mm}$., pode situar-se antes do meio, ou no meio do corpo, ou ao nível dos ovidutos. $\Lambda$ largura mínima nota-se, freqüentemente, um pouco antes da extremidade posterior. $\Lambda$ forma desta varía: pode ser tão arredondada como nas figuras da Dra. Hyman (1936, f. 1 ; 1943, f. 1), apresentando-se assim, nomeadlamente, nos vermes jovens das nossas populacões; ou pode ser ligeiramente dilatada (Fig. 1), como foi também desenhada por Okugawa (1930, f. 3). Véntralmente, o verme é achatado; no dorso, mais ou menos abobarlado, conforme o maior ou menor enchimento do intestino.

A côr (Est. XXXI, Fig. 1) é esbranquiçada ou o integumento tirante a acastanhado. Tons acastanhados exibem também as células intestinais, independentemente do estádio alimentício, e o conteúdo do intestino. A secrecão das glândulas faríngeas pode tornar a faringe purpúrea ou alaranjada. No parênquima, ocorre, às vezes, algo de pigmentação. Os 
ovócitos crescidos opacos e, à luz refletida, intensamente brancos, salientam-se nos vermes maduros.

No bordo anterior, os cílios são substituidos por ca. de 40-60 cônes rígidos, evidentemente, sensilos (Fig. 1, n). A zona dêstes delimita-se da epiderme ciliada adjacente por pequenas covinhas. Pêlos compridos (s), do caracter dos sensoriais, e mais flexíveis que os cônes anteriores, encontram-se ao longo do corpo e na extremidade caudal. Nos animais vistos por nós', são os pêlos sensoriais mais numerosos lateral que caudalmente, em oposição aos vermes de New York. Como aí, ocorrem os cílios sensoriais isolados, não em tufos (M. bulbostylum Ferguson 1939a f. 22, sh), sendo, várias vêzes, um cílio comprido acompanhado por 1-2 menores. Papilas adesivas ( $\mathrm{g}$ ) podem sair da extremidade posterior, fixando o verme; durante a locomoção, permanecem retraidas.

Os rabditos (r) são numerosos na cabeça e, aí, dispostos contínua e densamente. $\mathrm{Na}$ extremidade caudal, são igualmente mais cerrados que nos lados e no centro do corpo (veja a discussão, mais adiante), onde aparecem em feixes, separados um do outro por intervalos sem rabditos. Cada feixe abrange ca. de 6 rabditos. Os rabditos ventrais são menores e mais escassos que os dorsais e laterais. Numa área estreita, entre o cérebro e o bordo rostral correm alguns tractos, ("Stäbchenstrassen") de ramnitos adenóides. Glândulas cefálicas (frontais), de secreção acidófila, são presentes.

O cálice pigmentado dos olhos (Fig. 1, a) possue a pigmentação diversamente desenvolvida $\mathrm{e}$, às vêzes, até ausente. $\mathrm{O}$ citosoma da célula visual, a "clava da retina", é, em parte, refrativo, podendo tal porçãoplasmática funcionar como cristalino. Parece-nos escusada a terminologia de Kepner \& Stiff (1932, p. 223 e seg.) concernente ao olho de Macrostomum. O sistema nervoso, sem caracteres específicos, corresponde, pelo que foi visto pela Dra. Hyman (1943, p. 325-326), ao de $M$. viride (Luther 1905 , f. 3 no texto).

O tracto digestivo começa com a bôca (Fig. 1, b), cuja fenda ocupa quasi tôda a face ventral da faringe (h) musculosa. Bôca, faringe e intestino podem ser extraordinariamente dilatados. A dobra anelar entre faringe e intestino, a qual pode marcar-se como passagem estreita, não merece a denominação de esôfago. $O$ intestino (Fig. 1, i) é um saco alongado, de contornos ligeiramente ondulados e de revestimento formado por céhulas ciliadas altas, claviformes. A estensão caudal do intestino coincide, aproximadamente, com a vesícula seminal acessória (f) situada no ponto. la reunião dos dutos eferentes.

Dos elementos dos protonefrídios pudemos, em vermes jovens, comprimidos, verificar canais dorsais (pontilhados na Fig. 2) e ventrais multiplamente enovelados na zona da faringe e do intestino anterior. Nos canais, ohservaram-se tufos de cílios propulsores ("Treibwimperflammen"). Orgãos terminais, eujas ligações com os canais principais ainda não foram visłas, ocorrem em grande número, especialmente no terço caudal do corpo. Os poros excretores principais são os ventrais (Fig. 2, y), havendo, além disso, ainda acessórios, dorsais ( $\mathrm{x}$ ). Visto como as pesquisas até agora publicadas, p. e., as de Luther (1905, p. 18-22) não conseguiram descrevero sistema excretor inteiro de Macrostomum e êste, por isso, carece de valor 
para a identificação das espécies(Hyman 1943, p. 324), deixamos de ecmparar os nossos achados com os anteriormente realizados.

Do sistema reprodutivo, situam-se os testículos (Fig. 1, t), ligeiramente lobulados, nos dois lados da região anterior do intestino. Da extremidade posterior das gônadas masculinas saem os dutos eferentes ("vasa deferentia") (Fig. 1, e) que se reunem ao nível do fundo do intestino. Formam uma grande vesícula, de parede fina e dilatável (f), em que os espérmios são acumulados. Foi chamada, pela Dr. Hyman, de "spermiducal vesicle" (1943, p. 326) ; corresponde, com a sua configuração variável, a uma "vesícula seminal falsa ou acessória" (Bresslau 1933, p. 120) e comunica-se, por meio dum canal estreito, com a vesícula seguinte, de volume menor e igualmente cheia de espermatozóides (Fig. 1, v). A forma cilíndrica, constante, e a parede musculosa caracterizam esta como vesícula seminal verdadeira. Esta dirige-se para diante, ora para a direita, ora para a esquerda, e é seguida pelo reservatório da secreção granulosa (k). O reservatório fusiforme e sólido recebe a secreção eosinófila e granulosa das glândulas situadas ao redor da sua porção proximal (ental). A extremidade ectal (distal) do reservatório estreita-se tubularmente, encurva-se para trás, e segura o estilete cuticular do pênis (Fig. 1, p). O órgão copulador tem de comprimento 0,25-0,4 mm. (Gieysztor 1930, p. 310 menciona até $0,462 \mathrm{~mm}$.; Hyman 1943, p. 327, até $0,5 \mathrm{~mm}$.) e, na maior parte da sua longura, $0,01 \mathrm{~mm}$. de diâmetro. A largura na extremidade interna é um pouco maior, a saber, de $0,012 \quad 0,015 \mathrm{~mm}$. O encurvamento do pênis dá-se, em toda a sua estensão, num único plano e varía de intensidade nos indivíduos da mesma população. $O$ pequeno bulbo externo do pênis resulta dum espessamento da parede cuticular do tubo, cujo lume não se dilata. Em conseqüência da direção diversa assumida pela vesícula seminal verdadeira, ocorrem vermes com o reservatório e o pênis situados no lado direito, ou no esquerdo. Ao redor do átrio masculino, que é um tubo estreito, desembocam glândulas (Fig. 1, d), cujos citosomas são aprofundados e, destarte, situados no parênquima.

Os ovários encontram-se caudalmente aos testículos e compõem-se de numerosos pequenos lóbulos dispostos ao redor duma cavidade tubulosa central que continua como oviduto (Fig: 1, c). Os gonócitos femininos ováricos e os no início dos ovidutos são vacuolizados, enchendo-se, no oviduto, com vitelo. Ainda no trecho interno do oviduto atingem o seu tamanho definitivo, como foi descrito de $\boldsymbol{M}$. orthostylum (Meixner 1915, p. 474). Nos ovidutos, achatam-se os ovóeitos mutuamente. Na linha mediana do corpo, reunem-se os ovidutos v'ndos dos dois Iados, caracterizando-se o oviduto comum (Fig. 1, m). or' ginado pela reunião, freqüentemeute, pelo ovócito nêle abrigado. $\Lambda$ com ınicação do oviduto coinum com o átrio feminino (Fig. 1, 3, u), teoricamente significativa, será discutida mais adiante. No átrio, de revestimento ciliado, gira o ovócito e aí é fecundado. $\mathrm{O}$ número haplóide dos cromosomas é de três. $\mathrm{O}$ orifício do átrio (Fig. 3, w), igualmente ciliado, é circundado por numerosas glândulas eosinófilas, cuja secreção granulosa e refrativa gruda a casca do ovo a plantas aquáticas ou outros substratos. Na zona destas glândulas "de cimento", faltam os rabditos na epiderme. Os ovos esféricos, quando. postos, têem de diâmetro $0,150,18 \mathrm{~mm}$. 
Ocorrência: Dentro da cidade de São Paulo, no tanque cimentado situado no terreno da Faculdade de Filosofia, Ciências e Letras da Universidade de São Paulo; nos aquários do Departamento de Indústria Animal (bairro de Agua Branca); nas circunvizinhanças da cidade, comum em várias localidades, p. .e, em Tremembé, na serra da Cantareira, em córregos de correnteza rápida; no rio Tietê; na lagôa da Corôa, nágua parada; em remansos do rio Pinheiros, na ponte de Jaguaré; em poças e córregos perto do clube "Pinheiros"; ete.

Distribuição geográfica (veja a discussão sistemática): Japão; New York; em aquários com peixes não norte-americanos; provavelmente, nas águas paradas e correntes dos Estados norte-americanos de Virginia e Tennessee; Varsóvia, em aquários. O achado de Odessa, na Rússia, não está sistematicamente estabelecido.

\section{Notas biológicas sôbre Macrostomum gigas Okugawa}

A espécie pode ser facilmente mantida no aquário onde se multiplica durante muitos mêses. Como as outras espécies do gênero (Ferguson 1939, p. 1.t), é $M$. gigas comilão, e torna-se até nocivo num aquário em que se pretende criar Catenulida (Stenostomum-spec.) ou Rhabdocoela. Nas nossas culturas comeu, além disso, Naididae, p. e., espécies de Pristina; Rhizopoda, p. e., Arcella-spec.; e, de preferência, Cladocera, possivelmente, do gênero Chydorus. Dêstes, encontrámos 8-10 exemplares incorporados no intestino dum espécime de $\boldsymbol{M}$. gigas, deformado pelo volume da prêsa.

Reisinger (1933, p. 243) e Hyman (1943, p. 326) sugerem, independ'ntemente esta daquêle, a hipótese da ocorrência de digestão intracelular, em $\boldsymbol{M}$. thermale e $\boldsymbol{M}$. gigas, respectivamente. De fato, as células intestinais aumentam extraordinariamente de altura durante a resorpção do alimento. Tal evidencia, também, a pequena figura de Westblad (1923, f. 7e). Vimos as células tornarem-se tão altas que chegam a tocar-se com as extremidades iivres, fazendo, com isso, desaparecer o lume intestinal. Várias vêzes, verificámos, nos cortes corados com hematoxilina-eosina, predominar a côr azul nas células ventrais do intestino; a vermelha, nas dorsais. $\mathrm{O}$ citoplasma fica repleto de inclusões alimentícias.

Fagocitose, porém, no sentido de incorporação de partículas sólidas, unaiores que 0,1 micron (Jordan \& Hirsch 1927, p. 65), nas células intestinais, ainda não foi provada; Westblad (1923, p. 91) não a admite em Macrostomum. Com isso, não se exclue a possibilidade de digestão intracelular, pois a incorporação poderia ser do caracter de permeação de partículas menores. Parece auspicioso examinar $M$. gigas com os métodos aplicados em Dugesia dorotocephala (Woodworth) por Willier. Hyman \& Rifenburgh (1925).

A digestão no lume do intestino, fora do citoplasma das células intestinais, seria, no caso de se provar a intra-celular, uma pré-digestão ("Vorverdauung"). A eficiêucia da digestão extra-plasmática reconhece-se, facilmente, em cada corte de material fixado 1-2 horas depois da alimentação. $\Lambda$ casca bivalva dum Cladócero comido é completamente esvaziada jeela actuação dos fermentos de $M$. gigas. Em certas lâminas, em que a prêsa foi um Stenostomum, evidencia-se a digestão extra-plasmática no intestino dêste e a sua epiderme em desagregação, devida aos sucos digestivos do Macrostomum gigas. Ambos os gêneros abrangem espéeies macrófagas, engulidoras (Marcus 1945a, p. 35), havendo, em steriostomum, ainda outros tipos. 
Tigmotaxia positiva e fototaxia negativa foram observadas em M. vigas (Hyman 1943, p. 329); a última foi verificada por minha Espôsa (Marcus 1945a, p. 27-28) como sendo rápida e dirigida, i. é, tópica, no sentido de Kühn $(1919$, p. 8).

\section{Discussão sistemática de Macrostomum gigas Okugawa}

Depois de ter a Dra. Hyman (1943, p. 331) re-examinado os parátipos de M. iulbostylum Ferguson (1939a, p. 60), restaram 4 caracteres discordantes entre esta espécie e $M$. gigas. Três dêstes, relativos aos cílios compridos, aos cônes tácteis anteriores e às papilas adesivas posteriores, passam por disjunctivos apenas porque figuram na diagnose original. Podem ser verificados sòmente em vermes viventes, de modo que independem da dita re-examinação. O nosso matcrial concorda, quanto aos 3 caracteres indicados, como nos outros pormenores, com o da Dra. Hyman. No único sinal disjunctivo, porém, que ela pôde ver nas preparações, a saber, "rabditos mais numerosos nas extremidades anterior e posterior que no corpo restante", concordam os vermes de S. Paulo com $M$. bulbostylum. Isto prova ser a dita particularidade sem ralor específico. A identidade de $M$. bulbostylum e tambén a de $M$. tuba (Kepner \& Stiff 1932) com 1I. gigas torna-se, com isso, ainda mais verosímil. O mesmo número de cromosomas ocorri, freqüentemente, nas várias espécies dum gênero dos Turbellaria, mas, uma diversidade seria, naturalmente, significativa. Nos vermes de Kepner \& Stiff (Phillips 1936, p. 3.5.5) e de Ferguson (1939a, p. 66; 1940b, p. 245-246), há na fase haplóide, 3 eromosomas, como em 1 . gigas. Em M. viride, appendiculatum (Luther 1905, p. 45), e $M$. thermale (Reisinger 1933, p. 247), há dois.

No seu trabalho conclusivo. (1943), a Dra. Hyman incluiu, na sinonimia de M. gigas, M. tuba Graff 1882 (Beklemischev 1927a, p. 188, 202 t. 1 f. 5-6). Este verme possue, de fato, estilete penial ectalmente bulboso, e o bulbo origina-se por espessamento da parede, sem dilatação do lume (f. 6). Por outro lado, é o pênis do material russo muito curto (f. 5), exibindo a proporção entre a largura (na extremidade interna do tubo penial) e o comprimento do pênis de 1: 15. Isto difere muito de $M$. gigas, em que ocorrem as proporȩões seguintes: 1: 38 e mais (Gieysztor); 1 : ea. de 30 (Okugawa) ; $1: 35$ (Hyman 1943, f. 8) ; 1: 25-30 (material de São Paulo). A longura do estilete, é verdade, varía individualmente nos vermes do gênero Macrostomum (Gieysztor 1930, p. 311). O piênis cresce, nos vermes jovens, de trás para diante, e, destarte, possue a porporção aludida valor específico apenas quando verificada em indivíduos completamente adultos. O comprimento do corpo (4 mm.) indicado por Beklemischev faz crer tratar-se de material plenamente maduro. Em tal fase, o pênis de $M$. gigas é mais longo que o dos vermes russos. Por isso, parece recomendável não incluir, sem delongas, no quadro da distribuição total de $M$. gigas, por enquanto, as "poças dágua doce nos arredores de Odessa". Seja frisado, nêste conjunto, a forma aberrante do pênis em casos de regeneração (Ruhl 1927, f. 13B), os quais deveriam ser ponderados, quando se trata de achados isolados.

\section{O oviduto comum e o átrio feminino de Macrostomum gigas Okugawa}

Vários autores, p. e., Luther (1905, p. 49), Meixner (1923, p. 203; 1926 , p. 602 ; 1938 . p. 49 ), e Steinböck (1935, p. 236) apontaram samelhanças entre os Acoela e as Macrostomidae. Na última das passagens citadas, foram as Macrostomidae caracterizadas como sendo a família mais próxima aos Acoela, dentre todos os Turbelários límnicos. Para tal opinião contribuiram, em grande parte, as "Conclusões teóricas" de Reisinger (1933, p. 247), en que estabelece a homologia anátomo-comparativa entre as vias femininas das ditas entidarles. Trata-se, especialmente, da bursa seminalis com o duto espermático de certas Convolutinae que foi comparada ao átrio feminino com o aparelho de passagem do ovócito de Macros- 
tomum thermale Reisinger (1933, p. 240). O curto canal genital de Macrostomum (entre w e u na Figura 3), seria homólogo à vagina dos Acoela. No seu tratado, adotou Meixner (1938, p. 56) esta homologia integralmente.

Antes de a discutirmos, parece conveniente perguntar se deliberações filogenéticas, abundantes nos trabalhos sôbre a morfologia dos Turbellaria, nomeadamente nos da escola de Graz, se justificam. Em estensos sectores da Zoologia estão "fóra da moda", mas, a sua razão de existir parece-nos inegável. Abstenhamo-nos de discutir, especulativamente, as causas da evolução, mas, pesquizemos o sistema natural, pois a êste corresponde uma ordem na própria natureza. A paleontologia, em primeiro lugar, mas, também a anatomia e a embriologia comparativas estudam o sistema natural. Como é formulado por nós, carece, é claro, de valor absoluto; objectiva-se, nêle, sempre o nível científico de cada época. Westblad (1942, p. 11, nota) opõe-se à tradição fillogenética nos trabalhos sôbre Turbelários, chamando as considerações respectivas de estéreis. Certamente, a fisiologia dos Turbelários deveria ser mais pesquisada e isso justamente em continuação à excelente obra de Westblad (1923). Mas, "as questões da organização" aludidas por Westblad (1942, l. c.) devem ser resolvidas morfologicamente, quando se trata de aproximar a taxonomia da classe ao sistema natural.

Em Macrostomum gigas (Fig. 3), observamos as estruturas seguintes : o orifício feminino (w) circundado por glândulas aglutinantes. Concordamos com Reisinger (1933, p. 249) e Meixner (1938, p. 56) que vêem, nestas glândulas de secreção eritrófila, glândulas rabditógenas modificadas. Tal opinião é apoiada pelo aspecto histológiẹo das glândulas rabditógenas de $\boldsymbol{M}$. gigas, como também pela ausência de rabditos na zona em que as glândulas grudadoras desembocam. O canal genital feminino é cìliado, e os núcleos do seu epitélio são aprofundados no parênquima. Com o último caracter, o canal distingue-se tanto da epiderme, quanto do átrio feminino. Os epitelios do átrio e da epiderme possuem os núcleos intra-epitelialmente situados. Os limites celulares do epitélio atrial são, geralmente, nítidos, tormando-se apenas em maior ou menor estensão indistintos, quando o ovócito dilata o átrio. Na parede anterior do átrio, células lameladas constituem o "aparelho de passagem do ovócito" da terminologia de Reisinger (1933, p. 245 f. $2 \& 4$, x). Feixes de espérmios ficam com as suas caudas implantadas nas células lameliformes, sem entrar, evidentemente, no oviduto comum (Fig. $3 \mathrm{~B}, \mathrm{z}$ ). Uma túnica muscular circular circunda o canal genital, o átrio, o aparelho de passagem, e continúa ao redor do oviduto.

Nos traços gerais, correspondem as estruturas descritas às de $\boldsymbol{M}$. thermale cujo átrio carece, porém, de cílios e apresenta revestimento sincicial. Tal ausência de cílios no átrio de $M$. thermale e na bursa seminalis dos Acoela, em oposição à presença de cílios no canal genital de $M$. thermale e na vagina dos Acoela, pareceu a Reisinger argumento importante em favor da homologia acima resumida. Ocorre, porém, ragina sem cílios nas Convolutinae Monochoerus chuni, M. böhmigi (Brauner 1926, p. 41, 47), e Polychoerus carmelensis (Costello \& Costello 1938, p. 86). O outro apoio é o tubo curto, de calibre estreito, formado por células lameliformes e situado na parede rostral do átrio (da bursa). Nos Acoela, os espérmios atravessam o canal euticularizado da palheta da bursa ("Bursamund. stück") ; em Macrostomum, falta a cutícula, e os espérmios esperam, geralmente, o ovócito que desce do oviduto comum ao átrio. Em Macrostomum 
virginianum Ferguson (1937; 1940a, f. 23), os espérmios atravessam, ao que parece, o aparelho e entram no oviduto.

As indicações que se referem à redução de cílios no átrio feminino de Macrostomum, como, p. ex., de Luther (1905, p. 47, M. viride); Meixner (1915, p. 477, M. orthostylum); Riedel (1932, t. 3 f. 10, M. boreale); e Ferguson (1939c, f. 24, M. reynoldsi) tratam, em parte, de átrios dilatados pelos ovócitos, fase, em que também os limites inter-celulares desaparecem (Hyman 1943, p. 328). Por via de regra, o átrio feminino de Macrostomum é ciliado (Ferguson 1939, p. 144).

Histologicamente, as semelhanças não se moștram tão nítidas, como Reisinger pensou. Funcionalmente, ignoram-se as células lameladas de Macrostomum; talvez actuem como almofada alimentícia (Luther 1905, p. 47 ; Meixner 1926, p. 603; Cernosvitov 1932, p. 152; Riedel 1932, p. 70). Não obstante, impressiona a topografia geral idêntica dos órgãos femininos em Convoluta e Macrostomum (Meixner 1938, f. 34 A, B). Nestes esquemas, reconhecem-se também os complexos de glândulas eritrófilas (ibid., p. 56), que desembocam na vagina de várias Convolutinae ou ao redor do seu orifício vaginal externo, p. e., em Convoluta henseni Böhmig (1895, p. 43), Monochoerus illardatus Löhner \& Micoletzky (1911, p. 422), e Amphiscolops fuligineus Peebles (1915, p. 307). A ocorrência de glândulas do tipo das aglutinantes, nos Acoela digonopora, faz crêr que, em muitos gêneros dêstes, os ovos se evacuem pelo poro feminino, como foi observado em Polychoerus caudatus (Gardiner 1895, p. 155; fide Löhner 1910, p. 499). Na dita espécie (p. 498), como também em Monochoerus illardatus (Löhner \& Micoletzky 1911, p. 422), existem lacunas preformadas no parênquima que conduzem, provavelmente, os ovos ao átrio ou orifício feminino. Também em Monochoerus chuni e $M$. böhmigi foram os ovos encontrados perto do poro feminino (Brauner 1926, p. 46).

Tudo isto não contraría a homologia em questão. Mas, a direção evolutiva, segundo Reisinger (1933, p. 250) univocamente ("eindeutig") estabelecida, no sentido duma diferenciação dos Acoela às Macrostomidae, continúa, ao nosso ver, problemática. Pelos trabalhos de Findenegg (1930, p. 98-99) e Luther (1946, p. 11-14) sabemos que o aparelho de passagem ("Durchgangsapparat") não se restringe às Macrostomidae, mas, ocorre também nas Typhloplanidae Ascorphorinae.

\section{Macrostomum delphax, spec. nov. (Fig. 4-9)}

O comprimento é de 1-2 mm., ocorrendo com. maior freqüência indivíduos com 1,6 1,8 mm. Há vermes de $1,1 \mathrm{~mm}$., ao comprido, ainda carecentes de quaisquer primórdios das gônadas e, por outro lado, animais com ovo no átrio, que não ultrapassam $1 \mathrm{~mm}$. A largura varia entre 0,2 e 0,5 $\mathrm{mm}$., sendo a medida de $0,4 \mathrm{~mm}$. a mais freqüente. $\mathrm{O}$ máximo da largura pode situar-se no meio do corpo ou algo mais para diante ou para trás. Muitas vêzes, estreita-se o corpo antes da extremidade posterior, acentuando tal constrição o aspecto espatulado da cauda; outras vêzes, corresponde o contôrno do verme ao duma elipse. A face ventral achatada apõe-se ao substrato; a dorsal torna-se mais ou menos convexa, conforme o enchimento do animal com alimento ou ovócitos em crescimento. 
A côr dos vermes jovens é branca; a dos adultos, cinzento- amarelada com grumos de pigmento no parênquima, tons pardos no epitélio da faringe, e, em indivíduos bem velhos, certo colorido dos rabditos. Os ovócitos (Fig. 4, y) salientam-se pela sua côr branca brilhante; o conteudo do intestino (i) ecndiciona as várias côres da faixa mediana do corpo. Zooclorclas não ocorrem.

Os eílios locomotores medem 8 microns de comprimento; os seus batinientos podem parar e re-começar independentemente, nas várias regiões do corpo. Os golpes de correnteza provocados pelos cílios locomotores resultam, às vêzes, no encurvamento dos estereocílios rígidos (Fig. 4, s), cujo comprimento é de $0,07 \mathrm{~mm}$. Estes órgãos, provavelmente tangoperceptivos, são mais numerosos na cauda que nas partes laterais. $\mathrm{Na}$ cabeça, ocorrem sensilos (n), de $0,02 \mathrm{~mm}$., ao comprido, constituidos por cílios inutuamente grudados. $O$ bordo anterior, em que os sensilos se situam, delimita-se das zonas ântero-laterais adjacentes por reintrâncias inconspícnas.

Os rabditos (Fig. 9, r) são posterior e lateralmente sempre numerosos, mas, de resto, variam em número dum verme para outro. Geralmente há mais no dorso que no ventre. Ao redor da bôca e dos póros feminino (Fig. 9, w) e masculino (1) faltam rabditos. As células rabditógenas (Fig. 9, d), em que se produz, de uma rez, só um rabdito, situam.se no parênquima. $\mathrm{O}$ comprimento dos rabditos atinge $0,02 \mathrm{~mm}$. e, como a altura las células epidérmicas não ultrapassa 5 a 8 microns, os feixes dos rabditos elevam-se na superfície, como também atravessam, para dentro, o tubo músculo-dermático, entrando no parênquima (Fig. 9). Tractos de rabditos observam-se na cabeça; as glândulas formadoras (Fig. 5, m) dos feixes de rabditos situam-se à altura da faringe. Na cauda, podem ser protraidas as papilas grudadoras (Fig. 4, g), que são células providas de bastonetes pegajosos. As glândulas em que tais bastonetes se desenvolvem são longamente aprofundadas (Fig. 9, f), estendendo-se, para diante, até a região to poro masculino (l).

Os olhos (Fig. 5, a) encontram-se perto do bordo posterior do cérebro (Fig. 4,c), em contato com as células ganglionares cerebrais que revestem a massa central das fibras. Os cálices pigmentados são profundos; convergem em direção à linha mediana e ao bordo anterior da faringe. $\mathrm{Na}$ clava da retina distinguem-se duas zonas, a interna, circundada pelo eálice, e a externa, situada fora dêste. A primeira é a fotoperceptiva, de plasma opaco, acidófilo; a segunda, refrativa, poderia funcionar como cristalino. Dos elementos do sistema nervoso (Fig. 5) foram observados o cérebro (c); os nervos longitudinais ventrais; e os nervos anteriores. Dêstes vêem-se, na Fig. 5, um par de origem ventral, ladeando os tractos de bastonetes, e dois pares originados dorsalmente, que correm aos lados do par ventral.

$\Lambda$ bôca é tão comprida quão a faringe, i. é, ca. de $0,2 \mathrm{~mm}$. As células do epitélio faríngeo são ciliadas e pigmentadas; as glândulas faríngeas, abundantes (Fig. $5, \mathrm{~h}$ ). Sem esôfago intercalar, segue à faringe o intestino saculiforme (i), de contornos ligeiramente ondulados. $O$ trato digestivo estende-se caudalmente até o nível do orifício feminino (w), e mais para trás ainda. Nas bolsas ântero-laterais do intestino, encontram-se grupos de 
células claviformes de Minot (Fig. 5, x), de secreção granulosa. $O$ alimento consiste em Diatomeae, Flagellata verdes, Amoebea tecados, Rotatoria, Oligochaeta, Crustacea, etc. A prêsa está sujeita a uma digestão extraplasmática eficaz, no lume do intestino. Não sabemos se êste processo deve ser tido por pré-digestão, seguida por digestão ulterior dentro das altas células intestinais ciliadas. A ausência certa de fagocitose nãa exclue a possibilidade de se realizar digestão intra-celular de pequenas partículas permeadas. Apenas nunia das séries de cortes corados com hematoxilinaeosina observa-se o fenômeno, mais freqüente na espécie precedente, de predominar, no chão do intestino, a côr azul; no teto, a vermelha.

Afora observações incoerentes de um ou outro órgão terminal, não foi possivel reconhecer os emunctórios, apesar de que dispusemos dum amplo material, também de vermes imaturos, geralmente propícios ao estudo do sistema excretor, por meio de preparações de compressão. Os protonefrídios não podem ser usados na classificação das espécies do gênero, pois notririamente há casos em que os índices refrativos dos canais e do parênquima concordam e os corantes falham (Hyman 1943, p. 324, 326). Cortes não se prestam para a reconstrução do aparelho excretor de Macrostomum.

Os testículos são pequenos (Fig. $4,5, \mathrm{t}$ ), globosos e, às vêzes, presentes sòmente num lado, como foi confirmado nos cortes. Os espermatozóides frescos (Fig. 8) medem ca. de $0,04 \mathrm{~mm}$., ao comprido. Têem acrosoma ("feeler" Ferguson 1940b, p. 250; "flagellum" Hyman 1943, p. 327) alongado, em movimento contínuo. Este é executado pelos bordos ondulantes que ladeiam o eixo central do acrosoma, ao que parece, pouco móvel. $\Lambda$ eabeça reta e mais rígida passa, sem parte média discernível, à cauda móvel. Nesta, reconhece-se o filamento axial granuloso revestido, até a extremidade terminal, pelo manto plasmático. No início da cauda, inserem-se dois apêndices. Sendo imóveis, deveriam ser chamados de cerdas ("setae") acessórias, não de flagelos secundários ("Nebengeisseln"). Espérmios expostos à agua incham-se logo, deformando-se; a tal estádio refere-se a figura reproduzida da literatura por Meixner (1938, p. 53 f. $52 \mathrm{~B}$ ). Os dutos eferentes (Fig. 4, e) muito finos e não vistos por nós em tổa a sua extensão reunem-se caudalmente ao átrio feminino (Fig. 9, u), desembocando na vesícula seminal impar (v), cuja presença constante e parede musculosa a caracterizam como vesícula seminal verdadeira. Daí sae, geralmente para o lado direito, um duto curto e estreito (duto ejaculatório Luther 1905, p. 31) que liga a vesícula ao reservatório da secreção granulosa (Fig. 6; k), globosa. $\Lambda$ o redor da desembocadura do duto mostra-se ciliado o epitélio do reservatório. Nas outras partes, salientam-se os cônes da secreção fornecida por glândulas situadas no parênquima. A membrana basilar do reservatório continua como revestimento cuticular do estilete (p), cuja parte ental abriga ainda cônes da secreção granulosa.

O estilete ou pênis (Fig. 4, 6, p) estende-se, às mais das vêzes, dos lados direito e rostral para os lados esquerdo e caudal, ultrapassando um ponco o meio do corpo, onde se situa o poiro lidsculino (1). A longura do pênis pode ser medida apenas na parte pouco encurvada, que importa em $0,12 \mathrm{~mm}$. A parte ectal, de aproximadamente $0,03 \quad 0,04 \mathrm{~mm}$., forma uma espiral dirigida para a direita ou para a esquerda. Ao sair do reservatório, $o$ estilete tem de diâmetro ca. de $0,04 \mathrm{~mm}$. Ao longo dos dois primeiros 
terços da sua estensão, estreita-se sucessivamente, atingindo $0,02 \mathrm{~mm}$. de largura no ponto em que o comprimento é de $0,08 \mathrm{~mm}$. Aí se adelgaça repentinamente e continua, com 5 microns de diâmetro, até a extremidade. A estensão terminal de ca. de $0,012 \mathrm{~mm}$. é ocupada pelo orifício obliquo e terminal. No verme comprimido, a espiral pode ser desfeita e transformada em curva simples (Fig. 6), até com o orifício aparentemente dirigido para cima.

Os ovários (Fig. 4, o) são lobulados e encontram-se caudalmente aos testículos $(\mathrm{t})$. Nos ovidutos podem situar.se vários ovócitos $(\mathrm{y})$ em crescimento, um atrás do outro, caracterizados pelos seus contornos irregulares. Dos ovócitos esféricos, completamente crescidos, não há mais que um em cada oviduto. Ventromedianamente, reunem-se os dois ovidutos, e o oviduto cumum (Fig. 9, b), originado por essa reunião, corre como canal muito estreito, quando vázio, em direção caudal e dorsal, onde entra no átrio feminino (Fig. 9, u). A região da desembocadura, pela altura e a ausência de cílios distingue-se das outras células do epitélio atrial, que é chato e ciliado. Nos cortes de vermes sem ovo no átrio, situa-se a dita região mais dorsal que caudalmente; nos com ovo no átrio, mais caudalmente. Tal evidencia ser a parede anterior do átrio mais dilatada pelo ovo que a posterior. No centro das cẹ́lulas altas, não ciliadas, acumulam-se os espérmios, implantados com as suas caudas. Do átrio feminino sae um curto canal genital ciliado, que se abre numa reintrância ciliada da epiderme. O orifício externo desta concavidade é o poro feminino (Fig. 4, 9, w). Anel espêsso de glândulas eosinófilas (z), cuja secreção granulosa gruda o ovo ao substrato, circunda o poro feminino; são glândulas rabditógenas transformadas. O número haplóide dos cromosomas é de dois.

Ocorrência: $M$. delphax foi encontrado em biótopos bastante heterogêneos, a saber, nágua corrente e rica em matéria orgânica do rio Tietê, perto do bairro do Limão, entre as raizes de Trianea bogotensis e Heteranthera reniformis (21. X. 45: :alguns exemplares; abril de 45 e 46 : material abundante); nágua de correnteza lenta do rio Pinheiros, na ponte de Jaguaré (em V. e XII. 45), entre raizes de Eichhornia crassipes; nágua de correnteza rápida e intensamente contaminada dum córrego perto do bairro de Pinheiros (II. 46); e nágua húmica, estagnada, pobre em matéria orgânica duma fossa apenas periòdicamente aquífera num prado nas circunvizinhanças de Butantan (IV. 46).

\section{Notas biológicas e relativas ao crescimento do estilete}

Como material a ser criado no aquário, para estudos fisiológicos, a espécie $M$. delphax revelou-se, nas nossas culturas, inferior à precedente. Os adultos evacuaram os seus ovos e produziram novos, tanto num aquário volumoso quanto em vasos menores, mas, o tamanho dos vermes diminuiu sucessivamente, apesar da farta alimentação engulida. Os vermes jovens saidos dos ovos não alcançaram a maturidade sexual. Animais jovens nadam livremente, girando ao redor do seu eixo longitudinal. Ao atingirem ca. de $0,8 \mathrm{~mm}$. de comprimento, passam à locomoção rasteira. A fototaxia negativa de $M$. delphax é menos pronunciada que a de $M$. gigas. Autocopulação ocorre em $M$. delphax, como se verificou num indivíduo isolado (21. X.), sem gônadas. Em 31. X. teve, nos dois ovidutos, ovócitos quasi completamente crescidos, estilete penial de $0,05 \mathrm{~mm}$., ao comprido, e 
espêrmios implantados nas células altas, proximais, do átrio feminino. Se o verme tivesse sobrevivido à verificação do seu estádio, realizada debaixo dá lamínula, teria certamente produzido ovos fecundados, como foram observados de $M$. appendiculatum (Sekera 1906, p. 143).

Da espécie que chamou de $\boldsymbol{M}$. bulbostylum (provavelmente, M. gigas . Okug.), Ferguson (1940b, p. 259) criou a descendência de dois indivíduos com estiletes de $0,312 \mathrm{~mm}$. de comprimento, o têrmo médio do seu material. Dos bisnetos mediu 10 indivíduos, cujo têrmo médio de comprimento do estilete foi de $0,373 \mathrm{~mm}$. Disso concluiu, acertadamente, que o tamanho do estilete não representa base válida de novas unidades taxonômicas.

Da medição de 30 exemplares de $M$. delphax, com ovo no átrio, concluimos que é independente o comprimento definitivo do estilete do tamanho do corpo. Obtivemos, p. e., vermes de $1,2 \mathrm{~mm}$, com estilete de $0,09 \mathrm{~mm}$., e outros de $1,3 \mathrm{~mm}$. com pênis de $0,03 \mathrm{~mm}$.

Em 8 vermes maduros, mantidos isoladamente e alimentados do mesmo modo, durante 13 dias, cresceram os estiletes muito diversamente. Comeȩaram com estiletes de ca. de $0,05 \mathrm{~mm}$., e atingiram, no fim da experiência, $0,06 \quad 0,096 \mathrm{~mm}$.

\section{Discussão sistemática de Macrostomum delphax}

A chave (W. J. Hayes, jr.) das espécies tidas por válidas (Ferguson 1940a, p. 138 e seg.) levaria, na classificação de $M$. delphax, aos números seguintes: 22, estilete não alargado distalmente; 23 , ponta distal acuminada; 24, o estilete abre-se terminalmente; 28 , o estilete encurvado, não reto; 38 , o estilete não arqueado sucessivamente, mas, com flexura num ou outro determinado ponto; 44, uma ou mais flexuras perto da extremidade distal do estilete; 46, sem covinhas ciliadas; 48 , a extremidade distal do estilete cortada num ângulo de $40^{\circ}$ ou menos, o orifício estreito, elíptico; 50 , estilete menor que $0,2 \mathrm{~mm}$. As espécies que seguem na chave (51-70), a saber, gilberti, phillipsi, ruebushi e as variedades de ruebushi, possuem flexura distal do estilete situada naquêle plano que contem o eixo principal da parte proximal (ental). A parte distal de $\boldsymbol{M}$. deţphax, porém, forma uma espiral. Compressão enérgica do estilete pode đesfazer a espiral. Por isso, recomenda-se ainda o confronto rápido com as espécies que figuram na chave entre 51 e 70 . Em tôdas, coincide, aproximada ou nìtidamente, a flexura distal do estilete com o início interno (ental, proximal) do orifício do estilete. Em. delphax, pelo contrário, é a distância entre a flexura distal e o bordo interno do orifício duas vêzes maior que a entre êste bordo e a ponta do estilete.

Independentemente da chave aludida, convem comparar $M$. delphax com algumas espécies cujas proporções entre as partes proximal e distal dos estiletes oferecem certas semelhanças. Tais são 1) $M$. viride Van Beneden (1870, p. 4 ou 117), cujo orifísio do estilete se situa entalmente à ponta (Luther 1905, p. 33); 2) M. rhabdophorum Beklemischev (1927a, p. 187, 202) com extremidade obtusamente truncada do estilete; 3) M. japonicum Okugawa (1930, p. 79), de côr escura e a ponta do estilete igualmente truncada ; 4) M. intermedium $\mathrm{Tu}(1934$, p. 199), cujo estilete tem comprimento que corresponde à nona parte da longura do corpo; em $\boldsymbol{M}$. delphax, à décima quinta até vigésima.

Ferguson (1940, p. 32) chamou $M$. viride Luther (1905, p. 4 e seg.) de $M$. ruebushi var. finnlandensis, achando não ser a espécie de Luther idêntica à de Van Beneden (1. c.). Não obstante, menciona Ferguson (1940a, p. 134) tôdas as figuras de Luther na lista dos sinônimos de viride Van Bened., copiando até o lapso de Graff (1913, p. 51) que citou, de Luther, t. 3 f. 8 , em vez de 9 . Mais significativos que tais erros formais, são os da descrição de ruebushi var. finnlandensis: "o estilete é um funíl ligeiramente curvado com orifício terminal" Evidentemente, Ferguson não leu bem o trabalho de Luther, senão teria encontrado a descrição do encurvamento em espiral (Luther 1905 , p. 33, 35) e o orifício sub-terminal ("Oeffnung hinter der. 
Spitze"). A figura de Luther (t. 3 f. 9), que evidencia a posição aludida do orifício, foi copiada por Ferguson $(1940$, f. 13), até com indicação correta da procedência. Outra figura de Luther (t. 1 f. 1), também copiada por Ferguson (f. 12), embora ecm a repetição estranha de "t. 3 f. 9 " como procedência, mostra o estilete de viride Luther na posição natural, sem compressão forte, e, por isso, algo helicóide. Existe certa diferença entre esta e as figuras de Van Beneden, mas, não é maior que em outros desenhos provindos de autores e épocas diferentes. Sem, pelo menos, ter tido em mãos material de Louvain e da Finlândia meridional, Ferguson não deveria ter contestado a identidade específica de viride Van Beneden e viride Luther que foi aceita, p. e., por Hofsten (1912, p. 577) ; Graff (1913, p. 51); Meixner (1915, p. 469); Gieysztor (1931, p. 133); Reisinger (1933, p. 246-247); e Bresslau (1933, f. 116). Em nenhum caso, $M$. viride Luther deveria ter sido considerado uma variedade de M. ruebushi, pois esta espécie tem 3 cromosomas como número haplóide (Ferguson 1940 b, p. 245-246); M. viride tem dois (Luther 1905, p. 45).

Afora $M$. norfolkense Jones \& Ferguson (1940, p. 220), cuja anatomia não se depreende da passagem citada, comparamos com $M$. delphax as espécies seguintes, não contidas na moHografia de Ferguson: M. mystrophorum Meixner (1926, p. 602), eujo estilete se encurva, ectalmente, em forma de U; $\boldsymbol{M}$. auriculatum Nassonov (1935, p. 200); eujo estilete lembra o de $M$. gracile Pereyasl. (Graff 1905, p. 81 t. 2 f. 2 ) ${ }^{*}$ ); $M$. catarractae Gieysztor $(1938$, p. 216$)$, com encurvamento semilunar da terminação do estilete; duas variedades de $\boldsymbol{M}$. ruebushi Ferguson, a saber, var. kepneri Ferguson \& Jones (1940, p. 184-189) e var. schmitti Hayes \& Ferguson (1940, p. 27-30), ambas com o estilete de ruebushi: "a simple extended funnel with a terminal vend"; M. appendiculatum var. stirewalti (deveria ser chamado de stirewaltae) Jones \& Ferguson (1941, p. 53-56), cujo estilete se abre sub-terminalmente, no lado convexo da flexura distal; $M$. ontarioense Ferguson (1943, p. 425-428) com duas flexuras do estilete, uma ental, perto do meio, e a outra distal (ectal) que abrange sòmente a parte ccupada pelo orifício lateralmente situado; $M$. hustedi Jones (1944, p. 347-359), marinho, com orifício do estilete muito distante (a um terço do comprimento total do estilete) da ponta, e com número haplóide de 6 cromosomas, excepcional no gènero.

\section{Macrostomum evelinae, spec. nov. (Fig. 10-13)}

Vermes adultos atingem $1,5 \mathrm{~mm}$. de comprimento e $0,25 \mathrm{~mm}$. de largura máxima. Encontrámos indivíduos de meia idade com $0,6 \mathrm{~mm}$. de longura. A forma geral dos animais completamente crescidos vê-se pela Figura 10: o corpo é anteriormente truncado; para trás, alarga-se muito pouco até o nível do poro feminino (w). Mais caudalmente o corpo contrae-se. Atrás da constrição, alarga-se novamente, formando a placa caudal quasi orbicular, em 'ujo centro o poro masculino (l) se encontra. Os animais são incolores, mas, pouco transparentes; a granulação do cito-

) Ferguson (1939b, p. 201) chamou de $M$. graffi a espécie tida por Graft (l. c.) como idêntica a Macrostoma gracile Pereyaslawzewa $(1892$, p. 243, t. 3, f. 17, ai "Macrostoma gracil"'; na p. XVI: Macrostoma gracile), por serem os estiletes diferentes. Onde Ferguson desereve $M$. gracile, reproduz a figura de $\boldsymbol{M}$. megalogastricum Pereyasl. (1892, p. 243, t. 3, f. 18) e acreseenta, nesta, papilas adesivas que não existem na figura original. Repetidamente cita Ferguson a autora russa com o ano de "1902", copiando, com isso, um erro de Graff (1913, p. 50); reune na diagnose de gracilc a bôca da figura original 17 (gracile) com o estiletés da fig. 18 (megulogastricum); desenha (1939b, f. 21 na p. 200$)$ e interpreta (1940a, p. 139) como saliências ("conspicuous ridges") da parede cuticular do estilete de yracile o que, na verdade, sāo os interstícios entre os cênes de szereçĩo granulosia contidos no reservatório de megalogastricum. A leitura da "monografia" de Ferguson leva a concordar com o autor $(1939, \mathrm{p}, 7)$ o qual "is sure that there are many taxonomists who could have arcomplished this research with less error, fewer omissions and more clarity". 
plasma torna brancos os ovócitos (y) e o intestino (i). Olhos faltam, sendo não sòmente ausentes os cálices pigmentados, mas, também, as células visuais, como se evidência pelos cortes.

Os cílios locomotores são curtos (5 microns); no bordo anterior, ocorrem sensilos (10 microns). Poucos estereocílios (ca. de 15 microns) guarnecem tôda a superfície, especialmente a da cauda. Rabditos encontram-se apenas na cabeça (r) e na cauda (s) ; aparecem, pela primeira vez, em exemplares (Fig. 11) de tamanho médio $(0,6 \mathrm{~mm}$.). Os rabditos cefálicos, no bordo anterior do animal, dispõem-se em 14-20 feixes cerrados, aos quais podem ainda juntar-se, em cada lado, mais dois grupos ântero-laterais. $\Lambda \mathrm{s}$ glândulas eosinófilas, formadoras $(\mathrm{m})$ dos rabditos cefálicos (r), situam-se no parênquima, ao nivel do intestino anterior. Os rabditos caudais (s) ocupam o sector central da placa; lateralmente são substituidos, nos vermes adultos, pelas papilas adesivas (g). Espécimes de meia idade, com 0,6 mm. ao comprido (Fig. 11), apresentam as papilas na circunferência inteira da placa caudal.

Glândulas cianófilas massiças desembocam na frente, no dorso, e nos lados da eabeça. Ao redor do poro masculino (1), ocorrem glândulas eritrófilas (f), cuja secreção consiste em grânulos finos. As glândulas argamassadoras (Fig. 13, z) serão descritas no conjunto da via eferente feminina.

O cérebro (Fig. 10, c) compõe-se da comissura central, que é grossa e de dois pares de lóbulos, um anterior menor e um posterior mais volumoso, do qual os nervos longitudinais saem. Sendo nos vermes jovens bem conspícuo, o cérebro cresce, mais tarde, relativamente pouco.

A bôca (Fig. 10, d) tem comprimento menor que a faringe (h). A última é provida de cílios internos fortes e mostra-se, externamente, granulosa, em conseqüência das numerosas glândulas, cujos citosomas são extrafaríngeos. Como em outros Turbelários, p. e., Dalyelliidae, Phaenocorinae, e Plagiostomum, cresce o tronco, na vida post-embrionária, mais que a cabeça. Em $\boldsymbol{M}$. gigas e $\boldsymbol{M}$. delphax, os vermes jovens reconhecem-se, sem delongas, como pertencentes ao gênero Macrostomum, mas, em M. evelinae, diferem muito dos adultos. $\mathrm{O}$ mesmo fenômeno inexplicável foi notado em certas Monocelididae (Fig. 120, 123) da fauna acompanhadora de $M$. evelinae.

Sem esôfago, a faringe passa ao intestino (i), em cuja entrada pacotes de células glandulares de Minot ( $\mathbf{x}$ ) se destacam. Os contornos do intestino são lisos, sem divertículos; as células intestinais ciliadas são epitelialmente dispostas e providas de vacúolos basilares (Fig. 13).

Do emunctório observámos apenas : 1) o poro dorsal, num lado, situado à altura dos testículos, aproximadamente; e 2) o canal descendente rostral, pouco ondulado no seu percurso cefálico, e irregularmente meândrico ao nível do intestino anterior. $O$ poro excretor representa o orifício externo duma vesícula terminal do dito canal. Das outras espécies marinhas de Macrostomum, conhecem-se casos de ausência (M. hustedi Jones 1944, p. 350) e de presença (M. appendiculatum; M. beaufortense Ferguson 1937a, p. 232) dos protonefrídios.

Os testículos (t) apõem-se ao terço anterior do intestino, estreitando-o um tanto. São sáculos não lobados, de cuja extremidade caudal os dutos eferentes (e) saem. Não são ciliados. A vesícula seminal (v), de parede 
tênue, contem espérmios nos espécimes examinados. Situa-se caudalmente ao canal genital (a) e poro (w) femininos, ora no plano mediano, ora no lado esquerdo. A passagem entre a vesícula e o reservatório da secreção granulosa (k) é muito estreitada. As 'glândulas volumosas (n) da dita secreção desembocam no ápice do reservatório, que se torna longitudinalmente estriado pelas massas da secreção. Como células formadoras (Fig. 13, j) do tubo cuticular penial (p) consideramos: 1) as células externas do reservatório, e 2) as células internamente apostas à base do pênis. Sòmente as primeiras correspondem às descritas por Luther (1905, p. 32 t. 4 f. 2 , bck). Os dois grupos aqui reunidos têem aspecto igual e diferem das células eritrófilas do reservatório entumecidas pela secreção granulosa. Visto que conhecemos, de $\boldsymbol{M}$. delphax (Fig. 6, p), os tubos de secreção ("Sekretschläuche" Luther, l. c.), situados no lume da base do pênis, parece improvável que confundimos com eles as células cônicas internas do pênis. Sulcos na base dêste, que carecem de importância sistemáticł, correspondem às células matrizes externas do tubo cuticular, i. é, às células ectais (distais) do rèservatório. 0 epitélio do átrio masculino (q) é chato; a sua musculatura enroscada em espiral é muito forte; uma camada de músculos gira à direita; a outra, à esquerda. Com Reisinger (1933, p. 244), podemos considerar o átrio masculino de transformado em bainha do pênis.

$\mathrm{O}$ pênis (Fig. 12) tem de comprimento $0,12 \mathrm{~mm}$., e de diâmetro ental $0,022 \mathrm{~mm}$. Encurva-se de tal maneira que a concavidade se dirige para a direta. A ponta distal é truncada. O orifício situa-se na extremidade, e abre-se para o lado direito, sendo a estensão do poro maior que o diâmetro ectal ' 4 microns) do tubo. A 12 microns de distância da terminação do pênis, êste apresenta um processo, em forma de charrúa, dextro-ventral e de 12 microns, ao comprido. Entre as Macrostomidae tal esporão acessório ("Nebensporn" Graff 1913, p. 193) constitue novidade; conhece-se das Promesostomatinae Luther (1943, p. 85), sub-família das Proxenetidae Graff (1905, p. 83).

Os ovários (Fig. 10, o) não lobulados situam-se, nos dois lados, caudalmente aos testículos, aproximadamente no meio do corpo. Os ovidutos, visíveis devido aos ovócitos (y) em crescimento nêles contidos, reunem-se atrás do intestino, formando o oviduto comum (b). Este distingue-se, pela ausência de cílios, do átrio feminino (u), do qual é separado por um esfincter. No oviduto comum, nota-se uma corôa de células altas, correspondentes ao aparêlho de passagem, ("Durchgangsapparat") das espécies precedentemente descritas. Como se vê pela Figura 13, não impedem a entrada dos espérmios no trecho interno do oviduto comum, onde esperam o ovócito (y). O epitélio do oviduto comum mostra vacúolos, em que se encontram fragmentos de espérmios. Trata-se, muito provàvelmente, de resorpção do esperma nos vacúolos do oviduto, não de preservação, como nas células lameladas do átrio de M. gigas (Fig. 3) e nas do receptáculo seminal de Microdalyellia (Gieysztoria) evelinae (Fig. 30, m) e da bursa copulatória de Gyratrix hermaphroditus (Fig. 118, b).

Os cílios do átrio feminino (u) são especialmente compridos nas paredes caudal e ventral. Entre estas, sae o canal genital (a), de estensão inṿılgarmente grande. Exibe cílios, como a epiderme, mas, distingue-se 
desta pelo epitélio de núcleos aprofundados. 0 mesmo caracteriza ainda a circunferência do poro feminino (w). As glândulas argamassadoras (z) eritrófilas e refrativas desembocam nos trechos interno e médio do canal genital.

\section{Ocorrência de Macrostomum evelinae}

O material composto de aproximadamente 30 vermes adultos e 15 jovens foi isolado de ca. de meio litro de areia do mar colhida pela Snrta. Lic. D. Gabriella Zuccari, no litoral paulista, na práia de Guarujá, perto de Santos. A areia foi retirada da zona que mesmo durante a vasante continúa coberta por alguns centímetros de água do mar. Na fauna acompanhadora notaram-se: Kalyptorhynchia; Monocelididae; Macro. dasys-spec.; e Saccocirrus-spec.

\section{Discussão sistemática de Macrostomum evelinae}

O processo acessório do pênis distingue a espécie seguramente das outras do gênero. Das peculiaridades histológicas mencionadas na diagnose não se pode julgar o valor taxonômico, porque, a despeito das muitas espécies descritas, poucas foram analjsadas histològicamente. Nem mesmo sabemos, se a ausência dos olhos, na espécie atual assegurada pelos cortes, não se restringe, nas outras espécies "cegas", à falta do pigmento na célula caliciforme. Ao dizer "os olhos podem aparecer e desaparecer no mesmo indivíduo", Ferguson (1940a, p. 144) pensou, certamente, no pigmento aludido, não na célula do cálice ou na visual ("clava da retina"). Parece, destarte, pouco significativa a enumeração seguinte das especies de Macrostomum "sem olhos". São 2 dágua doce: $M$. thermophilum Riedel (1932, p. 54, 79, 86); e curvistylum Ferguson (1939b, p. 190); três (inclusive evelinae, 4) do mar: lineare Uljanin (1870; veja Graff 1913, p. 54); ophiocephalum Steinböck (1931a, p. 9); e boreale Riedel (1932, p. 81). Em $M$. evelinae, que vive dentro da areia, condiz a falta de olhos com o habitat; não verificámos desenvolvimento compensatório de outros órgãos sensoriais.

\section{Ordo: Rhabdocoela Graff}

Depois da separação dos Catenulida (Notandropora) e Macrostomida (Opisthandropora), têrmos acima discutidos (veja p. 7), permanecem, como representantes dos Rhabdocoela, apenas os Lecithophora Graff 1905 (p. 69, 72). Diferem pela faringe bulbosa e pelas gônadas femininas desenvolvidas como germovitelários ou como germários e vitelários, e produtoras de ovos ectolécitos, dos Catenulida e Macrostomida. Os Lecithophora foram, por Meixner (1924, p. 19), chamados de Bulbosa, e, mais tarde (1938, p. 9, 142), de Neorhabdocoela. A primeira mudança foi introduzida com o propósito de fazer desaparecer os nomes Hysterophora e Lecithophora, tidos por insignificativos; a segunda, ao que parece, porque a Seç̧ão foi elevada ao gráu sistemático de Ordem. Preferimos conservar o nome tradicional, num sentido certamente restricto, como tal acontece, tantas vêzes, com designações genéricas.

As três secções da sub-ordem Lecithophora (Rhabdocoela da nossa terminologia) do sistema de Bresslau (1933, p. 261) foram mantidas, como sub-ordens, por Meixner (1938, p. 9-10); são os: 1) Dalyellioida; 2) Typhloplanoida; 3) Kalyptorhynchia.

\section{Subordo: Dalyellioida Bresslau}

A primeira familia é a das Provorticidae (diagnose: Bresslau 1933, p. 265-266), introduzidas, como sub-família das Graffillidae, por Meixner (1926, p. 595). Beklemischev (1927, p. 130) considerou-as, pela primeira vez, como família, tendo tal escapado a Reisinger (1929, p. 69-70). 
Os gêneros das Provorticidae podemos agrupar na chave seguinte:

1 Germário ou germovitelário impar $\ldots \ldots \ldots \ldots \ldots$

2 - Germários ou germovitelários pares ....... . . . . . . . . . . é flanqueado por dois acúleos curvos.... Kirgisella Beklemischev (1927, p. 113)

- O germário e o vitelário formam um germovitelário; o pênis é um túbulo em forma de S... . . Archivortex Reisinger (1924, p. 3)

3 Vitelário impar; germários pares. Pilgramilla Sekera (1911, p. 12 ; 1925a, p. 9 e seg.)

- Vitelários ou germovitelários pares $\ldots \ldots \ldots \ldots \ldots$

4 Testículos situados na metade rostral do corpo, ao nível da zona entre a faringe e o intestino anterior $\ldots \ldots \ldots \ldots \ldots$

5 Testículos situados na metade caudal do corpo ................ Os germários e os vitelários são

- Os germários e os vitelários formam germovitelários ... . ....

6 Utero e bursa copulatória ausentes ou incluidos no ductus communis.... Vejdovskya Graff (1905, p. 73, 103)

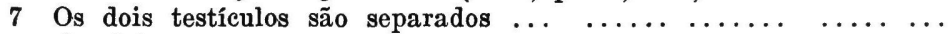

- Os dois testículos são concrescidos, formando uma ferradura. Baicalellia Nassonov (1930, p. 727)

8 Os germovitelários compõem-se de dois tubos ovígeros dirigidos para trás, e de dois vitelógenos dirigidos para diante, sendo os últimos providos de divertículos digitiformes. .. Haplovortex Reisinger (1924c, p. 232)

- Os germários e os vitelários dirigem-se para diante, sendo os últimos de paredes lisas ou fracamente gibosas... Oekiocolax Reisinger (1929, p. 64)

\section{Notas sistemáticas e zoogeográficas sôbre o gênero Baicalellia Nassonov}

Ao deserever as 7 espécies do gênero Baicalellia, incluiu Nassonov (1930, p. 737) neste, com razão, Provortex brevitubus Luther (1918, p. 51; 1921, p. 38). O texto de Bresslau (1933, p. 266: "Baicalellia Nassonov 1930 Figur 101") atualizou a legenda da figura 101, publicada em 1928. Não é certo, porém, chamar $P$. brevitubus de "Haplovortex", como Steinböck (1932a, p. 305) o fez. Meixner, é verdade, evita tal erro, mas, infelizmente, escreve "Baicaliella" (1938, p. 116) e Baikaliella" (p. 118).

A distribuição do gênero Baicalellia, que se apresenta como unidade taxonômica natural, seria, no estado atual das nosas noções, a seguinte:

1) Lago Baical, do litoral superior até a profundidade de $60 \mathrm{~m}$. (Nassonov 1930 , p. 735 , última linha; ibid., p. 729 : até $30 \mathrm{~m}$.).

2) Perto de Posiet, na fronteira russo-coreâna, num lago salobro (salinidade de 5,54 18,97 por mil), ligado, pelo rio Gladkaja, com a baía de Pedro o Grande do mar japonês.

3) Godthaab, na costa sudoeste da Groenlândia, na zona das marés do mar.

4) Golfo finlandès, do mar Báltico, nágua rasa, entre plantas, perto da estação Tvaerminne, salinidade de ca. de 5 por mil.

5) Brasil, nos arredores da cidade de São Paulo, no rio Tietê e numa lagôa (lagôa da Corôa, no bairro de Canindé) ligada ao dito rio. Botucatú, no Interior iu Estado de São Paulo, fazenda Barros (Vila dos Lavradores), no córrego limpo duma nascente. Umuarama, Campos de Jordão (Estado de São Paulo), 1750 m.

A biologia da espécie brasileira e a sua resistência, adiante descritas, como tam-

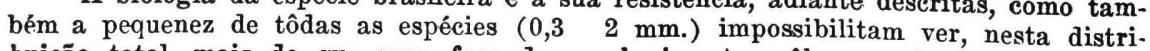
buição total, mais do que uma fase dos conhecimentos sôbre o gênero. Nassonov (1932, p. 94) interpretou o quadro zoogeográfico oferecido por Baicalellia como indice da origem marítima da fauna baicálica. Tal precisa, ao nosso ver, de rápido
comentário. A antiguidade do lago Baical, que data do Miocêno, reflete-se na sua fauna, principalmente de carater terciário-sibérico e riquíssima em endemismos 
(Marcus 1933, p. 124). A semelhança dos animais do Baical aos do mar deve-se:

a) à origem marítima de todos os animais límnicos, sendo os vestígios de tal ascendência especialmente nítidos em tipos antigos;

b) à convergência ecológica: grande profundidade (mais de $1.500 \mathrm{~m}$. ), temperatura baixa, e escassez de cálcio perfazem, no abissal do lago, um meio semelhante ao do abissal do mar;

c) à transgressão glaciária do mar polar, na bacia do rio Wiljui, que se estendeu até Lat. $62^{\circ} \mathrm{N}$. Dai possibilitaram os rios Angara, Lena e Witim a imigração, para - Baical, de vários Invertebrados marinhos; das Comephoridae; e de Phoca hispida Schreber (sub-genus Pusa ou, até, Baicalopusa) que costumadamente entra nágua doce (Mareus 1933, p. 120-121).

A organização da chave dicotômica das espécies de Baicalellia tornou-se difícil pela ausência de diagnoses claramente discernentes. As espécies são, ao que parece, todas válidas, porém, uma, B. posieti, foi deserita em 26 páginas com 2 estampas dobradas; outras, como B. albicauda, B. pellucida, B. maculata, e B. ocellata, em meia página e com figuras devéras primitivas ou até sem estas.

\section{Chave para a classificação das espécies e variedades de Baicalellia}

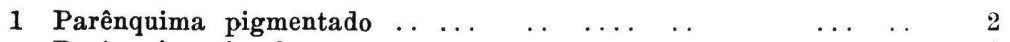

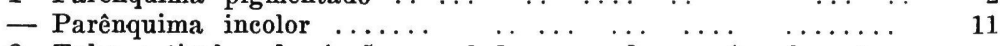

2 Tubo cuticular do órgão copulador curvado em ângulo reto. albicauda Nassonov 1930 (p. 731)

- Tubo cuticular do órgão copulador ligeiramente encurvado ou reto

3 Extremidade externa (ectal, distal) do pênis provida de apêndice cuticülar, em forma de placa pectinosa (Nassonov 1932, p. 90).. posicti Nassonov 1930 (p. 736).

- Placa pectinosa na extremidade ectal do tubo penial ausente, podendo, porém, ocorrer saliência gancheada .. ... ... ....

4 Orif́cío ectal do pênis, num lado, com saliêneia ganeheada, encur:

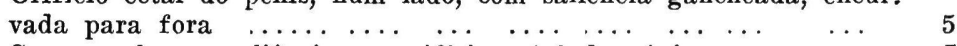

- Sem gancho ou saliência no orifício ectal do pênis .. ... 7

5 Corpo dilatado no fim do primeiro e do segundo terȩo.. maculata Nassonov 1930 (p. 734)

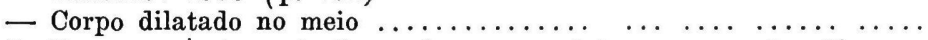

6 Dorso com pigmentação azul... maculata var. coerulea Nassonov 1930 (p. 734)

/ - Dorso com pigmentação preta.... maculata var. nigra Nassonov 1930 (p. 735)

7 Bainha do pênis e átrio inferior em comunicação direta .....

- Bainha do pênis e átrio inferior ligados por um canal comprido.. ocellata Nassonov 1930 (p. 735)

8 O órgão copulador é um tubo curto, entalmente mais largo, não encurvado.... nigrofasciata Nassonov 1930 (p. 732)

- O órgão copulador é entalmente dilatado, ectalmente encurvado,

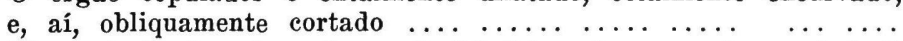

9 Pigmentação dorsal em forma de 2-3 faixas transversais... baical: var. fasciata Nassonov 1930 (p. 730)

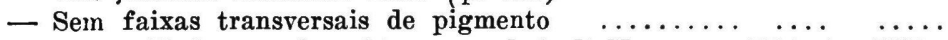

10 Extremidade anterior obtusa... baicali Nassonov 1930 (p. 729)

- Extremidade anterior com uma saliência no meio... baicali var. bicornis Nassonov 1930 (p. 731)

11 Bordo anterior da faringe provido de tentáculos.. evelinae, spec. nov.

- Bordo anterior da faringe liso, sem tentáculos ...........

12 Orgão copulador com duas curvas, uma côncava e outra convexa (forma de $S$, Luther 1921 , f. 29 no texto, p. 49)... brevitubus Luther 1918 (p. 51)

- Orgão copulador reto; no bordo externo provido duma lamela semicircular... pellucida Nassonov 1930 (p. 733) 
Ruebush \& Hayes (1939, p. 150, nota 6) acrescentam ao gênero Baicalellia ainda Dalyellia opaca Sibiriakova (1929, p. 240 , f. 5) do rio Angara (Irkutsk). O verme com dois germovitelários, testículos anteriormente concrescidos e gonóporo na extremidade caudal, não pertence, é verdade, ao gênero Dalyellia, nem às Dalyelliidae. A própria autora pondera sôbre a incorporação da sua espécie nas Graffillidae (no sentido de Graff 1913 , p. 69), mas, prefere inclúíla no gênero Dalyellia, por causa do aparelho cuticular do órgão copulador masculino semelhante ao de Dalyellia blodgetti (Silliman 1884, p. 67), hoje Microdalyellia (Gieysztoria) blodgetti. Se D. opaca fosse considerada como Baicalellia, a sistematização encontraria dificuldade quantu aos 2 reeeptáculos seminais, um em cada germoviteloduto, e à ausência do “órgãofagocitário" de Nassonov, a bursa seminal da terminologia aqui adotada. A bursa copulatrix de $D$. opaca distalmente estreita, proximalmente dilatada corresponde, talvez, à bursa copulatória de Baicalellia que é o átrio superior e funciona como utero. A estensão dos testículos de $D$. opaca até a faringe forma contraste de menor importância com as espécies de Baicalellia. O aparêlho cuticular do pênis, composto de 8 placas unidas num tubo estriado longitudinalmente, e provido de 8 espinhos distais (ectais), serviria para separar Baicalellia (\&)opaca (Sibiriakova) das outras formas pigmentadas do gênero.

\section{Baicalellia evelinae, spec. nov. (Fig.14-22)}

Os vermes recém-saidos dos ovos medem $0,2 \mathrm{~mm}$. de comprimento. Os adultos atingem $0,8 \quad 1 \mathrm{~mm}$., quando são distendidos pelos seus ovos. A largura é de $0,2 \quad 0,4 \mathrm{~mm}$., conforme a contração variável. A forma do corpo aproxima-se à dum fuso, sendo, porém, a extremidade anterior mais obtusa; a posterior, cuspidata. A largura máxima é situada, em vermes jovens, um pouco antes e, em adultos, um pouco atrás do meio.

A côr é branca, quanto ao intestino e o vitelo dos germovitelários, à luz refletida. Os órgãos restantes são transparentes, incolores, sendo também o parênquima sem pigmento. Sobrepostos à região anterior da faringe notam-se os dois olhos pequenos $(0,011 \quad 0,015 \mathrm{~mm}$.), eujos cálices pretos contêem grânulos de melanina, muitas vêzes, em número contável (15-20). Cada ôlho possue uma célula visual, a chamada clava da retina, cuja zona periférica se evidencia, no corte (Fig. 22, a), não no verme vivente, transformada. Apesar de não se reconhecer lente refrativa nós animais vivos, os espaços claros, visíveis no corte indicado, devem ser considerados como citoplasma especial da célula óptica.

A espessura da epiderme é de ca. de $0,006 \mathrm{~mm}$.; os limites intercelulares são, em geral, indistintos; os núcleos, não aprofundados. A longura dos cílios locomotores ultrapassa um pouco o diâmetro da epiderme. Além disso, ocorrem cílios maiores, até $0,03 \mathrm{~mm}$. ao comprido, provavelmentesensoriais, mais freqüientes na cabeça e na cauda do que no corpo restante. Nos rermes viventes, reconhecem-se os rabditos sòmente quando são expeliclos pois, então, constituem o envólucro do animal; nos cortes, apresentam-se refrativos, acidófilos e, destarte, coráveis com eosina. A sua ocorrência em tôda a parte do corpo concorda com as indicações relativas a B. posicti (Nassonov 1932, p. 70); em B. brevitubus, escasseiam ou faltam inclusões epidérmicas na cabeça (Luther 1921, p. 40). Nas duas espécies exóticas, trata-se de rabdóides basófilos, tingíveis com hematoxilina; em $B$. cvelinae, são rabditos verdadeiros.

O tubo músculo-dermático compõe-se de fibras anelares externas e de. longitudinais, internas, sem peculiaridades (Fig. 21). O parênquima do. corpo é parcamente desenvolvido. 
O cérebro (Fig. 14, a) é maior e mais complicado que nas outras Provorticidae, das quais é conhecido. Distinguem-se dois gânglios anteriores, a comissura central, que é grossa e dois gânglios posteriores. Aos gânglios anteriores apõem-se os olhos e, para diante, continuam os gânglios com os tractos sensoriais que suprem a extremidade rostral do animal. Da comissura e dos gânglios posteriorès saem, no total, quatro pares de nervos. Entre as raizes dêstes, as únicas partes vistas por nós, não se notam 'diversidades de grossura.

$\Lambda$ bôca tem posição sub-terminal (Fig. 20, m). O comprimento da faringe (h) varia muito, pois corresponde, em vermes jovens, a um quarto, ou mesmo à metade da longura do corpo; em adultos, a um sexto ou um sétimo desta. $\mathrm{O}$ comprimento máximo absoluto das faringes medidas, a saber, 0,2 mm., foi, inesperadamente, encontrado em indivíduos ainda não completamente crescidos (até $0,5 \mathrm{~mm}$.). Os vermes maiores possuiram, no hosso material, faringes de $0,15 \mathrm{~mm}$. e, só excepcionalmente, de $0,18 \mathrm{~mm}$. 0 bordo faríngeo anterior preensor ("Greifrand") tem ca. de 22 tentáculos (Fig. 20, 22, e) cada um com $0,03 \mathrm{~mm}$. ao comprido, no animal vivo. O tentáculo é um cône citoplasmático, em cujo centro há um outro cône, êste contráctil, eosinófilo, evidentemente mioplasmático. Os núcleos pertencentes aos tentáculos não se dispõem como na figura correspondente de B. posieti (Nassonov 1932, t. 7 f. 4), havendo, nêste pormenor, também diferença entre $P$. posieti e as espécies baicálicas. Em $\boldsymbol{B}$. evelinae, pertencem os tentáculos, quanto ao seu manto citoplasmático, ao epitélio pobre em núcleos e sem limites intercelulares, que reveste a faringe; a musculatura faríngea fornece o cône contráctil, no interior do tentáculo.

O parênquima da farínge é representado, quasi exclusivamente, por três pacotes de músculos radialmente dispostos ao redor do lume triangular (Fig. 22). A base do triângulo corresponde ao lado dorsal da faringe, havendo a mesma topografia em Haplovortex bryophiths (Reisinger 1924c, p. 290). Dos ditos pacotes, cada um contem 10-12 fibras, no corte transversal, cabendo, a cada ângulo, mais duas fibras adjacentes e quasi unidas. A musculatura interna circular da faringe compõe-se de ca. de 24 fibras que se sucedem de diante para trás (Fig. 20, h). Eventuais músculos internos longitudinais, possivelmente responsáveis pela disposição aos quadradinhos dos músculos radiais, evidenciada em cortes tangenciais da faringe, não se mostram nos cortes sagitais e transversais; em $\boldsymbol{B}$. posieti, faltam (Nassonov 1932, p. 78).

Glândulas faríngeas internas não ocorrem. Grandes glândulas cianófilas orais desembocam no ponto em que a reintrância bucal da epiderme passa à bolsa faríngea (Fig. 20, g). Estas glândulas circundam a faringe lateral e ventro-lateralmente; uma situa-se, com regularidade, dorsalmente à faringe, no meio entre os gânglios posteriores cerebrais (Fig. 20, 22, g).

Como esôfago poderia ser designado o curto trecho de células epiteliais relativamente altas (Fig. 20) entre a faringe e o intestino. As células glandulares na entrada do intestino (k) são chamadas por Luther (1921 p. 43) e Nassonov (1932, p. 79) de "clavas granulosas de Minot" Tão pouco quão em $B$. posieti, mostram, em $B$. evelinae, a afinidade à eosina, característica das células claviformes. Por isso, preferimos falar em "glân. dulas da entrada intestinal" O próprio intestino tem forma de saco e 
deixa, nos vermes jovens e meio-adultos, lugar para os órgãos reprodutivos volumosos. Quando, porém, os casulos passam do átrio ao intestino, é êste. dilatado e preenche tôda a metade caudal do verme (Fig. 17) Na cavidade intestinal, encontrámos Ciliata p. e., dos gêneros Paramaecium " Sty!onychia, como também Diatomáceas. Em fases digestivas iniciais, é o lume do intestino circundado por epitélio distinto. Ao progredir a resorpção, entumescem as células intestinais e ocupam a luz totalmente. Os limites entre as células desaparecem, e a prêsa situa-se no meio do sincício digestivo. Digestão intracelular, em vacúolos das células intestinais e no sincício formado pelo conjunto dessas células, foi descrita de $\boldsymbol{B}$. brevitubus (Luther 1921, p. 43) e de B. posieti (Nassonov 1932, p. 79), respectivamente.

Tanto nos vermes viventes quanto nos cortes, ocorrem, várias vêzes, algumas Zoochlorellae no epitélio do intestino. Talvez sirvam como fornecedoras de oxigênio, durante os longos períodos em que $\boldsymbol{B}$. evelinae vive enristadamente. Também Haplovortex bryophilus que se encista (Reisinger 1923, p. 59) possue Zoochlorellae (id. 1924c, p. 232, 234), aliás muito mais numerosas e regulares que na espécie actual.

$O$ emunctório termina com dois poros (Fig. 18, q) situados ventrolateralmente e aproximadamente ao nível do meio do intestino, mas, com variação considerável para diante e para trás. Varíam também as alças dos camais principais. Em geral, começa o canal ascendente, em cada lado, à altura do limite entre vitelário e germário e corre, daí, para diante. Ao nível do intestino anterior recebe outro canal, êste surgido pela reunião de dois canais vindos do ventre. Ao nível do bordo anterior da faringe, dobra o canal ascendente para trás. O canal descendente corre dorso-lateralmente até o meio do corpo, aproximadamente, onde desce, com algumas grandes alças, para o poro excretor.

O sistema reprodutivo abre-se com o poro genital (Fig. 20, p) situado ventralmente, não longe da extremidade caudal. Os órgãos masculinos são completamente ventrais, sub-intestinais (Fig. 15, 20). Começam com os testículos, em forma de ferradura, que pertencem, aproximadamente, ao plano tranversal que passa pelo meio do intestino. Os dois sacos testiculares laterais são mais grossos que a ligação rostral. Revelam-se, destarte, os testículos como órgãos, por princípio, pares, e secundariamente concrescidos. Os dois dutos eferentes são continuacõos tubulosas da túnica dos testículos e, vindos dos dois lados, reunem-se no meio. Do ponto da união dos dutos eferentes estende-se, para diante, a vesícula seminal esférica (s) ; para trás, o reservatório da secreção granulosa (x). Esta é um tubo grosso entalmente envolvido por músculos circulares, como ocorrem também em B. brevitubus (Luther 1921, p. 47) e nas espécies descritas por Nassonov $(1930$, f. 1, 2, 4, 7). Os músculos são atravessados pelas glândulas da secreção granulosa (Fig. 20, z) salientadas para fora do reservatório. Glândulas menores (y) abrem-se para dentro da bainha do pênis (c), esta, uma dilatação tubulosa do átrio. Dentro da bainha, situa-se o pênis, que ré um tubo de paredes cuticularizadas e estreitado de dentro para fora.

A diferença, aparentemente considerável, entre os três órgãos copuladores da Fig. 19, não é, na realidade, tão grande, pois o órgão, no plano do desenho encurvado em forma de C simples, revela-se, quando observado 
com uso do parafuso micrométrico, duplamente encurvado, em forma de S. A pressão diferente da lamínula pode provocar aparência diversa dos órgãos copuladores. O comprimento máximo do pênis é de $0,045 \quad 0,05$ mm.; o diâmetro ental, de ca. de $0,015 \mathrm{~mm}$; o diâmetro ectal, de ca. de $0,004 \mathrm{~mm}$.

As gônadas femininas são ovovitelários pares, cuja zona vitelógena se estende até a faringe. Ca. de 12-14 lóbulos ocorrem em cada lado de cada vitelário. Os ovários formam a parte caudal da gônada, tocando-se o ovócito mais crescido, por via de regra, um único em cada ovário, com o vitelário. A parte estreita do ovário, que contem os ovócitos mais jovens, pode estender-se para trás, como tal se vê no esquema geral da organização (Fig. 14), mas, pode também ser virada para o lado ventral ou para diante (Fig. 15). No último caso, surge a disposição normalmente presente em Oekiocolax plagiostomorum Reisinger (1929, f. 10) em que, aliás, há germários e vitelários separados.

Para entender os órgãos atriais, convem começar com o poro genital (Fig. 20, p). Funciona, na espécie atual, sòmente para a saida do pênis e a imissão no parceiro. Para dentro do poro, estendesse o átrio espaçoso. Nêste, podemos com Luther (1921, p. 50-51) e Nassonov (1930, legenda da f. 1) distinguir o átrio inferior (Fig. 20, r) e o superior, funcionando o último como útero $(\mathrm{u})$. Evidentemente, corresponde o útero ao órgão que Nassonov (p. e. 1932, p. 81) chamou de "bursa copulatrix" Nos dois lados, comunica-se o útero com os ovovitelários; a ligação ampla e curta poderia ser chamada de ovoviteloduto (Fig. 20, d).

Entre os ovários, situa-se a bursa seminalis da terminologia de Luther (1921, p. 48) e Meixner (1938, f. 69 C, bs) ; o receptaculum seminis ou órgão fagocitário de Nassonov (1930, p. 728). Em conformidade com as exposições de Bresslau (1933, p. 129), usamos a designação (Fig. 20, b) de Luther e Meixner. Glândulas especiais, parede grossa, e um tufo de espérmios em movimento ondulante, presente já em vermes jovens com o corpo de $0,36 \mathrm{~mm}$. de comprimento, caracterizam a bursa seminalis de B. evelinae. Os espérmios implantam-se na parede da bursa como nas células do "aparelho de passagem do ovócito" de Macrostomum gigas (veja p. 12) e M. thermale. A função da bursa nas espécies de Baicalellia é dupla : como receptáculo, abriga os espérmios que aqui aguardam o ovócito; como órgão fagocitário, utiliza o excesso dos gonócitos masculinos (Nassonov 1932, p. 83-86). Em Pseudograffilla arenicola. Meixner (1938, f. 69), concresce a bursa com o intestino, que, provavelmente, absorve os espérmios supérfluos. Segundo o sistema aqui adotado, pertence a dita espécie com o gonóporo na metade anterior do corpo (Meixner 1938, f. 9 C) às Graffillidae, família vizinha às Provorticidae.

Em Baicalellia evelinae, comunica-se o átrio superior (útero) com o intestino. Até 6 casulos, cada um com dois ovos, dilatam o útero enormemente, estirando a sua parede, que se torna muito fina. $O$ sincício vacuolizado do intestino adjacente ceede à pressão da casca do casulo, incorporando o casulo.

O comprimento dos casulos varía de 0,15 a $0,22 \mathrm{~mm}$. ; o diâmetro, de 0,1 a $0,14 \mathrm{~mm}$. Longura de 0,2 $\mathrm{mm}$. e grossura de 0,14 $\mathrm{mm}$. são medidas freqüientes. Quasi sempre (excepção, nas notas biológicas), fornece cada 
ovário, simultaneamente, um ovo para o casulo, cuja casca é produzida pelas células vitelinas. Os dois ovos são claros e os embriões continuam assim ; a casca é vítrea e de côr amarelada ou acastanhada.

Foi observada a eclosão dos filhotes no intestino materno. Igualmente foram vistos casulos livres nágua. Dêstes fatos deduzimos que ocorre viviparidade e oviparidade, ambas por via oral. Nunca vimos, em vermes com casulos no átrio, perto do poro genital, saida dos casulos pelo gonópcro. Acontece que indivíduos com casulos no intestino e no útero morrem. Nêstes casos, sobrevivem os embriões nas cascas e tornam-se livres pela desintegração do corpo do animal adulto.

Vermes jovens e adultos de Baicalellia evelinae nadam e deslizam sôbre o substrato; durante muito tempo, permanecem quietamente nos seus cistos.

\section{Observações biológicas sôbre Baicaleḷlia evelinae}

Num material de 200 espécimes de tôdas as idades, sòmente 5-6 exemplares foram encontrados com órgãos masculinos. Evidentemente, existem vermes que nunca desenvolvem testículos. De Graffilla parasitica, pertencente à familia vizinha das Graffillidae, ignoram-se os órgãos masculinos (Wahl 1910, p. 46); e proterandria combinada com órgãos masculinos transitórios ocorre em várias Graffillidae (Graff 1913, p. 79, 80; Reisinger 1929, p. 55) e Provorticidae. Haplovortex bryophilus Reisinger (1924c, p. 234, 290) possue o aparelho masculino insignificante e passageiro; Oekiocolax plagiostomorum (id. 1929, p. 66) tem os pequenos testículos bem desenvolvidos sòmente no exemplar mais jovem dos dois da diagnose original. Todavia, não constitue a involuȩão dos órgãos masculinos peculiaridade das ditas famílias: mostram-na também certos Kalyptorhynchia (Meixner 1925, p. 322 e seg.).

Partenogênese não se dá em Baicalellia evelinae, como se vê pelos espérmios sempre presentes na bursa seminalis de vermes de tamanho médio e adiantado. Nos poucos exemplares com órgãos masculinos vimos espérmios muito mais abundantes que nos outros, provavelmente, pelo menos em parte, só femininos. Tal achado leva a supor que haja autogamia, ao lado da fecundação de vermes em fase feminina por tais em fase masculina. Autogamia foi relatada, entre as Provorticidae, duma espécie (Sekera 1906, p. 149), mais tarde (id. 1911, p. 9-13) descrita como Pilgramilla spliagnorum.

Pela figura (Sekera 1911, t. 1 f. 12), menos pelo texto (l. c., p. 12; id. 1925a, p. 11-12), parece provável que os casulos de Pilgramilla entrem no intestino. Tal processo foi verificado em Bresslauilla relicta (Reisinger 1929, p. 58) e Ethmorhynchus anophthalmus (Meixner 1938, p. 70).

Na diagnose do gênero Baicalellia, notou Nassonov (1930, p. 729) que 2 ou 3 ovócitos juxtapostos podem tocar-se com o vitelário. Tal parece, em B. evelinae, fenômeno raro; todavia, observámos um indivíduo com 4 ovos ou embriões em cada um dos seus casulos. O ovário de cada lado revelou-se, nêste verme, longitudinalmente bipartido. A multiplicação da espécie atual, por meio de casulos bi-ovulares, já se mostra bastante intensa. O desenvolvimento do embrião dura ca. de 8-10 dias, na temperatura dágua de ca. 
de $18^{\circ} \mathrm{C}$. Dois dias depois da eclosão, exibem os vermes jovens as gônadas femininas, cujos vitelários se estendem até a faringe. Cinco dias depois da eclosão, continha a bursa seminalis do verme jovem um tufo de espérmios. Um indivíduo foi isolado e produziu, no decorrer de 11 dias, 14 filhotes. Depois dêste período, restaram ainda espermatozóides viventes na bursa seminalis do dito verme.

As localidades dos arredores de São Paulo e do interior do Estado, em que Baicalellia evelinae foi encontrada, figuram, sob 5), na resenha da distribuição total do gênero (veja p. 22). Um biotopo preferido da espécie é o muco coerente, amarelo ou acastanhado que é formado, entre plantas aquáticas, por Rotatoria e vários Protozoa, p. e., Flagellata dos gêneros Anthophysa e Rhipidodendron e Ciliata Heterotricha, principalmente, do gênero Metopus, mas também de Stentor. Nesta biocenose abundam Amebas nuas, Difflugia elegans Penard, e espécies de Lacrymaria; ocorrem ainda, em número menor, Rotatoria do gênero Metopidia e Cladocera. Nêste muco, encontra-se $B$. evelinae, freqüentemente, no seu cisto, parecendo-se com o desenho dado por Sekera (1911, t. 1 f. 14) de Pilgramilla sphagnorum. O cisto de Baicalellia evelinae é produzido pelos rabditos, dando-se, provavelmente, o mesmo com $P$ sphagnorum. Segundo Sekera (1. c.: p. 10), é verdade, soltar-se-ia, em P. sphagnorum, o epitélio (quer dizer, a epiderme) inteiro, mas, tal é deveras inverosímil. O encistamento de $P$. sphagnorum, de Haplovortex bryophilus Reisinger (1923, p. 59), Bresslanilla relicta Reisinger (1929, p. 51), e Baicalellia posieti Nassonov (1932, p. 94) acontece, quando a água diminue ou se deteriora. Baicalellia evelinae, porém, encista-se, quando repimpada, e digere, den. tro do seu envólucro, sem ser atingida por estímulos externos. Cistos dêste tipo conhecem-se de vários Rhabdocoela terricolas (Reisinger 1923, p. 25) e Tricladida Maricola (Wilhelmi 1909a, p. 726; Meixner 1938; p. 133). O material do cisto de $B$. evelinae é pegajoso, de modo que partículas de detrito aderem à superfície da gelatina. A pressão da lamínula ou golpes de correnteza provocados com a pipeta levam o verme a sair do seu cisto. Na placa de Boveri, nadam os vermes, de preferência, no bordo superior ou rente do fundo.

\section{Sôbre a comunicação gênito-intestinal de Baicalellia evelinae}

Da rica literatura relativa às ligações entre os sistemas reprodutivo e digestivo eitamos apenas: Bendl (1909); Bock (1927); Bresslau (1933, p. 130, 141, 148); Cernosvitov (1932,' p. 162); Cognetti de Martiis (1915, p. 231); Gilbert (1935, p. 302) ; Kepner, Stirewalt \& Ferguson (1939); Meixner (1928, p. 583; 1938, p. 65-68); Oparina-Charitonova (1927); Reisinger (1926, p. 441; 1929, p. 49, 61 e seg.); e Steinböck (1924; 1924b, p. $165 ; 1927$, p. $619-620 ; 1931$, p. 10$)$.

$\mathrm{Na}$ sua tentativa de sistematizar as várias comunicações gênito-intestinais, chamou Steinböck (1924, p. 473-474) de "duto gênito-intestinal" as ligações simples entre os aparelhos em questão. "Se, porém, houver bursa intestinalis. ., proponho, para o duto que vai do ponto da sua união com os ovidutos até a sua desembocadura na bursa, o nome de duto gênito-bursal..., para um duto entre a bursa e o intestino, o de duto bursa-intestinal".

A bursa seminalis que Steinböck encontrou no gênero Coelogynopora foi chamada por êle de "bursa intestinal" (1. c., p. 471), como está corretamente referido por Bresslau (1933, p. 131). Subentende-se, quando se fala duma "bursa intestinal", que. esta deriva, filogenèticamente, do intestino. 
A hipótese de Steinböck baseia-se na histologia e na ontogenia da bursa 1uß três espécies: Coelogynopora biarmata (1);C. bresslaui (2); e C. gynocotyla (3). O exame destas bursas revela que nenhuma reune os dois caracteres, ao nosso ver, valiosos como apoios da dita hipótese, a saber: a) passagem sucessiva dos sinais histológicos intestinais aos bursais (presente em 1 e 3) ; b) comunicação dos lumes intestinal e bursal (presente em 2). Em Monocelis lineata (Müll.) e $\boldsymbol{M}$. fusca Oerst., da mesma familia, porém, de outra sub-família que Coclogynopora, observou Oparina-Charitonova (l. e.) disposições semelhantes às de C. biarmata. Meixner descobriu espécies de Coclogynopora sem comunicação bursa-intestinal $(1938$, f. 58, 59). Quanto à ontogenia, verificu u Steinböck (p. 466-467), em C. biarmata, modificaçōes estruturais do epitélio intestinal na fase da formação do átrio, quando o primórdio erescido do aparelho genital se toca com o intestino. O mesmo foi visto em Monocelis fusca pela autora russa citada. Antes de se tornar pérvio o gonóporo, estabelece-se, em C. biarmata, a comunicação entre a cavidade da bursa e o canal genital feminino. Nisso, vê Steinböck mais uma prova de ser a ligação gênito-intestinal hơmóloga a um oviduto primitivo. Não, porém, descreve o processo com que se estabelece a dita comunicação. A julgar pelo que se conhece dos Tricladida, excava-se apenas uma proliferação sólida do átrio e articula-se, de fora para dentro, em canal da bursa e vesícula terminal. A última encrava-se na. parede intestinal à qual se iguala histologicamente; os lumes bursal e intestinal não se comunicam, em C. biarmata (Steinböck 1924, f. 5, 6). A concordância histológica levou Steinböek a considerar a bursa como parte do intestino. Por isso, interpreta o processo aqui presumido como sendo epitelialização do primórdio da bursa como estabelecimento da comunicação gênito-intestinal precedente à formação do gonópors.

Deixamos aos leitores decidirem se julgam provada a origem filogenética intestinal, da bursa de Monocelis e Coelogynopora e, admitida tal origem, aceitável a opinião que rê, em tôdas as comunicações gênito-intestinais dos Turbellaria Coelata, as vias eferentes femininas primordiais como sendo homólogas às dos Acoela.

A nossa opinião, geralmente contrária, no que diz respeito à bursa, baseia-se numa resenha geral dêste órgão. Raros são os casos de "canais (ou dutos) bursa intestinais" conhecidos, principalmente do gênero Phaenocora. No total, são orifícios largos ou poros bursa-intestinais mais freqüentes. O têrmo "duto gênito-bursal", em que se subentende a exclusão da bursa do aparelho genital, usamos apenas no gênero Phaenocora, c isso exclusivamente para não complicar, nèste gênero complicadíssimo, o confronto morfológico com os trabalhos de Gilbert $(1935 ; 1937$; 1938; 1938a) e Ruebush (1939). Geralmente, preferimos os têrmos conhecidos dos Tricladida, a saher, "canal da bursa" (canal de la bourse; bursa stalk; Bursastiel) e "vesícula terminal ou empôla diı bursa" (Endblase; bursa; bourse copulatrice). Já se conhecem três funções da bursa: 1) ela recebe os espérmios no ato da copulação, agindo como bursa copulatrix, de onde os espermatozóides migram, mais tarde, ao receptáculo seminal; 2) ela guarda, em espécies sem receptáculo, os espérmios recebidos na copulação; nêstes casos, é chamada de bursa seminalis; 3) cla absorve o excesso em espérmios, células vitelinas, e secreção granulosa. Esta função, muito freqüentements executada ao lado das anteriormente mencionadas, levou a uma dencminação especial, de vesicula resorbiens, sòmente nos Temnocephala (Bresslau \& Reisinger 1933, p. 305-306). Quando se forma uma comunicação bursa-intestinal, involue, freqüentemente, a resícula terminal da bursa, pois o intestino digere o excesso da produção dos órgãos reprodutivos.

Depois de ter Steinböck acrescentado às bursas copulatória, seminal e resorvente a bursa "filogenèticamente intestinal" encontra-se, infelizmente, o termo "bursa intestinal" usado indiscriminadamente, para a grande bursa seminal das espécies de Phaenocora (Gilbert, Ruebush), ou para uma pequeníssima área dentro do sincício intestinal situada perto da desembocadura do duto gênito-intestinal de Castrada lutheri (Kepner, Stirewalt \& Ferguson 1939). A última espécie possue, além disso, bursa copulatória e receptículo seminal, de maneira que a chamada "bursa intestinal" dela poderia ser apenas análoga à das Monocelididae acima referidas, mas, não homóloga, como os autores dizem.

A função fagocitária, a qual, coma vimos, não é a única da bursa, apoiaria, segundo Cernosvitov (1931, p. 320 e seg., 325-326), a hipótese de Steinböck. Mas, enı Psendograffilla arenicola Meixner (1938, p. 67), exerce o átrio feminino (útero; átrio superior) a mesma função, sem que possa ser tido por "intestinal". A única "bursa intestinalis" indiscutivel, hoje conhecida, é a de Gnosonesima antarctira Reisinger (1926, p. 436), cujo "Bursastiel", porém, conduz a uma vesícula terminal 
fundamentalmente diversa das observadas nas ditas Monocelididae. Nesta "empôla", trata-se dum vacúolo digestivo, possivelmente permanente (conhece-se sòmente 1 espécime conservado), com contornos marcados dentro do plasmódio intestinal. Ao nosso vêr, com Gnosonesima tem-se a prova da inaplicabilidade do têrmo "bursa intestinal" para todos os órgãos provindos, ontogenèticamente, do aparelho genital e apostos ao intestino ou conerescidos com êste. São bursas copulatórias, seminais ou resorventes; as suas comunicações com o intestino são próprias para facilitar a resorpação de espérmios, etc., sem que testemunhem vias femininas ancestrais. Seguimos, destarte, a Meixner, não a Steinböck, Reisinger e Bresslau.

Os dutos gênito-intestinais, que independem da bursa, precisam de consideração especial. Podem, funcionalmente, aproximar-se a uma bursa resorrente (Castrada lutheri), ou até dificultar, morfologicamente, a separação entre duto gênito-intestinal e comunicação bursa-intestinal (Kambanella agilis Steinböck 1931, p. 10). Também no último caso funciona o duto no sentido indicado por Bendl $(1909$, p. 299), desembaraçando o trato genital de espérmios e vitelo excedentes. O duto gênito-intestinal mais notável apresenta Glanduloderma myzostomatis. Nesta espécie das Fecampiidae, sem faringe e bôca, constitue o duto a única comunicação do intestino com o meio externo (Jägersten 1941, p. 8). Ignora-se a função dêste duto como a do mesmo em Oekiocolax plagiostomorum Reisinger (1929, p. 67); em Koinocystis neocomensis (Fuhrmann), evacua espérmios supérfluos (ibid., p. 72).

Em Bresslauilla relicta (ibid., p. 50), como também em Prop̌o:oplana jenseni (id. 1935; libertação dos ovos ignorada), faltam vias eferentes femininas. O ovo da primeira espécie passa, através dum orifício caudal do intestino, ao lume do saco digestivo. Tal considera Reisinger $(1929$, p. 61) como fenômeno primitivo, coms prova de ser o duto gênito-intestinal (ou poro gênito-intestinal) o oviduto original. Meixner (1938, p. 69) discute a espécie no conjunto dos seus parentes, julgando as disposiçōes deseritas como especializadas e secundàriamente modificadas. Acrescenta as suas descobertas relativas às Ethmorhynchidae (ihid.. f. 72). Nestas, existe ligação entre o germo-vitelário e o meio externo. Não obstante, entram os casulos no intestino, de onde saem, provavelmente, pela bôca. Segundo Meixner, seria também êste caso uma modificação secundária. Os casulos são tão enormes que devem, durante a "gravide” intestinal" impossibilitar a ingestão de alimentos.

Em Baicalellia evelinae, trata-se, como em Ethmorhynchus, dum representante dos Turbellaria Coelata cujos casulos passam ao intestino, apesar de existir, corn átrio e gonóporo, via eferente feminina normal. Ocorre ainda bursa seminalis, independente do intestino, o órgão fagocitário de Nassonov. O trânsito do casulo pelo gonóporo não parece inviável. Calculámos, para avaliar isso, a relação percentual entre a largura do casulo e a largura máxima do corpo, pois o próprio gonóporo não pode ser medido. Chegámos, para B. evelinae, a 45-50\%, mas, verificámos ovos em proporção com o corpo que os produziu mais grossos em várias espécies, cujos ovos ou casulos saem através do gonóporo. Do gênero Gieysztoria, p. e., tem G. ornata (Hofsten) ovos de $52 \%$; G. complicata (Fuhrmann), tais de $53 \%$; G. acariaia, n. sp., de 68\%. Plagiostomum evelinae, cujos casulos acusam grossura correspondente a $60-75 \%$ da largura máxima do corpo, evacua êstes do mesmo modo por meio do gonóporo, como Gyratrix hernaphroditus Ehrenberg; Macrostomum gigas Okugawa; Gieysztoria bellis, n. sp., e G. evclincie, n. sp. com $33 \% ; 20 \% ; 30 \%$ e $18 \%$ respectivamente.

Não parece possível, segundo esta exposição, entender como mecânicamente condicionada a ovipostura (ou viviparidade) oral de Baicalellia evelinae. Faltam, por outro lado, indícios seguros de antiguidade e primitividade do gênero Baicalellia. A distribuição geográfica, que talvez favoreça tal idéia, conhece-se, com certeza, só imperfeitamente; vermes tão pequenos nem sequer na Europa são pesquisados desde há muito tempo. 
$\mathrm{Na}$ biologia reprodutiva de Baicalellia evelinae, apresenta-se a involuçãó dos órgãos masculinos como atípica, antes secundàriamente modificada do que primitiva.

Convém, por enquanto, abster-se de formular opinião a respeito da hipótese de Steinböck, quando se trata de comunicação gênito-intestinal, independente de bursa; em vermes providos de vias eferentes femininas normais e transitáveis. Seja lembrado que até agora não se conhecem quaisquer comunicações gênito-intestinais dos Macrostomida (Kepner, Stirewalt \& Ferguson 1939, p. 234), tidos, por todos os autores, como a ordem mais primitiva entre os Turbellaria Coclata. Tal é desfavorável ̀̀ dita hipótese.

\section{Família: Dalyelliidae Graff $(1905$, p. 73,$102 ; 1913$, p. 85; Bresslau 1933, p. 269)}

\section{Genus: Microdalyellia Gieysztor (1938, p. 222)}

Nas espécies do gênero Dalyellia J. Fleming 1822 (Gieysztor 1934, p. 209-210 emend.), que corresponde ao $3 .^{\circ}$ grupo de Hofsten (1907, p. 519 , os ovos não são libertados pelo gonóporo. Saidos do germário, passam pelo duto comum, e entram na parte interna do átrio. Esta parte chamamos, eom Gieyzstor (l. c.) e Reisinger (1924e, p. 254) de útero. Falta, é verdade, um limite nítido entre átrio e útero. Por isso, Ruebush \& Hayes (1939, p. 146-147) caracterizam o gênero pela indicação "witbout an uterus". Da parte discutida, os ovos penetram sucessivamente para dentro do parênquima, onde permanecem até a morte do verme (Bresslau 1933, f. 83 na p. 96). O limite aludido entre átrio e útero ocorre nas espécies do gênero Microdalyellia, que possuem, nêste ponto, um esfincter ou um duto uterino ("Stiel des Uterus"). Os ovos são eracuados, um por um, pelo poro genital. O útero contem, por via de regra, de cada vez, sòmente um ovo, havendo, porém, excepções (Jones \& Hayes 1941, p. 597).

Tôdas as outras diferenças entre os dois gêneros não são rigorosamente disjun: tivas, como se depreende das diagnoses de Ruebush \& Hayes (l. e.).

Os autores norte-americanos subdividiram o gênero Microdalyellia em dois subgêneros, Microdalyellia (p. 147) e Gieysztoria (p. 149), com ca. de 40 espécies cada um. No subgênero Microdalyellia, que é o $2^{\circ}$ grupo de Hofsten (1907, p. 519), o aparelho copulatório cuticular compõe-se de dois cabos ("Stiele", Graff 1913, p. 89; "Proximal stalks, proximal branches" Ruebush \& Hayes) e duas hastes ("Endäste", Graff; "lateral distal branches", Ruebush \& Hayes) providas de espinhos (Fig. 26, e).: Em Gieysztoria, o $1 .^{\circ}$ grupo de Hofsten (1907, p. 518), o órgão é, por princípio, anelar (Fig. 33, 36). Atribuindo as várias espécies a um ou ao outro subgênero, Ruebush \& Hayes conservaram o aparelho cuticular como critério principal. Nas diagnoses subgenéricas, porém, acrescentaram ainda outro, a saber, testículos situados na metade anterior (Microdalyellia) e posterior(Gieysztoria) do corpo. Este caracter pouco auxilia ou até invalida a sistematização baseada no órgão copulador, como se vê pelos fatos seguintes:

1) pelo menos 12 espécies, atribuidas ao subgênero Microdalyellia por causa das partes cuticulares, foram descritas sem indicação da topografia dos testículos;

2) os testículos de quadridens (Böhmig 1897; veja Graff 1913, p. 106) e inflata Okugawa (1930, p. 81), incluidas em Gieysztoria, ignoram-se;

3) os testículos de blodgetti (Silliman 1884, p. 67) e eastmani Graff (1912, p. 37), também de Gieysztoria, situam-se no meio do corpo;

4) certas espécies apresentam o aparelho cuticular de Microdalyellia combinado com a posição posterior (Gieysztoria) dos testículos, a saber, mollosovi (Nassonov 1920; veja id. 1926, p. 835; aí inclusão de sphagnetica Beklemischer 1921 na sinonímia do mollosovi; não de karisalmica, como Ruebush \& Hayes 1939, p. 148 nota 6 , o indicaram); lutheri Nassonov (1925, p. 61; segundo Gieysztor, 1938, p. 226, pachyderma Steinböck 1931, p. 3 seria idêntica a lutheri) ; euchroa Gieysztor (1926, p. 634; 1938, p. 237-241); e'sawayai, a ser deserita mais adiante.

Convem, porisso, suprimir nas diagnoses dos dois subgêneros os dizeres relativos. ì posição dos testículos. 


\section{Subgenus: Microdalyellia Ruebush \& Hayes (1939, p. 147)}

Os autores citados distinguem, dentro do subgênero, vários grupos e subgrupos, cujos caracteres, publicados em revista e língua facilmente acessíveis, não precisam ser repetidos nêste lugar. Os grupos facilitam, por certo, a elassificação. No entanto, nem sempre bastará vèrificar a que grupo um certo material pertence e compará-lo com as outras espéeies dêste grupo. Convirá, muitas vêzes, estender o confronto aos grupos vizinhos, porque os conceitos dos autores divergem a respeito de várias espécies descritas há muito tempo.

\section{Microdalyellia (Microdalyellia) sawayai, spec. nov. (Fig. 23-27)}

O corpo é fusiforme nos espécimes cuja extremidade caudal é simplesmente cuspidata (Fig. 23) ; em outros, há cauda distinta, às vêzes, ligeiramente encurvada para cima. O comprimento é de $0,7-1,4 \mathrm{~mm}$.; a côr cinzento-esverdeada localiza-se no parênquima e, por isso, é mais carregada nas partes em que o parênquima é mais rico em células. A distância entre os dois olhos é relativamente pequena.

A epiderme contem rabditos formados em células rabditógenas subjacentes à epiderme. Papilas caudais chamadas de adesivas não ocorrem, mas, as glândulas que produzem bastonetes grudadores, descritas por Hofsten (1907, p. 466 e seg.), são presentes (Fig. 24, z).

A faringe é muito grande, quasi tão comprida quão o intestino. Num verme de $1,4 \mathrm{~mm}$., ao comprido, a faringe acusa longura de $0,4 \mathrm{~mm}$. 0 bordo rostral da faringe possue ca. de 20 papilas, cada uma provida dum tufo de cílios (Fig. 25). Há ca. de 10 músculos anelares externos na orla da faringe e 30-34 no corpo da mesma. O número total, quer dizer, na orla e no corpo faríngeos, dos músculos anelares internos é de 47-53. No corte transversal contam-se 22-25 músculos radiais.

Entre a faringe e o intestino salientam-se os corpos de glândulas eosinófila (Fig. 23, y) pertencentes ao intestino ${ }^{*}$ ).

Os testículos (Fig. 24, t) são muito pequenos e esféricos; situam-se caudalmente ao intestino, ao nível do ovário. Aproximadamente globular é também a vesícula seminal (s). Os cabos (Fig. 26, c) do órgão copulador atingem a vesícula, abraçando o reservatório da secreção granujosa (k).

() aparêlho cuticular (Fig. 26) compõe-se dos dois cabos compridos, cujos prolongamentos distais são as 2 hastes (h) espinhosas. A haste direita tem 9 espinhos proximais e 1 mais forte distal; a esquerda, 14 espinhos, dos quais o distal é mais comprido que os 2 precedentes. Os espinhos (e) são cuspidatos e ligeiramente encurvados. Aos cabos unem-se ainda as placas medianas, uma dorsal (Fig. 26, d) e outra ventral (n). A ligação dessas placas com os cabos é formada pela trave transversal (f). Não convem chamar, com Nassonov (1926, p. 834; 1926a, p. 205) as placas rcuticulares de "papila penial" (Meixner 1915, p. 494), pois o duto ejaculatório liga-se sòmente à placa dorsal, em cujo sulco dorsal corre ${ }^{* *}$ ) (Fig. 27). O comprimento do aparelho cuticular é de $0,1 \mathrm{~mm}$.

*) Ruesbush \& Hayes (1939; p. 137) descrevem as glândulas corretamente, mas, explicam-nas, na legenda da sua figura 1 (p. 138), como "pharyngeal glands".

**) A figura dos órgãos masculinos eferentes de M. sillimani (Graff 1912, t. 3 f. 14) mostra outra topografia, a saber, o duto ejaculatório correndo entre as duas placas medianas. Tal posięão do duto compreender-se-ia, do ponto de vista funcional, 
O ovário (Fig. 24, o) varía, quanto ao comprimento, conforme a idade; nunca é muito rico em gonócitos. O receptáculo seminal ( $\mathrm{r}$ ) faz parte do oviduto. Os vitelários (v) são pouco lobulados, e entram com un viteloduto comum no canal feminino (ductus communis) perto do ponto da desembocadura das glândulas da casca $(\mathrm{g})$. O casulo $(\mathrm{u})$, de polos largamente arredondados, tem $0,15 \mathrm{~mm}$. de diâmetro longitudinal e $0,1 \mathrm{~mm}$. de tranversal. O duto uterino separa-se do átrio por esfincter. $\mathbf{A}$ bursa copulatrix (Fig. 24, b) dirige o seu fundo dilatado para diante; o seu tubo ectal, que se comunica com o átrio, é provido de fortes músculos anelares. Glândulas argamassadoras (a), como são comuns nas Dalyelliidae que evacuam os casulos, circundam o gonóporo.

Ocorrência: Os primeiros exemplares (ca. de 30 ) obtivemos de plantas aquáticas que o Prof. Dr. Paulo Sawaya trouxe do córrego limpo duma nascente na Fazenda Barros (Vila dos Lavradores), em Botucatú, no Interior do Estado de Sáo Paulo. Mais tarde, verificámos alguns exemplares avulsos nos arredores da cidade de São Paulo, em águas estagnadas, tanto perenes (Itaim, julho de 1945), quanto transitórias (Joquei Clube, dezembro de 1945).

Num exemplar cortado, notámos dois casulos, um no útero, e o outro no parênquima. Apesar de ser provàvelmente excepcional, o caso mostra que ocorre certa transição entre os gêneros Dalyellia e Microdalyellia. A posição dos testículos de $M$. (M.) sawayai já foi mencionada na discussão do gênero, cuja subdivisão ulterior deveria restringir-se ao aparelhocuticular.

\section{Discussão sistemática de Microdalyellia (M.) sàwayai}

Segundo o aparelho cuticular, M. sawayai aproxima-se às espécies seguintes:

1) $M$. rossi (Graff 1912, p. 39) com testículos anteriores muito compridos e com faringe cuja longura não atinge a metade daquela do intestino. A variabilidade dos espinhos das hastes de $M$. rossi (Ruebush 1937, p. 249; Ruebush \& Hayes, 1939, p. 140) recomenda restringir o confronto com $M$. sawayai aos caracteres anatômicos indicados.

2) M. sillimani (Graff 1912, p. 42), cujo aparelho cuticular possue cabos curtos. e, na haste direita, o espinho distal em forma de charrúa ou placa triangular; na esquerda, espinhos lameliformes e unidos em forma de rêmo.

3) M. karisalmica (Nassonov 19i7, p. 1106; 1926, p. 829) seria, segundo Gieysztor (1926, p. 162), idêntica a M. rossi (Graff), pois "a ponta da papila penial fendida" (Nassonov 1926, p. 832) indicaria a presença das duas placas medianas, da dorsal e da ventral. Ruebush \& Hayes (1939, p. 149, nota 12) consideram improvável tal êrro de Nassonov e, por isso, manteem $M$. karisalmica separadamente e num outro grupo do subgênero.

4) M. aspinosa (Ruebush 1937, p. 248) tem hastes sem espinhos.

5) M. virginia (Ruebush 1937, p. 246, 253) possue testículos anteriores: receptáculo seminal comprido, salientado do oviduto; o átrio destituido de bursa; e geralmente 4 espinhos (sawayai: 10) na haste direita; 8 (sawayai: 14), na esquerda.

6) $M$. gilesi Jones \& Hayes (1941, p. 596), de 2-3,5 mm., ao comprido; faringe maior que o intestino; e testículos que se estendem até o nível do meio. da faringe (l. c., f. 1).

mais facilmente que a deserita aquí de $M$. sawayai. Apesar disso, mantemos a nossa observação, baseada em séries de cortes, em contraposição ao desenho de Graff, cuja preparação "comprimida ("Quetschpräparat") não pode averiguar tais estruturąs
delicadas. 


\section{Notas sôbre o subgênero Gieysztoria Ruebush \& Hayes (1939, p. 149)}

Subdividindo o subgênero, Ruebush \& Hayes estabeleceram dois grupos, grupo 1 (eastmani) com o aparêlho cuticular constituido por espinhos separados e grupo 2 (rubra) com o orgão em forma mais ou menos semelhante a uma corôa.

Das 7 espécies do $10^{\circ}$ grupo eliminamos thienemanni (Reisinger 193:, p. 251) e pachyderma (Steinböck 1931, p. 3); a primeira, por ter o aparêlho cuticular semelhante ao de complicata (Fuhrmann 1914, p. 794; Beauchamp 1939, f. 2, p. 58), virgulifera (Plotnikow 1906; citado segundo Graff 1913, p. 123), e espécies vizinhas; a segunda, porque a consideramos, com Gieysztor (1938, p. 226), sinônimo de Microdalyellia (Microdalyellia) lutheri (Nassonov 1925, p. 61). As figuras do órgão masculino de três outras espécies do grupo 1 contêem indícios de anel ou tubo cuticular: blodgetti (Silliman 1884, p. 68 fala dum tubo cuticular desenhado na t. 4 f. 17, a); eastmani (Graff 1912, t, 3, f. 8); e inflata (Okugawa 1930, p. 81 f. 23). Unicamente em $M$. (G.) cuspidata (Schmidt 1861, p. 25; Nassonov 1919b, p. 1182, f. 1-3 no texto) e quadridens (Böhmig 1897; citado segundo Graff 1913, p. 106) parece o aparelho formado por espinhos separados.

Tentando combinar o caracter do órgão copulador com outros critérios, indicaram Ruebush \& Hayes ainda: "testículos principalmente na metade posterior do corpo, usualmente antes do pênis; dutos eferentes (vasa deferentia) saindo da extremidade posterior dos testículos". A posição descrita dos dutos eferentes ocorre em cuspidata (Schmidt 1861, t. 4, f. 6), mas, segundo esta figura, estendem-se os testículos que foram só parcialmente desenhados até a metade anterior; em todo o caso, ignora-se nesta espécie tantas vêzes mencionada na literatura a topografia certa dos testículos (Dorner 1902, p. 41). Segundo Reisinger (1924 c, p. 278), são pequenos e posteriores. Em thienemanni atingem os testículos a metade anterior do corpo, e os dutos saem da extremidade rostral dêles. Os testículos e o ponto da saida dos dutos ignoram-se em quadridens e inflata. As gônadas masculinas de blodgetti e eastmani situam-se no terço médio do corpo; a saida dos dutos ignora-se.

Destarte, o grupo 1 apresenta-se como agrupamento embaraçosamente reunido, sem valor taxonômico. Do nosso material, nenhuma espécie se enquadra nêsse grupo.

o 2.0 grupo é útil; abrange a grande maioria das espécies de Gieysztoria. Adotamos a subdivisão de Ruebush \& Hayes em dois subgrupos, o $1 .^{\circ}$ com espinhos do aparelho cuticular desiguais entre si, e o $22^{\circ}$, com iguais. No Gltimo, distinguem os ditos autores duas seç̧ões, conforme a ausència (seç̧ão A) e a presença (seç̧ão B) do receptáculo seminal. Das Dalyelliidae de São Paulo, M. (G.) ornata (Hofsten 1907, p. 525) e duas espécies novas, bellis e tridesnia, pertencem à secção $\mathrm{B}$ do subgrupo 2 do grupo 2 (rubra). A seç̧ão A não se encontra representada no nosso material.

O subgrupo 1 propomos subdividir em duas seções, uma com espinhos sim ̀ेtricamente dispostos (seç̧ão A), a outra com espinhos assimétricos (secção B). As espécies do subgrupo 1 podem ser atribuidas às duas secções do modo seguinte: Secção A:

1. triquetra (Fuhrmann 1894 , p. 265).

2. infundibuliformis (Fuhrmann 1894, p. 272); sinônimo: succincta (Hofsten $1907 \mathrm{~b}$, p. 12).

3. koiwi (Eggers 1925, p. 461; Gieysztor 1938, p. 236).

4. dubitativa (Sibiriakova 1929, p. 240).

5. biwat (Okugawa 1930, p. 80).

6. triangulata (Robeson 1931, p. 599).

7 wiszniewskii Gieysztor (1938a, p. 366).

8. evelinae, spec. nov.

9. hymanae, spec. nov.

10. trisolena, spec. nov.

Secção B:

11. acariaia, spec. nov.

1. virgulifera (Plotnikow 1906; Beklemischev 1926, f. 1-8); sinônimo: pallida (Hofsten $1907 \mathrm{~b}$, p. 5; 1912, p. 614).

2. dodgei (Graff 1912, p. 354)

3. complicata (Fuhrmann 1914, p. 794). 
4. pavimentata (Beklemischev 1926, p. 243).

5. okugawai Ruebush \& Hayes $(1939$, p. 149); é Dalyellia gracilis Okugawa (1930, p. 81), cujo nome específico precisou ser modificado, pois D. gracilis já foi introduzida por Fulinski \& Szynal (1927, p. 158, 163). Ruebush \& Hayes incluem a espécie no subgênero Microdalyellia, e, realmente, descreve Okugawa o órgão cuticular com "two very short stalks", Possivelmente, são os "cabos" nada mais do que o corte óptico dum anel. Os espinhos distais lembram, em todo o caso, os que ocorrem $\mathrm{cm}$ espécies de Gieysatoriu da seçãa atual. Os testículos não foram descritos.

6. beltrani (Gieystor 1931, p. 137).

7. minima (Riedel 1932, p. 95).

8. thienemanni (Reisinger 1933, p. 251).

9. intricata, spec. nov.

10. uncia, spec. nov.

11. therapaina, spec. nov.

12. thymara, spec. nov.

13. cypris, spec. nov.

Dalyellia incerta Böhmig (1902, p. 6) foi incluida, por Ruebush \& Hayes (1939, p. 150), no subgênero Gieysztoria por pertencerem os testículos à metade posterior do corpo. O aparelho cuticular, porém, indica tratar-se dưma Microdalyellia, e 'êste critério consideramos como decisivo. Já mencionámos mollosovi, lutheri, euchroa, e sawayai como espécies do subgênero Microdalyellia com posição posterior dos testículos.

\section{Espécies de Gieysztoria com aparêlho cuticular anelar, provido de espinhos desiguais simétricamente dispostos}

\section{Microdalyellia (Gieysztoria) evelinae, spec. nov. (Fig. 28-37)}

Os vermes anteriormente arredondados, posteriormente cuspidatos, são convexos no dorso e ligeiramente achatados no ventre (Fig. 29). 0 comprimento dos indivíduos recém-saidos do ovo é de $0,3 \mathrm{~mm}$; a grossura, de $0,07 \mathrm{~mm}$. As medidas máximas de animais adultos são de $1,7 \mathrm{~mm}$. e 0,5 mm., respectivamente. Espécimes de 0,5-0,7 mm., ao comprido, já possuem o aparelho cuticular masculino desenvolvido, faltando apenas, em certos exemplares, ainda alguns espinhos do mesmo.

Os cálices pigmentados dos olhos são nìtidamente côncavos para 0 lado externo. Animais jovens são incolores; a côr dos de meia idade e dos adultos é, principalmente, castanho-alaranjada, situando-se os pigmentos no parênquima. Além disso, há melaninas no parênquima, ao redor do esôfago, onde formam um colar preto (Fig. 30, 1), ocorrendo pigmentos acastanhados entre o intestino e as gônadas. $\mathrm{O}$ intestino apresenta-se, freqüentemente, esverdeado, em consequência do seu conteúdo. Sobrepõem-se ao trato digestivo os vitelários, cuja gordura branca é opaca. Zooclorelas faltam tanto no intestino, quanto no parênquima. Vermes idosos escurecem-se, concentrando-se os pigmentos em massas irregulares. Este processo precede à morte dos animais (Hein 1928, p. 475). Em M. (G.) evelinae, as aglomerações de substâncias pretas não são zooclorelas mortas, como Haffner $(1925$, p. 25$)$ as viu na superfície do corpo de D. viridis, mas, escórias do metabolismo do Turbelário.

Tôdas as células epidérmicas possuem núcleos, também as velhas, como se reconhece nos cortes tangenciais. Os limites inter-celulares são nítidos; os espaços hialinos ("wasserklare Räume", veja Bresslau 1933, 
p. 60), numerosos. As células substituidoras da epiderme são indistintas. Os rabditos formam grupos de 2-5; são bastonetes curtos, de extremidades arredondadas. Embora os rabditos se situem, na sua maioria, horizontalmente, o citosoma das células epidérmicas apresenta-se verticalmente estriado. Sub-epitelialmente ocorrem as células rabditógenas (Fig. 30, r), como foram descritas, de Dalyellia styriaca, por Reisinger (1924c, p. 239).

Dos cílios locomotores, distinguem-se outros, maiores e rígidos, verosimilmente tácteis, que se acumulam na cabeça e na cauda. Na última, ressaltam ainda papilas, comumente em número de 4 , mas, variando de 3 a 7 . As papilas (Fig. 28, h) são providas de glândulas $(k)$ e de cílios tácteis. A forma das papilas lembra a dos tubérculos fiandeiros das aranhas. Na literatura, as papilas chamam-se de adesivas; as glândulas, de grudadoras, mas, os muitos vermes de $M$. (G.) evelinae vistos por nós não se fixaram por meio dos órgãos em questão.

0 cérebro, que estudamos apenas em uma espécie de Microdalyellia (veja Fig. 69-70), parece-se com o de $M$. (G.) bellis. Os nervos sensoriais anteriores são grossos em $M$. $(G$.) evelinae. O parênquima é formado por poucas células; no total, é parcamente desenvolvido. Os elementos pigmentados já foram mencionados.

A faringe tem de comprimento ca. de $0,2 \mathrm{~mm}$.; de diâmetro, ca. de $0,1 \mathrm{~mm}$. No fundo da bolsa faríngea externa (Fig. 31, d) inserem-se os músculos obliquos protractores (p) e retractores ( $r$ ). As papilas na orla faríngea, muito freqüentes nas Dalyelliidae (Meixner 1915, p. 4S4 e seg.), faltam completamente em $M$. (G.) evelinae. As glândulas faríngeas comumente encontradas ocorrem, tanto as chamadas bucais, de secreção eosinófila (acidófila) granulosa (Fig. 31, a), quanto as chamadas salivares, de secreção basófila (b). Das glândulas eosinófilas estendem-se as 4 visíveis no corte transversal (Fig. 32, a) longamente para trás. Na orla faríngea existe, em $\boldsymbol{M}$. (G.) evelinae, a estrutura tubulosa que Meixner (1915, p. 485) considerou como diferenciação do citoplasma epitelial, não como músculo (Hofsten 1907, p. 477). O aspecto histológico do material presente confirma a opinião de Meixner, que admitiu função sustentadora do tubo aludido.

Os músculos anelares externos da orla faríngea (Fig. 31, m) são 'em número de 7-10; os mesmos do corpo da faringe ou faltam, ou são tão finos que não pudderam ser contados. Dos anelares internos da orla há $7-8$; dos do corpo faríngeo, 28-32 (k). No corte transversal, existem 24-32 músculos radiais $(\mathrm{h})$. Dos músculos longitudinais, sòmente os internos (g), em número de 32, puderam ser contados; os externos do corpo da faringe são incognoscíveis; os da orla, tão cerrados que é impossível contá-los. As dificuldades mencionadas e a variação, já assinalada por Meixner (1915, p. 488), inutilizam indicar os dados numéricos pela fórmula de Reisinger (1924 c, p. 247-248). Verificámos apenas um anel nervoso da faringe (Fig. 31-32, n) ; êste muito mais fino que os nervos desenhados por Hofsten (1907, t. 24 f. 12). Os citosomas nucleados aprofundados do epitélio interno da faringe (Fig. 31, e) encontran-se, como em outras espécies da família, no chamado esôfago que pertence à faringe.

$\mathrm{Na}$ entrada do intestino, ocorrem as glândulas aprofundadas eosinófilas, cuja secreção (Fig. 31, s) e topografia correspondem às células 
claviformes de Minot (Meixner 1915, p. 486 t. 30 f. 9, dmd). Robeson (1931, p. 603) chama estas células de glândulas salivares. No fundo do saco digestivo, situam-se, em cada lado, verdadeiras clavas de Minot, como foram descritas de $M$. (G.) diadema e ornata (Meixner 1915, p. 489). As células digestivas são altas, vesiculosas e vacuolizadas. Entre estas, observam-se células basófilas, menores, evidentemente substituidoras (Fig. 30, e), que lembram as dos Catenulida (Marcus 1945a, p. 41 t. 7 f. 25, e). Parecese também o ritmo das células em função, na sua relação com a ingestão, com o processo correspondente de Stenostomum (ibid., p. 39).

Os emunctórios são, em grande parte, ocultados pelo parênquima. Caudalmente ao útero, reconhecem-se nêles tufos de cílios propulsores ("Treibwimperflammen"), que também ocorrem nos novelos dos'canais principais, atrás dos olhos. Os ditos órgãos de propulsão pertencem ao tipo em que a placa dos corpúsculos basilares dos cílios se situa lateralmente (Reisinger 1924c, p. 246 t. 1 f. 5 ).

Em vermes de 0,5 - 0,7 mm. de comprimento as gônadas começam a amadurecer, medindo, então, quasi a metade da longura do corpo, a saber, $0,3 \mathrm{~mm}$. Daquí em diante, cresce mais a região intestinal do animal, de maneira que o complexo dos órgãos reprodutivos acaba de ocupar apenas $0,6 \mathrm{~mm}$. dos indivíduos com tamanho máximo $(1,7 \mathrm{~mm}$.). No útero de exemplares de $0,8-0,9 \mathrm{~mm}$., ao comprido, já se encontra, várias vêzes, um casulo.

Os testículos (Fig. 30, t) situam-se no terço caudal do corpo; nos vermes jovens, mais para diante; nos velhos, mais para trás, eomo é a regra no subgênero Gieysztoria. A saida dos dutos eferentes (d) da extremidade rostral dos testículos ocorre, igualmente, em muitas espécies do subgênero. Os dutos reunem-se no ponto da sua entrada no ápice da vesícula seminal $(x)$, órgão aproximadamente esférico e de parede tênue. Ectal ou distalmente, salienta-se a vesícula para dentro do reservatório da secreção granulosa (Fig. 35, y). Este é um eilindro, cuja parede se compõe de dois aneis de células, um sobreposto ao outro. A época da produção da secreção granulosa parece durar só muito pouco tempo, pois em ca. de 100 espécimes cortados, ocorreram apenas num exemplar as glândulas com a coloração característica azul dos citosomas e vermelha da secreção granulosa. Os dutos pedunculiformes destas glândulas desembocam no reservatório ao nível do limite entre vesícula e reservatório. Do último, sae o duto ejaculatório (Fig. 35, e) que não merece o nome dé "duto" Trata-se duma massa cônica acidófila, sem núcleos, composta de glebas poliédricas, que se projeta por entre o aparelho cuticular. O espaço entre o chamado duto ejaculatório e os elementas cuticulares é preenchido pela massa plasmática formadora do aparelho cuticular (Reisinger 1924c, p. 262-263), a qual é, na fase funcional masculina, vacuolizada e sem núcleos.

$O$ pênis cuticular (Fig. 33-36) pertence ao tipo do grupo 2, sub: grupo 1, de Ruebush \& Hayes (1939, p. 150). Das espécies aí reunidas, possuem $M .(G$.$) triquetra (Fuhrmann 1894, p. 265) e triangulata$ (Robeson 1931) os aparelhos masculinos menos distantes do de $\boldsymbol{M}$. (G.) evelinae. A estrutura anelar, dorsalmente aberta, provida de espinhos, é caracter do subgênero. Na espécie presente, há dois aneis, entre si lig̣ados, 
o proximal (ental) com $0,05-0,06 \mathrm{~mm}$. de diâmetro e ca. de 0,036 $\mathrm{mm}$. de altura (Fig. 33,a), e o distal (ectal), ondulado (d), unido ao proximal pelas pontes ( $p$ ) muito variáveis. No anel distal penduram 4 triângulos (t) havendo 3 em triquetra e triangulata. Cada triângulo alonga-se com um espinho grosso e ôco (Fig. 33, g). O espinho encurva-se para o lado externo, salientando-se aí uma entumescência gibosa (m) e perfurada, que serve para a inserção dos músculos abductores (Fig. 35,m). Os feixes dêstes originam-se no bordo anterior (ental, superior) do anel proximal (a). Disposição semelhante foi descrita de $M$. (G.) diadema por Meixner (1915, p. 497 f. 15, fl). A contração dêstes músculos abduz os espinhos para fora (Fig. 34), lembrando o aparelho, em tal fase, um "home-made broom" (Hayes 1945, p. 441). Cada um dos três arcos entre os 4 espinhos grossos contem 7-9 espinhos finos (Fig. 33, f), mais compridos. São, no corte transversal, triangulares (Fig. 36) e, no bordo superior, concrescidos uns com os outros. Quando os 4 espinhos grossos são abduzidos, seguem-nos os mais finos passivamente, sem atividade muscular especial. A estensão rostro-caudal do aparelho inteiro é de $0,09-0,1 \mathrm{~mm}$., ocupando a parte espinhosa ca. de $0,06 \mathrm{~mm}$.

Ao redor do aparelho cuticular (Fig. 35, z), forma a bainha do penis um manto musculoso que se fixa no átrio (Fig. 30, a). A situação da bainha e, com esta, a do pênis, varía: uma vez localiza-se ao lado do ovário, perto do plano mediano; outra vez, mais para fora, perto da parede esquerda do corpo. Correspondentemente, ocorre a bursa copulatrix (Fig. 28, b) uma vez, mais no lado esquerdo; outra vez, mais medianamente. A passagem da bainha do pênis ao átrio marca-se, várias vêzes, por algumas células vacuolizadas de caracter glandular, havendn regularmente, nêste ponto, esfincter constituido por fibras anelares tênues. Outras fibras, estas grossas, circundam o poro genital (Fig. 30, p), juntamente com uma roseta de glândulas argamassadoras (f), cuja secreção gruda o casulo ao substrato.

O ovário (Fig. 30, o), ora reto, ora encurvado em 'forma de $\mathrm{S}$, situa-se, nos 17 espécimes examinados a respeito, no lado direito. No fundo do ovário, encontram-se as pequenas ovogônias; mais para trás, os ovócitos em crescimento uniserialmente dispostos. No ponto em que a túnica ovárica passa ao duto eomum (c), há uma dilatação, o receptáculo seminal (Fig. 30, m) quasi esférico. Conforme o seu enchimento, varía o seu diâmetro de 0,03-0,2 mm. Por via de regra, destaca-se o duto do receptáculo bem da empôla. Na parede desta, observamos os "locules" descobertos por Robeson (1931, p. 607) em $M$. ( $G$ r.) triangulata. São, como se evidencia pelos cortes, 3 vacúolos intracelulares dispostos ao redor de 1 maior. Todos podem conter espérmios, e isso, também em indivíduos cujos espérmios próprios ainda não são maduros. Secreção granulosa notada no receptáculo de $M$. (G.) triangulata (Robeson 1931, p. 608) não verificámos no de $\boldsymbol{M}$. (G.) evelinae, cuja secreção granulosa se produ\%, como foi dito, só passageiramente.

Os vitelários (Fig. 30, v) estendem-se da região rostral à caudal, e isso, inclinadamente, do lado dorsal ao ventral. Tingem-se, com hematoxilina-eosina, perifèricamente em azul; centralmente. onde o vitelo está formado, em vermelho. Quanto aos pormenores da vitelogênese, remetemos 
os leitores a Robeson (1931, f. 6-11). Cada lado dos dois ramos viteláricos possue ca. de 12 lóbulos. Os dois ramos reunem-se ao nível do fundo do intestino, de onde o viteloduto comprido ( $\mathrm{n}$ ) corre ao duto comum (c). Este recebe ainda a secreção de dois tufos de glândulas da casca (s). Quando há um ovo no duto comum, o trecho ectalmente às glândulas da casca dilata-se, formando um útero, de parede fina. Atrás de cada óvulo saido do ovário derrama-se uma porção de espérmios do receptáculo. $\Lambda$ fecundação realiza-se no duto comum ou no útero, onde espérmios se vêem ainda ao lado do casulo, i. é, o ovo provido de vitelo. Depois da saida dos espérmios dilata-se o viteloduto, comumente vazio, e enche-se de vitelo. O processo foi bem descrito por Ruebush \& Hayes (1939, p. 141). A quantidade de vitelo é determinada pelo calibre do viteloduto, e, destarte, recebe cada ovo porção idêntica de vitelo. $O$ ovo envolvido pelo vitelo é branco; quando a casca começa a formar-se, o casulo torna-se amarelo; mais tarde, acastanhado e, finalmente, mais escuro ainda.

Do útero sae o duto uterino que entra no átrio (a), revestido por epitélio nucleado e circundado por músculos. Ainda mais musculosa é a bursa (Fig. 30, b). Ao redor desta, células parenquimáticas faviformes, vesiculosas formam uma camada, como foi descrita de $M$. (G.) fusca por Meixner (1915, p. 529). Na empôla da bursa vimos espérmios. Na parede do fundo da bursa, inserem-se dois músculos (em triangulata, sòmente um), um em cada lado, que se originam na paredle do corpo, segurando, destarte, a posição da bursa.

O casulo (Fig. 30, u) tem forma irregularmente elipsóide, de cujos. lados um é achatado, o oposto mais abaulado. Disso resulta, em certa posição, o aspecto triangular do casulo da Fig. 37. O comprimento do casulo (a base do triângulo) é de 0,16 - 0,18 mm.; o lado menor do triângulo, de $0,096 \mathrm{~mm}$; o maior, de $0,12 \mathrm{~mm}$; . a altura, de 0,09 $\mathrm{mm}$. No polo mais obtuso do casulo reconhece-se o opérculo, enquanto a casca ainda se forma e tem côr amarela clara. Quando a casca se escurece, a sutura opercular não se distingue mais. Reaparece pouco antes da eclosão do embrião (Hein 1928, p. 476), quando êste acaba de consumir a vitelo opaco e se torna transparente.

\section{Sôbre a ocorrência e a biologia de Microdalyellia (G.) evelinae}

Os primeiros exemplares da espécie atual encontrámos, em setembro de 1944, na lagôa da Corôa, no bairro de Canindé da cidade de São Paulo. Com plantas do habitat natural foram criados, durante três mêses, no aquário. Alface cozida serviu para aumentar os organismos alimentícios de $M$. (G.) evelinae que come pedaços de rermes dos gêneros Aeolosoma e Dero, detrito rico em hactérias e Catenula lemnae. Pelo que observámos em vários anos de manutenção de pequenoz animais dágua doce, Catenula lemnae geralmente não é comida por outros animais.

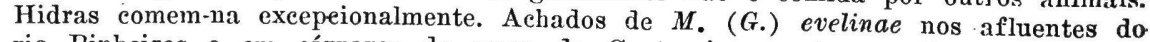
rio Pinheiros e em córregos da serra da Cantareira revelam a "euryoequia" da espécie que é, nos arredores da cidade de São Paulo, a mais comum da família. A permanêneia dos casulos no útero varia; uma vez, evacua-se um casulo aúreoamarelo; outra vez, um vermelho-acastanhado; ou um escuro castanho. Os casulos foram no aquário grudados às plantas e às conchas de Australorbis e das Ancylidae, mais raramente, ao fundo. Os vermes nadam elegantemente, girando ao redor do sou eixo principal. A observação debaixo da lâminuła mostra que os élios podem local e temporàriamente parar, em oposição ao que foi visto, por Alverdes (1922, p.
$303)$, em Dalyellia viridis. 


\section{Discussão sistemática de Microdalyellia (G.) evelinae}

A espécie faz parte do grupo 2 (rubra) de Gieysztoria, subgrupo 1, seç̧ão iA (triquetra). Os dois aparelhos cuticulares mais semelhantes são os de $M$. (G.) triquetra (Fuhrmann) e triangulata (Robeson), já mencionados na diagnose precedente, ambos com disposição triangular dos espinhos. Bôas figuras de triquetra encontram-se nos trabalhos de Hofsten (1907, t. 26 f. 4, corte transversal; 1911, t. 1 f. 9) e de Steinböck (1932, p. 215, f. 2, aparêlho total); o órgão de triangulata foi bem desenhado por Robeson (1931, p. 610, f. 16).

\section{Microdalyellia (Gieysztoria) hymanae ${ }^{*}$ ), spec. nov. (Fig. 38-40)}

O comprimento dos vermes é de 0,6 - 0,8 mm.; o diâmetro, de 0,2 - 0,3 mm. A Figura 38 foi desenhada dum indivíduo ligeiramente comprimido. A cauda, cujas papilas adesivas ( $k$ ) às vêzes não se salientam, é curta, mas, nítida. A côr do parênquima é alaranjada ; a do cálice ocular, preta. Na epiderme, ocorrem pequenos rabditos escassos e avulsos, como também inclusões refrativas, re-encontradas em $M$. (G.) bellis (Fig. $75, \mathrm{i})$.

A faringe (h) tem $0,2 \mathrm{~mm}$., ao comprido; $0,15 \mathrm{~mm}$., de grossura e é destituida de papilas e cílios anteriores. $O$ intestino (i) estende-se além da metade anterior do corpo. Na entrada do intestino, ocorrem as células glandulares aprofundadas (p), comuns nas Dalyelliidae.

Os testículos (Fig. 38, t) oblongos situam-se atrás do intestino. Do terço anterior dêles saem, no lado medial, os dutos eferentes (d) que entram na calota ectal (proximal) da vesícula seminal (Fig. 39, v), que é pequena. No espaçoso reservatório da secreção granulosa (r), esta ocupa o centro ental, ao passo que uma massa espumosa ( $\mathbf{x})$, a massa alveolar de Vejlovsky (1895, p. 132), Meixner (1915, p. 510), e Reisinger (1924c, p. 259: "massas faviformes de secreção") preenche o resto do lume do reservatório, deixando livre apenas estreito canal central, o duto ejaculatório.

O aparelho cuticular $(\mathrm{z})$, com $0,06 \mathrm{~mm}$. de alto, compõe-se do anel proximal. das pontes, do anel distal, e dos espinhos. $\Lambda$ interrupção dos aneis situada dorsalmente é de pequena estensão (Fig. 40). A escultura do anel proximal consiste em fibras ondeadas, transversais. Para fora, ajuntam-se ao anel proximal as pontes nítidas, que deixam ventro-medianamente uma lacuna retangular. Sem relação topográfica com-as pontes, saem do anel distal estreito os espinhos, dos quais há grossos (Fig. 40, g) e. finos (f). Ocorrem 4 espinhos grossos; entre dois grossos, situam-se, cadla vez, 4-6 finos. Em carla lado da brecha dorso-mediana, notam-se dois espinhos finos. Contando êstes como perfazendo dois grupos, chegamos ao total de 5 grupos de espinhos finos, em oposição a 3 em $\boldsymbol{M}$. (G.) evclinae. Os espinhos são todos ocos; dirigem os seus orifícios proximais para fora. Os bordos dos espinhos grossos, em que os músculos abdutores (Fig. 39, m) se inserem, são lisos, desprovidos das saliências gibosas ocorrentes em $M(G$.$) evelinae.$

*) A espécie foi denominada em homenagem à Dr. Libbie H. Hyman, American Museum of Natural History, New York. 
O ovário (Fig. 38, o) é curto; do oviduto salienta-se o receptáculo seminal (1), mas, não possue, nos indivíduos examirados, um duto especial. O duto comum (c), pouco musculoso, recebe o viteloduto (n) e dois tufos de glândulas da casea $(\mathrm{s})$. Os vitelários $(\mathrm{y})$ : lobulados estendem-se até o nível da faringe (h), e reunem-se dorsalmente ao intestino (i).

O casulo (u), no útero, é ovóide, medindo $0,13 \mathrm{~mm}$. , ao comprido; $0,07 \mathrm{~mm}$., de grossura. No útero, notaram-se espérmios livres, que ocorrem também avulsos, não reunidos em espermatóforos, na bursa copulatória (q). Nesta, reconhece-se, em alguns exemplares, a pseudo-cutícula descrita por Reisinger (1924e, p. 268), originada pelas partes basilares do epitélio bursal. Ao redor do gonóporo, situam-se as glândulas argamassadoras, de secreção moniliformemente disposta.

Ocorrência: 1) Num brejo, perto do rio Pirajussára, afluente do rio Pinheiros, ca. de $1 \mathrm{~km}$. ao sul de Butantan, em setembro e outubro de 1945. 2) Num pântano formado numa depressão do terreno de Brooklyn Paulista, subúrbio da cidade de São Paulo, em maio de 1946.

\section{Discussão sistemática de Microdalyellia (G.) hymanae}

A espécie mais vizinha de $M$. (G.) hymanae é $M$. (G.) evelinae. As diferenças principais são: 1) a ausência (hymanae) das saliências esculturadas (evclinae), em que os músculos abdutores se inserem nos espinhos grossos; a presença (hymanae) de mais dois espinhos finos dorsalmente a cada um dos espinhos grossos dorsolaterais e, destarte, de 5 (hymanae) grupos de espinhos finos, em vez de 3 (evelinae); a diferença menos pronunciada (hymanae) entre os espinhos grossos e finos, acentuada em evelinae; 2) a desembocadura ventro-ectal (hymanae) dos dutos eferent $:$ s na vesícula seminal, em contraposição à apical em evelinae; 3 ) o res rrvatório da secreção granulosa mais comprida que larga (hymanae), em oposição ao tão comprido quão largo, ou mais largo, de evelinae; 4) o receptáculo seminal simples e incluido no oviduto (hymanae), em lugar do vacuolizado e provido de duto, en evelinae; 5) o casulo ovóide (hymanae), não elipsóide e, em certa posição, triangular (evelinae).

\section{Microdalyellia (Gieysztoria) trisolena, spec. nov. (Fig. 41, 42, 45)}

Espécimes adultos medem 1-2 mm., ao comprido. O aspecto total é definido pela forma da cauda e pelas proporções da faringe e do intestino. A cauda é cuspidata e provida de $3-4$ papilas retrácteis. A faringe é comprida, e o intestino deixa livre o quarto posterior do corpo. Sobra, destarte, para as gônadas, apenas essa parte. O pigmento cinzento situa-se no parênquima; a côr é carregada nas zonas preenchidas por células em grande número, a saber, entre a faringe e o intestino e naquela região da parte caudal que não é ocupada pelos órgãos reprodutivos. Os olhos são pequenos, e a distância entre êles é maior que a existente entre cada um e o bordo lateral. Tal, porém, não se vê no desenho baseado $\mathrm{cm}$ vermes comprimidos (Fig. 41). Os rabditos formam grupos na epiderme, originando-se em células rabditógenas, subjacentes ìs epidérmicas.

A faringe tem de comprimento $0,3-0,4 \mathrm{~mm}$. e de diâmetro ('al. de $0,2-0,25 \mathrm{~mm}$. No bordo anterior, é provida de aproximadamente 20 papilas lisas, entre as quais se intercalam 5 tufos de cílios dispostos em intervalos iguais entre si. Dos músculos faríngess foram contaros ea. de 
18 anelares externos; 55 anelares internos; e 25-28 longitudinais internos. $\mathrm{Na}$ passagem da faringe ao intestino assinala-se a corôa das glândulas de secreção granulosa, eosinófila (Fig. 41, z), que desembocam na entrada do intestino.

Os testículos são pequenos e situados pronunciadamente na parte posterior (Fig. 41, t). Os dutos eferentes saem da extremidade rostral das gônadas masculinas. $\Lambda$ vesícula seminal (f) é volumosa e distintamente separada do reservatório da secreção granulosa (k).

No órgão copulador (p) distinguem-se o anel ental (proximal, rostral, anterior), a região das pontes, e os espinhas (Fig. 42). $O$ anel ental, de cutícula fina e ligeiramente estriada transversalmente, tem $0,012-0,014$ $\mathrm{mm}$. de altura e $0,04-0,06 \mathrm{~mm}$. de diâmetro. Sendo dorsalmente interrompido, é, realmente, um meio-anel. O seu bordo anterior é côncavo. A região das pontes é proximal e distalmente delimitada por aneis de cutícula mais espessa; entre as pontes destacam-se finas fibras cuticulares, como foram desenhadas, mais grossas, dum exemplar jovem de $\boldsymbol{M}$. (G.) experita por Meixner (1915, p. 499 f. G. no texto). Os espinhos são todos ocos (Fig. 45, p) e de mesmo comprimento, a saber, 0,08 $\mathrm{mm}$. O calibre, porém, é variável, havendo no meio e nos dois lados espinhos mais grossos e, entre o espinho mediano e os externos, 3-7 mais finos, em cada lado. O comprimento total do aparelho cuticular masculino é de $0,1-0,15 \mathrm{~mm}$.

O ovário é comprido e encurvado (Fig. 41, o); a sua túnica própria continúa como oviduto, cujo comprimento e diâmetro igualam à metade das medidas correspondentes do germário. $\Lambda$ supérfície melar do oviduto (Fig. 41, d) provem da disposição peculiar da membrana basilar dêste trecho. Ela se salienta por entre as células altas do epitélio do oviduto; as lamelas destarte formadas e alternadas com os citosomas provocam a aneladura como já foi dito por Hofsten (1907, p. 503). O corte (Fig. 45) mostra não se tratar de músculos anelares. Unilateralmente, dilata-se o oviduto, formando o receptáculo seminal (r). Nas células altas dêste, implantam-se os espérmios, e as consomem, a julgar pela diminuição sucessiva da substância dos citosomas (Luther 1904, p. 118-120; Hofsten 1907, p. 504; Meixner 1915, p. 506). Um esfincter (Fig. 45, s) separa o oviduto do duto comum (c), recebendo o último o viteloduto (w.) e as desembocaduras das glândulas da casca (g).

Os vitelários (Fig. 41, v) são pouco lobulados e relativamente inconspícuos. A disposięão periférica das células vitelógenas (e) e a central do vitelo (v) reconhecem-se pela Fig. 45. O casulo (u) no útero é de côr vermelho-acastanhada; seu diâmetro maior é de $0,17 \mathrm{~mm}$. e o menor mede $0,14 \mathrm{~mm}$. Esfincter forte (Fig. 45, m) separa o útero do átrio (Fig. 41, x). A bursa copulatória (Fig. 41, b) é um saco comprido revestido por epitélio alto e musculatura longitudinal interna e anelar externa (Fig. 45).

Ocorrência: Lagôa da Corôa, remanso do rio Tietê, no bairro de Canindé, na cidade de São Paulo; rio Tietê, entre Heteranthera reniformis, perto de Limão, subúrbio da cidade. 


\section{Discussão sistemática de Microdalyellia (G.) trisolena}

o hábito geral, o pênis e o oviduto anelado, aproximam a nova espécic a M. (G.) triquetra (Fuhrmann 189.4, p. 265), cujo aparelho cuticular se conhece pelos desenhos de Hofsten $(1907$, t. 26 f. 4 ; 1911, t. 1 f. 9) e Steinböck $(1932$, f. 2 no texto da p. 215). Os 3 espinhos grossos de trisolena não ocorrem em triquetra, em que há dois elementos maiores medianos e espinhos achatados, triangulares, cujo comprimento diminue em direção distal. Falta ainda, em triquetra, a profunda concavidade do anel ental. Steinböck nem mesmo admite a identidade específica do material japonês de triquetra (Okugawa 1930, p. 79). Em todo o caso, ultrapassam as diferenças entre trisolena e triquetra, de muito, a variação, aliás bastante estreita (Reisinger 1924 c, p. 292), como ocorre nas estruturas cuticulares masculinas das várias espécies das Dalyelliidae.

Comparando a anatomia dos outros órgãos de triquetra (Hofsten 1907, p. 529. 533) com a dos de trisolena notamos: testículos enormes (em trisolena, pequenos); e oviduto tão comprido quão o germário (oviduto com a metade do comprimento do germário em trisolena).

\section{Microdalyellia (Gieysztoria) acariaia, spec. nov. (Fig. 43, 46)}

Os vermes são pequenos, medindo $0,4-0,6 \mathrm{~mm}$. de comprimento; $0,2 \mathrm{~mm}$. de largura. $\mathrm{Na}$ extremidade anterior, são arredondados, quasi truncados; posteriormente, alongados e caudatos. A côr, pouco pronunciada, baseia-se num pigmento parenquimático escasso, acastanhađoeșcuro e de zooclorelas situadas nas células intestinais. Do aspecto total esverdeado-acastanhado destacam-se os vitelários brancos e os casulos ovulares castanho-avermelhados. A distância entre os dois olhos é maior que a existente entre caḍa um dêles e o bordo lateral; os cálices pigmentados são profundos.

A epiderme é grossa e contem, no dorso e nos lados, os rabditos reunidos em grupos de 2-6; no ventre, há grupos de 1.3 rabditos. O comprimento dos cílios locomotores ultrapassa a altura da epiderme. Cílios fortes, rígidos e muito longos, provàvelmente tácteis, acumulam-se nas extremidades cefálica e caudal. Na cauda arredondada ressaltam ainda ca. de 4 papilas adesivas (Fig. $46, \mathrm{~h}$ ).

A faringe mede ca. de $0,12 \mathrm{~mm}$., ao comprido e $0,08 \mathrm{~mm}$. de diâmetro. $\Lambda$ sua orla rostral é provida de 10 papilas largas sem cílios, dispostas de tal modo que 4 são dorsais ; 4 , ventrais; e uma situada em cada lado. $\mathrm{O}$ intestino (Fig. 46, i), mais comprido que a faringe, mostra, na sua entrada, as glândulas aprofundadas eosinófilas, correspondentes às clavas de Minot. $\Lambda$ secreção destas acumula-se em cálices intra-epiteliais.

Os emunctórios abrem-se com protonefridióporos (Fig. 46, p) situados no início do terço caudal. Daí corre o canal descendente para trás, até o nível da constrição do corpo. Aí, encurva-se para diante e reconhece-se, sempre na metade ventral do corpo, até a extremidade anterior (Fig. 46, n). Nêste ponto, passa à metade dorsal e corre, como canal ascendente, até a zona do estreitamento caudal.

Os testículos (Fig. 46, t) são pequenos; situam-se atrás do intestino, e emitem os dutos eferentes (Fig. 43, d), na sua extremidade rostral. A vesícula seminal $(x)$ é esférica; o reservatório da secreção granulosa (y).
cilíndrico e de parede grossa. 
O aparelho cuticular (Fig. 43), de 0,03-0,036 mm., ao comprido, compõe-se dum tubo central, aproximadamente claviforme, cujo diâmetro máximo é de 5 microns; e de 3 espinhos foliáceos e cuspidatos, menos compridos que o tubo central. Um espinho é dorsal; dois são ventro-laterais. As bases dos espinhos periféricos coalescem-se parcialmente, formando, destarte, uma estrutura anelar que lembra cesta. Essas bases são dilatadas e reticuladas.

O ovário (Fig. 46, o) situa-se no lado direito, ventralmente ans vitelários (v). Estes teem forma de duas salsichas, caudalmente reunidas e não são lobulados. O receptáculo seminal (Fig. 46, m) não se destaca permanentemente; é uma dilatação passageira, globosa, do oviduto. O último exibe, quando vazio, a aneladura' proveniente das lamelas intercelulares da membrana basilar descritas na diagnose da espécie precedente. No duto comum, desemboca o viteloduto, e entra a secreção das glândulas da casca (s). No útero saculiforme abriga-se o casulo $(\mathrm{u})$, de forma de limão. O seu diâmetro maior é de $0,12 \mathrm{~mm}$.; o menor, de 0,065 $0,07 \mathrm{~mm}$. A bursa copulatrix (b) é um saquinho pouco volumoso, mas, distintamente separado do átrio. Densa roseta de glândulas argamassadoras (f) circunda o gonóporo.

Ocorrência: As duas localidades em que a espécie foi encontrada são águas estagnadas, plenamente insoladas, com rica vegetação. Uma é um brejo perioddicamente sêco, $1 \mathrm{~km}$. ao sul do Instituto de Butantan, perto do rio Pirajussára (afluente do rio Pinheiros); no dia do achado houve pequenas quantidades dágua no brejo (9-X45). O outro habitat é uma poça, cuja parte central é perene, perto da ponte de Jaguaré, sem comunicação com o rio Pinheiros. Spirogyra, Azolla e Volvocidae caracterizaram esta poça na época da colheita (início de novembro e meados do dezembro de 1945).

\section{Discussão sistemática de Microdalyellia (G.) acariaia}

O aparelho cuticular, por princípio, anelar, define a espécie como Gieysztoria. Os testículos posteriores confirmam tal posição. Dos dois grupos do subgênero, podemos excluir, sem delongas, o chamado $10^{\circ}$ grupo (eastmani) cujo aparelho cuticular é constituido por espinhos separados. Do grupo 2 ( $r u b r a)$, o $2 .^{\circ}$ subgrupo com espinhos iguais entre si não poderia abrigar $M$. (G.) acariaia, pois, nesta é o tubo central mais comprido e mais grosso que os 3 espinhos eircunjacentes. A espécie atual entra, por isso, no 1.0 subgrupo, com espinhos do órgão copulador desiguais entre si. Dentro do dito subgrupo, faz parte da secção A, cujas espécies possuem disposição simétrica dos espinhos. M. (G.) acariaia diferé, porém, das outras espécies da $\cdot$ seç̧ão A pela falta de pontes. De resto, aproxima-se a $\boldsymbol{M}$. (G.) infundibuliformis (Fuhrmann 1894, p. 272), descrita, mais tarde (Hofsten 1907b, p. 12) com o nome de Dalyellia succincta. $\mathrm{O}$ tubo central do aparelho cuticular, a faringe e os vitelários são semelhantes em acariaia e infundibuliformis. Além de possuir pontes, exibe infundibuliformis outra disposição dos espinhos periféricos, que ainda são mais numerosos e menos compridos.

\section{Espécies de Gieysztoria com aparelho cuticular anelar, provido de espinhos desiguais entre si e assimètricamente dispostos}

Microdalyellia (Gieysztoria) complicata (Fuhrmann) (Fig. 47-48)

Vortex complicatus Fuhrmann 1894, p. 794-795 f. 1-2.

Dalyellia complicata Beauchamp 1939, p. 57-59 f. 2 no texto. 
Vermes adultos atingem $0,8 \mathrm{~mm}$. de comprimento e $0,2 \mathrm{~mm}$ de lar. gura. São caudalmente cuspidatos; anteriormente, arredondados. $\Lambda$ côr do parênquima é acastanhada, com tons violáceos. Os olhos distan um do outro mais que do bordo; a célula visual é refractiva. Os rabditos muito tênues formam grupos de 3-6 na epiderme. Entre os cílios, destacam-se alguns maiores, provàvelmente tácteis, na cabeça e na cauda.

$\Lambda$ faringe é mais curta (ca. de $0,2 \mathrm{~mm}$.) que o intestino, salientando. se. entre os dois trechos do canal alimentício, as glândulas de secreção acidófila (z).

Os testículos (t) são pronunciadamente posteriores; os dutos eferentes saem da região rostral das 'gônadas masculinas. A vesícula seminal (x) é relativamente rolumosa; o reservatório da secreção granulosa é quasi escondido pelo largo anel do órgão copulador.

$O$ aparelho cuticular (Fig. 48), cuja estrutura complicada motivou o nome da espécie, começa com um anel dorsalmente aberto, formado por cutícula reticulada. As malhas do retículo são maiores no bordo ental (proximal, rostral) do meio-anel, diminuindo sucessivamente para 0 bordo ectal (distal, eaudal). As expansões ectais do meio-anel são assimétricas. Pela sua complicação, subtraem-se a uma descrição pormenorizada. Sumàriamente podemos distinguir: 1) dois espinhos fortes (Fig. 48, a) e paralelamente encurvados para fora ; 2) uma corôa (b) de espinhos iguais entre si, convergentes; 3) uma escôva composta por espinhos (c), cujo comprimento e diâmetro diminuem do bordo do anel para fora. Os polígonos visíveis na Fig. 48 são as bases dêstes espinhos ocos; mostram o calibre máximo dos espinhos proximais (entais, rostrais) e a diminuição gradativa do mesmo em direção distal (ectal, caudal). $\mathrm{O}$ comprimento total do aparelho cuticular é de ca. de $0,1 \mathrm{~mm}$.

O ovário (Fig. 47; o) é curto e reto; os vitelários (v) do material de Fuhrmann e dos vermes atuais carecem de lóbulos; os espécimens de Beauchamp têm-nos fracamente entalhados. A bursa copulatória (b) é distintamente separada do átrio. 0 útero com o casulo elipsóide (u) estende-se para dentro da região estreitada, caudal. Nos animais aqui em mãos, o diâmetro maior do casulo é de $0,16 \mathrm{~mm}$.; o menor, de $0,08 \mathrm{~mm}$. Essas medidas concordam com a figura de Beauchamp; as de Fuhrmann são menores, mas o autor suisso dispôs apenas de vermes conservados. Provàvelmente, deve-se a essa condição desvantajosa do material também a indicação de Fuhrmann relativa a um pedúnculo do casulo que seria excepcional nas Dalyelliidae.

Ocorrência: Estado de Paraná, arrabaldes da cidade de Curitiba; no lodo dum rego de correnteza lenta, ao lado do rio Bariguy; Prof. Dr. P. Sawaya leg.

\section{Discussão de Microdalyellia (G.) complicata}

Obtivemos rico material vivente desta espécie que se manteve, durante vários mêses, no aquário, fixando os casulos acastanhados, com preferência, nas conchas das Ancylidae da mesma procedência. Até agora, não encontramos $M$. complicata nos arredores da cidade de São Paulo. Em prol de estudos futuros repetimos uma observação de Beauchamp (1939, p. 58): obteve vermes jovens de casulos postos por vermes isolados. Ocorre, portanto, auto-fecundação ou partenogênese nas Dalyel-
liidae. 
Sem o entendimento genial da morfologia, próprio a Beauchamp, não teriamos reconhecido o nosso material, nas figuras originais. Agora, porém, não hesitamos em seguir a Beauchamp.

Nistribuição geográfica: Colômbia, planalto de Bogotá, $2.650 \mathrm{~m}$.; Lago Titicaca, $3.840 \mathrm{~m}$., na parte peruana em sedimentos e no planeton.

\section{Microdalyellia (Gieysztoria) intricata, spec. nov. (Fig. 44, 50-52, 55)}

Os rermes adultos teem, no estado conservado, 0,75 $\mathrm{mm}$. de comprimento. São caudalmente estreitados: rostralmente arredondados. $\Lambda$ côr restringe-se a poucos grumos de pigmento pardo no parênquima e algumas inclusões, côr de mostarda, nas células intestinais. Os olhos, cujo grande cálice pigmentado se alonga pedunculadamente, distam mais do bordo do corpo do que entre si. Os rabditos formam grupos de 2-6 na epiderme. Papilas adesivas caudais não ocorrem, mas, glândulas grudadoras (Fig. 50, k).

A faringe, nos vermes fixados de $0,2 \mathrm{~mm}$., ao comprido, possue 10 músculos anelares externos na orla faríngea e 24 no corpo da faringe, sendo 65 o número dos músculos anelares internos situados entre os músculos radiais. As células glandulares com a sua secreção acidófila (e) na entrada do intestino são tìpicamente desenvolvidas. $O$ comprimento do intestino (i) iguala ao da faringe ou é menor.

Os testículos (Fig. 50, 51, t) situados na zona post-intestinal variam muito com respeito ao volume e à forma. Uma vez (Fig. 50), são tubularmente alongados e entram na cauda; outra vez, são ovóides e não atiıgem a região estreitada. Os dutos eferentes (d) podem sair da extremidade rostral dos testículos, mas, também, deslocar-se mais para o meio do bordo interno da gônada. São meramente continuações da túnica própria dos testiculos saculiformes. Entende-se que o lugar em que saem depende da distribuição dos espérmios. Se o saco testicular ficar alargado pelas massas de espérmios de tal modo que acaba formando um divertículo rostro-lateral, encurtar-se-há a parede oposta do saco e, com isso, a saida dos dutos será afastada da extremidade rostro-interna.

Os dutos eferentes, vindos do dorso, entram separadamente na calota ectal (caudal, inferior) da vesícula seminal (Fig. 50, x). No centro da vesícula reunem-se, e o duto seminal corre até o polo ental (rostral, superior), onde se abre. Dobras parietais separam a vesícula do reservatório da secreção granulosa (y). Esta se concentra esfèricamente no reservatório, cuja parede é grossa, e cuja parte inferior é circundada pela cutícula do pênis (Fig. 52, z).

No aparelho cuticular (Fig. 44, 55) notam-se estruturas que se assemelham às de $M .(G$.$) complicata. Ocorre o mesmo meio-anel, dorsal-$ mente aberto, cuja parte superior (ental) é reticulada; a inferior, provida de nódulos e traves. A assimetria dos apêndices ou expansões do bordo ectal observa-se em intricata como em complicata. mas, todos os elementos são diferentes. 1) Dos espinhos fortes, encurvados para fora e situados no lado direito de complicata, existe apenas um muito forte (Fig. 55, a), encurvado para dentro, e provido de pêlos cuticulares. 2) Mais para o meio, ocorre, em vez da corôa com espinhos convergentes, um complexo heterogêneo (b). Compõe-se de 3 espinhos de comprimento e direção 
variáveis, entre os quais há uma placa provida de espinhos ocos. 3) Uma escôva de espinhos ocos, não retos, como em complicata, mas, encurvados na ponta e, em oposição a complicata, com aumento gradual do comprimento e•do calibre em direção distal. 4) Externamente, no lado esquerdo, salienta-se um espinho grosso (d), sem estrutura homóloga em complicata, que exibe pêlos cuticulares. Nos espinhos maiores, quer dizer, no direito (a), no mais comprido do complexo paramediano (b), e no extremo esquerdo (d), ocorrem traves transversais. O comprimento total do aparelho cuticular é de $0,12 \mathrm{~mm}$.

O ovário (Fig. 50, o) é muito comprido; os vitelários são massiços e destituidos de lóbulos. O receptáculo seminal (m) faz parte do oviduto, constituindo uma simples dilatação do mesmo. $\mathrm{O}$ duto comum recebe o viteloduto e grande número de glândulas da casca (s). No útero (u) abrigase o casulo ovóide, cujo diâmetro maior é de $0,15 \mathrm{~mm}$. em vermes conservados. A casca do casulo no útero permanece amarela. Uma vez, observou-se o embrião, já com grandes olhos, dentro do casulo contido ainida no útero. A bursa copulatória (b) é volumosa e de parede musculosa, sendo ainda forte a musculatura anelar do átrio. Glândulas argamassadoras basófilas circundam o poro genital (Fig. 51, p).

Ocorrência: Obtivemos material suficientemente rico desta espécie numa poça, não longe do rio Tietê, mas, sem comunicação com êste, situada no subúrbio de Vila Leopoldina, entre Salvinia (no verão de 1943-1944); alguns exemplares foram, além disso, colhidos em fins de novembro de 1945, num brejo perto do rio Pirajussára, e (XII. 1945) numa poça isolada num prado perto da Avenida Thomas Edison.

\section{Discussão sistemática de Microdalyellia (G.) intricata}

Da espécie mais semelhante, $M$. (G.) complicata, a atual já foi suficientemente discriminada na descrição do aparelho cuticular. M. (G.) okugawai Ruebush \& Haycs (1939, p. 149, nota 11), descrita com o nome já anteriormente usado (Fulinski \& Szynal 1927, p. 158, 163) de Dalyellia gracilis por Okugawa $(1930$, p. 81), pertence, como dissemos anteriormente (veja p. 36), ao subgênero Gieysztoria. Possue 4 espinhos distais e uma projeção mediana, lembrando um dos distais uma lanterna, porquanto se compõe de ca. de 10 espinhos unidos. O estreitamento anterior constitue sinal invulgar da espéeie japônica; a sua faring€ é notàvelmente pequena. $M$. (G.) thienemanni (Reisinger 1933, p. 251) tem 5 espinhos distais, dos quais um se divide terminalmente em 4-5 ramos paralelos. Nesta espécie, o comprimento da faringe do verme adulto ultrapassa de duas vèzes o do intestino, atingindo a faringe quasi o meio do corpo. A espécie do Japão e a da ilha de Java não são idênticas; ambas diferem muito de $M$. (G.) intricata, eujo aparelho cuticular parece ser o mais .complicado entre tôdas as Dalyelliidae atualmente cornhecidas.

\section{Microdalyellia (Gieysztoria) uncia, spec. nov. (Fig. 49, 53)}

O comprimento dos vermes sexualmente maduros é de $0,6-0,8$ mm.; a largura, de 0,15-0,2 mm. A côr é cinzento-acastanhada; além dêste pigmento parenquimático, notam-se, ocasionalmente, substâncias alimentícias, de côr verde, no lume do intestino. A forma do cálice pigmentado dos olhos varia, ora é mais reniforme, ora em forma de gamela, ou quasi esférico. Os rabditos, reunidos em grupos de 2-8, são escassos na epiderme ventral ou faltam aí. Cílios provàvelmente tácteis destacamse na cabeça e na cauda. Na última, ocorrem 4-8 papilas adesivas dispostas em duas séries longitudinais (Fig. 53, h). 
A bôca (a) situa-se mais perto da extremidade anterior do que na maioria das espécies do gênero. $O$ comprimento da faringe é de $0,18 \mathrm{~mm}$.; o diâmetro, de $0,1-0,14 \mathrm{~mm}$. $O$ bordo rastral da faringe mostra 8 papilas destituidas de cílios. Na entrada do intestino, ressaltam as glândulas (e) de secreção granulosa, acidófila. A longura do intestino é bem maior que a da faringe.

Os testículos (Fig. 53, t) ocupam posição posterior e são pequenos; os dutos eferentes (d) saem da sua extremidade rostral. A vesícula seminal $(x)$ é inconspícua; a secreção granulosa no reservatório (y) é pouco refrativa.

O pequeno aparelho cuticular (Fig. 49) é um meio-anel largamente aberto no lado dorsal; a sua cutícula exibe escultura fibrilar. Situa-se, como geralmente nas espécies de Gieysztoria com espinhos desiguais e assimétricos, rostralmente ao fundo do intestino, i. é, bem para diante. Os espinhos do bordo ectal do meio-anel formam uma série contínua, mas, composta por dois grupos heterogêneos. O grupo direito abrange 4 espinhas grandes, até $0,018 \mathrm{~mm}$., ao comprido. O esquerdo contem grande número de espinhos menores, com 0,007 - 0,012 mm. O grupo esquerdo estende-se além do meio para o lado direito, tornando-se, com isso, a assimetria mais pronunciada ainda. $\mathrm{O}$ comprimento total do aparelho cuticular é de $0,027 \mathrm{~mm}$; a largura, $0,024 \mathrm{~mm}$.

O ovário (Fig. 53, o) varia em comprimento; pode ser tão longo que entra na zona caudal estreitada, Nêstes casos, sae o oviduto para diante, formando ângulo agudo com o germário. O receptáculo seminal $(\mathrm{m})$ faz parte do oviduto, dilatando-o. O duto comum, com a entrada do viteloduto e as glândulas da casca (s), corresponde ao tipo encontrado regularmente nas espécies de Gieysztoria. Os dois vitelários (v), sem lóbulos, reunem-se dorsalmente ao fundo do intestino. O útero aprcsenta-se, quando razio, como saco enrugado entre o duto comum e o átrio. $O$ casulo (u) ovóide tem de diâmetro maior $0,12 \mathrm{~mm}$., e de estensão menor $0,075 \mathrm{~mm}$. No seu polo mais arredondado, reconhece-se, nas fases da formação da casca, a sutura do opérculo. A bursa copulatória (b), ęn que várias vêzes encontrámos massas de espérmios, comunica-se com o átrio por um duto fortemente musculoso. $O$ orifício do átrio (poro genital, p), circundado por glândulas argamassadoras, situa-se mais rostralmente do que é a regra nas espécies vizinhas.

Ocorrência: Em poças perenes proximas à ponte de Jaguaré (rio Pinheiros), separadas do rio, com rica vegetação (maio e dezembro de 1945) ; poucos exemplares.

\section{Discussão sistemática de Microdalyellia (G.) uncia}

A espécie mais vizinha de $M$. (G.) uncia é $M$. (G.) pavimentata (B.klemischev 1926 , p. 243,247 f. 9 , com 8 papilas lisas no bordo anterior da faringe, mas, muito menor e com aparelho copulador alongado $(0,028 \mathrm{~mm}$. num verme de $0,3 \mathrm{~mm}$.). i altura do meio-anel ental do órgão cuticular ultrapassa de mais de dnas vêzes o comprimento dos espinhos, sendo ainda a escultura do anel e, também, os pormenores dos espinhos diferentes em pavimentata e uncia. 


\section{Microdalyellia (Gieysztoria) therapaina, spec. nov. (Fig. 54, 56)}

Vermes adultos teem de comprimento ca. de $0,7 \mathrm{~mm}$. e de largura $0,2 \mathrm{~mm}$. A côr baseia-se no pigmento parenquimático, que varia de vermelho-acastanhado a cinzento-negrejante, e no conteúdo verde do intestino; zooclorelas não ocorrem. Os olhos pequenos distam um do outro tanto quanto cada um dista do bordo. Os rabditos mostram a distribuição comum em pequenos grupos. O comprimento dos cílios locomotores é um. pouco maior que a altura das células epidérmicas; na cabeça truncada e na cauda estreitada notam-se estereocílios, provàvelmente tácteis. Há 3-9 papilas adesivas caudais (Fig. 56, h), cuja função de âncora pôde ser observada.

A faringe de $0,18 \mathrm{~mm}$., ao comprido, e de $0,12 \mathrm{~mm}$. de diâmetro, possue 10 papilas lisas no seu bordo rostral. São 4 papilas dorsais; outras tantas ventrais; e uma pequena em cada lado. As glândulas (Fig. 56, e) na entrada do intestino são volumosas. $O$ intestino (i), aproximadamente tão comprido quão a faringe, continha, nos vermes examinados a respeito, Diatomáceas, Protozoos verdes e Rotatórios.

Os testículos (t) situam-se caudalmente ao intestino. São pequenos e esféricos, de maneira que a saida dos dutos eferentes (d), por princípio rostral, não pode ser verificada, em muitos casos. Os dutos entram na calota ectal (distal, caudal, inferior) da vesícula seminal ( $\mathrm{x}$ ). A forma e o volume desta variam, em relação com o reservatório da secreção granulosa, conforme o gráu de enchimento da vesícula. O reservatório é ventralmente coberto pelo órgão copulador.

O aparelho cuticular (Fig. 54) tem ca. de $0,033 \mathrm{~mm}$. ao comprido, dos quais $0,013 \mathrm{~mm}$. cabem à altura do meio-anel ental, êste de cutícula muito fina com fibras entrelaçadas. Dorsalmente, nota-se a descontinuidade do anel conhecida de muitas espécies do subgênero. No lado. direito do semi-anel, destaca-se, em alguns exemplares, uma janela transparente aproximamente circular. O diâmetro do meio-anel é de ca. de $0.02 \mathrm{~mm}$. Entre os apêndices distais (ectais, caudais) do anel podemos. distinguir: 1) no lado direito, um pente pedunculado (Fig. 54, a); 2) um espinho ventro-mediano (b), encurvado, com $0,02 \mathrm{~mm}$. de comprimento, e com $0,007 \mathrm{~mm}$. de grossura; 3) para a esquerda, uma série de espinhos (c), cuja forma lembra escôva de dentes; 4) mais uma série de espinhos finos (d), também no lado esquerdo, mas, estendida até a face dorsal.

O ovário (Fig. 56, o) é curto ; o receptáculo seminal $(\mathrm{m})$, uma dilata(:ão simples do oviduto. Nêste, nota-se ligeira aneladura, provinda de dobras da membrana basilar. Um tufo de glânidulas da casca (s) e o viteloduto desembocam no duto comum; os vitelários (v) brancos não se ramificam.

O casulo (u) no útero permanece, por via de regra, com casca clara; o seu diâmetro maior é de $0,145 \mathrm{~mm}$; ; o menor, de $0,09 \mathrm{~mm}$. O opérculo da casca do ovo situa-se no polo mais cuspidato do casulo. A bursa copulatória (b), no material examinado sempre vazia, é um saco volumoso. A bursa é prêsa por um músculo à parede do corpo; na sua comunicação 
com o átrio, a bursa é provida de fortes músculos anelares. Ao redor do poro genital (p) dispõem-se as glândulas argamassadoras.

Ocorrência: A espécie foi colhida, em janeiro e abril de 1946, no lago de Umuarama (município de Campos de Jordão, Estado de São Paulo), na serra da Mantiqueira, a $1750 \mathrm{~m}$. de altura. O lago construido por estancamento parcial do leito de um rio é atravessado pela correnteza rápida de vários córregos. Nágua muito rasa, dentro da rica vegetação marginal, ocorrem os vermes não raramente.

\section{Discussão sistemática de Microdalyellia (G.) therapaina}

Certa semelhança com o aparelho cuticular da espécie atual apresenta $M$. (G.) virgulifera (Plotnikow 1906, fide Graff 1913, p. 123), cuja anatomia foi bem descrita por Hofsten (1907b, p. 5; 1912, p. 614: Dalyellia pallida). O aparelho cuticular e as suas variações estudou Beklemischev (1926, p. 237, 245 f. 1-8). Esta espécie tem testículos enormes, que ocupam tôda a região entre a zona do intestino posterior e a extremidade caudal. Os dutos eferentes desembocam no ápice, i. 6 , na calota ental (proximal, superior) da vesícula seminal. Os 4 apêndices do semianel são espinhos, em parte, aculeados, mas, todavia, bastante diferentes das estruturas complexas de therapaina. M. (G.) virgulifera vjatkensis (Nassonov 1919, p. 632 t. 3 f. 1) possue apenas um dos espinhos mais curto que os outros; não é mais próxima a therapaina que a forma típica de virgulifera.

\section{Microdalyellia (Gieysztoria) thymara, spec. nov. (Fig. 57-59)}

Os vermes são esbeltos; anteriormente, arredondados; posteriormente, estreitados e de cauda curta. O comprimento dos animais adultos é de ca de $0,7 \mathrm{~mm}$; os dois lados podem apresentar os bordos paralelos (Fig. 59 ) ou, ao nível entre o segundo e o último terço, ser algo dilatados. A côr acastanhada do parênquima acumula-se, especialmente, ao redor dos testículos (Fig. 59, t) e da vesícula seminal (s). Zooclorelas abarrotam as células intestinais. Os olhos possuem cálice pigmentado medialmente cuspidato. Entre os cílios destacam-se numerosos estereocílios na extremidade anterior e alguns na posterior. Os rabditos são numerosos e reunidos em grupos. As papilas adesivas são curtas, pouco salientes (g), distinguindo-se dois campos destas.

A faringe (h), cujo comprimento é de ca. de $0,13 \mathrm{~mm}$., possue 10 papilas sem cílios, das quais duas laterais são menores que as 8 dorsais e ventrais. Dos músculos, são os anelares externos especialmente fortes. $O$ intestino (i) mostra dois divertículos ímpares medianos, um anterior (x), subjacente à faringe $(\mathrm{h})$, e outro, posterior (y), estendido, para trás, até além da região dos órgãos reprodutivos. Na entrada do intestino, ocorrem, como geralmente, as células glandulares aprofundadas de secreção granulosa. Foram verificados Rotatoria no lume intestinal.

Os testículos ( $t$ ) podem ser muito compridos e estender-se, aproximadamente, por todo o terceiro quarto do corpo. $\mathrm{Na}$ extremidade rostral dos testículos, saem os dutos eferentes (e), que desembocam na vesícula seminal (s) ao nível do limite desta com o reservatório da secreção granulosa (k). Testículos, dutos eferentes e vesícula são circundados pelo pigmento parenquimático acastanhado. A vesícula é anteriormente esférica; posteriormente, achatada. A secreção granulosa dispõe-se, no 
reservatório, em dois pacotes $(\mathrm{k})$. O reservatório continua, para fora, como duto ejaculatório, cingido pelo anel do órgão copulador.

$O$ aparelho copulador tem $0,07 \mathrm{~mm}$. de altura, cabendo $0,02 \mathrm{~mm}$. ao anel, 0,05 aos apêndices. A descontinuidade comumente encontrada no perímetro dorsal do anel localiza-se, em $M$. (G.) thymara, no lado esquerdo (Fig. 57-58). A reticulação da cutícula do anel e as suas traves fibrilares entrelaçadas correspondem ao tipo comum do sub-gênero, mas, os 3 apêndices são muito peculiares. No meio do lado ventral, salienta-se uma formação que lembra uma escôva. Compõe-se de aproximadamente 150 cerdas finas, convergentes e dirigidas para o lado dorsal. São dispostas de tal modo que surge um desenho semelhante ao dos músculos estriados, em que se alternam zonas transversais de refração simples e dupla. Provàvelmente, as cerdas sobrepõem-se umas às outras. No lado direito, há uma haste proeminente, ectalmente provida dum pente formaido por 4-5 dentes curtos, que são rígidos e grossos. Do lado dorsal e esquerdo, sae outra haste, mais comprida que a direita, que termina com 6-7 espinhos, dos quais o externo é quasi reto; o interno, quasi semi-circular. O aparelho cuticular situa-se ventralmente ao intestino, como em $M$. (G.) thicnemanni, não caudalmente a êste, como na maioria das espécies do sub-gênero. A posição rostral do aparelho copulador torna a bainha do pênis especialmente comprida.

O ovário (Fig. 59, o), situado no lado direito, é reto e de longura medíocre. O oviduto apresenta as dobras conhecidas da membrana basilar; contem o receptáculo seminal, que é uma dilatação do oviduto, sem canal especial. As glândulas da casca e os vitelodutos desembocam no duto comum. Topogràficamente, distingue-se a via eferente feminina do tipo regular do sub-gênero, por ser situada longamente para trás. Os vitelários $(v)$, de contornos lisos, estendem-se, para diante, até a região anterior do intestino.

O casulo (u) no útero possue um polo mais obtuso que o outro; o diâmetro maior é de $0,1 \mathrm{~mm}$.; o menor, de $0,07 \mathrm{~mm}$. A bursa copulatória (r) estende-se extraordinàriamente para diante e comunica-se com o átrio por meio dum canal comprido, provido de músculos anelares fortes. Na bursa, e na vesícula seminal, os espérmios foram encontrados dispostos com regularidade. Da bursa, pendem as caudas dos espérmios para dentro do canal da mesma. O comprimento dos espérmios é de $0,1 \mathrm{~mm}$., sendo a metade anterior grossa a granulosa.

Ocorrência: 1) Nos arredores da cidade de São Paulo (Vila Sta. Maria), entre plantas aquáticas (Myriophyllum) e inundadas (capim) dum córrego que desemboca, perto da "Cachoeirinha", no rio Cabuçú; população grande. 2) Num pântano do "Brooklyn Paulista" (subúrbio da cidade de São Paulo), numerosos indivíduos.

\section{Discussão sistemática de Microdalyellia (G.) thymara}

Das 13 espécies de Gieysztoria com órgão copulador aproximadamente anelar (grupo 2), espinhos desiguais (subgrupo 1), assimétricos (seç̧ão B), as seguintes possuem os espinhos quasi continuadamente dispostos: complicata (n. 3 da lista, na p. 35) ; pavimentata (4); beltrani (6); intricata (9); e uncia (10). Espinhos mais isolados, compridos e ondulados ocorrem em: dodgei $(2)$; minima (7); e cypris (13). Grupos de espinhos (escôvas, pentes) e, além disso, espinhos isolados observam-se em: virgulifera (1); okugawai (5); thienemanni (8); e therapaina (11). Evidencia-se, 
destarte, M. (G.) thymara diferente das outras espécies da seç̧ão B pelos três grupos de espinhos, sem espinhos avulsos. Os divertículos intestinais constituem outro sinsl específico, grandemente invulgar.

\section{Microdalyellia (Gieysztoria) cypris, spec. nov. (Fig. 60-63)}

Os poucos vermes observados não ultrapassaram $0,7 \mathrm{~mm}$. de comprimento. O corpo do animal lembra um barril; a cauda é grossa; o intestino (i), muito curto, embora maior que em $M$. (G.) thienemanni. A côr é pouco pronunciada, havendo só pouco pigmento acastanhado no parênquima. $\mathrm{O}$ cálice pigmentado dos olhos é posteriormente algo mais largo que anteriormente. Os rabditos são pequenos e escassos. As papilas adesivas salientam-se pouco.

A faringe (h) mede $0,2 \mathrm{~mm}$. ao comprido; o intestino incolor (i) é de longura igual ou um pouco menor. O bordo faríngeo anterior é destituido de cílios e papilas. Na entrada do intestino, observam-se as glândulas aprofundadas de secreção granulosa, comumente encontradas nas espécies das Dalvelliidae.

Os testículos (t) situam-se ná região posterior, isenta do intestino. Dêles saem os dutos eferentes muito compridos. Conduzem os espérmios $\grave{a ̀ ~ v e s i ́ c u l a ~ s e m i n a l ~(s), ~ q u e ~ s e ~ e n c o n t r a ~ a ̀ ~ a l t u r a ~ d a ~ f a r i n g e . ~} O$ limita entre a vesícula e o reservatório (k) da secreção granulosa coincide, aproximadamente, com o nível entre a faringe e o intestino. $O$ reservatório é um cilindro comprido, de parede grossa. No pequeno material disponível, observou-se apenas exígua quantidade de secreção granulosa.

A bainha do pênis, musculosa e longa, contem o aparelho cuticular (c), cujo anel proximal, reticulado e fibrilar, ocupa posição obliqua. O anel possue a sua altura máxima no lado dorsal; ventralmente é aberto. Nos seús dois lados saem duas hastes triangulares, cada uma com ca. de 8 espinhos (Fig. 62-63). Os espinhos da haste direita encurvam-se para fora; os esquerdos, primeiramente, para dentro, mais distalmente, para fora. Os espinhos proximais (entais) são tão compridos que terminam ao nível dos curtos distais (ectais) ou mesmo sobressaem a êstes.

Pelo que foi observado, os órgãos femininos não oferecem sinais específicos. O receptáculo seminal $(\mathbf{r})$ faz parte do oviduto. $O$ útero (u) dos indivíduos vistos por nós estava vazio. O canal da bursa copulatória (b) é musculoso, medìocremente comprido, e conduz à empôla circundada por músculos espiralmente dispostos. 0 átrio espaçoso abre-se pelo gonóporo (p), ao redor do qual ocorrem músculos anelares.

Ocorrência: Só uma vez colhemos poucos exemplares, na localidade perto da Vila Sta. Maria (arredores da cidade de São Paulo) indicada com 1) na espécie precedente.

\section{Discussão sistemática de Microdalyellia (G.) cypris}

Apesar da escassez do material obtido, que impossibilita uma diagnose completa, a espécie revela-se como segura pela posição da vesícula seminal e pelo comprimento do reservatório da secreção granulosa. Niêstes caracteres, aproxima-se a $M$. (G.) thienemanni, cuja faringe é mais comprida; o intestino, mais curto; e o aparelho cuticular completamente diferente. O Gltimo distingue $M$. (G.) cypris 
facilmente de tôdas as espécies do grupo 2, subgrupo 1, secção B. A espécie menus distante parece ser $M$. (G.) dodgei, mas, os pormenores do órgão copulador diferem demais para justificar mesmo uma comparação detalhada.

Espécies de Gieysztoria com aparelho cuticular anelar, provido de espinhos de tamanho e forma semelhantes; receptáculo seminal presente

\section{Microdalyellia (Gieysztoria) ornata (Hofsten) (Fig. 64, 66-68)}

t. 26 f. 2.

Dalyellia ornata Hofsten 1907, p. 525-528 t. 24 f. 12,19 ; t. 25 f. 4, 13-14;

Referências principais: Hofsten 1911, p. 26 t. 1 f. 7 ; 1912, p. 581, f. 3; p. 612.

Graff 1913 , p. 95 f. 100.

t. 31 f. 43.

Meixner 1915, p. 478 , f. E no texto (p. 483 ) t. 30 f. 2, 10, 19-21, 23-26;

Luther 1918, p. 48 (nágua salobra do golfo da Finlândia).

Beauchamp 1920, p. 302 .

Reisinger 1924c, p. 293.

Nassonov 1924, p. $332 ; 1924$ a, p. $40 ; 1925$, p. 61.

Gieysztor 1931, p. 138 t. 14 f. 6; 1938, p. 223 (aí, Microdalyellia o.) t. 10 f. 10.

Ruebush \& Hayes 1939, p. 149, 150 (também nota 14), 151, f. 5 D (p. 146).

O comprimento dos vermes do material original atinge $1, \overline{\mathrm{mm}}$; 0 dos de Meixner, $1 \mathrm{~mm}$; o dos atuais, sòmente $0,8 \mathrm{~mm}$. A largura máxima é de $0,2 \mathrm{~mm}$. A cauda demarca-se nìtidamente; é provida, nos nossos espécimes, de 4 papilas adesivas (Fig. 67, z); nos de Meixner, de 2-5. A côr chamou Hofsten de acastanhado-vermelha; nos animais aqui em mãos é alaranjada; Meixner viu zooclorelas no intestino. Os olhos são bem distantes um do outro (w); o cálice pigmentado é profundo. A longura dos cílios locomotores é maior que a altura das células epidérmicas, havendo ainda estereocílios maiores, tácteis, na eabeça e na cauda. Os rabditos mostram a reunião habitual em grupos; os dorsais são maiores (6 até quasi 8 microns) que os ventrais (5.6 microns). Entre os bastonetes grudadores produzidos pelas glândulas caudais $(\mathrm{k})$ há grandes (até 6 microns) e pequenos (1 micron).

Dos músculos dermáticos, os anelares são tênues; os longitudinais, mais fortes, especialmente no dorso, onde se reconhecem, em forma de fitas, nos cortes tangenciais.

A faringe (Fig. 66, h) mede, em vermes viventes, até $0,15 \mathrm{~mm}$. de comprimento e $0,1 \mathrm{~mm}$. de largura. A orla faríngea é anteriorinente um pouco entalhada, porém, sem papilas verdadeiras e sem cílios. Hofsten contou 19 músculos anelares externos; $48-50$ internos; e 26 longitudinais internos. Quanto ao epitélio faríngeo e às glândulas aprofundadas (x), na entrada do intestino, repetem-se as estruturas descritas na diagnose de M. (G.) evelinae (p. 37). Os citosomas das glândulas cianófilas (mucosas, na terminologia de Hofsten 1907) situam-se na região ectal da faringe; os das eritrófilas ("salivares"), na ental, formando cada tipo uma corôa. Os dutos compridos correm um ao lado do outro na orla, alternando os cianófilos com os eritrófilos. Cada duto encontra-se no interstício entre duas séries dos músculos radiais. Na espécie atual, observou Hofsten (1907, p. 487) três aneis nervosos faríngeos, um grosso, no limite entre 
a orla e o corpo; e dois finos, um no corpo, perto da parede dorsal; o outro, na parte rostral da orla, entre os dutos das glândulas. $O$ intestino (i) é nitidamente mais comprido que a faringe.

Os testículos ( $\mathrm{t}$ ) são grandes sacos ovóides, que se estendem dum plano transversal pouco posterior ao meio do corpo até o gonóporo ou mais para trás ainda. Relativamente ao intestino e aos vitelários (d), situam-se as gônadas masculinas ventralmente. Os dutos eferentes (e) não vistos por Hofsten saem rostral ou quasi rostralmente dos testículas. A indicação de Meixner (1915, p. 492) referente à saida dos dutos ao nível do terço caudal dos testículos deve ser corrigida. Pelo que vimos em $M$. (G.) intricata, parece, todavia, possivel certo deslocamento dos dutos da extremidade rostro-medial, se houver acumulação dos espérmios num divertículo testicular rostro-lateral. Os dutos desembocam na constrição entre a vesícula seminal (Fig. 68 , v) e o reservatório da secreção granulosa $(\mathrm{g})$. A vesícula esférica é ladeada pelas glândulas (f) da secreção granulosa, que derramam esta na constrição aludida. A parede do reservatório é grossa, na sua parte ental, onde armazena a secreção em pacotes que lembram gomos de laranja. No trecho seguinte, corre o zanal ejaculatório (p), de pequeno calibre, no meio dum cilindro grosso formado por células não delimitadas mutuamente. Notam-se, nesta parte, fortes músculos anelares (an).

O aparelho cuticular (Fig. 64) é pequeno, a saber, de 0,04-0,044 mm. ao comprido. $\Lambda$ interrupção do anel importa apenas num quarto da circunferência. No anel, distinguem-se as partes proximal (p) e distal (d) ligadas por ca. de 17 pontes (b), de $0,008 \mathrm{~mm}$. de altura. Sem relação topográfica com as pontes, saem do anel ectal (distal, caudal, inferior) até 22 espinhos ocos (e), de $0,025 \mathrm{~mm}$. de comprimento, iguais entre si. Confirmamos, em oposição a Meixner (1915, p. 495-496); a ligação entre a parede (membrana basilar) do cilindro copulador e as bases dos espinhos descrita por Hofsten (1907, p. 495 t. 26 f. 2). No ponto da dita união, inserem-se os músculos abductores dos espinhos. Da calota ental da vesícula seminal até as pontas dos espinhos, a via eferente masculina mede $0,2 \mathrm{~mm}$.

O ovário (Fig. 66, o) encurvado para dentro, na sua extremidade rostral (veja discussão), contem os ovócitos em crescimento algo achatados. Hofsten disse (1907, p. 527) "os ovos não são achatados", mas, *esenhou os ovócitos (t. 25 f. 4, o) do mesmo modo com que se apresentam no material aquí em mãos. $O$ oviduto, mais curto que o germário, dilatase ventralmente, formando um receptáculo seminal ( $r$ ) mais ou menos pedunculado. No trecho seguinte, o duto comum, desembocam o viteloduto (y) e dois tufos de glândulạs da casca (c). A maioria destas é basófila, mas, algumas apresentam o citoplasma acastanhado (fixação: "Susa"; coloração : hematoxilina-eosina). Os vitelários (d) são concrescidos caudalmente e contíguos ou quasi assim rostralmente, na linha ventro-mediana. Cada vitelário exibe ca. de 12 lóbulos mediais, e outros tantos laterais (veja discussão). O canal feminino dilata-se como útero (u), em que " casulo se forma. Este é ovóide; as suas medidas variam, no nosso material, entre 0,15 e 0,16 mm., quanto ao diâmetro maior, e 0,08 e 0,105 mm., quanto ao menor. Um dos polos do casulo é mais cuspidato; o outro, 
mais arredondado. Perto do ponto da entrada da via masculina no átrio (a), situa-se a bursa copulatória (b) que se estende, para diante, quasi até o nível da vesícula seminal. Hofsten descreveu a musculatura da bursa como sendo internamente anelar; externamente longitudinal. $O$ epitélio da bursa é basófilo, na zona ental; no resto, neutro. Em cada ladoda bursa, insere-se um músculo originado na parede do corpo, segurando a bursa. O gonóporo é circundado pelas glândulas argamassadoras (s) e provido dum esfincter espiralado.

Ocorrência: Material pouco abundante (no total; 20 exemplares) foi colhido no rio Tietê, uma vez, no remanso chamado de Lagôa da Corôa (bairro de Canindé da cidade de São Paulo); outra vez, no próprio rio, perto do subúrbio de Limão.

Originalmente foi a espécie considerada como habitante típico (Meixner 1915, p. 478) das poças alpinas, na região do limite das arvores ("Almtümpel", congelados durante vários mêses), mas os achados de Luther, em água fracamente salobra, e do Beauchamp, numa poça de altas temperaturas estivais, provam que $M$. (G.) ornato está longe de ser "stenoeca". Se mesmo a montanha de Jaíla (Serra Taúrica, Criméa) fosse considerada uma fralda do Caúcaso (pelo que sabemos, tal denominação poderia ser aplicada apenas à península de Kertsch, que na verdade continua tectônicamente a de Taman, que é eaucásica), o achado de Beauchamp (perto de Dijon) impossibilitaria incluir $D$. ornata nas espécies bóreo-alpinas (Steinböck 1932, p. 254).

Distribuição geográfica: França, Dijon; Suissa, até $1950 \mathrm{~m}$. de altitude; Austria, nos Alpes orientars, na região alpina e subniveal; lagos de Lunz; Polônia, serra da Tatra; Rússia, Criméa (em altitude um pouco além de $1000 \mathrm{~m}$.), península de Kola (Lat. $69^{\circ}$ N.); golfo da Finlândia.

\section{Discussão sistemática de M. (G.) ornata}

A espécie mais vizinha de ornata é $M$. (G.) rubra (Fuhrmann (1894, p. 271), mais tarde estudada por Brinkmann (1905, p. 124); Wahl (1910; p. 43); Beklemischev (1917, p. 350 ; 1921, p. 644); Reisinger (1924e, p. 286); Gieysztor (1926, p. $633)$; e outros. A única diferença segura entro as duas espécies reside no comprimento do aparelho cuticular, que é de $0,056 \quad 0,08 \mathrm{~mm}$., em rubra; de 0,040 $0,044 \mathrm{~mm}$., em ornata.

Em rubra, haveria, segundo Reisinger (1924c, p. 287-288), tantas pontes quantcs espinhos, e as pontes alongar-se-iam nos espinhos. Em ornata, faltam tais relações numérica e topográfica entre pontes e espinhos. Hesitamos, porém, em ver nisto um segundo carater disjuntivo, pois várias descrições e figuras de rubra, p. e., as de Fuhrmann e de Gieysztor (1926) não evidenciam a regularidade indicada.

M. (G.) ornata var. drozdowicensis (Fulinski 1915, p. 6), não ilustrada, possue os dois aneis da mesma largura (em ornata típica, é o ental mais largo) e sem interrupção dorsal. M. (G.) rubra var. intermedia (Gieysztor 1931, p. 134) não interessa, quando se confrontam rubra e ornata, porque o aparelho cuticular àe intermedia é mais comprido ainda que o de rubra típica.

Para a classificação do material atual, o comprimento do aparelho cuticular foi decisivo. Os vitelários lobulados, porém, passam por carater específico de rubra. Visto que Gieysztor (1929, p. 156) observou 3 vermes de $M$. (G.) sibirica (Plotnikow 1905, p. 484) com vitelários completamente desenvolvidos e lisos, e um exemplar da mesma população com vitelários entalhados, desapareceu, ao nosso ver, o valor taxonômico da forma dos vitelários. Outro exemplo de indivíduos com vitelários lisos e lobulados pertencentes à mesma unidade sistemática fornece Microdalyeilia (Gieysztoria) triquetra orientalis (Nassonov 1929, p. 426). Exemplares do lago de Chanka, ao norte de Wladiwostok, tiveram os vitelários sem lóbulos; os de Fushiki, Japão Hondo, baía de Toyama) mostraram-nos com processos laterais, "quasi em forma de pinheiros". Gieysztor fez distinção (1931, p. 136) entre o ovário curtoe reto de ornata e o comprido, proximalmente encurvado para dentro, de rubra. Também tal eritério obrigaria determinar o material de São Paulo como rubra.. 
Mas, Reisinger (1924c, p. 137) encontrou rubra com germário igual ao de ornata. Ocorrem, portanto, os dois tipos em rubra e em ornata.

Ultimamente, Gieysztor (1938, p. 223) pensou ter encontrado dois sinais específicos de ornata, a saber: 1) a passagem do anel ental (proximal) ao ectal (distal) é diferente num e noutro lado, sendo desiguais também os espinhos (l. c., t. 10 f. 10). Tal não ocorre no nosso material (Fig. 64), nem se encontra mencionado ou desenhado na diagnose original; 2) a base dos espinhos ocos abre-se para o lado interno do anel. Contrasta com o nosso material e com o desenho original (Hofsten 1907 , t. 26 f. 2 : base do espinho cortado aberta para fora). Do material aludido da Tatra mencionou Gieysztor ainda: "comprimento considerável do orgão copulador" e, mais para diante, "pedúnculo comprido do receptáculo seminal", quer dizer, duto comprido. O primeiro sinal refere-se, evidentemente, ao aparelho eferente masculino na sua totalidade, da vesícula seminal até o átrio; o segundo, porém, não é compatível com a descrição de Hofsten. Não obstante, parece certa a determinação de Gieysztor, que estudou as Dalyelliidae durante muitos anos, com interesse especial.

\section{Microdalyellia (Gieysztoria) hellis, spec. nov. (Fig. 69-71, 74-76)}

O comprimento dos vermes é de $1,2-1,4 \mathrm{~mm}$; a largura, de ca. de $0,3 \mathrm{~mm}$. A côr de vermes adultos é alaranjada, situando-se o pigmento no parênquima; o intestino é ligeiramente acastanhado; os vitelários são incolores. Os olhos são alongados, reniformes, sendo a célula óptica mais distinta que na maioria das espécies. Os rabditos (Fig. 75, r), de 5-6 microns, ao comprido, originam-se em células formadoras sub-epidérmicas, das quais há 4-6 cefálicas, 2 caudais e várias outras, ao que parece, simètricamente dispostas, nas partes restantes do corpo. Além disso, conteem as células da epiderme tôda aincla inclusões refrativas (Fig. 75, i), que lembram as de Suomina evelinae (Marcus 1945, t. 3 f. $9 \Lambda$ ), e são largas, arredondadas e de 3-4 microns de diâmetro. Em indivíduos jovens, notam-se, às vêzes, papilas caudais, ausentes em vermes adultos, os quais, porém, mostram glândulas caudais grudadoras (Fig. $74,1)$.

O cérebro (Fig. 69-70), mais largo que comprido, emite oito pares de nervos maiores: dois anteriores $(1,2)$, um ântero-ventral (3), dois ânterodorsais $(4,5)$ e três longitudinais, a saber, um lateral (6), um ventral (7), e um dorsal (9). Ao ventral pertencem ainda dois ramos maiores, o cutâneo oral e post-oral (10) e o faríngeo (8). Mais para trás, saem do ventral ainda nervos menores. A origem dêstes nervos, os órgãos por êles supridos, e as relações dêles com os anteriormente indicados das Dalyelliidae serão discutidos no último parágrafo do capítulo relativo à espécie atual.

$O$ comprimento da faringe é de $0.24 \mathrm{~mm}$.; o seu diâmetro, de 0,17 $\mathrm{mm}$. A orla faríngea é lisa, sem papilas; a bolsa faríngéa externa marcase nìtidamente. $O$ intestino é duas vêzes mais comprido que a faringe; na entrada intestinal, ocorrem as glândulas aprofundadas de secreção granulosa, eosinófila, comuns nas Dalyelliidae. Para trás, estende-se o intestino até o segundo têrço do corpo.

Os testículos (Fig. 74, t) pouco volumosos são situados na região post-intestinal. Da sua região rostral, saem os dutos eferentes (e), cuja entrada na vesícula seminal (v) se distancia do ápice ental desta. Entre a vesícula e o reservatório da secreção granulosa (g) demarca-se uma 
constrição, ladeada pelas glândulas da dita secreção. O reservatório, de ca. de $0,05 \mathrm{~mm}$. ao comprido, tem parede formada por células altas e muitos músculos; a secreção é armazenada na região ental (proximal) do reservatório. Em espécimes velhos, a secreção espumosa dilata o reservatório de tal modo que êste se torna quasi esférico. A parte ectal (distal) do reservatório é, geralmente, encoberta pelo anel ental do órgão copulador $(\mathrm{p})$.

$O$ dito anel ocupa $0,01 \mathrm{~mm}$. do comprimento total $(0,04 \mathrm{~mm}$.) do aparelho cuticular (Fig. 71). O anel (a) é pouco interrompido dorsalmente, destituido de fibras, tênue, e pouco refrativo. Aproximadamente 12 pontes ( $p)$ compridas $(0,015 \mathrm{~mm}$.) e grossas encontram-se entre $o$ anel e as bases (b) dos espinhos. Em M. (G.) rubra var. caucasica (Nassonov 1919a, p. 1040) ocorrem pontes longas semelhantes. Os ca. de 19 espinhos de bellis não são alongamentos das pontes, mas, independem delas. Os espinhos sobrepõem-se com as suas bases às extremidades distais (ectais) das pontes. O comprimento total dos espinhos é de ca. de 0,016 $\mathrm{mm}$.; a sua forma, muito singular. Cada um dêles possue, na sua extremidade ectal, um pequeno cône (c), cujo orifício obliquo se abre para fora e para cima. No bordo externo do eône, insere-se o músculo abductor. A contração dos músculos abductores leva à posição ilustrada na Fig. 76 . Esta fase sugeriu o nome específico, pois os espinhos abduzidos lembram a flor de Bellis perennis. A abdução máxima dos espinhos pode leva-los a se encurvarem ainda mais do que foi desenhado na Fig. 76. A parede externa do cône tem 6 microns ao comprido.

O ovário (Fig. 74,0 ) contem ovócitos achatados. O receptáculo seminal ( $r$ ) insere-se, sem duto, no oviduto, perto do germário. Como em M. (G.) triangulata (Robeson 1931, p. 607.) e evelinae (Fig. 28, m) o receptáculo de bellis é formado por células vacuolizadas, aqui dispostas em 4 lóbulos. Nos vacúolos os espérmios são armazenados. As células teem o mesmo volume; uma ou outra pode estar vazia, ou tôdas as quatro repletas. Ectalmente ao receptáculo, entra o viteloduto (y) no duto comum, de parede grossa. Mais ectalmente ainda, desembocan as glândulas da casca (c) no duto comum. Os vitelários (d) possuem, cada um, 12-15 lóbulos compridos em cada lado. Quando o vitelo destinado a participar na formação dum casulo passa pelo viteloduto, é este consideràvelmente dilatado. O útero atinge, quando abriga um casulo $(\mathrm{u})$, a região caudal estreitada. $O$ casulo acastanhado situa-se de tal modo que a sua ponta mais cuspidata se dirige para trás. As duas outras são desiguais; na mais largamente arredondada, reconhece-se a sutura do opérculo. Entre a outra e a ponta posterior, observa-se ligeira concavidade da casca do casulo. A bursa copulatória (b) é quasi tão comprida quão o aparelho masculino, medido da vesícula seminal até a desembocadura da via masculina no átrio $(0,1 \quad 0,13 \mathrm{~mm}$.). A parede da bursa é musculosa, mas, fina; o seu duto, fortemente musculoso e de parede grossa. O gonóporo é circundado por músculos e glândulas argamassadoras (s), estas, muitas vêzes, dispostas em dois pacotes. Notam-se nelas grandes vesículas da secreção homogênea.

Os casulos aparecem muito cedo na vida dos vermes, quando êstes ainda são incolores e possuem apenas a metade do comprimento e gros- 
sura definitivos. Por isso, $M$. (G.) bellis apresenta-se com aspecto muito diverso, conforme a idade e o estádio reprodutivo, e isso, tanto no hábito geral quanto nos vários órgãos.

Ocorrência: No rio Tietê, perto do subúrbio de Limão, cidade de São Paulo. Colhidos no mês de julho, os vermes mantiveram-se até outubro no aquário, multiplicando-se. Das plantas disponíveis, Eichhornia crassipes, Trianea bogotensis, e Salvinia-spec., acumularam-se, com preferência muito pronunciada, entre as raizes de Eichhornia.

\section{Discussão sistemática de Microdalyellia (G.) bellis}

No grupo das espécies de Gieysztoria com aparelho anelar provido de espinhos iguais entre si e com receptáculo seminal, não conhecemos uma que possua espinhos com cônes distais. Talvez haja formaçōes semelhantes em M. (G.) erivanica (Plotnikow 1906, p. 397), pois, na figura respectiva (t. 22 f. 4), parece possível ver estruturas especiais nas pontas externas dos espinhos. Outro ponto semelhante seria o reservatório da secreção granulosa, volumoso em erivanica e bellis. 0 comprimento do aparelho cuticular de erivanica $(0,08 \mathrm{~mm}$.) exclue, porém, quaisquer conjeturas sôbre a identidade das duas espécies. De resto, passa erivanica por eventualmente idêntica (Graff 1913, p. 93; Meixner 1915, p. 500, nota 3) a expedita (Hofsten 1907, p. 520), espécie com aparelho muito menor (ca. de $0,022 \mathrm{~mm}$.) e, por isso, certamente diferente de erivanica. $M$. (G.) expedita, bem estudada, não mostra nem vestígios dos cônes e, tão pouco, receptáculo seminal lobulado.

\section{O cérebro e os nervos principais de Microdalyellia (G.) bellis (Fig. 69, 70)}

O primeiro que observou nervos anteriores, nas Dalyelliidae, foi Hofsten $(1907$, p. 486 ) ; ao examinar $M$. (G.) diadema, diferenciou Meixner (1915, p. 490-491), dentre êstes, os medianos (t. 30 f. 11, vn) e os mais laterais (f. 12, vnl). Reisinger (1924c, p. 251) observou, em Dalyellia styriaca, 3 pares de nervos que suprem a extremidade rostral. Certamente correspondem êstes aos pares 1-3 de $\boldsymbol{M}$. (G.) bellis (Fig. 70), dos quais os dois primeiros saem do bordo rostral do cérebro. 0 terceiro, que se reconhece sòmente na vista ventral do verme, corre ramificalo para as regiões oral e ântero-ventral. Dorsalmente à origem dos nervos anteriores, saem os nervos 4 e 5 . Correspondem aos "dois, talvez mesmo três, pares de nervos" vistos por Meixner (1915, p. 491) em $M$. (G.) diadema. Como nesta espécie (1. c., t. 30 f. 12, dn), é o nervo anterior (4) mais grosso que o posterior (5). Reisinger (1924c, p. 251) viu os dois nervos em Dalyellia styriaca, indicando o externo como sendo o mais forte. Possìvelmente, comparou os dois nervos no seu trecho encurvado para o lado dorsal, pois aí corre o nervo 4 mais para fora; o 5, mais para dentro. Ambos os nervos suprem a região ântero-dorsal da parede do corpo. Os três pares de nervos longitudinais $(6,7$ e 9$)$ já foram vistos por Hofsten. Ele observou corretamente a origem ventral comum dos laterais (6) e ventrais (7), e descreveu os dorsais (9) como sendo mais finos e originados na região póstero-dorsal do cérebro. Com êstes achades concordaram Meixner e Reisinger, acrescentando, às verificações de Hofsten, a ramificação do nervo longitudinal lateral (6). Ramifica-se tambrom o fino nervo longitudinal dorsal (9), visível apenas na vista dorsal do animal: 
Os nervos longitudinais ventrais $(7)$ e as duas ramificações $(8,10)$ reconhecem-se apenas na vista ventral. Cada nervo longitudinal ventral (7) emite, ao nível da orla faríngea, o nervo 10 . O ramo rostral dêste inerva o bordo ventral da bôca (o "lábio inferior"), suprindo os outros ramos a parede do corpo ventral na região da faringe. Os músculos faríngeos recebem a sua inervação por um outro nervo, o nervo faríngeo (8), igualmente emitido pelo nervo longitudinal ventral.

\section{Microdalyellia (Gieysztoria) tridesma, spec. nov. (Fig. 65, 72.73)}

O comprimento dos vermes adultos é de 0,5-0,8 mm.; a grossura, de $0,15-0,25 \mathrm{~mm}$. A côr é alaranjada; os olhos são muito distantes um do outro e teem cálices profundos. $\mathrm{O}$ número dos rabditos varia muito, mas, em geral, são bastante numerosos. Na cauda, ocorrem papilas adesivas (Fig. 72, p), cuja função fixadora foi observada. Na dita região e na cabeça, há estereocílios, maiores que os locomotores, e, provavelmente, tácteis.

A faringe, cujo comprimento é de $0,15-0,18 \mathrm{~mm}$., e cujo diâmetro importa em $0,1-0,15 \mathrm{~mm}$., possue orla lisa, isenta de papilas e cílios. Os citosomas das glândulas (Fig. 72, c), cuja secreção (e) se acumula no trecho rostral do intestino (i), são volumosos. O intestino é muito mais comprido do que a faringe.

Os testículos (t) são minúsculos, em vários exemplares examinados, mas, num espécime, são bastante volumosos, mostrando, assim, variação semelhante à observada em $M$. (G.) intricata (Fig. 50, 51). Num verme, situam-se os testículos rostralmente à vesícula seminal, mas, por serem pequenos, nem nesta posição saem do terço posterior do corpo. A vesícula seminal (Fig. 72, v) é pequena; o reservatório da secreção granulosa, inconspícuo.

O aparelho cuticular (Fig. 65, 73) tem de comprimento $0,055-0,06$ $\mathrm{mm}$. O anel, dorsalmente aberto e com ca. de $0,015 \mathrm{~mm}$. de altura (comprimento), é tênue e estriado transversalmente. No anel, inserem-se poucas (5.10) pontes fortes, cuja longura é de aproximadamente $0,013 \mathrm{~mm}$. Os espinhos (ca. de $0,027 \mathrm{~mm}$., ao comprido) não correspondem às pontes e formam três grupos, um ventral e dois dorso-laterais. A grossura é a mesma em todos os espinhos; êstes se inserem em níveis diferentes e atingem distalmente o mesmo plano transversal; são, portanto, de longura diversa, entre si. Os espinhos são ocos e proximalmente abertos para fora; nêstes orifícios, inserem-se os músculos abductores (Fig. 65, m) dos espinhos.

O ovário (Fig. 72, o) é recto; o receptáculo seminal (r), pequeno, sem duto, e, às vêzes, bilobado. As glândulas da casca (s) formam massas volumosas; os trechos filiformes ("dutos") das glândulas são compridos.

Os vitelários (d) são ricamente lobulados; os lóbulos são 2-3 vêzes mais compridos que largos. Em cada lado de cada vitelário, há 10-15 ióbulos; êles quasi se tocam na linha dorso-mediana. $O$ casulo (u) ovóide tem de diâmetro maior 0,135 - 0,15 mm.; e 0,075 - 0,08 mm., de diâmetro menor. 
O duto da bursa copulatória (b) pouco volumosa é provido de forte inusculatura anelar; ao redor do gonóporo, notam-se grandes massas de glândulas argamassadoras (g).

Ocorrência: O material desta espécie proveio de muitas localidades ecold̀gicamente diferentes, dos arredores da eidade de São Paulo, a saber, córrego de correnteza rápida de Tremembé (serra da Cantareira); lagôa da Corôa (remanso do 'Tietê; água muito rica em matérias orgânicas), no bairro de Canindé; nos rios Tietê (bairro de Limão) e Pinheiros, entre as raizes de Trianea e Eichhornia; num brejo perto do rio Pirajussára, em água rica em humo, paupérrima em matéria orgânica; e num riacho de correnteza rápida, nágua rica em matéria podre, perto do bairro de Pinheiros.

Freqüentemente, notaram-se os vermes habitados por Euglena leucops Hall, observada ainda em M. (G.) acariaia e Mesostoma ehrenbergii. Como se pode depreender das exposições de minha Esposa (du Bois-Reymond Marcus 1943, p. 362 e seg.), pertencem, possivelmente, à mesma espécie os Flagelados vistos por Gilbert (1935, p. 289) em Phaenocora virginiana, apesar de destituidos de estigma e flagelo. Deformações, como foram causadas pelo parasita em Stenostomum arevaloi (du Bois-Reymond Marcus, l. c., p. 366), não observámos nas Dalyelliidae e no Mesostoma infestados.

\section{Discussão sistemática de Microdalyellia (G.) tridesma}

Espinhos diversamente compridos, mas, simètricamente dispostos, tornam um tanto precária a incorporação da espécie atual no subgrupo 2 das espécies de Gicysztoria com aparêlho cuticular coroniforme. Não cabe, porém, no subgrupo 1, cuja secção com espinhos simétricos (triquetra, evelinae, etc.) tem-nos sempre de grossura diferente. Do subgrupo 2, por outro lado, não se excluem rigoròsamente espécies com espinhos de comprimento desigual. Os espinhos externos, p. e., de ornata ou kessleri (Plotnikow 1906, p. 398), não são tão longos quão os internos. Na última espácie (1,2 mm. ao comprido), cujo aparêlho cuticular tem $0,08 \mathrm{~mm}$. de longura, e cujo receptáculo seminal parece provido de duto próprió, são os espinhos reunidos em 5 grupos. Cada grupo compõe-se de 3-4 espinhos finos. Pelo que pudemos depreender da Jiteratura ao nosso alcance, seria kessleri a espécie menos distante de $M$. (G.) tridesma, mas, difere desta pelos caracteres indicados.

Para facilitar futuras análises de aparelhos cuticulares, seja frisado que a espécie atual foi tida, à primeira vista, por provida de cabos e hastes (Fig. 26). Do anel tênue, notou-se apenas, em cada lado, o corte óptico, simulando cabo. Os músculos abductores provocaram a aparência de hastes.

\section{Subordo: Typhloplanoida Bresslau}

\section{Familia: Typhloplanidae Graff (1905, p. 72,82; Bresslau 1933, p. 271)}

Como foi dito por Bresslau (1. c.), é esta, entre as famílias dos Rhabdocoeła, a mais rica em espécies. Ocorre, principalmente, nágua doce e na salobra (ca. de 5-6 por mil de salinidade), p. e., do golfo da Finlândia do mar Báltico (Luther 1946).

As 8 sub-famílias atualmente admitidas podem ser determinadas pela chave seguintr:

1 Os troneos terminais dos emunctórios desembocam com poros separados na superfície do corpo .... . . . . . . . . . .

- Os ditos troncos não desembocam com poros separados na super-

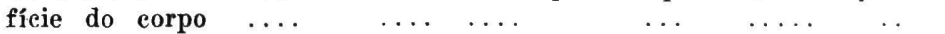


2 Os testículos situam-se ventralmente aos vitelários ... .. Protoplanellinae Reisinger (1924, p. 4)

- Os testículos situam-se dorsal, lateral, ou anteriormente aos vitelários

3 Perto do gonóporo, desemboca o "ascus", um órgão glandular, tubiforme .... Ascophorinae Findenegg (1924, p. 20; 1930, p. 85)

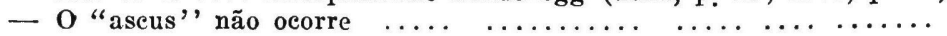

4 A bôca encontra-se no primeiro têrço do corpo; a faringe situa-se na parte anterior do intestino $\ldots . \ldots \ldots$........ Phaenocorinae Wahl (1910, p. 57)

- A bôca encontra-se atrás do primeiro têrço do corpo; a faringe situa-se na parte média ou posterior do intestino ..... Olisthanellinae Luther (1904, p. 147; Hofsten 1907, p. 408)

5 Os troncos terminais dos emunctórios desembocam no átrio genital .... Rhynchomesostominae Bresslau (1933, p. 271)

- Os troncos mencionados não desembocam no átrio genital ......

6 Os ditos troneos desembocam, unidos, num poro excretōr, entre a bôca e o poro genital ... .. Opistominae O. Sehmidt (1848, p. 21, 38)

- Os troncos protonefridiais desembocam no cálice excretor, ligado

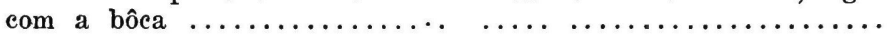

7 Os testículos situam-se ventralmente aos vitelários ... Typhloplaninae Luther (1904, p. 144, 148)

- Os testículos situam-se dorsalmente aos vitelários ... .. Mesostominae Luther (1904, p. 144, 217)

\section{Subfamilia: Typhloplaniae Luther 1904}

\section{Genus: Strongylostoma Oersted 1843}

Na monografia de Graff (1913, p. 215), o gênero figura com a diagnose de Luther (1904, p. 149) baseada em: 1) ausência de átrio copulatório; 2) receptáculo seminal desenvolvido como vesícula independente e separada do duto comum por um esfincter; e 3) presença de rabdóides epidérmicos. Acrescentam-se os caracteres da subfamília, a saber, a) cálice excretor ligado à bôca, e b) testículos situados ventralmente aos vitelários. As Typhloplaninae abrangem os 10 gêneros enumerados por Bresslau (1933, p. 271), Haloplanella Luther (1946, p. 18) e Thalassoplanella Luther (1946, p. 34).

\section{Foram descritas as espécies seguintes de Strongylostoma:} Genótipo.

1) radiatım (O. F. Müller 1774); Luther 1904, p. 149; Graff 1913, p. 216.

2) gonoccphal.um (Silliman 1884, p. 56). Segundo Luther (1904, p. 157-158), próximo a radiatum; segundo Graff (1912, p. 56-57), diferente pelas concavidades laterais do corpo, ao nível dos olhos. Apesar de Luther (1904, p. 121.122) ter chamado a atenção sôbre as anastomoses dos vitelários, Graff não esclareceu esta questão. Espécie não certa.

3) coecum Sekcra (1906, p. 146, como rariedade de radiatum; 1911, p. 18, como espécie). Sem receptáculo seminal; vitelários só na região caudal. Genèricamente não certo.

4) elongatum Hofisten (1907, p. 419). Espécie certa, re-examinada por Meixner (1915, p. 542). Mesostoma bologoviense Plotnikov (1906, citado seg. Graff 1913, p. 279) seria idêntico a elongatum (Sekera 1911, p. 18, nota; Bèklemischev 1921, p. 636; Nassonov 1924, p. 334). Hofsten, que discutiu o trabalho de Sekera no postescrito de "Neue Beobachtungen" (1911, p. 78-80), não se manifestou a respeito da dita sinonímia. Com Hofsten (1920, p. 5), continuamos a usar o nome elongatum.

5) simpiex Meixner (1915, p. 545). Apesar de faltarem o esfincter do receptáculo e a bursa, a espécie deveria, por enquanto, ser mantida no gênero em questão. 
6) rosaccum Higley (1918, p. 246). Não havendo deserição dos rabdóides da epiderme e dos órgãos auxiliares do sistema reprodutivo, é impossível definir a espécie genèricamente, dentro das Typhloplaninae, às quais pertence.

7) cirratum Beklemischer (1921, p. 636). Sem bursa; com receptáculo bipartido.

8) levandovskii Nassonov (1924a, p. 45). Diagnose e figura não caracterizam a espécie suficientemente. A ausência de espinhos no órgão copulador não é, sozinha, sinal específico disjuntivo, pois os espinhos são caducos.

\section{Strongylostoma dicorymbum, spec. nov. (Fig. 77-80)}

O comprimento dos vermes observados, que se encontraram tanto na fase sexual masculina quanto na feminina, não ultrapassou $1 \mathrm{~mm}$. A posição da faringe varia; uma vez, situa-se imediatamente atrás do cérebro; outra vez, observa-se entre êste e a faringe curto trecho do intestino (Fig. 7i). O gonóporo (p) encontra-se entre o terceiro e o quarto quinto do corpo. Da forma do corpo são constantes: a largura máxima atrás do meio e a extremidade caudal ogival. A' região anterior não mostra a constrição ao nível dos olhos, caraterística de radiatum, e raramente o contorno cefálico triangular desta espécie. Por via de regra, a extremidade anterior apresenta-se arredondada. A côr dos vermes é condicionada pelos pigmentos acastanhados escuros ou pretos do parênquima, pelos vitelários cinzentos, e pelas gotas oleosas amarelas, de 15-30 microns de diâmetro, acumuladas nas células intestinais. O pigmento dos olhos é vermelho, acastanhado, ou preto; o aspecto do cálice corresponde às indicações de Luther $(1904$, p. 150, 152) que se referem a radiatum, pois parece triangular, com aumento fraco; igual ao cálice duma flor, com objetiva maior, havendo, às vêzes, ligação pigmentada ramificada entre os dois olhos.

A epiderme é dorsalmente mais alta que no ventre. Entre os cílios salienta-se um tufinho médio-caudal. Os rabdóides epidérmicos exibem, depois da coloração com hematoxilina-eosina, mais tons azuis que vermelhos (Brinkmann 1905, p. 82; Hofsten 1907, p. 419). O tamanho dos rabdóides é de um a dois microns; êles ocorrem, sem que haja reunião em grupos, densa e uniformemente (Fig. 78, e), em tôda a parte. O cérebro (Fig. 77, e) é posteriormente mais largo que anteriormente. Os grupos de glândulas ramnitógenas (r), situadas nos dois lados da faringe (h), emitem para diante os tratos dos ramnitos altamente refrativos à luz refletida. Até o cérebro convergem os tratos; daí para diante, divergem flabeliformemente. No parênquima, observam-se numerosas glândulas cianófilas, em disposição aproximadamente simétrica.

() diâmetro da faringe (h) é de $0,14 \quad 0,18 \mathrm{~mm}$. Cílios faltam na bolsa faríngea externa, como sempre nas Typhloplanidae (Luther 1904, p. 43), dando-se o mesmo com o epitélio faríngeo interno; o externo é ciliado. Na bolsa, são os núcleos muito escassos; no epitélio interno, ocorrem duas corôas de quatro núcleos cada uma (Bresslau 1904, t. 16 f. 38-39, t. 18 f. 57-62). A posição dos núcleos do epitélio faríngeo externó (Fig. 78, i), no ângulo entre êste e a bolsa, corresponde, como as oứras estruturas, ao tipo das Typhloplanidae (Luther 1904, t. 2 f. 14, 24, k): 
Dá-se o mesmo com o septo musculoso que circunda a faringe e os músculos restantes dela. $O$ anel nervoso (f) é situado no meio da altura da faringe. Das glândulas intra-faríngeas distinguem-se 5 tipos: azuis, violáceas, vermelhas, rosáceas e acastanhadas. Sendo dispostas com certa simetria ao redor do lume da faringe, não são tôdas reunidas no mesmo sector, como ocorre com os quatro tipos de St. simplex Meixner (1915, p. 548-549). No corte mediano, desenhado na Fig. 78, reconhecem-se, do lume para fora, as glândulas violáceas, as vermelhas, e as acastanhadas. $\mathrm{Na}$ camada das vermelhas, seguem, para os lados, as rosáceas; as azuis, reconhecíveis na figura do animal total (Fig. 77), ocupam o plano transversal. Clavas de Minot ocorrem na entrada do intestino. Este se estende do bordo caudal do cérebro até a proximidade da ponta posterior.

No cálice excretor paucicelular, notam-se alguns cílios, menores que os epidérmicos. Um esfincter especial circunda o orifício externo do cálice.

A sucessão das fases masculina e feminina dos órgãos reprodutivos é menos pronunciada que em radiatum (Luther 1904, p. 87 t. 7 f. 4, 5). Como ein tlangatum (Hofsten 1907, p. 423), faltam os testículos ou o órgão copulador na fase em que o átrio é dilatado pelo casulo. Comparando a fase masculina de elongatum (Meixner 1915, p. 542) com a correspondente de dicorymbum, qualificariamos a discrepância entre os estádios masculino e feminino da espécie atual como ainda menor do que naquela.

Os testículos (Fig. 77, t) são sacos alongados, situados nos dois lados do complexo dos órgãos copulatórios ou caudalmente a êste. No primeiro caso, atingem o nível do bordo caudal da faringe. Para trás, não alcançam a terminação caudal do intestino, nem as extremidades dos vitelários (v) dispostos dorsalmente aos testículos. Os dutos eferentes (d) saem da terminação anterior dos testículos e entram no órgão copulador (Fig. 79), cujo comprimento é de $0,06 \quad 0,12 \mathrm{~mm}$. Vesículas seminais extra-peniais (falsas) aparecem, no material visto por nós, só excepcionalmente. O volume do órgão copulador é sempre inferior ao da faringe, em oposição a radiatum. A parede musculosa encerra a massa plasmática nucleada (o plasma epitelial da terminologia de Luther 1904, p. 96, 99). A vesícula seminal intra-penial (Fig. 78, s) estende-se transversalmente, ocupando a cúpola do órgão masculino. Os espérmios são conduzidos para fora por dum duto estreito ântero-mediano que chamamos de duto ejaculatório (1). Como em radiatum (Luther 1904, p. 101-102), é de calibre menor que o duto que evacua a secreção granulosa. Luther falou (l. c.) numa cisão do duto ejaculatório num ramo maior e num outro menor; preferimos denominar o ductus ejaculatorius e o ductus granulorum separadamente, conforme a função. Os filamentos caudais dos espérmios apresentam torsão espiral, e, como são dispostos paralelamente, o feixe dos espermatozóides aparece como que estriado transversalmente. A secreção granulosa (Fig. 80, k) acumula-se, dentro do órgão copulador, em três massas cilíndricas, situadas nos dois lados do (luto ejaculatório e ventralmente a êste. Daí desce a secreção em duas colunas pelo ·ductus 
granulorum (Fig. 79, g). Este é revestido de espinhos iguais aøs deradiatum, pois são constituidos por bases cônicas providas, cada uma, duma cerda fina. Os espinhos são caducos, podendo desfazer-se pela compressão do verme debaixo da lamínula. Em animais jovens, faltam os espinhos, e podem ser ausentes também nos exemplares que se encontram na fase feminina dos órgãos reprodutivos. Como os espinhos entram um pouco no orifício distal do duto menor (ductus ejaculatorius da nossa terminologia), entende-se ter Luther considerado êste como um divertículo do maior (ductus granulorum da designação aquí usada).

O ovário (Fig. 77,0 ) no lado direito é reto; os vitelários (v) são entalhados e estendem-se do nível da faringe $-(\mathrm{h})$ até a -extremidade caudal do intestino. Os vitelodutos (w) sáem da parte posterior dos vitelários, correm para diante, e reunem-se na sua desembocadura no trecho distal do duto comum $(\mathbf{x})$. No último, abre-se, na parte proximal, - receptáculo seminal (y), uma vesícula esférica, cujo canal é provido de dois esfíncteres. A delimitação indistinta do duto comum contra o átrio superior, descrita de radiatum (Luther 1904, p. 152), re-encontra-se na espécie atual; em elongatum, é nítida a demarcação dos dois órgãos (Hofsten 1907, p. 422). Como em radiatum, é também ímpar o diver4ículo sólido $(u)$, que corresponde a um útero e se encontra na parede anterior do átrio superior; em elongatum, ocorrem duas dilatações. A posição da bursa (b) no plano mediano motiva o deslocamento dela para a direita ou para a esquerda na preparação de compressão. Quando esférica, a bursa é mais curta que o órgão copulador. Nos cortes, apresenta-se contraida e, nêstes casos, mais comprida que êste. O epitélio da bursa e o do seu canal não são aprofundados; a musculatura é especialmente forte no canal da bursa, em cuja parede se notam vários músculos anelares grossos. $O$ epitélio alto do átrio inferior (Fig. 78, a) distingue-se muito do chato do átrio superior. $O$ gonóporo $(p)$ é circundado por glândulas cianófilas $(\mathrm{z})$. Ô casulo mede $0,12 \mathrm{~mm}$. de diâmetro; a casca é acastanhada.

Ocorrência: O material dos vermes que nadam livremente nágua foi obtido em duas poças, uma perto da ponte de Jaguaré (rio Pinheiros) e outra, no bairro de Limão, perto do rio Tietê. A primeira população (Jaguaré) colhida em dezembro do 1945 foi muito menos rica em indivíduos que a segunda (Limão), encontrada em junho e julho de 1946. Nas duas localidades, trata-se de água estagnada, vegetação rica e diversa, e circunvizinhanças pedregulhentas.

\section{Discussão sistemática de Strongylostoma dicorymbum}

Quanto aos pormenores, é St. radiatum a espécie mais semelhante à atual. Distingue-se da presente pela constrição cefálica; a posição do gonóporo mais perto da lốca; o pênis duas vêzes maior que a faringe na fase masculina; os testículos situados mais para diante e os dutos eferentes saindo da extremidade caudal dos testículos (Hofsten 1907, p. 421, nota 1; Sekera 1911, t. 1 f. 19 : sinonímia Hofsten $1916 a$, p. 8, nota 1). Nos caracteres enumerados, concorda St. dicorymbum com elongatum, mas, o último tem corpo esbelto, fusiforme, e apresenta, no órgão copulador, nos espinhos dêste, na bursa sem canal, no duto comum distinto do átrio, nos espessamentos pares do átrio superior, e em outros pormenores ainda, sinais disjuntivos. Nem radiatum, nem elongatum, ou qualquer outra espécie do gênero possue as duas colunas da secreção granulosa de St. dicorymbum. 


\section{Subfamilia: Phaenocorinae Wahl 1910}

\section{Genus: Phaenocora Ehrenberg 1836}

\section{Phaenocora bresslaui *), spec. nov. (Fig. 81-83)}

Os vermes têem mais de $3 \mathrm{~mm}$. ao comprido e ca. de $1,5 \mathrm{~mm}$. do largo. $O$ corpo varía muito quanto à forma; pode ser lingulado ou foliáceo, e apresenta, geralmente, constrição cefálica. No meio do dorso, é algo carinado; no ventre, achatado. Pequena cauda cuspidata apresenta-se sempre nos animais jovens; nos adultos, pode ser incorporada completamente, ou, como as mais das vêzes, salientar-se um pouco.

O diâmetro dos ovos varia entre 0,18 e $0,3 \mathrm{~mm}$. Quando os vermes jovens saem do ovo, já possuem faringe quasi completamente crescida, de modo que as proporções mútuas e, com isso, a feição dos vermes variam muito, conforme a idade. Pode, p. e., um animal jovem, imaturo, apresentar comprimento e largura do corpo de 0,9 e $0,3 \quad 0,4 \mathrm{~mm}$., respectivamente, combinados com faringe de $0,3 \mathrm{~mm}$. de longura; outro verme, adulto e com ovo, pode mostrar, na mesma seqüência, as medidas de' $1,5 \mathrm{~mm}$.; $0,6 \mathrm{~mm}$.; e $0,4 \mathrm{~mm}$. O terceiro exemplar acusa $2,5 \mathrm{~mm}$; $0,8 \mathrm{~mm}$; (e $0,4 \mathrm{~mm}$. (Fig. 82 ).

Os vermes adultos são amarelo-cinzentos, com a cabeça fireqüentemente avermelhada e olhos sempre vermelhos. O pigmento óptico pode manter-se nos cortes. Nos jovens, é a côr mais clara, e os animais são transparentes, em oposição aos adultos. A opacidade dos últimos deve-se aos vitelários e testículos ramificados em forma de pena nos lados ventraI e dorsal, respectivamente.

$A$ epiderme tem de altura 0,006 (lado dorsal) até 0,012 mm. (lado. ventral), com cílios cujo comprimento é aproximadamente igual à altura das células epidérmicas. Os limites do epitélio epidérmico são nítidos e formados por linhas simples, não denteadas, como em $P h$. jucunda (Cognetti de Martiis 1915, p. 194-196) e Ph. unipunctata (Lippitsch 1889, t. 8 f. 8 ; a f. 9 ilustra deformações pela fixação, p. 149). Rabditos epidérmicos faltam, como também as lacunas que são remanescentes dêles $(P h$. virginianum Gilbert 1935, p. 295, nota). Glândulas rabditógenas situam-se, principalmente, ao nível dos olhos e entre êstes, assim como nos dois lados: da faringe, de onde os tratos de rabditos ("Stäbchenstrassen") convergem para diante. Observam-se ainda, na extremidade anterior, glândulas cianófilas, pouco conspícuas.

O parênquima é rico em pequenas células, em oposição aos vermes de Dalyellia com poucas células volumosas, ou de Mesostoma, paupérrimos em células parenquimáticas (Prenant 1922, p. 28). Na espécie atual, destacam-se, especialmente, as células livres, do tipo das formadoras ("Stammzellen"), quando se agrupam, dando origem aos vitelários (l. c.,

*) O nome foi escolhido em memória do Professor Dr. E. Bresslau, autor da. ótima sinopse (1928-1933) dos Turbelários. 
p. 47-48; 61-62). O tubo músculo-dermático corresponde ao geralmente conhecido do gênero (Luther 1921 , p. 5) ; da musculatura interna (parenquimática) merecem ser mencionadas as fibras dorso-ventrais que não sòmente atravessam a parede do intestino, mas, até o lume do saco digestivo. De Bothromesostoma essenii (Luther 1904, p. 29, 254), Phaenocora jucunda (Cognetti de Martiis 1915, p. 203, t. 11 f. 18, fd), e vários Kalyptorhynchia (Meixner 1925, f. 18, no texto; Reisinger 1926, p. 422.) foram mencionados músculos que percorrem o intestino.

Dos olhos de Phaenocora bresslaui corresponde a parte perceptiva à de Ph. unipunctata (Hesse 1897, t. 28 f. 23-24) e difere da célula óptica de Ph. virginiana (Gilbert 1935, p. 295), por sua vez, do tipo de Mesostoma lingua e $M$. ehrenbergii (Luther 1904, t. 3 f. 24-25). Na espécie presente, situam-se os olhos no bordo ântero-lateral do cérebro. Possuem cálice pigmentado profundo, multicelular, como Derostoma (= Phaenocora) spec. (Hesse 1897, t. 28 f. 22 ) e uma única célula visual. Esta compõe-se duma parte central, comprimida nos cortes transversais, de citoplasma fibrilar (as neurofibrilas), e da orla periférica de bastonetes, tal como foi desenhado por Hofsten (1918, f. 8 c, no texto). O cálice destaca-se, como massa homogênea, mesmo nos cortes, em que o pigmento se dissolveu no líquido fixador.

A bôca (Fig. 83, 9) provida de fina dobra anelar encontra-se no quinto anterior do corpo, numa ligeira reintrância da epiderme. A bolsa faríngea externa (2) é pouco profunda e sem cílios e núcleos. A faringe ovóide situa-se no terço anterior do verme e inclina-se fortemente do lado dorso-caudal para o ventro-rostral. A orla faríngea contem uma dobra anelar, mas, não apresenta dentículos (Cognetti de Martiis 1915, p. 208), nem papilas ciliadas (Luther 1921, p. 8; Beklemischev 1929a, p. 537).

Entalmente à bolsa faríngea externa, desembocam as glândulas faríngeas eritrófilas (Fig. 83, 4) e cianófilas (5), de cujos citosomas se situa a maior parte intrafarìngeamente. Os epitélios externo e interno (6), destituidos de cílios, possuem escassos núcleos intra-epiteliais; limites inter-celulares faltam. Em $P h$. typhlops é outra a posição dos núcleos do epitélio externo (Luther 1921, p. 8. f. 2 no texto), pois situam-se no bordo da bolsa faríngea, onde os retractores (Fig. 83, 7) se inserem. 0 epitélio que reveste a superfície ental (proximal) da faringe é uma continuação do interno (6).

Os musculos faríngeos anelares internos são mais grossos que os externos, e o seu número é de ca. de 45. Dêstes, os 5 primeiros situados entalmente à desembocadura das glândulas pertencem à orla faríngea. Outros 5 músculos, no lado ental (proximal), constituem o esfincter proximal (Meixner 1915, p. 538; Beklemischev 1929a, p. 538) ou posterior (Cognetti de Martiis 1915, p. 210). A musculatura anelar externa apresenta-se, como em $P h$. typhlops (Luther 1921, p. 9), em três grupos: o do septo da faringe, composto de ca. de 32 músculos; o do esfincter inferior (distal), no ponto da inserção da bolsa externa (2); e o entre êste esfincter e a boca faríngea. Os músculos faríngeos longitudinais internos (Fig. 83, 8) são em número de ca. de 50; encontram-se subja- 
centes aos anelares internos. Os longitudinais externos (do septo), finos e de contagem incerta, sobrepõem-se aos anelares externos. Na região do esfincter inferior, porém, correm internamente aos anelares externos, como parece ser, segundo os dados disponíveis, a regra nas Phaenocorinae. Os músculos radiais faríngeos originam-se, no septo, de tal modo que há sempre dois anelares externos entre duas origens dos radiais. Disposição idêntica reconhece-se, segundo o desenho de Lippitsch (1889, t. 8 f. 7), em $P h$. unipunctata. Para dentro, continuam os músculos radiais como fitas relativamente largas; na região dos longitudinais internos, ficam comprimidos e inserem-se na membrana basilar do epitélio interno (6), cuspidatamente, em linhas transversais, entre os anelares internos.

Dos nervos faríngeos, notamos três aneis (Fig. 8⿳亠丷⿵冂丶 1) : um grosso, aproximadamente no meio da faringe, e dois mais finos, um para fora, o outro para dentro. Vimos também alguns nervos longitudinais, mas, não pudemos, até agora, reconstruir a grade nervosa de $P h$. typhlops (Luther 1921, f. 4 no texto; Bresslau 1933, f. 62). Além dos nervos, ocupam as glândulas (Fig. 83, 4 \& 5) o parênquima, e isso, dos músculos longitudinais internos (8) para fora. Ocorrem curtas glândulas extrafaríngeas. A entrada destas, na faringe, ventraimente à bolsa interna (Fig. 83, 3), corresponde ao que foi indicado de Ph. typhlops (Luther 1921 , p. 12). Dá-se o mesmo com a posição, em geral, mais central das glândulas de secreção eritrófila; mais periférica, das cianófilas. Entre os epitélios faríngeo interno (6), faríngeo ental (proximal), e da bolsa interna (3), não há limites; aumenta apenas a altura para dentro, e a maior parte dos núcleos situa-se no trecho da bolsa interna (posterior; "oesophagus pharyngealis" Beklemischev 1929a, p. 541), como foi descrito de Ph, unipunctata (Wahl 1910, p. 43).

O intestino começa, sem que haja tecido de transição entre êle e a bolsa interna. As células claviformes de Minot, frequentes na entrada intestinal dos Rhabdocoela, são numerosas, nesta zona de $P h$. bresslaui, apenas no teto, faltando ventralmente. O lume do intestino conserva-se aberto. As paredes sincíciais delimitam-se indistintamente do parênquima, e interpõem-se entre os órgãos reprodutivas adjacentes.

Os poros dos emunctórios (Fig. 82) situam-se nos dois lados do vèntre, imediatamente atrás do meio do corpo, e medialmente aos nervos longitudinais ventrais. Daí correm, como em outras espécies do gênero (Fuhrmann 1894, t. 11 f. 46 ; Sekera 1911, t. 1 f. 2 ; Luther 1921, p. 16), os canais descendentes para diante, onde se ramificam, dando origem a um canal rostral e a outro, caudal. Os últimos correm até as regiões anterior e posterior do corpo e aí recebem os canais aferentes correspondentes, cujos ramos de pequeno calibre sòmente de vez em quando aparecem nos cortes.

Phaenocora bresslaui é hermaphrodita proterândrico ; testículos maduros e órgão copulador estão desenvolvidos, enquanto o ovário é ainda pequeno, e os vitelários são representados apenas por acumulações de células parenquimáticas livres. $\mathrm{O}$ gonóporo (Fig. 81, 83, r) situa-se bem rostralmente ao meio do corpo e atrás do plano transversal que passa pelo bordo caudal da faringe. 
Os testículos (Fig. 82) encontram-se dorso-lateralmente; podem estender-se do nível do complexo copulatório até a extremidade caudal. No auge do seu desenvolvimento, são arboriformemente ramificados. A configuração da gônada masculina não fornece, aliás, sinal específico (Gilbert 1935, p. 296-297). Dois duto eferentes (Fig. 81, e), os "vasa deferentia" da literatura, de calibre grosso, evacuam os testículos e reunem-se onde desembocam na vesícula seminal (v), depois de terem cruzado as glândulas (s) da secreção granulosa. Os citosomas destas distanciam-se, em parte, muito do órgão copulador, e entremeiam-se, em vários pontos, com as glândulas da casca $(\mathrm{g})$. A vesícula seminal constitue a calota proximal, arredondada, do órgão copulatório, de forma geralmente bulbosa, mas, nos casos do retraimento máximo do duto ejaculatório, quasi esférica. $O$ órgão copulador situa-se, mais ou menos pronunciadamente, no lado esquerdo e dirige-se de diante para trás. Entra no átrio superior (Fig. 83, a), entre a parte esquerda dos apêndices "piriformes" (u) e o canal genital feminino (c). Numerosos músculos seguram e movem o órgão copulador, originando-se alguns dêles nos ditos apêndices. A vesícula seminal (v) e o reservatório da secreção granulosa (t) são separados por um diafragma (f); no epitélio das duas divisões mencionadas do aparelho masculino notam-se alguns núcleos. $O$ duto ejaculatório sinuoso abriga-se, na fase da sua invaginação, no reservatório da secreção granulosa.

O ovário (germário; Fig. 83, o) situa-se no lado direito, ao lado da faringe e caudalmente a ela. Encurva-se e dirige a zona germinativa para diante e para baixo. Na zona de crescimento caracterizada pela disposiৎ̧ão dos ovócitos em forma de pilha de moedas, exibe concavidade ventral bem pronunciada. Os ovócitos completamente crescidos, na parte mais caudal do ovário, aproximam-se à forma esférica. Na túnica ovárica, ocorrem alguns núcleas, eujo número aumenta para fora, onde o oviduto (d) ou germiduto começa.

No ponto em que o oviduto desemboca no canal genital feminino (ductus communis ; Fig. 83, c), acumulam-se vários órgãos. Dêstes, são os vitelodutos, possivelmente um viteloduto comum, indistintos, nos nossos cortes. Os vitelários (Fig. 83, w) ocorrem só ventralmente; exibem ramificação simples, sem anastomoses. No ponto referido, encontram-se ainda: a) uma grande glândula lobulada (z), que lembra, pelo núcleo único e pela configuração flabelada, o órgão correspondente de $P h$. virginiana (Gilbert 1935, p. 314-315) ; b) citosomas aprofundados (l) que correspondem, verosimilmente, à "small fan-like gland" de Ph. lutheri (Gilbert 1937, p. 58 f. 3, gl 2), cuja secreção se derrama no oviduto, muito perto da desembocadura dêle no canal genital feminino.

Oposto à desembocadura do oviduto, situada no lado direito, reconhece-se, nos cortes transversais no lado esquerdo, um divertículo (Fig. $81, \mathrm{x})$ pouco profundo do canal genital feminino. Dois tufos grandes de glândulas da casca (Fig. 83, g), com corpos celulares piriformes e dutos compridos, finos e, em parte unidos, esvaziam a sua secreção ligeiramente basófila no canal genital feminino. $O$ epitélio dêste mostra alguns 
núcleos não aprofundados e é, na superficie, algo viloso. Ectalmente, o canal é separado do complexo atrial por um esfincter forte $(y)$.

O primeiro órgão dêste complexo é a dobra ental ( $u$ ) do átrio superior (a). Corresponde aos lóbulos ou apêndices piriformes (Vejdovsky 1895, p. 115 t. 5 f. 34, 37, zb), universalmente encontrados nas espécies do gênero. Em $P h$. bresslaui, trata-se duma dilatação atrial muito musculosa, cujos dois sacos são unidos, no dorso, e, nos dois lados, asimètricamente desenvolvidos. Não são "piriformes" essas bolsas da espécie atual; a esquerda lembra uma salchicha; a direita, mais profunda, tem forma menos regular e paredes formadas por células mutuamente achatadas. Quando o ovo se encontra no átrio superior, dilatando-o, a dobra pode apagar-se completamente. Tal condição conserva-se também depois da ovipostura. Em tais fases, as células dos "lóbulos" dispõem-se epitelialmente. Vimos espérmios incorporados nelas e em outras células atriais. $O$ átrio com a sua dilatação funciona, portanto, como útero e como órgão fagocitário de espérmios excedentes. Lembra, destarte, a função do átrio de Pseudograffilla arenicola Meixner (1938, f. 69 na p. 67). Nos fundos cegos dos lóbulos piriformes notam-se células especiais dispostas em pequenos tufos; são homólogas às "glândulas uterinas" de Ph. (Megaloderostoma) polycirra Beklemischev (1929a, f. 10, 11, gl. u.) Conforme a idade, a fase reprodutiva, a contração e, finalmente, a direção dos cortes, apresenta-se a dobra muito diversamente, embora não possamos cháma-la, em qualquer fase, de "parcialmente intra-atrial", como se mostra em Ph. virginiana (Gilbert 1935, p. 335) e Ph. evelinae (Fig. 84, u). Várias figuras modernas, p. e., de Ph. unipunctata (Beklemischev 1921, t. 2 f. 13) ; Ph. typhlops (Luther 1921, t. 1 f. 3, 4, Bl) ; Ph. virginiana Gilbert (1935, t. 4 f. 41); Ph. lutheri (id. 1937, f. 1, psa 1) ; Ph. falciodenticulata (id. 1938, f. 4, bl ; f. 5, C 2) ; e Pseudophaenocora sulfophila (id. 1938a, f. 3, 4, 5, psa 1-3) justificam do mesmo modo que os hossos cortes a passagem de Gilbert (1937, p. 56) em que chama os lóbulos de "attached to and forming an integral part of the lateral walls of the superior genital atrium"

A grossa camada de músculos que circunda a dobra ental do átrio continua no átrio superior (Fig. 83, a), revestido por epitélio alto. Uma corôa de células cônicas, das quais 1-2 se apresentam nos cortes sagitais, separa o átrio superior do inferior (b). No fundo dêste último estendemse os cílios da epiderme. O átrio inferior abre-se (r) por um canal ricamente provido de músculos cutâneos e parenquimáticos.

Internamente ao ponto da desembocadura do oviduto, ocorre um esfincter que separa a comunicação gênito-intestinal do canal feminino (c). $O$ curto trecho, em que o esfincter se situa, poderia só forçadamente ser chamado de duto gênito-bursal. Comparando $\boldsymbol{P h}$. bresslaui com espécies de Phaenocora providas de duto gênito-bursal indubitável, p. e., $\boldsymbol{P h}$. unipunctata e Ph. megalops (Gilbert 1935, p. 303 f. 1 no texto, C \& D, dgb) ; Ph. lutheri (Gilbert 1937, p. 214 f. 3, dgb); e Ph. jucunda (Cognetti de Martiis 1915, p. 228, t. 11 f. 25), consideramo-la como destituida de duto gênito-bursal. A bursa intestinal (Fig. 83, m) tem parede grassa com numerosos divertículos, eujos lumes se eomunicam enm o lume 
central e contêem, como êste, espérmios. Entalmente, salienta-se a parede da bursa com poucas (ca. de 3 ) grandes células, seguindo um trecho curto de parede mediocremente alta. Esta parte corresponde, topogràficamente, a um duto bursa-intestinal, mas, não merece denominação especial. Várias células lameliformes ao redor do poro bursa.intestinal (p) formam um aparelho obturador, como ocorre também em outras espécies do gênero, p. e., Ph. jucunda (Cognetti de Martiis 1915, t. 11 f. 27, cc); Ph. typhlops (Luther 1921, t. 1 f. 6, 8, Va); e Pseudophaenocora sulfophila (Gilbert 1938a, f. 3A, va).

\section{Ocorrência de Phaenocora bresslaui}

Colhemos, em abril de 1943, espécimes da água estagnada e plénamente insolada num pequeno lago em Canindé (bairro da cidade de São Paulo), em que Mesostoma ehrenbergii foi encontrado pela primeira vez (Marcus 1943a). Em marso de 1945, encontrámos $P h$. bresslaui, na lagôa da Corôa, perto do dito lago e em condiçōes semelhantes, havendo, porém, comunicação da lagôa da Corôa com o rịo Tietè; nestes entrementes, a Prefeitura começou a entulhar o pequeno lago com lixo, e èle tornou-se azóico. Os achados na ponte de Jaguaré, no Rio Pinheiros, entre as raizes de Eichhornia crassipes (Aguapé), em novembro de 1945, mostram a espécie num outro biótopo, a saber, no fluvial. Em condições bem diversas, viveram os vermes que obtivemos, em novembro de 1944, dum riacho em Tremembé, na serra da Cantareira (Dr. Edmundo Nonato leg). Juntamente com Ph. bresslaui, ocorrem aí, p. e., os Tricladida Dugesia nonatoi; D. tigrina; Rhodax evelinae; vários Catenulida, entre os quais se destaca Stenostomum grande f. megis!a; dos Oligochaeta límnicos, Aeolosoma bengalense e Nais paraguayensis, sendo a última, tipicamente, encontrada entre as raizes de Eichhornia crassipes ausente no riacho em questão; larvas de Simuliidae, e muitos outros animais. O córrego tem correnteza rápida, mas, acha-se exposto, num trecho estenso do seu percurso, à insolação, e, por isso, a temperatura dágua não é baixa. Finalmente, foi a espécie encontrada, em fevereiro de 1946, nágua rica em matéria podre dum córrego de correnteza rápida, perto do bairro do Pinheiros.

Phaenocora bresslaui é, nos arredores de São Paulo, a espécie mais comum do gênero, revelando-a os biótopos, em que é freqüente, como "euryoeca". No aquário, mostra fototaxia negativa muito pronunciada; a reação é orientada (tópica). Segundo a estrutura dos olhos, devemos supor tratar-se de fototropotaxia, mas, tal ainda não foi demonstrada. A quimotaxia de Ph. typhlops foi provada como sendo tropotaxia (Müller 1936, p. 256 e seg.). O comportamento fisiológico diante de estímulos ópticos não pode, como Gilbert pensa (1935, p. 295), resolver a questão, se existem espécies de Phaenocora desprovidas de olhos ("cegas") ou apenas tais sem pigmento ao redor da célula fotoreceptora. Sekera (1904a, p. 442) chamou as formas "cegas" de "muito lucífugas", ao passo que Phaenocora chloroxantha (veja p. 80) não mostrou, quando exposta à luz difusa do dia, reação qualquer. Tal diferença poderia resultar tanto de sensibilidade foto-dermática diversa (Marcus 1945a, p. 27), quanto da existência de células visuais nas espécies vistas por Sekera e ausêneia das mesmas em Phaenocora chloroxantha.

\section{Discussão sistemática de Phaenocora bresslaui}

Segundo o órgão copulador masculino, pertence Ph. bresslaui ao tịn III de Gilbert (1935, p. 367; 1937, p. 67), exemplifieado por Ph. highlandensis (no original, p. 298 e seg. "highlandense"'), na figura 2 C, a-c no texto (1. c., p. 321). Dêste tipo, representam Ph. gracilis (Vejdovsky 1895, p. 128) e Ph. alticola Ruebush $(1939$, p. 50) as espécies com duto ejaculatório inerme. I primeira distingue-se logo de Ph. bresslaui pela ausência de pigmento visual, ou de olhos. Visto que, nêste caracter, pode haver exeepções (Roisinger 1923, p. 9; Gilbert 1935, p. 294), salientamos ainda o órgão copulador muito grande de $\mathbf{P h}$. gracilis e os vitelírios reticulados 
(Hofsten 1911, p. 44, 46). Além disso, possue $P h$. gracilis um duto bursa-intestinal, certamente ausente em $P h$. bresslaui. De $P h$. alticola separamos a espécie atual no parágrafo seguinte.

Restam, para o confronto disjuntivo, algumas espécies que não figuram na tabela citada, a saber: Ph. foliacea Böhmig (1914a, p. 89-91 f. 1-4), sem olhos (ou pigmento visual), e com órgão copulador do tipo I de Gilbert, i. é, o "sacwithin-a-sac plan"; Ph. cucurbitina Beklemischev (1920, p. 49, 74 f. 6, 7), com o duto ejaculatório distalmente armado de espinhos; Ph. subsalsa Beklemisehev (1927a, p. 193, 205 f. 1, no texto), com olhos pretos, e um órgão copulador provavelmente do tipo I, mas, não completamente compreensível (Gilbert 1935, p. 285, nota $1 ;$ p. 365); Phaenocora (Megaloderostoma) polycirra Beklemischev (1929a), pelo tamanho muito maior (10-11 mm.), os 2 úteros e vários outros caracteres (l. c., p. 555) diferente das espécies restantes de Phaenocora (quanto aos vitelários, veja, porém, Gilbert 1935 , p. 300, nota 1); Ph. beauchampi Sekera (1930, nome na p. 100), com órgão adesivo, aliás, não descrito, na extremidade posterior; espécie reconhecível apenas pelo hábito pseudo-parasitário; Ph chappuisi Beauchamp (1935, p. 148), que lembra muito $P h$. foliacc $a^{*}$ ), sem olhos, com duto gênito-bursal comprido e com órgão copulador, ao que pareee, do tipo I; Ph. lutheri Gilbert (1937, p. 53), com duto ejaculatório e pseudo-duto ejaculatório, ambos espinhosos; Ph. falciodenticulata Gilbert (1938, p. 208), com o órgão copulador do tipo I e o duto armado; $P h$. kepneri adenticulata Gilbert $(1938$, p. 220), com órgão copulador do tipo II, quer dizer, os espérmios e a secreção granulosa separados, por um diafragma, da loja distal, que abriga o duto muito comprido (Gilbert 1935 , f. 2 B, a-c, no texto da p. 321); Pseudophaenocora sulfophila Gilbert (1938a, p. 193), com átrio inferior enorme, ligado por um tubo, o duto copulatório, ao átrio superior, e com caracteres do órgão copulador masculino que justificam a separação genérica; Phaenocora alticola Rucbush $(1939$, p. 50$)$, com duto gênito-bursal e sem aparelho obturador na desembocadura do duto bursa-intestinal.

Segundo a comunicação gênito-intestinal, pertence $P h$. bresslani ao grupo I D (tipo 5) de Gilbert $(1935$, p. $350 ; 1937$, p. 66). As quatro espécies dèste tipo carecem de pigmento visual (ou de olhos) e possuem, todos, duto ejaculatório armado. São estas: Ph. typhlops (Vejdovsky 1880, p. 503, nota 2, n.o 7 ; Luther 1921, p. 4 e seg.) ; Ph. anomalocoela (Haswell 1905, p. 450 t. 27 f. 25-34; Graff 1913, p. 147); Ph. clavigera Hofsten (1907, p. 550; 1911, p. 39); Ph. vjatkensis Nassonev (1919, p. 633 , t. 1 f. $11-13$; id. 1924 , p. 333 , nota 6 ; Gilbert 1935, p. 284-285).

Do grupo duvidoso de Gilbert (1935, p. 350), foram Ph. (Megaloderostoma) polycirra Bekl. e Ph. beauchampi Sek. já separados no parágrafo relativo aos órgãos masculinos, de maneira que resta sòmente $P$ h. typhlops subsalina Luther (1921, p. 31), sem olhos, com duto ejaculatório espinhoso, e vesícula acessória glandular do ítrio inferior.

Admitindo a possibilidade de ser chamado de duto gênito-bursal o curto trecho entre a cntrada do oviduto (Fig. 83, d) no canal feminino (c) e a bursa (m), devemos comparar Ph. bresslaui ainda com as espécies, cuja comunicação gênitointestinal se compõe de duto gênito-bursal, bursa e póro bursa-intestinal, a saber, o tipo 1. As 3 espécies certa ou possivelmente pertencentes a êste grupo, e tôdas con olhos, são: Ph. rufodorsata Sekera (literatura: Graff 1913, p. 140), cujo órgāo copulador masculino é do tipo 1 e possue duto ejaculatório armado; Ph. achaeorum Nassonov (1919a, p. 1043) e Ph. virginiana Gilbert (1935, p. 292), ambas com órgão copulador do tipo I.

Quanto à nossa interpretação dos apêndices ou lóbulos piriformes, discutiremos ao tratar de Ph. evelinae (veja p. 75).

\section{Phaenocora evelinae, spec. nov. (Fig. 84, 88-91, Est. XXXI Fig. 2)}

Os vermes têem até $2 \mathrm{~mm}$. de comprimento e $0,4 \quad 0,7 \mathrm{~mm}$. de largura. A forma é menos variável que a da espécie precedente, sendo,

*) Depois de termos acabado o capítulo atual do manuscrito, recebemos $\mathbf{a}$ publicação de Beauchamp (1940), em que considera (p. 323, nota 1) Ph. chappuisi re-encontrada no material do Congo belga sinônimo de $\mathrm{Ph}$. foliacea. 
p. e., a extremidade caudal sempre cuspidata. Pelo desenvolvimento consideravel dos vitelários em animais maduros torna-se, às vezes, foliforme a região caudal do corpo. $O$ achatamento atinge mesmo as partes mais anteriores (Fig. 88). Em outras épocas, é o ventre convexo, não aplanado como em $P h$. bresslaui, podendo o corte tranversal, às vêzes, aproximar-se a um círculo. Constrição post-cefálica não se marca. $O$ diâmetro do ovo é de $0,190,24 \mathrm{~mm}$.

Os olhos são brancos brilhantes, à luz refletida; escuros, à transmitida, lembrando o efeito óptico produzido pela guanina. As inclusões das células do cálice ocular conservam-se, porém, raramente no bálsamo. Notam-se, ainda, no dorso, algumas manchas brancas; os vitelários podem, no ventre, originar formoso desenho reticulado em branco. $O$ parênquima dos vermes jovens exibe côr esbranquiçada; 0 dos velhos, trigueiro-esverdeada ou puramente verde, em conseqüência de zooclorelas (Est. XXXI Fig. 2).

$\Lambda$ epiderme mostra-se, nêstes animais quasi cilíndricos, sem diferença no dorso e no. ventre, de altura aproximadamente uniforme, entre 0,006 e $0,011 \mathrm{~mm}$. Os limites das células epidérmicas são simples, não denteados; os núcleos delas, fortemente lobulados. Rabditos ocorrem, como 'em Ph. bresslaui, sòmente nos tractos de bastonetes ("Stäbchenstrassen") anteriores, visíveis na cabeça do corte desenhado (Fig. 84). Ao lado dêstes elementos acidófilos, notam-se glândulas basófilas, que ocorrem ainda em outras regiões do corpo, atravessando a epiderme. Correspondem aos canalículos de secreção descritos de Ph. typhlops (Luther 1921, p. $5-6)$.

O parênquima é rico em células. Fios sinuosos e ramificados de secreção basófila passam pelo parênquima, e entremeiam-se, do mesmo modo que os músculos, nas paredes do intestina. Nas zonas periféricas do parênquima são numerosas as mitoses dảs células livres. Nos espécimens verdes, encontram-se zooclorelas com ca. de 0,006 mm. de diâmetro. São adquiridas por via oro-intestinal, como parece a regra nos Turbelários (Haffner 1925, p. 52 e seg.; Bresslau 1933, p. 230).

Ao lado dos tractos de bastonetes, encontram-se os olhos, reconhecíveis mesmo depois da dissolução do conteúdo das células do cálice pela. homogeneidade destas. A célula óptica corresponde à anteriormente descrita de $P h$. bresslaui. Mais para trás, confina o cérebro (Fig. 84, h) com. a parede anterior da faringe. Uma das glândulas rabditógenas vê-se, na Fig. 84, adjacente ao bordo anterior do cérebro.

A boea aprofundada (Fig. 84, 9) situa-se no quinto anterior do corpo. Glândulas bucais. desembocam ao nível da dobra anelar oral. $\Lambda$ bolsa faríngea externa (2) é pequena, sem cílios e núcleos. A faringe é rostral e ventralmente um pouco mais estreita que caudal e dorsalmente; o seu lume é circular, no corte transversal. O epitélio externo da faringe $1 \mathrm{em}$ os núcleos dispostos dentro do epitélio, como em Ph. bresslaui, e apresenta-se espessado na entrada da faringe, mas, sem cílios ou dentículos. O epitélio faríngeo interno (6), a bolsa faríngea interna (3), e o início repentino do sincício intestinal são semelhantes às partes corres-. pondentes da espécie precedente. Além das glândulas eritrófilas e cianó- 
filas, observam-se, no parênquima da faringe, núcleos em número maior que em Ph. bresslaui. Talvez por isso, foi verificado apenas um anel nervoso (1). Dos músculos faríngeos anelares internos, ocorrem ca. de 10 ınuito finos, na orla faríngea; 32 grossos, no corpo da faringe; e 10, un ponco menos fortes, formando o esfincter proximal (ental, posterior). Nos músculos anelares externos, distinguem-se os mesmos 3 grupos descritos de Ph. bresslaui: ca. de 27, no septo; um grupo do esfincter distal (ectal, anterior); e uma camada simples entre êste esfincter e a bôca faríngea. Repete-se também a inversão da posição dos músculos longitudinais externos, sobrepostos aos anelares, no septo; e subjacentes a êstes, do esfincter distal até a entrada faríngea. Os músculos longitudinais internos são menos numerosos que na espécie precedente, havendo ca. de 40 dêles. Dos radiais, ocorrem no corte transversal de $P h$. evelinae, ca. de 80 ; a sua origem, no septo, entre os anelares externos, e a sua inserção, na membrana basilar do epitélio interno, correspondem às precedentemente des-. critas.

O intestino (Fig. 84, i), de parede sincicial, pode perder o seu lume. A sua separação, do parênquima, é indistinta. Contribuem para apagar os limites do intestino as inclusões alimentícias, as zooclorelas, os músculos e os fios de secreção que se encontram no trato digestivo. Como se verifica pela Fig. 84, destacam-se células claviformeses de Minot no teto do intestino, havendo, porém, na espécie atual, também ventrais.

Os poros dos emunctórios situam-se latero-ventralmente, perto do meio do corpo. A disposição dos canais corresponde, por princípio, à que foi descrita de $\boldsymbol{P h}$. bresslaui e desenhada de $\boldsymbol{P h}$. chloroxantha (Fig. 86). Nas três espécies ocorre regularmente a ligação parenquimática pre-oral entre os canais direito e esquerdo, reconhecível na figura de Fuhrmann (1894, t. 11 f. 46). Confirmamos a observação (l. c., p. 281) de não se anastomosarem êstes eanais.

O gonóporo (Fig. 84. r) encontra-se no fim do quarto anterior do corpo. Os testículos (Fig. 88, te) foliculares, segundo a fase reprodutiva de estensão muito diversa, ocupam posição dorso-lateral, aproximadamente no terço médio e dorsalmente aos vitelários (w). Os dutos eferentes (Fig. 84, e) correm medialmente para diante, entrando unidos na vesícula seminal $(\mathrm{v})$, perto do limite entre a vesícula e o reservatório da secreção granulosa ( $\mathrm{t}$ ). O dito limite é formado por um diafragma (f). Nos epitélios da vesícula e do reservatório ocorrem núcleos. As glândulas produtoras da secreção granulosa (s) notam-se ventralmente ao órgão copulador. O duto ejaculatório é inerme e, no estado da invaginação, abrigado no reservatório. Corresponde, destarte, o órgão copulador masculino de $P h$. evelinae ao de $P h$. bresslaui, pertencendo; ambos ao tipo III A de Gilbert (1935, p. 367). A direção principal do órgão copulador bulboso corre do lado esquerdo para o plano mediano do corpo, de maneira que coincide com os cortes transversais dêste.

O ovário (Fig. 84, o) situa-se no lado direito, pouco caudalmente à faringe. A zona germinativa dirige-se dorsalmente. Na zona de crescimento com os ovócitos dispostos em forma de pilha de moedas, dirigese o germário em ângulo reto para trás. A concavidade do ovário é 
dorsal, contrastando com a de $P h$. bresslaui. A túnica propria do ovário é nucleada e continúa, em direção para o plano mediano, como oviduto curto (Fig. 84, d). Os vitelários ramificam-se, em oposição aos de $P \boldsymbol{h}$. bresslaui, de tal modo que surgem folículos secundários. Entre êstes, as anastomoses são freqüentes, sem que haja a rêde conhecida de $P h$. unipunctata (Graff 1913, f. 136a) e Ph. lutheri (Gilbert 1937, f. 1). Os vitelários começam, em Ph. evelinae, no lado ventral, mas, podem, quando màximamente desenvolvidos, estender-se, no terȩo anterior do corpe, laterodorsalmente (Fig. 88, w). Permanecem, todavia, em nível mais ventral que os testículos (te). Não foi possível distinguir os vitelodutos.

A glândula lobulada, uni-nucleada (Fig. 84, z), é menor que na espécie anterior. $O$ canal genital feminino (c) carece de glândulas da casca; o seu divertículo dirigido para o lado esquerdo encontra-se ( $\mathbf{x}$ ) muito mais distalmente (ectalmente) que em Ph. bresslaui. O esfincter (y) que separa o canal genital feminino do átrio superior (a) re-encontrase em $P$ h. evelinae.

Para dentro do átrio superior salientam-se, do lado caudal, os apêndices piriformes $(\mathbf{u})$. São unidos, circundados por músculos e formam um conjunto apepinado (Fig. 84, 90). Os apêndices permitem distinguir, como em Pseudophaenocora sulfophila (Gilbert 1938a, p. 196), três partes: a interna, alta, de protoplasma lamelado (psa 2 de Gilbert); a externa, igualmente lamelada (psa 1 de Gilbert); e a periférica (Fig. 90, 91, qa), não lamelada (psa 3 de Gilbert). Nas partes externas, ocorrem glândulas (q) unicelulares (gle de Gilbert). homólogas às g]ândulas uterinas de Ph. (Megaloderostoma) polycirra Beklemischev (1929a, f. 10, 11, gl. u.), presentes também em Ph. bresslaui (Fig. 81, q). A posição intra-atrial das lamelas da parte interna (Fig. 89) corresponde ao que foi descrito de Ph. virginiana (Gilbert 1935, p. 335). No caso de haver um ovo no átrio superior, incorpora êste as partes internas dos apêndices. A dilatação pelo ovo e a distensão pelos músculos atriais e os do envoltório dos apêndices transforma a parede do átrio e as pártes intra-atriais dos apêndices em epitélio baixo uni-estratificado, desaparecendo as lamelas. Sòmente nas partes externas dos apêndices, que não participam na formação do útero, conserva-se a estrutura lamelada. Com as partes externas, permanecem também as periféricas (Fig. 91, qa) inalteradas na fase da gravidez. No estádio epitelial achatado, que pode manter-se ainda depois da ovipostura, as células "uterinas", i. é, as do átrio superior e as das partes internas dos apêndices, fagocitam espermatozóides. A figura do "útero" grávido mostra que não se pode distinguir, nêste estado, entre o epitélio do átrio superior e as partes internas lameladas dos apêndices transformadas. Em certos casos. contrae a musculatura, depois da ovipostura, as partes internas dos lóbulos piriformes irregularmente (Fig. 84, u), re-aparecendo, então, as lamelas. Que estas são muito mais numerosas que os núcleos, e, destarte, não podem ser limites de cálulas, foi claramente dito por Gilbert $(1935$, p. 335). Quando se dá a contração irregular dos apêndices, não retoma o intestino, imediatamente, o espaço na fase grávida ocupado pelo ovo. I região respectiva conserva-se, durante certo tempo, preenchida por uma massa acelular. 
A comunicação gênito-intestinal de $P h$. evelinae corresponde, por princípio, à de $P h$. bresslaui (tipo 5 de Gilbert 1935 , p. 350), mas, distingue-se dela em vários pormenores. Começa, p. e., no ponto em que o oviduto (Fig. 84, d) desemboca no canal genital feminino (c), sem que haja um curto trecho provido de esfincter. A própria bursa (m) apresenta cavidades laterais, em larga comunicação com o lume central. Os espérmios excedentes são evacuados da bursa por um duto bursa-intestinal (n) que se dirige caudalmente. $O$ aparelho obturador do duto bursaintestinal é paucicelular e encontra-se, nos nossos cortes, dentro do sincício intestinal, do qual se demarca distintamente.

\section{Ocorrência de Phaenocora evelinae}

O material foi colhido (novembro de 1945) entre raizes de Eichhornia crassipes (Aguapé), na ponte de Jaguaré, no rio Pinheiros, juntamente com Ph. bresslaui e, além disso, nágua estagnada, húmica, dum brejo periòdicamente sêco perto do rio Pirajussara, ca. de $1 \mathrm{~km}$. ao sul do Instituto Butantan (março, abril, outubro de 1945; agosto de 1946). Na última localidade, abundam animais verdes habitados por zooclorelas, a saber: Flagellata; Amoebea testacea; espécies de Stentor e outros Ciliata; Hydridae; Rotatoria; Hirudinea; e Ancylidae. 0 terceiro achado (fevereiro de 1946) refere-se a um córrego perto do bairro de Pinheiros. A água era rica em matérias em putrefação; a correnteza, rápida. O quarto achado (18. IV. 1946) refere-se a uma pequena fossa, perto da segunda localidade. Como no brejo aludido, desaparece a água da fossa durante o inverno; na data indicada, abundaram os vermes.

No aquário, alimentámos Phaenocora evelinae com Naididas picadas. Dum verme obtivemos seis oviposturas consecutivas de um ovo, no decorrer de 12 dias. A fototaxia da espécie atual é menos pronunciada que a de $\boldsymbol{P h}$. bresslaui.

\section{Discussão sistemática e morfológica de Ph. evelinae}

A espécie precisa ser confrontada com $P h$. bresslaui, pois possue, como esta, cauda; olhos; órgão copulador masculino do tipo III $\mathrm{A}$; e comunicação gênitointestinal do tipo 5. Ph. evelinae distingue-se, principalmente, da dita espécie pela forma e a côr do corpo; pela côr dos olhos; pelos pormenores da estrutura da faringe, aludidos na diagnose precedente; pelo germário encurvado no sentido oposto; pela ausência de glândulas da casea; pela posição intra-atrial das partes internas dos apêndices piriformes, na fase não grávida; pela estensão dos vitelários ao dorso; e pelo duto bursa-intestinal.

Das espécies restantes do gênero pode-se separar a atual com auxílio dos critérios mencionados na discussão sistemática de $P h$. bresslaui. Refere-se isto aos parágrafos que tratam do órgão copulador masculino e aos dois primeiros relativos. à comunicação gênito-intestinal. O último parágrafo desta parte, em que a discriminação de $P h$. bresslaui se estende às espécies providas de duto gênito-bursal, não tem relação com $P h$. evclinae, pois, nesta, não existe, nem mesmo alusivamente, tal trecho.

Ph. evelinae foi decisiva para a nossa interpretação dos apêndices ou lóbulos "piriformes" como sendo dobras do átrio superior. A literatura a respeito dos órgãos em questão foi reunida por Beklemischev (1929a, p. 554) e Gilbert (1935, p.334-340), voltando o último ainda várias vêzes a êste assunto (Gilbert 1937, p. 56 ; 1938 , p. $211-213$; 1938a, p. 199-202). O confronto dos apêndices, na fase não. grávida e na grávida (Fig. 84, u), não explica, certamente, como os citosomas das células lameladas são transformados, dilatados pelo ovo e distendidos pelos músculos, em epitélio baixo. O processo, como tal, apresenta-se, porém, como certo. Verificando os lóbulos na função de útero, em $P h$. evelinae, e a sua participação no alargamento. do átrio superior, en $P h$. bresslaui, aproximamo-nos a Beklemischev (1927, p. 121, 
nota 1; 1929a, p. 554) e aos autores citados por êle que viram, no órgão em questão, Giteros rudimentares. Como se vê, podem os apêndices funcionar como atero, de maneira que o seu estádio "rudimentar" não é universal, no gênero. Em Strongylostoma existem espessamentos da parede atrial (Luther 1904, p. 152) ou botões sólidos da mesma (Hofsten 1907, p. 420) que passam por "Ǵteros rudimentares" A figura 11 de Beklemischev (1929a) é muito instrutiva e corresponde ao que se vê em $P h$. evelinae. O Gtero esquerdo não contem, na dita figura, casulo e possue apêndice piriforme volumoso ; o direito, com casulo, mostra o apêndice reduzido em conseqüência da distensão uterina, que absorve o material celular do lóbulo. Gilbert (1935, p. 338 e seg.) supöe que os apêndices funcionam como mecanismo preventivo de auto-fecundação. Na fase não grávida, tal função parece possível.

\section{Phaenocora chloroxantha, spec. nov. (Fig. 85-87, 92, 93)}

O comprimento dos vermes é de $2-3 \mathrm{~mm}$; a largura atinge $0,6 \mathrm{~mm}$. A forma do corpo lembra a base dum ferro de engomar. Anteriormente é o corpo cuspidato; posteriormente, largamente truncado ou até ligeiramente côncavo no meio, com extremidades latero-caudais salientes para trás. $O$ dorso é, anteriormente, carinảdo; o ventre, em tôda a sua estẹnsão, achatado. A largura máxima situa-se, em animais jovens, ao nível do bordo posterior da faringe; nos adultos, no meio do corpo, ou mais para trás.

A faringe é relativamente maior em vermes jovens; o sen crescimento atinge até a fase adulta o triplo das medidas que tem imediatamente depois da eclosão. $O$ corpo cresce até o sêxtuplo, aproximadamente. Em cinco indivíduos as medidas do comprimento (e da largura) do corpo foram: $0,45(0,15) ; 0,8(0,27) ; 1,1(0,4) ; 1,4(0,55) ;$ e $2,4(0,9) \mathrm{mm}$. A longura das faringes dêstes vermes importou em 0,$1 ; 0,16 ; 0,3 ; 0,33$; e $0,35 \mathrm{~mm}$. $O$ casulo tem de diâmetro ca. de $0,25 \quad 0,3 \mathrm{~mm}$; ; é acastanhado. A côr dos vermes adultos apresenta-se verde, na zona anterior, por causa de zooclorelas sitas no parênquima. Ocorrem zooclorelas de dois tipos: as pequenas e arredondadas (Fig. 93, zc), com 3-8 microns de diâmetro e as compridas (Fig. 92, zc) de até 20 microns de longura. Sòmente as primeiras podem ser comparadas com Chlorella vulgaris estudada por Haffner (1925, p. 4-5). A região posterior dos vermes é amarelada, com o intestino amarelo-avermelhado; o ventre e os dois lados da região postcefálica deixam, por transparência, ver os vitelários brancos. Animais jovens são incolores ou acinzentados. Olhos faltam.

A epiderme mede, no dorso, ca. de $0,008 \mathrm{~mm}$. de altura; no ventre, $0,0050,008 \mathrm{~mm}$., sendo o comprimento dos cílios um pouco menor. Os limites simples, não denteados, e os núcleos fortemente lobulados das células epidérmicas concordam com os elementos correspondentes de $P h$. evelinae. Os rabditos restringem-se aos tractos de bastonetes da região cefálica, faltando rabditos dermáticos. Cortes tangenciais revelamı ser cada célula da epiderme atravessada por canalículos de secreção basófila, dos quais alguns foram, evidentemente, esvaziados pouco antes ou no momento da conservação do material. Nos cortes que conteem tôda a altura das células epidérmicas, vê-se que os canalíeulos são, realmente, os trechos periféricos de glândulas sitas no parênquima. Glândulas cianófilas cefá- 
licas ocorrem, como nas outras espécies. Como particulariđade de $\boldsymbol{P h}$. chloroxantha destacam-se glândulas cianófilas caudais conspicuas.

No parênquima, repetem-se os fios de secreção descritos de $P h$. evelinae, percorrendo êstes também. as paredes do intestino.

A posição da bôca (Fig. 86, g), a da faringe, e os epitélios da última assemelham-se ao que foi descrito da espécie precedente. Os núcleos do revestimento da bolsa faríngea externa são raros. O contôrno da entrada da faringe (Fig. 86, h) é triangular, dirigindo-se uma das pontas do triângulo para trás. Os lados desta bôca faringea ("Pharynxmund") exibem pequenas saliências rígidas, cuticulares, que se apresentam como nódulos, nos cortes. Correspondem aos dentículos de $P h$. jucunda Cognetti de Martiis (1915, p. 208) : além disso, ocorrem cílios, como em outras espécies (Luther 1921, p. 8; Beklemischev 1929a, p. 537). Dos músculos anelares internos, há 10 finos, na orla da faringe; 36-39 grossos, no corpo faríngeo; e ca. de 5 que formam o esfincter interno. Os músculos anelares externos são tênues; 27-32 pares dêstes situam-se entre as origens dos músculos faríngeos radiais. Quanto ao esfincter externo, à disposição do terceiro grupo dos anelares externos, e à inversão da topografia dos músculos longitudinais externos, no septo e na parte entre o esfincter e a bôca faríngea, repetem-se os pormenores descritos de Ph. evelinae. Contam-se 39 músculos longitudinais internos nos cortes transversais. Das glândulas faríngeas, situam-se as cianófilas mais perto do septo e da bolsa faríngea interna; as eritrófilas, mais perto do lume da faringe e da bolsa externa. Como nas duas espécies anteriores, ocorrem minúsculas glândulas cianófilas extra-faríngeas. Verificąmos sòmente um anel nervoso na faringe.

$\mathrm{Na}$ entrada do intestino, há algumas células claviformes de Minot. $\mathrm{O}$ intestino não se separa nitidamente do parênquima. Músculos, já mencionados do intestino de $P h$. bresslaui e Ph.-evelinae, atravessam também o sincício intestinal de $P h$. chloroxantha.

O sistema excretor (Fig. 86), que foi estudado em vermes jovens das três espécies aqui descritas, concordam nelas de tal modo que parece suficiente descrevê-los apenas de $P h$. chloroxantha. Aproximadamente no meio entre a extremidade caudal do corpo e o bordo faríngeo posteribr desembocam os dois protonefridióporos ( $p)$, por via de regra, em níveis algo diversos. Os canais eferentes ( $\mathrm{s}$ ) correm perto do ventre para diante até o plano transversal que passa pela região posterior da faringe. Nesta altura, encurvam-se para trás e para fora, contiquando visíveis do lado ventral. Sùbitamente, dirigem-se para o dorso. A ramificação (u) que dá origem aos canais rostral (w) e caudal ( $x$ ) situa-se dorsalmente. Correm também no dorso os ditos canais; o rostral forma uma rêde ao nível cérebro-oral. Perto das extremidades anterior e posterior encurvamse os canais rostral e caudal para trás e para diante, respectivamente. Tanto o canal recurrente (aferente) rostral (f') quanto o eaudal ( $\left.\mathbf{y}^{\prime}\right)$ correm, novamente, no lado ventral. O rostral direito e o rostral esquerdo aproximam-se um ao outro na região pre-oral, formando o parênquima uma ligação entre estas alças. Os canais, porém, não se comunicam, como foi corretamente observado por Fuhrmann (1894, p. 281). Nas numerosas 
rámificações dos canais aferentes não foram encontrados cílios propulsores, nem órgãos terminais. Visto đue êstes não se apresentaram nas três espécies, num rico material de vermes jovens, imaturos, próprios para serem comprimidos, devem, pelo menos, ser raros e processar-se a excreção, principalmente, por meio de paranefrócitos.

O gonóporo (Fig. 87, r), situa-se no fim do quarto anterior do corpo. ()s testículos não se estendem, para diante ou para trás. além do segundo têrço do corpo. Ocupam, principalmente, a parte dorsal da dita região, mas, alguns dos seus folículos atingem a metade ventral do corpo, entre o intestino e os vitelários. Dos dutos eferentes (Fig. 92, e) vimos apenas o trecho terminal que desemboca, com crifício ciliado, na calota interna (proximal) da volumosa vesícula seminal (v). Um diafragma (Fig. 93, d) separa a vesícula seminal do reservatório da secreção granulosa ( $\mathrm{t}$ ), pequeno e excêntricamente situado. O reservatório comunicase com o duto ejaculatório (k), que é curto. inerme e sem espessamento especial. Com a estrutura descrita corresponde o órgão masculino ao tipo III $\Lambda$ da tabela de Gilbert (1935, p. 367).

() ovário (Fig. 87, o) dispõe-se no lado direito; a zona germinativa dirige-se ventralmente, e apresenta concavidade ventral ligeira. Quanto à topografia dos gonócitos, à túnica própria do germário, assim como à estrutura e à curteza do oviduto, há concordância com a espéeie precedente. Das glândulas do canal genital feminino (c) vê-se apenas a glândula lobulada, uni-nucleada (z).

Os vitelários fortemente ramificados situam-se ventralmente e estendem-se, na parte post-cefálìca do corpo, até o dorso. Algumas das ramificações podem unir-se, mas, como os dois ramos principais se destacam sempre, não se forma rêde verdadeira.

0 - divertíeulo dirigido para o lado esquerdo, que ocorre no canal genital feminino das duas espécies anteriores, não existe em Ph. chloroxantha. Repete-se, por outro lado, o esfincter antes da desembocadura do canal no átrio superior (a). O canal feminino entra pelo lado dorsal no átrio superior; o órgão copulador masculino, pela parede anterior. Quando vazio, apresenta-se o átrio superior achatado; em cada lado reconhece-se um tufo de células basófilas, pobres em citoplasma. São êstes elementos homólogos às glândulas desenhadas nas duas espécies precedentemente descritas (Fig. 81, 90, q). Dos apêndices piriformes reconhecem-se apenas vestígios em forma de dobras lameladas no átrio superior, depois da evacuação do casulo. Mesmo quando dilatado pelo casulo (Fig. 87), conserva-se o átrio superior (a) separado por uma dobra, do átrio inferior (b), que é ciliado.

O canal genital feminino (c) ou duto comum continua entalmente com a bursa (Fig. 87, m), sem que haja mesmo alusão de duto gênitobursal. A forma da bursa é aproximadamente esférica ; a sua parede, grossa; e no seu lume observam-se espérmios. Os divertículos da bursa, descritos das duas espécies anteriores, não se repetem em $P h$. ohloroxantha. Sae da bursa, em direção caudal, o duto bursa-intestinal, comprido e contrátil. Êste duto penetra no sincício intestinal, mas, o seu lume não se comunica com o do intestino. O duto bursa-intestinal dilata-se (Fig. 
$87, \mathrm{n}$ ), onde entra em contato com o intestino, sendo o trecho dilatado formado por células diferentes entre si. Algumas altas, ectais, pertencem ao duto bursa-intestinal; as restantes, ao intestino (i). Visto não se comunicar a cavidade intestinal com a do duto, faltam quaisquer inclusões alimentícias nas células intestinais que fazem parte da dilatação descrita. A função destas células reside, evidentemente, na digestão de espérmios excedentes.

\section{Ocorrência de Phaenocora chloroxantha}

Os 6 primeiros exemplares desta espécie encontrámos, em abril de 1943, no lago do primeiro achado de Mesostoma ehrenbergii, no bairro de Canindé da cidade de São Paulo, juntamente com Ph. bresslaui. Ao indicarmos a ocorrência desta ultima espécie, descrevemos as condições gerais do dito lago. Em novembro de 1945, obtivemos mais um exemplar, duma poça rica em plantas (Sagittaria, Azolla, e outras), nos prados do bairro de Limão, nos arrabaldes de São Paulo. Ambas as localidades pertencem ao sistema do rio Tietê; são plenamente insoladas; de água parada, limpa, a de vegetação abundante. Colhemos, finalmente, material abundante, em fevereiro de 1946, num oórrego de correnteza rápida, perto do bairro de Pinheiros, cuja água era cinzenta devido à grande quantidade de partículas em putrefação suspensas nela. Durante o mês indicado, a vegetação, quasi uniformemente formada por Heteranthera reniformis, foi removida e amontoada nas margens, para evitar que 0 curso dágua se transformasse em brejo. Não obstante, continuaram numerosos os vermes entre os pequenos grupos de Heteranthera, que se tinham mantido ou reestabelecido. A proporção entre chloroxantha (com zooclorelas), bresslaui (sem zooclorelas) e evelinae (com zooclorelas) foi de 100: 10: 4. Tal impossibilita ver nos simbiontes produtores de oxigênio o fator decisivo que levou à preponderância de chloroxantha no córrego descrito.

No aquário, Ph. chloroxantha foi alimentada com Naididas picadas. Não mostrou qualquer reação à luz difusa do dia, nem à dirigida duma lâmpada.

\section{Discussão sistemática de Phaenocora chloroxantha}

Na América (Gilbert 1938, p. 209) a espécie é a primeira do gênero com o corpo caudalmente tuncado e sem olhos. Pelo órgão copulador masculino, pertence ao tipo III A de Gilbert (1935, p. 367). Por isso, deve ser confrontada com as duas espécies precedentemente descritas, bresslaui e evelinae, assim como com alticola Ruebush (1939, p. 50) e gracilis (Vejdorsky 1895, p. 128).

$P h$. bresslaui e Ph. evelinae, ambas com olhos e com cauda, distinguem-se, logo à primeira vista, de $P h$. chloroxantha. Ph. alticola, distingue-se de chloroxantha pelo seguinte: a desembocadura dos dutos eferentes; a posição central, não excêntrica, do reservatório da secreção granulosa; a ocorrência dum duto gênito-bursal; a bursa muito espaçosa; e o curto duto bursa-intestinal, pérvio até o lume do intestino.

A separação entre chloroxantha e gracilis torna-se difícil pela ausência de indicações sôbre a modalidade da comunicação gênito-intestinal e sôbre os ap'êndices piriformes de gracilis. Também as figuras e as deserições da vesícula seminal de gracilis não constituem apoio para o confronto, pois, na diagnose original (Vejdovsky 1895, t. 6 f. 42 , vs) é de tamanho medíocre; no material de Fuhrmann (1894, t. 11 f. 32), re-examinado por Hofsten (1911, p. 33 f. 11 e 12, b, na p. 45), enorme, como em chloroxantha. O espessamento do duto ejaculatório, como se vê nos cortes de Fuhrmann e Hofsten (material idêntico), não foi desenhado nem descrito por Vejdovsky. Em chloroxantha, não existe o espessamento aludido. $O$ aparelho feminino conhece-se únicamente pela descrição de Vejdorsky, e, nesta, faltam, como foi dito, os apêndices piriformes e a ligação do duto bursa-intestinal com o intestino. Todavia, pode-se depreender da figura original que gracilis possue um curto duto gênito-bursal, 
ausente em chloroxantha. Felizmente, concordam Vejdovsky e Hofsten a respeito da estensão considerável dos testículos, em gracilis. Do segundo têrço (Vejdovsky, 1. c.) uo corpo ou do bordo caudal da faringe (Hofsten, l. c.) atingem quasi a extremidade posterior do verme; em chloroxantha, não ultrapassam o segundo têrço. Segundo Hofsten, iguala o comprimento do órgão copulador de gracilis quasi a um quinto da longura do corpo; em chloroxantha, quando muito, a um décimo.

A comunicaçã̃o gênito-intestinal de $P h$. chloroxantha é a do tipo 5 de Gilbert (1935, p. 350). Quatro espécies acaudatas e sem olhos pertencem ao dito tipo, a saber, typhlops, anomalocoela, clavigera, e vjatkensis, cuja literatura já foi eitada na discussão de $P h$. bresslaui (veja p. 72). Em tôdas as espécies enumeradas, é armado com espinhos o duto ejaculatório, de maneira que elas não precisam de confronto pormenorizado com chloroxantha.

Visto que a bursa das Phaenocorinae corresponde ao receptáculo seminal das Typhloplanidae restantes, está fora de dúvida a denominação das várias partes da comunicação gênito-intestinal de $P h$. chloroxantha. O receptáculo seminal pertence ao duto comum e, por isso, não seria possível chamar, em chloroxantha, de bursa, o que, na realidade, é uma dilatação do duto bursa-intestinal. Tal designação estabeleceria uma homologia apenas aparente entre a bursa da espéeie atual e a das espécies de Coelogynopora e outras Monocelididae (Alloeocoela Seriata). Influeneiado pela terminologia de Steinböck (1924, p. 472) talvez haja quem ehane de "bursa intestinal" o que nós consideramos dilatação do duto bursa-intestinal. A maior parte desta dilatação, pertence, por certo, ao tecido do intestino. Quem adotasse tal denominação, ao nosso ver, não certa, consideraria a parte aqui designada de bursa como uma dilatação do duto gênito-bursal. Tal interpretação obrigaria a comparar chloroxantha com as espécies do tipo 1 das comunicações gênito-intestinais (Gilbert 1935, p. 350), pois chloroxantha possuiria, então, duto gênito-bursal, bursa, e não teria duto bursa-intestinal. As espécies dêste tipo, rufodorsata, achaeorum, e virginiana, cuja literatura já indicámos na discussão de $P h$. bresslaui, são caudatas, providas de olhos, e de órgão copulador do plano "sac-within-a-sac".

Verificamos analogia interessante entre as comunicações gênito-intestinais de Coelogynopora e Phaenocora. Em C. bresslaui, comunicam-se os lumes do intestino e o da bursa, sendo diférentes os epitélios dos dois órgãos. Tal é a condição regular em Phaenocora, exemplificada, no material aquí em mãos, por $P h$. bresslaui e $P h$. evelinae. Em C. biarmata e C. gynocotyla, por outro lado, conservam-se os liumes dos dois órgãos separados, sem comunicação aberta. Mas, aquêle trecho da comunicação que mais se aproxima do intestino, possue epitélio que passa do tipo das vias reprodutivas ao do órgão digestico. Esta disposição encontrámos en Ph. chloroxantha.

\section{A posição sistemática das Phaenocora austrais}

As exposições seguintes foram sugeridas por uma passagem de Ruebush (1939, p. 64), e, como não levam a resultados positiros, têem de ser rápidas. "As 27 espécies de Phaenocora até agora descritas são vastamente distribuidas. Neste conjunto, é interessante notar que $P h$. anomalocoela, da Austrália, e Ph. foliacca, da Africa do Sul, são duas das mais primitivas espécies do gênero. Tal parece sustentar a ideia de ser o gênero de origem holárctica"

A última frase compreende-se, exidentemente, apenas à luz da teoria dos relictos, segundo a qual as ondas sucessivas de tipos mais especializados e originados no hemisfério setentrional fizeram reciar os mais primitivos para os continentes sulinos, onde sobreviveram.

Entende-se com muita dificuldade, o que devemos considerar como "primitivo" numa espécie das Phaenocorinae. Pertencem às Typhloplanidae, mas; aproximam-se, pela faringe, aos Dalyellioida. Parece-nos forçado deduzir disto ser a faringe mais horizontal (p. e., Ph. gracilis) sinal primitivo; a vertical (p. e., $P h$. clavigera Hofsten 1911, p. 46), mais adiantada, mais semelhante às Mesostominae. Nem mesmo se aproxima a faringe de anomalocoela, deserita como faringe rosulada 
(Haswell 1905, p. 455), dum modo especial, ao tipo "doliiformis". O texto e as figuras relativos a foliacea não proporcionam discussão da faringe desta espécie. A respeito dela, faltam também referências aos rabditos; os de anomalocoela são adenais; tractos de bastonetes não foram mencionados, de modo que, neste pormenor, seria anomalocoela "primitiva", aproximada aos Dalyellioida. As duas espécies em questão possuem o órgão copulador masculino do "sac-within-a-sac" tipo, mas tal ocorro também em muitas outras espécies do gênero. Parece "primitiva" a separação da vesícula seminal e do reservatório da secreção granulosa, presente em aucmalocoela; menos nítida, em foliacea. Em highiandensis, alticola, bresslaui, evelinae, e chloroxantha existe igualmente diafragma completo. O órgão copulador esférico de anomalocoela, e o mais largo que comprido de foliacea, não encontram paralelos nas outras espécies de Phaenocora, e afastam-se muito de Dalyellia. Consideramos os apêndiees piriformes predecessores de úteros permanentes. Em foliacea, ocorrem êstes órgãos; de anomalocoela não foram descritos. Se faltassem realmente, seria isso sinal primitivo, mas, eliminaria, juntamente com os emunctórios aberrantes e os testículos sem ductos a espécie australiana da sub-família (Gilbert 1935, p. 284, 372, 374). Julgamos a bursa de Phaenocora homóloga ao receptáculo seminal das Typhloplanidae restantes. Tentámos, com esta base, interpretar filogenèticamente os tipos de Phaenocora, em que o oviduto se aproxima à bursa (màximamente no tipo 5 de Gilbert), e os cm que se distancia da bursa (p. e., highlandensis). Desistimos, porém, desta tentativa, pois no gênero Olisthanella, pouco distante de Phaerocora, ocorrem espécies com canal do receptáculo (= duto gênito-bursal) e outras sem êste.

Como Ruebush não disse, porque considera foliacea e anomalocoela "duas das mais primitivas espécies", estamos impossibilitados de discutir os argumentos dêle. Ao nosso vêr, as duas espécies não mostram parenteseo especialmente estreito. A primitividade de anomalocoela reside nos caracteres negativos da ausência de tractos de rabditos e de lóbulos piriformes, sendo o último sinal incompatível eom "Phaenocora". A separação entre a vesícula seminal e o reservatório da secreção granulosa, outro caracter primitivo, liga a espécie de New South Wales à América do Sul, América do Norte e Asia Central. A espécie sul-africana não exibe qualquer primitividade peculiar.

As três espécies sul-americanas possuem, em comum, o tipo do órgão masculino, a falta do duto gênito-bursal, e a restricão dos rabditos aos tractos de bastonetes, na região anterior. Estes caracteres vêem-se igualmente em espécies européas; o segundo, também em anomalocoela. O órgão copulador masculino, como ocorre nas três espécies sul-americanas, encontra-se também na Eurasia (gracilis; alticola). Outros critérios usados no cstabelecimento de grupos, lentro do gênero, olhos e cauda, evidenciam-se diversos nas espécies sul-americanas. Em resumo, estas não permitem conclusões zoogeográficas baseadas na morfologia comparativa do gênero.

\section{Subfamilia: Olisthanellinae Luther}

\section{Genus: Olisthanella W. Voigt (1892, p. 248)}

Na monografia de Bresslau (1933, p. 273) admitè-se, além de Otisthanella, ainda Castradclla Nassonov (1926, p. 877) como eventualmente pertencente às Olisthanellinac. A julgar pela deserição de Braun (1885; citação segundo Graff 1913, p. 247), aprovada por Beklemischev (1920, p. 73-74), granea, a espécic típiea do Cástradella, possue testículos ventrais. Gieysztor \& Chmielewska (1929), que estabeleceram a identidade de Mesostoma aselli Kennel (1898, p. 639) com C. granea (Braun), não encontraram gônadas masculinas, mas, a afirmação dêles: "que os testículos não foram observados por algum autor", contrasta com a diagnos o original. C. andreja (Nassonov 1919, p. 638 t. 2 f. 3-6) ou é una subspécie de granea (Nassonov 1924, p. 335, 342, nota 5), ou idêntica a esta (Gieysztor 1929, p. 186). Em todo o caso, Castradella deve ser incluida nas Protoplanellinae. 
Com muita reserva, aørescentou Bresslau (l. e.) às Olisthanellinae ainda Sphagnella Sekera (1912, p. 16) e Taborella Sekera (1912, p. 18). Em Sphagnella lutheri, observada na fase maseulina, ocupam os testículos posição pronunciadamente ventral (t. 1 f. 13); os protonefridióporos da figura citada e do texto (p. 16) discordam entre si (Findenegg 1930, p. 76); os emunctórios de Taborella hofsteni (t. 1 f. 16) desembocam combinados com a bôca. Os dois gêneros não pertencem às Olisthanellinae.

Na diagnose da sub-família, naquêle tempo, tribu, seguiu Graff (1913, p. 203) a Hofsten (1907, p. 408) escrevendo: "testículos situados dorsalmente aos vitelários". Incluiu, porém, em Olisthanella, O. iphigeniae Graff (1905, p. 93) descrita com testículos ventralmente aos vitelários e Mesostomum hallezianum Vejdovsky (1880, p. 502), cujos testículos "se apõem à parede ventral". O. iphigeniae foi removida às Protoplanellinae, gênero Tauridella Sekera (1912, p. 21; Findenegg 1924, p. $26 ; 1930$, p. 111); O. halleziana (Vejd.), às Typhloplaninae, gênero Typhloplanella Sekera (1912, p. 3, 7; Findenegg 1924, p. 28; 1930, p. 120).

O gênero Olisthanella conta, na monografia de Graff (1913), com mais três espécies que possuem posição sistemática incerta: Mesostoma coecum Silliman (1884, p. 57) ; M. exignum Dorner (1902, p. 29); e Olisthanella hungarica Gelei (1904; veja Graff 1913, p. 209). Da primeira espécie conhecem-se sùmente os órgãos femininos; os protonefrídios ignoram-se. $M$. coecum é incognoseível. As duas outras espécies removeu Ruebush (1938a, p. 261), preliminarmente, às Protoplanellinae, gènero Krumbachia Reisinger (1924, p. 9). A figura original de exiguum é uma vista ventral. Nesta, sobrepõem-se os testículos aos vitẹlários, contrastando com a topografia do genótipo de Olisthanella (Findenegg 1930, p. 82). Pela descrição de hungarica, cuja figura original não vimos, supõe-se também que os testículos sejam situados ventralmente aos vitelários.

Estranhamente incluiu Findenegg (1930, p. 76) O. brinkmanni Sekera (1912, p. 3) e O. albiensis Sekera $(1912$, p. 5) na lista das espécies certas do gênero. A primeira, com testículo ímpar, mediano e ventral, nada tem que ver com Olisthanella; os poros dos protonefrídios ignoram-se (Sekera 1912, p. 4-5). A segunda mostra (t. 1 f. 3) testículos e protonefridióporos das Protoplanellinae.

Tão pouco quão Graff, a literatura subsequente atribuiu valor taxônomico à relação topográfica entre testículos e vitelários. Aliás, êste caracter nem sempro so verifica facilmente (Luther 1904 , p. 88). As fases masculina e feminina carecem de sincronismo, e o volume dos ditos órgãos varía conforme o período reprodutivo. Das espécies seguintes, em que a topografia aludida não foi especificada, é duvidoso se pertencem a Olisthanella: 1) arctica Nassonov (1925, p. 69; Steinböck 1932, p. $\left.313){ }^{*}\right)$; 2) caeca Sibiriakova $(1929$, p. 241) ; 3) elegans Nassonov (1919, p. 636); 4) isaevi Nassonov (1924a, p. 44); 5) multispina Beklemischev (1924, p. 296); 6) opaca Nassonov (1921, p. 145; 1926, p. 874); 7) opistomiformis Nassonov (1921, p. 145 ; 1926, p. 873); 8) palmeni Nassonov (1917; Beklemischev 1920, p. 70); 8a) palmeni rhynchocephala Beklemischev (1921, p. 635); 9) petropolitana Beklemischev (1924, p. 297); 10) septentrionalis Nassonov (1925, p. 68; Steinböck 1932, p. 313$)$; 11) tricirrata Sibiriakova (1929, p. 242).

Castrada otophthalma Plotnikov (1906; Graff 1913, p. 233) foi transferida a Olisthanella por Beklemischev (1921a, p. 19 subsp. tricuspidata), por causa dos poros do emunctório, mas, a presença dum átrio copulatório e os dentes no duto da bursa tornariam, a nosso ver, impossível tal transferência.

Olisthanella valaamica Nassonov (1917; Luther 1946, p. 4) é sinônimo de Dachmiotrema limicola Hofsten das Ascophorinae (Gieysztor 1938a, p. 376; Luther, 1. c.). Olisthanella virginiana Kepner \& Carter (1931, p. 87) e O. virginiana var. glandulosa Ruebush (1935, p. 135) foram incorporadas ao gênero Krumbachia Reisinger (1924, p. 9) das Protoplanellinae (Ruebush 1938a, p. 261).

Chegamos, destarte, à lista seguinte das espécies certamente pertencentes ao gênero Olisthanella: 1) trincula (O. Sehmidt 1858; Graff 1913, p. 204; Findenegg 1930, p. 77-85), o tipo do gênero; 1a) truncula lucida Nassonor (1926, p. 873);

* Da literatura russa dos anos após a penúltima guerra, citamos apenas passagens que tivemos em mãos, ainđa que nã̃o representem os trabalhos em que o nome respectivo aparece pela primeira vez. 
1b) truncula fusikorum Nassonov (1929, p. 428); 2) obtusa (M. Schultze 1851; Graff 1913, p. 205); 3) nassonoffii (Graff 1882; id. 1913, p. 206); 4) splendida (Graff 1882; id. 1913, p. 208); 5) scxmaculata Nassonor (1921, p. 145; 1926, p. 875), segundo a figura (t. 2 f. 16), com testículos dorsalmente aos vitelários. A nossa lista concorda com a de Ruebush (1938a, p. 261). Êste e Nassonov (1926, p. 872) consideram as espécies 3 e 4 como subspécies de 1 ; Beklemischev (1921, p. 633-635) e Gieysztor (1926, p. 652, 657), como idênticas a 1; Reisinger (1923, p. 43) e Findenegg (1930, p. 77) manteem-se reservados.

\section{Olisthanella parva, spec. nov. (Fig. 94-98)}

Q Olisthanella opistomiformis Nassonov 1921, p. $145 ; 1926$, p. 873 t. 2 f. 13-15.

Os vermes, de forma ovóide, medem $0,2 \quad 0,5 \mathrm{~mm}$. de comprimento e $0,08 \quad 0,13 \mathrm{~mm}$. de grossura; as Figuras 94 e 95 referem-se a indivíduos comprimidos pela lamínula. A região anterior pode destacar-se do corpo restante por uma constrição, vendo-se isso durante a natação livre. A extremidade posterior pode adelgaçar-se em forma de pequena cauda. Os vermes são incolores. O intestino apresenta-se amarelado; o pigmento do cálice óptico, cinzento-azulado, cinzo-violáceo, ou preto. O pigmento visual não se mantem nos cortes.

Os cílios locomotores teem comprimento igual à altura da epiderme ; entre os cílios maiores, provavelmente tácteis, distingue-se um tufinho especial, na ponta da cauda. As raizes dos cílios continuam dos corpúsculos basilares para dentro, provocando estriação da epiderme, ausente apenas numa camada basilar estreita. Os núcleos das células epidérmicas são arredondados, não lobulados mo em $O$. truncula (Findenegg 1930 , p. 78). Os limites entre as células da epiderme reconhecem.se só ocasionalmente. Rabditos faltam na epiderme, como também rabditos ou ramnitos adenais. Os tratos cefálicos (Fig. 94, 97, m) contêem secreção granulosa fracamente eosinófila de glândulas situadas no parênquima. Ocorrem ainda glândulas cefálicas cianófilas.

Os olhos (n) situam-se, como se vê pelo corte, dentro das células ganglionares, que perfazein a zona ântero-externa do cérebro. $O$ pigmento do cálice de cada ôlho alonga-se medialmente e pode encontrar-se com o do outro ôlho ou entrar em contato com uma acumulação mediana de pigmento. Tal disposição re-encontra-se em várias Typhloplanidae, p. e., em Krumbachia minuta Ruebush (1938a, p. 262) e Olisthanella opistomiformis Nassonov (1926, t. 2 f. 14); a ligação pigmentada não é, como o último autor disse (p. 973), "o nervo óptico" No corte (Fig. 97), em que o cálice (q) perdeu o seu pigmento, reconhecè-se o "éristälino", refrativo no animal vivente, denso no corte e aposto ao cálice. Mais lateralmente ainda, nota-se o núcleo da célula visual, de cujo citosoma o cristalino faz parte. O cérebro (c) é nitidamente bipartido em duas massas quasi esféricas.

A bôca (Fig. 95, 97, b) situa-se na região posterior do terceiro quarto do corpo, cujos cilios epidérmicos entram um pouco no tubo oral. A bolsa faríngea externa carece de cílios; o seu epitélio é muito chato. A estensão da bolsa ultrapassa a verificada em $O$. truncula (Findenegg 1930, p. 79), pois atinge quasi o meio da faringe (h). Esta é de 0,09 
mm., ao comprido, e tem $0,07 \mathrm{~mm}$. de diâmetro máximo. A configuração piriforme da faringe e o ângulo que forma com a face ventral contrastam com o aspecto e a posição do "pharynx rosulatus" típico. O epitélio que reveste a superfície da faringe é ciliado. Os cílios acabam um pouco antes do bordo anterior da faringe. Aí, na entrada da farínge, desémbocam as glândulas faríngeas ( $g$ ) numa pequena bolsa. Os citosomas glandu?ares, dos quais há cianófilas e eritrófilas, encontram-se externamente à bolsa faringea. $O$ anel nervoso ocorre um pouco caudalmente ao nível da inserção da bolsa no corpo da faringe. A bolsa interna, estreita, conduz à intestino (i), em cuja entrada se notam células de secreção eritrófila (k). Correspondem às clavas de Minot, mas, são mais largas e menos altas que estas. As células do epitélio intestinal são altas, vacuolizadas e destituidas de limites.

Os poros dos emunctórios (Fig. 95, x) situam-se na região da bôca (b), ao lado, anterior ou posteriormente a esta. Os troncos terminais ( $\mathrm{z}$ ) apresentam numerosas alças, ao nível da entrada do intestino. Nesta altura, os canais terminais bifurcam-se e emitem o canal anterior (w) e o posterior (y). O primeiro enovela-se no espaço entre o cérebro (c) e o intestino (i); o posterior serpenteia-se na zona dos órgãos reprodutivos, onde ocorre uma alça em cada lado. Órgãos terminais foram observados; os seus cílios podem parar e recomeçar a bater.

Os testículos são saquinhos pequenos (Fig. 96, t), situados dorsomedialmente. Para diante, não se estendem, no material visto por nós, para além da faringe. Os fundos dos sacos testiculares ocupam um plano horizontal mais dorsal que os vitelários. Os dutos eferentes (e) são curtos e desembocam, sem vesículas seminais extra-peniais (falsas), separadamente na vesícula seminal (f) intra-penial. Esta representa a cúpola proximal do órgão copulador, que é bulboso e de ca. de 40 microns, ao comprido. A secreção granulosa (s) apõe-se às paredes do pênis. A posição dos espérmios na vesícula e a da secreção granulosa variam; uma vez, o. bulbo é dividido transversal, outra vez, obliqua ou sagitalmente. $\mathrm{O}$ duto ejaculatório (Fig. 98, u), de 24 microns ao comprido, é revestido por cutícula um tanto refractiva, mole quasi gelatinosa. Perto da entrada do duto masculino no átrio, a bursa copulatória (Fig. 97, d) apresenta-se dirigida para diante, como se vê pelo corte; para um dos dois lados, no verme comprimido (Fig. 98).

0 ovário ( 0 ), no lado direito e caudalmente à faringe, corresponde ao tipo das Typhloplanidae (Luther 1904, p. 116); é curto e reto. O receptáculo seminal (r) constitue uma dilatação do oviduto. 0 trecho seguinte, o duto comum, é formado por células disciformes, como são freqüentes nêste órgão das Typhloplanidae. Os vitelários (v) podem apresentar contornos entalhados ou lisos; estendem-se do lado rostroventral ao caudal-dorsal, onde se unem. Flanqueiam os testículos, que começam, como foi dito, dorsalmente aos vitelários. A vista lateral ilustra esta topografia (Fig. 96). Ao redor dos núcleos celulares dos vitelários, notam-se as esférulas, com que a vitelogênese começa.

O átrio (a) possue, além da bursa (d) já mencionada, ainda outro divertículo, o uterino (1), dirigido caudalmente e menos distintamente 
separado do átrio que a bursa. O gonóporo (p), mais perto da extremidade posterior que da bôca, é circundado por músculos anularmente dispostos. O casulo de casca acastanhada, mede $0,1 \mathrm{~mm}$. de diâmetro maior e $0,07 \mathrm{~mm}$. de diâmetro menor; preenche o átrio totalmente.

\section{Ocorrência de Olisthanella parva e notas biológicas}

Com certa freqiiência, encontrámos a espécie apenas nos mêses frios, especialmente em junho e julho. Durante o verão, obtivemos só uma vez alguns exemplares. Em tôdas as localidades registradas (Limão, Vila Lcopoldina, ponte de Jaguaré, Butantan), trata-se de poẹas com água estagnada, rica em humo. Plantas, p. e., Cabomba, Ceratophyllum, Salvinia, e, especialmente, Hepaticas flutuantes (Ricciocarpus natans; Prof. Dr. Felix Rawitscher det.), figuram nos nossos protocolos dos achados.

O movimento de $O$. parva corresponde ao que Nassonov $(1926$, p. 874) descreveu de 0 . opistomiformis. Os vermes nadam rápida e elegantemente, mesmo na água hiemal, torcendo o seu corpo e mergulhando em curvas largas. A parte anterior é muito móvel; é protraida e retraida como uma tromba. O alimento principal são Rotatoria, mas, também Protozoa, p. e., Flagellata verdes são comidos.

\section{Discussão sistemática de Olisthanella parva}

A faringe cônica dirigida para trás distingue a espécie, à primeira vista, das congenéricas providas de "pharynx rosulatus" típico. Com isso, assemelha-se 0 . parva consideravelmente a $O$. opistomiformis Nassonov. Mas, visto que se ignoram os testículos e, com isso, a posição genérica desta, é impossível estabelecer a identidade que consideramos como muito provável. Apesar da procedência longemente distante de opistomiformis, encontrada nos arredores de Leningrad, é verosímil que parva represente um sinônimo de opistomiformis. Talvez seja a faringe da espécie russa um tanto menor que a da atual. Outras diferenças devem ser atribuidas a fases diferentes do desenvolvimento dos órgãos reprodutivos, a saber, a bursa menor, "em estádio reduzido" (1. c., p. 874); a vesícula seminal e a massa da secreção granulosa menos conspícuas. Evidentemente, encontrou-se o material de Nassonov mais no periodo feminino que o nosso, cujos ovos são raros. Ao que parece, 0 . opistomiformis não foi cortada. Por isso, não atribuimos importância à descrição dos "rabditos não muito numerosos e situados na extremidade anterior do corpo, sem formar tratos". A secreção granular, fràcamente eosinofila e refrativa das glândulas cefálicas, lembra, de fato, rabditos. A ausência dos rabditos precisa de cortes para a sua vẹificação.

\section{Subfamilia: Mesostominae Luther 1904}

\section{Genus: Mesostoma Ehrenberg 1836}

\section{Mesostoma ehrenbergii (Focke) (Fig. 101-104)}

Planaria ehrenbergii (partim) W. Focke 1836, Annalen des Wiener Museums der Naturgeschichte v. 1, p. 191 t. 17 f. 1-8, 11-12, 15-19) (citado segundo Graff 1913, p. 273).

Referências principais:

O. Schmidt 1848 , p. 47 t. 4 f. 9

Graff 1874, p. 146 , t. $15-16$

Kennel 1888, p. $477^{\circ}$ (primeiro achado americano, na ilha de Trinidad)

Luther 1904, p. 3, etc., 227-235, 52 figuras (morfologia pormenorizada)

Graff 1913, p. 273, f. 234-236 (literatura)

Steinmann \& Bresslau 1913, p. 202 e seg. Entre n. 97 e 155 B, 28 figuras; t.

1 f. 4-5 (morfologia, biologia, reprodução) 
Ferguson \& Hayes 1941, p. 22 f. 1 e outras cópias da literatura. Nas citações, muitas passagens, em que a espécie é mencionada apenas comparativamente

Os vermes atingem $15 \mathrm{~mm}$. de comprimento e $4 \mathrm{~mm}$. de largura, sendo, geralmente, a largura um terço da longura. A forma do corpo é achatada (Fig. 101) ; a largura máxima encontra-se atrás do meio. As extremidades são estreitadas; a anterior, mais suavemente que a posterior, que pode terminar, com pequena cauda cuspidata. O corpo é vítreo e transparente, ressaltando-se da água sòmente exemplares de meia idade e adultos pelos órgãos mais densos e esbranquiçados (cérebro, nervos, rabditos e ramnitos da região anterior, gônadas), pela côr do conteúdo do intestino, e eventuais ovos testáceos. Além disso, desenvolve-se, com a idade, um pigmento amarelado ou acastanhado no parênquima, especialmente na região dos úteros e dos outros órgãos reprodutivos, na zona adjacente à musculatura dermática, e mesmo na faringe. No material dos arredores de São Paulo, ocorrem, freqüientemente, já em espécimes vigorosos de meia idade, manchas pretas estreladas (Fig. 102). Situam-se. por via de regra, ao longo da linha dorso-mediana, havendo, muitas vêzes, 7 destas manchas dispostas em fila longitudinal. Pigmento radiado vê-se, ainda, no lado ventral, nos pontos em que os jovens dos ovos de desenvolvimento rápido sairam (Sekera 1904, p. 233).

A epiderme tem, na extremidade anterior, $0,008 \mathrm{~mm}$. de altura; no corpo restante, $0,004 \mathrm{~mm}$; na vista da superfície, são as células poligonais ; os núcleos, lobulados. Os cílios são uniformes nos jovens; nos velhos -são mais desenvolvidos no ventre que no dorso. Os rabditos dermais, hialinos e baciliformes, têem de comprimento $0,003 \quad 0,004 \mathrm{~mm}$; são arredondados nas suas duas extremidades e presentes no corpo inteiro. Os ramnitos adenais (Fig. 101, r) têem até $0,06 \mathrm{~mm}$. de longura; são, na sua ponta livre, alço claviformes e, aí, freqüentemente providos de zona central granulosa, distinta da cortiça hialina. Ramnitos ocorrem, . escassamente, em todo o corpo; abundam nos 4 tratos anteriores ("rodways"; "Stäbchenstrassen") que ligam os 2 pares de grancles feixes racemosos das glândulas ramnitógenas à superfície. Estas glândulas situam-se entre o cérebro e a faringe.

As glândulas mucosas, chamadas de fiandeiras, porque secretam fios, que suspendem os vermes nágua, localizam-se numa faixa ao longo do ventre. São mais cerradas nas extremidades, especialmente na posterior (Fig. 101, g). Aí, as glândulas são de 0,064 mm., ao comprido e ligadas à epiderme por dutos de longura semelhante. A musculatura longitudinal do tubo músculo-dermático é, no meio do dorso e do ventre, mais desenvolvida que nos lados. Na musculatura do corpo, os músculos dorsoventrais, que achatam o animal, são nítidos; as fjbras tangenciais, inconspícuas. Músculos correm da região cefálica posterior-dorsal para a anteriorventral. Encurvam a ponta anterior com a qual os vermes capturam a prêsa, principalmente Cladocera. No parênquima, predomina o líquido perivisceral sôbre as células, cujos prolongamentos anastomótioos formam malhas amplaș.

$O$ cérebro (Fig. 101, c) situa-se rostralmente à parte pré-faríngea do intestino e tem forma ovóide-transversal, ligeiramente bi-partida. Saem 
dêle, para diante, os tratos sensoriais (f) que suprem a extremidade anterior e as áreas sensoriais côncavas ("Grübchenflecke"). Mais para trás, originam-se, no cérebro, os nervos laterais ventrais e dorsais, como ainda os longitudinais dorsais e ventrais (n). Os últimos possuem comissura post-faríngea. Com o método de Golgi foi envidenciado o plexo nervoso dermático. Os olhos encontram-se completamente dentro da substância do cérebro. Cada olho tem uma célula visual (clava da retina). e cálice com pigmento preto de contôrno, muitas vêzes, irregularmente trilátero. Os olhos são equidistantes da extremidade anterior e da bôca. Duas áreas sensoriais, ligeiramente côncavas, destacam-se pela ausência de rabditos na epiderme ântero-dorsal, perto dos dois lados. Estes órgãos ciliados são provavelmente quimopereeptores.

A bolsa faríngea abrange apenas o terço ventral (ectal) da faringe rosular $(p)$. Destarte, sòmente o dito terȩo pode funcionar como lábio. preensor ("Greifwulst"). A bolsa não desemboca diretamente, mas, por meio do cálice excretor, que recebe os troncos terminais do emunctório. $\mathrm{Na}$ vista ventral, podem apresentar-se 5 orifícios, um sôbre o outro, a saber, o do cálice excretor, a bôca, a entrada da faringe, a entrada do esôfago e a do intestino. Os movimentos independentes dêstes orifícios. foram descritos por Bresslau (Steinmann-Bresslau 1913, p. 225-226). Dois feixes volumosos de glândulas salivares extra-faríngeas (h) desembocam na região do lábio preensor. O esôfago, de parede fina, é curto e semr cílios, como a faringe. O intestino (i), também sem cílios, é baciliforme e aproximadamente tão largo quão a faringe. Estende-se, anteriormente (a), quasi até o cérebro, e deixa, caudalmente, ca. de um sexto do corpo livre: A parte post-faríngea é ca. de 2 vêzes mais comprida que a préfaríngea. As duas terminações do intestino são arredondadas. Em vermes muito bem alimentados, a parede intestinal forma pequenos divertículos.

$O$ emunctório começa com capilares, cujas ramificações suprem o corpo inteiro. São providos de cílios propulsores ("Treibwimperflammen") e órgãos terminais, dos quais até 30 podem pertencer à mesma célula. 0 núcleo desta célula salienta-se na parede do sistema capilar por ela formado. Os capilares entais reunem-se, formando dois pares de canais ascendentes, que vão, do meio do corpo, para diante e para trás. Aproximadamente aos níveis das extremidades rostral e caudal do intestino, encurvam-se os canais ascendentes e correm, agora como canais descendentes, nos dois lados da linha mediana ventral, em direção ao centro. do corpo. Os canais descendentes anterior e posterior de cada lado. reunem-se, havendo, destarte, só um canal descendente direito, e outro, esquerdo. De cada um, sae um troneo transversal, terminal on eferente, em forma de $U$, que desemboca no cálice excretor, anteriormente descrito como fazendo parte da bolsa faríngea.

O gonóporo (Fig. 101, d) situa-se atrás da bôca (p), sendo a distân. cia entre o poro e a bôca aproximadamente igual à largura da faringe. Os testículos ( $\mathrm{t}$ ) localizam-se lateralmente aos vitelários (y), e ocupam, nos vermes adultos, os dois quartos centrais da longura do corpo. No lado. interno (medial), têem contornos lisos ou ligeiramente ondulados; no. externo, quer dizer, lateralmente, são entalhados, foliculares e providos. 
de dilatações. Estas podem, às vêzes, ser ligadas por bases muito estreitas à parte principal. Os lóbulos testiculares podem ainda separar-se tanto que a conexão do órgão é constituida apenas pela sua túnica própria. Desta saem, em cada testículo, no lado mediano, um pouco atrás do meio, os dutos eferentes, que passam dorsalmente aos vitelários. Podem formar vesículas seminais passageiras ("falsas") e entram, ou separadamente, um perto do outro, ou reunidos (duto seminal) na vesícula seminal (v) permanente ("verdadeira") do órgão copulador. Visto que o pênis se situa no lado esquerdo, é o duto eferente direito um pouco mais comprido que o esquerdo.

O pênis tem forma duma retorta de pescoço fortemente encurvado. A parte dilatada, o bulbo penial, contem a vesícula seminal, de onde saem os espérmios pelo duto ejaculatório. Extra-penialmente, situam-se as glândulas da secreção granulosa. Esta penetra, ao longo dım sulco, na musculatura do bulbo e entra, através de poros finos, para dentro do duto que corresponde ao peścoço da retorta. Ectalmente à entrada da secreşão granulosa, forma o duto ejaculatório um pequeno divertículo (Iuther 1904, p. 231), ausente numa sub-espécie norte-americana (Ferguson \& Hayes, l. c.). O duto continúa como tubo simples, que desemboca no átrio com pequena papila saliente. A museulatura do órgão copulador compõe-se duma camada de fibras longitudinais externas, e de duas internas dispostas em espiral. Estas terminam na região da entrada da secreção granulosa no duto ejaculatório e são, daqui para fora, substituidas por fibras anelares. Além disso, existem músculos locomotores do pênis, originados na parede do átrio e no corpo. Os espér. mios são compridos, filiformes, com 2 flagelos.

O germário (ovário) digitiforme ou claviforme (Fig. 101, o) encontra-se no lado direito $\left.{ }^{*}\right)$; entalmente, termina com a zona sincicial das ovogônias, revestida por fina túnica própria; ectalmente, dispõem-se os ovôcitos em crescimento como uma pilha de moedas, e o germário compacto passa ao germiduto (oviduto). Este é um tubo capilar circundado por epitélio de células muito altas, e dilata-se, na extremidade oposta ao ovário, esféricamente, formando o receptáculo seminal (s). Medialmente aos testículos, situam-se os vitelários (y), cujo estádio de desenvolvimento indica a disposição reprodutiva do indivíduo respectivo. Antes da formação dos ovos imediatos (e) (subitâneos; membranosos; estivais; de desenvolvimento rápido) e durante esta, são os vitelários inconspícuos e transparentes; durante a dos ovos duráveis (m). (latentes; testáceos; hiemais; de desenvolvimento lento), são êles os órgãos mais volumosos. e refletem a luz, apresentando-se, destarte, escuros sôbre fundo claro; brancos, sôbre fundo escuro. Nesta fase, estendem-se até as extremidades do intestino. O vitelário de cada lado abrange uma parte anterior, e outra, posterior, entre as quais há um interstício, aproximadamente ao nível do orifício genital. Os vitelodutos anterior e posterior reunem-se e formam os vitelodutos transversais, direito e esquerdo, êstes, por sua

*) Excepcionalmente, vimos o germário no lado esquerdo; o pênis, no direito. 
vez, unidos num curto trecho terminal, que desemboca no duto (ductus communis) saido do receptáculo.

O duto comum recebe ainda a secreção das glândulas da casca e corre, em forma de S, ao átrio. Este é musculoso, possuindo fibras internas, anelares; externas, longitudinais; e retractores originados na parede dorsal do corpo. Também o poro genital (d) é provido de esfincter forte.

Do átrio saem os úteros (u) direito e esquerdo, no início, baciliformes. Crescidos transversalmente, até o intervalo entre testículo e vitelário, emitem, em ângulo reto, um divertículo para diante, e outro, para trás. Nêstes divertículos entram os ovos (Fig. 101, m, e), dilatando-os de tal modo que os dois úteros juntos apresentam a configuração dum $\mathbf{H}$ (u). Outra dilatação do átrio é a bursa copulatória, vesícula pedunculada (b) ovóide, quando repleta; e, quando vazia. de empôla bilobadamente encolhida.

Ovos duráveis (Fig. 101, m) e imediatos (e) ocorrem, normalmente, em épocas diferentes da vida do verme. Dos imediatos, formados em primeiro lugar, contou Bresslau até 72 no mesmo indivíduo (SteinmannBresslau 1913, p. 285); no material de São Paulo ocorrem raramente mais que 30. Os ovos duráveis são biconvexos e lembram um tanto lentilhas. ınas são mais grossos. Quando completamente deseuvolvidos, têem casca acastanhada espessa. No material presente, o seu diâmetro é de 0,29 $0,4 \mathrm{~mm}$.; no europeu, de $0,450,5 \mathrm{~mm}$. Até 58 ovos duráveis foram observados num verme (ibid., p. 282) ; no material de São Paulo, até 20. O número dos eromosomas, na fase diplóide, é de 10 (Fig. 103).

Ocorrência: Assinalado, primeiramente (Marcus 1943a), duma poça no bairro de Canindé, dentro da cidade de São Paulo, foi Mesostoma ehrenbergii, desde então, freqüentemente encontrado no perímetro urbano. Ocorre tanto em remansos dos rios 'Tietê e Pinheiros e em localidades expostas à correnteza, quanto em brejos que dessecam durante o inverno.

Distribuição geográfica: Lago Titicaca, em altitudes de $3.8404 .700 \mathrm{~m}$. (Beauchamp 1939, p. 60); ilha de Trinidad, Indias Ocidentais Britânicas (Kennel 1888, p. 477) ; vários Estados da União Norte-Americana; Europa, em muitos países, da Irlanda até o Cáucaso; Sibéria Dshety-ssu, rio Ili, região do lago Balkash (Bendl 1908, p. 128); distrito de Tomsk; lago Baical; península de Kamshatka (Sabussowa 1929, p. 502)

\section{Notas gerais sôbre Mesostoma ehrenbergii}

O número dos cromosomas acima indicado garante a classificação do material aqui em mãos (veja Bresslau 1904, t. 15 f. 17). Há 8 cromosomas, na fase diplóide, em Mesostoma ehrenbergii wardii Woodworth (1896, p. 241; 1897, p. 11; Husted, Ferguson \& Stirewalt 1939; Ruebush 1940 , p. 531), que difere ainda em certos pormenores morfológicos (Ferguson \& Hayes 1941, p. 25).

O ciclo típico de Mesostoma ehrenbergii, como se conhece, graças ans trabalhos de vários autores europeus, principalmente Bresslau e Beauchamp, foi relatado, há pouco tempo (Marcus 1943a). Não deveria ser esquecida a observação de Sekera $(1904$, p. 236) sôbre a produção excepcional de ovos subitâneos verificada em vermes isolados e bem alimen- 
tados depois da época da formação dos ovos duráveis. A auto-fecundaȩão imposta aos vermes pelo isolamento, não precisa ser responsabilizada pela produção iterativa dos ovos imediatos. Como já foi observado por A. Schneider (1873; veja Bresslau 1903, p. 128), podem óvulos auto-fecundados tornar-se também ovos duráveis. Os ovos duráveis, capazes, mas, não necessitados de dessecação, libertam-se, na Europa Central, pela morte e decomposição do verme materno (Steinmann-Bresslau 1913, p. 282 ; Bresslau 1933, p. 158). São anormais os casos de ovipostura de ovos duráveis (Sekera 1910, p. 44; Steinmann-Bresslau 1913, p. 287). O seu número regular, sob bôas condições, é de $40 \quad 50$ (l. c., p. 282). Nos espécimes dos arredores de São Paulo não vimos mais do que 20 oros duráveis ao mesmo tempo, 10 em cada útero. Os ovos são menores que os europeus, como foi indicado na diagnose precedente. A ovipostura dos ovos duráveis constitue processo normal, no material brasileiro. Exceptuam-se apenas os casos em que os vermes grávidos morrem accidentalmente, sobrevivendo os ovos. Durante 30 dias foi registrado o tempo de permanência, no útero, de 121 ovos duráveis desenvolvidos em 10 vermies (veja o gráfico, Fig. 104). Numa temperatura dágua de $16 \quad 18^{\circ}$. C., notou-se que os ovos são retidos, no mínimo, durante 1 dia; no náximo, durante 6 dias, no têrmo médio, durante 3 dias e 20 horas, no útero.

Os vermes brasileiros que vimos não ultrapassaram $10 \mathrm{~mm}$. de comprimento. Em parte, pode isto ser atribuido à ovipostura, pois a acumulação de ovos, quer duráveis, quer imediatos, alonga e dilata o verme. Os nossos exemplares sairam com $2 \mathrm{~mm}$. de longura dos ovos imediatos.

A temperatura de $16 \quad 18^{\circ}$ C., acima indicada, enquadra-se entre os extremos que ocorrem na Europa Central, durante a formação dos ovos duráveis. Quanto ao cardápio, comportaram-se os vermes brasileiros menos especializados que o material de Bresslau (Steinmann-Bresslau 1913 , p. 273 e seg.), quasi exclusivamente cladocerófago. Os nossos vermes comeram Naididae picadas (Aulophorus-spec.) àvidamente e em grandes quantidades, tanto chupando o conteúdo do tubo músculo-dermático, quanto engulindo pedaços inteiros, de até ca. de 10 segmentos, inclusive as cerdas.

Ao compararmos a ovipostura de ovos duráveis, nos vermes brasileiros, com a libertação dêstes ovos pela decomposição do corpo morto, nos europeus, convem lembrar ser a ovipostura de ovos duráveis o modo reprodutivo regular na maioria das Typhloplanidae, às quais as Mesostominae pertencem. Biològicamente, apresenta-se esta maneira como vantajosa, pois o tipo europeu do ajuntamento dos ovos duráveis expõe a prole inteira ao aniquilamento por um predador turbelariófago. Seja, aliás, anotada a observação de Jeannette Carter $(1929$, p. 436) a respeito da sobrevivência dum ovo durável duma Phaenocora (a espécie, agassizi Graff 1911, é algo duvidosa: Gilbert 1935, p. 287) comido por Microstomum caudatum (Leidy).

Como se sabe, são as condições das baixas latitudes, em grosso, mais favoráveis para a vida dos animais que as das altas. Resulta daí, nós trópicos, luta pela existência intensa entre as muitas espécies; nas regiões 
frias, a das poucas espécies contra as condições do meio inânime. Entendese, destarte, o tipo reprodutivo verificado nos vermes brasileiros como vantajoso e filogenèticamente original. $O$ dos vermes europeus, embora menos vantajoso, não se tornou eliminatório, talvez por causa da luta menos violenta entre as relativamente poucas espécies, capazes de enfrentar as condições selectivas da natureza nas altas latitudes.

Ovos duráveis ocorrem nas Typhloplanidae em geral, assim como em muitos Rhabdocoela e Alloeocoela, mesmo marinhos (Steinmann-Bresslau 1913, p. 289-290; Bresslau 1933, p. 156-157). Comparados com êstes, são os ovos imediatos raros, constituindo adaptação especial. Garantem às Mesostominae uma distribuição maximamente rápida e vasta. Nos pormenores da produção dos ovos imediatos superam os vermes brasileiros, de muito, os europeus. Os vermes saidos dos ovos duráveis perfazem a 1.a geração, cujos indivíduos produzem todos, como primeiros ovos, os imediatos. Dêstes, saem os vermes da $2^{a}$ geração, "dos quais uma parte considerável não mais desenvolve ovos imediatos, mas, sòmente ovos duráveis" (Steinmann-Bresslau 1913, p. 300). Outra parte gera ovos imediatos, que dão origem à $3 .{ }^{a}$ geração. Nas criações de Beauchamp (1926a, p. 1437), na Alsácia, houve em 40\% dos vermes da $3 .^{a}$ geração ainda produção de ovos imediatos; o resto formou logo ovos duráveis. Numa população criada em São Paulo, que era a terceira no aquário (possivelmente, a inicial já foi uma saida de ovos imediatos, ou filha ou neta duma tal), houve $94 \%$ de vermes que passaram pela fase da produção de ovos imediatos. Com isso, aumenta, naturalmente, o número das futuras portadoras de ovos duráveis muito mais do que na Europa.

\section{Genus: Bothromesostoma M. Braun 1885}

\section{Bothromesostoma evelinae, spec. nov. (Fig. 99, 100, 105-107, Est. XXXI Fig. 3-4)}

Os vermes adultos têem ca. de $3 \mathrm{~mm}$., ao comprido, e ca. de $0,7 \mathrm{~mm}$. de largura. $O$ corpo é rostralmente obtuso; caudalmente, cuspidato. $O$ dorso é abobadado; o ventre, achatado e, destarte, próprio para a locomoção reptante. Em vista dorsal, delimita-se a sola rasteira ("Kriechsohle") nos dois lados com pequenas lamelas; estas, no corte transversal (Fig. $107 \mathrm{~A}$ ), marcadas por ângulos salientes. Imediatamente atrás da cabeça e um pouco antes da cauda, alargam-se as lamelas algo mais que no contôrno restante. Quando os animais se contraem e permanecem parados, destaca-se também o dorso por duas lamelas menores, assumindo, então, o corte transversal a forma da Figura 107 B.

No parênquima, existe uma rêde cerrada de pigmento esverdeadopreto, (Est. XXXI Fig. 3) ausente na sola, cuja côr amarelada ou alaranjada provem de grânulos contidos na epiderme. A pigmentação preta acentua-se particularmente em três estrias longitudinais e perto do bordo látero-ventral, onde aparece uma linha ligeiramente ondulada, mas, distintamente traçada. Pigmentos pretos faltam nas duas projeções ventrais do verme contraido em repouso; elas são puramente ama- 
relas. Alguns cromatóforos entram, mais ou menos simètricamente, nas lamelas dorsais; elas são incolores, como o é tôda a epiderme dorsal e lateral. Na cabeça, permanecem dois largos campos laterais sem melanó: foros; entre êstes espaços de côr amarela muito clara, encobre uma cúpola preta a extremidade rostral. Em vermes com ovos testáceos, transparecem as cascas vermelho-acastanhadas dêstes na metade posterior do corpo. A epiderme dorsal incolor condiciona o aspecto aveludado do verme visto de cima. Na vista de baixo, reconhecem-se, através da epiderme com pigmento amarelo, alguns melanóforos parenquimáticos por transparência. No escuro, concentram-se os melanóforos, e o animal torna-se cinzento claro com manchas pretas (Est. XXXI, Fig. 4); no claro, fica preto, devido à expansão do pigmento. Destarte, apresenta $B$. evelinae 0 fenômeno da mudança fisiológica da côr. Vermes recem-saidos dos ovos, de ca. de $1 \mathrm{~mm}$., de comprimento são incolores; os desenvolvidos no corpo materno nascem pigmentados. A epiderme dorsal tem de altura $0,004 \mathrm{~mm}$.; a ventral, $0,008 \mathrm{~mm}$. Os cílios são, aproximadamente, do mesmo tamanho. Os limites inter-celulares são nítidos nos cortes tangenciais (Fig. 100), exibindo as células bordos denticulados, talvez pontes intercelulares, que lembram a descrição da epiderme de Phaenocora jucunda (Cognetti de Martiis 1915, p. 195-196). Os contornos das células substituidoras (Fig. 100, s) são lobulados, como tal se vê nas células correspondentes de $\boldsymbol{B}$. essenii (Luther 1904, t. 1 f. 4) e Proxenetes karlingi (Luther 1943, t. 5 f. 2). Rabditos dermais não foram reconhecidos. Ramnitos adenais ocorrem em grande número (Fig. 100, r) ; são moles, flexíveis e atingem 0, $03 \mathrm{~mm}$. de comprimento. As glândulas ramnitógenas situam-se dorsal e ventralmente ao cérebro, nas saliências laterais, e no fundo do saco cutâneo (Fig. 106, rh). Os dutos ramníferos desembocam, na epiderme, intracelularmente (Fig. 100, c). Prolongamentos filiformes das células pigmentadas do parênquima entram na epiderme (Fig. 100, p), e o pigmento estende-se na região externa das células epiteliais (veja Fig. 106, o bordo ectal da epiderme ventral). Ocorrendo ventralmente e nos dois lados, não, porém, no dorso, o fenômeno concorda, até nos pormenores, com o processo correspondente de $B$. personatum, tido por Luther (1904, p. 12, 254) como excretório. Glândulas volumosas, cianófilas, provavelmente mucosas, encontram-se na região anterior (Fig. 99, k), onde desembocam sub-terminalmente, como também ao redor do saco cutâneo (Fig. $106, \mathrm{~s})$ ventral $(\mathrm{k})$.

O saco ventro-mediâno invagina-se no trecho entre o plano transversal que passa pelo bordo caudal do cérebro (Fig. 99, c) e o poro oroprotonefridial $(\mathrm{p})$, mais perto do último. Trata-se, no saquinho, dum tubo encurvado para diante, sem cílios. No lume desembocam glândulas cianófilas (Fig. 106, k) e outras, ramnitógenas (rh). Nada se vê de inervação ou de células interpretáveis como sensoriais. O fundo do saco é indiviso, cotmo em B. truncatum Bekl.

Do sistema nervoso mencionamos apenas o cérebro (Fig. 99, c), tão largo quão comprido, que emite, para diante, dois troncos sensoriais. ramificados arborifòrmemente para fora. Estes e os tractos de ramnitos ("Stäbchenstrassen") dirigidos também rostralmente abraçam um espaço 
lanceolado (Fig. 99, x) e transparente, que se demarca no parênquima em várias Mesostominae, p. e., M. productum ("Schizostomum" O. Sichmidt 1848, p. 54). Dos nervos longitudinais, foi possível verificar os nervos dorsais (3 da f. 58 de Bresslau 1933, p. 78) e os ventrais (ibid., 2) ; os últimos com a comissura post-faríngea (ibid., 10). O anel faríngeo (Fig. 106, q) situa-se ao nível da inserção da bolsa faríngea à faringe (h). Os olhos são nítidos nos vermes recem-saidos dos ovos; nos adultos, reconhecem-se, às vêzes, por transparência, na vista do lado ventral. Vê-se, pelos cortes, que os órgãos ópticos são muito grandes; ocorrem, p. e., em cortes sagitais, de $0,006 \mathrm{~mm}$. de grossura, em 6 cortes sucessivos. $O$ cálice pigmentado, provàvelmente uni-celular, delimita-se indistintamente contra o cérebro; a única célula visual tem forma de clava alongada em direção antero-posterior. A orla periférica de bastonetes apre. senta-se com rara nitidez.

A faringe rosulada (Fig. 106, h) situa-se antes do meio do corpo. $O$ cálice protonefridial ( $p)$, combinado com a bôca, reconhece-se sòmente nos indivíduos recém-saidos dos ovos, pois são sem pigmento, ou nos cortes. $O$ canal protonefridial terminal de cada lado converge ligeiramente sinuoso, de fora e obliquamente de trás, para o poro do emunctório. A bolsa da faringe é profunda e sem cílios ; os núcleos são escassos. $\mathrm{O}$ epitélio externo da faringe, porém, é orlado por curtos cílios rígidos. Os núcleos dêste epitélio (Fig. 106, nb) situam-se fora dêle, no bordo da bolsa faríngea, como foi observado em $M$. ehrenbergii (Luther 1904, p. 44-45 t. 2 f. 14). No epitélio interno da faringe, os núcleos são mais altos que as células, condicionando, destarte, saliências celulares, conhecidas também de outras Mesostominae (l. c., p. 45). Dá-se o mesmo com o septo musculoso, a musculatura interna, e a externa locomotora da faringe (Fig. 106, 1). Perto do ponto em que a última se insere no septo faríngeo, encontra-se, internamente, o anel nervoso faríngeo ( Fig. 106, q). Das glândulas intra-faríngeas vêem-se, na Fig. 106, as eritrófilas ladeadas pelas cianófilas, mucosas. Corresponde isto ao que foi indicado de Bothromesostoma personatum e Mesostoma mutabile (1. c., p. 48, 236-237, $255)$.

$O$ esôfago insere-se (Fig. 106, e) externamente ao orifício faríngeo interno; tem epitélio nucleado e estreita-se infundibuliformemente para dentro. O intestino (Fig. 99, i) estende-se do espaço entre os nervos anteriores $(x)$ até quasi a extremidade caudal. A acumulação de células (laviformes de Minot, ao redor da entrada do intestino, e o lume intestinal dorso-ventralmente achatado, que tende a desaparecer no auge da resorpção, nada apresentam de particularidades específicas.

O gonóporo (Fig. 99, n) situa-se a $0,2 \mathrm{~mm}$. de distância atrás do orifício oro-protonefridial, constituindo isso um dos mais importantes caracteres disjuntivos de $B$. evelinae. Os testículos (t) apresentam forma muito diversa: uma vez são reniformes (Fig. 106), outra vez lembrám salchichas (Fig. 99). Isto independe da época, pois podem ser assimètricamente desenvolvidos, nos dois lados. O tipo de testículo pequeno encontra-se látero-ventralmente ao ńtero repleto; o tipo comprido, dorsalmente a êste. Os testículos indivisos de $B$. evelinae concordam com os 
de $B$. truncatum, sendo foliculares os de $B$. personatum e $B$. essenii. Os dois dutos eferentes reunem-se formando a vesícula seminal intimamente ligada ao reservatório da secreção granulosa (Fig. 106. y), cujas glândulas (f) se vêem ental e ventralmente ao reservatório. $O$ duto ejaculador conduz ao órgão copulador $(\mathrm{m})$, de parede grossa. Tão pouco quão em B. truncatum, notou-se a retroflexão do pênis para dentro do bulbo ental descrita de $B$. personatum (Luther 1904, p. 256). O órgão masculino entra rostralmente e do lado esquerdo no átrio (a).

No lado do pênis, ou imediatamente atrás dêle, desemboca a bursa copulatória (Fig. 106, b) situada no plano mediano. O canal da bursa copulatrix é comprido; a empôla, pequena e musculosa. Os espérmios, durante a copılação recolhidos na bursa, passam, por meio do duto espermático $(\mathrm{z})$, ao receptáculo seminal $(\mathrm{r})$. A posição do ductus spermaticus, entre o canal da bursa e o canal genital feminino, corresponde à de $B$. personatum e $B$. essenii, contrastando com a de $B$. trunculum (veja a discussão taxonômica, mais adiante).

O ovário ou germário (o) dirige-se para diante e para o lado direito. $\Lambda$ disposição dos ovócitos em crescimento lembra a de Mesostomna ehrenbergii. As célnlas do oviduto (d) são altas, dilatando-se a via eferente feminina como receptáculo seminal (r) esférico. No trecho seguinte, o canal feminino, derramam as volumosas glândulas da casca (g) a sua secreção acidófila.

Perto do ponto em que o canal feminino entra no átrio, desembocam também os dois uterodutos. Os dois úteros (Fig. 99, u) são órgãos ciesenvolvidos sòmente na metade caudal do corpo, sem ramificação para diante, quando contêem ovos de desenvolvimento lento. Correspondem, destarte, à fase de B. essenii com ovos dêste tipo (Graff 1913, p. 290). Os úteros com ovos de desenvolvimento rápido estendem-se até a região anterior do verme, abrigando filhotes pigméntados em várias fases, como também ovos de desenvolvimento lento (Fig. 105). A produção simultânea dos dois tipos de ovos conhece-se de Bothromesostoma na Europa (Bresslau 1903, p. 133 - 135; Steinmann \& Bresslau 1913, p. 292 293). Foram observados até 3 ovos (diâmetro: $0,21 \quad 0,26 \mathrm{~mm}$.) testáceos (duráveis) enfileiradamente dispostos em cada útero. A côr da casca ó vermelho-acastanhada.

Os vitelários (Fig. 99, v) estendem-se, nos dois lados do corpo, quasi da extremidade rostral à caudal, com folículos ramificados para o dorso e ventre. Os vitelodutos (w) anteriores e posteriores reunem-se, desemboeando, em cada lado, o viteloduto comum, da parte de fora, no uteroduto correspondente. $\Lambda$ s células vitelinas prestaram-se, devido às numerosas mitoses, à contagem dos cromosomas, cujo número diplóide é de 4 , havendo dois páres de comprimento diverso.

\section{Ocorrência e biologia de Bothromesostoma evelinae}

A espéécie foi encontrada nágua estagnada, nas circunvizinhanças do rio Pinheiros e scus afluentes, perto da cidade de São Paulo. Nas localidades habitadas pelos vermes, tratou-se, em parte, de pequenas acumulações dágua perenes, de outra parte, de poças só transitoriamente aquíferas, e isso, ou na época relatiramente sêca depois 
de chuvas copiosas, ou no período com certa regularidado húmido, a saber, na primavera e no verão. A grande variação do tempo na cidade de São Paulo inutiliza quasi indicarmos os mêses dos achados: outubro até dezembro; março até maio. Em outubro de 1945, encontrámos, p. e., a espécie num brejo que estava sêco, alguns dias mais tarde. Vermes com filhotes no corpo materno encontrámos no outono (m'ês de abril).

Da Europa, conhece-se a ocorrência das espécies de Bothromesostoma em poças passageiras. Na Finlândia meridional, observou Luther $(1904$, p. 258) B. personatum nas águas acumuladas nas pisadas do gado vacum; e na Á́stria, Spandl (1925, p. 97) viu a mesma espécie nas águas transitórias formadas por chuvas ou pelo lençol dúgua aflorado. Perto de Perm, na Rússia européa oriental, descobriu Beklemischev (1921, p. 641) B. truncatum em poças primaverís que dessecam no estio.

Em oposição às indicações anteriores que evidenciam atividade acentuada das espécies de Bothromesostoma no escuro, p. e., B. personatum (Brinkimann 1905, p. 106) e B. essenii (Luther 1904, p. 253), nadam os indivíduos de B. evelinae na superfície dágua, em horas de plena insolação. Como os outros vermes do gênero, nadam também os atuais com o ventre para cima, na película dágua. 'Tal tipo de locomoção parece facilitado pela secreção das glândulas da invaginação cutânea, de função muito discutida (Luther 1904, p. 79-82: literatura anterior). Com êle, Brinkmann (1905, p. 106) e Reisinger (1923, p. 8), consideramos o órgão como glandular. De modo nenhum existe a pretensa concordância morfológica com as fossetas ciliadas de Stenostomum que estudámos há pouco (Marcus 1945a, p. 19-21). Ruebush (1941, p. 34), é verdade, fala duma bolsa sensorial, mas, isto, evidentemente só baseado nas indicações de Fuhrmann (1894, p. 253-254), Dorner (1902, p. 31) c outros autores citados por Luther (1. c.). No trabalho histo-fisiológico de Müller (1936, p. 265-290), que conseguiu corar electivamente os élios sensoriais de $R$. essenii, e discernir, operativamente, além dos cílios tácteis, os quimoperceptores e reoperceptores, falta qualquer referência ao saco cutâneo ventral. Tal omissão inesperada dụm brgão, cuja função se ventila, desde há mais de meio século, na literatura, diminue certamente a possibilidade de apelar à dita obra como prova de não ser sensorial o saco. Todavia, queremos crer que o azul de toluidina aplicado por Müller teria salientado as células do fundo do saco ventral, se fossem realmente sensoriais.

Bresslau (1933, p. 133) não considera averiguadas a inervação e as células sensoriais da invaginação em apreço e pensa que constitue, possivelmente, um órgão auxiliador do aparelho reprodutivo. Quando se vê a figura 14 de Brinkmann (1905, p. 107) relativa à copula de $B$. personatum (em $B$. essenii, realiza-se do mesmo modo, ibid., p. 108), não resta dúvida sôbre a função pegajosa da secreção do saco que gruda o corpo anterior do verme à película dágua.

Ao ficar, no aquário, um indivíduo de $B$. evelinae desalojado da superfície dágua por uma pequena gota derramada da pipeta, consegue o verme, freqüientemente, permanecer em contato com a superfície por meio de um fio mucoso que lembra o produto das chamadas glândulas fiandeiras de várias espécies de Mesostoma. Os animais suspensos pelo cordão de muco recuperam com facilidade a posição habituai na superfície. Quando a gota os levou até o fundo do aquário, rastejam na parede para cima. Evidentemente, não se locomovem comumente a nado livre, sem apoiar a sola.

Vermes mantidos no aquário, durante alguns dias, em meados de outubro, evacuaram ovos duráveis e continuaram viventes. Existe, portanto, ovipostura regular de ovos de casca grossa.

Mudança fisiológica da côr, como se observa em $B$. evelinate. não conhecemos de outros Turbelários. Com relação a $B$. essenii disse Brinkmann (1905, p. 108) o seguinte: "o animal varía fortemente na sua côr, resultando, disso, variedades locais constantes. Quando ocorre nas folhas de Nymphaea, Nuphar e Potamogeton, é de côr láctea ; no meio de vegetação cerrada (Stratiotes, Hydrocharis, Lemna). mais amarelado, até, ìs vêzes, de ocre escuro, aproximadamente como o lado inferior de $\boldsymbol{B}$. personatum" O têrmo "variedades constantes" não justifica adınitir que 
ocorra mudança fisiológica da côr em B. essenii; por outro lado, crescem as plantas mencionadas no mesmo biótopo, de maneira que parece bem possível que os vermes passem de umas às outras, mudando de côr.

Eliminação de pigmentos tida por excretora foi descrita de Bothromesostoma personatum (Luther 1904, p. 12), Mesostoma maculatum (Hofsten 1916, p. 712), e M. platygastricum (Hofsten 1925, p. 3) Westblad (1923, p. 136 e seg.), que considera também as células ramificadas e pigmentadas no parênquima das Mesostominae como armazenadoras de excretos, não observou (p. 138), eliminação de partículas dos corantes vitais por éle aplicados através do epitélio epidérmico. Diante da objeção de'Brinkmann $(1905$, p. 105$)$ às verificações de Luther relativas à passagem do pigmento através da epiderme, re-afirmamos o nosso achado correspondente em B. evelinae.

Quando os vermes permanecem durante uma hora no escuro (temperatura dágua: $20^{\circ} \mathrm{C}$.), apresentam-se cinzentos claros, com pontos pretos, os melanóforos concentrados. Expostos à lampada do microscópio, para serem desenhados, tornaram-se, dentro de meia hora, quasi totalmente cinzentos escuros, com os limites dos cromatóforos ramificados ainda distintos, devido à expansão não máxima de alguns dêles. Novamente removidos da luz, re-começou, já dentro de 10 minutos, a contração dos cromatóforos, mas, nem de longe atingiu o gráu anteriormente descrito das manchas pretas em fundo cinzento-claro. Numa nova experiência (27. XI., temperatura dágua: $22^{\circ}$ C.) observámos, depois de duas horas, o tipo ilustrado na Estampa XXXI Figura 4, em vários, não em todos os exemplares. Também a face ventral mostrou-se ocre-clara com pigmentos pretos vistos por transparência, não contíguos, estrelados, e algo maiores que os do dorso. Fluminação intensa resultou, novamente, em expansão dos cromatóforos.

\section{Discussão sistemática de Bothromesostoma evelinae}

Além das quatro espécies de Bothromesostoma descritas na monografia de Graff (1913, p. 286-291), conhecem-se ainda B. truncatum Beklemischev (1921, p. 639-641) e B. primitivum Sabussowa (1929, p. 498-502). Escusado é confrontar B. evelinae com $B$. primitivum, pois êste carece dos dois earacteres genèricamente disiuntivos de Bothromesostoma: o saco cutâneo ventral e o duto espermático. Deveria, ao nosso vêr, entrar no gênero Mesostoma. As espécies B. essenii M. Braun, B. marginatum $\mathbf{M}$. Braun, e B. lineatum M. Braun, cujas relações mútuas não conviria discutir aquí, sem material delas, distinguem-se, à primeira vista, pela șua côr láctea, ocre, ou, -em todo o caso, não preta, de $B$. evelinae. Além disso, nas ditas espécies o gonóporo segue imediatamente à bôca, situando-se os dois orifícios na mesma reintrância ventral. O último caracter separa também $B$. personatum (O. Schmidt), com pigmento preto, de B. evelinae. Em dois caracteres importantes, a saber, testículos indivisos e orifícios oral e genital distanciados um do outro, concorda $B$. truncatum com $B$. evelinac. A invaginação ventral ocorre, porém, em $B$. truncatum, pré-cerebralmente, e a distância oro-genital importa, na espécie russa, apenas em $0,04 \quad 0,05 \mathrm{~mm}$. contra 0,2 mm., em B. evelinae. Possue, além disso, B. truncatum duto espernático excepcional, que liga o átrio ao receptáculo seminal. Nas outras espécies do gênero, inclusive $B$. evelinae, situa-se o duto espermático entre o canal da bursa e o canal feminino. Finalmente, desemboca, em $B$. truncatum, o canal da bursa no átrio rostral. mente ao órgão copulador; em $B$. evelinae, lateral ou caudalmente a êste. 


\section{Subordo: Kalyptorhynchia Graff}

\section{Familia: Gyratricidae Graff $(1905$, p. 73,137$)$}

\section{Gyratrix hermaphroditus Ehrenberg (Fig. 118, 119)}

Referências principais:

Gyratrix hermaphroditus (Hemprich \&) Ehrenberg 1831, Symbolae Physicae, Phytoz. Turbell. fol. c, p. 9 (citado seg. Graff 1913, p. IX, 345, 480) f. $1-1 b$

Prostona. (na p. 66, correção: Prostomum) lineare. O. Schmidt 1848, p. 23 t. 1

Turbella notops; Gyrator hermaphroditus; G. furiosus Diesing 1862, p. 217, 246.

Prostonum lineare Hallez 1873, p. 559 t. 20-22 (anatomia, biologia).

Gyrator notops Dugès, Hallez 1900, p. 449 e seg. f. 201-219 (anatomia, biologia)

Gyrator notops (Anton Dugès 1828) Brinkmann 1905, p. 118 t. 1 f. 25-27

Gyratrix hermaphroditus Graff 1905, p. 137 t. 5 f. 10-11, t. 6 f. 16-17; 1912, p. 68 t. 4 f. $17-19$; 1913, p. 342 f. $309-311$ (literatura)

Hofsten 1912, p. 651 (distribuição na Suissa; lago de Lugano, $70 \mathrm{~m}$. de profundidade; St. Bernhard, $2560 \mathrm{~m}$. de altitude)

Fuhrmann 1914, p. 794 (Colômbia, $2580 \mathrm{~m}$. de altitude; lago de Neuchâtel, até $100 \mathrm{~m}$. de profundidade)

Reisinger 1922, p. 201 f. 1 (emunetório); 1923, f. 11, 26 (anatomia); 1933, p. 257 (Java)

Westblad 1923, p. 140 , ete. f. 12 t. 2 f. 11 (fisiologia da excreção)

Meixner 1915, p. 573 t. 3 f. $64-67$ (ovo); 1923a, p. 199 f. 2 (aparelho feminino); 1925 , p. $266,304,309$, ete. f. $4-7,19-20,22,30$, t. 3 f. $12,14-16$ (morfologia pormenorizada); 1929 , p. $768,784,789$, etc. f. 15 (taxonomia, excreção); 1939, p. 79 (variabilidade), 122 (distribuição) f. 47,98

Flory \& Showalter 1930 , p. 66 e seg. (bursa)

Karling 1931, p. 8 f. 1-2 (água salôbra)

Steinböck 1931, p. 21; 1932a, p. 322 (distribuição)

Bresslau 1933, p. 274 f. 25 (11), 97, 119

Kromhout 1943, p. 167 e seg. (emunctório)

Entre todos os Rhabdocoela, uma das espécies mais ágeis e de natação mais rápida. O corpo é muito contráctil; pode formar uma massa arredondada, em que o cabo da bainha penial (Fig. 119, q) se sobrepõeà tromba $(\mathbf{r})$, ou, ao contrário, estirar-se filiformemente. Quando o verme nada ou desliza tranquilamente, estreita-se o corpo cilíndrico na região da proboscis (tromba) e atinge a largura máxima no início do terço posterior. Mais para trás, diminue pouco e sucessivamente, terminando com extremidade redonda.

Vermes dágua doce atingem, quando adultos, até $2 \mathrm{~mm}$. de comprimento; marinhos (da Irlanda, do Mar de Norte, da Adria), 1 mm. (Meixner 1929, p. 784). Vermes jovens, recém-saidos do ovo e ainda. repletos de vitelo, tiveram, no material presente, límnico, $0,3 \mathrm{~mm}$. de longura. O estilete penial dêstes já acusou $0,15 \mathrm{~mm}$.

Rabdóides e, geralmente, também pigmentos faltam. Por isso, são os vermes esbranquiçados à luz refletida; hialinos, à transmitida. Exemplares das grandes profundidades dos lagos são rosáceos e especialmente transparentes. Côr amarelo-sulfúrea, concentrada nas lacunas da epiderme, e, destarte, disposta em forma de manchas, foi vista em espécimes que viveram perto de Woods Hole numa poça de alta salinidade no verão. (subspec. maculata, Graff 1912). 
A epiderme é sincicial; tem de altura 0,002 0,004 $\mathrm{mm}$; e é provida de cílios de $0,012 \mathrm{~mm}$., ao comprido. Na zona anterior do corpo, ocorrem estereocílios tácteis mais longos. A membrana basilar é grossa; o tubo músculo-dermático, forte. Pequenas glândulas cianófilas desembocam na extremidade anterior, lateralmente à tromba. Células glândulares grandes, com núcleos freqüentemente algo lobulados, encontram-se na região do cérebro (Fig. 118, g), e derramam a secreção mucosa (Westblad 1923 , p. 153) no orifício da bainha da tromba. O parênquima é fracamente desenvolvido, havendo, na região da proboscis e do cérebro, mais do que na parte ao redor dos órgãos reprodutivos. A musculatura do corpo diferencia-se em musculatura da tromba, da faringe. e do aparelho genital.

A porção do corpo que cabe à tromba, importa, aproximadamente, num quinto da longura total. A própria tromba (Fig. 118, r) é cônica e circundada pela bainha, i. é, uma invaginação do integumento com orifício terminal. Os epitélios da proboscis e da sua bainha carecem, já em vermes jovens, de núcleos e de cílios. Subjacente ao revestimento da tromba acumula-se a secreção eosinófila das glândulas que fazem parte das massas ao redor do cérebro. Na ponta do cône, predomina a secreção em forma de grânulos; mais para trás, a em forma de bastonetes. Sendo refractiva, condiciona a secreção o aspecto esbranquiçado do cône dos vermes viventes. A ponta da proboscis tem epitélio menos alto que a parte proximal, reconhecendo-se, sòmente na última, a musculatura anelar, sub-epitelial, com nitidez. O comprimento da ponta do cône é de um quarto a um terço do mesmo cône; como ela se separa, freqü̈entemente, por constrição muscular da parte proximal ou se acha algo retraida nesta, pelos músculos sub-epiteliais longitudinais, surge o caracter que ocasionou a denominação duma forma especial (vjatkensis Nassonov 1919, p. 643). Esta não deveria ser mantida (Meixner 1925, p. 267). Fibras da musculatura cutânea longitudinal encurvam-se para dentro e inserem-se ao redor do orifício da bainha, atuando como dilatadores. Quanto aos pormenores da musculatura interna da tromba, e os seus grupos de músculos fixadores, protractores e retractores, remetemos os leitores à descrição de Meixner (1925, p. 268-270). Na musculatura da tromba, nota-se estriação transversal, havendo, porém, também estádios funcionais lisos (ibid., p. 281). A tromba rapidamente protraida segura pequenos Crustáceos, por meio da secreção viscosa acumulada na ponta do cône.

Imediatamente atrás da tromba, situa-se o cérebro, de contôrno trapezóide (Fig. 118, c). Compõe-se duma massa transversal de fibras, que é um pouco mais alta que comprida. Circundam-na almofadas simétricas de células ganglionares. Dois grandes complexos destas salientam-se ventralmente; dois outros, dorsalmente; outros envolvem as raizes dos nervos anteriores e posteriores. Na massa de fibras, distingue-se uma forte comissura ventral (posterior); e outra longitudinal, rostro-caudal. Os dutos das glândulas da tromba e os retractores dela atravessam a camada das células gangfionares. Os três pares de nervos longitudinais posteriores continuam até a extremidade rostral do corpo (Reisinger 1925, 
p. 142). Os dois olhos encontram-se perto das raizes dos nervos anteriores sub-dorsais. Cada olho contem um cálice uni-celular, bicôncavo em virtude duma parede separadora, e, em cada metade, duas células ópticas. O pigmento aparece com grânulos grossos, que são pretos nos vermes que vivem nágua iluminada; vermelhos, alaranjados ou ausentes (coeca Vejdovsky 1880), nos espécimes das profundidades de lagos e rios ou dos poços sem luz.

O orifício bucal encontra-se rostralmente ao meio do corpo; é circundado por músculos radiais, e provido dum esfincter. Conduz ao tubo oral que se dilata como bolsa faríngea, sendo tubo e bolsa, já nos jovens, sem núcleos no epitélio. A faringe (Fig. 119, b) é um pouco mais comprida que grossa. A sua capacidade de sucção observa-se quando recebe, da tromba, um Crustáceo, e se fixa, nêste, entre as extremidades torácicas. Ao sugar, abre então um buraco numa das membranas intersegmentares, e, no fim da chupadura, pode puxar a cutícula abdominal para dentro do torax do Copépodo. Quanto aos músculos e glândulas faringeos remetemos os interessados a Meixner (1925, p. 289-292). Do intestino é a parte post-faríngea duas vêzes mais comprida que a pré-faríngea. $O$ lume do intestino é, pelo menos na região esofágica, distinto; o seu epitélio é sincicial. Quando repleto, delimita-se o intestino do parênquima escasso e dos órgãos reprodutivos, embora se ache apertado e lobulado por êstes, nomeadamente pelo vitelário.

Os emunctórios correm lateralmente (Fig. 119), sendo escassos os órgãos terminais e tufos de cílios propulsorès. No material presente, no de Meixner (1925, p. 293), e de Kromhout (1943, p. 170-171), os troncos terminais dos canais descendentes $(\mathrm{n})$ desembocam lateralmente, não ventralmente. São característicos dos vermes dágua doce, mas, ausentes nos dágua salôbra, os paranefrócitos (Fig. 119, z) dos canais distais (ascendentes), e as empôlas (y) dos proximais (descendentes). As últimas são sincícios acumuladores de excretos que secretam para dentro de divertículos tubulosos dos troncos terminais. Nos exemplares norte-americanos de Virginia (Kromhout, l. c.) e nos nossos, encurvam-se os canais descendentes em direção à linha mediana, estabelecendo-se, entre os pontos mais aproximados dos lados direito e esquerdo, uma comunicação transversal (Fig. 119, $x$ ), de calibre menor que os canais descendentes. Em vermes de procedência marítima, parece que até os grandes canais faltam.

Os vermes são hermafroditas proterândricos. O orifício sexual masculino ocupa a extremidade posterior. O átrio masculino, provido de musculatura circular forte e de ca. de 16 músculos longitudinais finos, liga-se à bainha do estilete, esta de $0,04 \quad 0,045 \mathrm{~mm}$., ao comprido. A bainha é um rego ("Halbrinne" Meixner 1925, p. 309) cuticular, cujas paredes laterais terminam, externamente, com pontas, encurvadas, por via de regra, ventralmente, mas, nem sempre presentes. Rostral e dorsalmente continua a bainha do estilete com o cabo da bainha (Fig. 119, q) igualmente cuticular; cujo comprimento é de 0,1 0,14 $\mathrm{mm}$. Dentro da bainha atua o estilete cuticular, tubuloso, e aguȩado ( $p)$. Nos vermes límnicos, tem de longura 0,15 0,17 mm.; nos marinhos, 0,11 $0,13 \mathrm{~mm}$. A sua parede ventral, grossa, contem o canal, em que corre a secre- 
ção granulosa, e que se abre, na ponta do estilete, com um poro obliquo, quasi dorsalmente dirigido. 0 lume principal do estilete situa-se no seu lado dorsal. Este lume comunica-se por uma fenda dirigida para o lado esquerdo com o canal genital masculino. A fenda é entalmente larga; ectalmente, estreita-se muito. 0 lume dorsal do estilete abre-se perto da ponta externa dêste órgão. $O$ uso do estilete como arma, com que o verme mata os Copepoda, foi observado por Hallez (1873, p. 567), atuando a secreção granulosa, inoculada nos Crustáceos, como veneno muito forte.

O átrio masculino continua, rostralmente, com o canal genital massulino, cujos músculos longitudinais formam dois feixes laterais fortes, inseridos na bainha e no estilete, funcionando como protractores do último. Abre-se, entalmente, no canal genital, o reservatório piriforme da secreção granulosa. E' revestido por músculos espirais, numa única camada (Meixner 1929, p. 784), e liga-se, pelo ductus granulorum, ao canal mencionado, na parede ventral do estilete. As glândulas dos grãos ocupam a extremidade ental do reservatório (Fig. 118, k).

Do lado esquerdo e ventral, entra ainda, no canal genital, o duto ejaculatório comprido e fino que evacua a vesícula seminal (Fig. 11.8, s). As vias eferentes dos espérmios são, destarte, completamente separadas do reservatório da secreção granulosa. A vesícula seminal comunica-se pelo duto seminal, originado pela reunião dos dois dutos eferentes, com o testículo (Fig. 118, t). Este é ímpar, situado no lado esquerdo e dorsalmente ao intestino; a forma é alongada, fracamente lobulada. Pode ocorrer, no meio do testículo, um sulco sstreito, mas, profundo, percorrido por um septo duplo da túnica testicular. Anteriormente ao sulco, sae, da parede medial do testículo, um duto eferente mais comprido e grosso que outro originado atrás do sulco. A parede do duto seminal é grossa, de caracter cuticular, sem núcleos. Os espérmios são filiformes, sem flagelos secundários, e, pelo menos, têem $0,2 \mathrm{~mm}$. ao comprido.

$\mathrm{O}$ orifício genital feminino (Fig. 118, d) serve sòmente à ovipostura. Encontra-se no fim do segundo terço da distância entre a faringe (h) e a extremidade caudal, e é provido de glândulas acessórias (Fig. 118, a). 0 curto trecho ectal do átrio feminino, contíguo com o poro, é ciliado e canaliforme; termina, entalmente, com um esfincter. Mais para dentro, segue o espaçoso átrio infundibuliforme, por sua vez dividido, por anel de células epiteliais altas, numa parte proximal (ental), e outra distal (ectal). Na primeira, entram, de diante, o duto uterino provido duma única fibra esfinctéria e, do dorso, o viteloduto, o germoduto, e o canal da bursa (duto espermático). Desembocam ainda, na loja interna do átrio, as chamadas glândulas da casca (Fig. 118, f). Fornecem sòmente o pedúnculo ou filamento da casca do casulo. O pedúnculo é irregularmente encurvado, de longura variável, freqüentemente de ca. de 0,11 mm., ao comprido. Termina com disco adesivo e começa, no casuln, com entumescência anelar. 0 casulo tem $0,17-0,23 \mathrm{~mm}$. de comprimento e $0,11-0,12 \mathrm{~mm}$. de grossura; às vêzes, é mais esférico $(0,17 \mathrm{~mm}$. de longura, 0,14 mm. de grossura), ocorrendo ainda casulos sucessivamente estreitados em direção ao pedúnculo. A casca é fina (ca. de 0,002 mm.) e tem esculptura externa que lembra obra entrançada; no polo oposto ao 
pedúnculo, marca-se o opérculo pela sutura no circúito do casulo. Cada casulo contem um único ovo ou embrião, excepcionalmente, dois. 0 útero (Fig. 118, u) apresenta-se, antes da maturação dos órgãos masculinos, como tubo epitelial simples; sòmente durante o período masculino diferenciam-se os seus músculos e glândulas. Depois da época feminina, durante a qual cada casulo se encontra no útero por ca. de 3-5 dias, diminue o volume do útero.

O ovário (Fig. 118, o) é ímpar e situado no lado esquerdo ; é curto e claviforme. O vitelário (v), igualmente ímpar, ocupa o lado direito e a região dorso-mediana. Quando maduro, assume aspecto reticnlar, com anastomoses. $\mathrm{Na}$ fase da produção da casca, apresenta-se o vitelário com estrutura tubulosa, com lume aberto; mais tarde, quando fornece vitelo, preenchem as células vitelinas parietais, agora crescidas, o lume.

Dois vermes que copulam juntam as extremidades posteriores mutua mente, ficando as duas trombas diametralmente opostas. A copulação realiza-se por meio dum poro (Fig. 118, e) dorso-caudal, provido dum esfincter. Conduz à vagina, cuja longura, nos vermes límnicos, é de $0,02 \mathrm{~mm}$. e mais; nos marinhos, de $0,012 \mathrm{~mm}$. Pela vagina entram os espérmios e a secreção granulosa na bursa (Fig. 118, b), um grande órgão dorsomediano. Da parede ventral da bursa, sae o canal da bursa, ou duto espermático, que desemboca na loja interna do átrio feminino. Apresenta-se, destarte, a bursa como apêndice do canal genital feminino. A bursa é constituida por um tecido sincicial, em que se notam escassamente os núcleos esféricos. O órgão é envolvido por fina membrana basilar, a túnica, que é, segundo Flory \& Showalter (1930), quitínica. O sincício alimenta (Reisinger 1923, p. 41) os espérmios, que giram reunidos em bolas dentro de vacúolos do tecido. Segundo a necessidade, saem pequenas quantidades de espérmios pelo duto espermático, inseminando os gonócitos femininos. Os espérmios excedentes são absorvidos pela bursa.

Ocorrência: A espécie foi encontrada em várias localidades das circunvizinhanças da cidade de São Paulo, mas, cada vez, sòmente em poucos indivíduos. Material vivente trouxe o Professor Dr. Paulo Sawaya, em dezembro de 1942, dos arredores de Curitibạ (Paraná).

\section{Complementos à diagnose de Gyratrix hermaphroditus}

Para distinguir os vermes incolores com pigmento visual dos amarelos (maculatd Graff) e dos sem pigmento óptico (coeca Vejdovsky), chamou Graff (1909, p. 134; 1912 , p. 68) os típicos de Gyratrix hermaphroditus hermaphroditus. Com Hofsten (1912, p. 651) e a maioria dos autores suprimimos o nome sub-específico.

As relações eventualmente existentes entre a proboscis dos Kalyptorhynchia e a dos Nemertini foram, desde Graff (1874, p. 142) até Kepner, Ferguson \& Stirewalt (1941, p. 249), muitas vêzes abordados; com consideração da literatura ponderou Meixner (1925, p. 283-284) o assunto, não julgando as ditas estruturas como realmente homólogas.

Material da Europa (Hallez 1873, t. 20 f. 2; 1900, p. 469; Sekera 1911, p. 28 t. 1 f. 30 ; Reisinger 1922, l. c.; Westblad 1923, l. c.) e da China (Tu .1934, t. 2 f. 2) não possue o encurvamento medialmente dirigido dos canais descendentes (primários, proximais) do emunctório, nem a ligação transversal dêstes (Fig. 119, x). 0 earacter re-encontra-se sòmente nos vermes da Virgínia (U. S. A.; Kromhout 1943 , p. 169 f. 1, 10), com os quais os brasileiros concordam ainda nos pormenores 
das sinuosidades dos canais principais. Possìvelmente, trata-se de uma particularidade das populaçōes límnicas de $G$. hermaphroditus nas Américas. Desistimos, porém, da denominação duma subespécie, e isso, por duas razões. Primeiramente, oferece justamente o aparelho exeretor de G. hermaphroditus, ao todo, espécie pouco variável, diversidades ecológicas notórias. Em segundo lugar, faltam indicaçōes correspondentes de outro material americano (Graff 1912, p. 68, Rochester; Higley 1918, p. 78, Illinois) observado em estádio vivente; o da Colômbia foi sòmente visto depois de conservado.

A bipartição do testículo (Meixner 1925, f. 22), que não é constante, foi interpretada, primeiramente (1. c., p. 299), como indicação de se tratar, na gônada masculina impar, de dois testículos coalescidos. Mais tarde (Meixner 1929, p. 784) foi o testículo considerado como órgão que tende, secundàriamente, à divisão.

Além do casulo no útero, ocorrem às vêzes, simultaneamente, 1-2 outros, mas, êstes encontram-se no intestino. Parece mais provável que foram incorporados, no trato alimentício, em conseqüência duma ruptura da parede intestinal (Meixner 1925, p. 301) do que por via oral, depois da ovipostura (id. 1923a, p. 201), pois a atuação da faringe é sugadora, não engulidora. O desenvolvimento do embrião no casulo contido no intestino continúa; sôbre uma eventual eclosão dos jovens ou a ejeção do casulo pela bôca não conhecemos observações.

$\mathrm{Na}$ literatura anterior fala-se dum germário direito raramente desenvolvido em vermes marinhos (ilha de Madeira); excepcionalmente, em límnicos. Na última ponderação dêste assunto, chegou Meixner (1929, p. 786-787) a negar a ocorrência de germários direitos. Exame pormenorizado mostron que se trata sempre dum grande complexo de glândulas de secreção granulosa. Os núcleos enormes destas lembram os de ovócitos jovens, mas, em oposição a êstes, conteem um volumoso nucléolo cromatóide, em que um pequeno nucléolo de cromatina se aprofunda.

Distribuição de G. hermaphroditus: Dos biótopos acessíveis aas Turbelários, habita $G$. hermaphroditus maior número do que qualquer outra espécic da classe. Ocorre na humidade dos musgos e entre folhas; nágua doce estagnada e corrente; nágua salobra; no mar de salinidade normal (ca. de 36 por mil); e numa fonte de salinidade de 43 por mil (Meixner 1938, p. 122). No mar, habita o detrito arenoso da vegetação costeira, como também profundidades de 15-18 m., perto da ilha de Helgoland (Mar do Norte), onde, na areia grossa com pouco detrito ("AmphioxusSand"), representa o único Turbelário existente (ibid., p. 129). No lago de Neuchâtel (Suissa ocidental), desce até $100 \mathrm{~m}$. de profundidade; nos Andes da Colômbia, sobe até a altitude de $2580 \mathrm{~m}$. (ambos os dados: Fuhrmann 1914, p. 794). Por isso, figura $G$. hermaphroditus, na literatura, como espécie cosmopolita e ubiquista. Não nos consta, porém, relação da espécie, na literatura especialmente dedicada aios Turbellaria, do reino zoogeográfico da Neogea (Austrália; Nova Zeelândia; Oceânia). De resto, conhece-se da Groenlândia até a região de São Paulo e Curitiba, no Brasil: da Suécia setentrional (Torne Lappmark) e da península de Kola até a Espanha e a Itália; da Irlanda até a China e o Japão (Tu 1939, p. 213); da ilha de Java; e da Africa equatorial oriental (lago de Victória). Os achados marinhos abrangem - Oceâno Arctico; os mares europeus, do Mar do Norte até a Adria e o Mar Negro; e o Oceàno Atlântico, onde foi relatada do litoral norte-americano; da costa da Irlanda; e da ilha de Madeira.

\section{Ordo: Alloeocoela Graff (Hofsten 1905, p. 626 emend.)}

\section{Sistematização atual dos Aleocelos.}

Dentro da ordem dos Alloeocoela, "grupo muito polimorfo, dificilurente definivel" (Meixner 1938, p. 141), distinguiu Meixner (!. c., p. 3) as 4 sub-ordens seguintes:

1) Archoophora Reisinger (1935, p. 256); figuram, no trabalho original, como sub-ordem dos Rhabdocoela.

2) Lecithoepitheliata Reisinger '(1924a, p. 147). Abrange esta sub-ordem a) as Gnosonesimidac Reisinger (1926, p. 429) e b) as Prorhynchidae Diesing (1862, p. 60; citado segundo Graff 1913, p. 57). As Hofsteniidae Bock (1923, p. 50), originalmente e até a obra de Bresslau (1933, p. 276) tidas por Aleocelos, eonsiderou 
Meixner (1938, p. 142) como Acelos especializados. Desapareceram, na sistematização de Meixner, os dois termos Typhlocoela (pela primeira vez: Reisinger 1923, p. 1) e Hemacoela, usados para as Prorhynchidae (Steinböck 1924a, p. 242) e as Hofsteniidae (id. 1924b, p. 165; ai Hemacolea), respectivamente.

Da subordo Lecithoepitheliata descrevemos, há pouco (Mareus 1944, p. 9, 13), duas espécies de São Paulo e de Paraná, a saber: Prorhynchus stagnalis M. Schultze e Geocentrophora applanata (Kennel). P. stagnalis ocorre muito comumerte nos arredores da cidade de São Paulo. Verificámos também G. applanata, desde 1944, no rio Tietê, perto da cidade de São Paulo, entre plantas aquáticas. Não se restringe, portanto, a sua ucorrência às Bromeliáceas, em que a encontrámos primeiramente. Dum afluente do rio Paraiba (no município de Sta. Branca) obtivemos P. stagnalis e $G$. applanata en plantas aquáticas gentilmente trazidas pela Snrta. Da. Gertrudes Siegel.

3) Cumulata Reisinger (1924a, p: 147; ai Cummulata). Steinböck (1925, p. 167) escreveu, pela primeira vez, Cumulata. Se as regras da prioriảade fossem aplicadas também às entidades taxonômicas superiores, o nome da sub-ordem deveria ser Holocoela (literatura: Graff 1913, p. 358). Meixner considerou como Cumulata: a) as Gastropharyngidae, introduzidas no mesmo trabalho $(1938$, p. 5,39 , f. 4 E, f. 39); b) as Solenopharyngidae, tidas por Graff $(1905$, p. 73,$105 ; 1913$, p. 293), Beklemischev (1929) e Bresslau (1933, p. 271) como Rhabdocoela, cuja remoção, para os Alloeocoela, foi recomendada por Meixner (1929, p. 770); c) as familias mencionadas por Bresslau (1933, p. 278) como membros da sub-ordem; cntre estas, as Plagiostonidae (veja mais adiante).

4) Uma sub-ordem que Meixner chamou de Seriata, apesar de que ela abrange os Seriata Bresslau (1933, p. 261, 278-279) juntamente com os Tricladida Lang (1884 p. 1), e, destarte, corresponde aos Metamerata Reisinger (1924a, p. 148; Steinböck 1925, p. 167). Os Seriata Bresslau, que são os Crossocoela Graff e Cyclocoela Graff (literatura: Graff 1913, p. 421, 452) unidos, denominou Meixner (1938, p. 6) de Proseriata. Abrange, além das famílias mencionadas na obra de Bresslau, ainda uma nova, a $4 .^{\text {a }}$ sub-família (Archimonocelidinae) das Monocelididae (Meixner 1938, f. 54, 55 ), e a nova família Nematoplanidae (ibid., f. 6 D, 44).

Com Beauchamp (1932, p. 117) e Bresslau (1.933, p. 257), mantemos, por enquanto, os T'ricladida separados dos Alloeocoela, conservando, destarte, o nome duma - unidade bem definida, a saber, Tricladida Lang 1884, ao lado do outro, Alloeocoela Graff 1882, que designa uma ordem apenas vagamente delimitada. "Suspeito muito", disse Westblad (1935, p. 74), "que qualquer leitor da última diagnose dos Alloeocoela possa entender que tipo de animal seja um Aleocelo". Pelo número e tamanho dos cromosomas, aproximam-se os Tricladida aos Polycladida (Ruebush 1938, p. 327-328).

\section{Subordo: Cumulata Reisinger (Holocoela Graff)}

\section{Família: Plagiostomidae Graff (literatura: Graff 1913, p. 360)}

No sistema resumido de Bresslau (1933, p. 278), são as Plagiostomidae a 6.a: família dos Allococoela e abrangem duas sub-famílias, as Plagiostominae e as Vorticerotinae. Meixner $\left(1938\right.$, p. 3) acrescentou, como sub-famílias, a $7 .^{\mathrm{a}}$ e a $8 .^{\mathrm{a}}$ família do sistema de Bresslau, reunindo, assim, todos os Cumulata com orifícios bucal egenital separados numa família. As sub-famílias poderiam ser classificadas pela chave. seguinte :

1 Bôca ua região anterior do corpo; poro genital, na posterior

- Bôca ântero-subterminal; poro genital ântero-ventral, perto da bôca ..... Baicalaretiinae

2 Um único órgão copulador

- Vários (ca. de 10) órgãos copuladores, em fases evolutivas sucessiras .... Multipeniatinae

3 Faringe do tipo do "pharynx plicatus" (Bresslau 1933, p. 95) : .... Vorticerotinae

- Faringe do tipo do "pharynx bulbosus variabilis" (Bresslau 1933, p. 97 ) .... Plagiostominac 
Os gêneros atualmente conhecidos das Plagiostominae podem ser agrupados do seguinte modo:

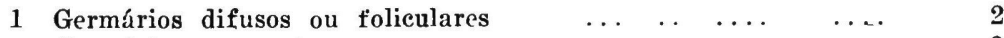

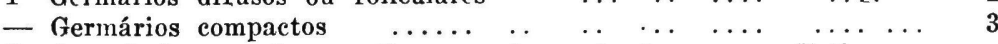

2 A vesicula granulorum atinge quasi o meio do corpo e distingue-se nitidamente da vesícula seminal, muito menor .. .Hydrolimax Haldeman 1842 (ef. Hyman 1938)

- A vesícula seminal não se estende além do quarto caudal do corpo para diante, e a vesícula granulorum constitue a parte distal da vesícula seminal, sendo ambas as partes de tamanho aproximadamente igual $\ldots . \ldots \ldots . . . \ldots . \quad \ldots . . . .$. Acmostomum Schmarda 1859 (cf. Steinböck 1933, p. 22-27) *)

3 Os gonócitos em cada um dos dois germários dispostos numa série

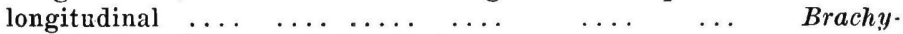
posthia Brandtner 1934 (p. 134)

- Os gonócitos dos germários (1 ou 2) amontoados, sem disposição semelhante a uma pilha de moedas .......... Plagios. tomum O. Schmidt 1852 (ef. Graff 1913, p. 361) **)

\section{As Plagiostominae dágua doce}

Conheciam-se, até agora, très espécies límnicas das Plagiostominae, a saber: 1) Plagiostomam lemani F. A. Forel \& G. du Plessis 1874, de euja rica literatura (Graff 1913, p. 386) se salientam Böhmig (1890, p. 412-421) e Hofsten (1907a, p. 93-132); 2) Plagiostomum lacustre Baylis (1927, p. 380), conhecido apenas por material conservado; e 3) Hydrolimax grisca Haldeman 1842, re-descoberta e descrita pela Dra. Hyman (1938).

Hydrolimax grisea foi, ùltimamente, encontrada nos arredores de Princeton, New Jersey; nutrora, também no Estado de New Jersey, em geral, e na parte oriental da Pennsylvania. Como se vê pela indicação "Delaware and Schuylkill rivers" (Hyman 1938, p. 1-2) trata-se de regiōes alcançadiças dum imigrante provindo do mar, como o são todas as Plagiostominac dágua doce.

Plagiostomum lacustre foi verificado no lago Tanganyika, ligado ao Atlântico pelos rios Congo e Lukuga (desde 1878), mas, dificilmente acessível do oceâno. A fauna do lago (Marcus 1933, p. 125) abrange, ao lado de habitantes típicos dágua doce, ainda halolímnicos, i. é, formas parecidas com marinhas. Juntamente com os Bryozoa Ctenostomata dos gêneros Victorella e Arachnoidea e vários Prosobranchia

*) A última apuraęão do nome genérico indicado encontra-se numa revista pouco espalhada e, por isso, convem repetir, ràpidamente, a história do nome Acmostomum. Foi introduzido (Schmarda 1859 , p. 3) com duas espécies não mais reconhecíveis, $A$. drnticulatum e A. crenulatum. Na descrição de $A$. dioicum Mecznikow 1865, de Helgoland (veja Graff 1913, p. 377), e de A. sarsii Jensen 1878, da costa noruegueza (ilid., p. 359), foi o nom demostomum noramente usado, desta vez, coinbinado com espécies reconhecíreis. 1 identidade das duas espécies (Reisinger $1926^{\circ}$, p. 452) parece provável, mas, yão pode, sem novo exame, ser cstendida a material de outras localidades, p. e., Plagiostomum dioicum Böhmig (1890, p. 407), df Trieste. No "Bronn", introduziu Graff (1908, p. 2010, 2548; fiłe Steinböck 1933, p. 23) o nome Hallezia, para substituir Acmostomum que carece de tipo genérico. Hallezia, jorém, já tinha sido usada anteriormente (Beauchaınp 1913, p. 302), para um gêrero dos Suctoria, e, por isso, chamou Boek (192?, 1. 47) o gênero dos Alloeocoela de Alvaëra. Este nome figura, como válido, no tratado de Bresslau (1933, p. 278). Steinböck re-introduziu Acmostomum, risto que a diagnose original é sufi eientemente ampla, para ser compatível com as espécies de Mecznikow c de Jensen.

p. 135$)$.

Alloeopharynx Steinböck (1932a, p. 324) é nomen nudum (Brandtner 1934, 
da profundidade do lago (até $1.435 \mathrm{~m}$ ), pertence Plagiostomum lacustre aos elementos halolimnicos do Tanganyika.

A distribuição de Plagiostomum lemani foi resumida, por Bresslau (1933, p. 232, explicação da f. 235), aproximadamente, da maneira seguinte: espécie vastamente espalhada em águas doces da Eurásia, até o Japão (Okugawa 1930, p. 84), ricas em oxigênio, paradas e correntes, mas, também nas profundidades (igualmente no litoral) de grandes lagos, no golfo finlandês do mar Báltico, e no mar Cáspico. Tal era o estádio dos conhecimentos da resenha de Steinböck (1932, p. 234-245), ao qual se devem os primeiros achados do verme no declive alpino meridional, no lago de Garda. Desde então, a espécie foi verificada no lago Esrom, na Dinamarca (K. Berg 1938, p. 38) e em mais duas localidades que dificultam, novamente, a explicação dificílima da distribuição de $P$. lemani. O primeiro achado (Beauchamp 1934, p. 209), no lago de Ochrida (na fronteira entre a Sérvia meridional e a Albânia), mostra $\boldsymbol{P}$. lemani, no sentido de Steinböck (1932, p. 244), como antigo habitante dágua doce. A fauna do lago de Ochrida, que o ictiólogo e zoogeógrafo russo L. S. Berg chamou de "lago de Baical balcânico", está relacionada com a asiática e a do Neógeno da Europa sul-oriental (Marcus 1933, p. 125). Foi Beklemischev (1927, p. 135) que admitiu primeiro a origem aralo-cáspica de Plagiostomum lemani. Outra vez, foi a espécie observada na costa meridional sueca, entre Fucus, perto de Karlskrona, no mar Báltico (Westblad 1935, p. 65). Esta nova verificação de $\boldsymbol{P}$ lemani nágua salobra, de salinidade entre 7 e 8 por mil (Schulz 1932, p. 56-57), apoia a opinião de Reisinger (1926, p. 461). Este considerou o verme recentemente imigrado nágua doce e que ainda não tinha abandonado complètamente o seu habitat marinho original. Baseou-se, nisso, na ocorrência de $P$. lemani no golfo finlandês (Luther 1918, p. 50-51).

Surge, agora, o primeiro representante da sub-ordem Cumulata nas águas doces da América do Sul. Ocorre dentro da cidade de São Paulo e nos seus arredores. Pertence ao gênero Plagiostomum e, sendo espécie ainda não descrita, foi chamado de $P$ evelinae, em honra de minha Esposa, Excelentíssima Senhora D. Eveline du Bois-Rexmond Marcus.

Os primciros exemplares colhemos num córrego de leito cimentado no parque da Luz, dentro da cidade. A água aí é rica em oxigênio, pois possue superfície larga e correnteza rápida. A matéria orgânica, disponível para a alimentação dos vermes, 6 abundante, mas, não se acha suspensa nágua; é contida e reunida em tufos densos de raizes. As plantas aquáticas são poucas. A temperatura do lugar do achado oscila menos que geralmente nas águas de SãoPaulo, mantendo-se relativamente baixa, devido à falta de insolação. Os vermes mantiveram-se, durante duas semanas, nágua estagnada do aquário, pondo aí ovos (janeiro de 1944). Nenhuma conclusão relativa ao habitat costumeiro de Plagiostomum evelinae pode ser deduzida dêste achado, pois os outros, realizados em 2 de maio e 6 de outubro de 1945, evidenciam condições ecológicas diferentes. Referem-se a pequenas poças razas, nas épocas em questão, isoladas das águas correntes vizinhas, com que poderiam comunicar-se durante as grandes chuvas. A água parada é exposta à insolação completa, sem qualquer sombra. A temperatura dágua deve, nesses prados abertos perto do subúrbio de Limão e de Butantan, participar de todas as oscilações tão consideráveis no perímetro de São Paulo. A vegetação aquática é bem desenvolvida.

Os vermes adultos das Plagiostominae límnicas até agora conhecidas poderiam ser determinados do modo seguinte:

1 Desenho formado por 3 faixas pigmentadas transversais no dorso, das quais as 2 anteriores se estendem aos lados ......... Plagiostomum lacustre

- Faixas pigmentadas transversais dorsais ou dorso-laterais não ocorrem

2 Desenho formado por manchas pigmentadas unidas por finas linhas estrelares ...... Hydrolimax grisea

- Desenho formado por finas linhas longitudinais pigmentadas ligadas por arastomoses ..

3 Com 4 olhos; numerosos pequenos poros excretores na região posterior, verificáveis sòmente nos cortes, nenhum poro exeretor principal visível no verme vivente .. .. Plagiostomum lemani 
- Com 2 olhos; além dos poros exeretores secundários, há 3 principais, 1 mediano, dorso-caudal, e 1 em cada lado, im pouco antes do meio; os poros principais destacam-se, por serem circundados por manchas brancas, da pigmentação negrejante ....

Plagiostomum evolinae

\section{Plagiostomum evelinae, spec. nov. (Fig. 108-117)}

Caracteres externos: 0 s vermes pepiniformes lembram pequenas lesmas, quer dizer, Pulmonata sem concha. Atingem de comprimento 2,5 $4 \mathrm{~mm}$., e de largura máxima, 0,8 1,2 $\mathrm{mm}$. Deslizam àgilmente, servindo o lado ventral como sola rasteira. Anteriormente, são arredondados; para trás, alarga-se o corpo, atingindo a largura máxima no terȩo posterior, de onde se estreita bruscamente e termina com canda curta. O corte transversal é quasi triangular. Sulco ciliado ventral não ocorre.

A côr do animal recem-saido do ovo pode ser branca; logo depois, começa a aparecer, no parênquima dorsal, pigmento preto, às vêzes, já presente no jovem dentro do casulo (Fig. 117). As melaninas concentramse na cabeça e na cauda. A epiderme incolor e transparente apresenta-se, no contôrno do corpo, como orla branca. Vermes adultos (Fig. 108, 109) são muito escuros e, na cabeça, completamente pretos. A disposição do pigmento faz surgir linhas longitudinais anastomóticas.

Duas faixas dorsais para-medianas manteem-se mais claras e correspondem, topogràficamente, aos nervos diorsais longitudinais (Hofsten 1907a, f. 4 na p. 107, dn ; Hyman 1938, f. 11, nervo 7). Entre as faixas, permanece, ao redor do poro excretor caudal (Fig. 112, p), uma mancha oval isenta de pigmentação. São igualmente brancas duas faixas laterais que pertencem aos dois terços posteriores do corpo, mas, não atingem a cauda propriamente dita (Fig. 109). Teem de largura $0,1 \mathrm{~mm}$. e correspondem às áreas glandulares laterais, a serem descritas mais adiante. Rostralmente às ditas faixas, marca-se a zona do orifício excretor lateral (Fig. 113, 3) por mancha branca. Através da epiderme incolor e do parênquima reconhece-se o intestino, ora incolor, ora amarelads, ou com outra côr ainda, conforme o conteúdo.

()s dois olhos (Fig. 111, 114, a) redondos, situados na profundidade do parênquima, estão, nos vermes adultos, quasi ou completamente ocultados pelo pigmento do parênquima. Olhos acessórios podem ocorrer.

Integumento e parênquima: A epiderme (Fig. 115, 8) corresponde à de $P$ lemani (Hofsten 1907a, p. 95), com que também espécies marinhas concordam (Reisinger 1926, p. 454; Brandtner 1934, p. 91). O epitélio compõe-se de células largas e baixas, cujos limites se reconheeem em cortes para-tangenciais. não, porém, nos transversais. Os núcleos não aprofundados, de nucléolos numerosos (Hofsten 1907a, f. 1, na estampa), ocupam tôda a altura das células epidérmicas (Fig. 115, 8). Os "vacúolos" intra-celulares são, como em Hydrolimax grisea (Hyman 1938, p. 3), zonas transparentes da substância celular. Na epiderme regular, quer dizer, naquela fora dos campos glandulares (Fig. 115, 1), predominam as zonas transparentes sôbre as fibrilarmente diferenciadas (os "strands"). A 
membrana basilar é fina. Rabditos dermáticos reunidos em feixes evidenciam-se no verme vivente, mas, desaparecem nos líquidos de conservação (Böhmig 1890, p. 185, 412; Brandtner 1934, p. 93), de maneira que faltam nos cortes e nas preparações totais.

As únicas glândulas da região cefálica de $P$. evelinae são as glândulas bucais (Fig. 112, g), faltando as frontais, regulares em outras espécies das Plagiostominae. Ao redor do poro genital desembocam glândulas que serão discutidas no conjunto da descrição dos órgãos reprodutivos. As glândulas laterais marcadas, externamente, pelas faixas brancas (Fig. 109) acima referidas, não se conhecem de outros membros da subfamília. São células epidérmicas aprofundadas, cujo citosoma não se delimita, e não se tinge nìtidamente. Os núcleos (Fig. 115, 1) situam-se no parênquima, são alongados, e atingem, às vêzes, a camada citoplasmática epidérmica externa. Como se vê pela Fig. 115 (6), ocorrem também na epiderme comum, vizinha às áreas laterais, mas, aí são tais glândulas escassas. Sòmente nas zonas das faixas brancas notam-se as modificações epidérmica e parenquimática correlacionadas com a acumulação das glândulas cutâneas. No parênquima, reduz-se o pigmento perto dos campos, e desaparece ao longo dos mesmos. Na epiderme, faltam os cílios da camada externa, e aí predomina o citoplasma fibrilar sôbre o transparente, em oposição ao tipo reinante na epiderme restante (Fig. 115, 8). Nesta última, provoca cada uma das células aprofundadas uma reintrância da camada externa sobreposta.

Os músculos cutâneos são do tipo comum, a saber, consistem numa camada externa anelar; e outra, interna, longitudinal.

O parênquima cerrado e sem lacunas espaçosas apresenta, nas camadas sub-integumentárias dorsais e laterais de vermes adultos, pigmentos pretos, cuja inclusão, em células, nem sempre se reconhece (Fig. 117, 7). Dá-se o mesmo em Hydrolimax grisea (Hyman 1938, p. 6). Como foi dito, resulta a disposição do pigmento em linhas anastomóticas. Os aparelhos digestivo e reprodutivo restringem a estensão do parênquima consideràvelmente. Este fato já relatado por Brandtner $(1934$, p. 96) dificulta a análise do parênquima. Não é de se estranhar ter Böhmig (1890, p. 197-206) chegado a interpretar o parênquima das espécies de Plagiostomum como constituido por células, cujo plasma se diferencia em plasma de andaime (espongioplasma) e plasma de suco (hialoplasma). $O$ andaime, que se estuda do melhor modo em cortes tangenciais da periferia do corpo, é cerrado. $O$ aspecto do parênquima de $P$ evclinae não difere muito da figura 20 (t. 12) de Böhmig (1890) relativa a uma espécie marinha; sendo, em Hydrolimax grisea, "as paredes das malhas" (Hyman 1938, f. 6) mais grossas do que na espécie presente. Nesta, são, além disso, numerosas as células sitas no "hialoplasma" Estas células chamou Böhmig de "núcleos do tecido conjuntivo" São as "células. livres" de Prenant (1922, p. 37 e seg.). O "hialoplasma" é substância intercelular; na literatura sôbre Turbelários, também chamada de "líquido perivisceral" $O$ "espongioplasma" é a rêde das células parenquimáticas fixas. cujos núcleos, não numerosos, ocupam um ou outro ângulo das malhas. Também em $P$ evclinae, apresenta-se $n$ parênquima da região: 
genital, o "stroma", rico em fibras, quer dizer, tem rêde densa de células fixas. O mesmo foi, com terminologia diversa, assinalado de $P$. girardi (Böhmig 1890, p. 200), P. lemani (Hofsten 1907a, p. 119), e P dahlgreni (Kepner, Stirewalt \& Ferguson 1941, p. 255, 257).

Sistema neuro-sensorial: O cérebro (Fig. 112, 114, c) sobrepõe-se ao bordo caudal da bolsa faríngea. Os nervos que pudemos verificar correspondem ao esquema de Hydrolimax grisea (Hyman 1938, f. 11), mas, não vimos todos os nervos descritos desta espécie muito maior que $P$. evelinae. Na Fig. 114, reconhece-se, no lado direito, a bifurcação do tronco principal ventral (13 da figura citada relativa a Hydrolimax), da qual saem um ramo sensorial ventro-cefálico e o nervo ventro-lateral do corpo. No mesmo corte, salientam-se ainda os nervos sensoriais cefálicos principais (Fig. 114, n), chamados, por nós, de tractos sensorias, pois conteem numerosas células ganglionares, como em Hydrolimax grisea (Hyman 1938 , p. 13). Cortes transversais mostram os 2 nervos laterais e os 2 dorsais. Perto da inserção da bolsa faríngea na faringe, situa-se o fin'o nervo faríngeo anelar.

Os dois olhos, cujos cálices se abrem para diante e para fora (Fig. 114, a), distanciam-se mais do cérebro do que comumente nas Plagiostominae. Nas outras espécies, são circundados pelas células ganglionares corticais do bordo rostral do cérebro (Weiss 1910, p. 364) ; sobrepostos ao cérebro; ou situados um pouco antes do mesmo ( $P$. makropharynx, $P$. vorax; Brandtner 1934, p. 101). Todavia, ligam-se também os ocelos de $\boldsymbol{P}$. evelinae à parte sensorial do cérebro, e isso, pelos tractos mencionados. Ocasionalmente, ocorre uma mancha pigmentada (ôlho secundário), distante do olho principal. Sulco ciliado ou covinha ciliada mediana (Brandtner 1934, p. 103) não existem. As reintrâncias laterais, nos fundos dos quais desembocam canais do emunctório, serão tratadas juntamente com os órgãos excretores. Células tácteis, do tipo descrito por Böhmig (1890, p. 270) duma espécie das Cylindrostomidae (família vizinha), encontram-se, em $P$ evelinae, entre as células epidérmicas da extremidade anterior. Estes órgãos tácteis são isolados; de resto, lembram a figura 19 da estampa 21 de Böhmig (1890). Numa das microfotogra. fias de Brandtner (1934, t. 2 f. 14, tk) vê-se uma célula correspondente de $P$ caudatum Levinsen.

Sistema digestivo: A bôca situa-se antero-ventralmente; é muitc pequena, por ser dobrada, e, por isso, percebe-se difìcilmente. $\mathrm{O}$ tubo bucal curto conduz à bolsa faríngea delimitada por membrana epitelial não ciliada, de núcleos escassos, e com musculatura fraca. No tubo bucal desaparecem os cílios externos, e diminue a altura da epiderme invaginada rapidamente, sem que se interponha aqui, entre a epiderme do corpo, e a membrana da bolsa, um trecho de células altas, como foram descritas de $P$. lemani (Hofsten 1907a, p. 99). Como nas 3 outras Plagiostominae límnicas, mas, também em certas marinhas (Brandtner 1934, p. 105), insere-se a bolsa faríngea mais perto do orifício faríngeo que do intestinal.

A faringe é muito volumosa; pode ocupar, em vermes jovens, mais do que a metade da longura do corpo (Fig. 110); em adultos, ca. de um 
terço. Brandtner (1934, p. 105) enumerou, além de $P$. lemıni, ainda outras espécies, e estas, marinhas, com faringe de tal tamanho, podendo P.album Hyman 1944 (f. 10) ser acrescentado a elas. O bordo anterior da faringe de $P$ evelinae é liso; o lume, no corte transversal, triangular (Hofsten 1907a, f. 4 no texto; Reisinger 1926, p. 455; Brandtner 1934, f. 1 no texto), e revestido por uma camada plasmática fracamente cuticularizada, sem núcleos. A mesma existe também na superfície externa livre da faringe, como em $P$ opisthogonimum (Reisinger, l. c.). A mussulatura externa e interna dispõe-se, em toda a estensão da faringe, do mesmo modo: a longitudinal, uni-estratificada situa-se externamente; a circular, também uni-estratificada encontra-se internamente, i. é, adjacente ao parênquima faríngeo. A julgar pela figura (Baylis 1927, p. 383 f. 3), apresenta $P$ lacustre faringe do mesmo tipo, que poderia, com a Dra. Hyman (1938, p. 8), ser chamado de "pharynx bulbosus", em vez de "bulbosus variabilis intextus" (Steinböck 1924a, p. 239). O tipo "textus", i. é, a disposição diversa dos músculos externos no trecho do septo e no da bolsa faríngea, encontra-se, p. e.. em $P$ lemani (Hofsten 1907a, f. 1 no texto), em $P$ album Hyman $(1944$, p. 4) e em $P$. torquatum (Karling 1940, p. 76) *). O parênquima da faringe de $P$ evelinae contem: a) os núcleos aprofundados, pertencentes às camadas citoplasmáticas externas e internas; b) os músculos radiais; c) glândulas faríngeas fracamente cianófilas (assim, também em Hydrolimax grisea) que desembocam, cada uma separadamente, no lume da faringe (como em $P$ megalopharynx; Brandtner 1934, f. 2 no texto, phdr); e d) o esfincter anelar (Fig. 113, q), na região anterior. $O$ anel nervoso (Fig. 112, n) já foi mencionado. No ponto em que a bolsa faríngea se fixa na faringe, inseremse os músculos locomotores, protractores e retractores da mesma.

Nos vermes conservados, o epitélio do primeiro trecho do intestino, dobrado para diante (Fig. 112, e), circunda a faringe, à maneira dum colarinho. Ventralmente, atinge a dita dobra quasi a inserção da bolsa faríngea. Seguindo as exposições de Hofsten (1918, p. 20-21), podemos chamar a dobra de "pseudo-esôfago endodérmico" Orgão semelhante, embora menor, existe em $P$. makropharynx e $P$ parasitorum (Brandtner 1934 , f. 2 e 3 , no texto). A "bolsa faríngea interna" de $P$. lutheri (Böhmig 1914, f. 3 no texto) pertence à faringe, e seria um "pseudo-esôfago ectodérmico" No início do pseudo-esôfago de $P$. evelinac, ocorrem células fortemente cianófilas (basófilas), cada uma com uma gota de secreȩão eritrófila (acidófila) que lembram as clavas granulosas de Minot conhecidas de muitos Turbelários e as glândulas correspondentes das Dalyelliidae.

$O$ epitélio intestinal mostra limites inter-celulares apenas em vermes f'amintos; no auge da digestão, faltam tais, e, nêste caso, delimita-se o intestino contra o parênquima mais pelas fibras musculosas circun-intestinais do que pelo quadro histológico. Intra-epitelialmente ocorrem, na

*) Mais tarde (1940, p. 240), Karling identificou $P$. torquatum a $P$. cinctum Meixner (1938, p. 38), mas, o desenho dêste (f. 38) mostra nitidamente o "pharynx intextus". 
região anterior do intestino propriamente dito (i. é, exclusive o pseudo-esôfago), secreções eosinófilas em forma de traves, como foram desenhadas-na Fig. 112, na parede intestinal dorsal. Vacúolos e outras inclusões intra-celulares, p. e., concentrações basófilas, variam, quanto ao número e à estensão, oonforme o estado alimentício. Os núcleos intestinais situam-se basilarmente; a superfície é provida de cílios finos. Vêemse êstes sòmențe ao redor dos pequenos espaços que perfazem o lume intestinal. Nos vermes adultos, os animais comidos enchem o lume quasi completamente. Os elementos histológicos dêstes, em parte, bem reconhecíveis nos cortes, evideneiam Prorhynchus stagnalis e, possivelmente, ainda outros Turbellaria como alimento de Plagiostomum evelinae. $\mathrm{O}$ intestino estende-se até a extremidade caudal ; aí, restringem-no os órgãos reprodutivos.

Sistema excretor: Em concordância com as duas outras espécies límnicas, cujo material foi fixado para fins histológicos, a saber, $P$ lemani e Hydrolimax grisea, possue também $P$. evelinae um sistema excretor complexo, mas, diferente das ditas espécies. Três poros principais, um caudal, dorso-mediano, e dois latero-ventrais, situados um pouco antes do meio do corpo, marcam-se pelas manchas brancas descritas anteriormente. Os orifícios laterais situam-se no fundo de fossetas ciliadas (Fig. 115, 3), êste caracterizado por epitélio ciliado de citoplasma uniformemente fibrilar. O canal excretor (Fig. 115, 2) possue, no trecho adjacente ao poro, parede musculosa, havendo ainda músculos oclusores no ponto em que o canal atinge a epiderme. Além do canal principal, desembocam ainda vias excretoras menores na fosseta ciliada, vindas das regiões dorsal e caudal. Na parte posterior do verme, existem ainda, dorsalmente à área glandular, orifícios excretores secundários, do tipo descoberto por Hofsten (1907a, f. 3, na estampa). Do poro excretor dorsal (Fig. 112, p) comparável ao sito mais rostralmente de Hydrolimax grisea, reconhece-se um curto canal dirigido para diante e, ainda no dorso, ramificado em dois canais, evidentemente ligados às vias excretoras laterais direita e esquerda.

Sistema reprodutivo: Plagiostomum evelinae é proterândrico, como H. grisea (Hyman 1938, p. 14), P. vittatum (Reisinger 1926, p. 456), e as espécies groenlândicas (Brandtner 1934, p. 117); P. levani, e $P$. opisthogonimum (Reisinger, l c.) são proterogínicos.

Orgãos masculinos: Os testículos (Fig. 112, t) são foliculares, sem túnica própria. Espermatogônias e os seus derivados ocorrem no parênquima lateral e latero-dorsal, tocando-se quasi na linha dorso-mediana. No parênquima ventral, são ausentes. Os gonócitos masculinos tornam $o$ parênquima vacuolizado. Os dúctulos eferentes ramificados conduzem as células germinativas masculinas para trás, onde se reunem em cada lado. Os dois dutos eferentes (Fig. 112, d), os "vasa deferentia" da literatura, desembocam com um curto trecho unido na vesícula seminal (Fig. 113, s), de forma esférica. Reservatório da secreção granulosa ("Kornsekretbehälter"), como órgão especial, falta, mas a parede distal (caudal, ectal) da vesícula seminal é vacuolizada, contendo os vacúolos a secreção granulosa (Fig. 112, r). Karling chamou (1940, p. 85) a vesícula seminal que abriga, além dos espérmios, ainda a secreção granulosa, adequàda- 
niente de "vesícula communis". Para fora, passa a vesícula, com comunicação larga, ao "saco distal" (Hofsten 1907a, p. 133; Reisiuger 1926, p. 457), o "duto ejaculatório" de Böhmig (1914, p. 28), o "bulbo penial" de Kepner, Stirewalt \& Ferguson (1941, p. 256). O saco distal (Fig. $112,9)$ é de parede musculosa com glândulas. O pênis é muito curto; encontra-se (Fig. 112, u), nos vermes conservados, invaginado para dentro do saco distal e será, na copulação, evaginado. Constituirá, então, o duto ejaculatório o revestimento externo do pênis. Tal revestimento é provido de acúleos formados pela secreção das glândulas peniais (Fig. 116, j) que desembocam no lume do pênis invaginado. Nesta fase, dispõem-se os músculos do pênis de tal modo que os anelares circundam o lume, ficando os longitudinais para fora. $O$ ponto da base do pênis, na fase invertida, a extremidade caudal dêle (Fig. 112, x), chamou Böhmig (1. c.) de diafragma; salienta-se, em forma de cône, para dentro do átrio genital. Outra dobra anelar, no corte visível como projetura da parede do átrio, é a bainha do pênis (Fig. 112, w). A musculatura longitudinal que liga o diafragma ao saco distal, mas, não continúa como delimitação externa da bainha do pênis, corresponde, nêste pormenor, à de $P$. lemani (Hofsten 1907a, p. 116.117, f. 5, na p. 115, ms) ; em $P$. opisthogonimum (Reisinger 1926, f. 21) e P. makropharynx (Brandtner 1934, f. 5, no texto), existe a continuação aludida. Com o epitélio atrial da última espécie concorda o tecido correspondente de $P$ evelinae, notável pelos núcleos salientados para o lume. Cílios não ocorrem no átrio da espécie atual, também não em $P$. lemani e P. makropharynx; havendo tais, p. e., em Hydrolimax grisea, P. opisthogonimum, e Brachyposthia cuticulata (Brandtner 1934, f. 8, na p. 127). O aparelho copulador de $P$. evelinae corresponde ao tipo de torquatum (Karling 1940, p. 88 f. $10 \mathrm{G}$ ).

Entre as espécies, cujos espérmios se conhecem, apresenta $P d r y$ galskii Böhmig (1914, t. 3 f. 28) os mais semelhantes aos de $P$ evelinae. Afora a epiderme, a parede, e o lume do intestino, encontram-se espérmios em todos os órgãos, p. e., no cérebro, no parênquima da faringe, nos germários, no parênquima do corpo, etc. (Fig. 115, 5). Isto já foi observado por Böhmig (1890, p. 340) e, novamente em $P$ dahlyrcni, por Kepner, Stirewalt \& Ferguson (1941, p. 255). Com os autores citados concordamos em considerar êstes espérmios como espérmios alheios ("exotic" ou "alien spermatozoa" de Kepner, Stirewalt \& Ferguson). Em 8 de dezembro de 1945, observámos entre espécimes de $P$. evelinae recémcapturados (na cidade, no parque da Luz) a copulação no vidro d̄e relógio. Trata-se de impregnação hipodérmica. De 5 vermes adultos, 2 emitiram os órgãos copulatórios, agitando-os com movimentos apalpadores. Quando um conseguiu tocar na região dorso-caudal do outro, aí fixou o pênis estirando do parceiro uma ponta do parênquima preto. Permaneceu, nesta atitude, durante 1-2 minutos e, depois, retirou o pênis. 0 lugar em que êste tinha penetrado, marcou-se por uma tampa de substância incolor, visível ainda 5 minutos mais tarde, quando entrou, no indivíduo há pouco inseminado, novamente o órgão copulador dum terceiro verme. Desta vez, foi o pênis imitido na epiderme sobreposta ao ovário, e o animal passivo contraiu-se tão intensamente que surgiram 
dobras no seu integumento. O ato durou, também neste caso, 1-2 minutos. Ambas as vêzes tentou o verme passivo realizar a cópula com os seus parceiros, sem, todavia, o conseguir. De Hydrolimax grisea, assinalam Hyman (1938, p. 16) e Kepner, Stirewalt \& Ferguson (1941, p. 258) a observação duma cópula descrita por Dahlgren. No dito caso, penetrou o pênis, pelo poro genital, no átrio, cuja parede atravessou, ejaculando os espérmios no parênquima. Em várias espécies, p. e., $P$ reticulatum (Böhmig 1890, p. 345), $P$ oyense (Beauchamp 1921, p. 172), $P$ makropharynx (Brandtner 1934, p. 119), e $P$ dahlgreni (Kepner e outros 1941, p. 256 t. 4 f. 4) faltam dutos eferentes ("vasa deferentia"), e os espérmios migram dos testículos à vesícula seminal, atravessando o parênquima e a parede da vesícula ou entrando, nesta, por um orifício (Böhmig 1890, p. 345-346). Sobram, destarte, as provas de locomoção dos espérmios, próprios e alheios, das espécies das Plagiostominae.

Em $P$. evelinae, abundam os espérmios alheios no corpo de vermes com vitelários jovens e escasseiam nos animais com aparelho feminino completo. Disso podem deduzir-se a proterandia e a resorpção dos espérmios supérfluos (Cernosvitov 1932, p. 156 e seg.), possivelmente, por atrócitos.

Os órgãos femininos: Os ovários, como os testículos, sem túnica própria, formam, em cada lado do corpo, uma aglomeração arredondada, frouxa, de oogônias e oócitos em várias fases. A posição dos gonócitos femininos depreende-se da Fig. 113 (o), que os mostra ao nível dos poros excretores laterais e mais para trás ainda. Ovócitos em crescimento são circundados por um halo claro, não célular, tido por nutritivo, em Hydrolimax grisea (Hyman 1938, p. 16), e assinalado também de Plagiostomum dahlgreni (Kepner e outros 1941, p. 255) como "camada gelatinosa" Nos oócitos em crescimento, ressaltam grânulos grossos na camada ovoplasmática externa, já descritas por Böhmig (1890, p. 322, drk, em várias figuras). Trata-se, nêstes grânulos, evidentemente, das pélas vitelinas, como as conhecemos de Stolella evelinae (Bryozoa Phylactolaemata; Marcus 1941, p. 121-122).

Inseminação mono-espermática (Fig. 115,4 ) realiza-se, em $P$ evelinae, durante o período de crescimento do ovócito. De $P$ lemani observou Hofsten (1907a, p. 119; 1909, p. 438), uma vez, a penetração dos espérmios nos gonócitos femininos ainda no ovário; ao que parece tratou-se de ovócitos completamente crescidos.

Os vitelários (Fig. 112, v), por princípio, foliculares, aparecem tarde, como, p. e., em P. sulphureum (Böhmig 1890, p. 366). Formam, quando completamente desenvolvidos, massas laterais compactas, de grande estensão (Böhmig 1890, p. 330). Atingem, rostralmente, quasi a bolsa faríngea e, caudalmente, ultrapassam um pouco o saco distal e a vesícula seminal, como em P. makropharynx (Brandtner 1934, p. 129). Visto que ocupam ainda muito espaço para o dorso e o ventre, restringem, consideravelmente, no auge do seu funcionamento, o intestino. As grandes células vacuolizadas viteláricas são reunidas em folículos, dentro dos quais se achatam mutuamente. 
Não vimos as ramificações internas dos dutos femininos, segundo: Hofsten (1907a, p. 124) e Reisinger (1926, p. 459), sem orifícios abertos; mas, as vias principais ciliadas dos ovo-vitelodutos (Fig. 112, f) reconhecem-se no seu percurso através dos ovários e vitelários. Os dutos femininos reunem-se, formando o curto oviduto comum (Hyman 1938, f. 13; sinal 14). O oviduto comum (Fig. 112, y) carece de cílios e faz parte do átrio genital, constituindo o divertículo dorso-caudal do átrio. Não ocorrem as glândulas da casca no oviduto comum, conhecidas de Hydrolimax grisea, $P$. opisthogonimum, $P$. lemani, e das espécies groenlândicas. Como em $H$. grisea (Hyman 1938, p. 17 ), fornecem também em $F$. evelinae os vitelários, provavelmente, a casca do casulo dos ovos. As glândulas do poro genital da espécie presente (Fig. 112, z), de secreção eritrófila, desembocam ao redor do dito poro (1). Correspondem às glândulas argamassadoras (Hofsten 1907a, p. 125; Brandtner 1934, p. 131) que produzem o pedúnculo do casulo e fixam-no ao substrato. Em $\boldsymbol{P}$ oyense. (Beauchamp 1921, p. 171), existem glândulas semelhantes; as de Hydrolimax grisea situam-se atrás do poro genital (Hyman 1938, f. 13, sinal 16).

Vimos casulos pedunculados de $0,68 \mathrm{~mm}$. de altura e $0,6 \mathrm{~mm}$. de diâmetro, contendo 4 filhotes (Fig. 117). O pedúnculo mede ca. de 0,3 mm. de comprimento. As medidas indicadas constituem o máximo visto. até agora, havendo casulos menores com 2 vermes apenas. A casca do casulo tem côr castanho-clara, é transparente e lisa, com excepção da calota oposta ao pedúnculo, granulosa. Esta parte representa uma espécie de tampa que é quebrada pelos vermes jovens, na sua eclosão. Em $P$. lemani, 9-11 ovos são reunidos num casulo igualmente provido de pedúnculo (Berg 1938, p. 39-40).

\section{Subordo: Seriata Bresslau (Crossocoela + Cyclocoela Graff; Proseriata Meixner)}

\section{Familia: Monocelididae Hofsten (1907, p. 626)}

\section{Subfamilia: Archimonocelidinae Meixner (1938, p. 6, 57, 58)}

Monocelididae que se distinguem das Monocelidinae pelo epitélio epidérmico, não aprofundado; das Coelogynoporinae, pelos orifícios massulino e feminino separados.

Sòmente pela combinação dos dois caracteres indicados é possíveI definir a subfamília. Meixner (l. c.) não lhe deu uma diagnose. Apontou, porém, na legenda das figuras dos dois novos gêneros, com que criou a subfamília, um terceiro sinal, por princípio, re-encontrado na espécie brasileira. Trata-se duma particularidade do epitélio faríngeo interno 'ou, como se impõe dizer, em consideração à espécie atual, do epitédio não digestivo do trato alimentício, i. é, do intestino ingestivo. O dito epitélio apresenta-se ectalmente (no ápice da faringe) ciliado e com núcleos aprofundados; entalmente (na raiz ou base da faringe) sem cílios e com núcleos em posição normal. Tal peculiaridade ocorre, porém, tanto com- 
binada com epiderme de núcleos aprofundados (Archiloa wilsoni Stirewalt, Kepner \& Ferguson 1940, p. 127; Minona evelinae, Fig. 134), quer dizer, na subfamília Monocelidinae, quanto em Coelogynopora gigantea Meixner (1938, f. 59; figura superior), cujo orifício sexual único justifica a posição nas Coelogynoporinae.

Como famílias consideramos, com Hofsten (1918, p. 57, 61) e Meixner 1938, p. 6, 17, 18), as Otoplanidae e, com Hofsten $(1918$, p. 57, 60), Steinböck $(1925$, p. 167) e Bresslau (1933, p. 279), as Otomestomidac.

Os gêneros das Archimonocelidinae podem ser diferençados pela chave seguinte:

1 Além dos poros masculino e feminino ainda um poro externo da bursa ... Meidiama, gen. nov.

- Sòmente os orifícios masculino e feminino como aberturas externas

2 Testículos numerosos ...................... Archimonocelis Meixner (1938, p. 57 f. 54)

- Apenas um par de testículos ... .......... . . . . Monotoplana Meixner (1938, p. 58 f. 55)

\section{Genụs: Meidiama, gen. nov.}

A bursa abre-se com orifício externo. A faringe é curta, pregueada e a sua direção oro-basilar forma com a ântero-posterior do corpo um ângulo quasi reto. Sòmente o epitélio ciliado, de núcleos aprofundados, reveste o lume da faringe; o trecho seguinte, o epitélio normal, sem cílios, confina com o lume do intestino digestivo.

Deixamos as papilas adesivas da espécie atual fora da diagnose genérica. Ocorrem, como adaptações à vida na areia, em várias famílias (Meixner 1938, p. 134). Mantemos, destarte, aberta a possibilidade de eventualmente adicionar vermes anatômicamente semelhantes, mas, talvez existentes em outros biótopos.

Consideramos ainda como específica, não genérica, uma dilatação (Fig. 122, w) do atrio feminino que funciona como "vesicula resorbiens" As células parietais da dita dilatação fagocitam o excedente dos espérmios, que daí passam ao intestino adjaccnte. São, dêsse modo, aproveitados como alimento. Tal função apresenta-se como a única do órgão em questão; a eliminação dos espérmios supérfluos poderia ser efetuada, mais simplesmente, pelo poro feminino. A comunicação gênito-intestinal da forma atual interpretar-se-ia difìcilmente pela hipotese de Steinböck, relatada na discussão de Baicalellia evelinae (veja p. 29). O vestígio da via eferente feminina dum verme ancestral, cuja ovipostura se realizou pelo orificio bucal, deveria ser esperado mais perto da bôca, não à distância máxima desta. A homologia da bursa pré-penial de Meidiama com a bursa copulatória ou a seminal das Monocelidinae ou Acoela está fora de dúvida. A dilatação posterior poderia ser chamada de "bursa intestinal", em analogia a Gnosonesima antarctica Reisinger (1926, p. 436). Êste têrmo, porém, foi usado para bursas copulatórias e seminais, como expusemos na discussão aludida. Além disso, a dilatação de Meidiama difere histològicamente mais do intestino que do átrio feminino. Por isso, falamos em bursa resorvente. Estruturas topogràficamente análogas desereveu Maristo $(1938$, p. 50, 57) de duas Monocelidinae, Automolus hamatus (Meixner 1938, p. 6: Paramonotus hamatus) e Archiloa spinosa. Na primeira espécie (Maristo 1938, p. 48 f. 27), trata-se duma "bursa intestinalis", no sentido de Steinböck (1924, p. 471), comparável à dàas Coelogynoporinae; na segunda (Maristo 1938, p. 48 f. 28), duma vesícula de parede fina, mas, completa, sem comunicação com o intestino, que Maristo chamou de recep- 
táculo seminal. A bursa seminal de Archilopsis unipunctata (Fabr.) tem posição idêntica (Meixner 1938, f. 56, bs).

Denominamos o tipo do gênero, Meidiama lutheri, em homenagem ao Professor Dr. Alexander Luther, Helsinki (Helsingfors).

\section{Meidiama lutheri, spec'. nov. (Fig. 120-127)}

$\mathrm{O}$ comprimento dos vermes é de $0,2 \mathrm{~mm}$. (os mais jovens observados) até ca. de $4 \mathrm{~mm}$; o diâmetro dos adultos, de ca. de 0,1 mm. A dissemelhança entre os vermes jovens, linguiformes (Fig. 123) e os velhos, filiformes (Fig. 120) é muito grande; os primeiros são quasi 5-6 vêzes nais compridos que grossos; os segundos, $30-40$ vêzes. A extremidade anterior dos vermes adultos é mais fina que a posterior, arredondada. A côr é branca, podendo o conteúdo do intestino tornar avermelhados os vermes. São muito contrácteis, e tôda a superfície é pegajosa. Na extremidade caudal dos vermes jovens, salientam-se 4-5 papilas adesivas (Fig. 123). Embora menos ressaltadas nos adultos (Fig. 122), funcionam também nêstes. Ocorrem, além disso, botões adesivos epidérmicos, dispostos em três cinturas, nos vermes jovens (Fig. 123) ; distribuidos irregularmente, nos adultos (Fig. 120). A cintura anterior coincide, aproximadamente, com o nível do bordo posterior da faringe; as duas seguintes situam-se entre a faringe e a extremidade caudal do intestino.

Outro caracter que condiciona o aspecto diferente dos vermes jovens e dos velhos, reside na posição da faringe (Fig. 120, 123, h) inicialmente, localizada antes do meio do corpo; mais tarde, no começo do têrço posterior. A situação mais caudal apresenta a faringe na fase masculina; na feminina, quando o desenvolvimento dos vitelários se intensifica, cresce a região post-faríngea, e, com isso, a faringe mostra-se, na sua posição definitiva, no fim do segundo têrço.

O comprimento dos cílios locomotores é maior (no corte, de 5 microns) que a altura da epiderme. Esta mede ca. de 3 microns, mas, varia, conforme o estado da contração na região examinada. $\Lambda$ superfície das células epidérmicas (Fig. 126, e) é ligeiramente convexa. Na cabeça, existe um tufo de cílios maiores, evidentemente tácteis, havendo ainida vários longos estereocílios nas partes anterior e posterior, e alguns poucos na zona intermediária, irregularmente distribuidos. Como nas outras espécies da subfamília, é o epitélio da epiderme normal, i. é, não aprofundado. O território poligonal, pertencente a cada núcleo, reconhece-se nos cortes tangenciais, de modo que o termo "sincício" parece inadequado, apesar da ausência de limites inter-celulares. Rabdóides faltam. Os músculos longitudinais do tubo músculo-dermático são mais grossos que as anelares. Para o lado da cabeça, diminuem os músculos longitudinais. Alguns músculos dorso-ventrais, muito finos, como nas Monocelidinae pesquisadas por Midelburg (1908, p. 85), ocorrem no parênquima, ao longo do corpo inteiro. O parênquima é fracamente desenvolvido; apenas nas extremidades (Beklemischer 1927, p. 93), onde o intestino falta, há espaço mais amplo preenchido pelo parênquima. 
As glândulas cutâneas, cuja presença se revela pelo grudamento dos vermes, não se tingem na coloração com hematoxilina-eosina, na sua maioria (Midelburg, l. c.) ; em alguns cortes, observam-se, sendo eosinófilas. Feixes de glândulas cefálicas (Fig. 127, f), de secreção cianófila, cujos citosomas se situam no parênquima pré-cerebral, desembocam na extremidade anterior. As glândulas caudais. (Fig. 125, g), eosinófilas, são glândulas argamassadoras, como se evidencia pela desembocadura no canal genital feminino, e pela sua ausência em vermes imaturos.

$\mathrm{O}$ cérebro (Fig. 120, e) mostra-se, no verme total, ovóide e de contorno liso. No corte, vê-se a forma irregular da massa central formada pelas fibras nervosas e circundada pelas células ganglionares.

Ao redor das células ganglionares, reconhece-se a cápsula cerebral com grande nitidez, embora apenas intervaladamente. Os nervos mais grossos que saem do cerebro são os troncos posteriores dos longitudinais ventrais. Também a continuação dêstes para diante (Fig. 127, n5) salienta-se pelo seu diâmetro. Como êstes, são os dorsais (n4) providos de células ganglionares. Os dois pares correspondem aos pares ventral e dorsal de Promonotus orientalis Beklemischev (1927, p. 95). Cs 3 pares rẹstantes (n1 -. n3) correm perifèricamente, nos dois lados (n2), e nos sectores dorsal (n1) e ventral (n3). Anteriormente ao cérebro, e mais dịstante dêste em relação ao que se observa na maioria dos Turbelários, encontra-se o estatocisto (Fig. 127, $\mathrm{x}$ ), cujo estatolito tem forma dum prisma hexagonal, de quinas arredondadas. Notam-se dois pares de células formadoras do estatolito (Fig. 127, y), dissolvido nos cortes, como em outras Monocelididae (Meixner 1938, p. 78). Mais quatro células (x) pertencem à parede do estatocisto; talvez sejam, em parte, sensoriais. No sector ventral do estatocisto, encontram-se, entre a cápsula e o estatolito, as fibras suspensoras ("Aufhängeapparat" Midelburg 1908, p. 95; Maristo 1939, p. 37) do estatolito.

A bôca (Fig. 126, b), situada nos adultos entre o segundo e o último têrço do corpo, condụz à bolsa faríngea externa, cuja estensão máxima coincide com a direção ântero-posterior do corpo. O epitélio da bolsa é chato, sem cílios; os núcleos teem posição normal. A faringe (Fig. 120, h) é pregueada (Fig. 126, p1) e curta. A direção funcionalmente principal do seu lume, da entrada faríngea à intestinal, forma um ângulo quasi reto com o eixo longitudinal do verme. A direção dextro-sinistral da faringe é maior que a dorso-ventral, e a ântero-posterior é até duas vêzes maior que a dorso-ventral. Os epitélios faríngeos externo e interno (p1) são ciliados e de núcleos aprofundados. Devido à contração diferente, as várias pregas podem tornar-se assimétricas no corte (Fig. 126). Dos músculos, há finos, longitudinais, apostos aos epitélios externo e interno, e anelares, sitos mais para dentro. Os anelares internos são especialmente fortes. Sòmente a êstes, não aos anelares externos, segue, mais para dentro ainda, segunda camada longitudinal. A variação da musculatura faríngea das Monocelididae parece considerável (Maristo 1938, p. 23) ; Stirewalt, Kepner e Ferguson (1940, p. 127) descreveram até disposição da interna igual à do tubo músculo-dermático, i. é, a anelar aposta ao epitélio e a longitudinal adjacente ao parênquima. As glândulas extra-faríngeas (k), 
eosinófilas e cianófilas, desembocam perto da entrada da faringe. O grosso anel nervoso (j) situa-se no têrȩo oral da faringe. O lume faríngeo comunica-se com o do intestino (i) por um orifício estreito. Ao redor dêste, ressalta-se uma dobra anelar conicamente para dentro. 0 trecho subseqüente (p2) da parede do trato alimentício pertence, anatômicamente, ao intestino, pois faz parte da parede intestinal ventral. Compõe-se de células baixas, sem cílios, e com núcleos em posição normal, i. é, não aprofundados. Funcional e histológicamente corresponde ao epitélio interno na raiz (base) da faringe de Archimonocelis e Monotoplana (Meixner 1938, f. 54, $\mathrm{ph}_{2}$, f. 55), que ocorre ainda em Archiloa wilsoni Stirewalt e outros (1940, p. 127), Minona evelinae (Fig. 134) das Monocelidinae e Coelogynopora gigantea Meixner (1938, f. 59). Não digere, pois não aumenta e diminue de altitude, como as células intestinais. Estas se intumescem e se encolhem, conforme o enchimento com substâncias alimentícias e a secreção de fermentos digestivos, respectivamente.

O intestino (Fig. 121, 125, 126, i) estende-se do bordo caudal do cérebro (c) até a extremidade posterior e preenche os espaços ao redor da faringe e das gônadas. Os seus contornos são quasi lisos, não lobulados, apresentando apenas ligeiras constrições. O trecho que confina com o cérebro é sólido, formado por grandes células lameladas, sem inclusões de matérias resorvidas. Lembra histològicamente mais o intestino refálico ("Kopfdarm") de Otoplana intermedia (Hofsten 1918, p. 23 t. $1 \mathrm{f}$. 6) que o de Nematoplana coelogynoporoides Meixner (1938, f. 44), e tem caracter dum tecido sustentador. As células digestivas do intestino pròpriamente dito são separadas por limites inter-celulares e mostram as inclusões esféricas e os vacúolos conhecidos das células alimentícias. Avulsas clavas de Minot ocorrem medianamente, na parede ventral do intestino.

Dos protonefrídios vimos uma lacuna tubular (Fig. 121, z), no parênquima ventral da região anterior, provàvelmente pertencente ao sistema excretor. Como geralmente, os cortes nada revelaram dos emunctórios. Ao nível do átrio feminino, observámos, uma vez, um trecho dum canal transversal.

Os testículos (Fig. 120, t) são folículos cerrados no lado ventral que deixam livre o primeiro têrȩo do intestino e acompanham os dois terços seguintes pré-faríngeos do mesmo. Terminam rostralmente aos ovários (o). Dentro de cada folículo testicular, os gonócitos encontram-se quasi na mesma fase da espermatogênese. Os folículos são separados por septos. Os dutos eferentes são finos demais para que possam ser reconhecidos nos cortes transversais. Anteriormente ao poro feminino (u), dilatam-se, formando vesículas seminais (Fig. 124, s) extra-peniais. Estas flanqueiam o reservatório ( $\mathbf{r}$ ) da secreção granulosa. O pênis (q) é um tubo cuticular, de 60 microns ao comprido, com 10 microns de diâmetro ental (proximal) e com 3-4 microns de diâmetro ectal ('distal). Êle encurva-se para diante. Ó átrio masculino é dilatado por ca. de 12 espinhos cuticulares, cada um com 30 microns de comprimento. O orifício masculino (m) aproxima-se mais do feminino (u) que do da bursa (a). 
Os dois ovários (Fig. 120, o), muito curtos, situam-se dorso-lateralmente e rostralmente à faringe. Cada um contém, de uma vez, apenas 1-2 ovócitos em crescimento. $O$ conjunto das células germinativas é circundado por uma túnica própria nucleada que separa o ovário nìtidamente do intestino. O envoltório ovárico continua, como oviduto, para trás, onde se liga aos folículos esféricos dos vitelários (v) dorso-laterais, estendidos entre a faringe e a bursa. A vitelogênese corresponde à relatada de Geocentrophora applanata (Marcus 1944, p. 19). Caudalmente à bursa seminal, observam-se ainda, no parênquima dorso-lateral, acumulações sucessivas de células do caracter de viteláricas jovens. Não se comunicam com o ovo-viteloduto (Fig. 122, d) ou duto comum que corre atrás da bursa, ventro-medianamente, dando a volta do pênis no lado esquerdo. $O$ ovo-viteloduto é ciliado e, no seu trecho pré-bursal, onde é representado por dois canais de parede grossa, cianófila. Ao redor do ponto em que os dois canais se reunem, encontram-se glândulas, que são, pela topografia, glândulas da casca. No dito ponto, dilata-se o ovoviteloduto, em conseqüência da desembocadura da bursa nêle, correspondendo êste orifício interno da bursa a um duto espermático. Aí passam os espérmios, na copulação introduzidos na empôla da bursa, às vias femininas. O epitélio da bursa seminal é ciliado, de altura medíocre e pouco tingível com hematoxilina-eosina. O orifício externo da bursa (a) ou duto vaginal encontra-se na linha ventro-mediana. $O$ trecho caudal do ovo-viteloduto ímpar dilata.se como átrio feminino, e êste se abre por meio dum curto canal feminino, com gonóporo feminino (u) ventromediano. Da parede caudal do átrio, sae um fino canal que se alarga como lume duma cavidade, a bursa resorvente (Fig. 125, w). Esta se apõe à parede ventro-caudal do intestino e contém, nas suas células parietais, vacúolos repletos de espérmios. Apesar de não existir comunicação aberta entre o lume da bursa resorvente e o do intestino, espérmios fagocitados passam, evidentemente, da bursa ao intestino.

\section{Ocorrência de Meidiama lutheri e notas biológicas}

Material abundante foi colhido, nos mêses de maio, junho e julho de 1946, em Guarujá, perto de Santos, na areia rica em fragmentos de conchas, no mar muito raso. No laboratório, mantiveram-se os vermes nágua estagnada, sem ventilação, durante 4 semanas. São proterândricos, mas, sem discrepância pronunciada das fases masculina e feminina. Os vermes adultos locomovem-se deslizando; os jovens podem nadar livremeitte. Os animais apõem quanto possivel o corpo aos grãos dareia e fragmentos de conchas. A parte anterior executa, durante a locomoção, movimentos serpenteantes, talvez farejando ou orientando-se pelo tato. $\mathrm{Na}$ temperatura dágua a $18^{\circ} \mathrm{C}$, percorrem $5 \mathrm{~mm}$. de distância, em 10 segundos. Se se produzir uma corrente nágua, p. e., com a pipeta com que se procura transportar os vermes para a lâmina, grudam-se com todo o corpo ans objetos de seu meio, enroscando-se ao redor dêles. Com a intenção de acumular o maior número possível de indivíduos, iscámo-los com um pedaço de carne de peixe colocado na superfície da areia no aquário. 0 enchimento do intestino provou que ingeriram o suco do tecido; massas sólidas, de forma definida, não observámo no lume do trato digestivo dos espécimes cortados. 


\section{Subfamilia: Monocelidinae Midellburg (1908, p. 104)}

\section{Genus: Minona, gen. nov.}

Além dos orifícios externos da bursa, do pênis e do canal genital feminino, ocorre ainda um poro do reservatório da secreção granulosa (órgão glandular), provido dum estilete. $O$ epitélio faríngeo interno apresenta-se, na parte oral, ciliado e com núcleos aprofundados; na basilar, sem cílios e com núcleos em posição regular, não aprofundada.

Ao caracter relativo à faringe, devemos acrescentar a ressalva de não existircm descrições pormenorizadas da histologia da faringe de todos os gêneros da subfamília. Em Archiloa wilsoni Stirewalt, Kepner \& Ferguson, também das Monocelidinae, ocorre diversificação igual do epitélio faríngeo interno (1940, p. 127). A independêneia da vesicula granulorum constitue particularidade extremamente singular. Estruturas, por princípio semelhantes, quer dizer, reservatório da secreção granulosa e vesícula de veneno armados e separados do duto ejaculatório observam-se entre os Typhloplanoida (Trigonostomidae; Beklemisehev 1927, p. 104-105), Kalyptorhynchia (Meixner 1925, p. 332), e Polycladida (Bock 1927a, p. 69 e seg.). Monocelis insularis. Meixner (1928, p. 605) pertence, provavelmente, ao gênero Minona.

Tipo do gênero: Minona evelinae, spec. nov.

\section{Minona evelinae, spec. nov. (Fig. 128-134, 136-137)}

O comprimento alcança $3 \mathrm{~mm}$; a largura dos adultos, $0,2 \quad 0,3 \mathrm{~mm}$., ou um pouco mais ainda. Os mais jovens registrados apresentam $0,6 \mathrm{~mm}$. de longura; $0,07 \mathrm{~mm}$. de largura. A diferença entre os vermes jovens e os velhos é menos pronunciada que em Meidiama lutheri. A largura máxima do corpo, cujo aspecto geral lembra o dos Sagittoidea, nota-se na região da faringe, por sua vez, situada muito para trás, freqüentemente, no quarto posterior do corpo. Vermes em plena fase feminina exibiem faringe disposta um tanto mais para diante, em conseqüência do crescimento post-faríngeo. A extremidade rostral é de contôrno ogival; a caudal, triangular e provida de ca. de 40-50 papilas adesivas (Fig. 136, 137, ]), no seu bordo. As glândulas pegajosas (Fig. 128, 1) formam pequenas verrugas ou saliências na superfície das papilas (Meixner 1938, f. 5 B 2, 6 D 2, 7 C-F). Nos vermes jovens, ressaltam as proeminências. apenas no lado dirigido para diante (Fig. $137 \mathrm{~A}$ ) ; nos adultos, para todos os lados (Fig. 137 B) tornando apincelada a aparência da papila (Midelburg 1908, t. 6 f. 2). A côr dos animais é branca; o conteúdo do intestino, ocasionalmente, avermelhado. Os olhos, que podem faltar uni ou bilateralmente, teem cálice acastanlıado tirante a vermelho.

A epiderme (Fig. 134, e) apresenta as partes nucleadas dos seus citosomas aprofundadas, sitas entalmente ao tubo músculo-dermático, como sempre nas Monocelidinae. Os cílios são ventralmente um pouco maiores: que no dorso; estereocílios ocorrem na cabeça e na cauda. Na extremidade anterior, destaca-se um campo de numerosas cerdinhas, provàvelmente tácteis, delimítado pelas desembocaduras das glândulas cefálicas (Fig. 136, f). Destas, há eritrófilas e cianófilas. Ao último tipo pertencem abundantes glândulas parenquimáticas, cuja secreção, em fios freqüente-- 
mente anastomóticos, atravessa a epiderme (Fig. 134, e) em tôda a parte. Os músculos longitudinais do tubo músculo-dérmatico, muito fortes, condicionam a disposição enfileirada dos dutos das glândulas cutâneas, pois êstes teem de passar pelos interstícios entre os feixes da dita musculatura. $\mathrm{Na}$ região caudal, observam-se dois tipos de glândulas eritrófilas, as argamassadoras (Fig. 128, g), perto do gonóporo feminino, e as das papilas adesivas (1).

O cérebro (Fig. 136, c) é mais largo que na espécie precedente, bipartido antero-posterior e dextro-sinistralmente. Ectalmente às células ganglionares, reconhece-se, de vez em quando, a cápsula cerebral. Segundo Midelburg (1908, p. 90), faltaria nas Monocelidinae, mas, foi verificada por Maristo (1938, p. 31), em Automolus (Meixner 1938: Paramonotus) hamatus (Jensen). Ocorre também nas Archimonocelidinae, a saber, em Monotoplana diorchis Meixner (1938, p. 72), e em Meidiama lutheri, assim como nas Coelogynoporinae (Steinböck 1924, p. 463). Os nervos não estudámos especialmente; a comissura caudal (Fig. 128, z) descoberta por Reisinger (1925, p. 129) é singularmente grossa. Entre os dois lóbulos cerebrais anteriores (Fig. 130,2) situa-se o estatocisto com estatolito (5) prismático, de quinas arredondadas. Como na espécie precedente, existem quatro células (3) na parede do estatocisto e outras tantas (4) produtoras do estatolito, cujos restos se conservam, às vêzes, nos cortes. Anteriormente ao estatocisto, dispõem-se os olhos con cálices pigmentados unicelulares (6) e uma célula visual, cada um. A última faz ver a larga orla de bastonetes (7), quer dizer as terminações das neurofibrilas; uma zona refractiva (8), esférica no verme vivente, que poderia funcionar como cristalino, e, aposto à zona refractiva, o núcleo (9) da célula óptica.

$\Lambda$ bôca (Fig. 134, b), como foi dito, no têrȩo, ou mesmo nó quarto posterior do corpo, conduz à bolsa faríngea, de comprimento quasi igual ao da faringe $(\mathrm{h})$. Células baixas, nucleadas e desprovidas de cílios revestem a bolsa. Entalmente, i. é, na inserção da bolsa, passa a musculatura externa faríngea, em certa estensão, à bolsa. $O$ epitélio faríngeo externo é ciliado e de núcleos aprofundados. Os cílios acabam um pouco lateralmente à entrada da faringe, deixando sem cílios o campo da desembocadura das glândulas faríngeas. Os citosomas destas (Fig. 134, k) encontram-se no parênquima lateral, ao redor da base (raiz) da faringe, estendendo-se para diante e para trás. Lateralmente ao anel nervoso $(j)$, por sua vez situado na parte ectal (oral) da faringe, correm os dutos das glândulas cianófilas; medialmente ao anel, os das eritrófilas. A disposição dos músculos externos, os longitudinais apostos ao epitélio, os anelares, ao parênquima, corresponde à descrita de outras Monocelidinae (Mideìburg 1908, p. 87; Maristo 1938, p. 23). A musculatura interna difere da observada por Midelburg, pois também a anelar é contínua e bem desenvolvida, embora menos forte que a longitudinal. A musculatura interna acaba no limite entre os dois trechos do epitélio interno, o ectal (p 1) ciliado, de núcleos aprofundados, e o ental (p 2), não ciliado, de núcleos em posição normal. Como foi dito, na discussão do gênero, tal diversidade do epitélio faríngeo interno ocorre também em Archiloa wilsoni 
(Monocelidinae) e nas duas outras subfamílias das Monocelididae, a saber, nas Archimonocelidinae e nas Coelogynoporinae.

A parede do intestino (Fig. 134, i) liga-se ao epitélio faríngeo ental, de núcleos em posição normal, sendo nítido o limite entre êste e o digestivo. $O$ intestino estende-se do bordo caudal do cérebro até além da vesicula granulorum (Fig. 128, r). A parede intestinal, sem membrana basilar e muscularis, compõe-se de grandes células claviformes, ricas em vacúolos e inclusões alimentícias, e células de Minot (Fig. 128, y) que correspondem às de outras Monocelidinae, na sua distribuição irregular.

Dos órgãos excretores vimos, uma vez, três poros dorsais, cada um com um trecho do seu canal, na região do estatocisto. Um dos canais desemboca um pouco na frente do ôlho esquerdo e medialmente a êste; os dois outros, posteriormente ao estatocisto, situando-se, todos, não longe do plano mediano. Visto que os canais se estendem pronunciadamente para - lado esquerdo, parece provável haver três outros poros paramedianos no lado direito. No trecho terminal (ectal) do mais caudal dos três canais, notou-se um tufo de cílios propulsores; outros cílios, uma vez observados no parênquima, poderiam pertencer a um órgão terminal, como foi desenhado por Maristo (1938, f. 17).

Os testículos (Fig. 136, t) estendem-se, no parênquima ventral, do cérebro até um pouco em frente da raiz faríngea. Aproximadamente 6 folículos encontram-se no mesmo nível transversal, mas, não são enfileirados. Dentro de um folículo, várias' fases da espermatogênese poden ocorrer. Os dutos eferentes reconhecem-se, como nas espécies examinadas por Maristo (1938, p. 39-40), evidentemente, apenas quando repletos de espérmios; tal não se dá nos cortes disponíveis. Os espérmios parecem ser fios simples, de ca. de 75 microns ao comprido, em que não vimos flagelos secundários. Mantiveram-se viventes nágua do mar durante 4 horas (temperatura: $18^{\circ} \mathrm{C}$.). A vesícula seminal esférica (s) situa-se entre a bursa seminal (w) e o reservatório da secreção granulosa (r), sendo maior que ambas. A parte ectal da cavidade da vesícula apresenta-se subdividida em 14-15 gomos, separados por septos finos; mas, completos; o corte transversal (Fig. 129) evidencia corresponder cada septo a uma célula provida do seu núcleo. O duto ejaculatório (q) é um tubo de calibre uniforme, que se encurva para trás. A sua parede é formada por músculos anelares externos e longitudinais internos. O lume é revestido por camada plasmática ciliada, destituida de núcleos. Os espérmios dispõem-se nos gomos descritos de tal modo, que os pacotes das caudas se encontram nas lojas; as cabeças saem destas e convergem para a parte ental, indivisa, da vesícula, onde o duto ejaculatório começa.

Sem comunicação com o aparelho masculino, e caudalmente a êle. abre-se o poro (n) do reservatório da secreção granulosa. A secreção eritrófila, granular, é produzida pelas glândulas médio-caudais, sendo a das laterais mais homogênea e fràcamente cianófila. Empôla e duto do reservatório são fortemente musculosos. Na saida da empôla, insere-se um estilete de ponta acuminada e encurvada. O seu comprimento é de 22-24 microns; o diâmetro, de 4 microns; é canaliculado, não sulcado, como o estilete penial de Peraclistus oofagus (Friedmann 1924, f. 4). 
A posição dos ovários (Fig. 132, o) é ventral, ao nível da base da faringe; são contíguos com os folículos testiculares mais caudais. Dos ovócitos pouco numerosos, o maior aproxima-se mais do ovo-viteloduto (d), em que se encontram espérmios (Fig. 134). O epitélio dos ovo-vitelodutos é baixo, sem limites entre as células; os núcleos não são aprofundados. Os vitelários (v) são dorso-laterais; no auge da fase feminina, estendemse da região post-cerebral até a da vesícula granulorum. Os dois ovo-vitelodutos reunem-se caudalmente à bôca (b). Na sua reunião, comunicam-se com a empôla da bursa seminal (w). Este órgão começa ventro-medianamente com um poro (a) que conduz ao duto da bursa (db) ou vagina. $O$ duto é encurvado para diante, ciliado e de núcleos aprofundados. Na dilatação ental, a empôla da bursa, faltam os cílios. A empôla é lobulada; os lóbulos são constituidos por celulas volumosas com grandes núcleos. Cada célula contém, geralmente, um vacúolo amplo, repleto de espérmios fagocitados, mas, ocorrem também vários vacúolos menores. Entre os lóbulos existem ligações pérvias, às vêzes, em forma de canais cuticularizados. Os espérmios são traspassados ao intestino através dos citosomas dos lóbulos periféricos. Além disso, existe um poro bursa-intestinal que liga o lume dà empôla central ao do intestino.

Os ovos saem do ovo-viteloduto anterior (d), entram na empôla da bursa (w), descem pelo duto da bursa (db, vagina), que abandonam à pequena distância do orifício (a) da bursa (poro copulatório), continuando o seu caminho pelo ovo-viteloduto posterior (d). Este começa, como canal ímpar, sem cílios, na parede caudal da vagina, corre lateralmente (no lado esquerdo) ao órgão eferente masculino (vesícula seminal), dorsalmente à vesicula granulorum, e desemboca pelo gonóporo feminino $(u)$, o quinto e último orifício ventro-mediano do corpo. Um átrio feminino dilatado não se observa em todos os casos; as glândulas argamassadoras derramam a sua secreção no trecho ectal do canal genital feminino.

\section{Ocorrência de Minona evelinae e observações biológicas}

A espécie foi colecionada juntamente com Meidiama lutheri, na areia rica em fragmentos de conchas ("shelly sand", "Schell") de Guarujá, perto de Santos, no mar muito raso. Em todos os mèses, em que o dito biótopo foi examinado, i. é, maio a agosto, obtivemos material, mas, apenas no último mês, houve hermafroditas maduros. Antes, existiram vermes em fase masculina (proterândricos?) e alguns poucos com apenas órgãos femininos (proterogínicos?). De Geocentrophora applanata conhecemos hermafroditismo simultâneo, proterandria e proteroginia (Marcus 1944, p. 32), mas, de Minona evelinae ainda não dispomos de material suficiente para estabelecer o mesmo. Os vermes suportam a manutenção no aquário, até em quantidades pequenas dágua; uma fêmea, p. e., viveu durante 3 semanas, é verdade, sem evacuar os seus ovos, num vidro com dois centímetros eúbicos dágua, de vez em quando renovada, e areia, com earne de peixe como alimento. No fim do dito período foi fixada. A locomoção dos vermes adultos lembra a de Meidiama lutheri, mas, os da espécie atual são mais rápidos e mais pegajosos ainda. Podem grudar-se com a cauda e, nesta posição, executar movimentos farejantes com a parte anterior. Os jovens nadam livremente e manteem-se, muitas vêzes, parados perpendicularmente nágua, como Stenostomum uronephrium Nuttyc. (Marcus 1945, p. 51). 


\section{Notas teóricas sôbre os órgãos generativos de Minona evelinae}

Como em Monocelis insularis Meixner (1928, p. 605), o aparelho masculino da espécie em mãos corresponde perfeitamente às idéias de Lang (1884, p. 231), Bock (1913, p. 35), e outros. Segundo êstes, a vesícula granulorum seria um órgão originalmente com o caracter de arma, ao qual o duto eferente dos testículos se uniu secundàriamente. As disposições de Minona evelinae correspondem a uma fase em que tal ligação ainda não se realizou. Também no sistema feminino ocorrem certos traços que poderiam ser interpretados como ancestrais. A vagina e a bursa seminal lembram as estruturas correspondentes dos Acoela, sendo a semelhança com as Uteriporidae (Tricladida Maricola) mais distante. Nos Acoela, faltam ovo-vitelodutos; em Minona evelinae, independem o aparelho bursal e o canal genital feminino, sendo apenas topográfica a conexão entre os dois. Das gônadas femininas, correm os ovovitelodutos pares à bursa e o duto ímpar sae da vagina, conservando os trechos anterior e posterior, entre si histològicamente concordantes, o seu caracter próprio, diferente do da bursa e do duto da mesma. Poderiam ser entendidos como néo-formações, acréscimos secundários à bursa primordial. A cuticularização de alguns canais bursais lembra, um pouco, a das palhetas ("Bursamundstücke") dos Acoela.

Sòmente a diferença histológica entre os ovo-vitelodutos anteriores e a bursa dificultam interpretar a comunicação bursa-intestinal de $M$. evelinae no sentido de Steinböck, vendo nela o resto da via eferente ancestral dos ovários. Talvez possa ser pesquisada, mais tarde, o desenvolvimento dos dutos femininos e, destarte, auferido material interessante para o entendimento da hipótese aludida.

A posição da comunicação bursa-intestinal ajusta-se bem às idéias de Steinböck. o ôvo, fecundado ao sair do ovário ou ao entrar na empôla da bursa, ganharia o intestino, perto da bôca. Outros exemplos de Monocelidinae com relações topográficas entre a reunião dos ovo-vitelodutos e o intestino são $M$. lineata e $M$. fusca (OparinaCharitonowa 1927), nas quais a homologia com as estruturas correspondentes da espécie atual é completa. Além disso, possue Archiloa spinosa bursa pré-penial (Maristo 1938) e na parede sincicial do intestino adjacente (p. 53) cavidades repletas de espérmios. Em Automolus hamatus, forma o intestino um divertículo profundo, contíguo com a região em que os ovo-vitelodutos se reunem. A histologia da vagina de Monocelis lincata, M. fusca, e da espécie aqui em mãos (Fig. 128, db) re-encontra-se em certos trechos do canal eferente feminino das Monocelidinae pesquisadas por Maristo, a saber, no ovo-viteloduto ímpar inteiro (A. hamatus), e da vagina para trás (A. spinosa). Nenhum dêstes trechos, porém, pode ser reputado como homólogo ao canal duma bursa seminal.

\section{Familia: Bothrioplanidae Hofsten (1907, p. 627)}

\section{Bothrioplana semperi M. Braun (Fig. 135, 138)}

Bothrioplana semperi M. Braun 1881, Archiv für Naturkunde Liv-, Esth- und Kurlands (ed.: Dorpater Naturforschende Gesellschaft) ser. 2 (Biologische Naturkunde) v. 9, p. 335 f. 1, 4-12 (citado segundo Graff 1913, p. 457)

Referências principais:

Vejdorsky 1895, p. 163-199 t. 8-10 f. 1-50 (anatomia)

Sekera 1906, p. 151 (encistamento, dessecação) ; 1911a, p. 1-5 f. 1.7 (duplicação, regeneração); 1926, p. 313-314 (duração da vida)

Hofsten 1907, p. 599 e seg. t. 26 f. $11-16$ (sinonímia; anatomia); 1912, p. 660 (distribuição)

Graff 1913, p. 453-459 f. 391-394: Euporobothria bohemica (Vejd.); E. dorpatensis (M. Braun); Bothrioplana semperi M. Braun; B. alacris Sekera; B. silesiaca Zacharias; B. brauni Zacharias

Thienemann 1921, p. 121 (morfologia, ecologia)

Reisinger 1923, p. 9 (sinonimia), 50-52 (partenogênese, embriologia), f. 7 (movimentos dos cílios), f. 27 (anatomia); 1925 (sistema nervoso); 1933, p. 258 (primeiro achado nos trópicos) 
Nassonov 1924, p. 336; 1925, p. 56, 72 (distribuição); 1926, p. $88 \Omega$ (ecologia, sobrevivência no gêlo)

Steinböck 1928, p. 73 (ecologia, distribuição); 1932, p. 331 (distribuição)

Carter 1929, p. 431 (primeiro achado nos U. S. A.; também em Science, Ne'w York, 1929, v. 69 . n.o 1791) *)

Okugawa 1930, p. 84 (primeiro achado na Asia)

Bresslau 1933, p. 167 (dioogonia), 279 (diagnose): f. 60, 61 (sistema nervoso), f. 90,253 (organização)

Os vermes atingem $7,5 \mathrm{~mm}$. de comprimento, sendo a largura de 1 mm. O corpo é dorso-ventralmente achatado e lembra o de pequenos Tricladida Paludicola. A extremidade anterior é ligeiramente truncada, mas, durante a reptação muda constantemente de forma; a posterior é arredondada. Ao rastejar, o verme apresenta.se uniformemente estendido, ou da mesma largura em tôda a parte, ou com ligeira constrição postcefálica. Querendo o animal mudar de direção, alarga subitamente a extremidade caudal, adere com ela ao substrato, gira em volta do ponto fixo, solta a cauda, estende-se novamente, e começa a rastejar na nova direção. Os vermes são incolores ou brancos, com intestino amarelado ou outra côr condicionada pelọ conteúdo.

A epiderme tem de altura 3 a 6 microns; a do ventre é mais alta que a do dorso e dos lados. Os núcleos são achatados e lobulados. O comprimento dos cílios locomotores é de ca. de 6 microns. Os rabditos (Fig. 135, r) fusiformes (8-12 microns, ao comprido) são reunidos aos 20 e mais em pacotes, de forma de garrafa, cujo número varía muito, mesmo nos vermes completamente adultos. As glândulas rabditógenas situam-se perto da epiderme; sòmente as rostrais são mais aprofundadas e, por isso, providas de dutos compridos, que lembram tractos de bastonetes ("Stäbchenstrassen"). Os pacotes de rabditos condicionam o aspecto manchado dos vermes, à luz transmitida, e, juntamente com os grânulos dos vitelários (v) e o conteúdo intestinal, freqüentemente escuro, tornam os animais viventes bastante opacos.

Distinguem-se, dentre as glândulas cutâneas, as eritrófilas, de secreção de grânulos grossos, e as cianófilas (mucosas), de grânulos finos. Os dois tipos são especialmente numerosos na cabeça, onde os dutos compridos dum feixe de glândulas frontais cianófilas (órgão frontal, Fig. $\left.138, f^{f}\right)$ desembocam no meio do bordo rostral. A adesão da extremidade posterior é causada pela secreção eritrófila, de grânulos miúdos, das glândulas grudadoras caudais. Os finos dutos delas desembocam no bordo posterior, ventralmente às outras estruturas cutâneas aí ricamente desenvolvidas, a saber, rabditos e glândulas eritrófilas comuns.

Do tubo músculo-dermático, são os músculos diagonais e anelares mais fortes que os longitudinais. Os músculos dorso-ventrais do corpo encontram-se, nas regiões pré e post-intestinal, em tôda a largura; na intestinal, só nos dois lados, principalmente entre os divertículos do intestino, como também entre a faringe e os dois ramos intestinais laterais.

*) Foi Dra. Jeannette S. Carter a primeira a encontrar Bothrioplana semperi nos Estados Unidos da América do Norte, não W. Nicoll, como Steinböck \& Reisinger $(1930$, p. 23-24) indicaram. 
Os órgãos sensoriais são as fossetas ciliadas (w) e as cerdas rígidas; olhos faltam. As fossetas encontram-se em cada lado da zona anterior, no fundo de ligeiras reintrâncias. Dos dois pares de fossetas, um marca-se, às vêzes, só muito indistintamente. Os orifícios situam-se lateral ou dorsolateralmente e são providos de esfíncteres; as invaginações são tubulosas; no fundo da fosseta desembocam glândulas cianófilas (mucosas). Provàvelmente, são órgãos quimoperceptivos. No verme vivente, não em cortes, foi observada ainda a covinha dorso-mediana, situada dorsalmente ao bordo caudal do cérebro. Caracteriza-se pelo seu halo claro, que resulta da ausência de rabditos e glândulas eritrófilas. Os estereocílios, de 0,02 mm. de comprimento, evidentemente tácteis, são numeroşos na cabeça. Ocorrem tanto como cílios únicos quanto em grupos de 3-4 basilarmente reunidos.

O sistema nervoso abrange: 4 pares de nervos longitudinais com as suas comissuras; o cérebro (Fig. 138, c) e os seus nervos rostrais; e o plexo cutâneo, fino e irregular, localizado entre a membrana basilar da epiderme e o tubo músculo-dermático. Os nervos longitudinais são: ventrais, ventro-laterais, laterais, e dorsais. As comissuras post-cerebrais são quasi tôdas completas, reunindo os 4 pares de nervos; as anteriores são modificadas e não aneis completos. Vermes recém-saidos do casulo teem 10-20 comissuras; adultos, 25-36. O cérebro, mais largo que comprido e caudalmente entalhado, possue rostralmente dois bulbos, dos quais saem os nervos que suprem as fossetas ciliadas e a face anterior do verme.

O tracto digestivo começa com a bôca (b) situada no têrço posterior. Para dentro, segue a bolsa faríngea $(\mathrm{m})$ dirigida para diante e revestida por epitélio fino. A faringe (h) muito móvel e contráctil corresponde ao "pharynx plicatus" dos Tricladida. Como nêstes, inverte-se, na bôca faríngea, a séqüência das camadas musculosas anelares e longitudinais; nêste ponto, faltam os cílios que cobrem a superfície externa da faringe e revestem o lume dela. Na região em que o corpo da faringe passa à bolsa, inserem-se fortes retractores faríngeos originados nas paredes dorsal e ventral do corpo. Glândulas extra e intra-faríngeas desembocam ao redor da bôca faríngea, na zona sem cílios. Um pouco ectalmente ao meio, é a faringe percorrida por um anel nervoso.

$\Lambda$ parede interna da faringe continúa, para diante, com tuło curto, chamado de esôfago, por ser histològicamente diferente dos trechos precedente e seguinte. Do esôfago estende-se o intestino para diante quasi até o nível do bordo caudal do cérebro, e atinge, para trás, quasi a extremidade caudal. Aos dois lados da faringe, são os trechos anterior (i) e posterior ( $\mathrm{s}$ ) do intestino reunidos por dois tubos de comunicação (e). Vermes jovens exibem intestino baciliforme ou fracamente lobulado; adụltos mostram divertículos simétricos, menos distintos em indivíduos que se fartaram. Como aproximação numérica seja repetida a indicação de Vejdovsky (1895, p. 182) de um divertículo anterior impar, seguido por 3.4 pares laterais, menores, e ca. de 9 pares maiores; no trecho posterior, distinguiu Vejdovsky 5-6 pares de divertículos e alguns lóbulos inconspícuos. Os tubos lateraị são menos distintamente lobulados. As células intestinais são providas de cílios compridos; dispersas entre as 
digestivas, ocorrem células claviformes de Minot, de secreção eritrófila, granulosa.

O protonefridióporo situa-se na face ventral, ao nível do esôfago. Para êle convergem dois tubos transversais, os canais eferentes ( $\mathrm{n}$ ) do emunctório. Estes canais se ramificam e dão origem a um canal anterior e a outro, posterior, ambos correndo quasi até as extremidades do corpo e aí encurvados para o meio (canais recurrentes). Ramificações capilares e órgãos terminais são numerosos; à altura do cérebro, o canal anterior forma um complexo de alças.

Os testículos pequenos ocorrem dorso-lateralmente à bolsa faríngea. A túnica propria dêles prolonga-se como dutos eferentes. ciliados e providos de fraca musculatura anelar. O testículo dum lado e o seu duto podem faltar. Os dutos reunem-se na sua entrada na vesícula seminal revestida por cílios compridos dirigidos para fora. A vesícula é ligada ao reservatório da secreção granulosa por um trecho mais estreito, em que as glândulas da dita secreção desembocam. O reservatório, não ciliado, continúa com o duto ejaculatório, ciliado. O pênis é representado apenas por uma pequena papila, que se salienta um pouco na parede ânterodorsal do átrio.

O átrio "(a) é ciliado e situa-se caudalmente à boca, rostralmente à reunião dos dois tubos intestinais comunicantes. O poro genital (p) é circundado por uma roseta de glândulas $(\mathrm{g})$, provàvelmente grudadoras do casulo. Vejdovsky (1895, p. 187) observou estas glândulas; nos cortes de Hofsten (1907, p. 613) faltaram, mas, nos nossos, ocorrem (Fig. 135).

Os dois ovários (Fig. 138, o) situam-se nos lados do átrio, ventralmente aos tubos intestinais comunicantes. Os ovócitos em crescimento, 5-9 simultâneos, em cada germário, dispõem-se enfileiradamente. Os vitelários (v) compõem-se dum grande número de folículos, contíguos, mas, separados um do outro pela túnica própria. Entre a bôca e o cérebro, assim como an longo do intestino posterior, preenchem os folículos viteláricos as partes laterais do corpo. Cada metade do vitelário, a prè-faríngea e a post-faríngea, emite um viteloduto. Os vitelodutos anterior e posterior de cada lado reunem-se ao nível do átrio, formando o viteloduto comum (d) direito e esquerdo, Os últimos correm transversalmente, em linha reta, e estabelecem comunicação com os ovários, cujos produtos evacuam. Entre o ponto de tal comunicação e o átrio podem ser chamados de ovo-vitelodutos direito e esquerdo. Reunem-se no meio; sobe, então, o canal genital feminino (duto comum) até o meio da altura do átrio e entra nêste pela parede caudal. Aí, nota-se uma dilatação, o saco glandular (Hofsten 1907 , p. 613 ; f. 8 na p. 609), em que glândulas da casca acidófilas e basófilas desembocam. Para trás, comunica-se o saco glandular com o trecho posterior do intestino pelo duto gênito-intestinal (Reisinger 1923, f. 27 na p. 44), cujos cílios levam o excesso de vitelo ao órgão digestivo.

Ocorrência: Num brejo, perto do rio Pirajussára, afluente do rio Pinheiros, ca. de $1 \mathrm{~km}$. ao sul de Butantan (25. XI. 1945), dois exemplares. Os vermes foram encontrądos em água rica em humo, depois de ter o lenẹol dágua aflorado, em consequềncia de chnvas. Durante o ano inteiro continuam húmidas as camadas profundas da vegetação espessa do dito brejo. As acumulações dágua líquida desaparecem da superfície do brejo depois de algumas semanas sem ou quasi sem chuvas, como 
ocorrem nos mêses de junho a agosto. Quinze outros indivíduos, alguns com casulos, foram colhidos, numa fossa dum prado baixo, perto do dito rio, a ca. de $500 \mathrm{~m}$. de distância de Butantan (18. IV. 1946). A fossa não é aquifera durante o inverno; na data indicada a profundidade dágua não ultrapassou $10 \mathrm{~cm}$. Coneordam, destarte, certas condiçõés ecológicas dos primeiros achados sul-americanos de Bothrioplana semperi com as da Escócia (Martin 1907, p. 32), Bohêmia (Sekera 1906, p. 152), Styria e Carinthia (Reisinger 1925, p. 120).

Distribuição geográfica: Europa, vários países; nos Alpes, até $1500 \mathrm{~m}$. do altitude; na Rússia, para o Norte, até a península de Kola; Japão; Sumatra; Estados Unidos da América do Norte, Virgínia; Grocnlândia ocidental.

\section{Notas sôbre o desenvolvimento de Bothrioplana semperi}

Depreende-se da literatura (Reisinger 1923, p. 50; 1924b, p. 22) que a espécie atual se multiplica sòmente por partenogênese. Na fase da maturidade completa dos brgãos femininos, estão os masculinos desaparecidos, sem que ocorram auto-inseminação ou inseminação mútua precoces. Em cada casulo entram dois gonócitos femininos, segundo Reisinger, ovócitos de $1 .^{\mathrm{a}}$ ordem. A dioogonia (Bresslau 1933, p. 167) foi confirmada por Meixner (1923a, p. 198, nota 4), que não se refere à fase dos gonócitos reunidos. Estes formam um blastema embrionário, e, além disso, células migratórios que constituem o envoltório do sincício vitelino. Depois das primeiras clivagens, realiza-se a ovipostura. No grande material de Meixner (1924, p. 5), estabeleceu-se o casulo sempre durante a noite e o casulo foi libertado de madrugada. Mrazek viu os casulos vermelho-acastanhados no fim do verão (Vejdovsky 1895 , p. 191). Os traços principais da embriogênese, que mostra até certa linhagem germinativa feminina, foram descritos por Reisinger (1923, p. 51-52). De cada casulo desenvolve-se um único verme jovem.

\section{Ordo: Tricladida Lang}

\section{Sôbre a terminologia dos órgãos reprodutivos dos Tricladida}

Ultimamente, propôs a grande autoridade dos Tricladida, Dra. L. H. Hyman (1945, p. 476), várias inovaçôes da terminologia, das quais ovovitelodutos ou germovitelodutos (em vez de ovidutos) e canal ou duto da bursa (em vez de "bursa.stalk", "Bursastiel") merecem adopção imediata. A substituição de "atrium" por "antrum" parece-nos desuecessária; "antrum", que significa gruta, carerna, não pode ser aceito como melhoramento. Visto que a vesícula seminal situada dentro do bulbo dos Tricladida não abriga espérmios, propõe a autora citada falar em lume do bulho. Morfològicamente, porém, continua defensável a denominação atual, talvez na forma de "vesícula seminal intra-penial". rem oposição às extra-peniais discutidas mais adiante. Do mesmo modo que $\mathrm{em}$ muitos Rhabdocoela, origina-se a vesícula seminal interna dos Tricladida pela união das vias eferentes mascrlinas ou por dilatação do duto seminal. Urge seguir a Dra. Hyman na abolição de "vasa deferentia", e isso, em todos os Turbelários e animais em geral. Não são vasos, e não se dirigem para baixo. O têrmo proposto, para os Tricladida, "sperm ducts" ou espetmiodutos, assemelha-se, ao nosso ver, demais ao outro, "ductus spermatici" (dutos espermáticos), de significação morfológica diferente (Bresslau 1933, p. 118, 129). Por isso, usámos, já em trabalhos anteriores, dutos eferentes (ductus efferentes), em vez de "vasa deferentia" Sabemos que os pequenos canais ("Samenkapillaren" Bresslau 1933, p. 133-134), que conduzem os espérmios dos testículos aos "vasa deferentia", foram chamados de "vasa efferentia" ou, às vêzes, de "duotus efferentes". Por isso, chamamos êstes de "ductuli efferentes" (dútulos eferentes). As vesículas seminais falsas, denominadas de "spermiducal vesicles" (vesículas do espermioduto) pela Dra. Hyman, poderão ser designadas assim, se o têrmo espermioduto fôr aceito. Por enquanto, preferimos chamá-las de vesículas seminais transitórias ou, nos Tricladida, de vesículas seminais extra-peniais, pois, encontram-se fora do bulbo. Como vesículas seminais proximais (entais), em oposição às verdadeiras, distais (ectais) poderiam ser denominadas uniformemente nas várias ordens dos Turbellaria. 


\title{
Subordo: Haploneura Steinböck (Planariida Schmarda)
}

\author{
Sectio: Paludicola Hallez (Probursalia Steinböck)
}

\section{Familia: Planariidae Stimpson (Kenk 1930, p. 290 emend.)}

\section{Genus Bopsula, gen. nov.}

Planariidae cujos ovovitelodutos abraçam o átrio feminino e entram nêste por trás, situando-se a entrada dos ovovitelodutos junto da bursal. As glândulas da casca desembocam no átrio um pouco distalmente (ectalmente) aos ovovitelodutos. A empôla da bursa coloca-se anteriormente ao pênis. Os átrios masculino e feminino abrem-se independentemente um do outro, na face ventral; o poro maseulino encontra-se rostralmente ao feminino. $O$ átrio feminino comunica-se com a cavidade do pênis por um canal. Os dutos eferentes reunem-se caudalmente ao pênis, entrando nêste o duto seminal originado pela dita reunião. Orgãos músculo-glandulares (adenodáctilos) faltam.

Tipo do gênero: Bopsula evelinae, spec. nov.

Diseussão: O estabelecimento da diagnose dum gênero com uma única espécie significa apenas uma tentătiva provisória, pois não se podem prever achados futuros. Se tais houver de outras Planariidas com orifícios masculino e feminino separados, recomendar-se-á eliminar, da diagnose precedente, os caracteres eventualmente inexistentes nessas, restringindo-a à dita separação, que constitue o sinal principal.

\section{Bopsula evelinae, spec. nov. (Fig. 139-143)}

O comprimento do verme fixado é de $7 \mathrm{~mm}$.; a largura, de $1,7 \mathrm{~mm}$. Visto que o intestino não atinge a extremidade posterior, e esta contém grande número de células formadoras, no parênquima, o único exemplar disponível poderia ter regenerado, há pouco tempo, a cauda. Tal eventualidade diminue a significação taxonômica do comprimento indicado. A cabeça é de contôrno triangular, com aurículas distintas. A distância entre cada olho e o bordo corresponde, aproximadamente, à entre os dois olhos. que se encontram, como comumente nas Planariidae, cada um sobposto a um halo claro. A côr é preta, no dorso, notando-se aí manchas circulares brancas, difusamente espalhadas; também as aurículas são brancas. A faringe é pigmentada; o ventre, branco. O pigmento situa-se no parênquima e nos rabditos, êstes muito escassos na epiderme ventral. A aitura da epiderme dorsal é duas vêzes maior que a da ventral, com ' excepção das partes laterais da cabeça, de epiderme baixa. Orgão frontal não existe; o bordo cefálico anterior exibe as glândulas grudadoras cosinófilas, conhecidas de muitas espécies da família.

A faringe origina-se, aproximadamente, no meio do corpo e estendese, para trás, até o fim do terceiro quarto. No caso de se tratar dum animal com cauda recém-regenerada, tal indicação topográfica não poderia ser considerada como definitiva. Dá-se o mesmo com a posição da bôca, situada, no verme presente, entre o $2^{\circ}$ e o último têrȩo do corpo (Fig. 
140, f), um pouco antes da extremidade caudal da faringe (h). Os divertículos intestinais estendem-se, anteriormente, quasi até a região entre os olhos; posteriormente, não atingem a extremidade caudal. A faringe é interna e externamente ciliada. A disposição dos músculos faríngeos internos é a das Planariidae, a saber, os músculos anelares formam a camada interna; os longitudinais, a externa.

Os testículos ocupam posição dorsal; começam caudalmente aos ovários, e estendem-se até a zona atrás do átrio feminino (Fig. 139, a), onde ocorrem ainda alguns folículos (Fig. 140, t). Estes são dorsalmente arredondados; ventralmente, onde a túnica testicular se estreita, formando o dútulo eferente, são cuspidatos. Os dutos eferentes são muito finos, na região anterior do corpo; correm ventralmente, ao que parece, medialmente aos nervos longitudinais ventrais, perto dêstes. Ao nível da extremidade caudal da faringe (Fig. 139, h), dilatam-se os dutos eferentes (n). Transpõem a zona do órgão copulador masculino, passando nos dois lados dêle, e atingem a região entre os átrios masculino e feminino. Equidistantes dos dois poros genitais (m, p), os dutos encurvam-se em ângulo reto, dirigindo-se medialmente. Os trechos transversais, que correm para o meio do corpo, são revestidos por músculos espessos. No ponto em que os tubos transversais se encontram, forma-se uma dilatação, a vesícula seminal extra-penial (Fig. 139, v), que, no verme em mãos, é pequena e esférica. Da reunião dos dois dutos eferentes origina-se o duto seminal (Fig. 140, d), também de parede musculosa, que sobe c entra no órgão copulador masculino pela parede dorsal dêsté.

O pênis apresenta-se, no nosso animal completamente maduro, como órgão quasi globoso, situado entre a faringe (h) e o átrio feminino (a). O. eixo maior do pênis iguala, aproximadamente, a 4 quintos da altura do corpo, e coincide, quanto à sua direção, com o eixo dorso-ventral do verme. As partes típicas do pênis dos Paludicola, papila e bulbo, distinguem-se dificilmente na espécie atual, por causa da redução da musculatura da parede do pênis. Nomeadamente na parte ventral, na papila, existem apenas finos músculos parietais. A musculatura espessa-se dorsalmnente ao nível da desembocadura do duto seminal (d), i. é, na base da papila, que é provida de fortes músculos anelares. Outro espessamento musculoso observa-se nos dois lados da parte dorsal do pênis, definindo-a como bulbo. A cavidade do pênis (Fig. 140, s), i. é, o lume delimitado pelo epitélio interno, é preenchida por secreção fracamente eosinófila. Lembra, destarte, o órgão copulador de $B$. evelinae o da Dendrocoeliida Procotyla fluviatilis Leidy (Hyman 1928, p. 234-235; Kenk 1944, p. 36) e, mais ainda, de $P$ typhlops Kenk (1935, p. 115-116). O epitélio produtor da dita secreção salienta-se para dentro do lume com várias dobras de comprimento e direção variáveis, dispostas sem simetria. Morfològicamente, corresponde todo o espaço circunscrito pelo epitélio interno. à vesicula seminal verdadeira dos Paludicola em geral. Os espérmios, porém, ocupam, no verme em questão, apenas uma parte da papila. Da desembocadura do duto seminal, os espérmios passam em forma decordão torcido e compactó, envolvido pela secreção, até o meio da calota 
inferior da papila. O epitélio externo desta é baixo; os núcleos são, em parte, aprofundados.

O átrio masculino (Fig. 140, i), cujo lume tem forma de hemisfério ôco, é revestido por epitélio semelhante ao externo da papila, mas, algum tanto mais alto. A parede caudal do átrio masculino é atravessada por um canal curto e musculoso, cujo orifício externo é o poro masculino (m).

Os ovários são situados ventralmente, um pouco caudalmente ao $5 .^{\circ}$ divertículo intestinal. Nos ovários maduros aquí presentes, os ovócitos dispõem-se isoladamente entre as malhas distintas formadas pelas células nutritivas do estroma ovárico (Gelei 1913, p. 58 e seg.). Rostralmente aos ovários, encontram-se 3-4 folículos vitelinos, cujas células são mais compactamente agrupadas que as ováricas. Os vitelários estendem-se caudalmente tanto quanto o intestino e são, na região atrás dos órgãos copuladores, mais nụmerosos que os testículos. Como os dutos eferentes, os ovovitelodutos são tênues e difîilmente verificáveis nas regiões anterior e" média do corpo. A tuba, i. é, a parte éntal do ovoviteloduto ligada ao ovário, é algo dilatada e mostra, no seu orifício, as células altas obturadoras conhecidas de alguns outros Paludicola (veja Fig. 161, 176). Da região entre os dois átrios para trás, os ovovitelodutos correm do lado ventral sucessivamente para o dorsal. No ponto mais caudal atingido pelos ovovitelodutos, êstes recebem o vitelo dos folículos posteriores dos vitelários. Daí se encurvam para diante; sendo, nêste trecho, aprofundados os núcleos do epitélio ciliado das vias eferentes femininas. Os ovovitelodutos atravessam separadamente a parede caudal daquela parte em que o átrio não ciliado (a) confina com o duto ciliado da bursa $(\mathrm{k})$. Um pouco ectalmente a êste ponto, desembocam também as glândulas da casca, fortemente eosinófilas (Fig. 140, g).

$\mathrm{O}$ átrio feminino (Fig. 139, a) abre-se pelo poro feminino (p) provido de esfincter e situado caudalmente aos trechos transversais dos dutos eferentes. Do poro, o átrio estende-se vèrticalmente em direção dorsal e dilata-se, prìncipalmente, para diante. A musculatura atrial é bem desenvolvida; o epitélio, irregularmente alto, destituido de cílios e provido de núcleos aprofundados. Glândulas argamassadoras (y) desembocam no átrio. No plano horizontal equidistante do dorso e do ventre, o átrio feminino continúa com um canal dirigido anteriormente, que se comunica com o bulbo do pênis. $O$ epitélio dêste canal caracteriza-o como pertencente ao átrio; apenas na parte rostral, termina o aprofundamento dos seus núcleos, havendo algumas células epiteliais regulares também no teto da parte caudal. As células do canal distinguem-se do epitélio penial mesmo na zona adjacente ao bulbo, devido à sua altura muito maior.

O duto ou canal (Fig. 140, k) da bursa, de epitélio regular, quer dizer, não aprofundado, ciliado, começa infundibuliformemente dilatado, no ponto indicado da desembocadura dos ovovitelodutos e das glândulas da casca. O duto bursal encurva-se para diante e estreita-se; a sua parede é provida de músculos anelares e longitudinais; os últimos especialmente fortes. $O$ epitélio do duto continua ciliado. O canal dilata-se sùbitamente, dando origem à empôla da bursa (b) situada entre a parede 
caudal da bolsa faríngea e a rostral do pênis. $O$ epitélio da empôla $e$ alto, viloso, de núcleos não aprofundados, sitos na base das células, cujas zonas distais são ocupadas por vacúolos, em parte com conteúdo, em parte vazios. Não existe comunicação entre a bursa e o intestino.

\section{Ocorrência de Bopsula evelinae}

Em 20 de janeiro de 1946, encontrámos o único exemplar *) da nova espécie, sôbre um pedaço de madeira, na margem da pequena reprêsa de Umuarama, no município de Campos de Jordão (Estado de São Paulo), na serra da Mantiqueira (altitude de ca. de $1750 \mathrm{~m}$.). O lago de Umuarama, já mencionado eomo localidade da ocorrência de Microdalyellia therapaina (veja p. 51), possue bordos rasos, plenamente insolados, com rica vegetação. $E$ habitado por carpas, cuja presença sugeriu o nome do novo gênero (R. Kipling: "How the first letter was written"). Apesar de termos examinado, durante as semanas seguintes, o lugar do primeiro achado, as margens pouco extensas do lago, e os vários córregos que entram nêle, não encontrámos a espécie mais uma vez. Todos os Paludicola obtidos pertenceram às duas espécies descritas mais adiante. Presumivelmente, habita Bopsula evelinae o fundo do lago que atinge, segundo fomos informados, $6 \mathrm{~m}$. O exame dêste biótopo tivemos de deixar para uma futura oportunidade.

\section{Posição sistemática de Bopsula evelinae}

As estruturas dos nervos ventrais, do intestino, das gônadas, e da bursa caracterizam $B$. evelinae como pertencente aos Tricladida Haploneura Paludicola (Probursalia). A disposição dos músculos faríngeos internos (Kenk 1930, p. 150-151 f. 1; Bresslau 1933, f. 277) e a ausência dum órgão frontal (Kenkiidae Hyman 1937a) possibilitam incluir o gênero nas Planariidae Kenk 1930, sem necessidade de modificar a diagnose dada por Bresslau (1933, p. 282). Tendo apenas um único espécime em mãos, hesitámos em estabelecer, para $B$. evclinae, uma família especial, cuja caracterização teria sido, necessàriamente, uma repetição da genérica.

Todavia, apresenta-se como muito singular a separação dos orifícios masculino e feminino e, talvez mais ainda, a comunicação átriopenial. O estádio completo das vias eferentes afasta a interpretação de se tratar duma das anomalias, encontradas na natureza (Kenk 1927, f. 2) e surgidas depois da união artificial de partes sexuada e estéril (Kenk 1941a, p. 65 e seg., f. 5). Inverosímil parece a hipótese de representar o órgão copulatório de $B$. evelinae um adenodáctilo que assumiu a função do pênis, compensando a falta dêste. Se quisermos entender a organização de $B$. evelinae, baseando-nos sòmente nas estruturas presentes nas Planariidae, oferece-se uma explicação muito menos complicada que a dum adenodáctilo vicário do pênis que se perdeu por mutação. As Figuras 141143 mostram, como uma rotação do pênis, de $120^{\circ}$, transformaria a topografia comum das Planariidae naquela de $B$. evelinae; os dutos eferentes, que geralmente entram do lado dorso-rostral, acompanhariam a rotação

*) Na mesma represa de Umuarama obtivemos, em dezembro de 1946, um segundo exemplar, também sôbre um páu. 
e entrariam do lado dorso-caudal. A ligação átrio-penial, funcionalmente incompreensível, seria, nesta hipótese, o resíduo do átrio masculino antigo.

Não teriamos ponderado esta hipótese quasi suspeitosamente simples se o confronto com famílias vizinhas tivesse resultado em paralelos convincentes. Tal, porém, não aconteceu. Ditremagenia macropharynx Palombi $(1928$, p. 614) foi, dos Trieladida Maricola, removida aos Polycladida Cotylea (Bresslau 1933, p. 290), de maneira que resta apenas uma espécie dos Tricladida com dois orifícios genitais, a saber, Digonopyla harmeri (Graff 1897, p. 114; 1899, p. 536 t. 19 f. 41-43; Fischer 1926, p. 257 e seg.). Pertence aos Terricola, possue o orifício masculino situado rostralmente 20 feminino, mas, de resto, não se assemelha, de modo algum, a B. evelinae. D. harmeri não tem bursa, nem ligação entre os aparelhos masculino e feminino; os dutos eferentes entram no pênis do lado rostral; o átrio masculino compōe-se duma parte rostral, em que o pênis se salienta, e de outra, caudal; os testículos são ventrais, etc.

Dos Maricola, despertaram o nosso interesse: a) as duas espécies gonocorísticas, Sabussowia dioica (Claparède 1863, p. 18-20 t. 3 f. 7-13) e Cercyra teissieri Steinmann (1930, p. 147 e seg. f. 1-5); b) as Uteriporidae com dois orifícios genitais (Böhmig 1906 , p. 329-331; Wilhelmi 1909 , p. 254; 269-270). S. dioica poderia, talvez, contribuir para entender a ligação átrio-penial de $B$. evelinae, pois possue bursa, também no macho. Se não fosse excepcional a separação dos sexos, entre os 'Turbellaria, poder-se-ia inaginar ter o verme hermafrodita conservado a bursa masculina (receptáculo seminal) que se uniu ao átrio feminino. Impossibilitam, porém, tal hipótese: 1.) a histologia da dita ligação que a define como parte do aparelho feminino; 2) a inversão do pensamento certo (Steinmann-Bresslau 1913, p. 65), que derivaria uma espécie hermafrodita dos Tricladida de outra, gonocorística. As Uteriporidae são hermafroditas com dois orifícios genitais, como o é $B$. evelinae. Ocorre até ligação entre os dois aparelhos, como na espécie atual. Não obstante, permanece o zonfronto só nas semelhanças superficiais. 0 orifício anterior das Uteriporidae pertence à bursa. Esta comunica-se com os ovovitelodutos por dois dutos espermáticos.

Resumindo as tentativas de estabelecer relação entre os órgãos copuladores de B. evelinae e os dos outros Trieladida, verificamo-las frustradas. Estendê-las aos Polycladida, de orifícios genitais separados, parece-nos inoportuno, diante da estrutura completamente diferente das gônadas femininas da dita ordem. Sem separação de germários e vitelários e, conseqüentemente, com ovos endolécitos, são os Polycladida, nêste ponto, aneestrais. Ligação dos órgãos eferentes masculinos e femininos desconhecemos dos Polycladida.

Os Seriata (Proseriata Meixner 1938), entre os Alloeocoela, são os únicos em cuja morfologia encontramos semelhanças algo ponderáveis com B. evelinae. Em muitas espécies da dita sub-ordem, abre-se o orifício masculino anteriormente ao feminino. Comunicação entre o aparelho feminino (bursa) e o masculino (átrio) ocorre, havendo, p. e., a chamada vagina antralis em Archiloa rivularis Beauchamp (1910, p. 211 e seg., f. 1-2) e Archilopsis unipunctata (Fabr.) (Graff 1913, p. 438; Meixner 1938, p. 60-61 f. 5 A, 56). Não pensamos em homologia entre a ligação átrio-penial de $B$. evelinae e a vagina antralis, pois os órgãos ligados pelos dois tipos de comunicação são diferentes. Existe, todavia, certa concordância e, destarte, a possibilidade de ser entendida històricamente a anatomia da nova espécie por aquêles que não querem admitir o acontecimento da rotação demonstrada nas Figuras 141-143.

\section{Genus: Rhodax, gen. nov.}

Planariidae cujos dutos femininos se bifurcam, em cada lado, emitindo um ramo anterior, o ovoviteloduto e um ramo posterior, o viteloduto. $\mathrm{O}$ duto feminino comum (oviductus communis, ductus glandula 
ris) desemboca no átrio genital, a saber: na parte chamada de átrio comum. A bursa pequena situa-se caudalmente ao órgão copulador.; o canal da bursa não é circundado pelos dutos femininos. Orgãos músculoglandulares (adenodáctilos) faltam.

Tipo do gênero: Rhodax evelinat, spec. nov.

A estensão da zona testicular até atrás do aparelho copulador não foi incluida na diagnose genérica, porque êste caracter, indicado, por Kenk (1930, p. 292-293), das espécies eurasiáticas de Phagocata (tem prioridade sôbre Fonticola; Hyman 1937, p. 300-301), falta em alguns representantes norte-americanos (Hyman 1931, p. 328; Kenk 1935, p. 96 ; id. 1944 , p. 22,34 ). A comunicação bursa-intestinal foi, de propósito, deixada fora da diagnose, pois a existência de espécies com bursa ainda menor e separada do intestino torna-se verosimil pela ontogênese da bursa eun Rh. evelinae.

Provavelmente, pertence Planaria fissipara Kennel (1888, p. 468), cujas gônadas se ignoram, ao novo gênero; as diferenças entre evelinae e fissipara serāo tratadas no fim do capítulo sốbre a divisão.

\section{Descrição de Rhodax evelinae, spec. nov. (Fig. 144-153, Est. XXXI Fig. 5)}

Caracteres externos: Os vermés atingem $9 \mathrm{~mm}$. de comprimento máximo, sendo a largura de $1-1,5 \mathrm{~mm}$. 0 bordo anterior é nìtidamente convexo, com área adesiva ligeiramente marcada. Aurículas faltam. Ds dois lados do corpo são paralelos, não havendo constrição cervical. A cauda é mais ou menos cuspidata. A côr (Est. XXXI Fig. 5) do dorso tem fundo amarelo-rosado, localizando-se êste tom especialmente nos rabditos. Além disso, ocorrem cromatóforos vermelhos (vermes jovens), acastanhados ou até pretos (vermes velhos). Estas células estreladas são mais cerradas na linha mediana e deixam quasi livre a eabeça, onde ainda falta a côr do fundo na área adesiva. As porções marginais do corpo e o ventre são mais claros.

Os dois olhos, estreitamente juxtapostos, podem ser acompanhados, cada um, de 1-2 olhos secundários; tais aparecem, nomeadamente, em indivíduos adultos. As áreas sobrepostas aos olhos são incolores.

O conteúdo do intestino pode salientar-se com côr amarela, acastanhada ou vermelha (sângue de Naididas). Ao redor da faringe (proboscis) e do aparelho copulador, deixa o intestino um halo claro livre, de. maneira que os vermes sexuados já se reconhecem com aumento fraco.

Animais em que a divisão se prepara (Fig. 151), caracterizam-se; primeiramente, pelo seu comprimento, e pela posição da faringe anteriormente ao centro; depois, pela constrição bilateral situada posteriormente à faringe e ao orifício genital. Nos cortes, reconhecem-se as células formadoras (células substituidoras; neoblastos) acumuladas. Depois da divi: são, marca-se a cicatriz contraida pela côr quasi preta dos cromatóforos aí concentrados (Fig. 144).

Órgãos cefálicos: Na cabeça, desembocam, no meio e sub-marginalmente, glândulas geralmente basófilas (Fig. 148 k), cujos citosomas muito aprofundados ("versenkt") atingem a região da faringe. O tufo destas glândulas cianófilas é circundado por glândụlas eritrófilas, iguạl ${ }_{i}$ 
mente aprofundadas. $O$ conjunto das desembocaduras glandulares forma a área adesiva (Fig. 144, 148, z), com que vimos um exemplar apanhar um Aeolosoma. A área é delimitada por 2 grossos nervos cefálicos, havendo oụtros ramificados em tôda a estensão do bordo cefálico anterior. Por fora dos 2 nervos mencionados, situa-se, em cada lado, uma pequena zona de células epiteliais aprofundadas, sem rabditos. Correspondem aos órgãos sensoriais auriculares de Phagocata morgani (Kenk 1935, p. 95).

Aparelho nutritivo: O orifício oral circundado por esfincter bem desenvolvido encontra_se ao nível do meio da faringe (Fig. 147, 150). Esta é incolor, relativamente curta e tem, geralmente, o bordo provido de lóbulos irregulares. Freqüentemente, a faringe termina obliquamente truncada. 0 . lume da faringe apresenta cílios cerrados, seguindo, para fora: 1) a parte sem núcleos do epitélio faríngeo interno (endotélio); 2 ) os músculos faríngeos internos, constituidos po ca. de 3 camadas de músculos anelares e 1 camada de longitudinais; 3 ) a parte nucleada do endotélio; 4) as glândulas eosinófilas longitudinalmente dispostas e acompanhadas por fibras; 5) a parte nucleada do epitélio faríngeo externo; 6) os rnúsculos externos com 1 camada longitudinal e 1 anelar; 7 ) a parte anucleada do epitélio cobertor, com cílios.

$O$ intestino (Fig. 147, i) atinge apenas o bordo caudal do cérebro. Os 3 ramos intestinais possuem numerosos divertículos laterais, por sua vez, sub-ramificados. Os dois ramos posteriores são, na maioria dos exemplares, separados completamente, ao longo de tôda a sua estensão; raramente ocorre uma anastomose entre êles, esta situada perto da extremidade caudal. $O$ número dos divertículos do ramo ímpar varia de 7 a 10, em cada lado. Os ramos pares podem ter 10-20 divertículos, conforme a separação dum zoóide posterior realizada há pouco ou há muito tempo, respectivamente. Segundo o mesmo critério, varia a posição da faringe no centro ou anteriormente a êste.

Sistema reprodutivo: 1) Órgãos masculinos. Os testículos estendem-se, nos dois lados da face ventral, do terceiro divertículo do ramo intestinal ímpar até além do último divertículo caudal dos ramos pares (Fig. 147 t). Os vários folículos testiculares são de tal modo coalescidos que formam, em cada lado, um tubo único, de lume contínuo. Os espérmios apresentamse como massas enoveladas, não sendo produzidos espermatóforos.

A parede de cada testículo continúa, ao nível da metade caudal da faringe, com um canal estreito, dirigido para dentro e obliquamente para trás (Fig. 145, e). Os dois eanais são os dutos eferentes ("vasa deferentia" da literatura) que deslocam para baixo os graudes nervos longitudinais $(n)$, situados ventralmente aos dutos eferentes. Com a unificação do testículo são suprimidos os numerosos dútulos eferentes ("vasa efferentia", Bresslau 1933, p. 134; também chamados de "dnetus efferentes"), evacuadores dos folículos separados na maioria dos Paludicola. Os dutos eferentes apresentam reticulações na região em que passam por bạixo dos ramos pares do intestino (i), e, novamente, no espaço postfaríngeo. Aí, dilatam-se os dutos eferentes, formando, cada um, uma vesícula seminal (falsa), que se reunem numa ímpar, extra-penial (Fig. 
152, f). O epitélio das vesículas seminais falsas é sincicial, chato e pobre em núcleos.

Da vesícula seminal extra-penial ímpar, sae o duto seminal, que é curto, em conformidade com a pequenez do pênis (Fig. 149, p). o duto seminal dilata-se, dando origem a uma exígua vesícula seminal intrapenial (verdadeira) (v), revestida, como o duto, por epitélio cilíndrico, ciliado, e de limites intercelulares nítidos.

O pênis cônico, cujo bulbo é regularmente musculoso, salienta-se' para dentro do átrio masculino cordiforme. $O$ epitélio que reveste o pênis é destituido de limites intercelulares; é chato e de núcleos escassos. Contrasta, destarte, com o revestimento do átrio masculino (a), formado por células altas, aproximadamente claviformes, e dispostas anfractuosamente.

2) Õrgãos femininos: Os ovários (germários, Fig. 147, 153, o) situam-se perto do nível do tercéciro divertículo do ramo intestinal ímpar. Pela sua .transparência, destacam-se nos vermes viventes. Os vitelários (d) atingem o cérebro, havendo, portanto, vários folículos pré-ováricos. Os ovovitelodutos $(\mathrm{w})$ correm internamente aos dois nervos ventrais. longitudinais $(\mathrm{r})$. Para trás, estendem-se os vitelários até a região terminal dos testículos. A evacuação dos vitelários da metade caudal do corpo realiza-se, em cada lado, por um viteloduto especial, reunido, ao ovoviteloduto anterior, no ponto em que êste se encurva para dentro. (Fig. 145, 152). Surge, assim, uma bifurcação do duto feminino, única entre os Tricladida (veja p. 141).

$\mathrm{O}$ ovoviteloduto e o viteloduto são ciliados ao longo de tôda a sua estensão. $\mathrm{O}$ ovoviteloduto dilata-se um pouco, à altura do ovário (Fig. 153), apresentando-se, aí, como funíl repleto de espérmios. A parede do saco ovárico é formada por células chatas com núcleos pequenos. Onde estas células marginais ("Randzellen") passam às do oviduto (região da chamada tuba), são os núcleos mais volumosos e cerradamente dispostos. Para diante, estreita-se o ovo-viteloduto, que, nesta zona, se torna exclusivamente viteloduto. Supre, aí, pelos funís vitelinos, os folículos: pré-ováricos do vitelário. Os mesmos funís vitelinos encontram-se no viteloduto, que evacua'os vitelários caudais.

Os dois dutos femininos, igualmente ciliados, reunem-se dorsal e caudalmente ao órifício genital (Fig. 146, r). Da união dêles, origina-se o ovoviteloduto comum $(\mathrm{m})$, que se abre no átrio comum $(\mathrm{u})$, e recebeas desembocaduras das glândulas da casca eritrófilas (g). Os citosomas. piriformes destas glândulas vêem-se, desde a região das falsas vesículas: seminais até o espaço inter-intestinal, atrás da bursa (Fig. 152).

Do átrio comum, revestido por epitélio semelhante ao do átrio masculino, sae, para trás, um canal ciliado, o canal ("Stiel", "stalk") da bursa (Fig. 149, c). Ele dilata-se e forma a empôla da bursa (b) (chamada, na literatura, também simplesmente de bursa), esta sem cílios. Em cortes. das fases sucessivas do desenvolvimento do sistema reprodutivo, podeser acompanhada a aproximação da bursa ao intestino (Fig. 150), seguida pelo contato dos epitélios bursal e intestinal (Fig. 146). Nos vern!es sexualmente maduros, tornam-se os lumes da bursa e do intestino amplamenteentínuos (Fig. 145, 149, 152). 
Os testículos tubulosos, os dutos femininos bifurcados, a bursa dirigida para trás e a comunicação bursa-intestinal (veja ainda p. 139) perfazem um conjunto anatômico deveras estranho entre os Tricladida Paludicola.

Os casulos ovulares teem de diâmetro 0,7-0.9 mm. São desprovidos de pedúnculo e brancos, enquanto ainda no átrio. Depois da ovipostura, são vermelhos-escuros, lembrando os ovos de desenvolvimento lento de Mesostoma ehrenbergii. No decorrer de alguns dias, tornam-se sempre mais escuros, acabando completamente pretos.

\section{, Procedência de Rhodax evelinae}

o material foi encontrado em várias localidades dos arredores e subúrbios da cidade de São Paulo, p. e., na lagôa da Corôa, no bairro de Canindé, en água poluida, rica em matéria orgânica e pouco movimentada; no rio Tietê, perto do bairro de Limão, em água igualmente abundante em substâncias orgânieas, mas, com correnteza pronunciada; em córregos de água limpa e de correnteza rápida, do tipo de riachos da serra, nas zonas de Tremembé (capoeira da Cantareira) e de Butantan (afluentes do rio Pinheiros), e nágua estagnada limpa (brejos de Butantan).

Quando bem alimentada, mantem-se Rhodax evelinae durante 18 meses no aquário, reproduzindo-se por divisão e sexualmente.

\section{Divisão de Rhodax evelinae}

$\Lambda$ espécie multiplica-se, principalmente, por divisão (Fig. 151). A fenda bilateral, que precєde à separação, situa-se bem caudalmente à faringe e também ainda atrás dum aparelho copulador eventualmente presente. Nos vermes observados durante um ano no aquário aparecia sòmente um primórdio dum novo zoóide, mas, os cortes revelaram, às vêzes, duas constrições e, destarte, dois zoóides esboçados. O mais desenvolvido era sempre o caudal. Os dois primórdios abrangiam ca. de dois - quintos da longura total da cadeia. Em agosto de 1945, elevou-se a temperatura invulgarmente $\left(22^{\circ} \mathrm{C}\right.$., no aquário). Dispusemos, além disso, de alimentação especialmente abundante, a saber, de massas de Naididas (Aulophorus furcatus) e Tubificidas (Limnodrilus hoffmeisteri), oferecidas em estádio picado. Nestas condições, acelerou-se a divisão de Rhodax evelinae de tal modo que a segunda fenda de divisão se esboçou, como constrição externamente visível, antes da individualização do zoóide caudal. A 2." fenda divisória situa-se caudalmente à faringe do zoóide anterior e anteriormente à $1 .^{\mathrm{a}}$ constrição. No tipo divisório regular, i. é, na bipartição, abrange o primórdio do novo zoóide um quarto até um terço do comprimento total do verme em brotamento.

O desatamento realiza-se dẹpois de se ter, durante pelo menos dois dias, apresentado a constrição mencionada, referindo-se tal indicação à temperatura dágua de $23^{\circ}$. Os órgãos do zoóide posterior, como cérebro, olhos, faringe, etc., diferenciam.se sòmente depois de sua individualização. Como, porém, as células formadoras (regeneradoras; substituintes; neoblastos) se acumulam na cadeia ainda coerente. o tipo divisório deve ser classificado como paratomia precoce (Marcus 1943, p. 134). 
A constrição, que inicia a divisão e progride dos dois lados simètricamente em direção à linha mediana, distingue à paratomia precoce "de Rhodax evelinae dos tipos divisórios observados na maioria dos Paludicola (Stringer 1909, p. 259; Child 1913 ; 1914; Vandel 1922, p. 375 e seg.; Sekera 1925; Castle 1927; 1928: Beauchamp 1932, p. 294; Kenk 1944, p. 25-26; e muitos outros). Nêstes, fragmenta-se o rerme, às vêzes, multiplamente, ou desprendem-se pequenos pedaços da extremidade caudal que se arredondam formando cistos de muco (Phagocata velata, Ph. vernalis). Tôdas estas divisões são arquitômicas; realizam-se sem preparação regenerativa ou, em certos casos, depois da perda do pigmento e de processos histolíticos (Castle 1928, p.: 418,454 e seg.; Beauchamp 1,931, p. 1003 ; 1932, p. 297; Kenk, 1. e.).

A falta de zoóides pré-estabelecidos, nas arquitomias aludidas, levou Steinmann (1916, p. 3255-57) e Vandel (1922, p. 386 e seg.) a discordar da teoria de Child (1941, p. 42-43, 321). Elaborada em estudos contínuos (Child 1906, p. 114-115, $123 ; 1910$, p. 163,$170 ; 1911$, p. $309-316 ; 1912$, p. $6 ; 1913$, p. 196) a dita teoria atribue a individualização duma extremidade caudal da Planariida à isolação fisiolo. gica, provinda do crescimento longitudinal. Este levaria, segundo Child, o zoóide posterior a uma distância tão grande do zobide anterior e dominante que o posterior, com isso, subtrair-se-ia à influência do anterior. Steinmann chamou a teoria de Child de "teoria de mala", pois poderia ser tirado da mala o que se colocou para dentro dela. O sentido da objeção de Vandel é o mesmo, quando diz ter Child concebido a sua opinião d'antemão e serem as suas experiências apenas verificaçốes a posteriori. Convem, porém, frisar a polifaringia de várias espécies, p. e., de Phagocata gracilis, Ph. woodworthi (Hyman 1937, p. 302, 305), de Sphalloplana mohri Hyman (1939a, p. 276), da família Kenkiidae Hyman (1937a, p. 473), e de outras (Bresslau 1933, p. 95), como também a quadruplicação do aparelho copulador de Dugesia dorotocephala (Kenk 1935a, p. 446 fig. 1). Estes fenômenos foram interpretados como indices da existência de zoóides, cuja separação não se realiza, apesar da regeneração paratomicamente antecipada dos seus órgãos (literatura principal: Mrazek 1904, p. 36-39; Heider 1909, p. 584-586; Mrazek 1914, p. 265-276; Steinmann 1916, p. 3303 ; Kenk 1935a, p. 449-452; 1941a, p. 67). O valor selectivo da supressáo da paratomia (Steinmann 1908, p. 9-11) não discutimos aqui.

Em Rhodax evelinae, seria, possivelmente, viável examinar "teoria de.Child cortando o cérebro do zoóide anterior nos primeiros indícios da futura divisão .ou eliminando, por anestesia, o centro nervoso dominante.

Dugesia paramensis (Fuhrmann 1914, p. 798), talvez D. mertoni (Steinmann 1914, p. 116-117), e Planaria fissipara Kennel (1888, p. 468) são os Tricladida paratômicos, ao lado de Rhodax evelinae. Em $D$. paramensis situa-se o plano divisório prêfarìngeamente (l. c., t. 18 f. $3-4$ ); em $D$. mertoni, no meio da faringe. Destas duas espécies, conhece-se sòmente material conservado. Em Planaria fissipara, originam-se - cérfbro com os olhos e a faringe, inclusive a bôca, no zoóide posterior antes de sua individualização (l. e., t. 18 f. $5,19-20$ ).

Reside na paratomia completa de Planaria fissipara a única diferença de Rhodiax evclinae, com paratomia precoce. De resto, concordam as duas espécies tão bem que ponderámos até aplicar o nome mais antigo. Tal, porém, parece prematuro antes da re-examinação da fauna dos Pạludicola de Trinidad. Por enquanto, ignoram-se as gônadas de Planaria fissipara, e, por isso, nem mesmo é possível saber se pertence ao gênero Rhodax.

\section{Divisão e reprodução por células germinativas em Rhodax evelinae}

Baseado nas suas experiências e nos resultados da literatura, correlacionoun Vandel (1922, p. 485-488) a reprodução regetativa 'com um estádio ("structure". Vandel) não diferenciado; a sexual, com o máximo de diferenciaçắo. A fase sexuada inhibe, segundo Vandel, provisoriamente a" divisibilidade ("réflexe de scisstion" Vande]), mantendo-a latente. No verme reconduzido ao estádio não diferenéiado, manifesta-se, novamente, o reflexo de cisão. Convẹ lembrar. que tôdas as éspésies 
manipuladas por Vandel e os predecessores dêle são. Tricladida arquitômicos, pois de Planaria fissipara, Dugesia paramensis, e D. mertoni conhecem-se sòmente espécimes conservados.

Vimos, de Rhodax evelinae, as gônadas, até agora, apenas nos nossos aquários, não em vermes capturados na natureza. Apareceram, principalmente, nas culturas alimentadas, de novembro de $1944 \mathrm{em}$ diante, com pedaços cortados de Oligochaeta (Naididae dos gêneros Dero e Pristina, e, nomeadamente, Nais paraguayensis). Algumas vêzes, formaram-se gônadas também em habitantes de aquários sem acréscimo de alimentos. Os primeiros animais sexuados foram obtidos em meados de março de 1945 ; os últimos, na segunda metade de junho. Os resultados negativos das poucas excursões, que conseguimos realizar na dita época, absolutamente não provam a ausência de gônadas na natureza. Possivelmente, multipliea-se Rhodax evelinae, durante a'époea quente, por divisão e, no outono e inverno, por células reprodutivas. A questão continúa ainda aberta.

Não houve, nos vermes sexuados, no aquário, interrupção da reprodução vegetativa durante a fase sexuada. Até alguns dias antes da ovipostura dividiram-se os vermes. Na individualização, levaram os zoóides posteriores, agora indivíduos incompletos (sem cérebro, olhos, faringe, etc.), testículos com espérmios maduros e vitelários consigo. Resta ainda pesquisar se os rebentos completam o sistema reprodutivo ou o desdiferenciam.

A interrupção da propagação vegetativa pela formação dos órgãos sexuais nos Trícladida Paludicola arquitômicos.: e a simultaneidade dos dois processos, pelo menos até a fase média do desenvolvimento das gônadas, em Rhodax evelinae, espécie dos Paludicola de paratomia precoce, teem paralelos nótaveis nas Aeolosomatidae e Naididae vistas por nós. Em Nais paraguayensis, que se divide arquitomicamente, acaba a fragmentação, quando as gônadas se desenvolvem. Espécies paratômicas de Aeolosoma (du Bois-Reymond Mareus 1944, p. 6; Mareus 1944, p. 44), de Dero (id. 1943 , p. 38), e de Aulophorus (ibid., p. 83, aí literatura com observações, em parte, discordantes) continuam a dividir-se ainda $\mathrm{em}$ fase média da formação dos órgãos reprodutivos.

\section{A ligação bursa-intestinal}

Merece consideração especial a comunicação entre a bursa e o intestino em Rhodax evelinae. De nove exemplares examinados a respeito, abre-se a bursa 6 vêzes no ramo intestinal posterior direito, 3 vêzes, no ésquerdo. Nos vermes jovens, esboça-se a bursa, perto do átrio, sem sé comunicar com o intestino (Fig. 150). Nos animais adultos, distinguem-se, nitidamente, o epitélio não aprofundado, ciliado, do canal da bursa, o epitélio mais alto, não ciliado, da empôla da bursa, e o granuloso do intestino (Fig. 152, b, i). Foram vistos espérmios no canal e na empôla da bursa dos vermes maduros; com isso. torna-se verosímil a passagem dos gonócitos masculinos ao intestino.

Em comparação com os Rhabdocoela e Alloeocoela mencionados na discussĩo de Baicalellia evelinae (veja p. 30), são raras as comunicą̧ões gênito-intestinais entre os Tricladida. Dos Maricola, durante muito tempo sẹ referência correspondente (Meixner 1926, p. 605), conhece-se agora o canal bursa-intestinal (10, nas figuras 243 b, 2430 de Bresslau 1933, .p. 245) de Miroplana trifasciata Kato (1931, p. 
365-366). Dos Terricola, descreveu Beauchamp (1930, p. 727-737) dutos gênitointestinais muito especiais.

Dos Paludicola, conhecem-se comunicaçōes gênito-intestinais: a) das Planariidae Curtisia foremanii (Kenk 1935, p. 80-82); Geopaludicolia absoloni (Komarek 1919 , p. 38 ; 1920, p. 825 ; Steinböck 1924, p. 490-491); e Dugesia nonatoi, spec. nov. (Fig. 169); e b) das Dendrocoelidae Dendrocoelum carpathicum (Beauchamp 1932, p. 159); D. sphaerophallus (id. ibid., p. 164); D. adenodactylum (p. 210); Microden. drocoelum parisi (p. 248); e Acromyadenium maroccanum (p. 254). Tôdas as espécies enumeradas são Probursalia típicos, quer dizer, possuem bursa situada anteriormente ao pênis. Além disso, diferem ainda os pormenores das suas comunicaçōes gênito-intestinais da encontrada em Rhodax evelinae. Nas duas primeiras espécies das Planariidae mencionadas, falta a bursa pròpriamente dita, i. é, a empôla, comunicando-se o eanal ("stalk", "Bursastiel") com o intestino. Dá-se o mesmo com $A$. maroccanum. Nas Dendrocoelidae restantes, existe a bursa, mas, toca-se apenas com o intestino. Apesar da contiguidade íntima dos tecidos, não há continuidade entre o lume da bursa e o do intestino. O caso não esclarecido duma espécie de Sorocelis. (Meixner 1928, p. 583) deixamos de lado.

Reisinger descreveu a função resorvente da bursa de Bresslauilla rẹlicta (1929, p. 62 e seg.). Perto do poro gênito-intestinal, no fundo caudal do saeo intestinaI, ocorrem, no sincício digestivo, vacúolos com espérmios. A cópula realiza-se, provavelmente (l. e., p. 58), por via oral, e, destarte, funcionaria a parede eaudal do intestino oomo bursa seminal e resorvente. A analogia é indiscutível. Está igualmente provado que a comunicação gênito-intestinal funciona como oviduto em Bresslanilla relicta; Ethmorhynchus anophthalmus Meixner 1938 (p. 70); e Baicalellia evelinae (Fig. 20). Não está provada: a) a primitividade das espécies enumeradas, das quais a primeira, p. e., tem ovírio assimétrico; b) a origem filogenèticamente intestinal da bursa, que executa, entre outras funções, a de fagocitar o excedente de espérmios, células vitelinas e secreção granulosa ou de conduzílo ao intestino.

Ontogenèticamente, independe a bursa do intestino. Atrio e bursa teem o material constituidor em comum (Vandel 1922, p. 458-459); Kenk 1923, p. 233-234; aí, literatura anterior). Simultaneamente com a formação do lume atrial, ou um pouco. antes, esboça-se o canal da bursa, anexo ao complexo das células do átrio. As células formadoras do canal originam-se no próprio lugar, por células indiferentes; não derivam, ao que parece, da acumulação do material formador do átrio. A empôla da bursa organiza-se duma aglomeração de células na extremidade ental do canal. São estas as observações de Kenk e os fatos que se depreendem dos desenhos de Vandel. Referem-se a estádios muito mais jovens que o da nossa Fig. 150. Relaçäo ontogenética entre o intestino e a bursa não existe nos Tricladida examinados a respeito (Bock 1927, p. 13; Beauchamp 1932, p. 140).

Dugesia nonatoi, com o seu duto bursa-intestinal enorme (Fig. 167), mostra a diferença histológica entre bursa e intestino tão nitidamente que a origem diferente se evidencia sem delongas.

A bursa dos Tricladida funciona, principalmente, como bursa copulatória (Hyman 1925 , p. 73 e seg.; Cernosvitov 1931, p. 314; Beauchamp 1932, p. 142), pois recebe, na copulação, os espérmios. Muitos dêstes migram, mais tarde, aos ovidutos (Steinböck 1926, p. 3; Cernosvitov, l. e.) onde se vêem na nossa Fig. 145 (w). Encontramos também massas enoveladas de espérmios próximos dos ovários de $R h$. evelinae (Fig. 153), no ovoviteloduto, e outras, bem longe caudalmente aos órgãos copulatórios, no viteloduto.

\section{A posição do gênero Rhodax no sistema}

Conservamos, como foi exposto precedentemente (veja p. 104), os Tricladida Lang (1884, p. 1) e os Seriata Bresslau (1933, p. 261) separados. Até há 20 anos, vigorou a sub-divisão dos Tricladida em três seções: 1) Maricola; 2) Paludicola; 3) Terricola, introduzida por Hallez $(1892$, p. 107). Apesar de possuir cada uma das ditas entidades peculiaridades anatômicas (Meixner 1928, p. 571), foram os nomes ecológicos criticados, dizendo, p. e., Wilhelmi (1909, p. 7) que lembram a distinção de animais terrestres, aquáticos e volantes na "História Natural" de Plinius. 
São, certamente, indistintos os limites entre os Paludicola e os Terricola, porque os áltimos precisam também de humidade. Existem, além disso, Turbelários em musgos e em humus húmidos (Reisinger 1924, p. 2). Geopaludicolia absoloni encontrada debaixo de pedras, numa caverna dalmática, e descrita, conseqüentemente, como pertencente aos Terricola (Komarek 1919, p. 32, 40; 1920, p. 824, 827), faz, anatômicamente, parte dos Paludicola. Entre êstes, deve ser classificada (Steinböck 1925 , p. 186). O Ǵltimo autor e Meixner (1928, p. 599, nota) supõem até que Geopaludicolia absoloni viva, por via de regra, nágua. Entre os Maricola e Paludicola interpõem-se espécies marinhas que entram nágua salobra, suportando, temporà. riamente, o meio límnico (Schmidt 1861, p. 18; Böhmig 1902;.p. 12; Steinböck 1925, p. 187). Dendrocoelum lacteum ocorre em águas fracamente salobras do mar Báltico (Beauchamp 1932, p. 332).

Nada disso e nem eventuais futuras verifícações ecológicas obstariam ao uso continuado dos termos de Hallez, que são designações sistemáticas, não definiçōes. Nomes sistemáticos devem ser conservados independentemente da sua conformidade com os conceitos morfológicos e filogenéticos de cada decênio. No caso contrário, realizado na sistematização dos Alloeocoela (veja p. 104), embarranca a taxonomia com dificuldades terminológicas.

Aos Terricola de Hallez correspondem os Diploneura de Steinböck (1925, p. 185). Nêstes, ocorre, separado do plexo nervoso cutâneo, um plexo nervoso do corpo, que contem os nervos ventrais longitudinais. Os Maricola e Paludicola constituem os Haploneura (ibid., p. 186), cujos nervos ventrais longitudinais se encontram, essencialmente (Bresslau 1933, p. 261-262), no plexo nervoso cutâneo; o plexo do corpo falta.

Steinböck chamou (1925, p. 187, 189) os Paludicola de Probursalia. Aproveitou-se dum caráter já verificado por Hallez (l. c.) : "utérus", quẹr dizer, bursa, "situé entre le pharynx et le pénis" O termo Probursalia foi bem acolhido (Kenk 1930, p. 289 ; Hyman 1931, p. 318) ; na monografia de Bresslau (1933, p. 282), figura como segundo nome dos Palu. dicola. O gênero Rhodax evidencia a precariedade da nova denominação. Segundo a posição da bursa, deveria Rhodax entrar nos Retrobursalia, i. é, uma das três secções dos Maricola, no sistema de Steinböck (1925, p. $189 ; 1926$, p. 3$)$. Os Retrobursalia correspondem à família Procerodidae. Desta, sòmente a subfamília Cercyrinae possue certas espécies com dutos eferentes ("vasa deferentia" da literatura) reunidos fora do bulbo penial. O aparelho feminino das Cercyrinae (Böhmig 1906, t. 18 f. 1; Wilhelmi 1909, t. 16 f. 12 ; Meixner 1928, p. 573 f. 1) difere tanto do complexo correspondente de Rhodax evelinae, que o confronto pormenorizado parece excusado. $O$ gênero Rhodax pertence aos Paludicola, apesar de não corresponder ao têrmo "Probursalia" Nêste sentido, ocupa posição tão especial quão Probursa veneris Hyman (1944, p. 6), entre os Maricola.

Dentro dos Paludicola, faz Rhodax parte das Planariidae, como foram definidas por Kenk $(1930$, p. 150-151, 290). Nesta família, formam as fibras anelares e longitudinais dos músculos faríngeos internos duas camadas distintas.

Os dutos femininos, porém, separam Rhodax de todos os gêneros das Planariidae. Não conhecemos tal tipo de ovovitelodutos anteriores e vitelodutos posteriores de quaisquer Tricladida. Nas espécies em que os vitelários se estendem caudalmente ao orifício genital, desembocam êstes nos ovovitelodutos, e isso, na região da flexão dos' dutos em direção à linha mediana (veja, p. e., Iijima 1884, p. 417 t. 20 f. 1). Indicações 
contrárias (Mattiesen 1904, p. 279 f. 1 no texto; Neppi 1904, t. 10 f. 15) foram corrigidas por Meixner (1928, p. 576, nota 5). Nomeadamente a rectificação do desenho de Valeria Neppi, cujas preparações foram vistas por Meixner, reveste-se agora de grande importância. $O$ ramo caudal do oriduto (viteloduto) de Dugesia schauinslandi (Neppi) foi publicado nüma tese de doutoramento de Graz, e, destarte, com tôdas as premissas imagináveis de fidedignidade. A dita espécie é a única dos Tricladida Paludicola conhecida da Nova Zelândia (Beauchamp 1939, p. 73). Sem a correção de Meixner, tal organização teria levado a discussões zoogeog'rá: ficas, no momento, em que o. mesmo caráter se verifica na nova espécie súl-americana. Não entre os Tricladida, mas, entre os Seriata Bresslau (= Proseriata Meixner) encontramos semelhanças. Otomesostorna e Bothrioplana (Hofsten 1907, p. 594-597, f. 6 na p. 582; p. 611-613; Bresslau 1933 , f. 252,253 ) possuem dutos femininos topogràficamente comparáveis ạos de Rhodax evelinae.

Os vitelários pré-ováricos da espécie atual seriam, segundo Meixner (1928, p. 578), outros caracteres que ligariam Rhodax aos Seriata.

Em vários pormenores aproxima-se $R h$. evelinae às espécies do gênero Phagocata Leidy (= Fonticola Komarek; Hyman 1937). Em Phagocata (Kenk 1930, p. 292293 ; Beauchamp 1932, p. 272-273) ocorrem espécies relativamente pequenas; na sua maioria, fracamente pigmentadas, sem tentáculos e aurículas e, freqüentemente, providas de área adesiva frontal. A relação entre os ovidutos e a bursa, a desembocadura das glândulas da casca no duto feminino comum e a ausência de órgãos músculoglandulares são as mesmas em Phagocata e Rhodax. Como Rh. evelinae, possuem muitas espécies de Phagocata os testículos estendidos quasi até a extremidade postẹrior: a ausêneia de túbulos coletores dos espérmios e a fusão dos testículos de Rh. evelinae lembram as disposiçōes de Ph. vernalis (Kenk 1944, p. 23, 27 f. 2), onde, porém, os testículos são curtos e restritos à zona pré-faríngea. A ausência do pedúnculo dos casulos ovulares, verificada em $R h$. evelinae, foi indicada também de'Ph. velata e Ph. morgani (Castle \& Hyman 1934, p. 163 ; Kenk 1944, p. 34). Os órgãos reprodutivos aparecem raramente nas espécies de Phagocata, das quais $P h$. vitia, $P h$. velata, $P h$. morgani e $P h$. vernalis se reproduzem por fragmentação. $P h$. albissima (Vejd.), mencionada nêste conjunto (Heider 1909, p. 582; Steinmann 1916, p. 3249,3259 ; Bresslau 1933, p. 218), parece não possuir a dita multiplicação (Beauchamp 1932, p. 313); as observações contrárias referem-se, evidentemente (ibid., p. 311 ), a $P$. vitta (A. Dug.).

Com a bursa situada caudalmente ao órgão copulador (Maricola), os dutos femininos bifurcados (Otomesostoma, Bothrioplana), e pré-ovàricamente estendidos (Seriata em geral), ao lado de vários caracteres concordantes com Phagocata, segundo Meixner (1928, p. 575, 579-580, f. 7), um gênero especializado, revela-se Rhodax como tipo morfològicamente colectivo, que reune sinais tidos por primitivos com outros, secundários.

\section{Genus: Curtisia Graff 1916}

Planariidae cujos dutos femininos desembocam no trecho ectal (distal) do canal da bursa, entrando on na forma de dois ovovitelodutos ou na dum ovoviteloduto comum, formado pela reunião dos 2 ovovitelodutos que se realiza caudalmente ao canal da bursa. Os testículos são dorsais, pouco numerosos e estendem-se, para trás, não além do nível da empôla da bursa.

Tipo do gênero: Curtisia foremanii (Girard 1852). 
Baseada na exposição de Carohine Stringer (1918, p. 355), a. Dra. 'L. H. Hyman (1931, p. 322). estabeleceu o genótipo. A diagnose genérica foi emendada por. Kenk $(1930$, p. 290). O gênero distingue-se pouco de Dugesia, como foi salientado por Beauchamp (1940, p. $314 ; 1940 \mathrm{a}$, p. 8). A espécie aquí em mã̉os diminue ainda mais a pequena diferença, pois posssue testículos mais numerosos do que as outras espécies de Curtisia, embora sejam em numero menor que em Dugesia. As 4.espécies de Curtisia até agora conhecidas, três sul-americanas e uma norte-americana, loderiam ser determinadas pela chave seguinte:

1 Os testículos estendem-se, para trás, até a base (raiz) da faringe

- Os testículos estendem-se, para trás, até a região dos ramos pares, posteriores do intestino $\ldots \ldots \ldots \ldots \ldots \ldots \ldots \ldots \ldots \ldots \ldots$

2 Os dois ovovitelodutos desembocam no canal da bursa ...... patagonica (Borelli 1901, p. 1)

- Os dois ovovitelodutos formam um ovoviteloduto comum (impar) que desemboca no canal da bursa (Meixner 1928, p. 574, legenda da f. 4) ............ michaelseni (Böhmig 1902, p. 20)

3 Auriculas inconspícuas; 1 -6 folículos testiculares; um ovoviteloduto

$\because \ldots \quad$ comum desemboca no canal da bursa; ocorre comunicação bursa-

$\because \ldots \quad$ comum desemboca no canal da bursa; ocorre comunicação bursa-

$:$ - Aurículas conspícuas, cuspidatas; mais de 6 -folículos testiculares; os ovovitelodutos permanecem separados até a desembocađura; não ocorre comunicação bursa-intestinal ........ schubarti, spec. nov.

De Planaria ambigna Böhmig (1902, p. 23) conhece-se apenas material imaturo; possìvelmente, pertence ao gênero Curtisia.

\section{Curtisia schubarti, spec. nov. (Fig. 154, 156-157, 160-161, Est. XXXI Fig. 6)}

Vermes sexualmente maduros teem, quando viventes, $20 \mathrm{~mm}$. de eomprimento e $\mathbf{2 , 5} \mathrm{mm}$. de largura máxima. Depois da conservação, con "Susa" quente, as medidás correspondentes são $14 \mathrm{~mm}$. e $3 \mathrm{~mm}$. Os vermes apresentam-se como massiços, fortemente achatados, e de ponta anterior cuspidata. Ao longo de todo o corpo, os dois lados são paralelos. A cauda estreita-se sucessivamente; a cabeça é bulbiforme. $O$ ângulo anterior da última tem menos de 60 graus. As aurículas são.duas vêzes mais compridas que largas, de côr mais clara que o corpo restante, de cujo contôrno proeminam particularizadas desde as suas bases. Os olhos pequenos são sob-postos a halos claros, equidistantes um do outro e do bordo lateral. A côr do dorso é ocre com uma estria escura ao longo do. corpo inteiro. A faringe é pigmentada na raiz; na parte ectal, provida de manchas escuras sôbre fundo branco. O ventre é mais claro e, nêle, destacam-se como especialmente claros os nervos ventrais longitudinais, a bôca, e o gonóporo.

A epiderme dorsal é duas vêzes mais alta que a ventral (Fig̣. 160, r, s) atingindo as células 0,030 e $0,016 \mathrm{~mm}$. de altura respectivamente. Também as massas de pigmento, situadas. no grosso tubo músculo.dermático e no parênquima, são dorsalmente mais rolumosos que no ventre. Na cabeça, ocorrem as glândulas adesivas eosinófilas, mas, nenhum órgão frontal especial. As aurículas carecem de rabditos numa área dorsal; possuem-nos pequenos e ventrais. A lita área, o órgão sensorial auricular, caracteriza-se, além disso, pela epiderme aprofundada e por células ganglionares subjacentes, que perfazem um lóbulo lateral do cérebro. 
A faringe começa algo antes do limite entre o segundo e o último têrço. A bôca (Fig. 156, b) encontra-se anteriormente à extremidade caudal da faringe, no limite entre o terceiro e o último quarto. $O$ poro genital (g) aproxima-se mais à boca do que à ponta caudal. 0 intestino (Fig. 156, i) ricamente ramificado ultrapassa, anteriormente, o nível dos olhos; na região atrás do aparelho copulador, ocorrem anastomoses entre os dois ramos pares do intestino.

Os testículos (Fig. 156, t), mais numerosos que nas outras espécies do gênero, estendem-se, no dorso, da zona post-ovárica até o nível da bursa (u). Podem ocorrer até 12 grupos de 1-5 folículos, havendo, frequientemente, assimetrias numéricas e topográficas nos lados direito e esquerdo. Os folículos dum grupo são, às vêzes, ligados entre si, por coalescência parcial da túnica testicular; outras vêzes, são separados e perfazem o efeito dum grupo apenas em consequiência dos ramos intestinais interpostos. A túnica de cada folículo forma, ventralmente, o canal estreito do dútulo eferente (Fig. 160, e). Pela reunião dos dútulos origrinam-se os dois dutos eferentes (Fig. 156, 160, d) ou espermiodutos. Correm na metade ventral do corpo, dorso-medialmente aos ovovitelodutos (Fig. 160, v) e aos nervos longitudinais ventrais (n). Alargam-se na região bucal, formando vesículas seminais extra-peniais ("fảsas") enoveladas. Um pouco rostralmente ao nível do gonóporo ( $\mathrm{g}$ ), recurvam-se para diante e entram no bulbo do pênis (Fig. 156, p). Aí se dilatam e dão, assim, origem a duas vesículas seminais intra-peniais esvaziadas pelo largo duto ejaculatório fortemente musculoso, que se abre na ponta da papila penial.

O pênis (Fig. 157) é bastante grande e mais comprido que largo. A papila penial é coberta por epitélio de núcleos aprofundados; mais para dentro, continúa o epitélio externo com disposição regular dos núcleos, dando-se o mesmo com o revestimento do lume penial e o do átrio masculino ( $p, e)$. O último comunica-se com o átrio comuin (a) por um canal estreito.

Os ovários (Fig. 156, o) volumosos, ora arredondados, ora um pouco lobulados, situam-se ventralmente, médio-dorsalmente aos nervos longitudinais ventrais (Fig. 161, n) e atrás dos ramos anteriores do intestino (Fig. 156, i). Em séries cortadas transversalmente, aparecem em até 30 cortes sucessivos, de 8 microns cada um. 0 parênquima forma ao redor do ovário um envoltório de células tênues (Fig. 161). Entre os ovócitos crescidos, observam-se pequenas células do estroma. O ovoviteloduto (v) entra na superfície dorso-lateral do ovário, formando-se aí, na chamada tuba, um aparelho obturador (Castle \& Hyman 1934, p. 158) constituido por células claviformes, associadas a fibras musculares (m).

Os vitelários (Fig. 160, x) começam, em vermes jovens, no lado ventral, e estendem-se, no auge da época reprodutiva, até o dorsu. Começam anteriormente aos ovários e atingem quasi a extremidade caudal. Mesmo entre as células vitelinas de vitelários completamente crescidos (Fig. 154), conservam-se algumas células não diferenciadas do caracter das células formadoras ("Stammzellen"), não das ovogônias. Não se trata de vestígio de germo-vitelário, como foi mencionado de Curtisia foremanii (Bresslau 1933, p. 137). Na fase jovem, observa-se cada grupo 
de células vitelinas separado do ovoviteloduto por uma volumosa célula obturadora; que involue na época da ovipostura (Iijima 1884, p. 416). Originam-se, então, os infundíbulos vitelinos, em cujos lumes se veem novelos de espérmios (Fig. 154, 160, p), possivelmente aquí alimentados pelo vitelo.

Os ovovitelodutos ciliados (Fig. 154, v) vindos dos dois lados desembocam separadamente, no ponto em que o canal (k) da bursa, provido de cílios, se comunica com o átrio (a), não ciliado. As glândulas da casca (c) fortemente eosinófilas derramam a sua secreção ectalmente ao dito ponto. Na região das desembocaduras das glândulas argamassadoras (y), fracamente ęosinófilas, dilata-se o átrio (a); e isso, tanto para os lados direito e esquerdo (Fig. 156), quanto para diante e para trás (Fig. 157). Do epitélio atrial destaca-se um trecho de células altas, situado entre os divertículos aludidos e o gonóporo $(\mathrm{g})$. $\mathrm{O}$ epitélio do canal da bursa (k) é, em parte, aprofundado. Os citosomas nucleados situan-se abaixo da musculatura do canal, que é forte e principalmente composta por fibras anelares. Mais para baixo ainda, encontram-se as glândulas cianófilas, cujos dutos atravessam a musculatura e o epitélio do canal. A empôla musculosa da bursa (Fig. 157, u) é muito volumosa e, em oposição à de $C$. foremanii, sem comunicação com o intestino. Preenche tôda a região entre o pênis e a bolsa faríngea $(h)$. $O$ epitélio da empôla consiste em células claviformes com núcleos basilares e vacúolos distais. Entre o canal e a empôla da bursa nota-se um esfincter grosso.

\section{Ocorrência de Curtisia schubarti}

A espécie denominada em honra do primeiro eolecionador, Dr. Otto Schubart, foi encontrada, até agora, sòmente em águas de regiōes montanhosas. As localidades atualmente verificadas são: 1) Serra da Mantiqueira, região do Itatiáia (Estado do Rio de Janeiro), a $900 \mathrm{~m}$. e $1830 \mathrm{~m}$. de altitude, havendo, no mês de novembro, vermes sexualmente maduros. 2) Umuarama, município de Campos de Jordĩo (Estado de São Paulo: serra da Mantiqueira), $1750 \mathrm{~m}$. Houve vermes sexuados no mês dés janeiro. Os vermes foram especialmente comuns num trecho de correnteza rápida que liga as duas partes da reprêsa de Umuarama, mas, ocorreram também na margem: da própria reprêsa, nágua pouco movimentada. A julgar pelos lugares em que os vermes se mantecm, durante o dia, são negativamente fototácticos e, como todos os Paludicola, positivamente tigmotácticos. 3) Na serra da Cantareira, perto da cidadè de São Paulo, obtivemos, em maio, grande população de vermes imaturos, a cá. de $900 \mathrm{~m}$. de altitude. 4) Um exemplar sexualmente maduro foi colecionado na região de Monte Alegre, a ca. de $700 \mathrm{~m}$. de altitude perto de $100 \mathrm{~km}$. ao norte da cidade de São Paulo. aquário.

¿. Divisão arquitômica ocorreu em material mantido durante várias semanas nó

\section{Genus: Dugesia Girard 1850}

Planariidae cujos dutos femininos desembocam no canal da bursa ou separadamente ou com um curto trecho unido. Os testículos numerosos estendem-se até atrás do aparelho copulador. $O$ pênis é provido de papila externa e de bulbo interno; no último, entram os dois dutos eferentes ("vasa deferentia", da literatura) independentemente um do outro. 
A cabeça, de contôrno triangular, possue aurículas laterais. Além dos dois olhos principais, podem ocorrer ainda olhos secundários. O corpo é, pelo menos no dorso, pigmentado, sendo os grânulos de pigmento incluidos em células periféricas do parênquima. Órgãos músculo-glândưlares (adenodáctilos) faltam na grande maioria das espécies. Os casulos ovulares são pendunculados nas espécies de que êstes sé conhecem. Nas espécies americanas descritas até agora, dilatam-e os dutos eferentes no bulbo penial, formando aí duas vesículas seminais (Kenk 1941, p, 7).

'Tipo do gênero: Planaria gonocephala Dugès (1830, p. 83 t. 2 f. 22).

Depois das exposições de Hyman (1939, p. 264-265), impõe-se substituir, sem discussã.o ulterior, Euplanaria Hesse (1897, p. 549), por Dugesia Girard (1850, p. 265).

O gênero abrange, atualmente, ca. de 35 espécies espalhadas em todos os continentes, inclusive a Austrália e a Nova Zeelândia. Beauchamp (1939, p. 72) distinguiu três tipos estruturais de vesículas seminais, dois no velho mundo, representados por D. gonocephala (Dugès 1830, p. 83) e D. lugubris (O. Schmidt 1861a, p. 91), c um terceiro, nas Américas.

\section{Dugesia tigrina (Girard 1850) (Fig. 155, 158, 159, 162, Est. XXXI} Fig. 7-12)

Referências principais:

Planaria maculata Leidy 1848, p. 251 (non Planaria maculata Fabricius; nec Darw̧in ; ef. Kenk 1935, p. 84)

Dugesia maculata Girard 1850, p. 264 ; id. 1893 , p. 181 t. 6 f. $51-58$

Planaria tigrina Girard 1850, p. 264

Planaria maculata Woodworth 1896, p. $240 ; 1897$, p. 8 f. 2,3

Planaria maculata Curtis 1902, p. 515 e seg. t. 9-19

Planaria lata Sivickis 1923, p. 114-117 f. 2, 4, 6, ete.

Euplanaria maculata Hyman 1931, p. 325

Euplanaria novangliae Hyman 1931, p. 326 t. 33 f. 8

Euplanaria tigrina Kenk 1935, p. 83 f. 2,16

Euplanaria tigrina Beauchamp 1939, p. 70-71

Dugesia tigrina Hyman 1939, p. 266 f. 1-6

Dugesia tigrina Kenk 1944, p. 13 t. 1 f. 2,3

Caracteres externos: Exemplares sexualmente madû̀ros medem de comprimento $6-18 \mathrm{~mm}$. e de largura $1.3 \mathrm{~mm}$. Espécimes não maduros podèm atingir até $25 \mathrm{~mm}$. Os vermes pequenos são esbeltos, caudalmente estreitados; os sexuados são mais robustos, mas, igualmente, de cauda cuspidata. No animal que deslisa calmamente, apresenta-se a cabeça como. de contôrno triangular, sendo o ângulo anterior, conforme a atividade muscular do verme, mais cuspidato (Est. XXXI Fig. 12) ou mais arredondado (Fig. 7). Quando se adelgaça a cabeça, chega a formar um ângulo de $60^{\circ}$, na extremidade anterior, sendo tal o mais agudo que vimos cm D. tigrina. $\Lambda$ s aurículas, que marcam os ângulos laterais, sãc curtas e largas. Por contração podem desaparecer e, então, o contôrno da cabeça pode tornar-se rectangular. Ambas as aurículas, ou uma delas. erigem-se, durante a locomoção, por via de regra, do substrato; nesta posição, apresentam-se ligeiramente encurvadas.

A côr varia largamente quanto aos tons e à intensidade, sendo também diversos os tipos do desenho que resultam da disposição do pigmento (Fig. 7-12). A côr pode, p. e., ser avermelhada, acastanhade-dourada, castanho-escura, ou quasi preta. Ligeiras tonalidades violáceas e roxas ocorrem. O mesmo indivíduo pode mostrar côr amarelada e vários tons 
acastanhados, pardos e quasi negros. No dorso, reconhecem-se, muita vêzes, manchas, a olho nú, mas, ocorrem também exemplares, cujas manchas se vêem sòmente com auxílio da lupa. Freqüentes são ainda outros tipos de desenho, como a reticulação, o listrado, e a granulação. Nas populações vistas por nós, os vermes reticulados ou listrados são os mais comuns. Os reticulados possuem uma rêde de células pigmentadas acastanhadas, pardas ou amareladas, entre as quais se destaca o parênquima não pigmentado em forma de pontos brancos. Em indivíduos jovens, mas, também em adultos, cada mancha pigmentada pode corresponder a um cromatóforo, de $0,0250,03 \mathrm{~mm}$. de diâmetro. Podem também confluir várias células pigmentadas e compor mancha de $0,1 \mathrm{~mm}$. de diâmetro. Nos vermes histrados, ocorre, em cada lado da linha mediana dorsal, uma estria acastanhada escura, contínua ou interrupta. A côr da linha mediana varía: pode repetir a côr geral do fundo, ou ser mais clara que êste, ou ainda carecer de pigmento, mostrando-se branca. Por via de regra, os vermes da mesma localidade possuem o mesmo desenho geral, e diferem entre si sòmente com respeito aos gráus de claridade, que dependem do estádio alimentício (veja discussão, p. 149). Ocasionalmente, encontramse também vermes reticulados (manchados) e listrados no mesmo lugar. Na metade caudal das aurículas, i. é, na zona das covinhas sensoriais, como também nos pontos sobrepostos aos olhos, falta sempre o pigmento; as manchas brancas supra-oculares são, nos seus bordos, denteadas. A face ventral é mais ou menos intensamente cinzenta, em todo o caso, mais clara que a dorsal. Pigmentos no parênquima ventral não são freqüentes, devendo-se, geralmente, a côr do ventre aos pigmentos dorsais, que transluzem. Freqüientemente, destacam-se, ao longo do ventre, duas linhas brancas, cuja posição corresponde à dos nervos ventrais longitudinais (Fig. 8).

Os dois olhos normalmente presentes situam-se um pouco rostralmente ao plano transversal determinado pelas pontas das aurículas. A distância entre os dois olhos importa num quinto ou num quarto, aproximadamente, da largura cefálica total, medida ao nível dos olhos. A faringe reconhece-se, as mais das vêzes, bem, e isso, tànto do dorso quanto do ventre. Afora a zona oral da faringe, sem pigmento, êsse órgão possue pigmentação cinzenta; a estensão da parte não pigmentada varia de um quinto a um terço da longura total da faringe. Quando há, no dorso do verme, malhas cerradas, escuras, ocorrem igualmente manchas na faringe. Em espécimes de colorido mais uniforme, é a faringe também uniformemente cinzenta. 0 comprimento da faringe, em proporção com o corpo, varia muito, nomeadamente, nos períodos de reprodução agâmica.

$\therefore$ Caracteres internos: O intestino dos vermes de São Paulo fartamente alimentados com fígado picado e carvão granulado "Merk" ressaltase e assume o aspecto da Fig. 155. Troncos longitudinais acessórios, presentes nos ramos intestinais anterior e posteriores dos vermes desenhados por Curtis (1902, t. 9-11), não vimos nos nossos exemplares; tal diferença é taxonômicamente insignificativa. Anastomoses transversais que reunem os dois ramos pesteriores ocorrem em $60-70 \%$ do material de São Paulo. Anastomoses situam-se ém regiões diversas, e elas são variáveis até no 
mesmo verme. As terminações caudais dos ramos intestinais posteriores manteem-se sempre separadas.

Orgãos reprodutivos: Os numerosos testículos dispõem-se no lado ventral, em duas zonas longitudinais, uma em cada lado da linha mediana. Da região post-ovárica, estendem-se quasi até a extremidade caudal. Na parte post-copulatória do corpo, há folículos testiculares entre os ramos intestinais caudais e lateralmente a êstes. Os dois dutos eferentes (Fig. 162, e), vindos dos dois lados e do dorso, entram no bulbo esférico do pênis, dirigem-se, nêle, ventral e caudalmente, e dilatam-se, formando duas vesículas seminais fusiformes. Ectalmente às vesículas, reunem-se os dois dutos eferentes, constituindo o duto ejaculatório (Fig. 158, x) que desemboca na ponta da papila penial. Esta é um órgão largo, cônico: e curto, que se dirige para o lado ventral e para trás. Em certa fase da atividade reprodutiva, dilatam-se as vesículas e o trecho ental do duto ejaculatório de tal modo que se origina, transitòriamente, uma cavidade aproximadamente esférica.

Os ovários situam-se na região delimitada pelo $5 .^{\circ}$ e $7 .^{\circ}$ divertículo intestinal. Os vitelários são mais massiços na zona pré do que na postcopulatória do corpo. O átrio feminino forma uma bolsa caudal (Fig. 158, y), de estensão variável. No espécime da Fig 158 (S. Paulo), é mais profunda que no material norte-americano visto por nós (Massachusetts, Michigan, Illinois). Nos vermes de Porto Alegre, é mais acentuada ainda. Outros exemplares de São Paulo (Fig. 159) são quasi destituidos da bolsa caudal. Provàvelmente, dilata-se esta bolsa, quando se formam os casulos nela. O canal da bursa (c) sae da parede dorsal do átrio feminino e corre, primeiramente, em direção dorsal. Mais para dentro: forma um ângulo agudo; dirige-se rostralmente, e dilata-se, produzindó a empôla saculiforme da bursa. Dos dois lados póstero-laterais aproximamse os ovidutos (w) ao ângulo do canal da bursa; e aí desembocam, um muito perto do outro, ou, segundo alguns autores, unidos. Ventralmente aos orifícios dos ovidutos, abrem-se numerosas glândulas da casca. (gi) entre as células epiteliais do átrio feminino.

Os núcleas dos epitélios que revestem os órgãos copulatórios são, em grande parte, aprofundados, a saber, os dos átrios comum e masculino; o do canal da bursa, ectalmente aos ovidutos; e o duma parte do pênis. No material de São Paulc, restringe-se o aprofundamento do epitélio penial à superfície dorsal do órgão; no norte-americano, é universal, afora o campo situado ao redor do orifício externo do duto ejaculatórib (Kenk 1935, p. 86). Vermes de Porto Alegre correspondem, neste porme: nor, aos norte-americanos de Massachusetts, Michigan e Illinois, afastandose dos de São Paulo. Com isso, evidencia-se, quão pouco tais diferenças morfológicas mínimas poderiam servir como base de denominações especiais (Hyman 1939, p. 270-271). A Snra. Dra. Hyman que estudou enorme material de Dugesia tigrina, considera (1. c.) a espécie como sendo, atualmente, na fase da sub-especificação geográfica. Tal opinião encontraria apoio no confronto do canal da bursa, nas várias regiões. Os vermes de São Paulo e norte-americanos concordam, apresentandc epitélio aprofundado apenas na parte externa, ectalmente à desembocadura dos 
ovo-vitelodutos; os de Porto Alegre têem tal epitélio no canal inteiro, àté a empôla.

1: Os casulos ovulares, de côr preta, são esféricos (1-1,5 mm.) e conteem, no material dos arredores de São Paulo, até 5 ovos ou embrióes. O casulo é pedunculado, sendo o pedúnculo de $1-5 \mathrm{~mm}$., ao comprido e de $0,06 \mathrm{~mm}$. de diâmetro. Termina com disco adesivo que fixa o casulo ao substrato, p. e., pedras ou plantas.

\section{Discussão sistemática de Dugesia tigrina}

A diagnose precedente segue de perto, em muitas passagens, a dada por Kenk (1944, p. 13 e seg.). Também a sinonímia, reunida na resenha das "referências principais" (p. 146), baseia-se nas opiniões concordantes de L. H. Hyman e R. Kenk. Quanto à especificidade de Dugesia microbursalis (Hyman 1931, p. 326; 1931a, p. 339), divergem ainda as opiniōes de Kenk (1935, p. 85) e Beauchamp (1939, p. 70).

Concordámos com a Snra. Dra. Libbie H. Hyman (carta de 18-VI-1943) è̉ não ser verosimil a existência, na América do Sul, duma espécie dos Tricladida dágua doce idêntica a uma norte-americana. Por isso, identificámos a "planária" mais comum da cídade de São Paulo e dos seus arredores a Dugesia tigrina sòmente, porque não conseguimos distingú-la das diagnoses e figuras relativas à dita espécie. Pedimos, então, a opinião autorizada da Snra. Dra. Hyman, obtendo a resposta seguinte (20 de maio de 1946): "I find the idea that Dugesia tigrina shculd occur in South America rather strange but I confess now that you have called my attention to it that I cannot see any difference between the copulatory apparatus of $U$. S. specimens of tigrina and the specimens I got from Brazil".

Também entre os Paludicola do velho mundo há casos de distribuição vastíssima, p. e., o de Dugesia gonocephala (Dugès) que ocorre na Europa; Asia, inclusive a região tropical; Africa, não sòmente ao norte, mas, também ao sul do Sahara (Beauchamp 1939, p. 72-73). Seja frisado, de passagem, que a ocorrência de $D$. gonocephala, no Brasil (Bresslau 1933, p. 247), não está provada; parece até inverosímil (Beauchamp 1939, p. 63).

Como a Snra. Dra. Hyman disse, na sua carta de 20 de maio de 1946, a bolsa caudal do átrio feminino (Fig. 158, 159, y) é sem valor taxonômico, pois é "not constant in shape or occurrence" (Curtis 1902, p. 545), varía no material de São Paulo consideravelmente, e apresenta-se diversamente nas duas figuras de Sivickis (1923, p. 116 f. 3, 4), que se referem a espécies idênticas.

Das espécies sul-americanas de Dugesia merecem consideração especial: 1) $D$. iheringii (Böhmig 1887, p. 482), a única descrita do Brasil; 2) D. dubia (Borelli 1895 , p. 2; hoje: D. anceps Kenk 1930, p. 292) re-examinada por Böhmig (1902, p. 15), e, segundo Beauchamp (1939, p. 71), a melhor conhecida da América do Sul; 3) D. dimorpha (Böhmig 1902, p. 18) aproximada, por Beauchamp (1939, p. 72), a D. tigrina.

A espécie 1 foi descrita incompletamente e sem figura; a posição sòmente dorsal dos testículos poderia, se assim fosse re-encontrada numa espécie dos arre. dores de Porto Alegre, esclarecer $D$. iheringii (Böhmig).

Em $D$. anceps Kenk, há dois caracteres, pelo menos, disjuntivos de $D$. tigrina, a saber: a) longura do pênis igual à altura dorso-ventral do corpo, a qual, em $D$. tigrina é menor que a altura: b) epitélio atrial regular; em $D$. tigrina, aprofundado.

A dobra do átrio, anteriormente discutida, é, em $D$. dimorpha, pronunciada, como no nosso material de $D$. tigrina. Possue, porém, a espécie chilena glândulas cianófilas e eritrófilas, extra-penialmente situadas, que desembocam no lume do pênis e na superfície da papila, respectivamente. Não ocorrem as últimas glândulas em D. tigrina.

\section{Observação sôbre a coloração de Dugesia tigrina}

0 estádio alimentício individualmente diferente, mesmo em vermes procedentes da mesma localidade, condiciona, em grande parte, a diversi- 
dade da côr. Indivíduos bem alimentados tornam-se mais claros, pois a distensão do corpo aumenta os intervalos entre os melanóforos ou manchas pigmentadas. Além disso, a gordura armazenada, de côr branca, tem efeito aclarador. Vermes famintos e magros são escuros, porque as células pigmentadas estão contíguas umas às outras.

Em D. dorotocephala (Woodworth), espécie criófila (Kenk 1944, p. 21), a perda e o re-aparecimento do pigmento relacionam-se com o calor e o frio, respectivamente (Behre 1918, p. 281-282; Hyman 1925, p. 59). Em Dugesia tigrina, espécie euriterma, não se repete tal fenômeno. Espécimes removidos dum grande aquário aquecido $\left(30^{\circ} \mathrm{C}\right.$.), e instalado na penumbra, foram transferidos para outro, menor, com água a $22^{\circ} \mathbf{C}$., e exposto à luz difusa do dia. Aí. aclararam-se dentro de três dias.

Quando vermes jovens, com cromatóforos de 0,025 - 0,03 mm. de diâmetro, alcançam comprimento de $6 \mathrm{~mm}$., assumem os elementos colorativos a disposição definitiva: anelada, malhada, manchada, listrada, constituida de risquinhos ou de grânulos, ou quasi incolor.

\section{Ocorrência e tipos reprodutivos de Dugesia tigrina}

A espécie, conhecida em tôda a parte dos Estados Unidos da América do Norte (Stringer 1918, p. 356), é a "planária" mais comum nos parques da cidade de São Paulo e nos arredores dela. A bôa análise do "Parênquima de Triclades do gênero Euplanaria" (R. de Barros 1943) refere-se a D. tigrina. A enumeração completa das localidades, em que encontrámos a espécie, parece excusada; mencionamos apenas: o tanque cimentado no terreno da Secção de Ciências Naturais da Faculdade de Filosofia, Ciências e Letras, situado na Alameda Glete, dentro da cidade; tanques nos parques Anhangabaú, da Luz, e da Avenida Paulista; lagôa de Tbirapuéra, também no perímetro urbano; lagôa da Corôa, no bairro de Canindé; nos rios Pinheiros e Tietê; em riachos da Cantareira (Tremembé). Entre as águas mencionadas, há paradas e correntes; barrentas e transparentes; umas ricas e outras pobres em matérias orgânicas. Em Porto Alegre colheu Dr. Herm. Kleerekoper material de D. tigrina.

Da América do Norte, sabe-se, desde a monografia de Curtis (1902, p. 515 e seg., 556), que $D$. tigrina se multiplica, em localidades diferentes, diversamente. Num biótopo, ocorre só reprodução sexual; num outro, apenas propagação agâmica, por divisão; e, num terceiro lugar, alternam, conforme a estação do ano, os dois tipos reprodutivos. Os pormenores do problema, em parte, ecológico, em parte, genético, são discutidos nos trabalhos de Kenk $(1937$; 1940; 1941a) e Hyman (1939, p. 271 e seg.). A última autora observou gônadas sòmente em populações que viveram em água movimentada, quer pela correnteza, quer pelas ondas. No material de São Paulo, tal não se repete. Obtivemos vermes sexuados, durante o ano inteiro, nágua parada do tanque no terreno da Secção de Ciências Naturais, e nos vermes criadōs nágua estagnada dos nossos aquários. Observaçōes idênticas foram realizadas por Kenk (1940, p. 471-472; 1941a, p. 56).

Nas nossas culturas, havia, p. e., em novembro e dezembro, i. é, primavera e início do verão, de 1944, oviposturas. Dos casulos produzidos no aquário (27. XII.), sairam, três semanas mais tarde (18. I.), os jovens com $2 \mathrm{~mm}$. de comprimento. $A$ temperatura dágua era, na dita época, entre 22 e $26^{\circ} \mathrm{C}$. Continnou tal temperatura nas três semanas seguintes, no fim das quais os vermes jovens alcançaram $8 \mathrm{~mm}$. de comprimento (6. II.). Nesta data, foi possível reconhecer, com a lupa, o primórdio do äparelho copulador nos vermes viventes. A medida de $8 \mathrm{~mm}$. ao comprido, 
observada neste momento, não era a definitiva dos animais, pois êstes cresceram, mais tarde, até $18 \mathrm{~mm}$. Até agora, passou o aparecimento das gônadas, nos Tricladida dágua doce, por índice do tamanho definitivo dos vermes respectivos (Kenk 1941a, p. 57): "it is well known that in those fresh-water triclads that reproduce sexually, the genital organs appear very late in the course of development. Only when the animal approaches its full size, the genital glands (testes and ovaries) begin to differentiate, and soon after that the formation of the highly complex copulatory apparatus starts" Em São Paulo, exceptua-se Dugesia tigrina, freqüentemente, desta regra, e, torna-se sexualmente madura com metade ou menos ainda do seu tamanho definitivo.

A prematuridade e a freqüencia da fase sexuada constituem particularidades fisiológicas de Dugesia tigrina de São Paulo. Fazem prever ainda diferenças no comportamento regenerativo, mas, tudo isso se subtrae à discriminação taxonômica (Hyman 1939, p. 270.271). A exigência ideal obrigaria a restringir um determinado nome específico a indivíduos "isoreagentes" em tôdas as fases da sua vida, mas a impossibilidade prática de fazêslo, evidencía os limites do trabalho taxonômico.

Também em São Paulo, propaga-se Dugesia tigrina por divisão. Visto que os zoóides isolados regeneram os órgãos que lhes faltam, trata-se de arquitomia (fragmentação, scisão).

\section{Distribuição geográfica de Dugesia tigrina}

Os achados norte-americanos de $D$. tigrina abrangem tôda a região caracterizada pelos limites: Maine; Long Point, no lago Erie, Canadá (Kenk 1943, p. 5); Michigan; Wisconsin; Minnesota; Washington e Califórnia; Louisiana; Flórida. Além disso, conhece-se a espécie de várias localidades da Alemanha (Meinken 1925; 1927; Thienemann 1928; Heidenreich 1931; Tu 1938; Arndt 1939, p. 90 nota 2). Atribue-se a ocorrência na Alemanha a uma importação involuntária, com plantas aquáticas (Cabomba). Na mesma planta, mas também em muitas outras (p. e., em Ceratophyllum, Eichhornia, Elodea, Trianea, Utricularia), vive Dugesia tigrina em São Paulo, sendo, como foi dito, comuníssima. Por isso, e por causa da sua ocorrência em Porto Alegre, supomos ser a espécie autóctone no Brasil, não importada acidentalmente. Falta, porém, ainda a prova de tal autoctonia, a saber, a evidência do quadro contínuo da distribuição norte-eentral-sul-americana. A "minhoca louca" é igualmente muito comum e, não obstante, é notòriamente forasteira.

\section{Dugesia nonatoi, spec. nov. (Fig. 163-169, Est. XXXI Fig. 13)}

Caracteres externos: 0 comprimento atinge, ao máximo, $18 \mathrm{~mm}$., sendo a largura de $1,5 \mathrm{~mm}$; as regiões cefálica e faríngea são as mais largas. Durante a locomoção, mantem-se a ponta anterior muito cuspidata ; mesmo no material conservado, continua ponteaguda. Daí para trás, notasẹ, primeiramente, uma concavidade, seguida, ao nível dos olhos, por convexidade (Fig. 163). Ao farejar o verme intensamente ou deslisar na película superficial dágua, assume a cabeça forma ainda mais estreita e alongada (Fig. 164, 166). O pescoço é um pouco mais apertado que a região dos olhos. As aurículas são, no verme em locomoção (Fig. 165) 2 vêzes mais compridos que largos; nos vermes em repouso, podem ser - completamente retraidos. 
A côr (Est. XXXI Fig. 13) é acastanhada com manchas pretas, euja estensão principal é a longitudinal. A cada mancha corresponde uma acumulação de pigmento, talvez melanóforo, no parênquima. De cada aurícula para trás, estencle-se uma zona clara em forma de crescente, sendo, destarte, as aurículas escuras na metade rostral; claras, na caudal. Halos claros sobrepõem-se aos olhos situados pré-auricularmente e muito grandes $(0,12 \mathrm{~mm}$. de comprimento). Distam mais do bordo, do que um olho do outro. A côr do corpo é, no ventre, menos escura que no dorso. Ao redor do septo musculoso do bulbo penial nota-se um anel de pigmento.

A faringe (Fig. 167, h) encontra-se, aproximadamente, no meio do corpo. A raiz da faringe nota-se, as mais das vêzes, em posição anterior ao centro do corpo; a bôca, sempre, posterior a êste. A faringe apresenta-se de ponta branca, sendo de resto uniformemente preta, sem manchas. $\mathrm{O}$ pigmento da faringe pertence ao parênquima, sendo a epiderme dela incolor. $O$ intestino termina, rostralmente, antes dos olhes; na sua parte anterior há ca. de 12 divertículos em cada lado, dos quais os 4 rostrais quasi não apresentam ramificações laterais. Nos ramos posteriores do intestino, contam-se, em cada lado, 15-25 divertículos, em parte muito longos e ulteriormente ramificados.

Os vermes rastejam dum modo semelhante a $D$. antillana Kenk (1941, p. 2-3), levantando quasi tôda a metade anterior e farejando em tôdas as direções. Quando dispõem de muita água, deslisam por meio dos músculos e dos cílios, sem que se notem as contrações e dilatações uniformes e rápidas: com pouca água, porém, tornam-se as ondulaçñes irregulares e, por isso, nítidas. Freqüentemente, fixam-se, por meio das glândulas adesivas ventrais e permanecem com a cabeça e os tentáculos imóveis e encolhidos, quasi amorfos. A estímulos mecânicos reagem, nesta fase, no início, com secreção mucosa; apenas quando repetidamente irritados, começam a locomover-se. Não os vimos rastejar para trás, como acontece em $D$. antillana.

Caracteres internos: A secreção das glândulas adesivas é de grãosgrossos e eritrófila; a das cefálicas (Fig. 169, k), cujos citosomas se estendem até a zona da faringe, cianófila. A musculatura da faringe, tanto a externa quanto a interna, corresponde ao tipo da família; noparênquima entre as camadas externa e interna, ocorrem sòmente algumas fibras musculosas, não estrato especial.

Os testículos (Fig. 167, t) começam com alguns poucos folículos situados rostralmente aos ovários (o) ; folículos cerrados ocorrem apenas caudalmente aos ovários e, daí, estendem-se até a região caudal. A posição dos testículos é, inicialmente, dorsal; na fase da maturação geral dos órgãos reprodutivos é ventral, com apenas alguns folículos dorsais na zona post-copulatória. Como os vermes são proterândricos e o aparecimento dos testículos precede ao dos vitelários, parece que os últimos condicionam a deslocação dos testículos para o lado ventral. Estes esvaziam-se e perdem a sua turgidez mais cedo que os vitelários. Doos dutos eferentes (Fig. 167, f) reconhecem-se sòmente os trechos colectores, aproximadamente, ao nível da boca; daí para trás, são.dilatados, e formam vesículas seminais extrapeniais, (passageiras ou falsas), que correm ser- 
pentinamente. Ao subirem para o lado dorsal, estreitam-se os dutos eferentes novamente e entram no bulbo penial.

Os ovários (Fig. 167, o) situados, aproximadamente, ao nível do 7. $\quad 8^{\circ}$ divertículo intestinal começam ovóides, indivisos; quando maduros, são sub-divididos pelos músculos dorso-ventrais, apresentando-se trilobulados. O número dos cromosomas contado na meiose dos ovócitos é de 10, na fase haplóide.

Alguns folículos dos vitelários (Fig. 167, v) encontram.se rostralmente (w) aos ovários (o). Ocupam posição ventral, ao nível do 6..$^{\circ}$ $7 .^{\circ}$ divertículo intestinal. Mais para trás, situam-se os vitelários dorsalmente aos testículos e lateralmente a êstes. Os cvo-vitelodutos (Fig. 167, 168 , d) entram, vindos do lado caudal, no átrio feminino $(\mathrm{y})$; sòmente nêste desembocam as glândulas da casca (c).

Pelo poro genital (Fig. 168, r) abre-se o átrio comum, em que as grossas glândulas argamassadoras (q) desembocam. São ligeiramente eritrófilas. Com o átrio comum revestido por epitélio regular, sem cílios, comunica-se, para diante, o átrio masculino ( $x)$, cujo epitélio, também sem cílios, exibe pequenas vilosidades. Os núcleos são, nesta parte, na sua maioria, aprofundados. Ao epitélio apõe-se a musculatura anelar; ao parênquima, a longitudinal. O átrio feminino (Fig. 168, y) forma uma profunda bolsa caudal (z), cuja função presumível, a formação dos casulos, foi mencionada na diagnose de $D$. tigrina. $O$ epitélio do átrio feminino carece de cílios; os núcleos são aprofundados. As glândulas da casca (c), de secreçãơ intensamente eritrófila, desembocam no átrio feminino, que termina no ponto em que nêłe se abrem, de trás, os ovovitelodutos (d); de diante, o canal da bursa (n).

A forma do pênis é, no material fixado, a dum cône truncado, com uma dobra circhlar ao redor da papila penial (Fig. 168, p). Como se sabe pelas exposições de Beauchamp (1939, p. 70), tais dobras do órgão copulador dependem da contração no momento da fixação e, destarte, variam muito. $O$ bulbo do pênis é volumoso e contem numerosas glândulas ( $\mathrm{g}$ ) basófilas; a musculatura do bulbo é escassa. O pênis é revestido de epitélio regular, não aprofundado; ao epitélio apõe-se a musculatura anelar; ao parênquima, a longitudinal.

Os dutos eferentes (Fig. 167, f), de paredes musculosas, penetram dos dois lados no bulbo. Devido à contração muscular, apresentam-se, no material fixado, de calibre pequeno. No meio do bulbo, formam os dutos reunidos a vesícula seminal (Fig. 168, s), cuja parede é formada, exclusivamente, por células glandulares basófilas. Estas glândulas (g) são tão numerosas que preenchem todo o bulbo penial e, em parte, ainda se ressaltam fora do septo musculoso do bulbo. Na parede do duto ejacùlatório (e), ocorrem as mesmas glândulas. Rostralmente à dobra anelar externa da papila, evagina-se o duto ejaculatório e forma uma bolsa dorsal e outra ventral, revestida, no lado ectal (externo) de epitélio regular. Daí para fora, são os núcleos do duto ejaculatório escassos.

O canal da bursa (Fig. 168, n) tem epitélio ciliado regular, não aprofundado. Corre dorsalmente ao pênis para diante, e, aí, dilata-se como empôla da bursa (m), de epitélio alto, vacuolizado. Nos vacúolos, 
encontram-se massas azuis. provavelmente espérmios. Da empôla sae um canal de calibre estreito, com epitélio cilíndrico regular, sem cílios. E' um duto bursa-intestinal que corre entre o tubo músculo-dermático dorsal e a parede dorsal da bolsa faríngea. $O$ percurso do duto é ligeiramente ondulado. Rostralmente à bolsa faríngea (Fig. 169), dilata-se o duto (u) e, mais rostralmente ainda, desemboca por meio dum tubo capilar, ao nível da raiz da faringe. $\mathrm{O}$ orifício intestinal do duto bursa-intestinal (a) encontra-se exatamente no ponto limitativo entre os epitélios faríngeo e intestinal.

Divisão arquitômica foi observada no início de outubro; a observação refere-se a material mantido no aquário durante 6 mêses e, no momento da divisão, em certo declínio.

No início de novembro, houve, no aquário e na natureza. alguns poucos indivíduos com gônadas.

Ocorrência: Arredores da cidade de São Paulo, Tremembé, na serra da Cantareira. O Sr. Dr. Edmundo Nonato, em honra de quem a espécie foi denominada, colheu o material num córrego, perto da estação de Tremembé, que tem os caracteres dum riacho da serra, dentro duma região intensamente povoada. É de correnteza rápida, de leito arenoso e rico em pedras, sendo a água medìocremente rica sm substâncias orgânicas. Os vermes vivem nas faces inferiores das pedras, conjuntamente com $D$. tigrina, como também entre as raizes da grama e de outras plantas ribeirinhas. Acumulação especial, tanto de $D$. nonatoi quanto de $D$. tigrina, foi observada debaixo duma ponte, onde os vermes permaneceram reunidos por efeito da sua fototaxia negativa.

\section{Sôbre a comunícação gênito-intestinal de Dugesia nonatoi}

Da nossa resenha das comunicações gênito-intestinais dos Tricladida (p. 139) depreende-se ser Dugesia nnnatoi a primeira espécie do gênero com tal órgão. Quanto ao tipo da ligação dos aparelhos reprodutivo e nutritivo, o atual não se encontra, pelo que se conhece da literatura, em outros membros da Seção Paludicola. Nem mesmo entre as numerosas modalidades de comunicação gênito-intestinal, que existem nos outros Tricladida, ocorre uma igual à de $D$. nonatoi. Dos Haploneura Maricola conhece-se a ligação dorso-mediana de Miroplana trifasciata Kato 1931, mas, a desembocadura do duto, no intestino post-faríngeo, diminue a semelhança. Na SubOrdem Diploneura, presta-se, de certo modo, Rhynchodemus terrestris (O. F. Müller) à comparação. Apesar de ser situada a bursa desta espécie (literatura: Steinböck 1924, p. 486; Hyman 1939b, p. 431-433) caudalmente ao pênis, encurva-se o seu canal do ponto em que os ovo-vitelodutos desembocam para diante e dilata-se, formando a empôla da bursa. Com isto, porém, terminam as possibilidades do confronto, pois da empôla da bursa de $R h$. terrestris correm dois dutos bursa-intestinais, que - entram nos ramos intestinais post-faríngeos.

O epitélio do duto bursa-intestinal de $D$. nonatoi é igual ao da empôla da bursa, sendo diferentes o do canal da bursa e o do intestino. Seria de grande interesse poder acompanhar a ontogênese do duto bursa-intestinal, nias, por enquanto, não dispomos das fases necessárias. Visto como a empôla da bursa de $D$. nonatoi parece funcionar tanto como bursa copulatória e receptáculo seminal quanto como "vesicula resorbiens", ignora-se a possível função do duto bursa-intestinal.

No sentido da hipotese filogenética de Steinböck, discutida no capítulo relativo a Baicalellia evelinae (p. 29), o duto seria a via eferente feminina ancestral. Fisiologicamente, tal caminho que conduz à raiz da faringe e, com isso, tão perto quão 
possível da bôca, seria provavelmente exaltado como testemunha especialmente primordial. Porém, sem prejuizo de eventaais resultados contrários de futuras pesquisas ontogenétieas, mênuma relação entre os orgãos bursais e intestinais verificamos, além da comuniogeção dos seus lumes.

\section{Dugesia arndti $*$ ), spec. nov. (Fig. 170-176, Est. XXXI Fig. 14)}

Vermes viventes e sexualmente maduros atingem $18 \mathrm{~mm}$. de comprimento; quando conservados, teem $13 \mathrm{~mm}$. de longura e até $3 \mathrm{~mm}$. de largura. A forma da cabeça lembra, de perto, a de $D$. tigrina, sendo o ângulo médio-anterior pouco inferior ao reto, e os lados da região pré-auricular ligeiramente convexos. As aurículas, de base larga e ponta cuspidata, são curtas e, por isso, pouco ressaltadas. A côr é cinzento. amarela clara com desenho preto em forma de manchas alongadas. Pode ocorrer uma estria longitudinal dorsal, ou duas. $O$ ventre é tão manchado quão o dorso, mas, os nervos longitudinais ventrais e os orifícios oral e genital destacam-se por serem brancos. Os campos igualmente brancos dos órgãos sensoriais auriculares marcam-se na base das aurículas, havendo ainda um halo claro sobreposto a cada olho. A distância entre os olhos é menor que a entre cada olho e o bordo correspondente do corpo. Medidos em direção céfalo-caudal, os olhos apresentam $0,1 \quad 0,13 \mathrm{~mm}$. de comprimento.

A epiderme (Fig. 176, z) é, geralmente, de altura uniforme no dorso e no ventre, ambos providos de rabditos, sem diferença numérica notável. Muitos rubditos dorsais e ventrais são acastanhados nos cortes corados com hematoxilina e eosina. Nas células rabditógenas, no parênquima, são vermelhos (Fig. 176, r). Mostra-se igualmente acidófila a secreção das glândulas adesivas do anel ventral. Na cabeça, estendem-se os citosomas das glândulas eritrófilas até além do cérebro, lembrando um órgão frontal, sem que sejam reunidos como tal. Constituem apenas o sector anterior do anel adesivo.

A faringe (Fig. 170, h) uniformemente pigmentada começa antes do meio do corpo; a extremidade caudal dela coincide com o meio do corpo. $\mathrm{O}$ comprimento da faringe corresponde, no verme conservado, aproximadamente a um sétimo da longura do corpo. A bôca (Fig. 170, b) situa-se um pouco rostralmente à extremidade posterior da faringe. A histologia desta é típica, seguindo-se, de dentro para fora: cílios; epitélio sem núcleos; músculos anelares; músculos longitudinais; núcleos do epitélio interno; parênquima com pigmento e glândulas, principalmente eritrófilas; núcleos do epitélio externo; músculos anelares; músculos longitudinais; epitélio externo sem núcleos; e eílios externos curtos. O intestino atinge a região adiante dos olhos; é rico em clavas granulosas de Minot, e contem restos de Oligochaeta límnicos e Cladocera.

*) A espécie foi denominada em homenagem póstuma a Walther Arndt, do Museu Zoológico de Berlin, suplieiado em 26 de junho de 1944; a nobreza do seu caracter e a fidelidade do seu zêlo científico ficarão gravadas indelevelmente nos corações dos seùs amigos. 
Os testículos (Fig. 176, t) começam, em vários dos exemplares examin nados, anteriormente aos ovários; em outros, ao nível dêstes ou posteriormente. Estendem-se, para trás, até a região caudal. Situam-se sempre ventralmente aos vitelários (w), cuja estensão para os lados não acompanham. Folículos testiculares ocorrem também entre os divertículos intestinais, nas regiões média e posterior do corpo. Os dutos eferentes, muito finos e sem cílios, correm sobrepostos aos nervos longitudinais ventrais, e são revestidos por epitélio de núcleos grandes (Fig. 173, d). Ao nível da bôca (Fig. 170, b) dilatam-se os dutos eferentes, formando vesículas seminais extra-peniais, de percurso ondulado ou intermitentemente alçado. Caudalmente à empôla da bursa, sobem os dutos eferentes em linha reta e atingem o bulbo do pênis, cuja parede musculosa atravessam, vindos dos dois lados. Abrem-se no lume do pênis (Fig. 173, p) ou vesícula seminal intra-penial (verdadeira, permanente), cuja forma, geralmente, é esférica, às vêzes, ligeiramente bipartida por alongamentos nas entradas dos dutos. O lume do pênis, mesmo quando vazio, tem de largura 0,07 $\mathrm{mm}$. A parede dos dutos eferentes torna-se, entre as vesículas seminais extra-peniais e o lume do pênis, algo mais espessa que no trecho anterior. $O$ epitélio interno do pênis é mais baixo que o dos dutos, mas, como êste, normal, não aprofundado, e destituido de cílios.

Os ovários (Fig. 176, o) são grandes e situam-se posteriormente a vários dos divertículos intestinais, medialmente aos nervos ventrais (n). A reserva conspícua de ovogônias lembra o parovário de Phagocata gracilis (Woodworth 1891, p. 33 t. 2 f. 21). Os vitelários (w) encontramse dorsalmente aos testículos (t); começam anteriormente aos ovários e estendem-se até muito além do complexo dos órgãos copulatórios. Nos vermes completamente maduros, ocorrem folículos vitelinos dorsal e ventralmente ao intestino. Os ovovitelodutos (Fig. 175, 176, v) começam com a dilatação ("tuba") no lado externo e dorsal do ovário. Na tuba musculosa notam.se espérmios enovelados, separados do ovário, por altas células do epitélio da tuba, no corte, semilunares. Tal placa obturadora ("Verschlussplatte") conhece-se dos Maricola (Böhmig 1906, p. 461), Paludicola (Mattiesen 1904, p. 278; Micoletzky 1907, p. 416; Weiss 1910, p. 576, etc.), e Terricola (Busson 1903, p. 419). O epitélio dos ovovitelodutos é ciliado, sendo os núcleos aprofundados. A parede dos ovovitelodutos é fortemente musculosa; para trás, correm externamente aos dutos eferentes e dorsalmente aos nervos ventrais. Dêstes, são separados por grossa camada do parênquima. Ao nível de cada folículo vitelino, sobem e comunicam-se com êste; nos interstícios entre os folículos vitelinos, descem. Os ovovitelodutos encurvam-se em direção dorso-mediana, atrás do átrio. Vindos do lado caudal, entram no canal da bursa, e isso, no ponto, em que êste se liga à chamada vagina (Fig. 172, m). 0 último trecho dos ovovitelodutos, cujo comprimento igala ao duplo da largura dos mesmos, ostenta epitélio normal, não aprofundado. No ponto em que tal epitélio começa, os dutos podem reunir-se, desembocandc, nêstes casos (Fig. 174), um ovoviteloduto comum no canal da bursa, na passagem dêle na vagina $(m)$. Quando os ovovitelodutos continuars separa- 
dos (Fig. 175), as suas desembocađuras situam-se látero-caudalmente, uma perto da outra.

$O$ pênis (Fig. 172, 173) tem tamanho médio; é alongado, e estende-se quasi horizontalmente, de diante para trás. O parênquima contem músculos concèntricamente dispostos ao redor do lume e glândulas pouco pronunciadas. Glândulas eritrófilas desembocam na parte ectal do lume, na região em que a vesícula esférica se estreita passando ao canal ejaculatório. O revestimento externo do pênis apresenta-se diversamente nos lados ventral e dorsal. Ventralmente, ocorre epitélio chato, normal, sobreposto a uma camada tênue de músculos, principalmente, anelares. Dorsalmente, músculos longitudinais formam a camada adjacente ao parênquima; para fora, segue estrato espesso de fibras anelares, em várias camadas. $O$ epitélio externo dorsal é altp; os seus núcleos são intra-epiteliais, na parte que reveste a ponta da papila e o bulbo; aprofundados, numa zona intermediária (Fig. 172, s). O diâmetro do campo em que os núcleos são aprofundados é de $0,1 \mathrm{~mm}$.

A profundidade do átrio masculino (Fig. 172, e) apresenta-se, nos cortes, muito diversa, conforme a contração da musculatura no momento da conservação. Uma vez (Fig. 170), salienta-se o pênis para dentro do átrio comum (a) ; outra vez (Fig. 171), o órgão masculino encontra-se abrigado numa bolsa mais nitidamente delimitada. Ventralmente, é o atrio masculino revestido pelo mesmo tipo de epitélio chato e normal, como ocorre na superfície penial ventral, havendo sòmente na região ectal, perto do átrio comum, células mais altas. Mesmo aí não iguala o epitélio do átrio masculino ao do átrio comum (a), cujas células altas, claviformes, e de núcleos distais perfazem um revestimento anfractuoso. Os múseulos atriais são muito fortes, especialmente os anelares. Entalmente ao gonóporó (Fig. 172, g), desembocam as glândulas argamassadoras $(y)$, de secreção fracamente acidófila.

$\mathrm{O}$ átrio comunica-se com o canal da bursa $(\mathrm{k})$ por um trecho verticalmente disposto, chamado, na literatura, de "vagina" (m). I estrutura histológica desta comunicaęão constitue o caráter especificico mais importante de $D$. arndti. $O$ epitélio é mais alto ainda que o do átrio e carece de cílios, lembrando, destarte, o atrial, não o do canal da bursa. A musculatura forte, que é, no lado do epitélio, anelar; no do parênquima; longitudinal, poderia atuar como esfincter e separar o lume estreito vaginal do atrial. As cerradas glândulas da casea (c) desembocam na vagina, ectalmente ao ponto da entrada dos ovovitelodutos ou do ovoviteloduto comum $(v)$. O epitélio do último trecho dos ovovitelodutos, normal e ciliado, re-encontra-se no canal da bursa ( $k$ ), que se dilata bruscamente ao nível da calota anterior do bulbo penial. A empôla da bursa ; de volume medíocre; topográfica e histològicamente corresponde ao tipo do gênero.

Os casulos acastanhado-escuros são pedunculados; no únieo caso observado, saiu um verme jovem do casulo. 


\section{Ocorrência de Dugesia arndti}

Amplo material de $D$. arndti foi colhido, em janeiro de 1946, na serra da Mantiqueira, a $1750 \mathrm{~m}$. de altura, no lago de Umuarama, município de Campos de Jordão (Estado de São Paulo). Com preferência, os vermes viveram nágua pouco movimentada dos bordos da represa, debaixo da cortiça de galhos e no lado inferior de folhas. Na dita época, houve reprodução sexual generalizada. Dum casulo, que a Lic. D. Gabriella Zuccari trouxe, em 20-IV-46, de Umuarama, saiu, em 27-IV-46, um verme, de $3 \mathrm{~mm}$. ao comprido. No aquário (temperatura dágua: $20-22^{\circ} \mathrm{C}$.), aleançou o animal diariamente alimentado com 1 larva das Chironomidae, que ocasionalmente deixou de comer, depois de 18 dias, $9 \mathrm{~mm}$. de longura e primórdiós dos órgãos reprodutivos. Depois de 32 dias, decorridos desde a eclosão, as gônadas estiveram completas; o verme mediu $16 \mathrm{~mm}$. Cresceu até $18 \mathrm{~mm}$. e apresentou $2.3 \mathrm{~mm}$. de diâmetro. Como se sabe, não ocorre autofecundação nos Tricladida Paludicola (Goetsch 1925, p. 670; literatura anterior: Hyman 1925, p. 67-68).

\section{Discussão sistemática de Dugesia arndti}

Consideramos a vagina musculosa e de epitélio muito alto como sinal de primeira importância na separação de $D$. arndti das outras espécies do gênero, pois o dito órgão difìicilmente poderia ter passado despercebido, por ocasião das descrições precedentes.

Discernimos ainda $D$. arndti das espécies sul-americanas anteriormente descrítas, sem discutir eventuais sinonímias mútuas entre estas. Em iheringii insufieientemente descrita, são os testículos situados dorsalmente (Böhmig 1887, p. 483). 0 canal da bursa de aurita (Kennel 1888, t. 19 f. 21) encurva-se sucessivamente, não é angulado (arndti), dando-se o mesmo em festae (Borelli 1898, f. 1; Hyman 1939b, f. 47C; a Snra. Hyman considera titicacana um sinônimo de festae; melhor seria festai). o lume penial bipartido ou, na terminologia antiga, duas vesículas seminais veriadeiras (intra-peniais) separadas distinguem anceps (Kenk 1930, p. 292; novo nome de dubia Borelli 1895 , p. 2) de arndti, tendo Böhmig (1902, p. 17) confirmado a bipartição aludida. Pelo mesmo caracter e pelo átrio comum comprido, ausente em arndti, destaca-se andina (Borelli 1895, p. 4), cujos testículos se encontram dorsal e ventralmente (Borelli 1897, p. 6; err. tipogr. deveria ser 4). A côr de laurentiana (Borelli 1897, p. 1) e similis (Böhmig 1902, p. 22) lembra a de arndt, mas, as duas espécies foram descritas sem gônadas, sendo, por isso, incognoscíveis. Gônadạs jmaturas tornam igualmente impossível julgar ambigua (Böhmig 1902, p. 23); eventualmente pertence ao gênero Curtisia. Glândulas eritrófilas desembocam nưma zona anelar da face externa da papila do pênis (Böhmig 1902, p. 19) de dimorpha; em arndti, tais glândulas derramam a sua secreção no duto ejaculatório. Das espéeies colombiânas (Fuhrmann 1914), possuem paramensis (p. 798) e cameliae (p. 802) testículos dorsais; as aurículas de cameliae são cilíndricas; parameneis divide-se paratomicamente. Em longistriata (p. 796) não ocorre vesícula seminal intra-penial; polyorchis (p. 802) carece de folículos vitelinos pré-ováricos.

\section{Summary}

Macrostomum gigas Okugawa thoroughly described by Dr. Hyman (1943) is common in the vicinities of São Paulo (Fig. 1-3; t. XXXI Fig. 1): Of the synonyms indicated by Dr. Hyman the russian material (Beklemischev 1927) seems to be doubtful, because the length of its stylet is only 15 times the width of the ental (proximal) end against 25-38 times in sure gigas. As rhabdites are more numerous on the ends than elsewhere in our worms, the material of S. Paulo which suits with 
that of New York, makes the identity of $M$. bulbostylum Ferguson (and I tuba Kepner \& Stiff) with $M$. gigas probable.

Intracellular digestion may occur, but food is always first decomposed extracellularly, viz. in the cavity of the intestine.

The female atrium is, as in most other species of the genus, ciliated and the cell boundaries of its lining epithelium disappear only when the atrium is stretched by an ovocyte. The histological resemblance hetween the atrium of Macrostomum and the bursa of the Acoela is not as striking as Reisinger (1933) thought. On the other hand cilia can miss in the vagina of the Acoela. The homology between mouth-piece and bursa (Acoela) and "passage-apparatus" and female atrium (Macrostomidae) seems acceptable. However the cement glands connected with the vagina or the female orifice of various digonoporous Acoela suggest that also in the Acoela eggs are frequently evacuated through the female pore. Mouth-piece and bursa (Acoela) may as well be remainders of "passageapparatus" and atrium (Macrostomidae) as precursors of the latter. A "passage-apparatus" is also known from some Ascophorinae (Findenegg 1930 , p. $98-99$; Luther 1946, p. 11-14).

In the key of W. J. Hayes (Ferguson 1940a) the new species Macrostomum delphax (Fig. 4-9) agrees with the characteres that lead to no. 50. The species and varieties of the following numbers (51-70) have flexures of the stylet that lie in the same plane as the principal axis of the shaft. $M$. delphax has the distal end spiralled (Fig. 7), although strong compression may open the spiral (Fig. 6). Besides in the species of nos. 51-70 the opening of the stylet occupies the entire length of the part beyond the distal flexure, whereas in M. delphax the terminal opening neeapies at most one third of the distal spiral. $M$. viride has the opening of the stylet sub-terminal; $M$. rhabdophorum and $M$. japonicum have the distal end bluntly truncated; in $M$. intermedium the stylet is one ninth of the body-length; in $M$. delphax one fifteenth to one twentieth.

The difference between $M$. viride Van Ben. and $M$. viride Luther is thot greater than that between other figures from so different times. With Hofsten, Graff, Meixner, Gieysztor, Reisinger, and Bresslau we consider Luther's description an amendment of Van Beneden's. By no means viride Luther with its spiralled stylet, sub-terminal opening, and 2 haploid chromosomes can be regarded as a variety (finnlandensis) of ruebushi.

We further compared $M$. delphax with mystrophorum Mx., the stylet of which is bent in U-form; auriculatum Nass. with stylet similar to that of graffi Ferg.; catarractae Gieys. with semilunar termination; var. schmitti Hay. \& Ferg. and var. kepneri Ferg. \& Jon. with the typical ruebuishi-stylet; appendiculatum var. stirewaltae Jon. \& Ferg. with subterminal opening; ontarioense Ferg. with two flexures of the stylet; and hustedi Jon. different in many respects. Of norfolkense Jon. \& Ferg. we know only a preliminary note (1940).

". "The testicles of $M$. delphax are exceptionally small; the haploid number of chromosomes is 2 . The length of the stylet is not correlated with that of the body. Mature worms were observed with $1,2 \mathrm{~mm}$ : (body) 
and $0,09 \mathrm{~mm}$. (stylet) and others of $1,3 \mathrm{~mm}$. and $0,03 \mathrm{~mm}$. The stylet continues to grow after having attained the functional stage, and this growth varies individually. Eight worms isolated with stylets of about $0,05 \mathrm{~mm}$. had them from 0,06 to $0,096 \mathrm{~mm}$. 13 days later.

Macrostomum evelinae, sp. n. (Fig. 10.13) was found in the sand of the beach of Guarujá near Santos in the zone that is covered by some centimeters of sea-water even during low tide. In the accompanying fauna Kalyptorhynchia, Monocelididae, Macrodasys-spec. and Saccocirrusspec. were noted.

Eyes are absent, not only the pigment cups but also the retinal cells. The penis stylet has an accessory spine directed to the right and ventral side, that is quite singular among the Macrostomidae and resembles the "Nebensporn" (Graff) of some Promesostomatinae Luther (1943). Of the female organs the common oviduct and the genital canal are specially remarkable. The latter is unusually long and the nuclei of its epithelium are sunken in (depressed). In the epithelium of the common oviduct a ring of high cells corresponds to the "passage-apparatus" of other Macrostomum-species, but it does not hinder the passage of sperms completely. Some of these are resorbed in vacuoles of the lesser cells that line the inner chamber of the common oviduct.

Although we separate the Catenulida and Macrostomida as distinct orders, we maintain the name Rhabdocoela for the former Lecithophora. With Beklemischev (1927) we consider the Provorticidae as a special family. The genera (Bresslau 1933; Karling 1940) included in it are arranged in a key (p. 22).

In the vicinity of the city of São Paulo and in the interior of the state of S: Paulo Baicalellia evelinae, sp. n. (Fig. 14-22) occurs under very different conditions. Geographic distribution of the genus, see p. 22 . Dalyellia opaca Sibiriakowa (1929) from the river Angara does certainly not belong to the Dalyelliidae; it may be (Ruebush \& Hayes 1939), a Baicalellia, but it is imperfectly described and still more insufficiently illustrated. B. evelinae is one of the three species with colourless parenchyma. It has about 22 tentacles on the rostral border of the pharynx; $B$; brevitubus (Luther) and B. pellucida Nass. are without tentacles.

The male organs were seen only in 5-6 out of more than 200 examined worms. Already half-grown females without traces of male organs (that are perhaps never developed in most of the worms) had spermatozoa in the bursa seminalis (the phagocytarious organ of Nassonov's description). The cocoon contains 2 (exceptionally 4) eggs. It passes from the superior or female atrium (uterus) into the intestine by temporary dehiscence of the walls of the two cavities. The young worms either hatch in the mater: nal intestine or the egg-capsule is freed, very likely, through the mouth as in Breslauilla, Ethmorhynchus and perhaps Pilgramilla. If the pregnant worm dies, the embryos in the eggs may survive. Up to 6 cocoons were found simultaneously in the uterus of one worm. As the few animats we saw with testes (Fig. 15, 20), seminal vesicle (s), vesicula granulorum $(x)$ and penis ( $z$ ) had much more spermatozoa in the bursa seminalis than those without signs of male organs, autogamy seems to occur besides 
fecundation of worms in female phase by such in male phase. One isolated worm produced 14 young in the course of 11 days and had living spermatozoa remaining in the bursa. At $18^{\circ} \mathrm{C}$. the embryo develops in 8-10 days.

'The predilected habitat of $B$. evelinae is the yellow or brownish slime produced by Anthophysa, Rhipidodendron, Metopus and Rotatoria. The worms feed on Paramaecium, Stylonychia, Diatoms and other microorganisms. Few Zoochlorellae were sometimes found in the cells of the gut. Cysts formed by rhabdites are frequently secreted by well-fed animals which digest for whole days in the cyst.

There are two principal types of genito-intestinal communications in the Turbellaria, viz. those established by means of a bursa and the direct. ones. The first cannot always be considered as phylogenetically primary oviducts, and the term "bursa intestinalis" should not be used, except for Gnosonesima, not even for the Coelogynoporinae, although one of the functions of the bursa is the digestion or evacuation of the excess of sperms, granular secretion, etc. The second type seems still more difficult to judge, if it occurs in a species as B. evelinae with gonopore and cocoons, the diameter of which is not as excessive as in Ethmorhynchus. In $B$. evelinae the width of the egg-capsule is $45-50 \%$ of the maximal breadth of the body, against Gieysatoria ornata (52\%), G. complicata (53\%), G. acariaia (68\%), and Plagiostomum evelinae (60-75\%), all these laying eggs through the gonopore.

All the 14 species of the Dalyelliidae described from the state of São Paulo (principally from the vicinities of the city of S. Paulo) belong to the genus Microdalyellia and 13 of them to the subgenus Gieysztoria. It seems advisable not to classify the species of Microdalyellia after the position of the testes, because: 1) at least 12 species with a cuticular apparatus consisting of proximal and distal branches (subgenus Microdalyellia Rueb. \& Hay.) were described without an indication of the position of the testes ; 2) in quadridens and inflata, both with a cuticular apparatus of Gieysztoria, the position of the testes is unknown; 3 ) in some species of Gieysztoria, blodgetti and eastmani, the testes lie in the middle of the second third of the body; 4) mollosovi (= sphagnetica), lutheri (=-pachyderma), euchroa, and the new species sawayai have a cuticular apparatus of the Microdalyellia-type combined with testes in the posterior body-half (Gieysztoria-type).

Microdalyellia (M.) sawayai, sp. n. (Fig. 23-27) has a pharynx almost as long as the intestine (in rossi the pharynx is not half as long; in gilesi it is longer) and posterior testes. The cuticular apparatus with 10 spines on the right lateral distal branch, 14 on the left differs from that of sillimani, karisalmica (perhaps identical with rossi), aspinosa (lateral distal branches without spines) and virginia; the latter is also distinct by its salient receptaculum and wanting bursa.

The eastmani-group of Gieysztoria is artificial. Gieysztor considers pachyderma a synonym of lutheri, a true Microdalyellia; thienemanni has a cuticular apparatus similar to that of complicata, virgulifera and their allies. The figures of blodgetti, eastmani and inflata show signs of 
a ring-shaped apparatus, so that only the apparatus of cuspidata and that of quadridens consist of separate spines.

The rubra-group of Gieysztoria with its two sub-groups is systematically useful. The first sub-group can be divided into two sections: A, with symmetrical spines; $B$, with asymmetrical spines. We consider okugawai to belong to the latter section, not to the subgenus Microda:lyellia; the short proximal spines described by Okugawa are probably the optical section of the ring (basal plate). We presume that incerta is a Microdalyellia, since the cuticular apparatus is more important than the position of the testes.

Sub-group I, Section A. M. (G.) evelinae, sp. n. (Fig. 28-37) is the most common of the Dalyelliidae in the surroundings of the city of São Paulo. It has a cuticular apparatus similar to those of triquetra and triangulata, both with 3 triangles ( 4 in evelinae). The locules of the receptaculum are intracellular vacuoles. The locomotory cilia can temporarily stop moving in a part of the body, in contrast to what was. seen by Alverdes in Dalyellia viridis.

$M$. (G.) hymanae, sp. n. (Fig. 38-40) has a cuticular apparatus similar to that of evelinae, but the thicker spines are smooth, the thin. ones form 5 groups, not 3, and the difference between the two types of spines is less marked. The efferent ducts enter the seminal vesicle not apically but ventro-distally. The granular vesicle is longer. The receptaculum seminis is included in the oviduct and without locules. The egg-capsule is ovoid, not ellipsoid and triangular in certain views.

$M$. (G.) trisolena, sp. n. (Fig. 41-42, 45) differs from triquetra by its $3 \mathrm{big}$, hollow spines, the small testes, and the oviduct half as long as the ovary.

In $M$. (G.) acariaia, sp. n. (Fig. 43, 46) the central tube of the euticular apparatus, the pharynx and the vitellaria are similar to infundibuliformis, but the latter has bridges (absent in acariaia), and the peripherical spines are shorter, more numerous (in acariaia 3 ) and disposed differently.

Sub-group I, Section B. $M$. (G.) complicata (Fuhrm.) (Fig. 47-48) was classified with help of Beauchamp's description (1939); the originar figures of the cuticular apparatus are sketchy.

$M$. (G.) intricata, sp. n. (Fig. 44, 50-52, 55) has a cuticular apparatus still more complicate than complicata; okugau'ai and thienermuni are related but further remote from intricata.

$M$. (G.) uncia, sp. n. (Fig. 49,53) is nearest to pavimentata that is also provided with 8 smooth (not ciliated) papillae on the anterior border of the pharynx. The worms of uncia are longer $\left(\begin{array}{lll}0,6 & 0,8 & \mathrm{~mm}\end{array}\right)$ than pavimentata $(0,3 \mathrm{~mm}$.), and the cuticular apparatus is comparatively shorter $(0,027 \mathrm{~mm}$. in uncia; $0,028 \mathrm{~mm}$. in pavimentata $)$. The proximal ring is as high as the spines are long in uncia, twice the length of the spines in pavimentata. Also the structure of the ring and details of the spines are different.

$M$. (G.) therapaina, sp. n. (Fig. 54, 56), from the Mantiqueira mountains $(1750 \mathrm{~m}$.) in the state of São Paulo (municipality of Campos. 
de Jordão) is very different even from the nearest species, $M$. (G.) virgulifera $(=$ pallida $)$ and its var. vjatkensis.

In $M$. (G.) thymara, sp. n. (Fig. 57-59), a species with zoochlorellae in the intestinal cells, the proximal (ental) half-ring of the cuticular apparatus: is interrupted on the left, not on the dorsal side. The spines are united in 3 different groups, a brush and two combs; there are no single spines. As in thienemanni the cuticular apparatus lies in the middle of the body, under the intestine, not caudally to it as in most species. The atrium is situated near the beginning of the last third of the body as generally in Gieysztoria; and therefore the penis-sheath is exceptionally long. So is also the bursa canal. The oviduct includes the receptaculum seminis and lies far behind the cuticular apparatus. The intestine is provided with two unpaired diverticula, one (Fig. 59, $\mathbf{x}$ ) below the pharynx, and the other ( $y$ ) beyond the genital region.

$\therefore M$. (G.) cypris, sp. n. (Fig. 60-63) has a short intestine and a position of the seminal vesicle that resembles thienemanni, but the cuticular apparatus is very different. The proximal half-ring is open ventrally and disposed obliquely in the penis-sheath. The two distal branches have each 8 spines that are curved differently on the right and the left side. Few specimens were seen.

Sub-group II, Section B. In the present material of $M$. $(G$. $)$ ornata (Hofsten) (Fig. 64, 66-68) the cuticular apparatus is $0,040,044 \mathrm{~mm}$. long, that of rubra measures $0,0560,08 \mathrm{~mm}$., and that of rubra var. intermedia still more. Besides there is no relation between the number of bridges and spines, as it occurs, after Reisinger (1924c), in rubra: Since Gieysztor (1929) saw smooth as well as lobate vitellaria in sibirica, the lobes indicated for rubra, not for ornata, but present in the worms from São Paulo, cannot decide the classification. Gieysztor (1931) distinguishes between the long and curved ovary of rubra and the short and straight one in ornata. That of our worms is long and curved. Reisinger however found it short both in rubra and ornata. Gieysztor (1938) mentioned two important characters of ornata: 1) the proximal (ental) ring unites with the distal (ectal) one in a different way on both ends, and also the peripheric spines are different on both sides; 2) the basal (proximal) openings of the spines are directed inwards. Neither Hofsten's figures nor our worms show either of these characters: the ring is nearly symmetrical on both ends, and the spines open upwards and outwards as in many other species of Gieysztoria.

$M$. (G.) bellis, sp. n. (Fig. 69-71, 74-76) has small distal cones $(0,006$ $\mathrm{mm}$.) on the spines $(0,016 \mathrm{~mm}$.) of the cuticular apparatus $(0,04 \mathrm{~mm}$. in length) and 4 locules in the receptaculum seminis. Structures that might be similar cones were drawn in erivanica (Plotnikow 1906, t. $22 \mathrm{f}$. 4 ), the apparatus of which is $0,08 \mathrm{~mm}$. long. The latter was considered a possible synonym of expedita, but this has a cuticular apparatus (clearly without distal cones) of $0,022 \mathrm{~mm}$. Neither of the species shows the locules of the receptaculum.

$M$. (G.) tridesma, sp. n. (Fig. 65, 72-73) has thick, hollow spines of similar shape but different length. They form 3 groups, 1 ventral and 
2 dorso-lateral ones. The most similar species seems to be kessleri with 5 groups of 3-4 slender spines each.

Among the species of Strongylostoma (p. 62), simplex andicirratum without a bursa do not require further separation from dicorymbum, sp. n. (Fig. 77-80). Of the others only radiatum and elongatum (perhaps identical with bologoviense) are well defined. From both dicorymbum differs by the two columns of granular secretion in the ductus granulorum (Fig. 78, g). Besides radiatum is characterized by the anterior constriction of its body, the genital pore near the mouth, a copulatory organ that is twice the size of the pharynx in the male phase, testes extending forward beyond the pharynx, and efferent ducts beginning at the posterior end of the testes. The slender and spindle-shaped body of elongatum is far different from that of dicorymbum; other differences are the form of the spines in the ductus granulorum, the bursa without a muscular duct, the ductus communis distinct from the atrium superius, and the paired uterine diverticles of the atrium superius. In spite of Hofsten's and.Meixner's figures we suppose that the sperms of elongatum are released in the same manner as in radiatum and dicorymbum, viz. by an ejaculatory duct completely separated from the ductus granulorum.

Phaenocora bresslaui, sp. n. (Fig. 81-83) has red eyes, no zoochlorellae, a small tail that may disappear as the form of the body varies, a male copulatory organ (Fig. 81) of type III A (Gilbert 1935, p. 367), and a communicatio genito-intestinalis of type 5 (ibid., p. 350), because the small part with a sphincter between the inner part of the female genital canal (Fig. 83, c) and the bursa (m) can not be considered as a ductus genito-bursalis. The wall of the bursa is provided with recesses that open into the central lumen; these pouches differ from the secondary cavities ("Nebenhöhlen") in the wall of the bursa in Coelogynopora (Steinböck 1924, p. 465-466). Body-muscles do not only run through the wall of the intestine, but also cross the digestive cavity. The pearshaped appendages (Fig. 83, $\mathrm{u}$ ) partake in the enlargement of the atrium superius (a), when it contains a cocoon (egg). Phagocytosis of sperms occurs in the atrial cells and in those of the pear-shaped lobules that are indistinguishable from the former while the atrium superius is extended.

The species lives under varied conditions and shows directed (topic) negative phototaxis.

$P h$. bresslaui must be compared principally with gracilis with the type III A of the male organ. This species is eye-less, or without visual pigment, has a ductus bursa-intestinalis, a very big male organ, and reticulated vitellaria that are simply ramified in $P h$. bresslaui.

Phaenocora evelinae, sp. n. (Fig. 84, 89-91, plate XXXI f. 2) has white eyes, zoochlorellae (acquired with food), and always a tail. The male organ and the comunicatio genito-intestinalis correspond to those of Ph. bresslaui. The pear-shaped appendages resemble those of Pseudophaenocora sulfophila Gilbert with internal pads, external lobes, and tertiary lobes (Fig. 90, qa). The external ones bear uni-cellular glands (q), the uterine glands of Ph. (Megaloderostoma) polycirra Bekl. The cytoplasm of the 
internal and external parts is laminated. While there is no egg in the atrium superius (Fig. 84, a) the internal pads lie within the atrium (Fig. 89, u); the other parts are outside of it and continue so when an egg is lodged in the atrium superius (Fig. 91). In this stage the internal lobes are incorporated into the thin wall of the atrium superius. After releasing the egg the atrium superius may remain extended. In this condition phagocytosis of sperms as described above was seen. Later on the atrium superius shrivels and the internal lobes of the appendages are irregularly contracted by its muscles. Then the lamellae re-appear. The Fig. 84 shows the aspect of the atrium superius with an egg as well as in the contracted phase. The valvular apparatus guarding the entrance of the ductus bursa-intestinalis into the intestine lies within the intestinal syncytium.

The species is less common and its negative phototaxis is not as distinet as in bresstaui. From the latter $P h$. evelinae is distinguished by the shape and colour of the body, by the colour of the eye-cup, details of the structure of the pharynx, ovary bent in an opposite angle, absence of shell-glands, vitellaria extending to the back, and presence of a ductus bursa-intestinalis.

Phaenocora chloroxantha, sp. n. (Fig. 85-87, 92-93) without eyes has zoochlorellae in the anterior region and the form of a smoothing-iron. Like the two preceding species it lacks' dermal rhabdites and has cephalic rod-tracts. The epidermic cells are pierced by numerous pores, viz. the peripherical parts of cyanophil glands that lie in the parenchyma. Threads of basophil secretion occur also in the parenchyma and in the wall of the intestine. The excretory system (Fig. 86) is very similar in the 3 species and suits well to Fuhrmann's figure $(1894$, t. $11 \mathrm{f} .46)$. The male organ (Fig. 93) corresponds to the type III A of Gilbert. The very small pear-shaped appendages are hardly discernible in the stage of the atrium superius extended by an egg. As the bursa of Phaenocora corresponds to the receptaculum seminis of the other Typhloplanidae, we consider the outermost spherical dilatation (Fig. 87, m) of the communicatio genito-intestinalis, as being the bursa of $P h$. chloroxantha. Therefore we call the remaining part of the communicatio a ductus bursa-intestinalis (Fig, 87, n). In chloroxantha its innermost portion is expanded and for the most part lined with an epithelium of intestinal type. As no communication with the lumen of the gut exists, alimentary inclusions in the cells of this epithelium are wanting; their function is to digest exceeding sperms. In the most species of Phaenocora the communicatio genito-intestinalis is in open connection with the gut, but the two tubes are lined differently. Such a condition occurs also in Coclogynopora bresslaui Steinböck. In $\boldsymbol{P h}$. chloroxantha a connection does not exist, but the inner part of the communicatio shows a transitional epithelium. The same was described for $C$. biarmata and $C$. gynocotyle. Apart from this interesting analogy we do not think that the "bursa intestinalis" of Coelogynopora and other Monocelididae should be identified with the "bursa seminalis" of Phaenocora. 
$P h$. chloroxantha showed no reactions to diffuse day-light or directed lamp-light.

With its unarmed maje organ of the type III Ph. chloroxantha must be compared with bresslaui, evelinae, alticola, and gracilis. The first two species with eyes and tails are quite different; bresslaui. the tail : of which may disappear, has no zoochlorellae. $P h$. alticola has a ductus genito-bursalis, a very large bursa, a short ductus bursa-intestinalis, and also differences in the opening of the "vasa deferentia" and the position of the granular vesicle. Ph. gracilis is not well known,. but the original figure shows a short ductus genito-bursalis, absent in chloroxantha. In Fuhrmann's slides re-examined by Hofsten the wall of the ductus ejaculatorius has a central thickening, not present in chloroxantha. Vejdovsky and Hofsten described the testes much longer than those in chloroxantha, that do not extend beyond the second third of the body. The comunicatio of $P h$. chloroxantha is considered as type 5, to which typhlops, anomalocoela, clavigera, and vjatkensis belong, all without eyes and caudally truncated. They have, however, a spiny ductus ejaculatorius. If the internal widened part of the communicatio. in chloroxantha is considered as a bursa, the whole distal rest, that is the spherical and the tubular portion, becomes a ductus genito-bursalis. In case of this terminology chloroxantha must be compared with virginiana, rufodorsata, and achaeorum, all of them with tail, eyes, and a male organ built on the sac-within-a-sac plan (Gilbert type I).

Ruebush (1939) said that anomalocoela and foliacea are very primitive species and that this seems to indicate a holarctic origin of the genus. Such a conclusion can evidently only be understood if the zoogeographical theory of relicts is an implied condition. Primitive characters of anomalocoela are perhaps: the absence of rod-tracts (they were not described), the separation between vesicula seminalis and vesicula granulorum (much less distinct in foliacea; very perfect in hightandensis, alticola, bresslau, evelinae, chloroxantha), the absence of pear-shaped appendages (not described by Haswell). If the latter are really wanting, anomalocoela cannot be maintained in Phaenocora (Gilbert). The protonephridia with caudal openings. and the testes without efferent ducts are further characters of anomalocoela incompatible with Phaenocora. We do not see why anomalocoela should be especially primitive, and even less foliacea, that is very different from the australian species. On the other hand, foliacea and chappuisi are identical (Beauchamp 1940).

The three south-american species have the following characters in common: the type of the male organ, the absence of a ductus genitabursalis, and the rhabdites restricted to cephalic rod-tracts. 'The first sign occurs also in gracilis and alticola, the second in european species and in the australian anomalocoela, the last in european. species. Other critexia used in grouping the species of Phaenocora, as eyes, tail, and colour, differ in the south-american species that do not represent-a mopphological unit.

Our list of species that safely belong to. Olisthanella agrees with that of Ruebush (1938a). One subspecies of truncula, viz, lucida Nassonov 
(1926, p. 873), must be added. The list of Findenegg (1930, p. 76) contains species (exigua, hungarica) with testes probably ventral to the vitellaria and others (brinkmanni, albiensis) in which that position is certain. A species with atrium copulatorium and a toothed bursa, as is Castrada otophthalma (Plotn.) and its subspecies tricuspidata Bekl. can hardly be considered as an Olisthanella as Beklemischer did. The orifices of the protonephridia show that it does not belong to Castrada or an other genus of the Typhloplaninae. Among the Protoplanellinae a copulatory atrium occurs f. ex. in Castradella, and otophthalma must probably be placed in this subfamily.

Olisthanella parva, sp. n. (Fig. 94, 95-98) agrees in several important characters with $O$. opistomiformis Nassonov (1921, p. 145; 1926, p. 873), from which it would not have been separated by a specific name, if the testes of opistomiformis and thus the latter's generic position were known. 0 . opistomiformis was evidently not sectioned. "The rhabdites are not very numerous, they lie at the anterior extremity of the body and do not form any rhabdite tracts" says Nassonov. Sections of $O$. parva show that there are no rhabdites at all; the outlets of refractive, granular and weakly eosinophil cephalic glands resemble rhabdites. The pharynx of opistomiformis is perhaps a little smaller than that of parva. Nassonov says that the tiny bursa copulatrix of opistomiformis was described from a reduced stage of this organ. Such occurs in the female phase of the development of the reproductive organs.

Typical Mesostoma ehrenbergii (Fig. 101-104) with 10 diploid chromosomes (Fig. 103), not 8 as in wardii, is common in the surroundings of the eity of São Paulo. It lives in permanent. stagnant and slowly current water, frequently between the roots of Eichhornia crassipes, as well as in swamp-pools that dry up periodically. Compared with european worms the brazilian ones are much more fertile: in Europe (Alsace) a considerable part even of the second generation in the anmal cycle produces only" thick-shelled "winter" eggs (Steinmann-Bresslau 1913, p. 300 ), in the third generation only $40 \%$ developed thin-shelled "summer" eggs (Beauchamp 1926a, p. 1437). In São Paulo worms considered as first generation but perhaps hatched from "summer" eggs were brought to the laboratory, where $94 \%$ of the third generation produced thinshelled yolk-poor eggs.

In Europe thick-shelled resting eggs are freed by the death of the mother worm. In São Paulo such eggs are a little smaller $(0,29$ $0,4 \mathrm{~mm}$. in diameter) than the european ones $(0,450,5 \mathrm{~mm}$. $)$ and are laid by the living worm after a permanence of 1-6 days in the uterus. The graph (Fig. 104) shows how many: thiek-shelled eggs of 121 observed during 30 days (10 animals; water-temperature $16-18^{\circ}$ C.) stayed how many days in the maternal uterus.

Laying yolk-laden thick-shelled eggs is the common process not only in the Typhloplanidae but also in Rhabdocoela and Alloeocoela in general. Retaining them all heaped up in the body. is biclogically disadvantageous because all can be eaten by one turbellariophagous animal. It is true that Jeannette Carter (1929, p. 436). has seen an egg of Phacnocora suryive 
after it had been eaten by a Microstomum. That the disadvantageous type of reproduction known from Central Europe has not eliminated $M$. ehrenbergii there, can be taken as one proof more for the "struggle for existence" being in higher latitudes less intensely fought between the various species of animals than between the organisms and the inanimate nature (Hesse).

Bothromesostoma evelinae, sp. n. (Fig. 99-100, 105-107, plate XXXI Fig. 3-4) was found in small permanent pools and temporary plashes in the vicinities of São Paulo (X-V). The worms swim in full sun-light with the ventral side upwards on the surface. If they are pushed cautiously downwards by some drops of water, they fall only a short way and remain suspended to the surface by a mucous thread, like Mesostoma ehrenbergii. The greenish-black pigment in the parenchyma is usually expanded, and the worms are uniformly very dark (Plate XXXI Fig. 3 A); the ventral side and its lateral rim are orange-yellow (Fig. 3 B). Bothromesostoma evelinae changes its colour physiologieally: after 1-2 hours in the dark, the animals become light grey with black spots (Fig. 4), the contracted melanophores. As Brinkmann (1905) spoke of "constant, local varieties" in $B$. essenii, it does not seem that his description of the colour must be understood in the same manner (in any case, none of the later authors did). The ventral pouch (Fig. 106, s) does not show any sensorial elements; histologically it differs much from the sensorial pits of Stenostomum. With Luther, Brinkmann, and Reisinger we consider this organ as secretory with mucous (k) and rhamnite-glands ( rh). Even in Müller's paper (1936) there is no evidence for a sensory function of the epidermic ventral sac.

From the other species of the genus mentioned by Graff (1913) $B$. evelinae differs immediately by the distance $(0,2 \mathrm{~mm}$.) between the mouth (combined with the excretory cup) and the genital opening (Fig. $99, \mathrm{n})$ and by the compact testes that may be of different form on both sides in the same animal (Fig. 99, 106, t). The uteri (Fig. 99, $u$ ) are developed in the posterior half of the body only, when the worm contains winter-eggs. When summer-eggs and young worms (found in april) are present, that occur together with winter-eggs (Fig. 105), the uteri become $\mathrm{H}$-shaped and extend to the anterior region of the body. Up to 3 thick-shelled eggs were observed in every uterus. These eggs are freed by the living worm. Non-follicular testes, and mouth and gonopore distant $(0,040,05 . \mathrm{mm}$.) from one another, occur in B. truncatum Bekl., but this species has a pre-cerebral ventral pouch, a spermatic duct between the atrium and the receptaculum seminis, and an other disposition of copulatory organ and bursa than $\boldsymbol{B}$. evelinae. The species deseribed as Bothromesostoma primitivum Sabuss. has neither the ventral sac nor the ductus spermaticus of Bothromesostoma and must be considered as a species of Mesostoma.

Specimens of Gyratrix hermaphroditus Ehrbg. (Fig. 118-119) were found in the environments of the cities of São Paulo and Curitiba (Paraná). They had the transverse connective (Fig. 119, $x$ ) of the 
descending (primary, proximal) canals of the emunctory decribed by Kromhout (1943) and absent in european and chinese materials.

Of the Alloeocoela previously described from São Paulo (Marcus 1944) Geocentrophora applanata is not restricted to Bromeliaceae, but lives also in current water. Of the family Plagiostomidae (sensu Bresslau 1933) 3 limnic species, viz. $P$ lemani, $P$. lacustre, and Hydrolimax grisea are known. $P$ evelinae, sp. n. (Fig. 108-117) is the fourth species that occurs in current and stagnant waters in the city of São Paulo and its surroundings. Peculiar morphological characters are: the two eyes (Fig. 114, a) situated far before the brain with which they are connected by the sensory tracts (n); two lateral areas of depressed glands (Fig. 115, 1) that appear as white stripes (Fig. 109) in the adult black worms; the volumous pharynx bulbosus (= variabilis intextus); the large (Fig. 112, e) "entodermic pseudo-oesophagus" (Hofsten 1918, p. 20-21) with cells resembling the club-shaped cells of Minot; the emunctories with three principal pores: two lateral ones on the bottom of ciliated pits (Fig. 113, 3), and one caudal-median one (Fig. 112, p). Their orifices appear as white spots (Fig. 109).

The species is protandrous; the ovocyte is inseminated by a single sperm (Fig. 115, 4) during the growing period. As in other species (Böhmig 1890, p. 340; Kepner, Stirewalt \& Ferguson 1941, p. 255) alien sperms (Fig. 115, 5) are numerous in all tissues, except those of the epidermis and the intestine. The short penis (Fig. 112, $\mathrm{u}$ ) when everted is covered with papillae secreted by the penis-glands (Fig. 112, j). The worms were observed copulating by hypodermic impregnation into the back or side of the mate. The shell-glands, absent on the common oviduct (Fig. 112, y), seem functionally substituted by the vitellaria that also in Hydrolimax grise a furnish material for the egg-capsule. Eosinophilous glands $(z)$ around the genital pore (l) corrsepond to the cement glands of many Plagiostomids, and probably their secretion attaches the capsule to the substratum: The stalked egg-capsule contains up to 4 eggrs.

The Archimonocelidinae are distinguished from the Monocelidinae by normal, not depressed, epidermal nuclei, and from the Coelogynoporinae by separate male and female gonopores. The pharyngeal epithelium divided into an ectal ciliated part with depressed nuclei and an ental not eiliated part with normal nuclei occurs also in some Monocelidinae (Archiloa wilsoni; Minona evelinae, Fig. 134) and Coelogynoporinae (C. gigantea Mx.). In the new genus Meidiama the bursa seminalis has a pore that is inexistent in Archimonocelis and Monotoplana.

The type of the new genus, Meidiama lutheri, sp. n. (Fig. 120-127), lives in coarse shelly sand of the beach of Guaruja, near Santos. The surface of the worm is sticky and has adhesive papillae chiefly on the tail. The statocyst with a prismatic statolith lies a little in front of the brain. The lumen of the short frill-shaped pharynx is perpendicular to the antero-posterior axis of the worm. It is lined with a ciliated depressed inner epithelium (Fig. 126, p1), while the normal, non-ciliated epithelium partakes of the lining of the intestinal cavity. The anterior narrow portion of the intestine is solid and consists of lamellar curved cells like- 
those of the cephalic gut of Otoplana intermedia. The penis is a cuticular curved tube; the male atrium is stiffened by about 12 spines. The ovovitelloduct widens to form the female atrium, the caudal wall of which communicates with a pouch, the bursa resorbiens (Fig. 125, w). In the wall of this phagocytarious organ spermatozoa are incorporated into vacuoles that pass them on to the adjacent intestine. The cavity of the latter and the bursa resorbiens do not communicate.

The new genus Minona belongs to the sub-family Monocelidinae, as it has depressed epidermic nuclei and the male and female pores are separated. Like other genera it has a pre-penial bursa seminalis with an external orifice. Its principal particularity is that the vesicula granulorum is independent from the male organ and provided with a hollow acuminate stylet. Probably Monocelis insularis Meixner (1928, p. 605) belongs to the genus Minona.

The type of the new genus, Minona evelinae, sp n. (Fig. 128-134, 136-137), lives in the shelly sand of the beach near Santos where the preceding species was found. Cutaneous glands and adhesive papillae around the tail make the worms extremely sticky. The pharynx shows the two types of inner epithelium, ciliated depressed and non-ciliated not depressed, that occurs in the Archimonocelidinae, Coelogynopora gigantea, and Archiloa wilsoni. The ventral part of the vesicula seminalis is divided by septa into 14-15 locules that house the tails of the sperms, the heads of which are directed to the dorsal undivided cavity, where the ductus ejaculatorius begins. The latter is an unarmed ciliated and muscular tube. The ciliated bursa canal (vagina) with depressed nuclei differs histologically very far from the ovo-vitelloduct. The cavity of the bursa communicates by a pore with the lumen of the intestine. Secondary bursal vesicles, viz. large vacuolized cells phagocyte sperms, and pass them on to the intestine. Thus the disposition is similar to that described for two species of Monocelis (Oparina-Charitonowa 1927) and Archilou spinosa (Maristo 1938). The eggs are fertilized when they leave the ovaries and enter one of the two anterior ovo-vitelloducts; then they pass through the cavity of the bursa ( $w)$ and the bursa canal $(\mathrm{db})$ to the posterior unpaired ovo-vitelloduct, that begins in the external (ectal) part of the bursa canal and runs backwards.

Of Bothrioplana semperi M. Braun (Fig. 135, 138) we found two specimens in a swamp, after heavy rain-falls had raised the level of the underground water, and further ten in a meadow-ditch that dries up during the dry season.

In Bopsula evclinae, g. n., sp. n. (Fig. 139-143) of the Tricladida Paludicola, the male atrinm is separated from the female atrium and opens before it. The efferent ducts or sperm ducts (Hyman 1945) unite between the male and female atrium to form a seminal duct or common "vas deferens" that begins with a small, extra-penial or false seminal vesicle (spermiducal vesicle) and enters the penis through its caudal wall. The large penis lumen is lined with a thin epithelium that produces a faintly eosinophil secretion, comparable to that described of Procotyln 
fluviatilis Leidy (Hyman 1928; Kenk 1944) and P. typhlops Kenk (1935). The sperms form a twisted strand in the middle of the secretion. The testes are only dorsal and extend beyond the female atrium. The ovaries lie at the level of the fifth branch of the intestine, close to the medial side of the ventral nerve cords. The yolk glands, some of which are anterior to the ovaries, extend to the posterior end of the body. The ovovitelline ducts open separately into the female atrium together with the bursa canal and just dorsally to the shell-glands. The sac-shaped bursa lies between pharynx and penis. A wide canal unites the female atrium with the bulbar lumen of the penis. This canal has the same epithelinm as the female atrium and, for the most part, also the same depressed nuclei (the "insunken epithelium" of Young 1912, p. 255). "The inner muscle zone of the pharynx corresponds to the planariid type. The species was found in the Mantiqueira mountains $(1750 \mathrm{~m}$.).

The organisation of the copulatory organs of Bopsula evelinae might be understood by the hypothesis that a typically disposed penis of a Dugesia-species has undergone rotation (Fig. 141-143). As Ditremagenia macropharynx Palombi (1928) deseribed as a marine Triclad belongs to the Polyclads, the hitherto only. Triclad with separate male and female pores is the terricole Digonopyla harmeri (Graff 1897; 1899; Fischer 1926). It is very different from Bopsula evelinae. Neither do the two gonochoristic marine Triclads, Sabussowia dioica (Claparède 1863) and Cercyra teissieri Steinmann (1930) nor the Uteriporidae (Böhmig 1906; Wilhelmi 1909), offer possibilities for homologies with Bopsula evelinae. In some Seriata (Proseriata Meixner 1938) we find at least worms not too distant from the Triclads with the male pore situated before the female one and with a communication (vagina antralis) between the bursa and the male atrium, viz. Archiloa rivularis Beauchamp (1910) and Archilopsis unipunctata (Fabr.) (Meixner 1938, p. 60-61 f. 5 A, 56).

The new genus Rhodax (family Planariidae) is based on $R h$. evelinae, sp. n. (Fig. 144-153, plate XXXI Fig. 5) found in dirty ponds, rivers and clear-water brooks near the-city of São Paulo. The animals were observed during 18 months in the laboratory, where they multiplied by division (precoeious paratomy) and from march to june developed reproductive organs and layed instalked spherical cocoons. The worms attain a length of $9 \mathrm{~mm}$. and a width of $1,1,5 \mathrm{~mm}$. The anterior end is round, without any auricles, with a median adhesive area $(z)$. The tail is more or less pointed. The colour is pink or brownish, due to red, brown or black pigment- cells that are smaller and scaree on the ventral side. The normally, two eyes are close to the middle line and surrounded by two white. areas. The short pharynx (one tenth of the body-length) lies before the middle of the body; the mouth before the middle of the pharynx. About two days before division occurs, the last third to fifth of the body begins to separate by a constriction on both sides (Fig. .151).

The testes (Fig. 154) are fused to form a continuous tube ventrally on each side of the body from the ovaries to the hind end. On the level of the pharynx they give off a pair of efferent dncts ("vasa deferentia"). 
As little as testicular follicles efferent ductules ("ductus efferentes") occur. The efferent ducts unite in an extra-penial seminal or spermiducal (Hyman 1945) vesicle. The copulatory complex is about the size of the pharynx and lies immediately behind the pharynx. The ciliated seminal duct widens in the muscular bulb of the penis to form a small intrapenial (true) seminal vesicle and opens at the tip of the small papilla into the male atrium. The atrium is lined with a high villose epithelium.

The ovaries lie between the 2nd. and 3rd. diverticle of the intestine over and outside the nerve cords. The ciliated ovovitelline ducts begin close behind the brain to take up the pre-ovarian yolk glands, form a cup on the inner side of each ovary, and run backwards medially to the nerve cords. At the level of the genital pore they turn inwards and unite in a common ovovitelline duct that opens from the dorsal side into the common atrium, near the bursa canal. The common ovovitelline duct connects with numerous eosinophilous shell glands. At the point where the ovovitelline ducts bend inwards, each of them gives off a posterior ciliated branch, the posterior vitelloduct. It has the same diameter as the anterior ovovitelline duct. The bursa canal runs tailwards from the atrium and widens into a small funnel-shaped bursa that opens into a branch of the intestine, oftener into a right than into a left branch. As the figures of worms with beginning development of the reproductive organs show (Fig. 146, 150), the young bursa does not communicate with the gut, but starts its growth already backwards. As fission continues during the development of the reproductive organs, the tubular testes and the strands of yolk glands on the sides of the body are parted by the division, so that the posterior individual receives a portion of both.

The only known Paludicole with paratomy seen alive was hitherto Planaria fissipara Kennel. As its reproductive organs are unknown, the generic position of $P$. fissipara cannot be judged. The unsexual animal seems very similar to $R h$. evelinae. In the latter the bilateral constriction and the accumulation of formative cells in the fission-zone are the only preparatory steps for division. In $\boldsymbol{P}$. fissipara the paratomy is typical, because a brain with eyes, and a pharynx with mouth are anticipatory regenerated before fission takes place. Dugesia paramensis (Fuhrm.) and perhaps D. mortoni (Steinm.) are further paratomical Planariids, but they are only known from preserved specimens.

The genus Rhodax is a collective type: its branched ovovitelline ducts are unknown among the Tricladida (Meixner 1928, p. 576 note 5) and resemble Otomesostoma and Bothrioplana; the pre-ovarian yolk glands and female ducts are another character of the Seriata (Bresslau 1933; Proseriata Meixner 1938); the bursa behind the copulatory organs occurs in the Maricola. Various traces connect Rhodax with Phagocata, a highly specialized genus of the Planariidae. Such are: small size, absence of auricles, colour, connection of the shell glands with the common oviduct that opens into the atrium, and unstalked cocoons ( $P$ h. velata, morgani). Great extension of the testes is frequent in european Phagocataspecies (Beauchamp 1932, p. 272); in Ph. vernalis the testes are fused. 
Fission occurs in several species of Phagocata (vitta, velata, morgani, vernalis), and in many of them reproductive organs develop rarely.

The genus Curtisia differs from Dugesia by the smaller number of testicles that are dorsal in all 4 species. In C. schubarti, sp. n. (Fig. 154, 156-157, 160-161, plate XXXI Fig. 6) up to 12 groups of 1-5 follicles may occur on each side and extend from the post-ovarian region to the level of the bursa. The auricles are much longer and more pointed than those of foremanii and, as far as can be judged from the preserved specimens, of patagonica and michaelseni. The ovovitelline ducts open separately from the sides into the vertical part of the bursa canal at the limit between the ciliated epithelium (bursa canal) and the nonciliated (vagina) that belongs histologically to the atrium. Ventrally to this limit the shell glands enter the vagina.

Dugesia tigrina (Gir.) (Fig. 155, 158-159, 162, plate XXXI Fig. 7-12) is the most common "planaria" in the municipal parks of São Paulo and in the neighbourhood of the town. It was also collected in the vicinity of Porto Alegre (southern Brazil) by Dr. Herm. Kleerekoper. D. tigrina lives in current and stagnant. muddy and limpid waters, in such with organic matter and in others without these substances. Although there is no continuity between the north-american distribution of $D$. tigrina (from Maine, Canada, State of Washington, southward to California, Louisiana and Florida) and its occurrence in southern Brazil, we think that the species is autochtonous in Brazil, not unintentionally imported with water-plants as in Germany.

As Dr. Libbie H. Hyman (American Museum of Natural History) kindly has sent us series of north american individuals of $D$. tigrina (Massachusetts, Michigan, Illinois) together with others from São Paulo (material of the thesis of Dra. R. de Barros, 1943) and Porto Alegre, we could verify some slight histological particularities of the various lots. The depressed nuclei of the epithelium of the penis-bulb are restricted to the dorsal surface (São Paulo); the whole bulb is covered by depressed epithelium with exception of a field around the opening of the ductus ejaculatorius (North America; Porto Alegre). The nuclei of the bursa-canal between the bursa and the entrance of the ovo-vitelloducts are normal and those of the posterior part of the bursa-canal are depressed (São Paulo; North America); the whole length of the bursa-canal has depressed nuclei (Porto Alegre). These facts support the opinion that D. tigrina is in process of evolution into several species (Hyman 1939, p. 270-271), "but the powers of a taxonomist are limited and it is impossible to assign specific rank to such slight variations"

Some specimens from São Paulo and those from Porto Alegre differ from the north american worms in the deeper atrial fold (Fig. 158, y). In other worms from São Paulo this fold is very small (Fig. 159, y). D. iheringii, the only species of the genus hitherto known from Brazil, is incompletely described; it has dorsal testes.

Besides the known colour types we noted that well-fed worms become lighter by the white droplets of fat accumulated in the wall of the intestine and the distension of the body that extends the space between 
the chromatophores. Our worms began to develop reproductive organs at an age of three weeks, a length of $8 \mathrm{~mm}$., and 6 weeks from the deposition of the egg-capsules (temperature 22-26 $6^{\circ}$ C.). Growth continued in these worms up to $18 \mathrm{~mm}$. On the whole the sexual reproduction is very frequent in D. tigrina from São Paulo and takes place also in laboratory dishes without running water.

Dugesia nowatoi, sp. n. (Fig. 163-169, plate XXXI Fig. 13) from the vicinities of São Paúlo is characterized by a very peculiar genitointestinal communication. The copulatory organs are typical of the genus with a large eopulatory bursa. From its proximal (ental) end towards the: head a long ductus bursa-intestinalis runs between the body-wall muscles and the pharynx in the median line and opens into the digestive tract on the limit between the epithelia of the intestine and the pharynx.

Dugesia arndti, sp. n. (Fig. 170-176, plate XXXI Fig. 14) is characterized by the very high epithelium in the powerfully muscular tract (vagina) that cohnects the bursa canal with the atrium. The external epithelium of the dorsal and ventral side of the penis is of different height and besides in a certain area (Fig. 172, s) of the dorsal side it has depressed nuclei. A common ovo-vitelloduct may occur (Fig. 174), but the two ovovitelline ducts can also enter the bursa canal separately (Fig. 175). Only in the ectal part the ciliated epithelium of the female genital ducts is normal ; farther inwards it has depressed nuclei. As a rule the bulbar lumen is undivided. The species was found in the Mantiqueira mountains.

Of the south-american species of Dugesia, the synonymy of which is not discussed, laurentiana, similis, and ambigua are described without gonads or with incompletely developed ones. Perhaps ambigna belongs to Curtisia. D. iheringii (Böhm.) has dorsal testes (arndti ventral); auvita and festae, better festai, have an evenly curved bursa canal, not bent in a right angle as in arndti. In anceps and andina the bulbar lumen is divided in two seminal vesicles. The erythrophilous glands that open in a belt on the outer surface of the penis in dimorpha empty into the ejaculatory duct in arndti. D. paramensis divides by paratomy and has dorsal testes. D. cameliae also with dorsal testes has cylindrical auricles. The bulbar lumen of longistriata is not dilated. Pre-ovarian yolk glands are absent in polyorchis.

\section{Literatura}

Alverdes, F. 1922, Untersuchungen über begeisselte und beflimmerte Organismen. Arch. Entw. Mech. v. 52, p. 281-312. Berlin.

Arndt, W. 1939, Fonticola-Funde in der Mark Brandenburg, etc. Märk. Tierw. v. 4, p. 86-100. Berlin.

Barros R. de 1943, O Parênquima de Triclades do gênero "Euplanaria". Bol. Fac. Fil. Ci. Letr. v. 36 Biologia Geral no. 4, p. 73-117 t. 1-5. São Paulo.

Baylis, H. A. 1927, 'Turbellaria from Lake Tanganyika. Ann. Mag. Nat. Hist. ser. 9 v. 20 , p. 380-385. London.

Beauchamp, P. de 1910, Archiloa rirularis n. g. n. sp. Turbellarié Alloeocoele d'eau douce. Bull. Soc. Zool. France v: 35, p. 211-219. Paris. 
1913; Un nouvean Rhabdocacle marin, Prơhynchopsis minuta n. g. n. sp. Bull. Soc. Zool. France v. 37 (1912) n. ${ }^{\circ} 10$ (31-1-1931), p. 299-302. Paris.

1913a, Planaires des Broméliacées de Costa Riea. Deuxième note. Arch. Zool. expér. génér. v. 51, Notes et Revue n.o 2, p. 41-52. Paris.

1920, Sur quelques Rhabdocoeles des environs de Dijon. C. R. Ass. Franc. Avancem. .Sci. Congrès de Strasbourg (1920), p. 300-303. Paris 1921.

1921, Sur un nouveau Plagiostomum (Turbellariés Rhabdocoeles) et ses rapports avec un Isopode. Bull. Soc. Zool. France v. 46, p. 169-176. París.

1926, Obtention de 23 générations d'oeufs immédiats chez Mesostoma ehrenbergi (Focke). C. R. Soc. Biol. Paris v. 95 fasc. 36, p. 1435-1436. Paris.

1926a, Proportion des porteurs d'oeufs immédiats dans les générations successives. chez Mesostoma ehrenbergi (Focke). C. R. Soe. Biol. Paris v. 95 fase. 36, p. 1437-1438. Paris.

1930, Turbellariés de l' Inde méridionale. Rev. Suisse Zool. v. 37 no. 23, p. 673743 t. 8. Genève.

1931, Races et modes de reproduction chez la planaire Fonticola vitta (Dugès), ete. C. R. Soc. Biol. v. 107, p. 1001-1005. Paris.

1932, Biospeologica 56. Turbellariés, Hirudinées, Branchiobdellidés (2. sér.). Arch. Zool. expér. génér. v. 73, p. $113-180$ t. 6-8. Paris.

1934, Quelques Turbellariés des Balkans et d'Asie Mineure. Bull. Soc. Zool. Franco v. '59, p. 203-209. Paris.

1935, Turbellariés et Bryozoaires. Mission scient. de l'Omo (Mus. Nat. Hist. Nat.) v. 3 fase. 23, p. 141-153. Paris.

1939, Rotifères et Turbellariés. Transact. Linn. Soc. London ser. 3 v. 1 part. 1 (Percy Sladen Trust Exped. Lake Titicaea), p. 51-79 t. 4. London.

1940, Turbellariés et Rotifères. Croisière du Bougainville aux îles australes françaises. Mém. Mus. Nat. Hist. Nat. n. sér. v. 14, p. 313-326 t. 9. Paris.

1940a, Sur les Triclades Paludicoles de l'Hémisphère Sud. C. R. somm. Soc. Biogéogr. v. 17 no. 141, p 7-9. Paris.

Behre, E. H. 1918, An experimental study of acclimation to temperature in Planaria dorotocephala. Biol. Bull..v. 35, p. 277-317. Woods Hole, Mass.

Beklemischev, W. 1917, Turbellariés, collectionés dans le Gouvernement de Kalouga, ete. Ann. Mus. Zool. Acad. Seienc. v. 21 (1916), p. 347-368. St. Pétersbourg.

1920, Observations sur les Turbellariés des environs de Pétrograd. Trav. Soc. Natural, v. 49 fase. 1, p. 38-77 f. 1-10. Petrograd.

1921, Matériaux concernant la systématique et la faunistique des Turbellaria de la Russie de 1' Est. Bull. Acad. Sei. Russie sér. 6 v. 15, p. 631-656 t. 1-3. Petrograd.

1921a, Les 'Turbellariés des steppes disposées à l'Ouest des monts Urals. Trav. Soc. pour l'étude du pays Kirguise, livre 2 (1922), p. 17-42 t. 1. Orenburg.

1924, Sur quelques formes de Rhabdocoeles nouveaux ou peu connus. Bull. Inst. Rech. Biol. Univ. Perm v. 2 no. 8, p. 295-302 1 t. Perm.

1926, Sur la morphologie de l'organe copulateur du genre Dalyellia. Bull. Inst. Rech. Univ. Perm v. 4 no. 6, p. 237-248 1 t. Perm.

1927, Ueber die Turbellarienfauna des Aralsees. Zool. Jahrb. Syst. v. 54 (1928) fase. 1-2 (1927), p. 87-138 t. 2. Jena.

1927a, Ueber die Turbellarienfauna der Bucht von Odessa und der in dieselbe mündenden Quellen. Bull. Inst. Rech. Biol. Univ. Perm. v. 5 no. 5, p. 177-207 t. 1. Perm.

1929, Zur Kenntnis der Solenopharyngiden. Public. Staz. Zool. Napoli v. 9 fase. 2, p. 161-194 t. 8-9. Napoli.

1929a, Die Anatomie von Phaenocora (Megaloderostoma n. subg.) polycirra n. sp. Zeitschr. wiss. Zool. v. 134, p. 533-557. Leipzig.

Bendl, W. E. 1908, Rhabdocoele Turbellarien aus Innerasien. Mitteil. Naturwissensch. Ver. Steiermark, Jahrg. 1908 v. 45, p. 128-130. Graz.

1909, Der Ductus genito-intestinalis der Platlielminthen. Zool. Anz. v. 34, p. 294-299. Leipzig.

Berg. K. 1938, Studies on the bottom animals of Esrom Lake. Mém. Acad. Roy. Sei. Lettr. Danemark Sect. Sci. sér. 9 v, 8, p. 1-255 t. 1-17, 15 tabelas. Köbenhavn.

Bock, S. 1913, Studien über Polycladen. Zool. Bidr. Uppsala v. 2, p. 31-344 t. 3-10. Uppsala. 
1923, Eine neue marine Turbellariengattung aus Japan. Uppsala Univers. Aarsskr. 1923, Matem. Naturvetenskap. 1, p. 1-55 t. 1-2. Uppsala.

1927, Duetus genito-intestinalis in the Polyelads. Ark. Zool. v. 19A no. 14, p. 1-15. Stockholm.

1927a, Apidioplana eine Polycladengattung mit muskulösen Drüsenorganen. Göteb. Vetensk. Vitterh. Samh. Handl. 4. Följd. v. 30 no. 1, p. 1-116. Göteborg.

Böhmig, L. 1887, Planaria Iheringii, eine neue Triclade aus Brasilien. Zool. Anz. จ. 10 no. 258 , p. $482-484$. Leipzig.

1890, Untersuchungen über rhabdocoele Turbellarien. II. Plagiostomina und Oylindrostomina Graff. Zeitschr. wiss. Zool. v. 51 (1891) fase. 2 (1890), p. 167-479 t. 12-21. Leipzig.

1895, Die Turbellaria acoela der Plankton Expedition. Ergeb. Plankt. Exp. v. 2. H. g. 48 p. 3 t. Kiel \& Leipzig. (Lipsius \& Tischer).

1902, Turbellarien. Rhabdocoeliden und Tricladen. Hamburg. Magalh. Sammelreise v. 3 , p. 1-30 t. 1-2. Hamburg.

1906, Tricladenstudien I. Zeitschr. wiss. Zool. v. 81, p. 344-504. t. 12-19. Leipzig.

1914, Die Rhabdocoelen Turbellarien und Tricladen der Deutschen Südp. Exp. 1901-1903. D. Sü.dp. Exp. v. 15, Zool. v. 7, p. 1-33 t. 1-3. Berlin.

1914a, Phaenocora foliacea (Derostoma foliaceum) n. sp. ein Strudelwurm aus ،dem Süsswasser von Kapland. D. Südp. Exp. 1901-1903 v. 16, Zool. v. 8 (1921) fasc. 1 (1914) p. 87-92. Berlin \& Leipzig.

du Bois-Reymond Marcus, E. 1943, Protozoa associados a vermes límnicos. An. Ac. Bras. Cienc. v. 15, p. 359-371 1 t. Rio de Jañeiro.

1944, Notes on fresh-water Oligochaeta from Brazil. Com. Zool. Mus. Hist. Nat. Montivedeo v. 1, no. 20, p. 1-8 t. 1-2. Montevideo.

Borelli, A. 1895, Viaggio del Dott. Alfredo Borelli nella Repubblica Argentina e nel Paraguay. 13. Planarie d'aequa dolee. Boll. Mus. Zool. Anat. Comp. R. Univ. Torino v. 10 no. 202, p. 1-6. Torino.

1897, Viaggio del Dott. Alfredo Borelli nel Chaco Boliviano, ete. V. Planarie d'acqua dolce. Boll. Mus. Zool. Anat. Comp. Torino .v. 12 n.o 288, 4 p. Torino.

1898, Viaggio del Dr. Enrico Festa nell'Ecuador, etc. IX. Planarie d acqua dolce.

Boll. Mus. Zool. Anat. Comp. Torino v. 13 no. 322, p. 1-6. Torino.

1901, Di una nova Planaria d'acqua dolce della Repubblica Argentina. Boll. Mus.

=Zool. Anat. Comp. Torino v. 16 no. 400, p. 1-5. Torino.

Brandtner, P. 1934, Plagiostomidac. Ergebn. Reisinger \& Steinböck Reise in Grönland. Vidensk. Meddel. Dansk. Naturh. Foren. v. 97, p. 87-150 t. 1-4. Köbenhavn.

Brauner, K. 1926, Die Turbellaria acoela der Deutschen Tiefsee Expedition. Wiss. Ergeb. D. Tiefsee Exp. v. 22 fase. 2, p. 29-56 t. 3-5. Jena (G. Fischer).

Bresslau, E. 1903, Die Sommer und Wintereier der Rhabdocoelen des süssen Wassers, ete. Verhandl. D. Zool. Ges. 13. Vers. p. 126-139. Leipzig.

1904, Beiträge zur Entwicklungsgeschichte der Turbellarien. Zeitschr. wiss. Zool. v. 76, p. 213-332 t. 14_20. Leipzig.

1933, Turbellaria. W. Kükenthal \& Th. Krumbach, Handb. Zool. v. 2, 1. ${ }^{a}$ metade, p. 52-293, 310-320 Berlin \& Leipzig (W. de Gruyter).

Bresslau, E. \& E. Reisinger 1933, 6. Ordung der Klasse Turbellaria: Temnocephalida. W. Kükenthal \& Th. Krumbach, Handb. Zool. v. 2, 1. ${ }^{2}$ metade, p. 294-309. Berlin \& Leipzig (W. de Gruyter).

Brinkmann, A. 1905, Studier over Danmarks Rhabdocöle og Acöle Turbellarier. Vidensk. Meddel. Dansk. Naturh. Foren. 1906, IV + 159 p. (paginação da separata) t.
1-5. Köbenhavn.

Busson, B. 1903, Ueber einige Landplanarien. S. Ber. Akad. Wissensch. Mathem. Naturw. Kl. v. 112 Abtlg. 1, p. 375-429 t. 1, 2 (unidas). Wien.

Carter, J. S. 1929, Observations on Rhabdocoeles of Albemarle County, Virginia. Transact. Americ. Mierose. Soc. v. 48 no. 4, p. 431-437. Menasha, Wise.

Castle, W. A. 1927, The life history of Planaria velata. Biol. Bull. v. 53 no. 3, p. 139-144. Woods Hole, Mass.

1928, An experimental and histological study of the life-cycle of Planaria velata. .Journ. Exper. Zool. v. 51 no. 4, p. 417-483 t. 1-2, Philadelphia, Pa. 
Castle, W. A. \& L. H. Hyman 1934, Observations on Fonticola velata (Stringer), ineluding a deseription of the anatomy of the reproductive system. Transact. Americ. Mierose. Soc. v. 53 no. 2, p. 154-171 t. 12. Menasha, Wisc.

Cernosvitov, L. 1931, Studien über die Spermaresorption. III. Die Samenresorption bei den Trieladen. Zool. Jahrb. Anat. v. 54, p. 295-322 t. 5-7. Jena.

1932, Studien über die Spermaresorption. IV Verbreitung der Samenresorption bei den Turbellarien. Zool. Jahrb. Anat. v. 55, p. 137-172 t. 3. Jena.

Child, C. M. 1906, The relation between regulation and fission in Planaria. Biol. Bull. v. 11 no. 3, p. 113-123. Woods Hole, Mass.

1910, Analysis of form regulation with the aid of anaesthetics. Biol. Bull. v. 18 no. 4, p. 161-173. Woods Hole, Mass.

1911, Experimental control of morphogenesis in the regulation of Planaria. Biol. Bull. v. 20 no. 6, p. 309-331. Woods Hole, Mass.

1912, The process of reproduction in organisms. Biol. Bull. v. 23 no. 1, p. 1-39. Woods Hole, Mass.

1913, The asexual cycle of Planaria velata in relation to senescence and rejuvenescence. Biol. Bull. v. 25 no. 3, p. 181-203. Woods Hole, Mass.

1914, Asexual breeding and prevention of seneseence in Planaria velata. Biol. Bull. v. 26 no. 5, p. 286-293. Woods Hole, Mass.

1941, Patterns and Problems of Development. IX +811 p. 224 f. Chieago, Illin.

Claparède, R. E. 1863, Beobachtung über Anatomie und Entwicklungsgeschichte wirbelloser Thiere. VIII + 120 p., 18 t. Leipzig. (W. Engelmann).

Cognetti de Martiis, L. 1915, Ricerche sulla struttura della Phoenocora jucunda Cogn. Arch. Zool. Ital. v. 8 (1916) art. 7 (4-X-1915), p. 189-247 t. 11-12. Torino.

Costello, H. M. \& D. P. Costello 1938, Copulation in the acoelous Turbellarian Polychoerus carmelensis. Biol. Bull. v. 75 no. 1, p. 85-98 t. 1-2 Woods Hole, Mass.

Curtis, W. C. 1902, The life history, the normal fission, and the reproductive organs of Planaria maculata. Proc. Boston Soc. Nat. Hist. v. 30 no. 7, p. 515-559 t. 9-19. Boston.

Diesing, K. M. 1862, Revision der Turbellarien. Abtheilung: Rhabdocoelen. S. Ber. Ak. Wiss. Mathem. Naturw. Cl. v. 45 pars 1, p. 191-318 (suplemento: ibid. v. 16 pars 1, p. 173-188). Wien.

Dorner, G. 1902, Darstellung der Turbellarienfauna der Binnengewässer Ostpreussens. Schr. Phys. Oekon. Ges. Königsberg Jahrg. 43, p. 1-58 t. 1-2. Königsberg i. Pr.

Dugès, A. 1830, Aperȩu de quelques observations nouvelles sur les Planaires et plusieurs genres voisins. Ann. Sci. Nat. (sér. 1) v. 21, p. 72-92 t. 2. Paris.

Ferguson, F. F. 1937, The morphology and taxonomy of Macrostomum virginianum n. sp. Zool. Anz. v. 119 fase. 1-2, p. 25-32. Leipzig.

1937a, The morphology and taxonomy of Maerostomum beaufortensis. Zool. Anz. v. 120 fase. 9-10, p. 230-235. Leipzig.

1939, A monograph of the genus Macrostomum O. Schmidt 1848. Parts I; II. Zool. Anz. v. 126 fasse. 1-2, p. 7-80; v. 127 fase. 5-6, p. 131-144. Leipzig.

1939a, Part III. Zool. Anz. v. 128, p. 49-68. Leipzig.

1939b, Part IV. Zool. Anz. v. 128, p. 188-205. Leipzig.

1939c, Part V. Zool. Anz. v. 128, p. 247-291. Leipzig.

1940, Part VI. Zool. Anz. v. 129, p. 21-48. Leipzig.

1940a, Part VII. Zool. Anz. v. 129, p. 120-146. Lieipzig.

1940b, Part VIII. Zool. Anz. v. 129, p. 244-266. Iseipzig.

1943, Notes on the Turbellarian Fauna of Rochester (N. Y.) with... Macrostomum ontarioense. Americ. Midl. Natural. v. 29 no. 2, p. 425-428. Notre Dame, Ind.

Ferguson, F. F. \& W. J. Hayes Jr. 1941, A synopsis of the genus Mesostoma Ehrenberg 1835. Journ. Elisha Mitchell Scient. Soc. v. 57 no. 1, p. 1-52. Chapel Hill, N. C.

Ferguson, F. F. \& E. R. Jones Jr. 1940, Studies on the Turbellarian Fauna of the Norfolk Area. Americ. Midl. Natural. v. 24 no. 1, p. 184-189. Notre Dame, Ind.

Findenegg, I. 1924, Beiträge zur Kenntnis der Familie Typhloplanidae. Zool. Anz. v. 61, p. 19-30. Leipzig.

1930, Untersuchungen an einigen Arten der Familie Typhloplanidae. Zool. Jahrb. Syst. v. 59, p. 73-130 t. 4-5. Jena. 
Fischer, O. 1926, Digonopyla (Dolichoplana) harmeri (Graff), eine Landtriclade aus Celebes, etc. Zool. Anz. 66 fasc. 9-12, p. 257-261. Leipzig.

Flory, W. S. jr. \& H. M. Showalter 1930, The histology of the bursa copulatrix of the Turbellarian Gyratrix hermaphroditus Ehrhg. Transact. Microse. Soc. v. 49, p. 66-71 t. 10 Menasha, Wise.

Friedmann, G. 1924, Monocelis oofaga, nor. sp., eine neue parasitische Alloeocoele. Bull. Inst. Rech. Biol. Univ. Perm v. 3 fase. 2, p. 81-92, 1 t. Perm.

Fuhrmann, O. 1894, Die Turbellarien der Umgebung von Basel. Rev. Suisse Zool. v. 2, r. 215-290 t. 10-11. Genève.

1914, Turbellariés d'eau douce de Colombie. Mém. Soc. Neuchât. Sei. Nat. v. 5, p. $793-804$ t. 18 . Neucbâtel.

Fulinski, B. 1915, Materyaly do fauny wirkow Ziem Polskich. Rozpr. wiad. Muzeum im. Dzied. v. 1 fase. $3-4$, p. 1-17. Lwow.

Fulinski, B. \& E. Szynal 1927, Zwei neue Turbellarienarten aus der Gattung Dalyellia. Kosmos (Journ. Soc. Polon. Natural. "Kopernik") v. 52 fase. 1-2, p. 157. 166. Lwow.

Gelei, J. v. 1913, Ueber die Ovogenese von Dendrocoelum lacteum. Arch. Zellforsch. v. 11 fase. I, p. 51-150 t. 4-5. Leipzig \& Berlin.

1930, "Echte" freie Nervenendigungen. Zeitschr. Morphol. Oekol. Tiere v. 18, p. 786-798. Berlin.

Gieysztor, M. 1926, Ueber die Rhabdocoelidenfauna aus der Umgebung von Warschau. Bull. Aead. Polon. Sei. Lettr. Classe Sei. Mathém. Natur. sér. B, Sci. Nat. 1926, p. 617-671 t. 17-19. Cracovie.

1929, Zur Kenntnis einiger Dalyellia, Castradella und Castrada-Arten. Bull. Acad. Polon. Sci. Lettr. Classe Sei. Mathém. Natur. sér. B. Sci. Nat. (II) 1929, p. 155-195 t. 8-10. Cracovie.

1930, Sur deux espèces rares du genre Macrostomum (Rhabdocoela). Arch. Hydrobiol. Ichthyol. v. 5 (1931) no. 3-4 (1930), p. 305-314. Suwalki.

1931, Contribution à la connaissance des Turbellariés Rhabdocèles d'Espagne. Bull. Mém. Acad. Polon. Sei. Lettr. Classe Mathém. Natur. sér. B. Sei. Nat. (II) 1931, p. $125-153$ t. 13-14. Cracovie.

1934, Ueber die Dalyellia viridis-Artengruppe. Mém. Acad. Polon. Sci. Lettr. Classe Sci. Mathém. Natur. sér. B. Sei. Nat. 1934, p. 207-219. Cracovie.

1938, Systematischanatomischè Untersuchungen an Turbellarien Polens. Zoolog. Polon. v. 2, p. 215-248 t. 1-2. Lwow.

1938a, Ueber einige Turbellarien aus dem Süsswasserpsammon. Arch. Hydrobiol. Ichthyol. v. 11 no. $3-4$, p. $364-383$ t. 3 . Suwalki.

Gilbert, C. MeL. 1935, A comparative study of three new american species of the genus Phaenocora, ete. Acta Zoologica v. 16 fasc. 3, p. 283-386 t. 1-5. Stockholm.

1937, A remarkable North American species of the genus Phaenocora. Zeitschr. Morphol. Oekol. Tiere v. 33 (1938) fase. 1. (11-V-1937), p. 53-71. Berlin.

1938, Two new North American Rhabdocoeles -- Phaenocora falciodenticulata \& J'h. kepneri adenticulata. Zool. Anz. v. 122 fase. 7-8, p. 208-223. Leipzig.

1938a, A new North American Rhabdocoele - Pseudophaenocora sulfophila, ete. Zool. Anz. v. 124 fase. 8, p. 193-216. Leipzig.

Girard, Ch. 1850, A brief account of the fresh-water Planariae of the United States. Proc. Boston Soc. Nạt. Hist. v. 3, p. 264-265 (não visto; cit. seg. Kenk 1944, p. 42). Boston, Mass.

1852, Deseriptions of two new genera and two new species of Planaria. Proc. Boston Soc. Nat. Hist. v. 4, p. 210-212 (não visto; eit. seg. Kenk 1944, p. 42). Boston, Máss.

1893, Recherches sur les Planạriés et les Némertiens de l'Amérique da Nord. Arn. Sei. Nat. Zool. sér. 7 v. 15, p. 145-310 t. 3-6. Paris.

Goetsch, W. 1925, Versuche über Selbstbefruchtung bei Planarien. Biol. Zentralbl. v. 44 fase. 12, p. $667-671$. Leipzig.

Graff, L. 1874, Zur Kenntnis der Turbellarien. Zeitschr. wiss. Zool. v. 24, p. $123-160^{\prime}$ t. $14-19$. Leipzig.

1897, Die, von. P. und F. Sarasin auf Celebes gesammelten Landplanarien. Verhandl. D. Zool. Ges. 7 . Vers. p. 111-114. Leipzig." 
1899, Monographie der Turbellarien, II. Tricladida Terriçola. v. 1, XIII +574 p. v. 2, 58 t. Leipzig (W. Engelmann).

1905, Marine Turbellarien Orotavas, etc. II. Rhabdocoela. Zeitschr. wiss. Zool. v. 83 , p. $68-150$ t. 2-6. Leipzig.

1912, Acoela, Rhabdocoela und Alloeocoela des Ostens der Vereinigten Staaten von Amerika. Zeitschr. wiss. Zool. v. 99 fasc. 1 (1911), p. 1-108 t. 1-4. Leipzig.

1913, Turbellaria. II. Rhabdocoelida. Das Tierreich (Preuss. Akad. Wissensch.) fasc. $35, \mathbf{X} \mathbf{X}+484$ p. Berlin (R. Friedländer \& Sohn).

Haffner, K. v. 1925, Untersuchungen über die Symbiose von Dalyellia viridis und Chlorohydra viridissima mit Chlorellen. Zeitschr. wiss. Zool. v. 126 fase. 1, p. 1-69, Nachtrag p. 180, t. 1. Leipzig.

Hallez, P. 1873, Observations sur le Prostomum lineare (Oersted). Arch. Zool. expér génér. (sér. 1) v. 2, p. 559-585 t. 20-22. Paris.

1892, Classification des Triclades, Bull. Soc. Zool. France v. 17, p. 106-109. Paris.

1900, Rhabdocoeles. Zool. descript. Anatomie-Histologie et Dissection des formes typiques d'Invertébrés (L.Boutan, sécrétaire de la rédaction) v. 1 Chap. 16, p. 449-483 f. 201-219. Paris.

Haswell, W. A. 1905, Studies on the Turbellaria. Quart. Journ. Micr. Sci. n. sér. v. 49 (1906), p. 425-467 t. 25-27. London.

Hayes, W. J. 1945, Rhabdocoela of Wisconsin. II. Morphology and taxonomy of Castrella pinguis. Americ. Midl. Natural. v. 33 no. 2, p. 440-448. Notre Dame, Ind.

Hayes, W. J. \& F. F. Ferguson 1940, Notes on the Morphology of Macrostomum ruebushi var. schmitti. Journ. Washington Aead. Science v. 30 no. 1, p. 27-30. Washington, D. C.

Heidenreich, E. 1931, Das Vorkommen freilebender Planaria maculata Leidy in Deutschland. Zool. Anz. v. 93 fase. 11-12, p. 334-336. Leipzig.

Heider, K. 1909, Ungeschlechtliche Fortpflanzung und Regeneration. Korschelt \& Heider, Lehrb. vergl. Entwicklungsgesch. der wirbellosen Tiere, Allg. Teil, 4. Abschn. 1 \& 2. ed. fase. 3 , p. $471-896$ f. 322-649. Jena.

Hein, Ch. 1928, Zur Kenntnis der Regenerationsvorgänge bei den Rhabdocoelen. Zeitschr. wiss. Zool. v. 130 fase. 3-4, p. 469-546 t. 13. Leipzig.

Hesse, R. 1897, Untersuchungen über die Organe der Lichtempfindung bei niederen Thieren. II. Die Augen der Plathelminthen, etc. Zeitschr. wiss. Zool. v. 62, p. 527-582 t. 27-28. Leipzig.

Higley, R. 1918, Morphology and Biology of some Turbellaria from the Mississippi Basin. Illinois Biol. Monogr. v. 4 no. 2, p. 195-289 (na separata: 3-94) t. 1-3. Urbana, Illin.

Hofsten, N. v. 1907, Studien über Turbellarien aus dem Berner Oberland. Zeitsehr. wiss. Zool. v. 85 fase. 3, p. 391-654 t. 22-27. Leipzig.

1907a, Zur Kenntnis des Plagiostomum lemani (Forel \& du Plessis). Zool. Stud. tilägn. Prof. T. Tullberg, p. 93-132, 1 t. Uppsala.

1907b, Drei neue Rhabdocoelen aus schwedischen Binnengewässern. Ark. Zool. v. 3 no. 27 , p. 1-15 t. 1. Stockholm.

1909, Ueber die frühzeitige Besamung der Eizellen bei Otomesostoma auditivum, etc. Zool. Anz. v. 34 fasc. 13-14, p. 431-443. Leipzig.

1911, Neue Beobachtungen über die Rhabdocölen und Allöocölen der Schweiz. Zool. Bidr. Uppsala v. 1, p. 1-84 t. 1-2. Uppsala.

1912, Revision der schweizerischen Rhabdocölen. und Allöocölen Rev. Suisse Zool. จ. 20 no. 12 , p. 543-688. Genève.

1916, Turbellarien der nordschwedischen Hochgebirge. Naturwiss. Untersuch. Sarekgebirge Schwedisch Lappland v. 4, Zool. fasc. 6, p. 697-742. Stockholm \& Berlin. Uppsala.

1916a, Ueber die Gattung Castrada O. Schm. Zool. Bidr. Uppsala v. 5, p. 1-14.

1918, Anatomie, Histologie und systematische Stellung von Otoplana intermedia du Plessis. Zool. Bidr. Uppsala v. 7, p. 1-74 t. 1-2. Uppsala.

1920, Die Turbellarienfauna des Taakern. Sjön Taakerns Fauna och Flora (K. Svenska Vetenskapsakademien) v. 3, p. 1-12. Stockholm.

1925, Rhabdocoele Turbellarien. Rep. Sei. Res. Norweg. Exped. Novaya Zemlya 1921 no.28, p. 1-5. Oslo. 
Husted, L., F. F. Ferguson, \& M. A. Stirewalt 1939, Chromosome association in Mesostoma ehrenbergii (Focke) Schmidt. American Naturalist v. 73 no. 745 , p. 180-185. Lancaster, Pa.

Hyman, L. H. 1925, The reproductive system and other characters of Planaria dorotocephala Woodworth. Transact. Americ. Microse. Soc. v. 44 no. 2, p. 51-89 t. 4-6. Menasha, Wise.

1928, Studies on the Morphology, etc. of North American Triclad Turbellaria. I. Procotyla fluviatilis, commonly but erroneously known as Dendrocoelum lacteum. Transact. Americ. Microse. Soc. v. 47 no. 2, p. 222-255 t. 32 . Menasha, Wise.

1931, Studies, etc. IV Recent European Revisions, ete. Transact. Americ. Microsc. Soc. v. 50 no. 4 , p. $316-335$ t. 33 . Menasha, Wisc.

1931 a, Studies, etc. V. Description of two new species. Transact. Americ. Microse. Soc. v. 50 no. 4 , p. $336-343$ t. 34 . Menasha, Wise.

1936, Studies on the Rhabdocoela of North America, I. On Macrostomum tubum (von Graff 1882). Transact. Americ. Microse. Soc. v. 55, p. 14-20 t. 3. Menasha, Wise.

1937, Studies.. Triclad Turbellaria. VII. The two species confused under the name Phagocata, ete. Transact. Americ. Mierose. Soc. v. 56, p. 298-310 f. 1-6. Menasha, Wisc.

1937a, Studies. Triclad Turbellaria. VIII. Some cave Planarians, etc. Transact. Americ. Mierose. Soc. v. 56 no. 4, p. 4, p. 457-477, 21 f. Menasha, Wisc.

1938, North American Rhabdocoela and Alloeocoela. II. Rediscovery of Hydrolimax grisea Haldeman. Americ. Mus. Novitates no. 1004, p. 1-19. New York.

1939, North American Triclad Turbellaria. IX. The priority of Dugesia Girard 1850 over Euplanaria Hesse 1897, ete. Transact. Americ. Microse. Soc. v. 58, p. 264-275. Menasha, Wisc.

1939a, North American Triclad Turbellaria. X. Additional species of eave Planarians. Transact. Americ. Microse. Soc. v. 58, p. 276-284 t. 1-2. Menasha, Wise.

1939b, New species of Flatworms from North, Central, and South America. Proceed. U. S. Nat, Mus. v. 86 no. 3055, p. 419-439. Washington, D. C.

1943, On a species of Macrostomum (Turbellaria; Rhabdocoela) found in tanks of exotic fishes. Americ. Mid̆l. Natural. v. 30 no. 2, p. 322-335 f. 1-15. Notre Dame, Ind.

1944, Marine Turbellaria from the Atlantic Coast of North America. Americ. Mus. Novitates no. 1266, p. 1-15. New York.

1945, North American Trielad Turbellaria. XI. New, chiefly cavernicolous, Planarians. Americ. Midl. Natural. v. 34 no. 2, p. 475-484. Notre Dame, Ind.

Iijima, I. 1884, Untersuchungen über den Bau und die Entwicklungsgeschichte der Süsswasser-Dendrocoelen (Tricladen). Zeitschr. wiss. Zool. v. 40, p. 359-464 t. t. 20-23. Leipzig.

Jägersten, G. 1941, Zur Kenntnis von Glanduloderma myzostomatis, n. g., n. sp. etc. Ark. Zool. v. 33A no. 3, p. 1-24 t. 1-2. Stockholm.

Jones, A. W. 1944, Macrostomum hustedi, a morphological and eytological study of a rhabdocoel Turbellarian. Journ. Morphol. v. 75 no. 3, p. 347-359 t. 1. Philadelphia, $\mathrm{Pa}$.

Jones, E. R. \& F. F. Ferguson 1940, Studies on the Turbellarian Fauna of the Norfolk Area. IV. Macrostomum norfolkensis. Virginia Journ. Sci. v. 1 no. 7, p.219220. Lexington, Va.

1941, Studies, etc. VI, Macrostomum appendiculatum var. stirewalti. Journ. Elisha Mitchell Scient. Soc. v. 57 no. 1, p. 53-56! t. 1. Chapel Hill, N. C.

Jones, E. R. Jr. \& J. W. Hayes Jr. 1941, Microdalyellia gilesi, a new Turbellarian Worm from Mountain Lake, Virginia. Americ. Midl. Natural. v. 26, p. 596-602. Notre Dame. Ind.

Jordan, H. J. \& G. C. Hirsch 1927, Einige vergleichend physiologische Probleme der Verdauung bei Metazoen. Bethe. A., Handb. norm. \& pathol. Physiol. v. 3, p. 24-101. Berlin.

Karling, T. G. 1931, Untersuchungen über Kalyptorhynchia aus dem Brackwasser des Finnischen Meerbusens. Acta. Zool. Fennica fasc. 11, p. 1-66. Helsinfors.

1940, Zur Morphologie und Systematik der Alloeocoela Cumulata und Rhabdocoela Lecithophora. Acta Zool. Fennica fase. 26, p. 1-260 t. 1-17. Helsingfors.

Kato, K. 1931, A new Triclad Turbellarian. Proc. Imper. Acad. v. 7 no. 9, p. 363-366. Tokyo. 
Kenk, R. 1923, Die Entwicklung und Regeneration des Kopulationsapparates der Planarien. Zool. Jahrb. Anat. v. 45 (1924) fase. 2 (1923), p. 213-250 t. 11 Jena.

1927, Eine eigentümliche Verdoppelung des Kopulationsapparates bei Polycelis tenuis Iijima. Zool. Anz. v. 72 fase. 9-10, p. 243-249. Leipzig.

1930, Beiträge zum System der Probursalier (Tricladida Paludicola). I-III. Zool. Anz. v. 89 fase. $5-6$, p. 145-162; fase. 11-12, p. 289-302. Leipzig.

1935, Studies on Virginian Triclads. Journ. Elisha Mitchell Scient. Soc. v. 51 no. 1 , p. 79.125 t. 45 (f. 1-8), f. 9-29 (7 t.) Chapel Hill, N. C.

1935a, A morphological proof of the existence of zooids in Euplanaria dorotocephala. Physiol. Zool. v. 8 no. 4, p. 442-456. Chicago, Illin.

1937, Sexual and asexual reproduction in Euplauaria tigrina (Girard). Biol. Bull. v. 73 no. 2, p. 280-294. Woods Hole, Mass.

1940. The reproduction of Dugesia tigrina (Girard). Americ. Natural. v. 74, p. 471-475. New York.

1941, A fresh-water Triclad from Puerto Rico, Dugesia antillana, new species. Oecasion. Papers Mus. Zool. Univ. Michig. no. 436, p. 1-7 t. 1. Ann Arbor, Mich.

1941a, Induction of sexuality in the asexual form of Dugesia tigrina (Girard). Journ. Experim. Zool. v. 87 n. ${ }^{\circ}$ 1, p. 55-69. Philadelphia.

1943, Notes on the Planarian Fauna of Canada. The Canadian Field Naturalist v. 57, p. 5-6. Ottawa.

1944, The fresh-water Triclads of Michigan. Miscell. Public. Mus. Zool. Univ. Michigan no. 60, p. 9-44 t. 1-7. Ann Arbor, Mich.

Kennel, J. v. 1888, Untersuchungen an neuen Turbellarien. Zool. Jahrb. Anat. v. 3 (1889) fasc. 3 (1888), p. 447-486 t. 18-19. Jena.

1898, Mesostoma aselli, n. sp. Zool. Anz. v. 21, p. 639-641. Leipzig.

Kepner, W. A. \& J. S. Carter 1931, Olisthanella virginiana nov. sp. Zool. Anz. v. 95, p. 87-94. Leipzig.

Kepner, W. A., F. F. Ferguson \& M. A. Stirewalt 1941, A new Turbellarian from Beaufort, North Carolina, Trigonostomum pryterchi, n. sp. Journ Elisha Mitehell Scient. Soc. v. 57, p. 243-252 t. 3. Chapel Hill, N. C.

Kepner, W. A: \& M. W. Stiff 1932, Observations upore the American representative of Macrostomum tuba. Journ. Morphol. v. 54 fase. 1, p. 221-231 t. 1. Philadelphia, $\mathrm{Pa}$.

Kepner, W. A., M. A. Stirewalt \& F. F. Ferguson 1939, The ductus genitointestinalis in the genus Castrada, based upon Castrada lutheri n. sp. Zool. Anz. v. 125 fase: $9-10$, p. 225-235. Leipzig.

1941, A new Turbellarian (Alloeocoele) from Beaufort, North Carolina, Plagiostomum Dahlgreni n. sp. Journ. Elisha Mitchell Scient. Soc. v. 57 no. 2, p. 253-260 t. 4. Chapel Hill, N. C.

Komarek, J. 1919, O temnostich Tricladach (Vermes, Turbellaria) krasu balkhanskych,' etc. Casopis Moravského Musea zemeského v. 16, p. 1-50 t. 1-3. Brno.

1920, Ueber höhlenbewohnende Tricladen der balkanischen Karste. Arch. Hydrobiol. v. 12 , p. $822-828$. Stuttgart.

Kromhout, G. A. 1943, A comparison of the protonephridia of fresh-water, brackish-water, and marine specimens of Gyratrix hermaphroditus. Journ. Morphol. จ. 72 no. 1, p. 167-181 t. 1-2. Phidadelphia, Pa.

Kühn, A. 1919, Die Orientierung der Tiere im Raum. IV + 71 p. 40 f. Jena (G. Fischer).

Lang, A. 1884, Polycladen. Flora \& Fauna Golf. Neapel fasc. 11, IX +688 p. 39 t. Leipzig (W. Engelmann).

Leidy J. 1848, Descriptions of two new species of Planaria. Proceed. Acad. Natur. Sci. Philadelphia v. 3, p. 251-252. Philadelphia, Pa.

Lippitsch, K. 1889, Beiträge zur Anatomie des Derostoma unipunctatum Oe. Zeitschr. wiss. Zool. v. 49 (1890) fasc. 1 (13-XII-1889), p. 147-167 t. 8. Leipzig.

Löhner, L. 1910, Untersuchungen über Polychoerus caudatus Mark. Zeitschr. wiss. Zool. v. 95 fase. 3, p. 451-506 t. 15-17. Leipzig.

Löhner, L. \& H. Micoletzky 1911, Ueber zwei neue pelagische Acölen des Golfes von Triest. Zeitschr. wiss. Zool. v. 98 fase. 3, p. 381-429 t. 19-20. Leipzig.

Luther, A. 1904, Die Eumesostominen. Zeitschr. wiss. Zool. v. 77 fase. 1-2, p. 1-273 t. 1-9. Leipzig. 
1905, Zur Kenntnis der Gattung Macrostoma. Festschr. Palmén v. 1 no. 5, p. 1-61 t. 1-4. Helsingfors.

1907, Ueber die systematische Stellung der Rhabdocoelen-Familie Catenulidae s. str. (= Stenostomidae Vejd.). Zool. Anz. v. 31 no. 23, p. 718-723. Leipzig.

1908, Ueber "Weldonia parayguensis" C. H. Martin. Zool. Anz. v. 33, p. 300. Leipzig.

1918, Vorläufiges Verzeichnis der rhabdocoelen und alloecoelen Turbellarien Finnlands. Meddel. Fauna Flora Fenn. v. 44 (1917-1918), p. 47-52, mapa. Helsingfors.

1921, Untersuchungen an rhabdocoelen Turbellarien. Acta Soc. Faun. Flor. Fenn. v. 48 no. 1 , p. $1-59$ t. ${ }^{1} 1$. Helsingfors.

1943, Untersuchungen an rhabdocoelen Turbellarien IV. Ueber einige Repräsentanten der Familie Proxenetidae. Acta Zool. Fenn. v. 38, p. 1-95 t. 1-6. Helsingfors. 1946, Untersuchungen an Rhabdocoelen Turbellarien. V. Ueber einige Typhloplaniden. Acta Zool. Fenn. v. 46, p. 1-56. Helsingfors.

Marcus, E. 1933, Tiergeographie. F. Klute, Handb. geograph. Wissenseh. Allg. Geogr. v. 2, p. 81-166 t. 7-11. Potsdam (Athenaion, Akad. Verlagsges.).

1941, Sôbre Bryozoa do Brasil. Bol. Fac. Fil. Ciêne. Letr. Univ. S. Paulo 22, Zoologia 5, p. 3-208 t. 1-18. São Paulo.

1943, Sôbre Naididae do Brasil. Bol. Fac. Fil. Ciênc. Letr. Univ. S. Paulo 32, Zoologia 7, p. 3-247 t. 1-33. São Paulo.

1943a, O turbellário Mesostoma ehrenbergii (Focke 1836) no Brasil. Bol. Industria Animal n. ser. v. 6 no. 1-2, p. 12-15. São Paulo.

1944, Sôbre duas Prorhynchidae (Turbellaria), novas para o Brasil. Arqu. Mus. Paranaense v. 4, art. 1, p. 3-46 t. 1-2. Curitiba.

1944a, Sôbre Oligochaeta límnicos do Brasil. Bol. Fac. Fil. Ciêne. Letr. Univ. S. Paulo 43, Zoologia 8, p. 5-135 t. 1-17. São Paulo.

1915, Sôbre Microturbellários do Brasil. Com. Zool. Hist. Nat. Montevideo v. 1 no. 25 , p. 1-74 summary p. 1-4; t. 1-11. Monterideo.

1945a, Sôbre Catenulida brasileiros. Bol. Fac. Fil. Ciêne. Letr. Univ. S. Paulo, Zoologia 10, p. 3-133 t. 1-16. São Paulo.

Maristo, Lauri 1938, Beiträge zur Kenntnis der Monocelidinen. Ann. Soc. Zool. Bot. Fenn. Vanamo v. 6 no. 3, p. I-IV, 1-69 t. 1. Helsinki.

Martin, C. H. 1907, Notes on some Turbellaria from Scottish Lochs. Proceed.

Roy. Soc. Edinb. 1907-08 v. 28, part 1 nos. 2-3, p. 28-34 t. 3-4. Edinburgh.

1908, Weldoniai parayguensis. Zool. Anz. v. 32, p. 758-763. Leipzig.

Mattiesen, E. 1904, Ein Beitrag zur Embryologie der Süsswasserdendrocölen. Zeitschr. wiss. Zool. v. 77, p. 274-361 t. 10-13. Leipzig.

Meinken, H. 1925. Ein verkannter Laichräuber. Wochenschr. Aquar. Terrar. Kunde v. 22, p. 94-96. Braunschweig.

1927, Planaria maculata, ein aus Nordamerika eingeschleppter Laichräuber und seine Vertilgung. Blätter Aquar. Terrar.-Kunde v. 38, p. 131-133. Stúttgart.

Meixner, J. 1915, Zur Turbellarienfauna der Ostalpen, insonderheit des Lunzer Seengebietes. Zool. Jahrb. Syst. v. 38, 459-588 t. 30-32. Jena.

1923, Ueber das Ovarium von Microstomum lineare, etc. Zool. Anz. v. 58, p. 195 213. Leipzig.

1923a, Ueber den Bau des Geschlechtsapparates bei Calyptorhynchiern und die Bildung des Eistieles, etc. Zool. Anz. v. 57 no. 9-13, p. 193-207. Leipzig.

1924, Studien zu einer Monographie der Kalyptorhynchia und zum System der Turbellaria Rhabdocoela. Zool.Anz. v. 60 p. 1-29 (paginação da separata). Leipzig.

1925, Beitrag zur Morphologie und zum System der Turbellaria-Rhabdocoela. I. Die Kalyptorhynchia. Zeitschr. Morphol. Oekol. Tiere v. 3 fase. 2-3, p. 255-343 t. 2-3. Berlin.

1926, Beitrag... Turbellaria-Rhabdocoela. II. Ueber Typhlorhynchus nanus, ete. Zeitschr. Morphol. Oekol. Tiere v. 5 fase. 4, p. 577_624. Berlin.

1928, Der Genitalapparat der Trieladen, etc. Zeitschr. Morphol. Oekol. Tiere v. 11 fase. 5, p. 570-612. Berlin.

1929, Morphologisch-ökologische Studien an neuen Turbellarien aus dem Meeressande der Kieler Bucht. Zeitsehr. Morphol. Oekol. Tiere v. 14 fase. 3, p. 765-791. Berlin.

1938, Turbellaria (Strudelwürmer). G. Grimpe, Tierwelt Nord \& Ostsee pars IVb, 1-146, 100 f. Leipzig (Akad. Verlagsges.). 
Menthe, A. 1939, Euplanaria tigrina (Girard) im Ueberwinterungshafen Bellinchen, Oder. Märk. Tierwelt v. 4 fasc. 1, p. 119-120. Berlin.

Micoletzky, H. 1907, Zur Kenntnis des Nerven- und Exkretionssystems einiger Süsswassertricladen, ete. Zeitschr. wiss. Zool. v. 87, p. 382-434 t. 21-23. Leipzig.

Midelburg, A. 1908, Zur Kentnis' der Monocelididae. Zeitschr. wiss. Zool. v. 89, p. 81-108 t. 6. Leipzig.

Mrazek, A. 1904, Ueber eine neue polypharyngeale Planarienart aus Montenegro (Planaria montenegrina n. sp.). Sitz. Ber. K. Böhm. Gessellsch. Wissensch. 1903 (math.-nat. Classe) no. 33, 1-43 t. 1-2. Prag.

1914, Regeneration an der tripharyngealen Planaria anopthalma. Arch. Entw. Mech. v. 38 no. 2, p. 252-276. Leipzig \& Berlin.

Müller, H.-G. 1936, Untersuchungen über spezifische Organe niederer Sinne bei rhabdocoelen Turbellarien. Zeitschr. vergleieh. Physiol. v. 23, p. 253-292. Berlin.

Nassonov, N. 1917, Sur la faune des Turbellaria de Finlande. Bull. Acad. Sci. Russie sér. 6, 1917 n. ${ }^{\circ}$ 14, p. 1095-1112 t. 1-3; n.o 15, p. 1235-1258. Petrograd (não visto; eit. seg. Luther 1918, p. 47).

1919, Contribution à la faune des Turbellaria de la Russie I. Bull. Acad. Sei. Russie ser. 6 v. 13 (2. ${ }^{\mathrm{a}}$ parte) 1919 , p. 619-646 t. 1-3. Petrograd.

1919a, Contribution à la faunè des Turbellaria de la Russie II \& III. Bull. Acad.

Se. Russie sér. 6 v. 13 (2. ${ }^{\text {a }}$ parte) 1919, p. 1039-1053 t. 4. Petrograd.

1919b, Contribution à la faune des Turbellaria de la Russie IV. Bull. Acad. Sci. Russie sér. 6 v. 13 (2. ${ }^{\mathrm{a}}$ parte) 1919, p. $1179-1197$ t. 5. Petrograd.

1921, Compte-rendu d'une mission scientifique en été 1921 aux environs de Petrograd, etc. Bull. Acad. Sci. Russie sér. 6 v. 15, p. 145-146. Petrograd.

1924, Les traits généraux de la distribution géographique des Turbellaria rhabdocoelida dans da Russie de l'Europe. Bull. Acad. Śei. Russie 1924, p. 327-352, 1 mapa. Leningrad.

1924a, Sur la faune des Turbellaria rhabdocoelida de la Crimée. Bull. Acad. Sci. Russie 1924, p. 35-46, 1 t. Leningrad.

1925, La faune des Turbellaria de la péninsule de Kola. Bull. Acad. Russie 1925, p. 53-74, 1 t. Leningrad.

1926, Die Turbellarienfauna des Leningrader Gouvernements, I \& II. Bull. Acad. Sei. de I'URSS 1926, p. 817-836, 869-884 t. 1-2. Leningrad.

1926a, Sur quelques Turbellaires des environs du lac Baikal. C. R. Akad. Sci. URSS 1926, p. 203-206. Leningrad.

1929, Zur Fauna der Turbellaria Rhabdocoelida der japanischen Süsswasserbecken.

C. R. Acad. Sci. URSS 1929, p. 423-428. Leningrad.

1930, Vertreter der Fam. Graffillidae (Turbellaria) des Baikalsees, Bull. Acad. Sci. URSS, elasse Sei. physico-mathém. 1930, p. 727-738. Leningrad.

1932, Zur Morphologie der Turbellaria Rhabdocoelida des Japanischen Meeres. Trav. Lab. Zool. Expér. et Morphol. Animaux v. 2, p. 1-115 t. 1-8. Leningrad.

1935, Ueber den Heliotropismus der Turbellaria Rhabdocoelida des Baikalsees. Trav. Lab. Zool. Expér. Morphol. des Animaux v. 4, p. 195-204. Leningrad.

Neppi, V. 1904, Ueber einige exotische Turbellarien. Zool. Jahrb. Syst. v. 21 ete. Mem. Coll. Sei. Kyoto Im. Univ. ser. B v. 5 no. 1, p. 75-888 t. 3-4. Kyoto.

Okngawa, K. 1930, A list of the fresh-water Rhabdocoelids found in middle Japan, etc. Mem. Coll. Sci. Kyoto Imp. Univ. ser. B v. 5 no. 1, p. 75.88 t. 3-4. Kyoto.

Oparina-Charitonowa, N. 1927, Ueber den Zusammenhang zwischen dem Geschlechtsapparat und dem Darm in der Gattung Monocelis Ehrenberg. Bull. Inst. Rech. Biol. Univ. Perm v. 5 no. 5, p. 209-218 f. 1-4. Perm.

Palombi, A. 1928, Report, on the Turbellaria (Cambridge Exped. Suez Canal 1924). Transact. Zool. Soc. London v. 22 part 5 no. 1, p. 579-631 t. 1. London.

Peebles, F. 1915, A description of three Acoela from the Gulf of Naples. Mitteil. zoolog. Stat. Neapel v. 22 no. 9, p. 291-312 t. 10. Berlin.

Pereira, C. \& R. Cuocolo 1941, Estudos sobre "Temnocephalidae Monticelli 1899 ", com estabelecimento de dois novos gêneros, ete. Arqu. Inst. Biol. v. 12 art. 9, p. 101-127. São Paulo.

Pereyaslawzewa, S. 1892, Monographie des Turbellariées de la Mer Noire. Separata de Zapiski Novoross. Obsheh. (Denkschr. neuruss. Ges. Naturfoseher) v, 17, $\mathbf{X X}+303$ p. 16 t. Odessa 1893. 
Phillips, H. M. 1936, A eytological study of Macrostomum tuba von Graff. Zool. Anz. v. 114 fasc. 11-12, p. 322-330. Leipzig.

Plotnikow, W. 1905, Ueber einige rhabdocoele Turbellarien Sibiriens. Zool. Jahrb. Syst. v. 21 fase. 4, p. $497-490$ t. 25 . Jena.

1906, Die rhabdocoelen Turbellarien des Goktscha-Sees. Zool. Jahrb. Syst. v. 23 fase. 3 , p. $395-400$ t. 22 . Jena.

Prenant, M. 1922, Recherches sur le parenchyme des Plathelminthes. Arch. Morphol. Génér. Expér. v. 5, p. 1-175 t. 1-8. Paris. (Gaston Doin).

Reisinger E. 1922, Untersuchungen über Bau und Funktion des Exkretionsapparates bei rhabdocoelen Turbellarien. Zool. Anz. v. 54 fase. 9-10, p. 200-209. Leipzig.

1923, Turbellaria. P. Schulze, Biol. Tiere Deutschl. fase. 4, p. 1-64. Berlin. (Gebr. Borntraeger).

1924, Die terricolen Rhabdocoelen Steiermarks. Zool. Anz. v. 59, p. 1-45 (paginação da separata). Leipzig.

1924a, Zur Anatomie von Hypotrichina... nebst einem Beitrag zur Systematik der Alloeocoelen. Zool. Anz. v. 60 fasc. 5-6, p. 137-149. Leipzig.

1924b, Die Gattung Rhynchoseolex. Zeitschr. Morphol. Oekol. Tiere v. 1 fasc. 1, p. 1-37 t. 1-2. Berlin.

1924c, Zur Turbellarienfauna der Ostalpen. Zool. Jahrb. Syst. v. 49, p. 229-298 t. 1. Jena.

1925, Untersuchungen am Nervensystem der Bothrioplana semperi, ete. Zeitschr. Morphol. Oekol. Tiere v. 5 fasc. 1, p. 119-149. Berlin.

1926, Zur Turbellarienfauna der Antanktis. Deutsche. Südpolarexp. v. 18, Zoologio จ. 10, p. 415-462. Berlin \& Leipzig (W. de Gruyter).

1929, Zum Ductus genito-intestinalis-Problem, etc. Zeitsehr. Morphol. Oekol. Tiere v. 16 (1930) fase. 1-2 (1929), p. 49-73. Berlin.

1933, Turbellaria der Deutschen Limnogisehen Sunda-Expedition. Arch. Hydrobiol. 1933, Suppl.-Bd. 12 “Trop. Binnengew. v. 4”, p. 239-262. Stuttgart.

1935, Ergebnisse einer... Reise in Grönland. 6. Proporoplana jenseni, nov. gen., etc. Vidensk. Meddel. Dansk. Naturh. Foren. v. 98, p. 243-259. Köbenhavn.

Riedel, G. 1932, Ergebnisse einer... Reise in Grönland. 3. Macrostomida. 4. Dalyelliidae. Vidensk. Meddel. Dansk. Naturh. Foren. v. 94, p. 33-107 t. 1-4. Köbenhavn.

Riester, A. 1938, Beiträge zur Geoplanidenfauna Brasiliens. Abhandl. Senckenb. Naturf. Ges. fasc. 441 , p. 1-88 t. 1-2. Frankfurt a. M.

Robeson, J. M. jr. 1931, The macro- and microscopic anatomy of Dalyellia triangulata, nov. sp. Zeitschr. Morphol. Oekol. Tiere v. 20, p. 599-612. Berlin.

Ruebush, T. K. 1935, The genus Olisthanella in the United States. Zool. Anz. v. 112 fase. $5-6$, p. 129-137. Leipzig.

1937, The genus Dalyellia in Ameriea. Zool. Anz. v. 119 fase. 9-10, p. 237-256. Leipzig.

1938, A comparative study of the Turbellarian chromosomes. Zool. Anz. v. 122 fase. 11-12, p. 321-329. Leipzig.

1938a, Krumbachia minuta n. sp. (Turbellaria, Rhabdocoela). Zool. Anz. v. 122 fase. $9-10$, p. $260-265$. Leipzig.

1939, Report on the Rhabdocoele Turbellaria... North India Exped. Zool. Anz. v. 126 fasc. $3-4$, p. 49-67. Leipzig.

1940, Mesostoma ehrenbergii wardii for the study of the Turbellarian type. Seience v. 91 no. 2370, p. 531-532. New York.

1941, A key to the American freshwater Turbellarian genera, exclusive of the

Trieladida. Transact. Americ. Microse. Soc. v. 60, p. 29-40 t. 1-3. Menasha, Wisc.

Ruebush, T. K. \& W. J. Hayes jr. 1939, The genus Dalyellia in America, II. Zool. Anz. v. 128 fase. 5-6, p. 136-152. Leipzig.

Ruhl, L. 1927, Zur Kenntnis der Biologie, Fortpflanzung und Regeration der rhabdocoelen Turbellarien. Inaug. Dissert. Phil. Fakult. Marburg, 66 p. 16+11 fig. (em parte, também: Zool. Anz. v. 72, p. 160-175; 180-190). Marburg (Leipzig).

Sabussowa, Z. 1929, Die Turbellarien der Kamtschatka-Halbinsel. Zool. Jahrb. Syst. v. 57, p. 497-536 t. 4. Jena.

Schmarda, L. K. 1859, Neue wirbellose Thiere. v. 1, 1. a metade ('Turbellaria, Rotatoria, Annelida), XVIII + 66 p. 15 t. Leipzig (W. Engelmann). 
Schmidt, E. O. 1848, Die rhabdocoelen Strudelwürmer des süssen Wassers. 66 1. 6 t. Jena (Friedrich Mauke).

1861, Untersuchungen über Turbellarien von Corfu und Cephalonia. Zeitsehr. wiss. Zool. v. 11 (1862) fase. 1 (1861), p. 1_30 t. 1-4. Leipzig.

1861a, Ueber Planaria torva Autorum. Zeitschr. wiss. Zool. r. 11 (1862) fase. 1 (1861), p. 89-94 t. 10. Leipzig.

Schulz, B. 1932, Einführung in die Hydrographie der Nord- \& Ostsee. G. Grimpe, Tierwelt Nord- \& Ostsee, fasc. Id, p. 45-88. Leipzig (Akad. Verlagsges.).

Sekera, E. 1904, Ueber die Viviparität der Sommertiere bei den Eumesostominen. Zool. Anz. v. 28 fase. 7, p. 232-243. Leipzig. Leipzig.

1904a, Neu Mitteilungen über Rhabdocöliden. Zool. Anz. v. 27 fase. 14, p. 434-443.

1906, Ueber die Verbreitung der Selbstbefruchtung bei den Rhabdocoeliden. Zool. Anz. v. 30 fase. 5, p. 142-153. Leipzig.

1910, Noch einmal über die Fortpflanzungsfähigkeit von Mesostoma ehrenbergi in Zahlen. Kleinwelt (ed. R. Francé) Jahrg. 2 (1910-1911), p. 43-44. München.

1911, Studien über Turbellarien. S. Ber. K. Böhm. Ges. Wissensch. II. Classe, no. 13, p. 1-38 t. 1. Prag.

1912, Monographie der Gruppe Olisthanellini. S. Ber K. Böhm. Ges. Wissenseh. Prag 1911 no. 24, p. 1-93 t. 1-2. Prag.

1925, O autotomii plostenky Planaria vitta (Sur l'autotomie de l'espèce P. v.). Publ. Biol. école hautes études Vétérin. Brno, Tchécoslov. v. 4 no. (Sign. B 51), p. 1-35. Bruo. Leipzig.

1925a, Ueber die Graffilliden im Süsswasser. Zool. Anz. v. 63 fase. 1-2, p. 9-12.

1926, Beiträge zur Kenntnis der Lebensdauer bei einigen Turbellarien, etc. Zool. Anz. v. 66, p. 307-318. Leipzig.

1930, Ueber die pseudoparasitische Lebensweise einer Art aus der Turbellariangattung Phaenocora. Zool. Anz. v. 91, p. 97-101. Leipzig.

Sibiriakova, O. A. 1929, La fauna des Turbellaria Rhabdocoela du fleuve Angara. Russ. Hydrobiol. Zeitschr. v. 8, p. 273-250. Saratov.

Silliman, W. A. 1884, Beobachtungen über die Süsswasserturbellarien Nordamerikas. Zeitschr. wiss. Zool. v. 41 fase. 1, p. 48-78 t. 3-4. Leipzig.

Sivickis, P. B. 1923, Studies on the physiology of reconstitution in Planaria lata, etc. Biol. Bull. v. 44, p. 113-152. Woods Hole, Mass.

Spandl, H. 1925, Die Tierwelt vorübergehender Gewässer Mitteleuropas. Arch. Hydrobiol. v. 16, p. 74-132. Stuttgart.

Steinböck, O. 1924, Untersuchungen über die Geschlechtstrakt-Darmverbindung bei Turbellarien. Zeitschr. Morphol. Oekol. Tiere v. 2 fase. 3-4, p. 461-504. Berlin. 1924a, Eine neue Gruppe allóocöler Turbellarien: Alloeocoela Typhlocoela. Zool. Anz. v. 58 fasc. 11-12, p. 233-242. Leipzig.

1924.b, Die Bedeutung der Hofstenia atroviridis Bock für die Stellung der Alloeocoela, etc. Zool. Anz. v. 59, p. 156-166. Leipzig.

1925, Zur Systematik der Turbellaria metamerata. Zool. Anz. v. 64 fasc. 7-8, p. 165-192. Leipzig.

1926, 1. Nachtrag zur Systematik der Turbellaria metamerata. Zool. Anz. v. 66 fase. 1-4, p. 1-4. Leipzig.

1927, Monographie der Prorhynchidae (Turbellaria). Zeistchr. Morphol. Oekol. Tiere v. 8 fasc. $3-4$, p. 538-662. Berlin.

1928, Beiträge zur Kenntnis der Turbellarienfauna Grönlands. Meddel. Grönlands. Meddel. Grönland v. 74, p. 71-82. Köbenhän.

1931, Freshwater Turbellaria. Zoology of the Faroes, part. 9, p. 1-32. Copenhagen.

1931a, Marine Turbellaria. Zoology of the Faroes, part 8, p. 1-26. Copenhagen. Jena.

1932, Zur Turbellarienfauna der Südalpen, ete. Zoogeographica v. 1, p. 209-262.

1932a, Die Turbellarien des arktischen Gebietes. Fauna aretica v. 6 fase. 4, p. 295-342. Jena (G. Fischer). 
1933, Die Turbellarienfauna der Umgebung von Rovigno. Thalassia v. 1 no. 5, p. 1-33. Jena.

1935, Turbellarien aus Ostgrönland. Vidensk. Meddel. Dansk. Naturh. Foren. v. 98, p. 235-241. Köbenhavn.

Steinböck, O. \& E. Reisinger 1930, Ergebnisse einer. . Reise in Grönland 1926, Vidensk. Meddel. Dansk. Naturh. Foren. v. 90 (1930-1931), p. 13-43 (8-VIII-1930). Köbenhavn.

Steinmann, P. 1908, Die polypharyngealen Planarienformen und ihre Bedeutung für die Deszendenztheorie, Zoogeographie und Biologie. Internat. Revue ges. Hydrobiol. Hydrogr. v. 1, p. 1-12. Leipzig.

1914, Beschreibung einer neuen Süsswassertriclade von den Kei-Inseln, ete. Abhandl. Senckenb. Naturf. Ges. v. 35 fase. 1, p. 109-121 t. 7. Frankfurt a. M.

1916, Autotomie, ungeschlechtliche Fortpflanzung dureh Teilung... der Tricladida. Bronn's Kl. Ordn. Tier-Reichs v. 4 (Vermes) Ie. Turbellaria (1904-1917), p. 32493332 t. 64. Leipzig (C. F. Winter).

1930, Eine neue getrenntgeschlechtliche marine Triclade von der bretonischen Nordküste, etc. Zool. Anz. v. 92 fase. 5-6 p. 147-152. Leipzig.

Steinmann, P. \& E. Bresslau 1913, Die Strudelwürmer (Turbellaria). Monogr. einheim. Tiere (H. E. Ziegler \& R. Woltereck). v. 5, XI + 380 p. 2 t. Leipzig (W. Klinkhardt).

Stirewalt, M. A., W. A. Kepner \& F. F. Ferguson 1940, A new Turbellarian worm from Beaufort, N. C. Journ. Elisha Mitchell Scient. Soc. v. 56 n. ${ }^{\circ}$ 1, p. 123-133 t. 2-3. Chapel Hill,N. C.

Stringer, C. E. 1909, Notes on Nebraska Turbellaria with deseription of two new species. Zool. Anz. v. 34 fase. 9, p. 257-262. Leipzig.

1918, The free-living flatworms (Turbellaria). H. B. Ward \& G. C. Whipple, Fresh-Water Biology, Chapter XII, p. 323-364 f. 589-650. New York (J. Wiley \& Sons) \& London (Chapman \& Hall).

Thienemann, A. 1921, Ueber Euporobothria bohemica (Vejd). Zool. Anz. v. 53, p. 121-124. Leipzig.

1928, Die nordamerikanische Planaria maculata Leidy in Deutschland: Arch. Hydrobiol. v. 19, p. $366 \cdot 368$. Stuttgart.

Tu, Tseng-Jui 1934, Notes on some Turbellarians from the Tsing Hua Campus. Seient. Rep. Nat. Tsing Hua Univ. ser. B v. 1 fasc. 6, p. 191-206 t. 1-3 Peiping.

1938, Ueber das Vorkommen von Euplanaria tigrina (Girard) in der Umgebung son Berlin. Zool. Anz. v. 124 fasc. 3-4, p. 81-85. Leipzig.

1939, Geschichtlicher Ueberblick über das Studium der Turbellarien in Ostasien, ete. Zool. Jahrb. Syst. v. 73, p. 201_260. Jena.

Van Beneden, E. 1870, Étude zoologique et anatomique du genre Macrostomun, etc. Bull. Acad. Roy. Belg. sér. 2 v. 30 no. 8, p. 1-20 (114-133 do Bull.) 1 t. Bruxelles.

Vendel, A. 1922, Recherches expérimentales sur les modes de reproduction dés Planaires Triclades Paludicoles. Bull. Biol. France et Belgique v. 55, p. 343-518. Paris.

Vejdovsky, F. 1880, Vorläufiger Bericht über die Turbellarien der Brunnen von Prag. Sitz. Ber. K. Böhm. Ges Wissensch. Prag 1879, p. 501-507. Prag.

1895, Zur vergleichenden Anatomie der Turbellarien (pars I \& II). Zeitschr. :wiss. Zool. v. 60, p. 90-240, t. 4-10. Leipzig.

Voigt, W. 1892, Das Wassergefässsystem von Mesostoma truncatum O. Sch. Zool. Anz. v. 15, p. 247-248. Leipzig.

Wahl, B. 1910, Beiträge zur Kenntnis der Dalyelliiden und Umagilliden. Festschr. 60. Geburtstag R. Hertwig v. 2, p. 39-60 t. 2. Jena. (G. Fischer).

Weiss, A. 1910, Beiträge zur Kenntnis der australischen Turbellarien. II. Rhabdocoelida. Zeitschr. wiss. Zool. v. 96, p. 336-372 t. 14-15. Leipzig.

Westblad, E. 1923, Zur Physiologie der Turbellarien. Lunds Universitets Aars. skrift N. F. Avd. 2, v. 18 no. 6 (Kungl. Fysiogr. Sällsk. Handl. N. F. v. 33; no. 6), p. 1-212 t.1-2. Lund \& Leipzig.

1935, Pentacoelum fucoideum, ein neuer Typ der Turbellaria metamerata. Zool. Anz. v. 111 no. 3-4, p. 65-82. Leipzig.

1924, Studien über skandinavische Turbellaria Acoela .II. Ark. Zool. v. 33A no. 14, p. 1-18 t. 1-3. Stockholm. 
Wilhelmi, J. 1909, Tricladen. Fauna Flora Golf. Neapel fase. 32, XII +405 p. 16 t. Berlin (R. Friedländer \& Sohn).

1909a, Ernährungsweise, Gelegenheits, Pseudo- und Dauerparasitismus bei Seetricladen. Zool. Anz. v. 34 fasc. 24-25, p. 723-730. Leipzig.

Willier, B. H., L. H. Hyman \& S. A. Rifenburgh 1925, A histochemical study of intracellular digestion in triclad flatworms. Journ. Morphol. v. 40 no. 2, p. 299-340. Philadelphia, Pa.

Woodworth, W. M. 1891, Contributions to the morphology of the Turbellaria: I. On the structure of Phagocata gracilis. Bull. Mus. Comp. Zool. v. 21, no. 1 p. 1-42 t. 1-4. Cambridge, Mass.

1896, Report on the Turbellaria collected by the Michigan State Fish Commission, etc. Bull. Mus. Comp. Zool. v. 29 no. 6, p. 239-243 1 t. (f. 1, 2). Cambridge, Mass.

1897, Contributions to the Morphology of the Turbellaria. II. On some Turbellaria from Illinois. Bull. Mus. Comp. Zool. v. 31 no. 1, p. 1-16 1 t. (f. 1-15). Cambridge, Máss.

Young, R. T. 1912, The epithelium of Turbellaria. Journ. Morphol. v. 23 no. 2, 255-268. Baltimore (The Waverly Press). 



\section{Estampas}


ESTAMPA I

\section{Macrostomum gigas Okugawa}

a, ôlho. b, bôca. c, ovócitos no oviduto. d, glândulas ao redor do poro masculino. e: duto eferente. f, vesícula seminal acessória. g, papilas adesivas. $h$, faringe. i, intestino. $\mathrm{k}$, reservatório da secreção granulosa. $\mathrm{m}$, ovócito no oviduto comum. n, sensilos cefálicos. o, ovário. p, pênis. r, rabditos. $s$, cílios sensoriais. $t$, testículo. $\mathrm{u}$, átrio feminino. $\mathrm{v}$, vesícula seminal verdadeira. $\mathrm{w}$, orifício feminino. $\mathrm{x}$, protonefridióporo acessório situado no dorso. y, protonefridióporo principal situado ventralmente.

Fig. 1 - Vista ventral.

Fig. 2 - Vista ventral dum verme jovem vivente com os órgãos de excreção. Os canais ventrais desenhados com contornos completos; os dorsais, pontilhados. Ainda não foram vistas as ligações entre muitos órgãos terminais e os canais.

Fig. 3A - Corte mediano do átrio feminino vazio. 

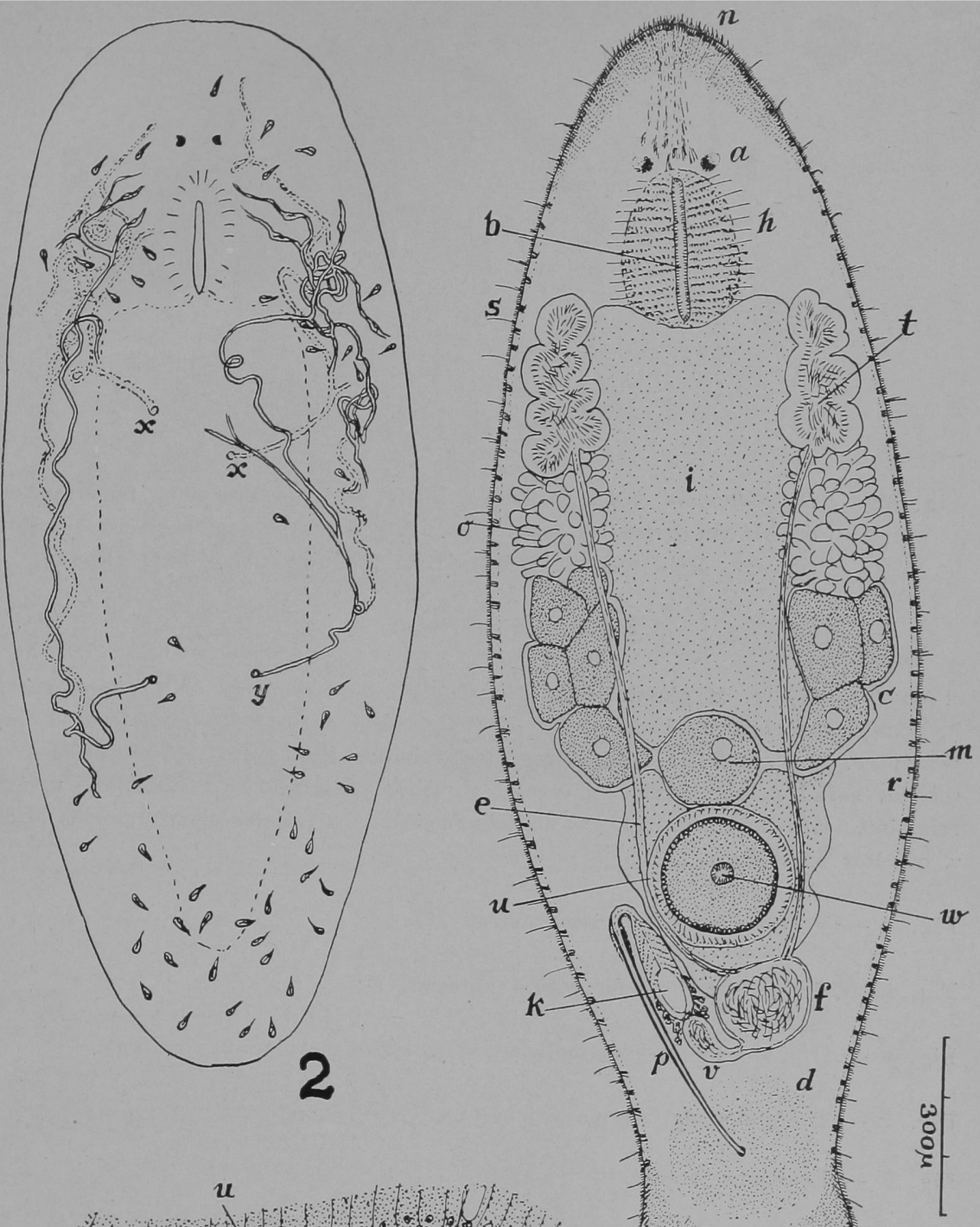

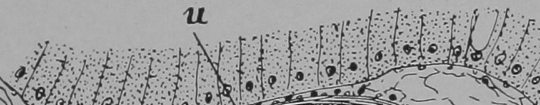

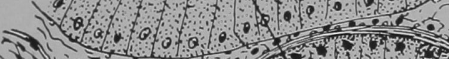

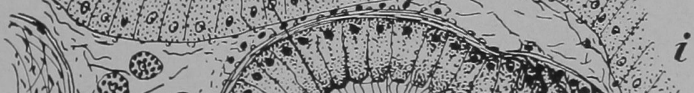

1)

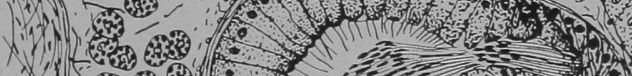

$f$ ( )

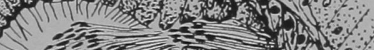

- 1510

W o of

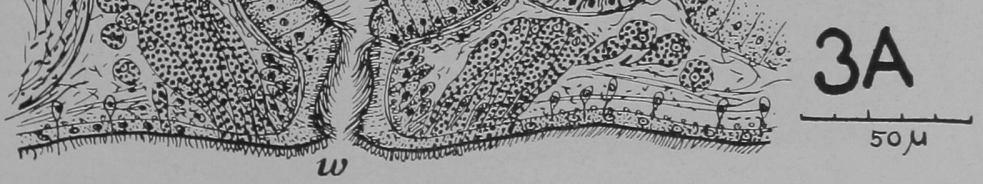


ESTAMPA II

Fig. 3B - Macrostomum gigas Okugawa, corte mediano do átrio feminino com ovócito em divisão de maturação. f, vesícula seminal acessória. i, intestino. $\mathrm{u}$, átrio feminino. $\mathrm{w}$, orifício feminino. $\mathrm{z}$, oviduto comum.

\section{Macrostomum delphax, sp. n.}

a, ôlho. c, cérebro. d, glândulas rabditógenas. e, duto eferente. g, papilas adesivas. h, glândulas faríngeas. i, intestino. k, reservatório da secreção granulosa. l, poro masculino. m, glândulas formadoras dos rabditos dos tratos de bastonetes. $n$, sensilos cefálicos. o, ovário. p, pênis. $s$, cúlios sensoriais. t, testículos. u, átrio feminino. $\mathrm{v}$, vesícula seminal. w, orifício feminino. $\mathrm{x}$, células claviformes de Minot. $\nabla$, ovócitos no oviduto.

Fig. 4 - Verme adulto, em vista ventral.

Fig. 5 - Corte horizontal da região anterior.

Fig. 6 - Orgãos eferentes masculinos comprimidos debaixo da lamínula.

Fig. 7 - Estilete penial em posição natural; vista dorsal.

Fig. 8 - Espérmio vivente. 


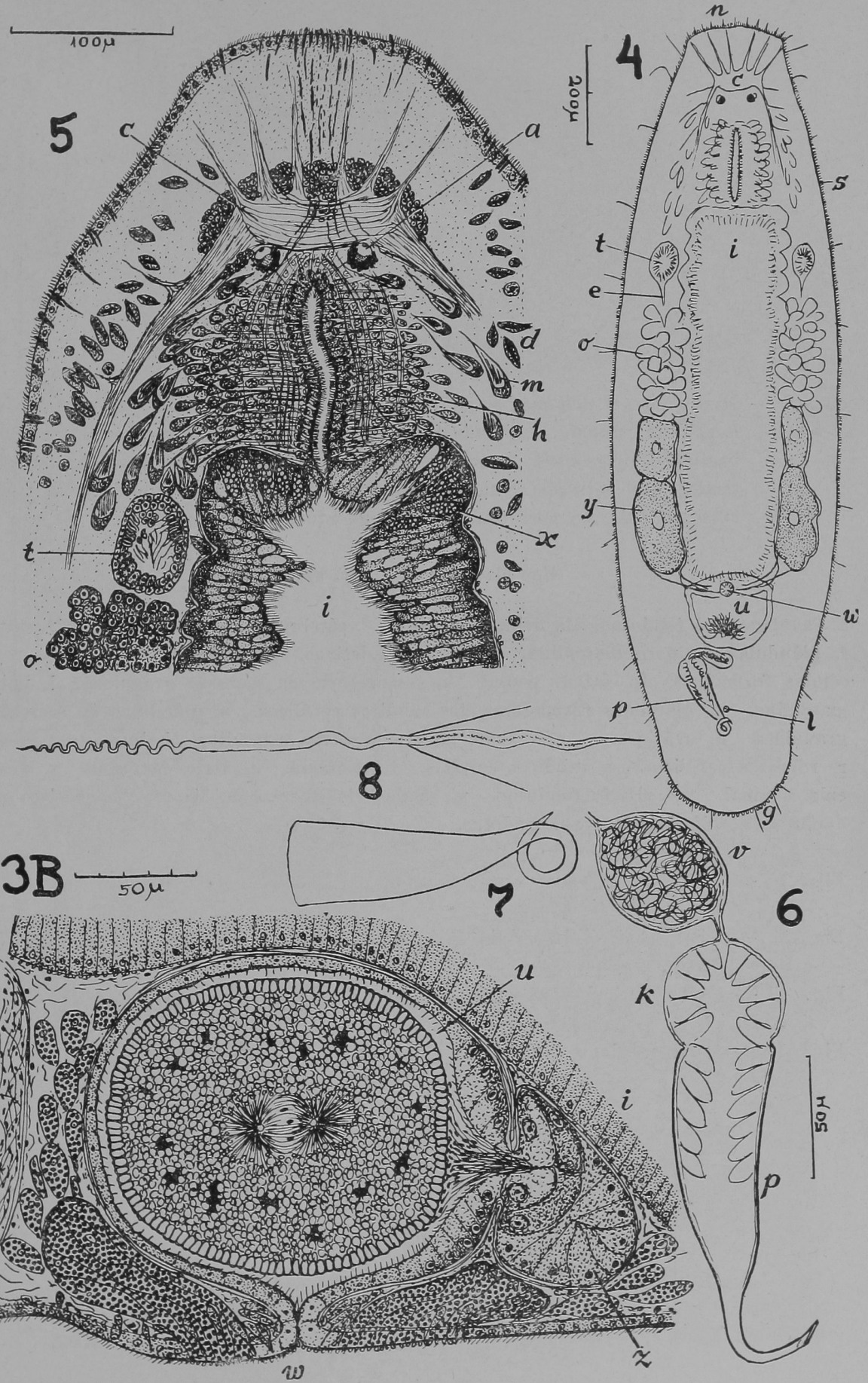




\section{ESTAMPA III}

Fig. 9 - Macrostomum delphax, sp. n., corte mediano da região dos poros genitais. b, oviduto comum. d, glândulas rabditógenas. f, glândulas formadoras dos bastonetes pegajosos. i, intestino. l, poro masculino. p, lume do estilete penial com secreção granulosa. r, rabditos. u, átrio feminino. v, vesícula seminal. w, poro feminino. z, glândulas argamassadoras.

\section{Macrostomum evelinae, sp. n.}

a, canal genital feminino. b, oviduto comum. c, cérebro. d, bôca. e, duto eferente. f, glândulas do poro masculino. g, papilas adesivas. $h$, faringe. i, intestino. j, células formadoras do 'stilete penial. k, reservatório da sécreção granulosa. l, poro masculino. m, glândulas formadoras dos rabditos cefálicos. n, glândulas da secreção granulosa. o, ovário. p, estilete do pênis. q, átrio masculino (bainha do pênis). $\mathrm{r}$, rabditos cefálicos. s, rabditos caudais. t, testículo. u, átrio feminino. v, vesícula seminal. w, orif́cicio feminino. $\mathrm{x}$, células claviformes de Minot. $\mathrm{y}$, ovócitos no oviduto. z, glândulas argamassadoras.

Fig. 10 -- Vista ventral dum verme adulto.

Fig. 11 - Vista ventral dum animal de meia idade.

Fig. 12 - Orgão cuticular masculino.

Fig. 13 - Corte mediano (combinado) da região do poro feminino. 


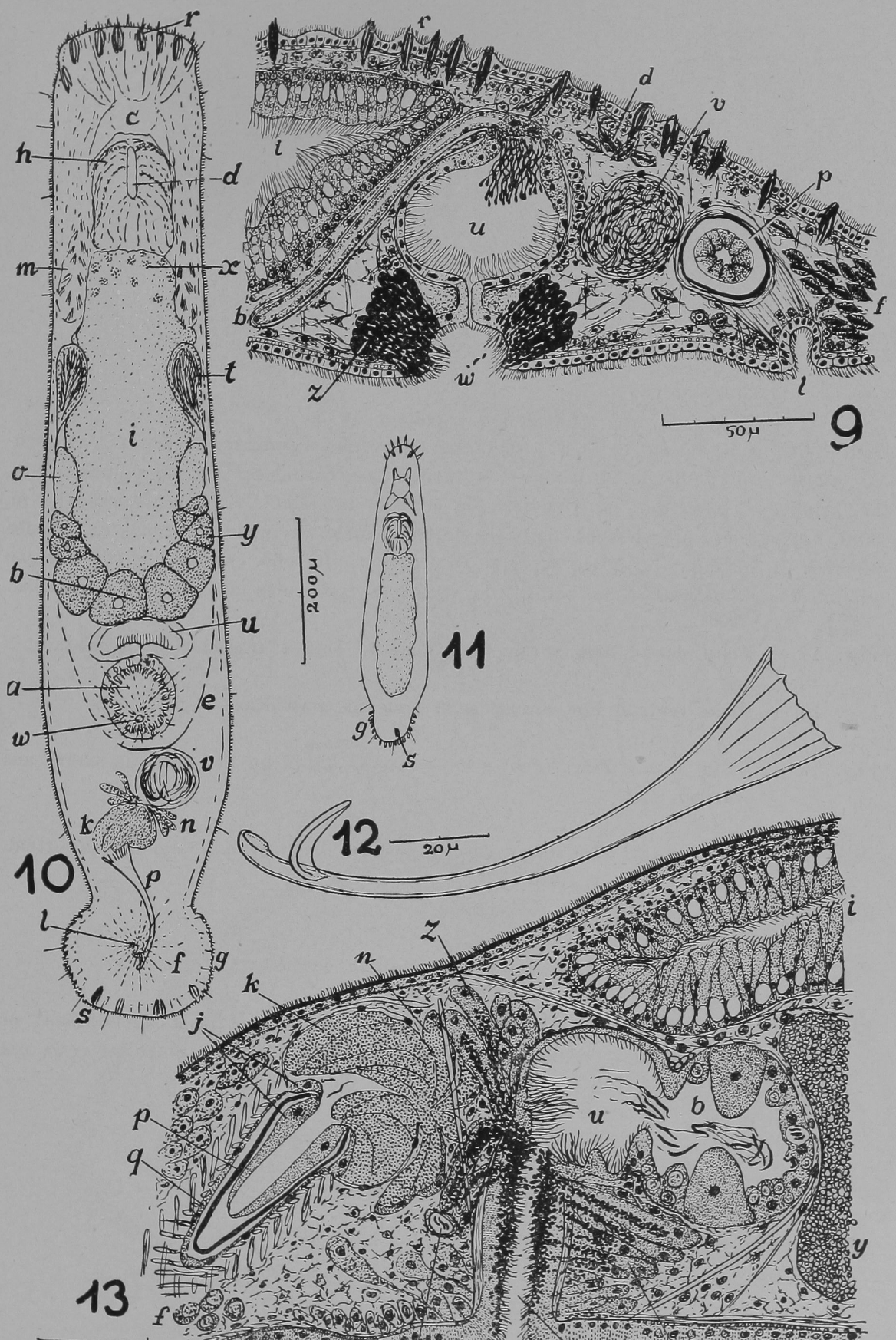

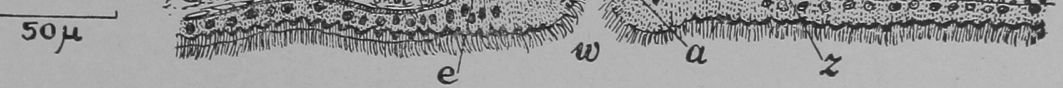




\section{ESTAMPA IV}

\section{Baicalellia evelinae, sp. n.}

a, cérebro com olhos. b, bursa seminalis. c, órgão copulador euticular. d, ovoviteloduto; foi indicado o dircito. e, tentáculos faríngeos. g, glândulas orais. h, faringe. i, intestino. k, glândulas da entrada intestinal. l, lume intestinal. m, bôca. o, ovário. $p$, gonóporo. $q$, poro do emunctório. $\mathrm{r}$, átrio inferior. $\mathrm{s}$, vesíeula seminal. t, testículo. u, átrio superior (útero). $\mathrm{v}$, vitelário. $\mathrm{x}$, vesícula da secreção granulosa. y, glândulas da bainha do pênis. z, glândulas da secreção granulosa.

Fig. 14 - Vista dorsal dum verme com sòmente órgãos reprodutivos femininos.

Fig. 15 - Vista ventral dum animal com gônadas masculinas e femininas.

Fig. 16 - Vista dorsăl dum verme com 4 casulos ainda no átrio, caudalmante aos ovários.

Fig. 17 - Vista ventral dum verme, cujos 6 casulos já entraram no sincício intestinal.

Fig. 18 - Vista lateral, com emunctório.

Fig. 19 - Aspectos de vários órgãos copuladores cuticulares.

Fig. 20 - Esquema da metade esquerda com gônadas masculinas e femininas; no átrio superior (útero, u), dois casulos, com 2 ovos ou embriñes cada um. 


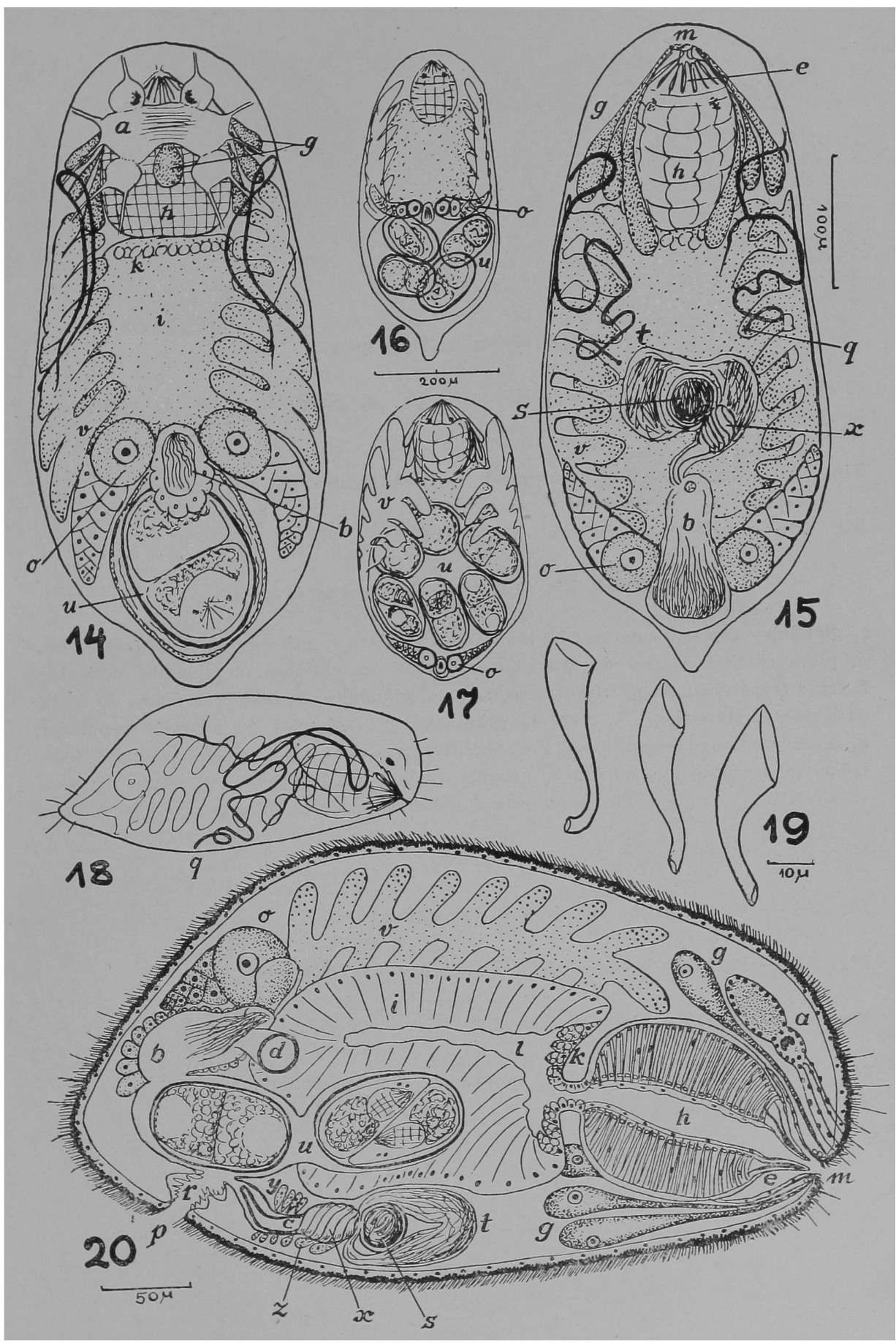




\section{ESTAMPA V \\ Baicalellia evelinae, sp. n.}

a, cérebro com olhos. e, tentáculos faríngeos. g, glândulas orais. h, faringe. i, intestino. $\nabla$, vitelário.

Fig. 21 - Corte transversal ao nível do bordo rostral da faringe.

Fig. 22 - Corte transversal ao nível dos olhos.

Microdalyellia (Microdalyellia) sawayai, sp. n.

a, glândulas argamassadoras. b, bursa copulatória. e, cabo do aparelho eopulador. d, placa mediana dorsal do aparêlho copulador. e, espinhos do aparêlho cuticular. f, trave transversal do aparêlho masculino. g, glândulas da casca. h, haste do órgão cuticular. i, intestino. $\mathrm{k}$, secreção granulosa. $\mathrm{m}$, músculos do aparêlho copulador. n, placa mediana ventral do órgão cuticular masculino. o, ovário. p, órgão copulador. $r$, receptáculo seminal. s, vesícula seminal. $t$, testículos. u, casulo no útero. v; vitelários. y, glândulas do intestino anterior. z, glândulas grudadoras caudais.

Fig. 23 - Vista lateral do verme vivente.

Fig. 24 - Vista ventral dos órgãos reprodutivos.

Fig. 25 - Parte do bordo anterior da faringe do verme vivente.

Fig. 26 - Aparêlho cuticular masculino, vista ventral.

Fig. 27 - Corte transversal do aparêlho cuticular masculino. 

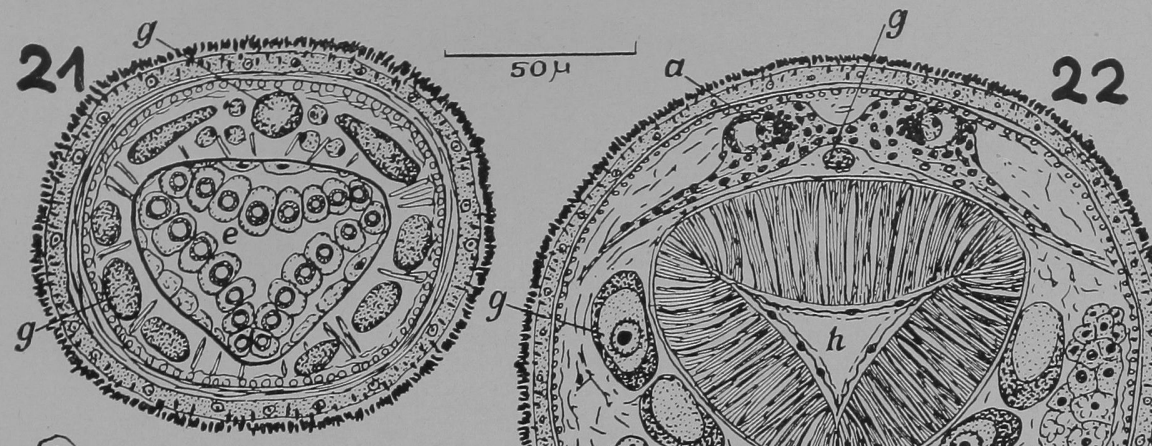

9
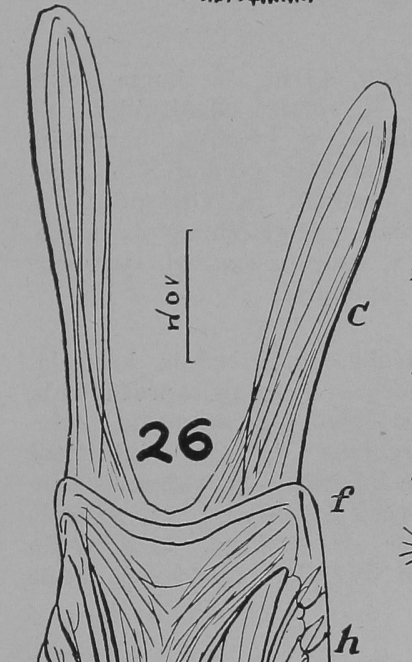

(1) 25
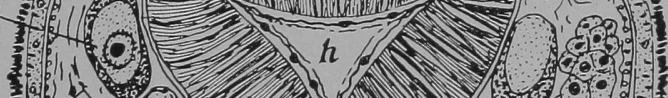
(1) (1)

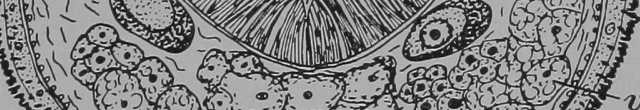
a
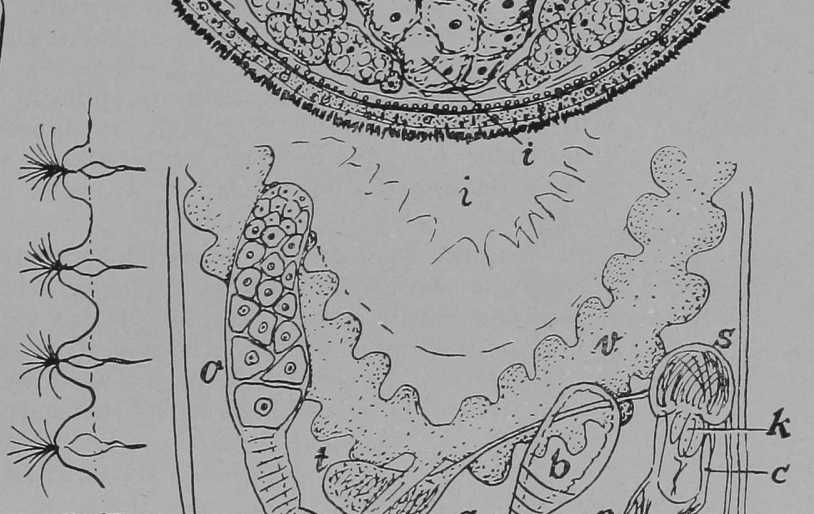

N.

A.VI

N.

1.N

Niv

1)

(4)

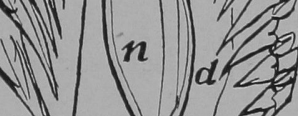

(
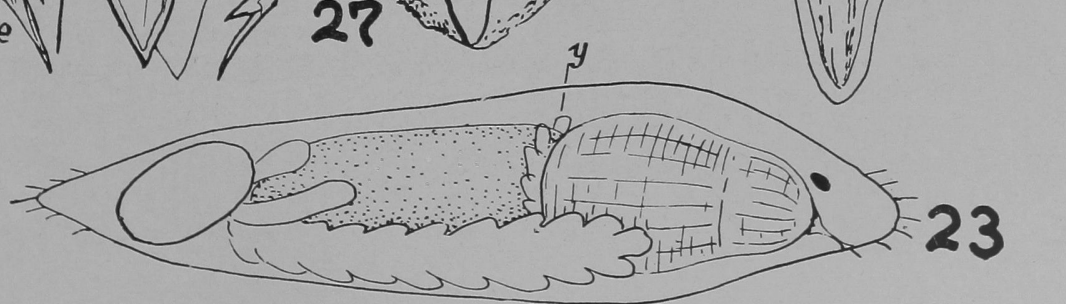


\author{
ESTAMPA VI \\ Microdalyellia (Gieysztoria) evelinae, sp. n.
}

Fig. 28 - Esquema da organisação em vista dorsal. i, intestino. w, faringe. As letras restantes eomo na Fig. 30 .

Fig. 29 - Vista lateral do verme vivente.

Fig. 30 - Esquema da organisação em vista lateral. a, átrio. b, bursa copulatória. e, duto comum. d, duto eferente. e, célula substituidora do epitélio intestinal. f, glândulas argamassadoras. g, cérebro. h, papila adesiva caudal. i, trecho do emunctório. k, glândula grudadora caudal. 1 , pigmento no parênquima. $\mathrm{m}$, receptáculo seminal. $\mathrm{n}$, viteloduto. o, ovário. p. poro genital. r, célula rabditógena. s, glândulas da casca. t, testículo. u, easulo no útero. v, vitelário. $\mathrm{x}$, vesícula seminal. $\mathrm{y}$, reservatório da secreção granulosa. z, aparêlho copulador.

Fig. 31 -- Corte sagital da faringe. a, glândula acidófila. b, glândula basófila. c, esfincter da bôca. d, bolsa faríngea externa. e, célula aprofundada do epitélio faríngeo interno. f, esfincter esofágico. g, músculos faríngeos longitudinais internos. $h$, músculos radiais. $i$, célula intestinal substituidora. $\mathrm{k}$, múseulos faríngeos anelares internos. $\mathrm{m}$, múseulos anelares externos da orla faríngea. $n$, anel nervoso da faringe. $p$, múseulo protractor da faringe. $r$, músculo retractor da faringe. $\mathbf{s}$, secreção granulosa da célula aprofundada na entrada do intestino. $t$, célula do parênquima faríngeo.

Fig. 32 - Corte transversal da faringe ao nível do anel nervoso. As letras como na Fig. 31.

Fig. 33 - Aparêlho cuticular em vista ventral. a, anel proximal (ental). d, anel distal (ectal). f, espinhos finos. $\mathrm{g}$, espinho grosso. $\mathrm{m}$, ponto de inserção dum músculo abductor. p, pontes entre os aneis. th, base dum dos espinhos grossos.

Fig. 34 - Aparêlho masculino, em vista ventral, com os espinhos abduzidos.

Fig. 35 - Corte sagital dos órgãos eferentes masculinos. a, anel proximal. d, duto eferente. e, duto ejaculatório. $\mathrm{m}$, músculo abductor $\mathrm{x}$, vesísula seminal. $\mathrm{y}$, vesícula granulorum. $\mathrm{z}$, espinho grosso.

Fig. 36 - Corte transversal do órgão copulador ao nível da inserção dos músculos abductores $(\mathrm{m})$.

Fig. 37 - Casulo (ovo), em vista lateral. 


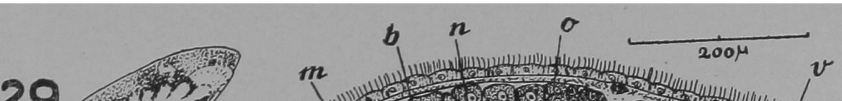

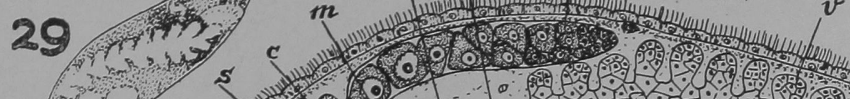

(1)

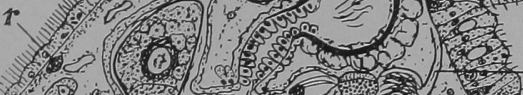
4. (1) o.

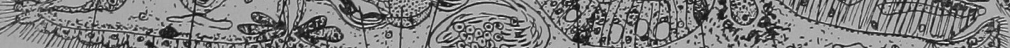
( $u$ a p i zyx
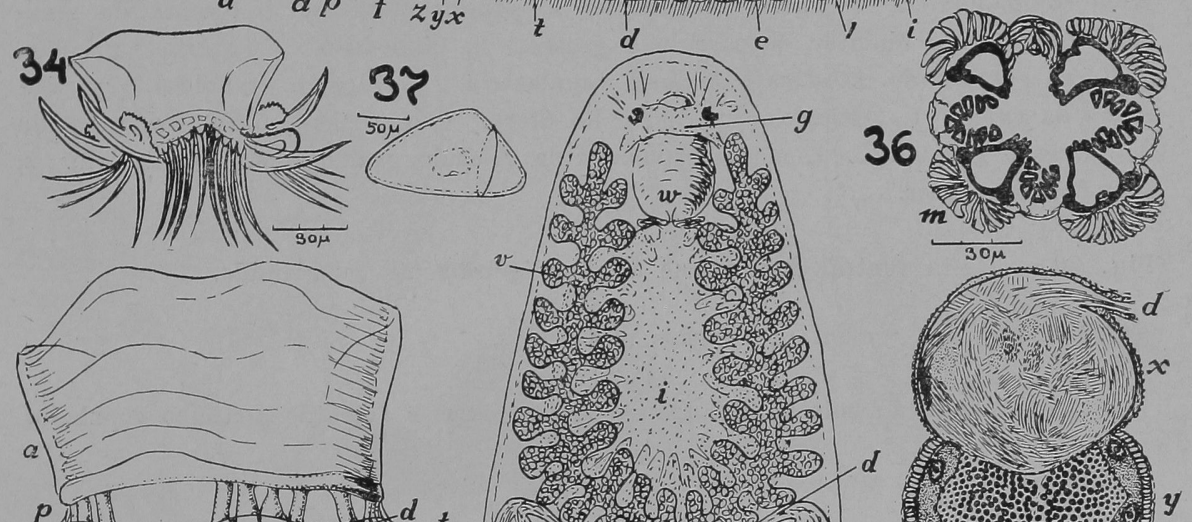

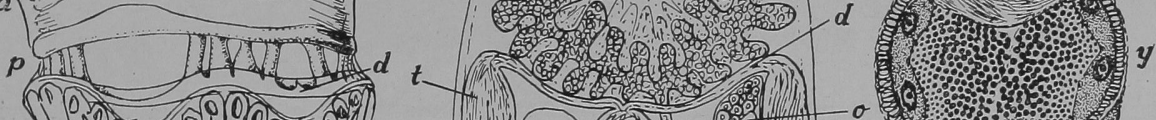

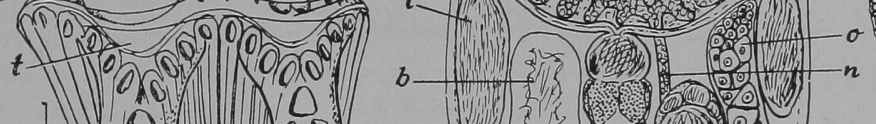

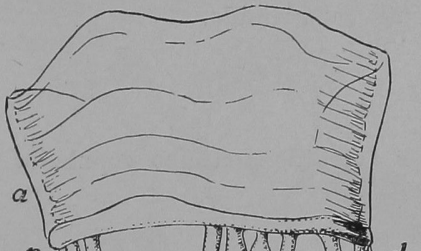

$v$

S 015

S

Fis 100

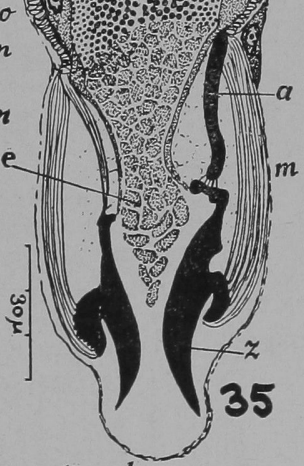

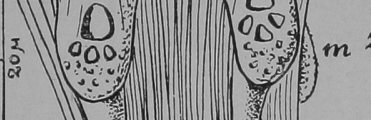

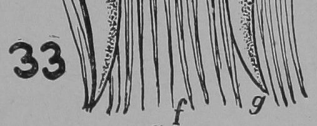

(a)
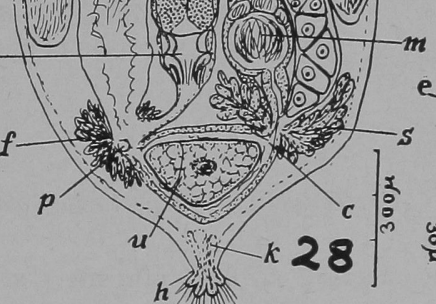

f r.

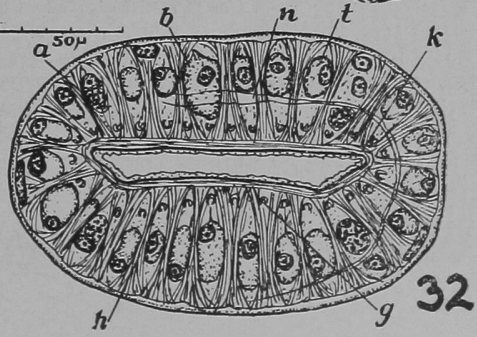

$$
k \quad b
$$




\section{ESTAMPA VII}

\section{Microdalyellia (Gieysztoria) kymanae, sp. n.}

a, bainha do pênis. b, bôca. c, duto comum. d, duto eferente. e, glândulas argamassadoras. f, espinhos finos do aparêlho copulador. g, espinhos grossos do aparêlho copulador. $\mathrm{h}$, faringe. i, intestino. $\mathrm{k}$, papilas adesivas. $\mathrm{l}$, receptáculo seminal. $\mathrm{m}$, músculo abdutor dum espinho grosso. $\mathrm{n}$, viteloduto. o, ovário. p, glândulas na entrada do intestino. q, bursa copulatória. r, secreção granulosa. s, glândulas da casca. t, testículos. $u$, casulo no útero. v, vesícula seminal. w, glândula da secreção granulosa. $\mathrm{x}$, massa espumosa na vesícula granulorum. $\mathrm{y}$, vitelário. z, aparètho copulador.

Fig. 38 - Vista ventral dum verme adulto, ligeiramente comprimido.

Fig. 39 - Vista ventral ḋos órgãos masculinos.

Fig. 40 - Vista do lado caudal dos espinhos grossos e finos do aparêlho copulador.

$$
\text { Microdalyellia (Gieysztoria) trisolena, sp. n. }
$$

Fig. 41 - Esquema da organisação. b, bursa copulatória. c, duto comum. d, oviduto. f, vesícula seminal. i, intestino. k, secreção granulosa. o, ovário. $\mathrm{p}$, pênis. r, receptáculo seminal. t, testículo. u, casulo no útero. v, vitelário. $\mathrm{x}$, átrio. $\mathrm{z}$, glândulas da entrada do intestino.

Fig. 42 - Aparelho euticular.

\section{Microdalyellia (Gieysztoria) acariaia, sp. n.}

Fig. 43 - Orgão copulador. d, duto eferente. x, vesícula seminal. y, reservatório da secreção granulosa.

Microdalyellia (Gieysztoria) intricata, sp. n.

Fig. 44 - Aparelho cuticular no verme não comprimido. a, espinho forte direito. b, grupo de estruturas paramedianas. c, escova de espinhos esquerda. 


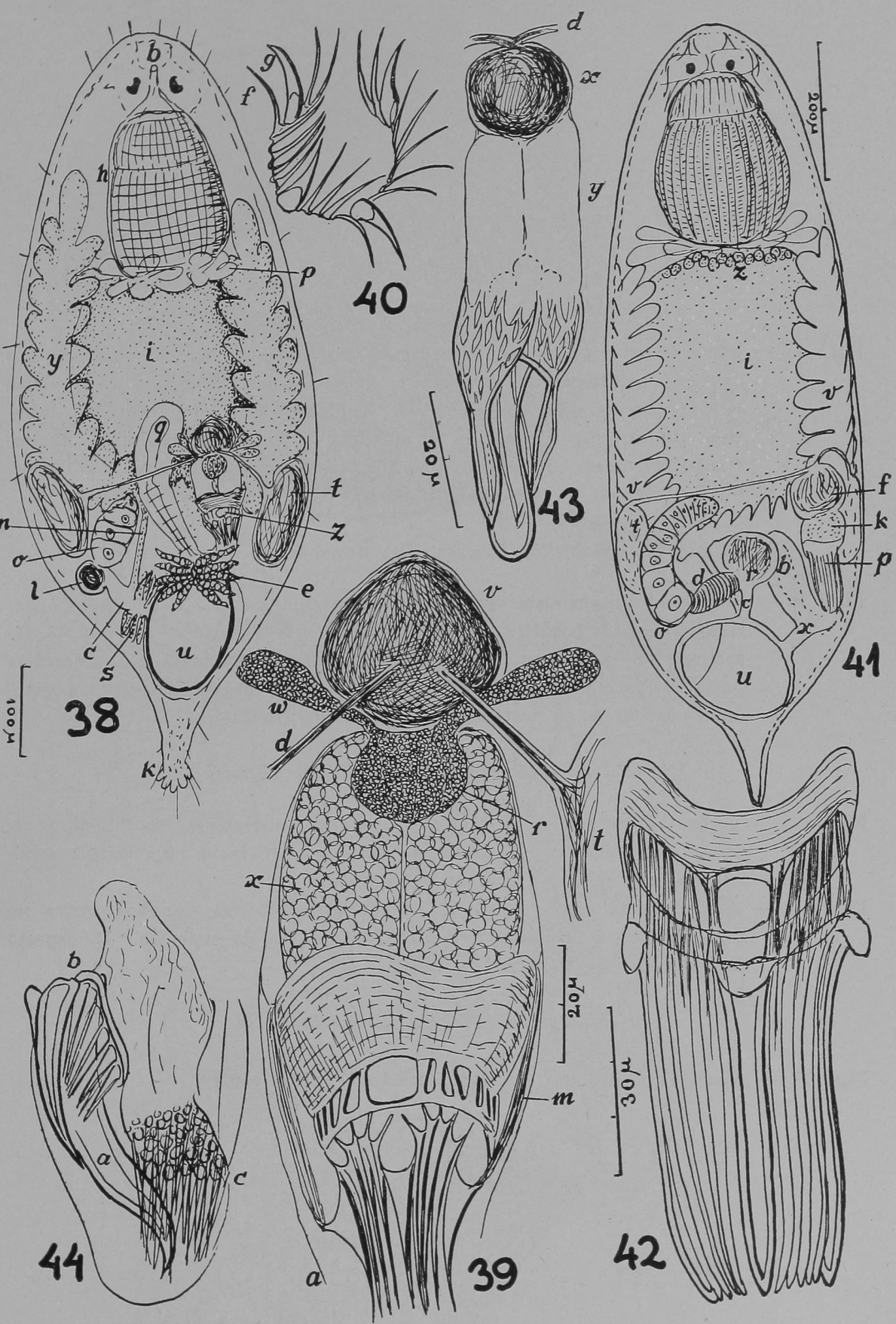




\section{ESTAMPA VIII}

Microdalyellia (Gieysztoria) trisolena, sp. n.

Fig. 45 - Corte transversal ao nível dos órgãos reprodutivos. a, múseulos cutâneos anelares. b, bursa copulatória. c, duto comum. d, oviduto. e, células vitelógenas. g, glândulas da casca. h, pigmento no parênquima. i, intestino. k, secreção granulosa. l, músculos cutâneos longitudinais. m, esfineter do útero. o, ovário. $\mathrm{p}$, pênis. $\mathrm{r}$, receptáculo seminal. s, esfincter do oviduto. $\mathrm{t}$, testículos. $\mathrm{u}$, útero. $\mathrm{v}$, vitelário. $\mathrm{w}$, viteloduto.

\section{Microdalyellia (Gieysztoria) acariaia, sp. n.}

Fig. 46 - Verme adulto em vista ventral. b, bursa copulatória. f, glândulas argamassadoras. h, papilas adesivas caudais. i, intestino. $\mathrm{m}$, receptáculo seminal. $n$, ponto em que o canal ascendente (dorsal) do emunctório passa ao descendente (ventral). o, ovário. p, protonefridióporo. s, glândulas da casca. $t$, testículo. u, útero. $v$, vitelário.

\section{Microdalyellia (Gieysztoria) complicata (Fuhrm.)}

Fig. 47 - Verme adulto em vista ventral. b, bursa copulatória. i, intestino. o, ovário. $t$, testículo. $u$, casulo no útero. $\mathrm{v}$, vitelário. $\mathrm{x}$, vesícula seminal. z, glândulas na entrada do intestino.

Fig. 48 - Aparelho cuticular. A, fortemente comprimido. a, espinhos fortes no lado direito. b, corôa paramediana. e, escova de espinhos. B, aspecto do aparelho não comprimido.

Microdalyellia (Gieysztoria) uncia, sp. n.

Fig. 49 - Aparelho cuticular. A, vista dorsal. B, vista ventral. 


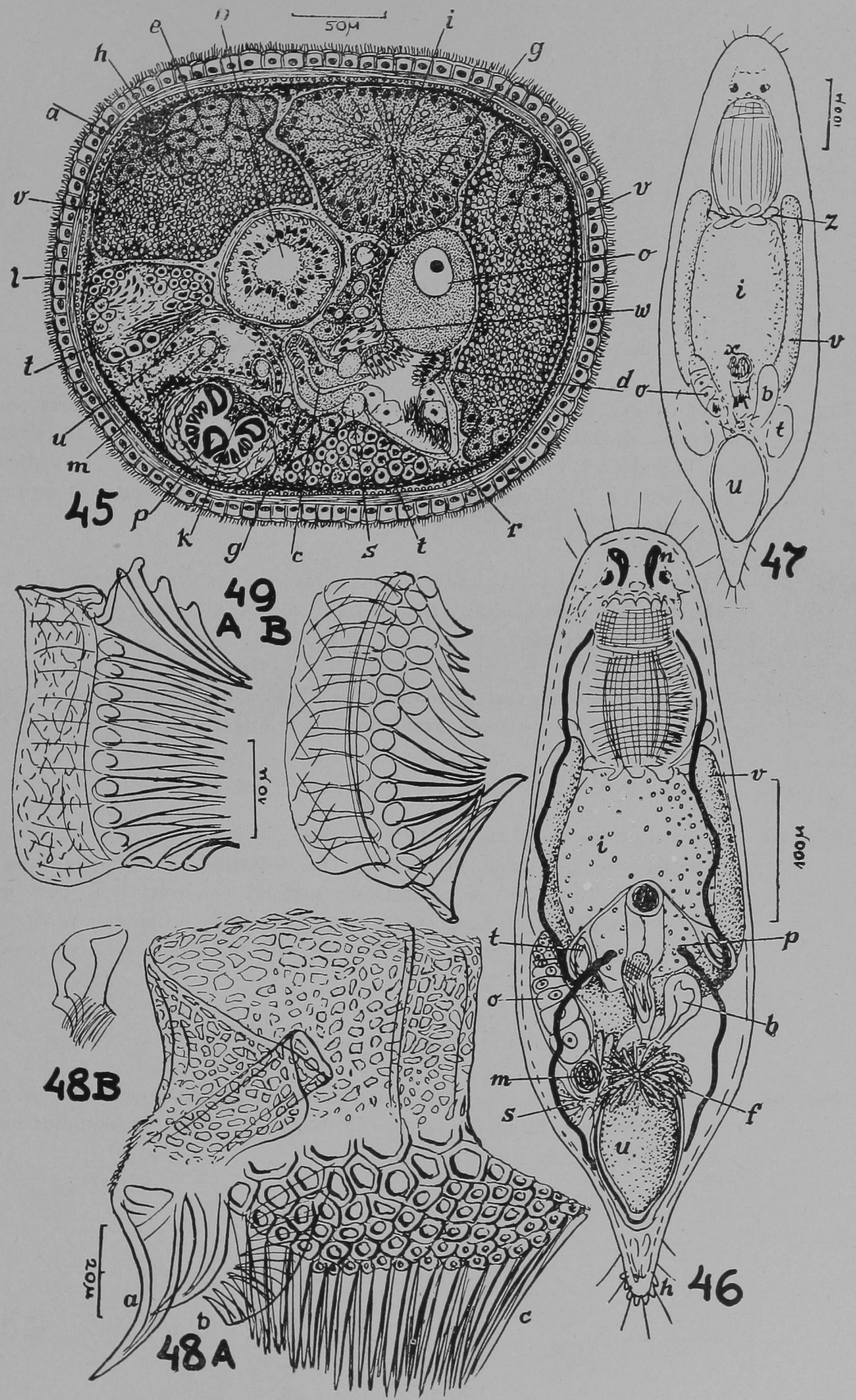




\section{ESTAMPA IX}

Microdalyellia (Gieysztoria) intricata, sp. n.

Fig. 50 - Vista dorsal dum verme adulto com testículos compridos. b, bursa copulatória. d, duto eferente. i, intestino. k, glândulas grudadoras caudais. $\mathrm{m}$, receptáculo seminal. o, ovário. $\mathrm{s}$, glândulas da casca. $\mathrm{t}$, testículo. $\mathrm{u}$, útero. $\mathrm{v}$, vitelário. $\mathrm{x}$, vesícula seminal. $\mathrm{y}$, reservatório da secreção granulosa.

Fig. 51 - Vista ventral da região caudal dum verme com testículos curtos. d, duto eferente. p, poro genital. t, testículo. $v$, vitelário. $x$, vesícula seminal. $\mathrm{z}$, aparelho cuticular.

Fig. 52 - Vista ventral das vias eferentes masculinas. d, duto eferente. $\mathbf{x}$, vesícula seminal. y, secreção granulosa. $\mathrm{z}$, aparelho copulador.

Microdalyellia (Gieysztoria) uncia, sp. n.

Fig. 53 - Verme adulto em vista ventral. a, bôca. b, bursa copulatória. d, duto eferente. e, glândulas na entrada do intestino. h, papilas adesivas caudais. i, intestino. $\mathrm{m}$, receptáculo seminal. o, ovário. $\mathrm{p}$, poro genital. s, glândulas da casca. t, testículo. u, casulo no útero. v, vitelário. $\mathrm{x}$, vesícula seminal. $\mathrm{y}$, reservatório da secreção granulosa. $\mathrm{z}$, aparelho copulador.

\section{Microdalyellia (Gieysztoria) theropaina, sp. n.}

Fig. 54 - Aparelho cuticular. a, pente pedunculado. b, espinho mediano. c, série de espinhos em forma de escova de dentes. d, série de espinhos encurvada para o lado dorsal. 


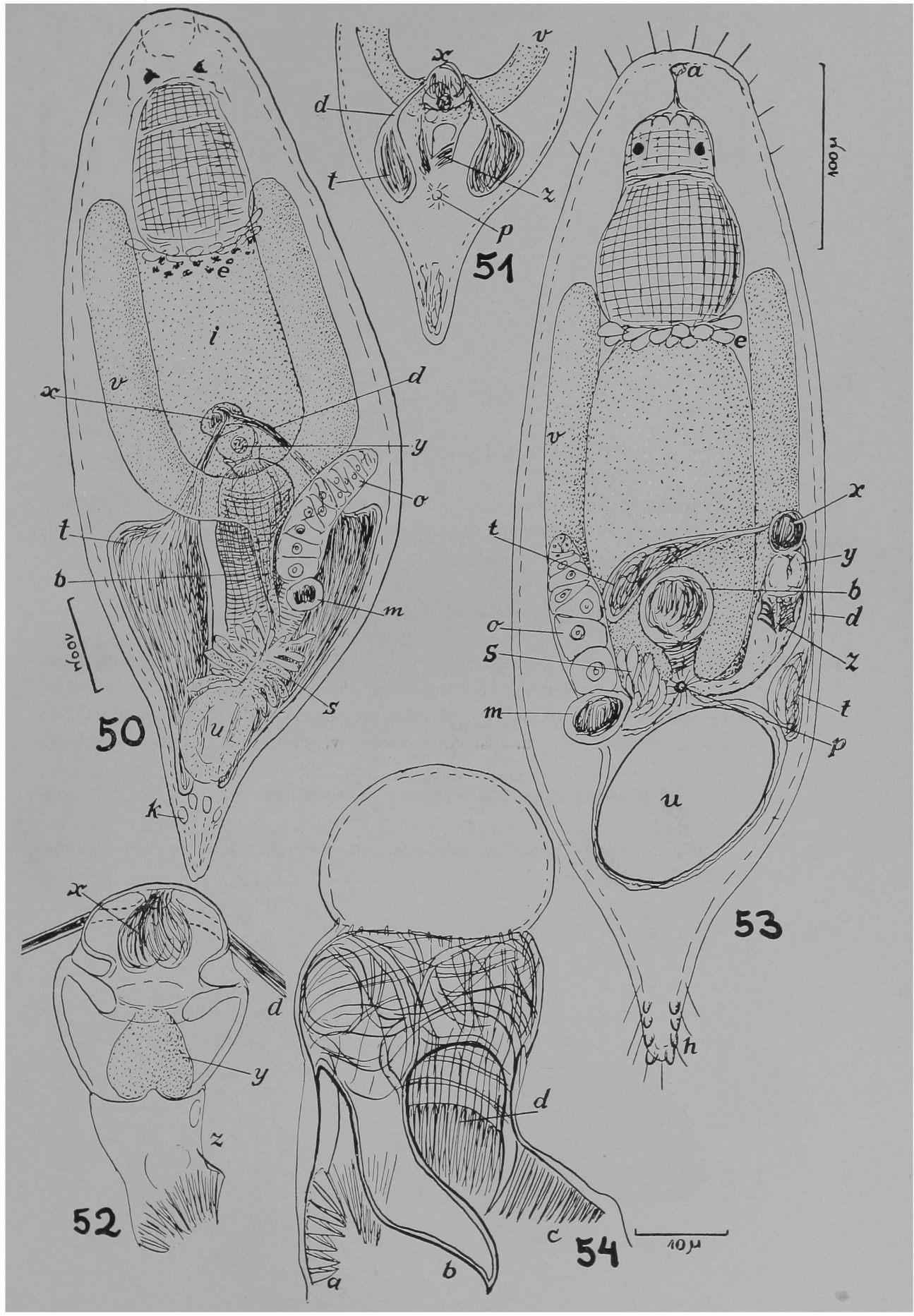




\section{ESTAMPA $\mathrm{X}$ \\ Microdalyellia (Gieysztoria) intricata, sp. n.}

Fig. 55 - Aparelho cuticular fortemente comprimide. a, espinho muito forte direito. b, grupo de estruturas paramedianas. e, escova de espinhos asquerda, d, espinho grosso externo esquerdo.

Microdalyellia (Gieysztoria) therapaina, sp. n.

Fig. 56 - Vista ventral dum verme adulto. b, bursa copulatória. d, duto eferente. e, glândulas na entrada do intestino. h, papilas adesivas. i, intestino. $\mathrm{m}$, receptáculo seminal. o, ovário. $\mathrm{p}$, poro genital. s, glîndulas da casca. t, testículo. $\mathrm{u}$, casulo no útero. $\mathrm{v}$, vitelário. $\mathrm{x}$, vesícula seminal.

Microdalyellia (Gieysztoria) thymara, sp. n.

Fig. 57 - Vista dorsal do aparelho cuticular. m, músculo abductor dos espinhos dorsais esquerdos.

Fig. 58 - Vista ventral do aparelho euticular. 


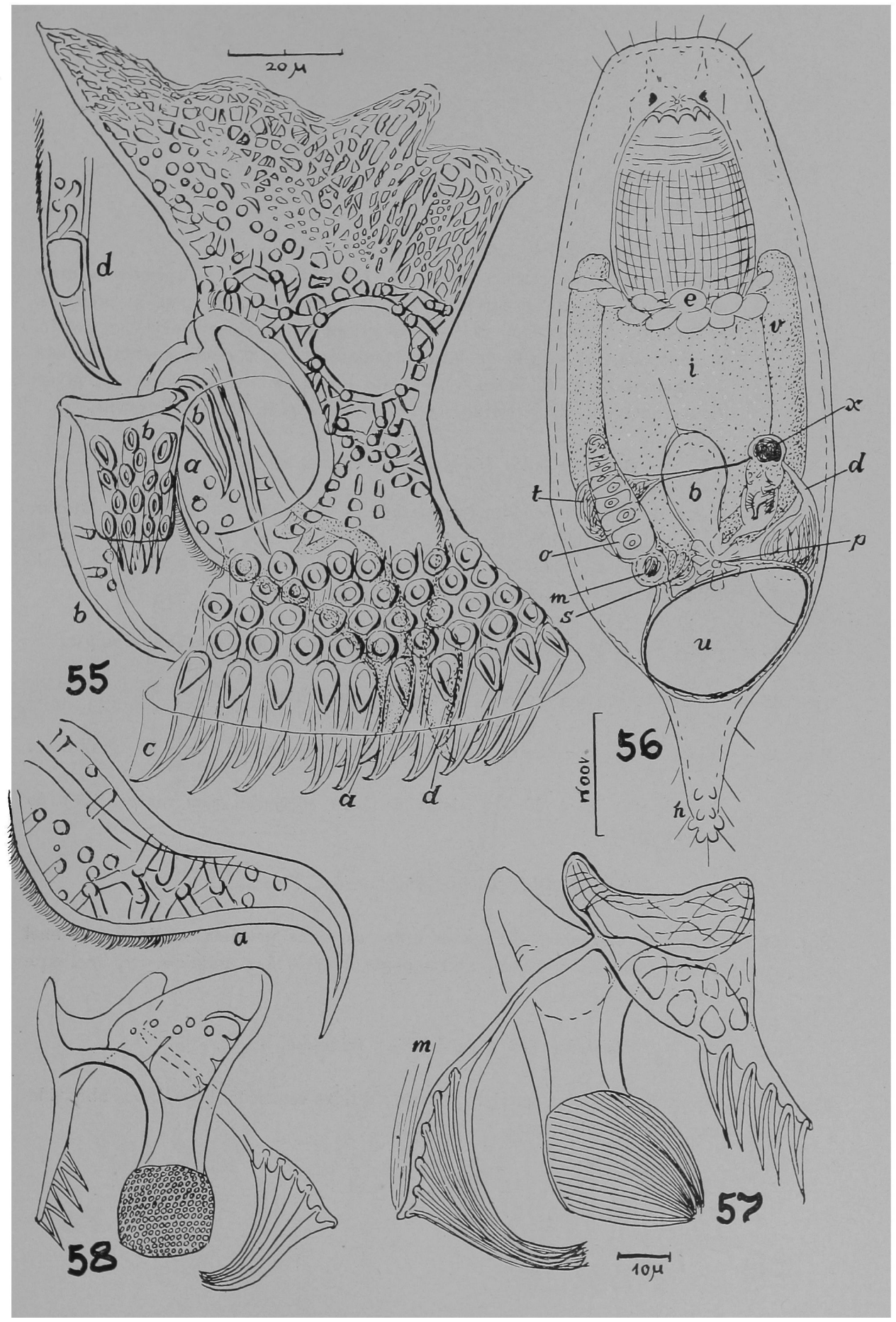




\section{ESTAMPA XI}

Microdalyellia (Gieysztoria) thymara, sp. n.

Fig. 59 - Vista ventral dum verme adulto. a, ôlho. b, bôca. c, apêndice ventromediano do aparelho cuticular. e, duto eferente. g, papilas adesivas. h, faringe. i, intestino. k, secreção granulosa no reservatório. o, ovário. p, gonóporo. r, empôla da bursa copulatória. s, vesícula seminal repleta de espérmios. $t$, testículo. $\mathrm{u}$, casulo no útero. $\mathrm{v}$, vitelário. $\mathrm{x}$, divertículo anterior do intestino. $\mathrm{y}$, divertículo posterior do intestino.

Microdalyellia (Gieysztoria) cypris, sp. n.

Fig. 60 - Vista do lado direito dum verme adulto. b, canal da bursa copulatória. e, aparêlho cuticular. $\mathrm{h}$, faringe. i, intestino. $\mathrm{k}$, reservatório da secreção granulosa. o, ovário. p, gonóporo. r, receptáculo seminal. s, vesícula seminal. $t$, testículo direito. $u$, útero.

Fig. 61 - Vista do lado esquerdo do aparelho cuticular. k, secreção granulosa.

Fig. 62 - Vista da haste esquerda do aparelho copulador.

Fig. 63 - Vista da haste direita do aparelho copulador. k, secreção granulosa. As Figuras 62 e 63 são vistas do lado esquerdo, com marca (X) do mesmo ponto.

\section{Microdalyellia (Gieysztoria) ornata (Hofsten)}

Fig. 64 - Aparelho cuticular. b, pontes entre os aneis proximal e distal. d, anel distal (ectal). e, bases externamente abertas dos espinhos. p, anel proximal (ental).

\section{Microdalyellia (Gieysztoria) tridesma, sp. n.}

Fig. 65 - Aparelho cuticular em vista ventral; o feixe esquerdo de espinhos abduzido. $\mathrm{m}$, músculo abductor. 


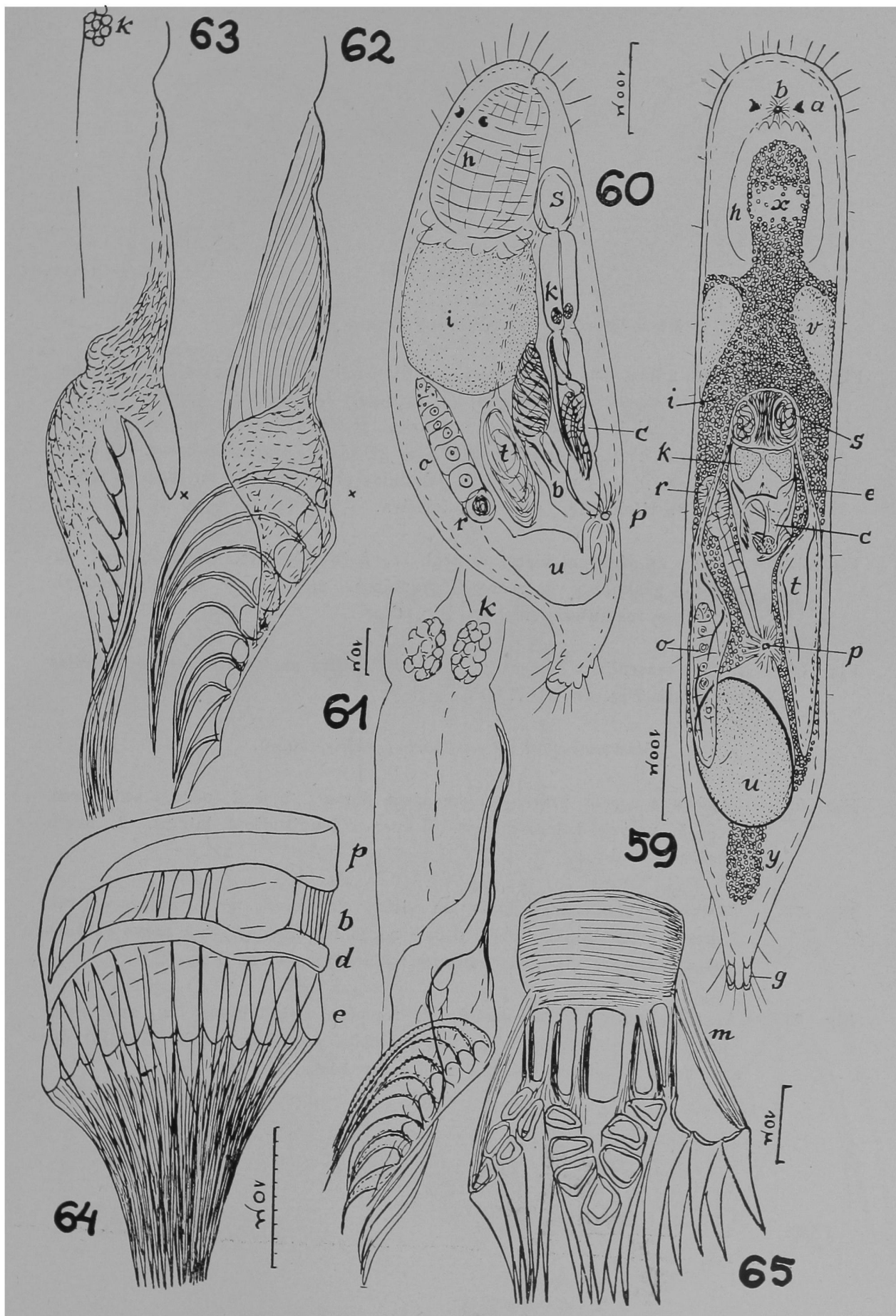




\section{ESTAMPA XII \\ Microdalyellia (Gieysztoria) ornata (Hofsten)}

Fig. 66 - Verme adulto em vista dorsal. a, átrio. b, bursa copulatória. c, glândulas da casca. d, vitelários. h, faringe. j, intestino. k, glândula grudadora caudal. n, cérebro. o, ovário. p, duto ejaculatório. q, aparelho cuticular. r, receptáculo seminal. s, glândulas argamassadoras. t, testículos. u, útero. w, olhos. $\mathrm{x}$, glândulas eritrófilas na entrada do intestino. $\mathrm{y}$, viteloduto. $\mathrm{z}$, papila adesiva.

Fig. 67 - Verme adulto em vista ventral. e, duto eferente. f, glândulas da secreção granulosa. g, secreção granulosa. m, bôca. $\mathrm{v}$, vesícula seminal. As letras restantes como na Fig. 66.

Fig. 68 - órgãos masculinos eferentes. an, musculatura anelar. As letras restantes como nas Fig. 66 e 67.

\section{Microdalyellia (Gieysztoria) bellis, sp. n.}

Fig. 69 - Cérebro e nervos principais em vista dorsal. 1 \& 2, nervos anteriores. $4 \& 5$, nervos ântero-dorsais. 6, nervo longitudinal lateral. 9, nervo longitudinal dorsal.

Fig. 70 - Cérebro e nervos principais em vista ventral. 3, nervo ântero-ventral. 7, nervo longitudinal ventral com o nervo faríngeo (8) e o nervo cutâneo oral e post-oral (10). Os números restantes como na Fig. 69.

Fig. 71 - Aparelho cuticular em posição de repouso, vista ventral. a, anel ental (proximal). b, bases entais dos espinhos. c, eônes ectais (distais) dos espinhos. $p$, pontes entre o anel e as bases dos espinhos. 


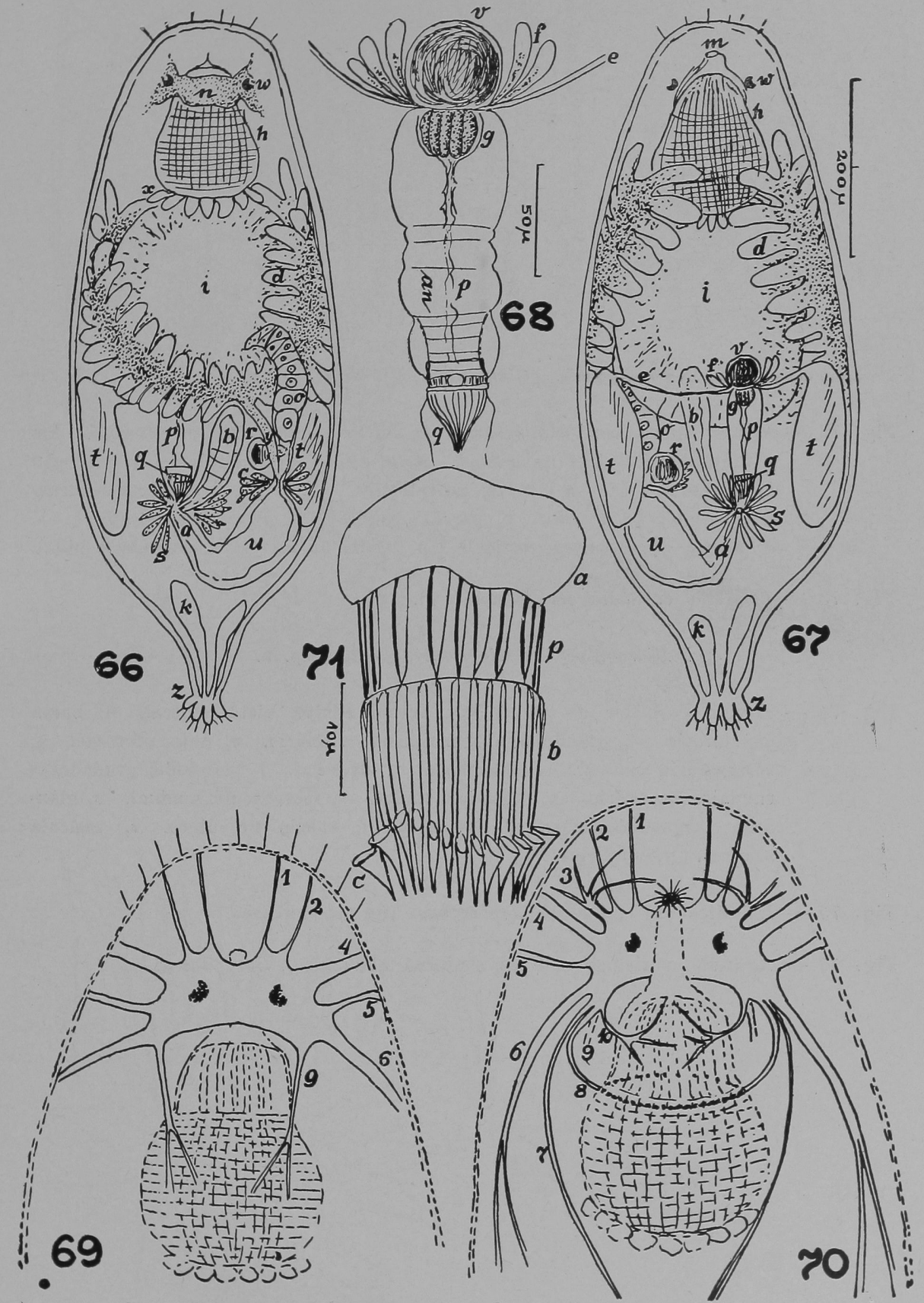




\section{ESTAMPA XIII}

Microdalyellia (Gieysztoria) tridesma, sp. n.

Fig. 72 - Verme adulto, em vista ventral. b, bursa copulatória. c, citosomas das glândulas eritrófilas na entrada do intestino. d, vitelário. e, secreção das glândulas (c) na entrada do intestino. g, glândulas argamassadoras. $\mathrm{i}$, intestino. 0 , ovário. $\mathrm{p}$, papilas caudais. $\mathrm{r}$, receptáculo seminal. s, glândulas da casca. t, testículo. u, casulo no útero. v, vesícula seminal.

Fig. 73 - Aparelho cuticular em vista lateral.

Microdalyellia (Gieysztoria) bellis, sp. n.

Fig. 74 - Região posterior do corpo dum verme adulto, vista ventral. b, bursa copulatória. e, glândulas da casca. d, vitelário. e, duto eferente. g, reservatório da secreção granulosa. i, intestino. l, glândulas grudadoras caudais. o, ovário. p, órgão copulador. r, receptáculo seminal. s, glândulas argamassadoras. $t$, testículos. $u$, casulo no útero. $v$, vesícula seminal. y, viteloduto.

Fig. 75 - Rabditos (r) e inclusões refrativas (i) na epiderme.

Fig. 76 - Aparelho cuticular com os espinhos abduzidos, vista dorsal. 


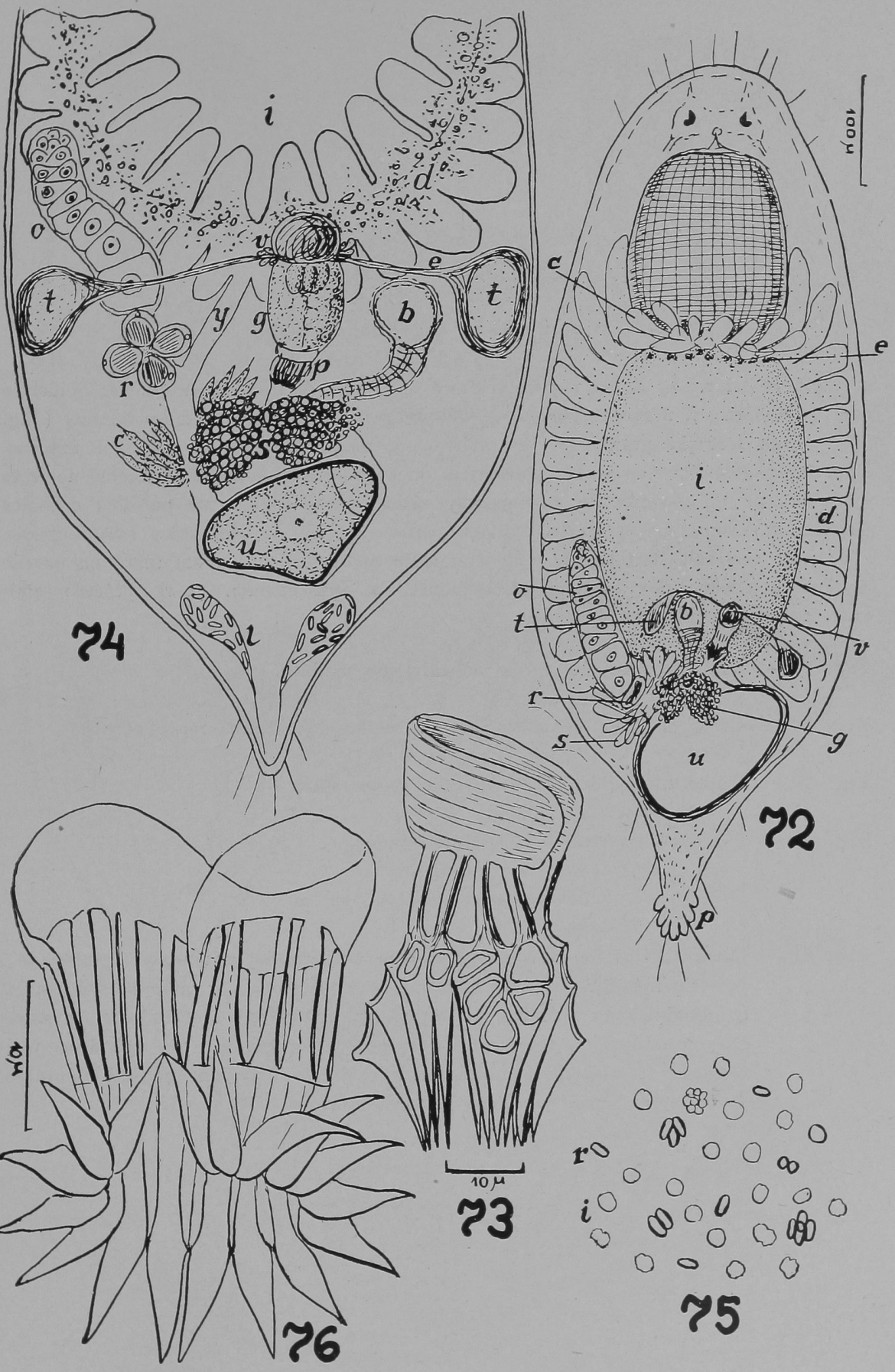




\section{ESTAMPA XIV}

Strongylostoma dicorymbum, sp. n.

a, átrio inferior. b, bursa copulatória. c, cérebro. d, duto eferente. e, epiderme com rabdóides. f, nervo faríngeo. g, duetus granulorum com as duas colunas (Fig. $79,80)$ da secreção granulosa. h, faringe. i, núcleo do epitélio faríngeo externo. $\mathrm{k}$, secreção granulosa na massa plasnática do órgão copulador. l, espérmios no duto ejaculatório. $\mathrm{m}$, entrada da faringe. $\mathrm{n}$, eálice excretor com um ou dois orifícios dos canais terminais. o, ovário. p, gonóporo. q, átrio. r, glândulas ramnitógenas. $\mathrm{s}$, vesícula seminal. $\mathrm{t}$, testículo. $\mathrm{u}$, divertículo correspondente a um útero na parede do átrio superior. $\nabla$, vitelário. $\mathrm{w}$, viteloduto. $\mathrm{x}$, duto comum. $\mathrm{y}$, receptáculo seminal. z., glândulas do gonóporo.

Fig. 77 - Vista ventral do verme sexualmente maduro.

Fig. 78 - Corte mediano (combinado) da região dos órgãos reprodutivos.

Fig. 79 - Orgão copulador, preparação de compressão.

Fig. 80 - Corte transversal do órgão copulador.

Phaenocora bresslaui, sp. n.

Fig. 81 - Corte sagital do lado esquerdo com o aparelho masculino (combinado). b, átrio inferior. e, duto eferente. f, diafragma. g, glândulas da easca. q, glândulas do apêndice piriforme. r, gonóporo. s, glândulas da secreção granulosa. t, reservatório da secreção granulosa. $u$, apêndices piriformes. $\mathrm{v}$, vesícula seminal. $\mathrm{x}$, divertículo do canal genital feminino $y$, esfincter ectal do canal genital feminino. 


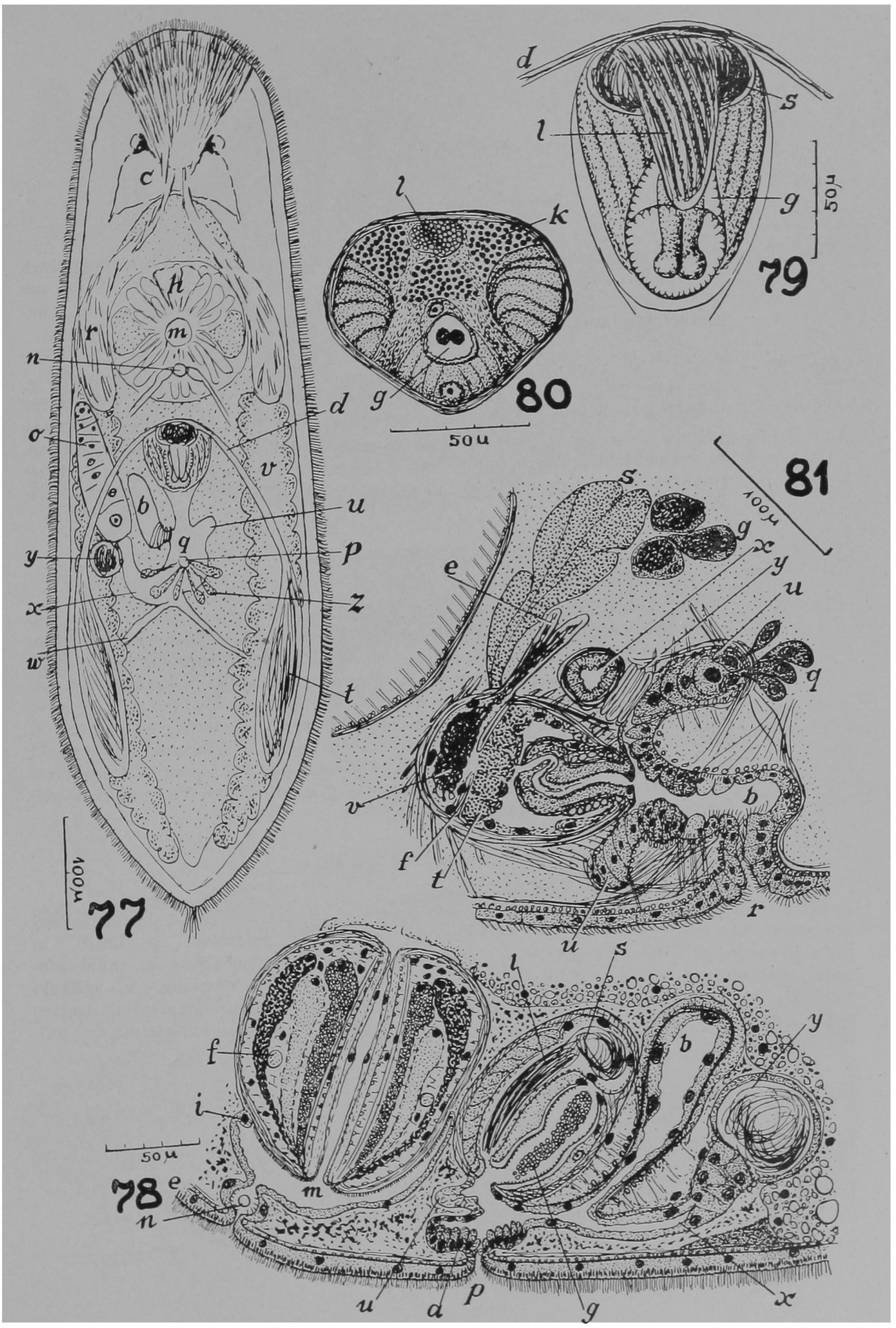




\section{ESTAMPA XV}

\section{Phaenocora bresslaui, sp. n.}

Fig. 82 - Animal recém-saido do ovo. Individuo meio adulto, em vista ventral, com bôca, gonóporo e protonefridióporos; por transparência, vê-se um ovo. Verme adulto, em vista dorsal, com os testículos ainda não completamente crescidos.

Fig. 83 - Corte sagital do lado direito com o aparelho feminino (combinado). g, glândulas da casca. l, glândulas na desembocadura do oviduto. As letras restantes como na Fig. 84. 1, nervos faríngeos. 2, bolsa faríngea externa. 3, bolsa faríngea interna. 4, glândulas faríngeas eritrófilas. 5, glândulas faríngeas cianófilas. 6, epitélio faríngeo interno. 7, músculos retractores da faringe. 8, músculos faríngeos internos longitudinais. 9 , bôca.

Phaenocora evelinae, sp. n.

Fig. 84 - Corte sagital da região anterior. Combinação duma fase êm ovo no útero com outra, depois la ovipostura, com apêndice piriforme contraido. a, átrio superior. b, átrio inferior. c, eanal genital feminino. d, oviduto. e, duto eferente. f, diafragma. h, cérebro. i, intestino. k, clavas granulosas de Minot. m, bursa. $\mathrm{n}$, duto bursa-intestinal. o, ovário. $\mathrm{p}$, poro bursa-intestinal. r, gonóporo. s, glândulas da secreção granulosa. t, reservatório da secreção granulosa. u, apêndices piriformes. v, vesícula seminal. w, vitelário. $\mathrm{x}$, divertículo do canal genital feminino. $y$, esfincter ectal do canal genital feminino. z, glândula lobulada, unj-nucleada. Os algarismos como na Fig. 83.

Phaenocora chloroxantha, sp. n.

a, átrio superior. b, átrio inferior. e, canal genital feminino. f, canal protonefridial ascendente rostral. g, bôca. $\mathrm{h}$, entrada da faringe. i, intestino. $\mathrm{m}$, bursa. $\mathrm{n}$, duto bursa-intestinal. o, ovário. p, protonefridióporos. r, gonóporo. s, eanal eferente do emunctório. $\mathrm{u}$, ramificação do canal protonefridial eferente. v, vesícula seminal. w, canal protonefridial descendente rostral. $\mathrm{x}$, canal protonefridial descendente caudal. y, canal protonefridial ascendente caudal. z, glândưla lobulada, uninucleada.

Fig. 85 - Vermes viventes, em vistas dorsal e latıral.

Fig. 86 - Sistema excretor no verme vivente, achatado debaixo da lamínula.

Fig. 87 - Corte sagital (combinado) da região dos órgãos reprodutivos. 


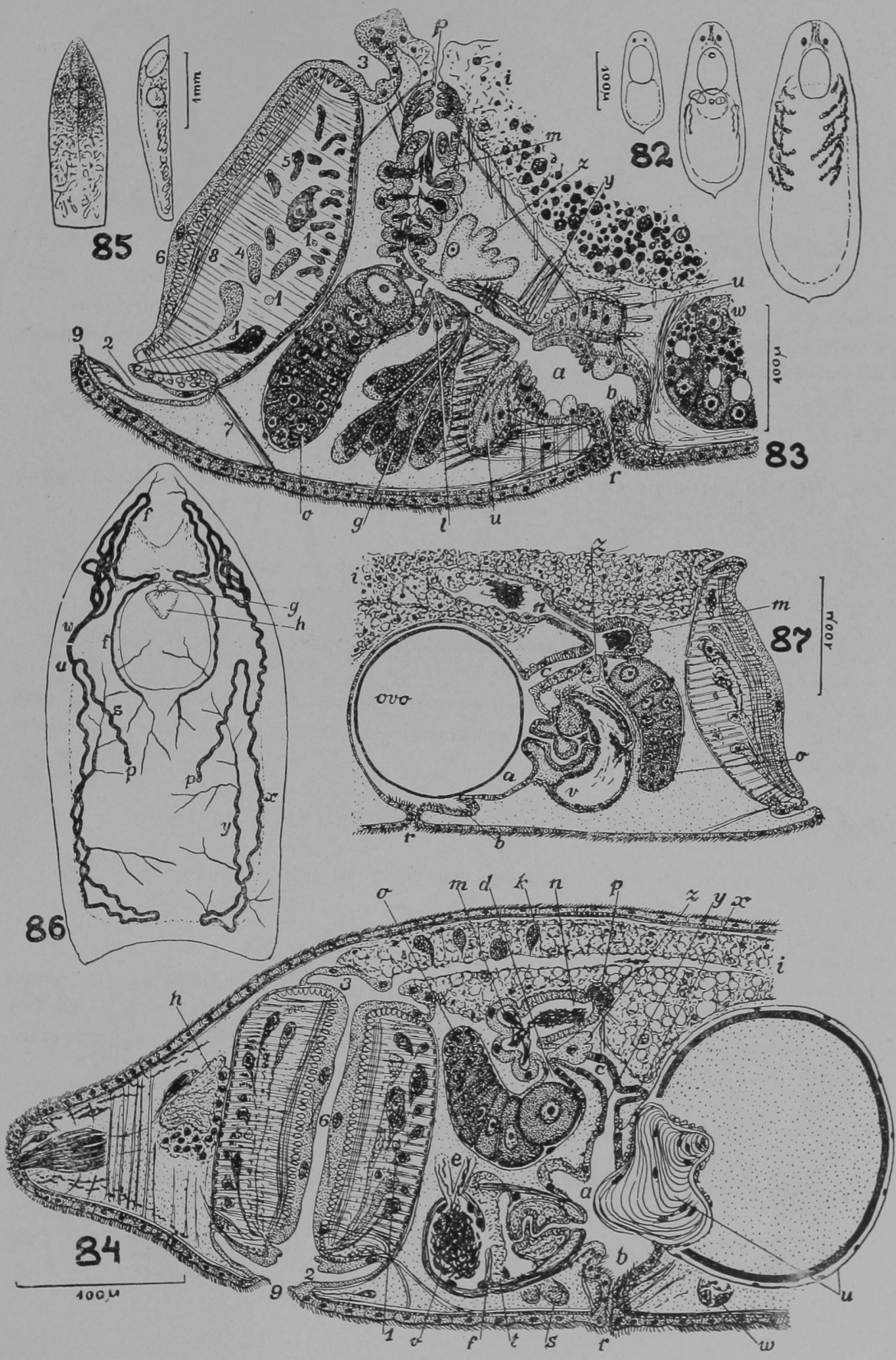




\section{ESTAMPA XVI}

Phaenocora evelinae, sp. n.

a, átrio superior. b, átrio inferior. $d$, oviduto. i, intestino. o, ováric. q, glândulas dos apêndices piriformes. qa, parte periférica do apêndice piriforme. r, gonóporo. te, testículos. u, apêndices piriformes. w, vitelário. z, glândula lobulada, uni-nucleada.

Fig. 88 - Corte transversal do terȩo anterior.

Fig. 89 e 90 - Dois cortes transversais, pouco distantes entre si, da mesma série, dos apêndices piriformes e do átrio superior.

Fig. 91 - Corte transversal do "útero" com ovo; na parede uterina, as partes externa e periférica (qa) dum dos apêndices piriformes.

Phaenocora chloroxantha, sp. n.

a, átrio superior. d, diafragma entre a vesícula seminal e o reservatório. e, duto eferente. $\mathrm{k}$, duto ejaculátório. $\mathrm{t}$, reservatório da secreção granulosa. $\mathrm{v}$, vesícula seminal. ze, zooclorelas.

Fig. 92 - Corte do órgão copulador masculino em estádio invaginado.

Fig. 93 - Corte do órgão copulador masculino em estádio evaginado.

Olisthanella parva, sp. n.

b, bôca. c, cérebro. g, glânđulas faríngeas. h, faringe. i, intestino. k, células glandulares na entrada do intestino. m, secreção das glândulas cefálicas. n, ôlho. p, gonóporo. r, receptáculo seminal. $w$, tronco anterior do emunctório. $\mathrm{x}$, poro excretor. $y$, tronco posterior do emunctório. $\mathrm{z}$, troneo terminal do emunctório.

Fig. 94 - Vista ventral dum verme maduro, ligeiramente comprimido.

Fig. 95 - Emunctório visto do lado ventral, num verme ligeiramente comprimido. 


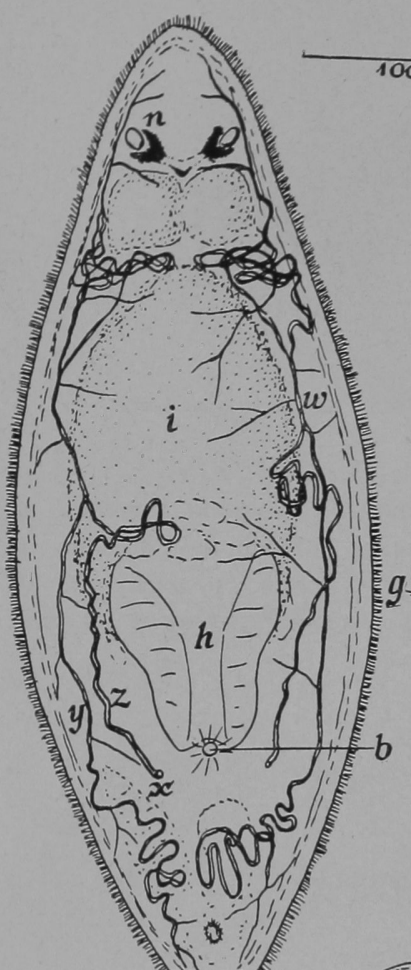

95 . $88^{200 \mu} w^{2}$
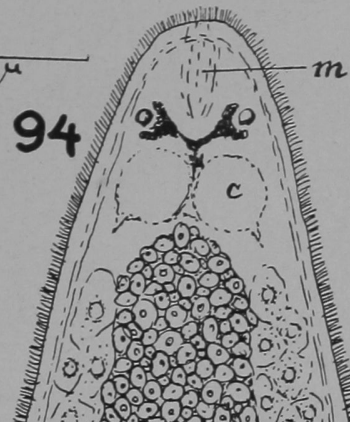

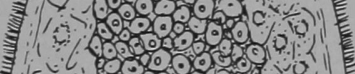

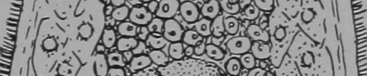

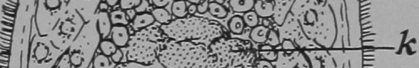

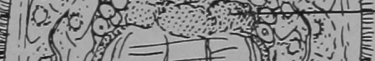

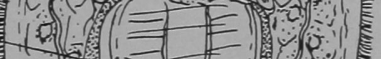

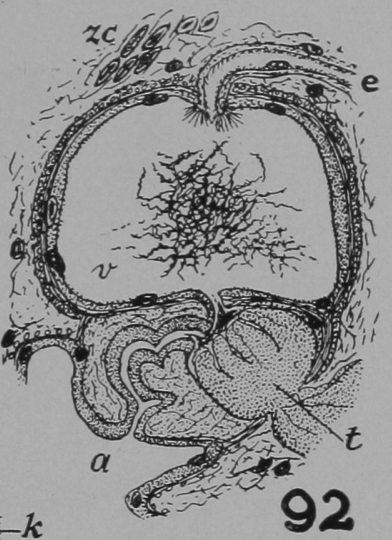

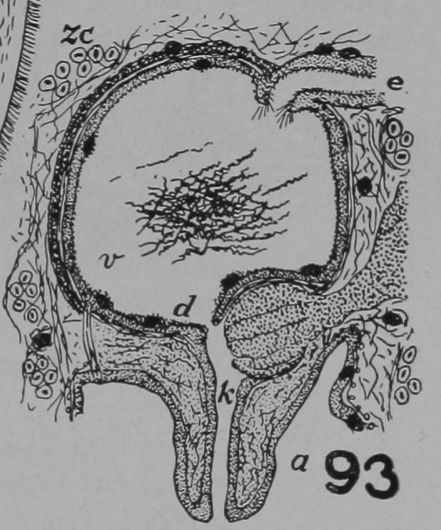
年 (2)

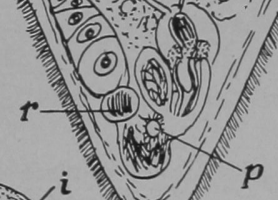

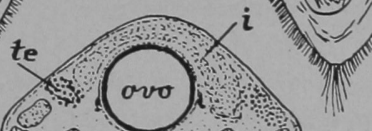

저용

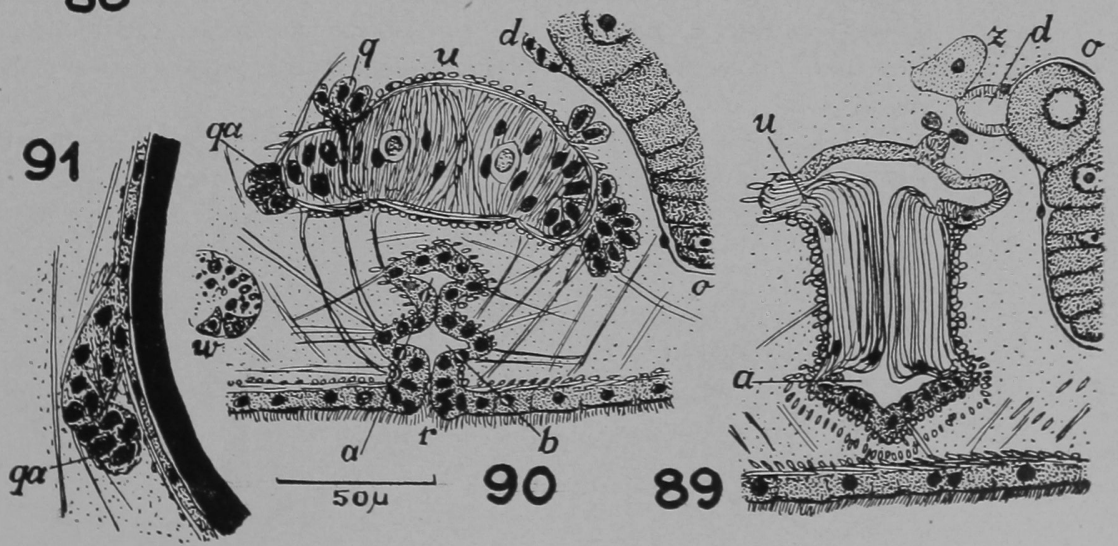




\section{ESTAMPA XVII}

Olisthanella parva, sp. n.

a, átrio. b, bôca. d, bursa copulatória. e, duto eferente. f, vesícula seminaı. g, glândulas faríngeas. i, intestiuo. k, células glandulares na entrada do intestino. l, divertículo uterino. m, secreção das glândulas cefálicas. o, ovário. p, gonóporo. q, cálice óptico, sem pigmento. $r$, receptáculo seminal. $s$, secreção granulosa. $t$, testículos. $\mathrm{u}$, duto ejaculatório. $\mathrm{v}$, vitelário.

Fig. 96 - Vista lateral dum verme maduro.

Fig. 97 - Corte sagital (combinado).

Fig. 98 - Aparelho reprodutivo no verme total, comprimido.

Bothromesostoma evelinae, sp. n.

Fig. 99 - Esquema da organisação. a, átrio. b, empôla da bursa copulatória. c, cérebro. e, esôfago. g, glândulas da casca. h, faringe. i, intestino. k, glândulas cianófilas (mucosas). m, órgão copulatório. $\mathrm{n}$, gonóporo. o, ovário. p, poro excretor combinado com a bôca. r, receptáculo seminal. $\mathrm{s}$, saco ventral. $\mathrm{t}$, testículo. $\mathrm{u}$, ovo testáceo no útero. $\mathrm{v}$, vitelário. $\mathrm{w}$, viteloduto. $\mathrm{x}$, espaço transparente no parênquima entre os nervos anteriores.

Fig. 100 - Corte tangencial da epiderme dum dos lados. c, desembocadura dum duto ramnífero. p, pigmento dentro da epiderme. r, ramnitos. s, célula substituidora. 


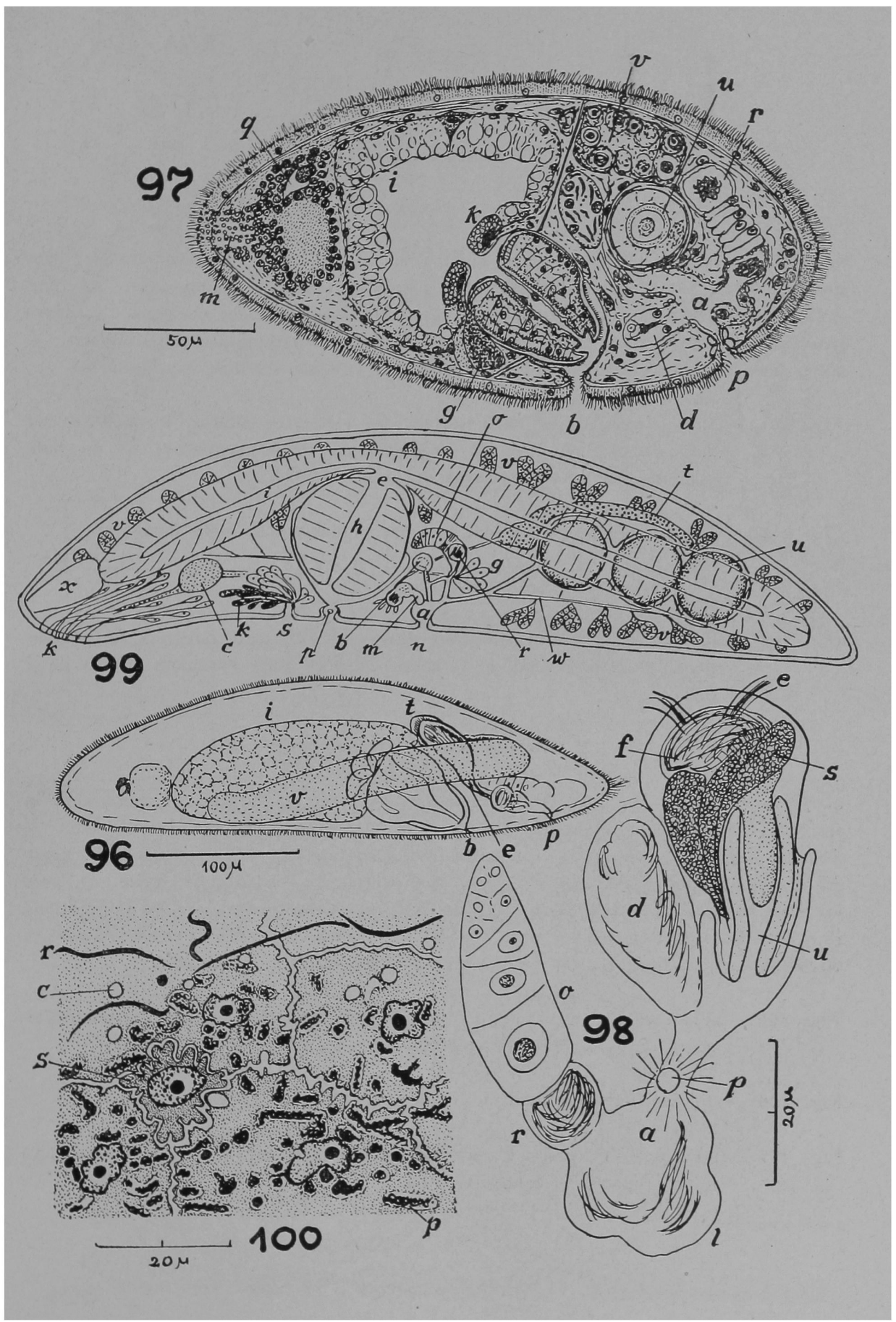


ESTAMPA XVIII

\section{Mesostoma ehrenbergii (Focke)}

a, intestino pre-faríngeo. b, bursa copulatória. e, cérebro. d, gonóporo. e, ovos imediatos. f, trato nervoso anterior. g, glândulas mucosas (fiandeiras). h, glândulas faríngeas (salivares). i, intestino post-faríngeo. $\mathrm{m}$, ovos duráveis. $\mathrm{n}$, nervo longitudinal ventral. o, ovário. p, faringe com bôca. r, glândulas ramnitógenas. s, receptáculo seminal. $\mathrm{t}$, testículos. $\mathrm{u}$, úteros. $\mathrm{v}$, vesícula seminal. $\mathrm{y}$, vitelários.

Fig. 101 - Vista ventral, sem emunctórios. Os testículos, úteros, e vitelários do lado direito, na fase da produção dos ovos imediatos; os do lado esquerdo, na époea dos ovos duráveis.

Fig. 102 - Verme de meia idade, com manchas pigmentadas; vista dorsal.

Fig. 103 - Ovo, no início da $1 .^{\mathrm{a}}$ segmentação.

Fig. 104-Duração da permanência (1-6 dias) de 121 ovos duráveis nos úteros de 10 animais; vendo-se o maior numero (52) evacuado depois de 4 dias.

\section{Bothromesostoma evelinae, sp. n.}

a, átrio. b, empôla da bursa copulatória. d, oviduto. e, esôfago. f, giândulas da secreção granulosa. g, glândulas da casca. h, faringe. i, parede do intestino. k, glândulas cianófilas (mucosas). l, músculos locomotores da faringe. m, órgão copulador. $\mathrm{n}$, gonóporo. $\mathrm{nb}$, núcleo do epitélio externo da faringe. o, ovário. p, poro excretor combinado com a bôca. q, anel-nervoso faríngeo. r, receptáculo seminal. $\mathrm{rh}$, glândulas ramnitógenas. s, saco ventral. t, testículo. u, útero. v, vitelário. w, viteloduto. $\mathrm{y}$, reservatório da secreção granulosa. $\mathrm{z}$, duto espermático.

Fig. 105 - Vista ventral dum verme com filhotes originados de ovos de desenvolvimento rápido e com ovos testáceos, de desenvolvimento lento.

Fig. 106 - Região ântero-central do corpo; combinação de vários cortes.

Fig. 107-Contornos de cortes transversais de vermes durante a locomoção (A) e em repouso e contraido (B). 


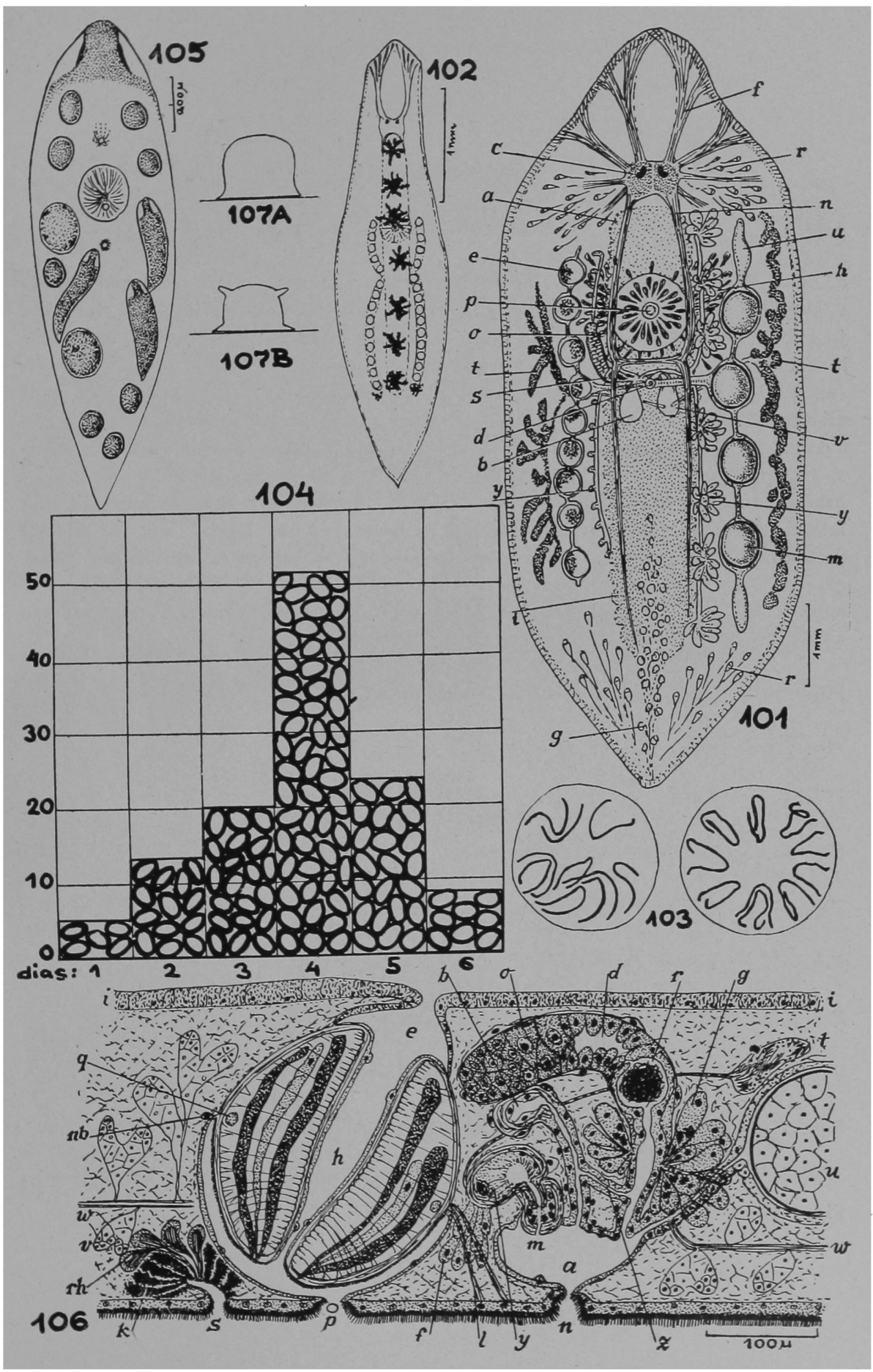




\section{ESTAMPA XIX}

Plagiostomum evelinae, sp. $\mathrm{n}$.

a, ôlho, b, bôca. e, cérebro. d, duto eferente (um dos dois). e, pseudo-esôfago. f, ovo-viteloduto (um dos dois). g, glândulas bucais. h, bolsa faríngea. i, intestino. j, glândulas do pênis. k, glândulas intestinais do tipo das clavas de Minot. 1, poro genital. $\mathrm{m}$, músculos locomotores faríngeos. $\mathrm{n}$, nervo anelar faríngeo (na Figura 112); trato nervoso sensorial (na Figura 114). o, ovário. p, poro excretor dorso-mediano. q, múseulo esfincter faríngeo. $r$, zona da secreção granulosa. $\mathrm{s}$, vesícula seminal. $\mathrm{t}$, testículos (sòmente alguns desenhados). u, pênis. $\mathrm{v}$, vitelários, ainda jovens. $\mathrm{w}$, bainha do pênis. $\mathrm{x}$, diafragma (base do pênis). $\mathrm{y}$, oviduto comum. z, glândulas do poro genital. 1, glândulas aprofundadas da área lateral. 2, canal protonefridial lateral. 3, fosseta ciliada lateral, em que o canal protonefridial desemboca. 4, ovócito inseminado. 5, espérmios alheios no parềnquima. 6, glândulas aprofundadas fora do campo lateral. 7, aglomeração de pigmento. 8, célula epidérmica superficial, não aprofundada. 9, saco distal, para que o pênis se invagina.

Fig. 108 - Verme adulto, vivente; vista dorsal.

Fig. $109-$ Verme adulto, vivente; vista lateral.

Fig. 110 - Verme jovem, vivente; vista dorsal.

Fig. 111 - Verme de meia idade, vivente; região anterior em vista dorsal.

Fig. 112 - Esquema da organisação do lado direito.

Fig. 113 - Corte horizontal.

Fig. 114 - Corte horizontal da região ântero×dorsal.

Fig. 115 - Corte horizontal da região látero-ventral.

Fig. 116 - Corte transversal do órgão copulador masculino, ao nível da linha $\mathbf{r}$ da Fig. 112.

Fig. 117 - Casulo com 4 vermes jovens. 

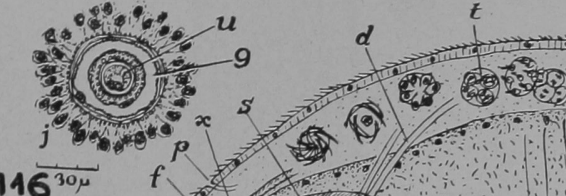

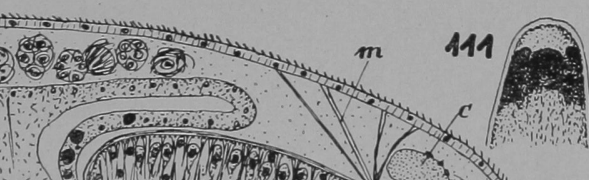

$146^{30 \mu} f$. $f$.

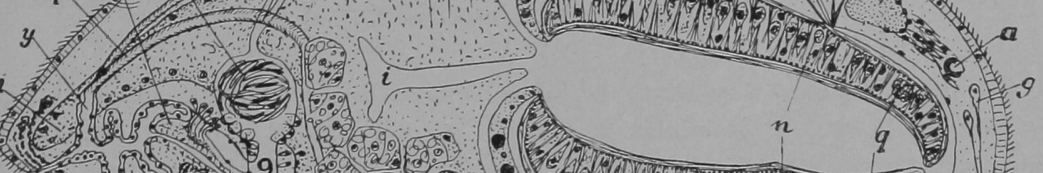

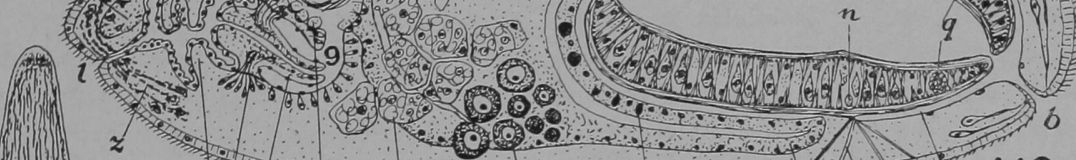

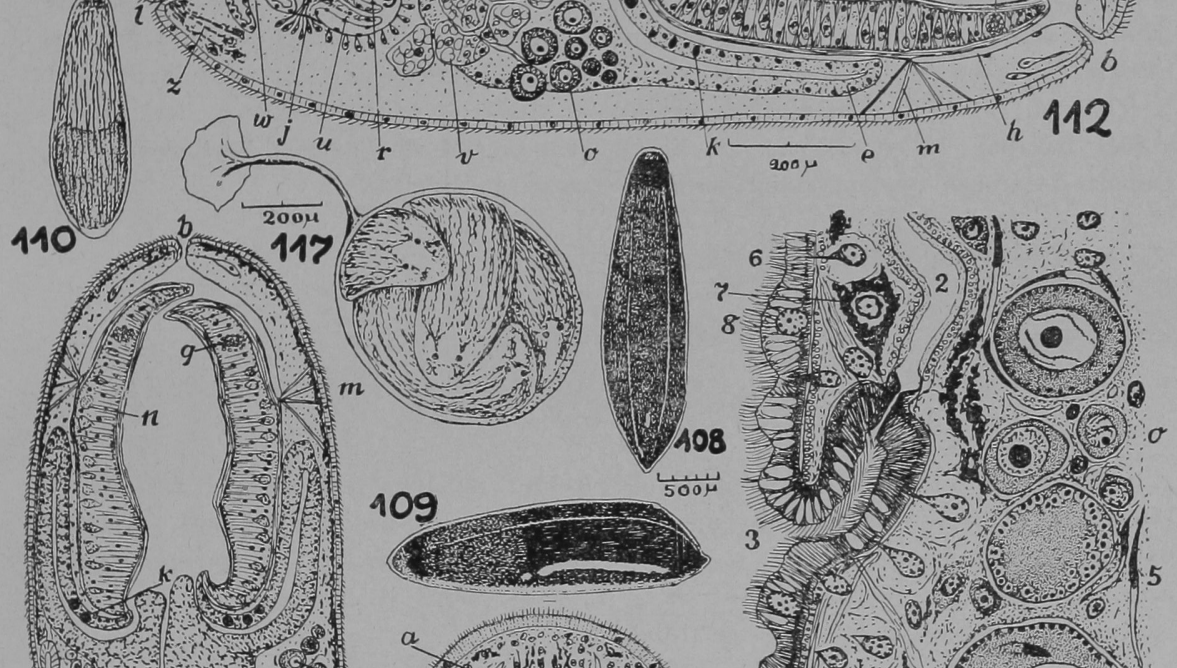

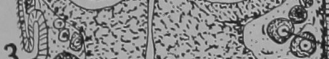

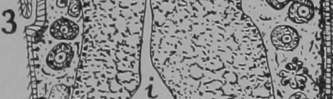

- $50.7 \%$.

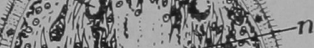

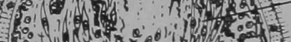

7.

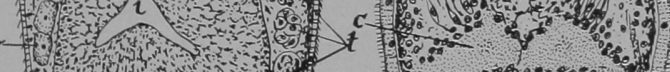

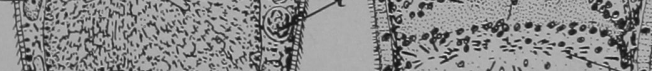

H

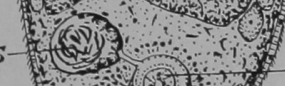

$10,1010,10794$

(3)

. $x$

113 z

3004
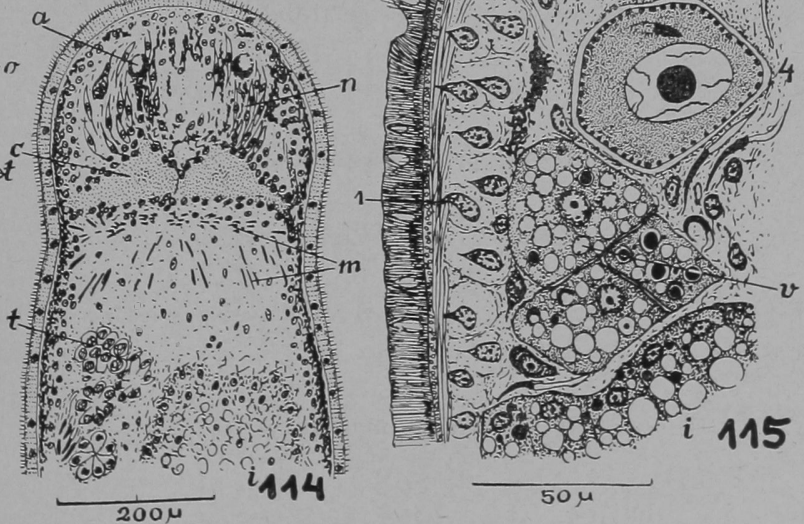
ESTAMPA $\mathrm{XX}$

\section{Gyratrix hermaphroditus Ehrenberg}

a, glândulas do poro feminino. b, bursa copulatrix. c, cérebro. d, poro feminino. e, poro da bursa. f, glândulas da casca. g, glândulas da tromba. h, faringe. i, intestino. k, reservatório da secreção granulosa com glândulas. m, canal ascendente (distal) do emunctório. n, canal descendente (proximal) do emunctório. o, ovário. p, estilete. q, cabo da bainha do estilete. r, tromba (proboseis). s, vesícula seminal. t, testículo. $u$, utero contendo um casulo. $v$, vitelário, na fase imatura. w, ramificações internas do emunctório. $x$, ligação transversal dos canais descendentes. $y$, empôla do troneo protonefridial terminal. z, paranefrócitos.

Fig. 118 - Vista ventral, sem intestino.

Fig. 119 - Vista dorsal, sem órgãos reprodutivos.

\section{Meidiama lutheri, g. n, sp. n.}

a, orifício externo da bursa seminal. c, cérebro. d, ovo-viteloduto. $h$, faringe. i, intestino. $\mathrm{l}$, intestino sólido. $\mathrm{m}$, gonóporo masculino. o, ovário. $q$, pânis. $\mathbf{r}$, reservatório da secreção granulosa. $s$, vesícula seminal. $t$, testículos. $u$, gonóporo feminino. $\mathrm{v}$, vitelário. $\mathrm{w}$, bursa resorvente. $\mathrm{x}$, estatocisto. $\mathrm{y}$, estatolito. $\mathrm{z}$, lacuna no parênquima provavelmente protonefridial.

Fig. 120 - Verme adulto vivente, em vista ventral.

Fig. 121 - Região anterior dum verme vivente.

Fig. 122 - Vista ventral da região posterior.

Fig. 123 - Vista ventral dum verme jovem, vivente; no lado, a extremidade caudal dum outro exemplar.

Fig. 124 - Orgão copulador masculino. 

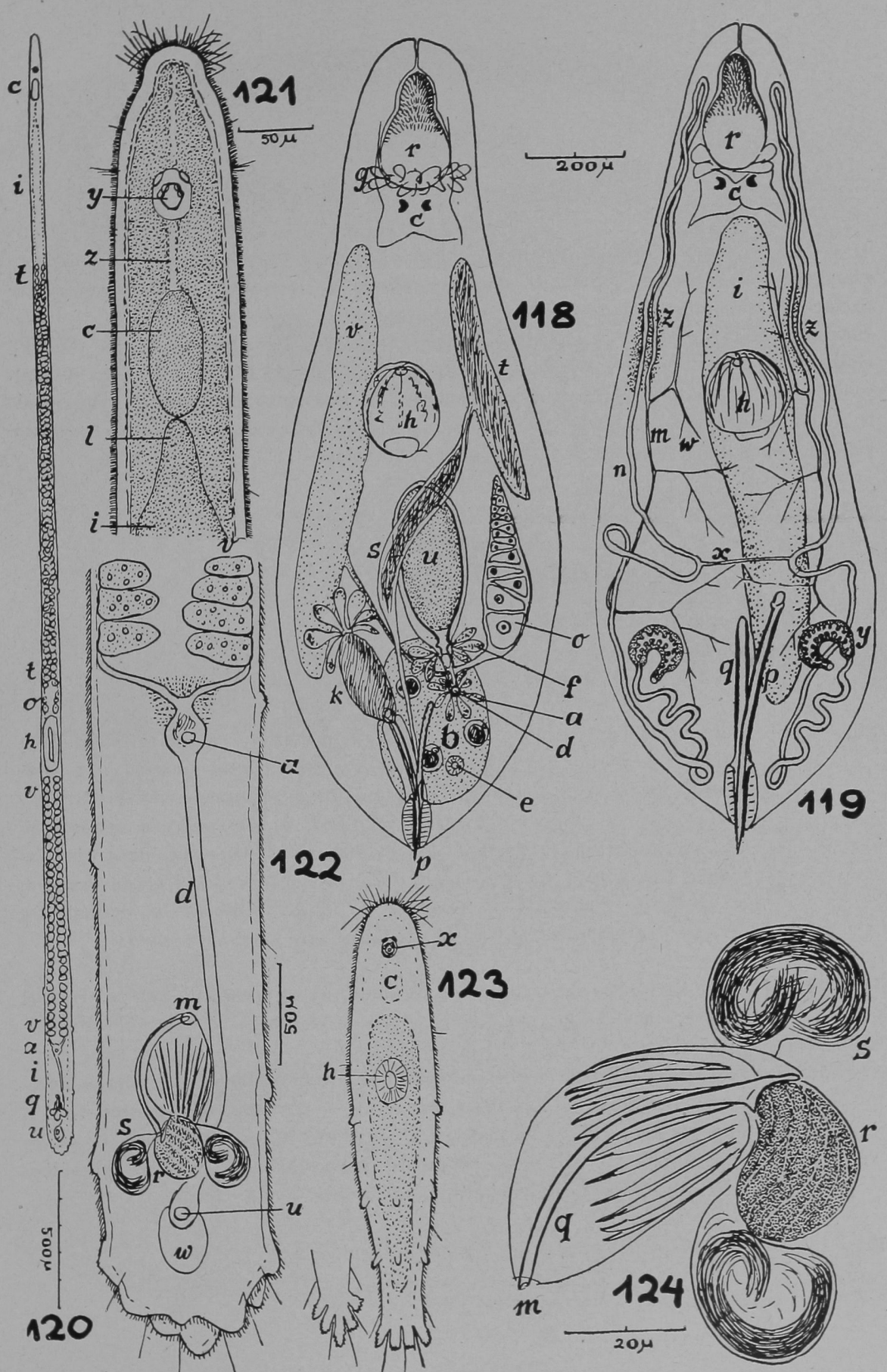


\section{ESTAMPA XXI}

Meidiama lutheri, g. n., sp. n.

a, orifício externo da bursa seminal. b, bôca. d, ovo-viteloduto. ?, epiderme. f, glândulas cefálicas. g, glândulas argamassadoras. i, intestino. j, nerro faríngeo anelar. k, glândulas faríngeas. m, gonóporo masculino. $n^{1}-n^{5}$, nervos. $p^{1}$, epitélio faríngeo interno ciliado, que reveste o lume e aparce numa prega cortada tangen(ialmente. $\mathrm{p}^{2}$, epitélio não ciliado, que corresponde a $\mathrm{ph}^{2}$ da f. 54 de Meixner (1938, p. 57). r, reservatório da secreção granulosa. u, gonóporo feminino. v, vitelários. $\mathrm{w}$, hursa resorvente. $\mathrm{x}$, núcleos das células parietais do estatocisto. $\mathrm{y}$, núcleos das células formadoras do estatolito, dissolvido nos cortes.

Fig. 125 - Corte mediano (combinado) da região posterior.

Fig. 126 - Corte mediano (combinado) da região da faringe.

Fig. 127 - Corte transversal ao nível do estatocisto.

Minona evelinae, g. n., sp. n.

Fig. 128 - Corte mediano (combinado) da região posterior. a, orifícío do duto bursal. b, bôca. d, ovo-viteloduto. db, duto bursal (vagina). e, epiderme com secreção cutânea. g, glândulas argamassadoras. h, faringe. i, intestino. l, papilas adesivas com glândulas. m, orifício externo do duto ejaculatório. $\mathrm{n}$, orifício da vesícula granulorum. q, duto ejaculatório. r, cavidade da vesícula granulorum. s, lume da vesícula seminal. $\mathrm{u}$, gonóporo feminino. $\mathrm{w}$, empôla da bursa seminal. $\mathrm{x}$, estilete da vesícula granulorum. y, clava de Minot. z, comissura caudal.

Fig. 129 - Corte horizontal da parte ectal, loculada, da vesícula seminal; no centro, o duto ejaculatório; em alguns gomos, espérmios.

Fig. 130 - Corte horizontal da região do cérebro. 1, neuropilema. 2, lóbulos anteriores cerebrais. 3, núcleos das células parietais do estatocisto. 4, núcleos das células formadoras do estatolito. 5, estatolito. 6, cálice pigmentado. 7 , orla dos bastonetes (neurofibrilas). 8, zona refractiva (cristalino) da célula visual. 9, núcleo da célula visual.

Fig. 131 - Estilete canaliculado da vesícula granulorum. 

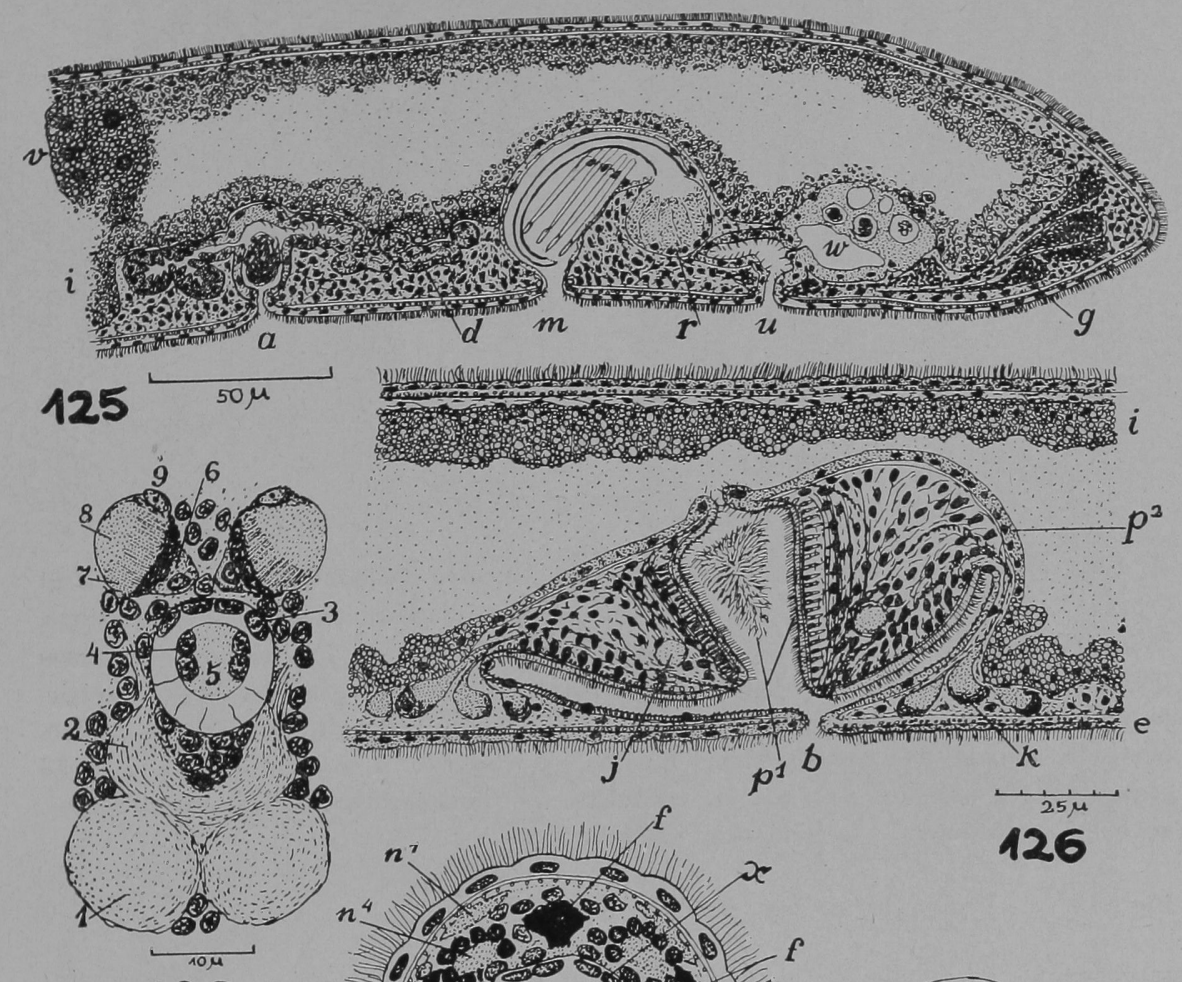

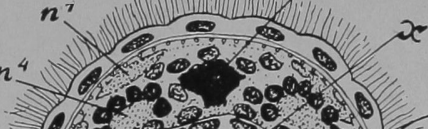

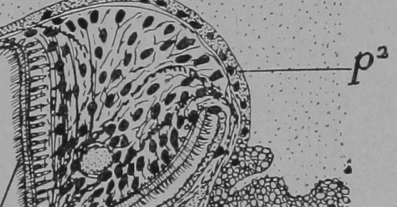

10.0 Sul

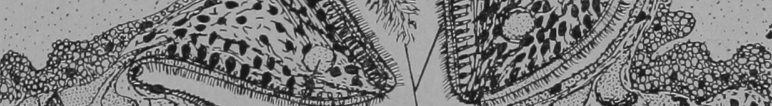

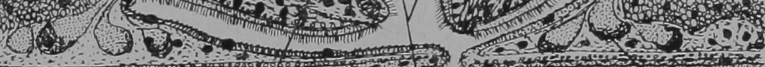

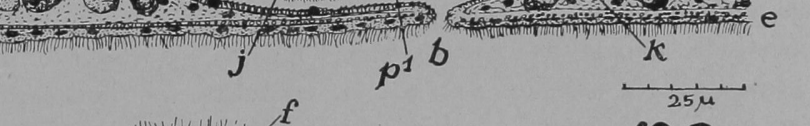

130 H. H. $127 x^{2}$. 20. $y$

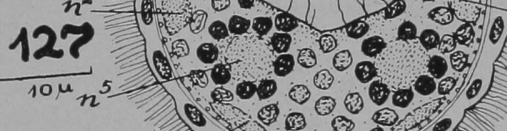

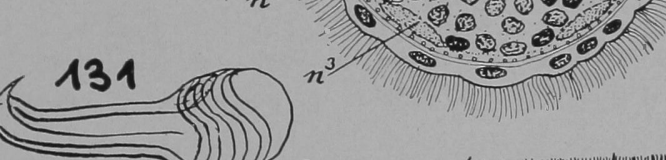

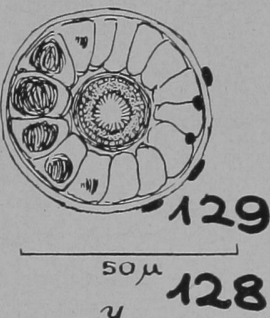

$y$ $10 \mu \quad d$ f .1.

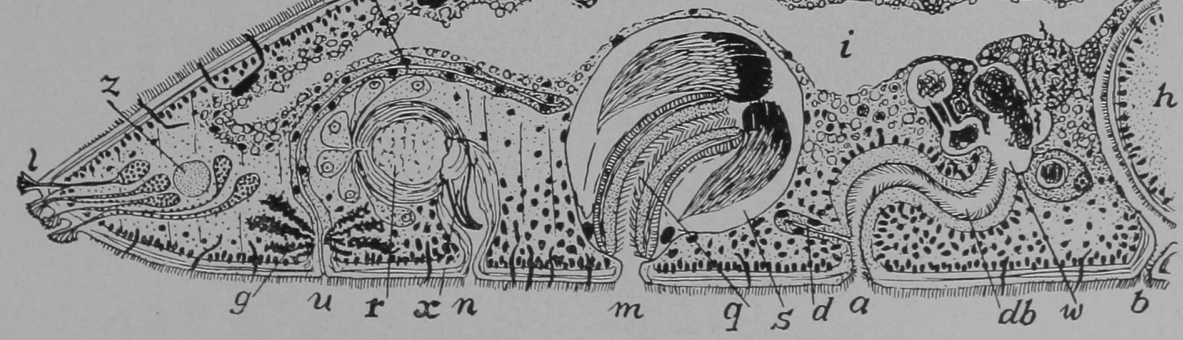




\title{
ESTAMPA XXII
}

\author{
Minona evelinae, g. n., sp. n.
}

a, poro externo da bursa seminal. b, bôca. d, ovo-viteloduto. db, duto bursal (vagina), e, epiderme com secreção cutânea. g, glândulas argamassadoras. h, faringe. i, intestino. j, nervo faríngeo anelar. k, glândulas faríngeas. l, papilas adesivas com glândulas. $\mathrm{m}$, gonóporo masculino. $\mathrm{n}$, orifício da vesícula granulorum. 0 , ovário. $\mathrm{p}^{1}$, epitélio faríngeo interno, parte ciliada, aprofundada. $\mathrm{p}^{2}$, epitélio faríngeo interno, parte não ciliada, não aprofundada. q, duto ejaculatório. r, reservatório da secreção granulosa. s, vesícula seminal. t, iestículos. u, gonóporo feminino. v, vitelários. w, empôla da bursa. z, comissura caudal.

Fig. 132 - Vista ventral da região posterior.

Fig. 133 - Vista lateral da região posterior.

Fig. 134 - Corte horizontal da região faríngea.

\section{Bothrioplana semperi M. Braun}

Fig. 135 - Corte transversal ao nível do gonóporo. a, átrio. d, viteloduto. g, glândulas ao redor do gonóporo. o, ovário. p, gonóporo. s, intestino. $\mathrm{v}$, vitelário. 


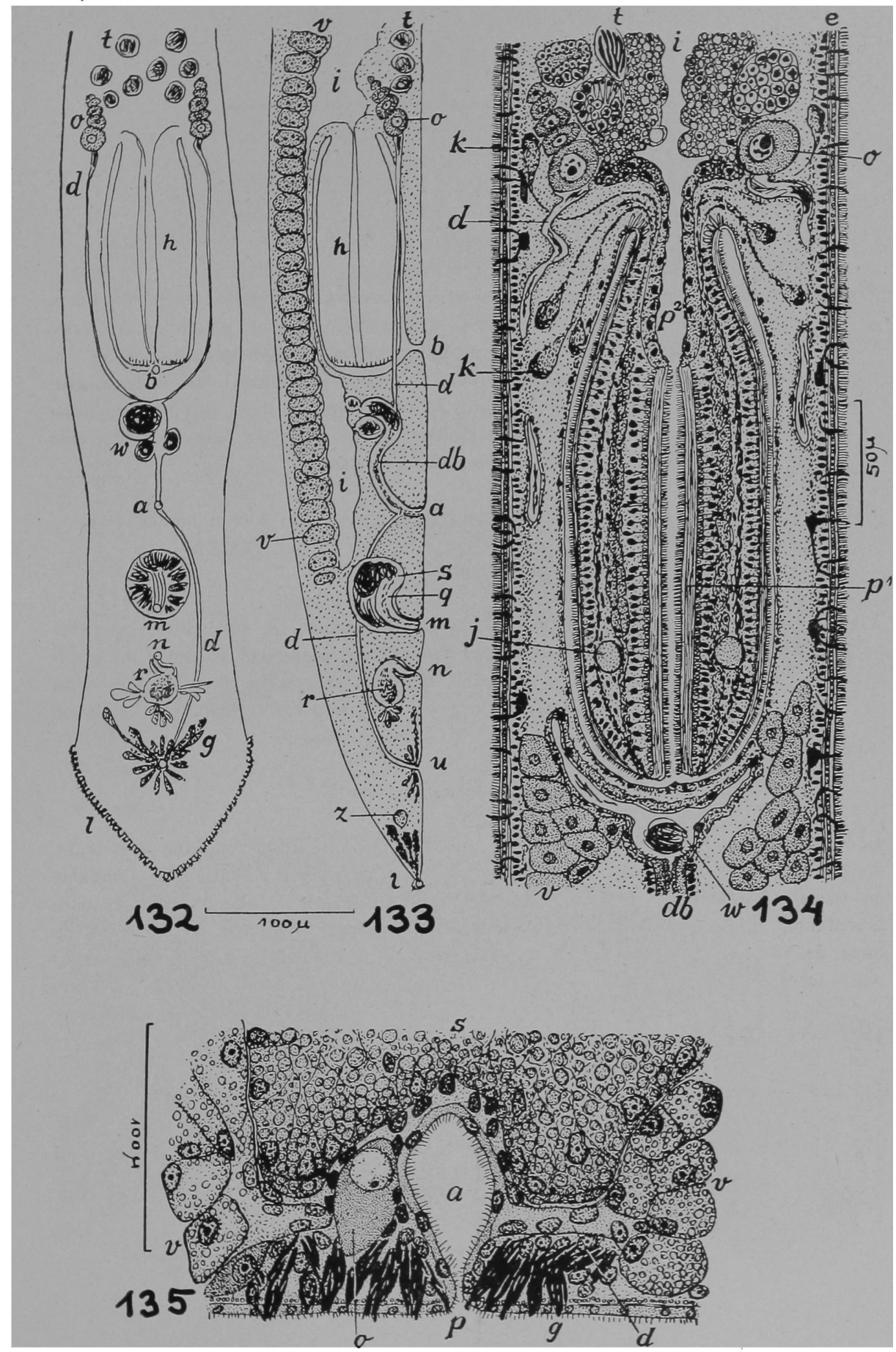




\section{ESTAMPA XXIII}

Minona evelinae, g. n., sp. n.

Fig. 136 - Verme adulto, vivente, visto do lado ventral. a, poro externo da bursa seminal. b, bôca. e, cérebro. d, ovo-viteloduto. f, glândulas cefálicas. $\mathrm{h}$, faringe. i, intestino. l, papilas adesivas. m, gonóporo masculino. $\mathbf{n}$, orifício da vesícula granulorum. o, ovário (germário). r, vesícula granulorum. s, vesícula seminal. t, testículos (no lado direito, não desenhados). u, gonóporo feminino. v, vitelários (no lado esquerdo, não desenhados). w, empôla da bursa seminal.

Fig. 137 - Papilas adesivas caudais dum verme jovem (A) e dum adulto (B).

\section{Bothrioplana semperi M. Braun}

Fig. 138 - Vista ventral. a, átrio. b, bôca. c, cérebro. d, viteloduto. e, parte lateral do intestino. f, órgão frontal. g, glândulas ao redor do gonóporo. $\mathrm{h}$, faringe. $\mathrm{i}$, intestino anterior. $\mathrm{m}$, bolsa faríngea. $\mathrm{n}$, duto protonefridial terminal. o, ovário. p, gonóporo. $\mathrm{r}$, rabditos. $\mathrm{s}$, intestino posterior. v, vitelário. w, fossetas ciliadas.

Bopsula evelinae, g. n., sp. n.

a, átrio feminino. b, empôla da bursa. c, canal entre o átrio feminino e o bulbo do pênis. d, duto seminal. e, orifício da papila do pênis. f, bôca. g, glândulas $\mathrm{da}$ casca. $\mathrm{h}$, faringe. $\mathrm{i}$, átrio masculino. $\mathrm{k}$, duto (canal) da bursa. $\mathrm{m}$, poro masculino. $\mathrm{n}$, duto eferente. o, ovo-viteloduto. $\mathrm{p}$, poro feminino. $\mathrm{s}$, secreção no lume do pênis. $t$, testículos. $v$, vesícula seminal extra-penial. y, glândulas argamassadoras.

Fig. 139 - Esquema da região dos órgãos copuladores.

Fig. 140 - Corte mediano (combinado) da região dos órgãos copuladores.

Fig. 141, 142, 143 - Esquema hipotético interpretando a organização de Bopsula evelinae como originada por rotação do pênis. 


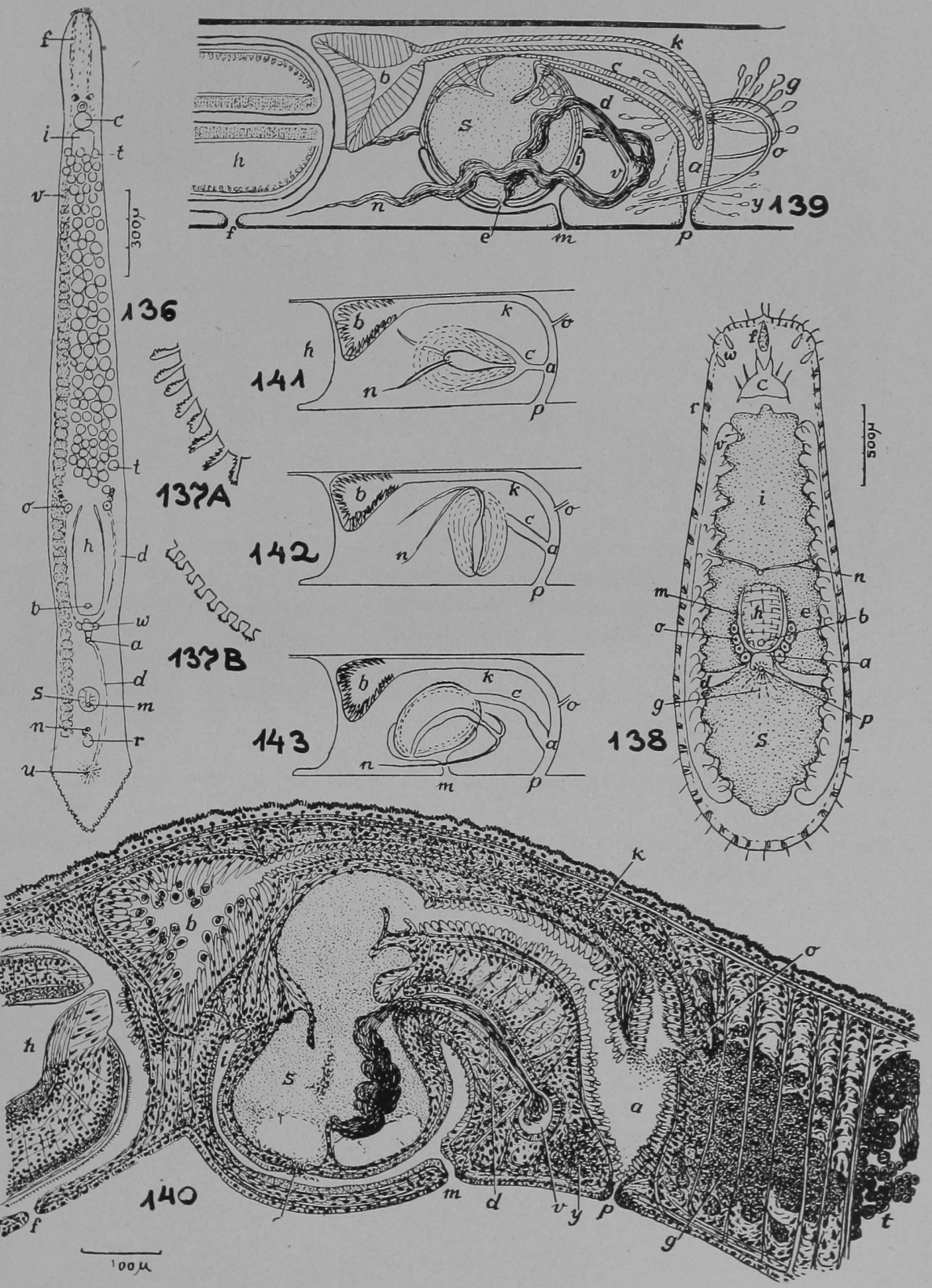


a, átrio masculino. b, empôla da bursa ("bursa"). d, vitelários. e, duto eferente. $\mathrm{f}$, vesícula seminal extra-penial. g, glândulas da casca. $\mathrm{h}$, faringe. i, intestino. $\mathrm{m}$, ovo-viteloduto comum. n, nervo longitudinal ventral. p, pênis. r, poro genital. t, testículo. w, ovo-viteloduto. z, área adesiva.

Fig. 144 - Vista dorsal dum espécime, cujo zoóide posterior se individualizou, há pouco tempo.

Fig. 145 - Corte horizontal (combinado) da região do aparêlho copulador.

Fig. 146 - Corte mediano da regiąo do poro genital dum verme com os órgãos reprodutivos quasi completamente desenvolvidos. 


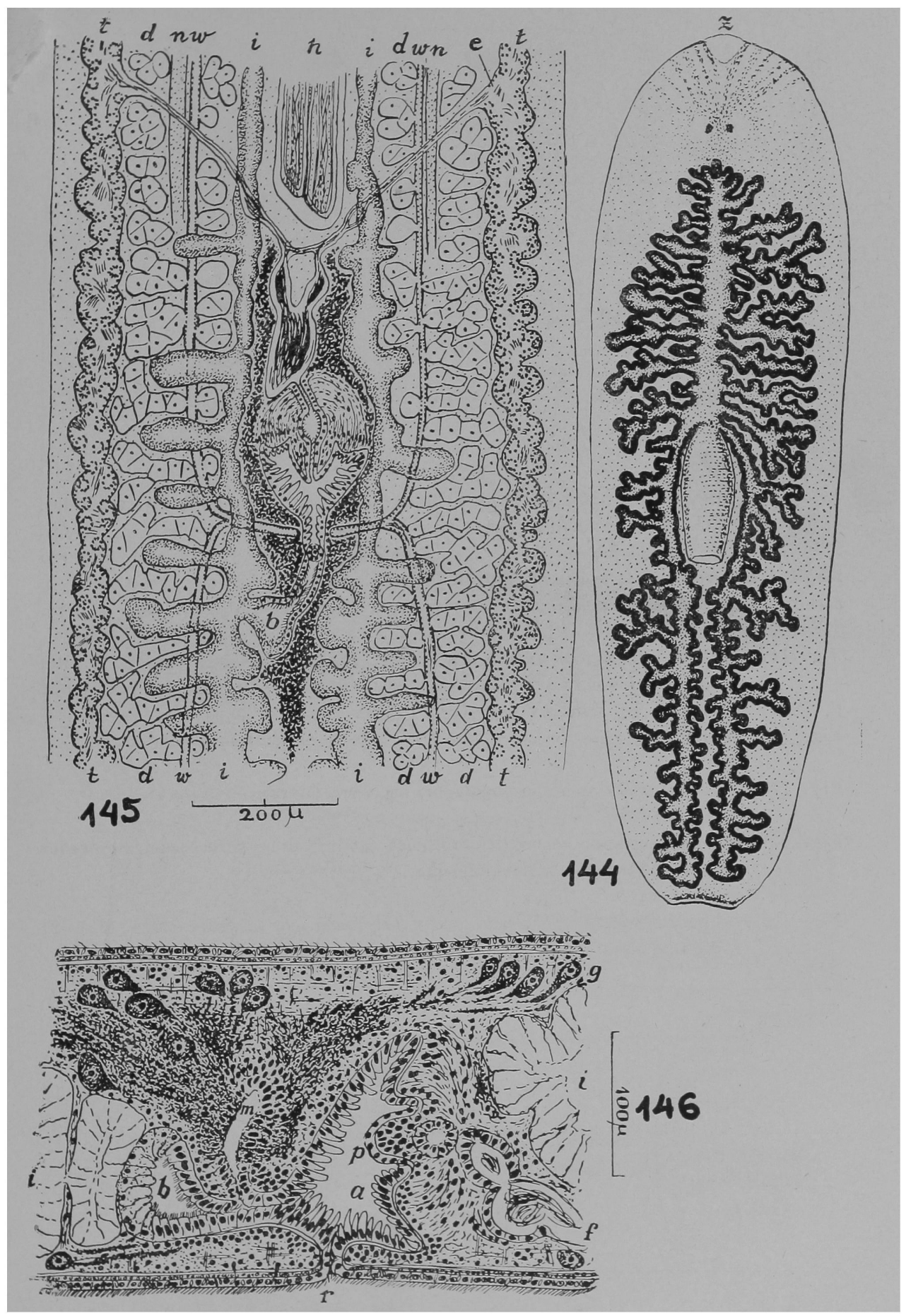




\section{ESTAMPA XXV}

Rhodax evelinae, g. n., sp. n.

a, átrio masculino. b, empôla da bursa ("bursa"). c, canal da bursa. d, vitelários. c, duto eferente. f, vesícula seminal extra-penial. g, glândulas da casca. h, faringe. i, intestino. k, glândulas cefálicas. 'l, cérebro. m, ovo-viteloduto comum. n, nervo longitudinal ventral. o, ovário. p, pênis. $r$, poro genital. s, bôca. t, testículo. u, átrio comum. $\mathrm{v}$, vesícula seminal intra-penial. $\mathrm{w}$, ovo-vitelodutos. $\mathrm{z}$, área adesiva.

Fig. 147 - Vista ventral dum exemplar sexuado. Foram suprimidos, no lado direito, os vitelários e os ovo-vitelodutos; no esquerdo, os divertículos intestinais.

Fig. 148 - Esquema, baseado em cortes horizontais, da extremidade anterior.

Fig. 149 - Esquema do aparêlho copulador, em vista lateral.

Fig. 150 - Corte mediano da região do poro genital dum verme com os órgãos reprodutivos em desenvolvimento.

Fig. 151 - Um indivíduo com a sua prole, originada por divisão, entre 13 e 21 de dezembro de 1944. 


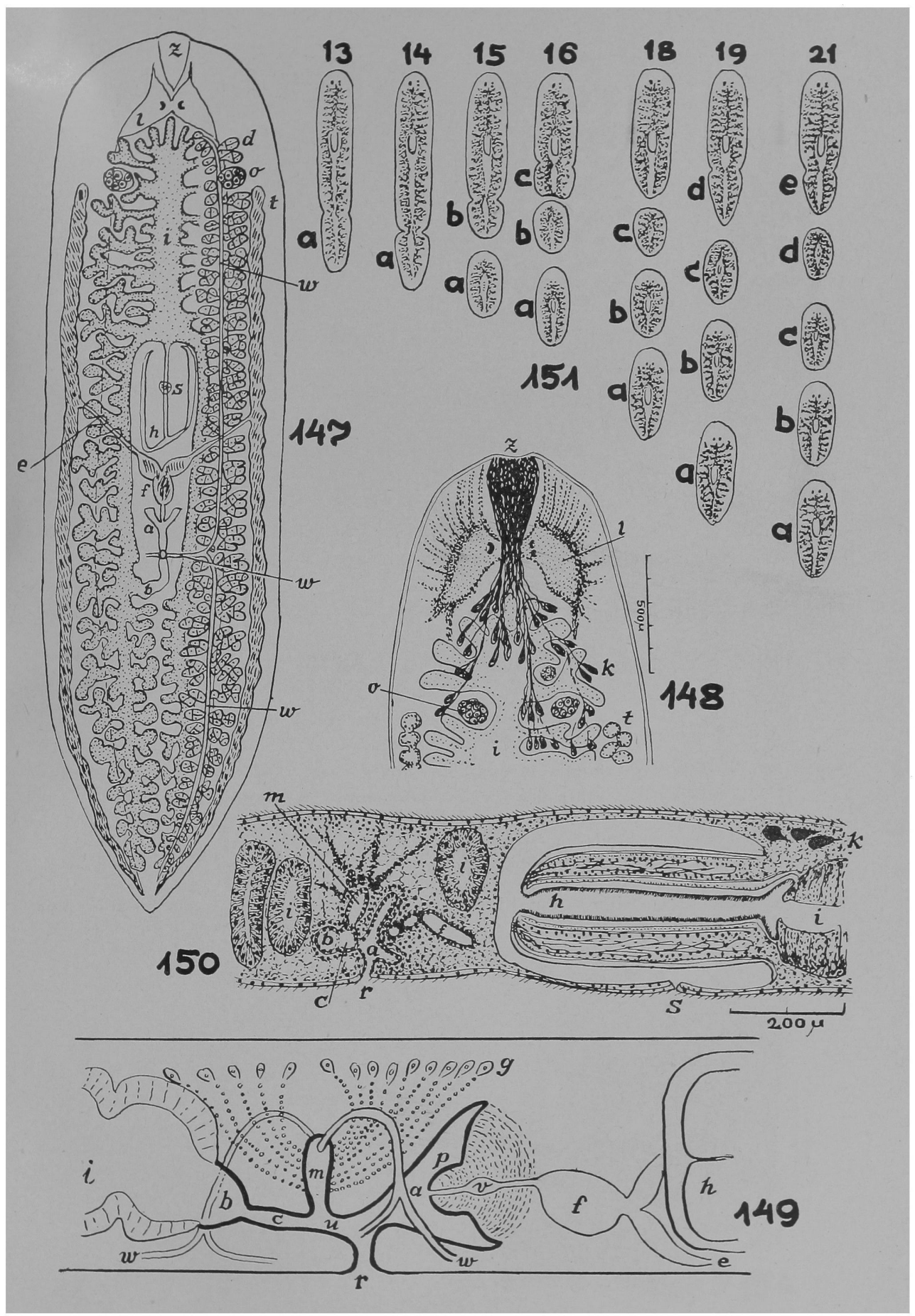




\section{ESTAMPA XXVI}

Rhodax evelinae, g. n., sp. n.

a, átrio masculino. b, empôla da bursa ("bursa"). d, vitelários. f, vesícula seminal extra-penial. g, glândulas da casca. i, intestino. k, glândulas cefálicas. n, nervo longitudinal ventral. o, ovário. $\mathrm{r}$, poro genital. w, ovo-viteloduto.

Fig. 152 - Corte horizontal (não combinado) da região do aparêlho copulador.

Fig. 153 - Corte horizontal (combinado) da região do ovário direito.

Curtisia schubarti, sp. n.

Fig. 154 - Corte sagital dum infundíbulo vitelino com espérmios. m, fibras musculares. p, espérmios. $\mathrm{v}$, ovo-viteloduto. $\mathrm{x}$, vitelário.

\section{Dugesia tigrina (Girard)}

Fig. 155 - Intestino dum verme fartamente alimentado com fígado picado mais carvão granụlado. 


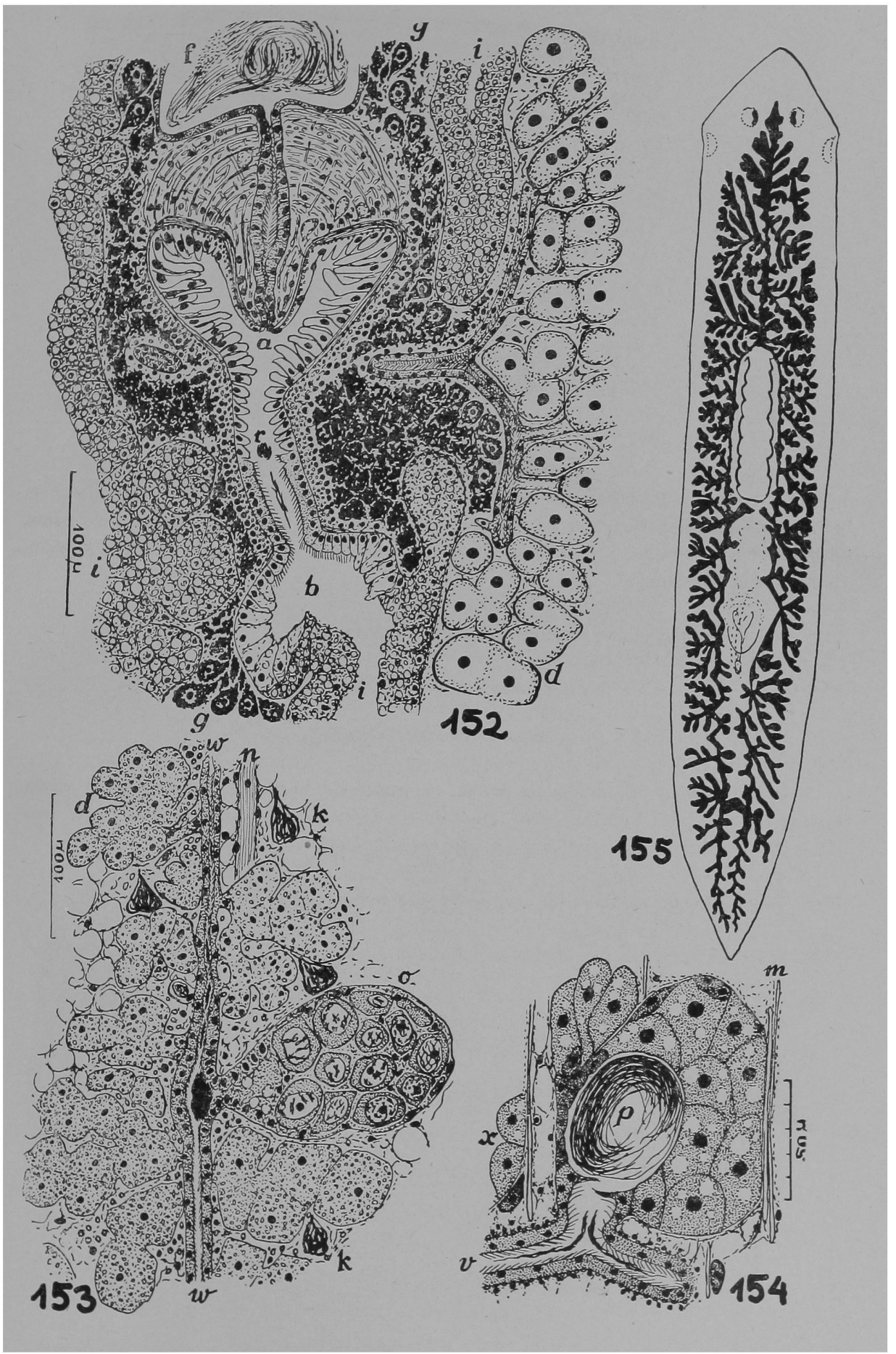




\section{ESTAMPA XXVII}

Curtisic schubarti, sp. n.

a, átrio comum. b, bôea. e, cérebro. d, dutos eferentes. e, átrio masculino. $\mathrm{g}$, gonóporo. $\mathrm{h}$, bolsa faríngea. i, intestino. $\mathrm{k}$, canal da bursa. o, ovário. $\mathrm{p}$, pênis. q, glândulas da casca. t, testículos. u, empôla da bursa. v, ovo-viteloduto. J, glândulas argamassadoras.

Fig. 156 - Esquema da organização, vista ventral.

Fig. 157 - Corte mediano (combinado) da região dos órgãos copuladores.

\section{Dugesia tigrina (Girard)}

a, átrio masculino. b, empôla da bursa. e, canal da bursa. g, glândulas da casca. $\mathrm{h}$, faringe. $\mathrm{i}$, intestino. $\mathrm{r}$, poro genital. $\mathrm{t}$, testículo. $\mathrm{u}$, átrio comum. $\mathrm{w}$, ovoviteloduto. $\mathrm{x}$, duto ejaculatório. $\mathrm{y}$, divertículo do átrio feminino.

Fig. 158 - Corte mediano da região do aparelho copulador.

Fig. 159 - Contornos dos órgãos copuladores no corte mediano dum outro indivídur 


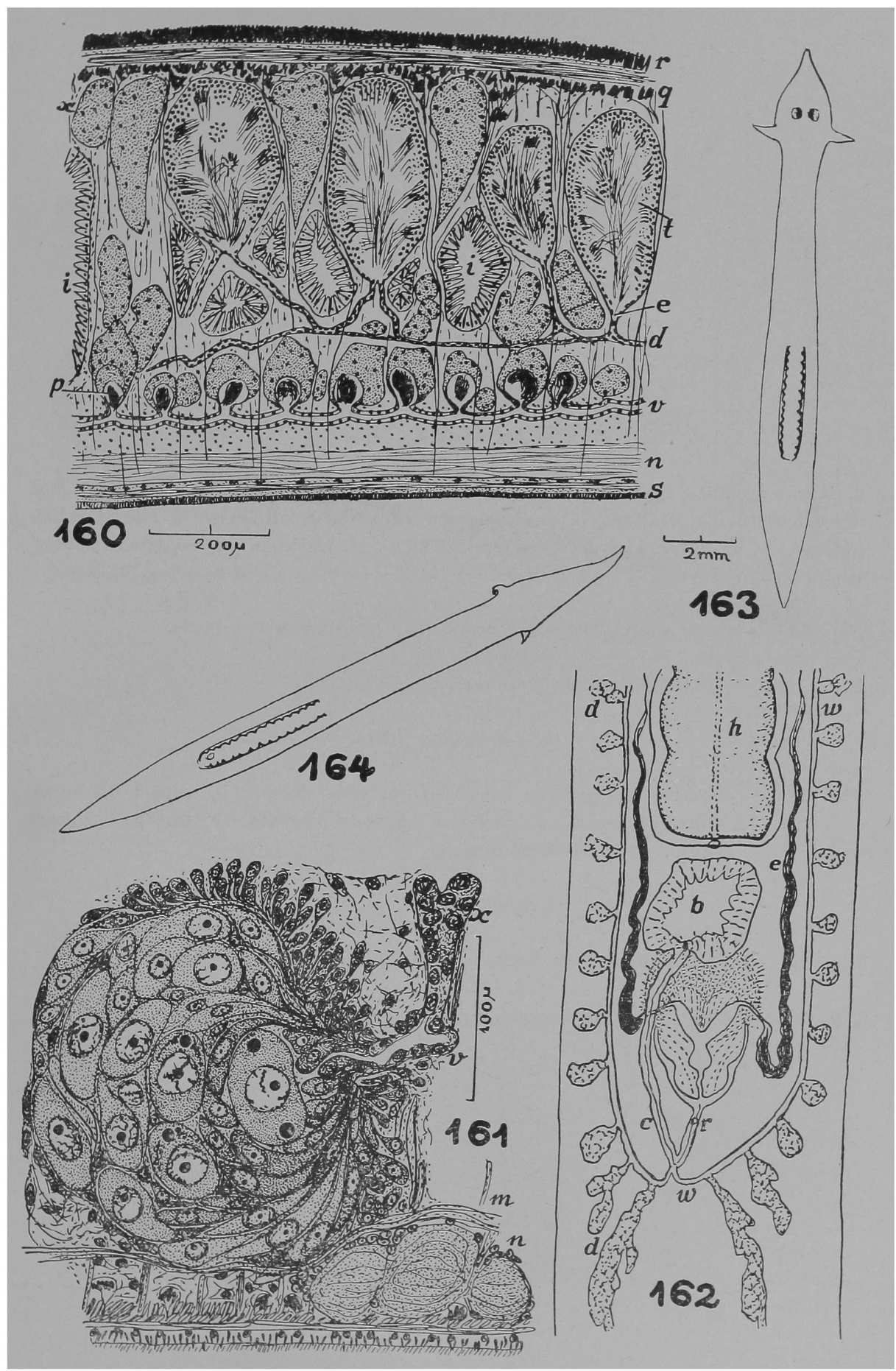




\section{ESTAMPA XXVIII}

Curtisia schubarti, sp. n.

d, duto eferente. e, dútulo eferente. i, intestino. m, músculos dorso-ventrais. n, nervo longitudinal ventral. p, espérmios nos infundíbulos vitelinos. $q$, células rabditógenas. r, epiderme dorsal. $\mathrm{s}$, epiderme ventral. t, testículo. $\mathrm{v}$, ovo-viteloduto. $\mathrm{x}$, vitelário.

Fig. 160 - Corte sagital, ao nível dos nervos longitudinais ventrais.

Fig. 161 - Corte transversal dum ovário.

\section{Dugesia tigrina (Girard)}

Fig. 162 - Esquema do aparelho copulador em vista dorsal. b, empôla da bursa. c, canal da bursa. d, vitelários. e, duto eferente. h, faringe. r, poro genital. w, ovo-viteloduto.

Dugesia nonatoi, sp. n.

Fig. 163 - Hábito regular do verme que deslisa no fundo do vaso.

Fig. 164 - Hábito dum verme que se locomove na película dágua. 

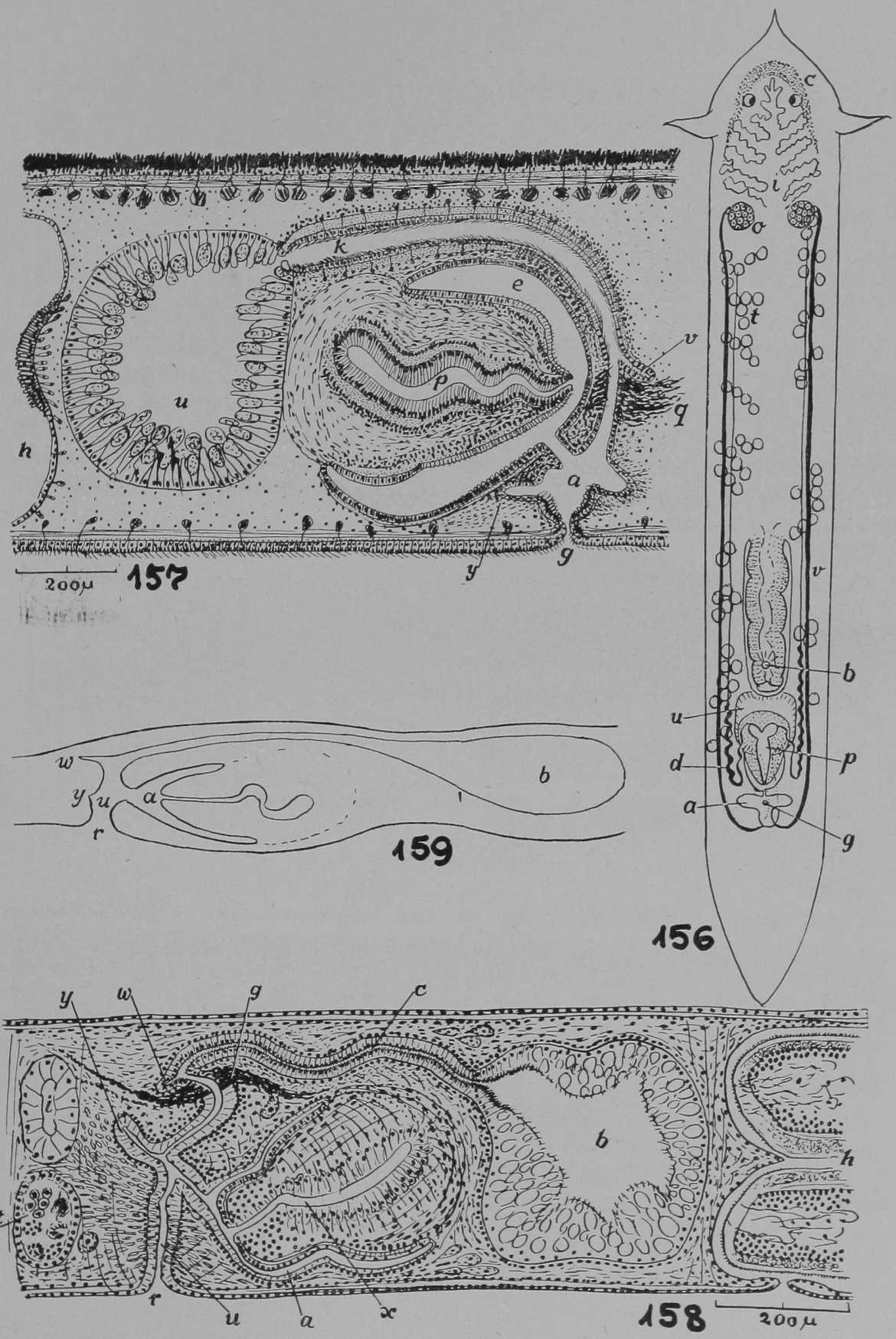


\section{ESTAMPA XXIX}

Dugesia nonatoi, sp. n.

a, desembocadura do canal bursa-intestinal. b, bolsa faríngea. e, glânđulas da casea. d, ovo-vitelodutos. e, dilatação do duto ejaculatório. f, duto eferente. g, glândulas peniais. $h$, faringe. i, intestino. k, glândulas cefálicas. l, bôca. m, empôla da bursa. n, canal da bursa. o, ovário. p, papila penial. q, glândulas argamassadoras, $\mathrm{r}$, poro genital. s, vesícula seminal verdadeira. $\mathrm{t}$, testícrilos. $\mathrm{u}$, duto bursa-intestinal. $\mathrm{v}$, vitelários. $\mathrm{w}$, folículos vitelinos pre-ovários. $\mathrm{x}$, átrio masculino. $\mathrm{y}$, átrio feminino. $\mathrm{z}$, bolsa do átrio feminino.

Fig. 165 - Cabeça dưm verme em locomoção.

Fig. 166 - Cabeça dum verme que fareja.

Fig. 167 - Esquema; duas vêzes interrompido.

Nig. 168 - Corte mediano da região dos órgãos copulatórios.

Fig. 169 - Corte mediano da comunicação bursa-intestinal.

\section{Dugesia arndti, sp. n.}

a, átrio comum. b, bôca. c, glândulas da casca. d, duto eferente. e, átrin masculino. $\mathrm{g}$, gonóporo. h, faringe. $\mathrm{k}$, canal da bursa. $\mathrm{m}$, comunicação ("vagina") entre o canal da bursa e o átrio. p, lume do pênis. u, empôla da bursa. v, ovo-viteloduto. y, glândulas argamassadoras.

Fig. 170 - Topografia dos órgãos copulatórios com pênis proeminente.

Fig. 171 - Topografia dos órgãos copulatórios com o pênis retraido. 

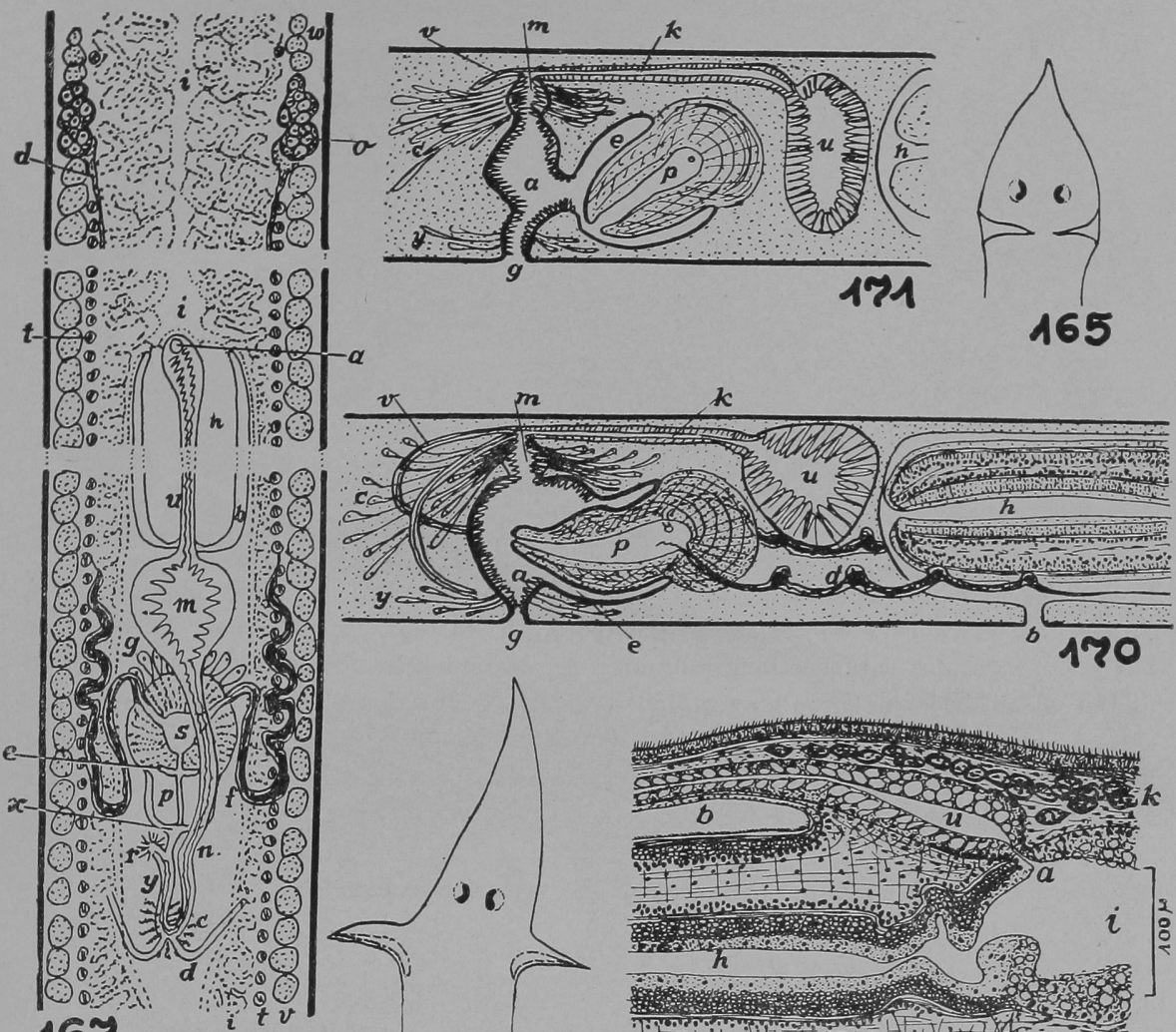

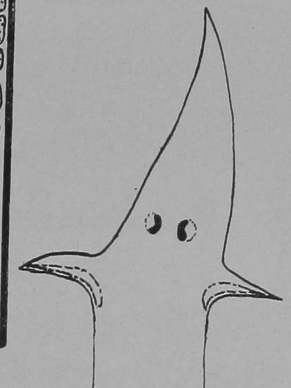

166

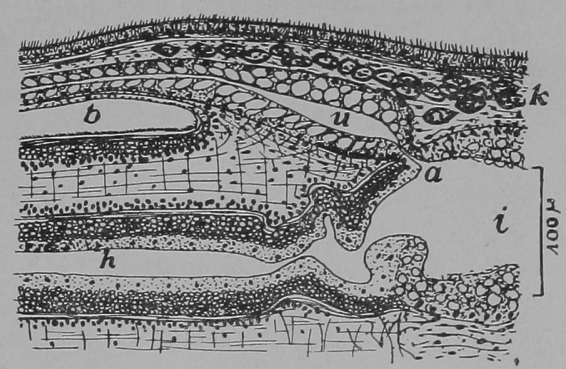

169

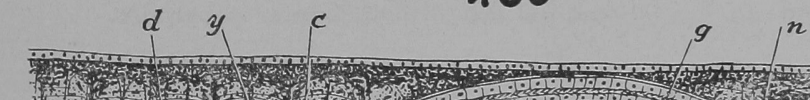

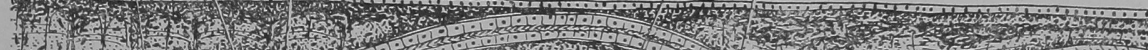
H H.

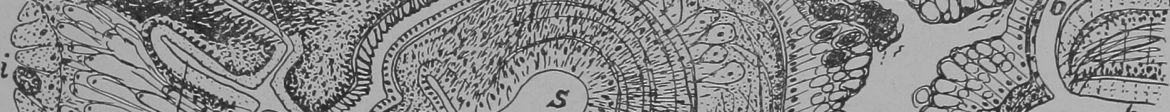

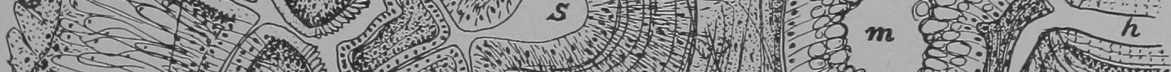

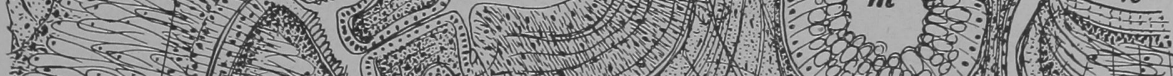
1. जि है

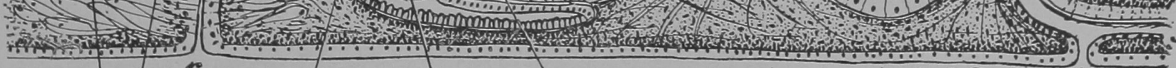

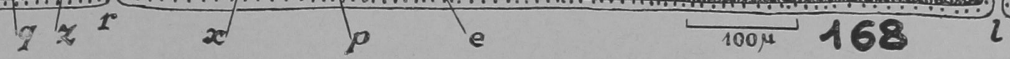




\section{ESTAMPA XXX}

\section{Dugesia arndti, sp. n.}

a, átrio comum. e, glândulas da casca. d, duto eferente. e, átrio masculino. $f$, fibras da musculatura do corpo. g, gonóporo. $\mathrm{h}$, faringe. i, intestino. $\mathrm{k}$, canal da bursa. l, músculos cutâneos longitudinais. m, comunicação ("vagina") entre o canal da bursa e o átrio. n, nervo longitudinal ventral. o, ovário. p, pênis. r, rabditos nas células sub-cutâneas. s, epitélio dorsal da papila penial. t, testículo. u, empôla da bursa. v, ovo-viteloduto. w, vitelário. x, músculos cutâneos anelares. y, glândulas argamassadoras. $\mathrm{z}$, epiderme.

Fig. 172 - Corte mediano (combinado) do aparelho eopulador.

Fig. 173 - Corte horizontal do pênis.

Fig. 174 - Corte horizontal da desembocadura dos ovo-vitelodutos unidos.

Fig. 175 - Corte horizontal da desembocadura dos ovo-vitelodutos separados.

Fig. 176 - Corte transversal do ovário. 
$\pi$

$k$
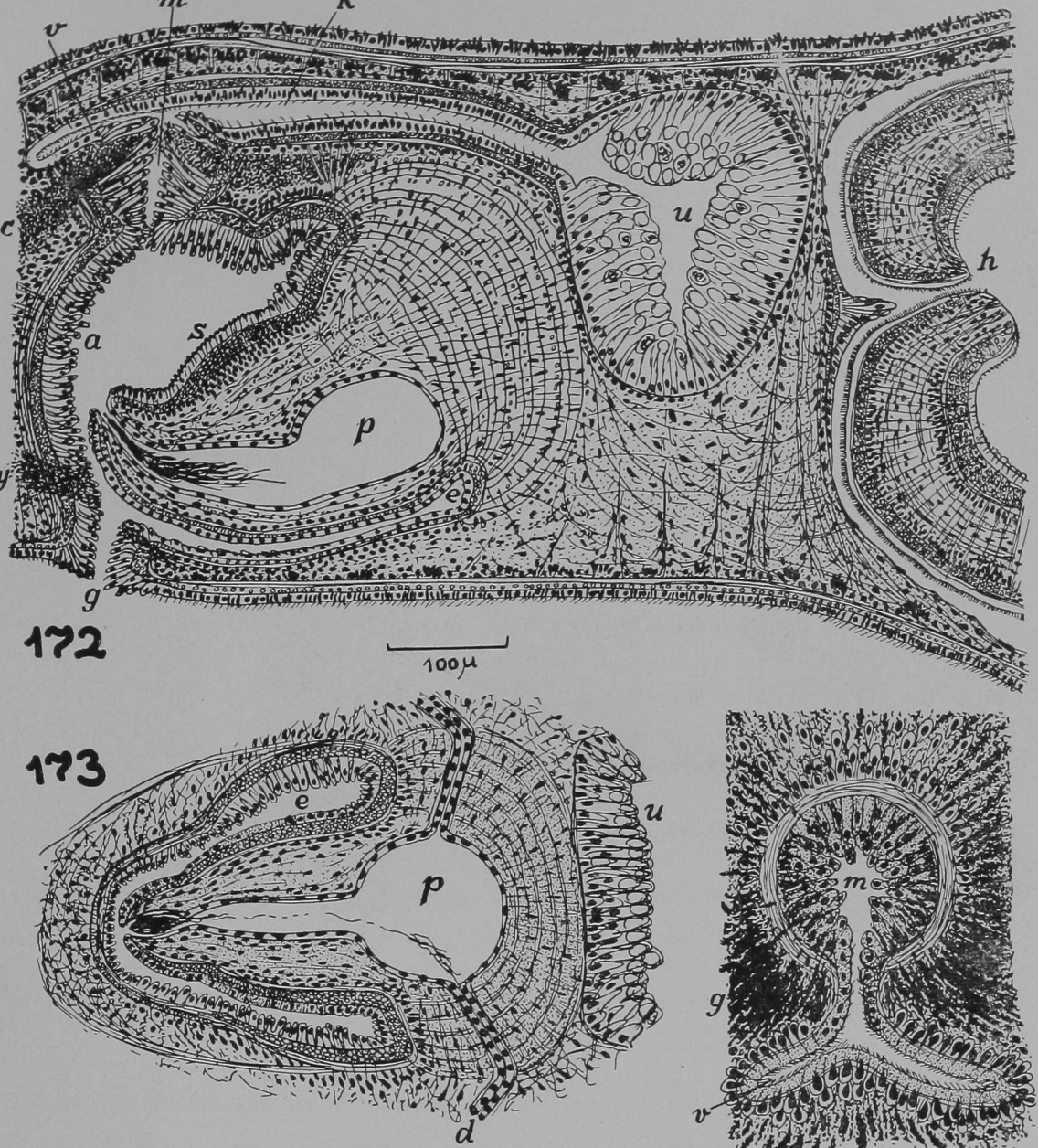

$176 i$ i ${ }^{i}$ \% 7. 30 (1)

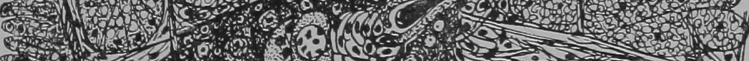

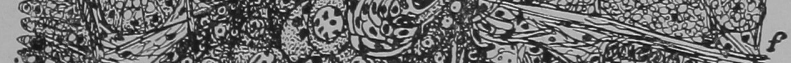

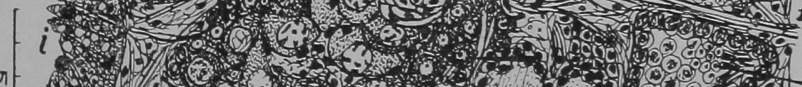

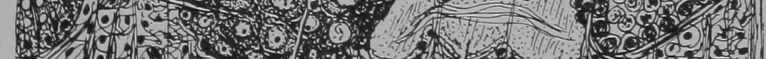
(1) 0.

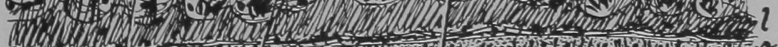
$x$

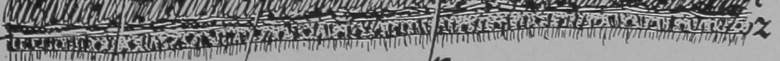
mintion

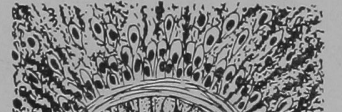

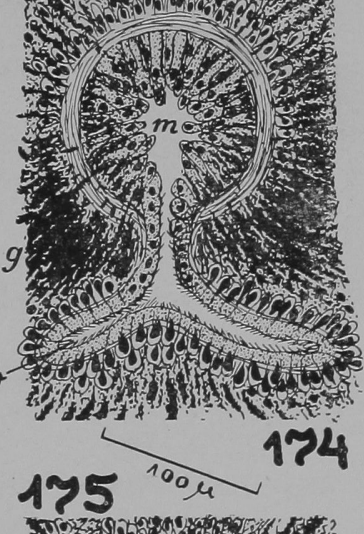

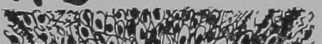

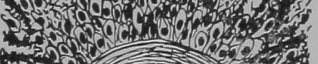
$-10$ ind 18 min

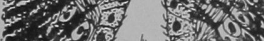
10. M (⿸⿰𠄌⿻コ一⿱丿丶㇀ ano 010 s. 4040

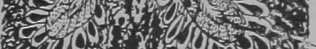
of 


\section{ESTAMPA XXXI}

Animais em eôres naturais

Fig. 1 - Macrostomum gigas Okugawa.

Fig. 2 - Phaenocora evelinae, sp. n.

Fig. 3 - Bothromesostoma evelinae, sp. n.; no claro. A, vista lateral. B. vista rentral.

Fig. 4 - Bothromesostoma evelinae, sp. n.; no escuro.

Fig. 5 - Rhodax evelinae, sp. n.

Fig. 6 - Curtisia schubarti, sp. n.

Fig. 7 - Dugesia tigrina (Girard), vista dorsal dum verme do tipo colorativo reticulado (manchado). São Paulo.

Fig. 8-Dugesia tigrina (Girard), vista ventral do verme da Fig. 7, vendo-se os orifícios bucal e genital.

Fig. 9-12 - Dugesia tigrina (Girard), vistas dorsais de vermes diversamente pigmentados. São Paulo.

Fig. $13-$ Dugesia nonatoi, sp. n.

Fig. $14-$ Dugesia arndti, sp. n. 


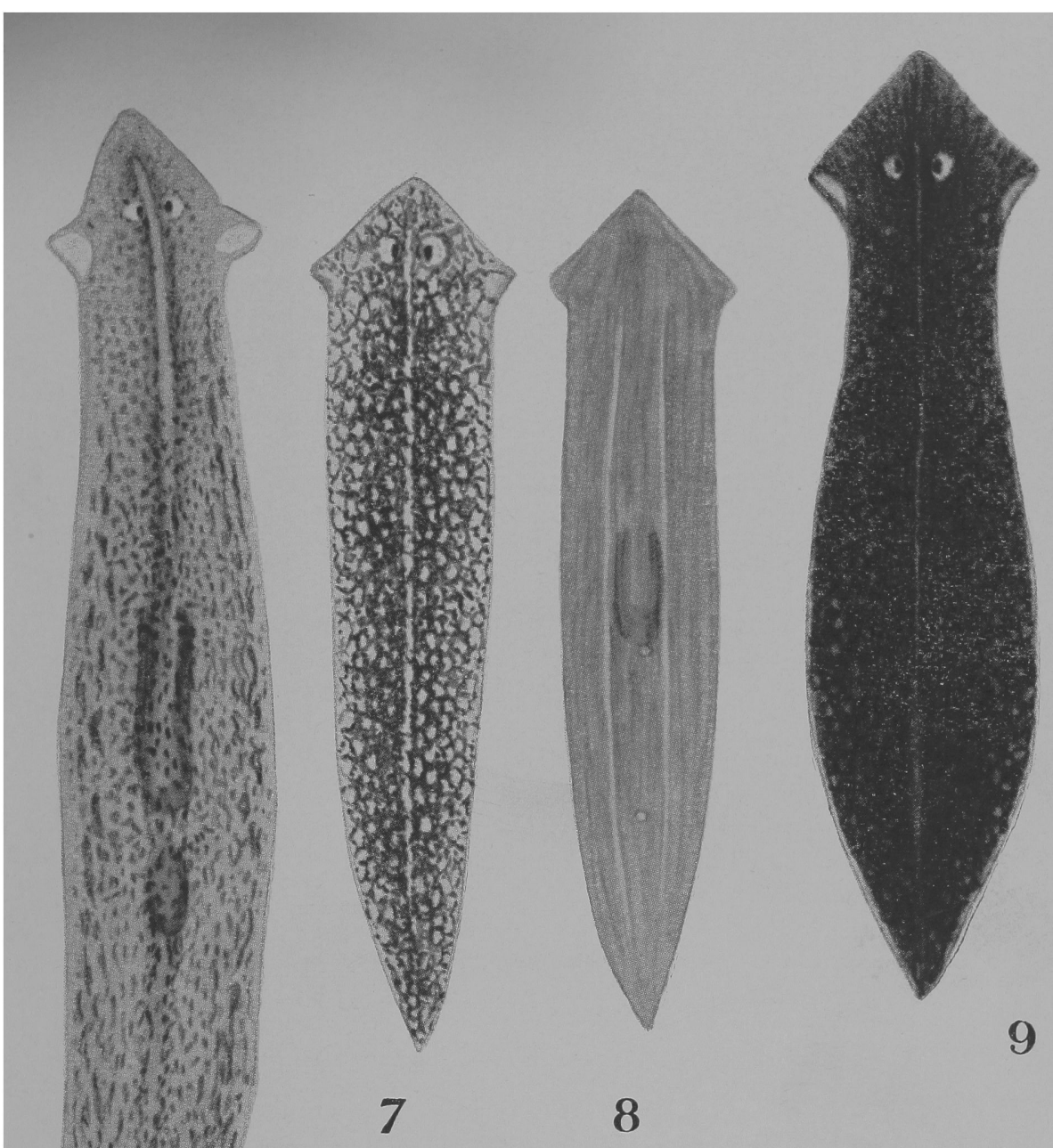

3.

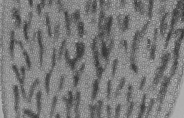

(1.) $(1,1)$

livisifis

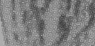

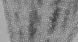

$1 \%$

12
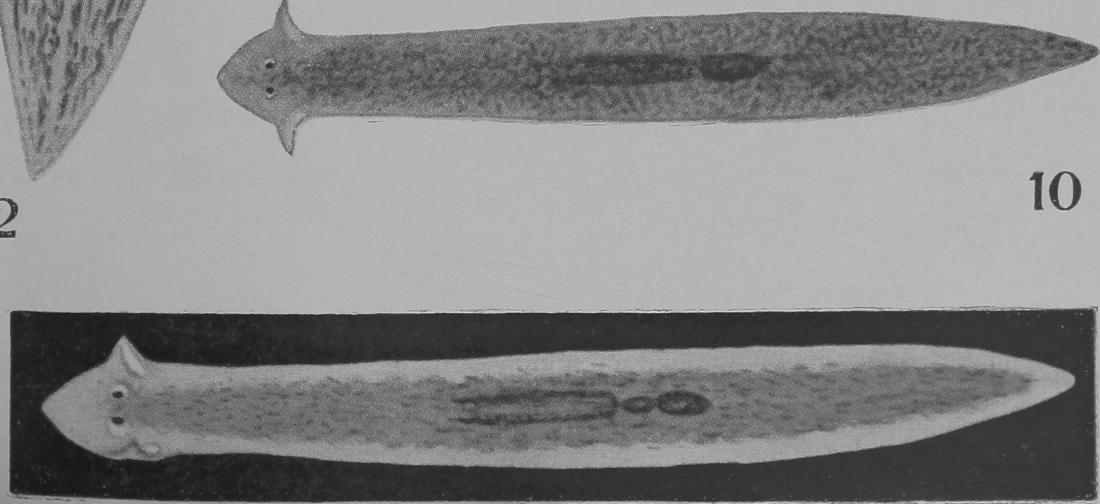



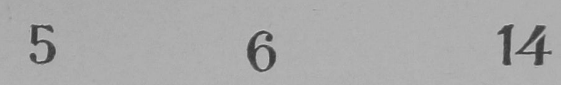

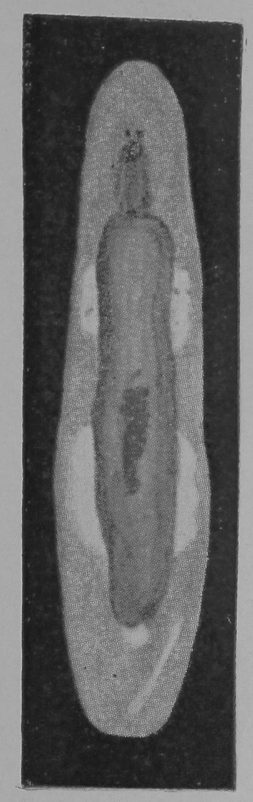

1

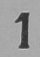

2

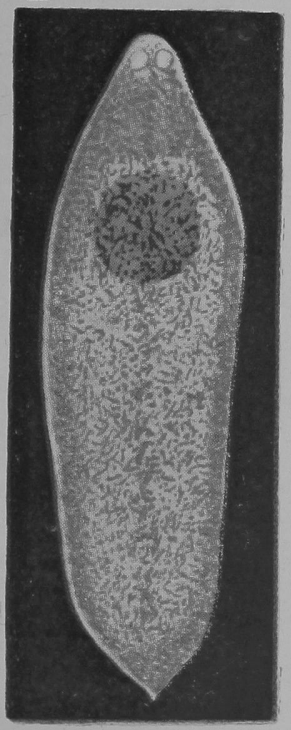

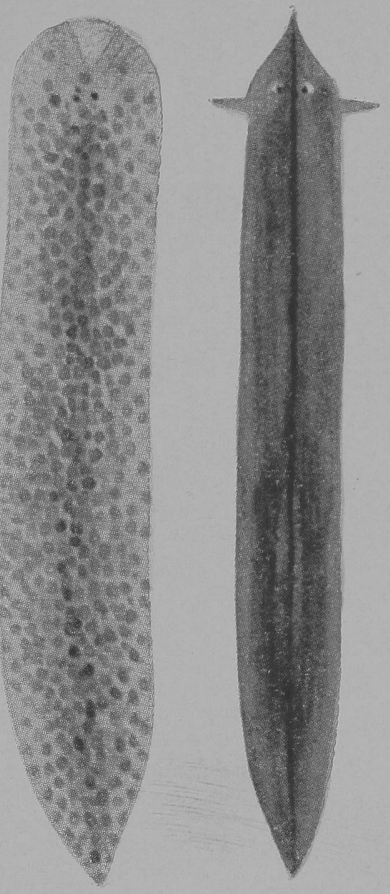

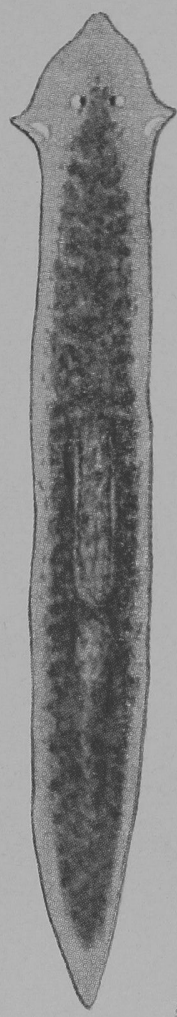

13
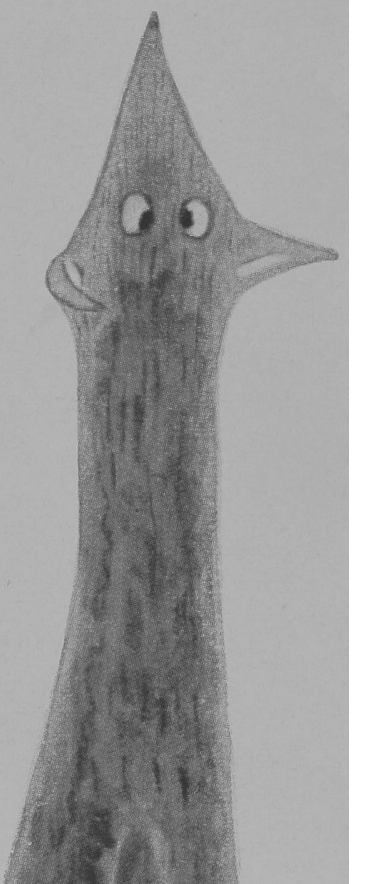

4i:
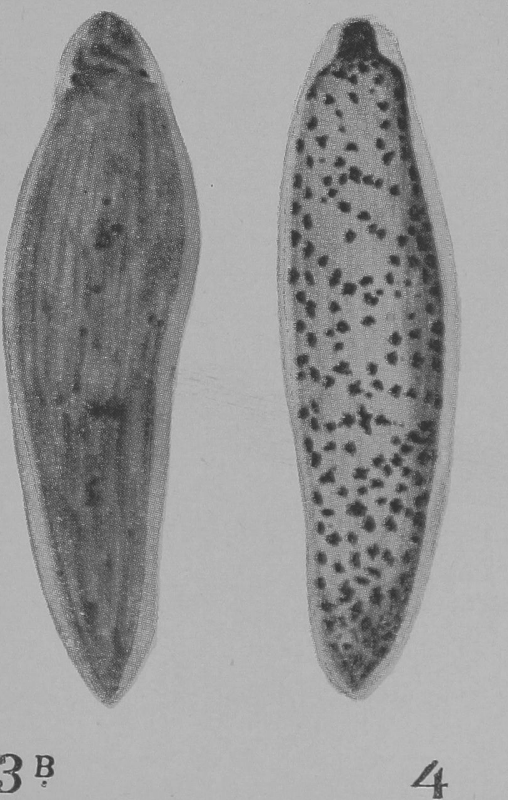